\title{
GEOLOGICAL SURVEY RESEARCH 1970 Chapter B
}

\section{GEOLOGICAL SURVEY PROFESSIONAL PAPER 700-B}

Scientific notes and summaries of investigations in geology, hydrology, and related fields

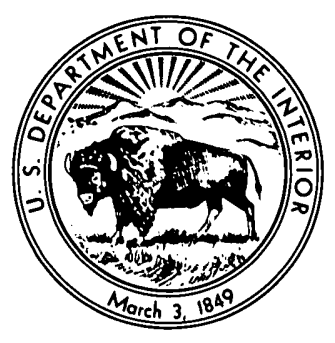

UNITED STATES GOVERNMENT PRINTING OFFICE, WASHINGTON: 1970 


\section{UNITED STATES DEPARTMENT OF THE INTERIOR \\ WALTER J. HICKEL, Secretary \\ GEOLOGICAL SURVEY \\ William T. Pecora, Director}




\section{CONTENTS}

\section{GEOLOGIC STUDIES}

\section{Petrology and petrography}

Copper in biotite from igneous rocks in southern Arizona as an ore indicator, by T. G. Lovering, J. R. Cooper, Harald Drewes, and G. C. Cone..

Relation of carbon dioxide content of apatite of the Phosphoria Formation to regional facies, by R. A. Gulbrandsen ...Extensive zeolitization associated with hot springs in central Colorado, by W. N. Sharp. Mafic and ultramafic rocks from a layered pluton at Mount Fairweather, Alaska, by George Plafker and E. M. MacKevett,

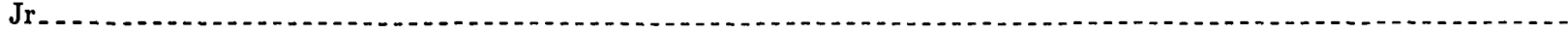
Authigenic kaolinite in sand of the Wilcox Formation, Jackson Purchase region, Kentucky, by J. D. Sims............ Blueschist and related greenschist facies rocks of the Seward Peninsula, Alaska, by C. L. Sainsbury, R. G. Coleman, and Reuben Kachadoorian

Structural geology

Allochthonous Paleozoic blocks in the Tertiary San Luis-Upper Arkansas graben, Colorado, by R. E. Van Alstine.....

\section{Geophysics}

Calculated in situ bulk densities from subsurface gravity observations and density logs, Nevada Test Site and Hot Creek

Valley, Nye County, Nev., by D. L. Healey . _ Geologic and gravity evidence for a buried pluton, Little Belt Mountains, central Montana, by I. J. Witkind, M. D. Kleinkopf, and W. R. Keefer.

Aeromagnetic and gravity features of the western Franciscan and Salinian basement terranes between Cape San Martin and San Luis Obispo, Calif., by W. F. Hanna .

Reconnaissance geophysical studies of the Trinidad quadrangle, south-central Colorado, by M. D. Kleinkopf, D. L. Peterson, and R. B. Johnson

\section{Geochronology}

Whole-rock Rb-Sr age of the Pikes Peak batholith, Colorado, by C. E. Hedge

Distribution of uranium in uranium-series dated fossil shells and bones shown by fission tracks, by B. J. Szabo, J. R. Dooley, Jr., R. B. Taylor, and J. N. Rosholt.

\section{Economic geology}

Iron deposits of the Estes Creek area, Lawrence County, S. Dak., by R. W. Bayley High-calcium limestone deposits in Lancaster County, southeastern Pennsylvania, by A. E. Becher and Harold Meisler.Geology and mineral potential of the Adobe Range, Elko Hills, and adjacent areas, Elko County, Nev., by K. B. Ketner.-

\section{Paleontology}

Early Permian plants from the Cutler Formation in Monument Valley, Utah, by S. H. Mamay and W. J. Breed.---.-Stratigraphic micropaleontology of the type locality of the White Knob Limestone (Mississippian), Custer County, Idaho, by Betty Skipp and B. L. Mamet... Triassic conodonts from Israel, by J. W. Huddle Middle Pleistocene Leporidae from the San Pedro Valley, Ariz., by J. S. Downey New discoveries of Pleistocene bisons and peccaries in Colorado, by G. E. Lewis

\section{Stratigraphy}

Geology of new occurrences of Pleistocene bisons and peccaries in Colorado, by G. R. Scott and R. M. Lindvall.....-.Clay mineralogy of selected samples from the middle Miocene formations of southern Maryland, by Karl Stefansson and J. P. Owens _ . The Gardiners Clay of eastern Long Island, N.Y.-A reexamination, by J. E. Upson. 


\section{Sedimentation}

\section{Geomorphology}

The glaciated shelf off northeastern United States, by R. N. Oldale and Elazar Uchupi

\section{Analytical methods}

Determination of cobalt in geologic materials by solvent extraction and atomic absorption spectrometry, by Wayne Mountjoy......... A field method for the determination of cold-extractable nickel in stream sediments and soils, by G. A. Nowlan ....... The fluorimetric method-Its use and precision for determination of uranium in the ash of plants, by Claude Huffman, Jr., and L. B. Riley.

Chemical extraction of an organic material from a uranium ore, by M. L. Jacobs, C. G. Warren, and H. C. Granger. A die for pelletizing samples for X-ray fluorescence analysis, by B. P. Fabbi.

\section{Ground-water recharge}

\section{HYDROLOGIC STUDIES}

Transmissivity and storage coefficient of aquifers in the Fox Hills Sandstone and the Hell Creek Formation, Mercer and Oliver Counties, N. Dak., by M. G. Croft and E. A. Wesolowski

Preliminary analysis of rate of movement of storm runoff through the zone of aeration beneath a recharge basin on Long Island, N.Y., by G. E. Seaburn

Ground-water inflow toward Jordan Valley from Utah Valley through valley fill near the Jordan Narrows, Utah, by R. W. Mower

\section{Ground-water contamination}

Waterborne styrene in a crystalline bedrock aquifer in the Gales Ferry area, Ledyard, southeastern Connecticut, by I. G. Grossman

\section{Surface water}

Meandering of the Arkansas River since 1833 near Bent's Old Fort, Colo., by F. A. Swenson... Trends in runoff, by P. H. Carrigan, Jr., and E. D. Cobb

\section{Relation between ground water and surface water}

Ground water-surface water relation during periods of overland flow, by J. F. Daniel, L. W. Cable, and R. J. Wolf ...The relationship between surface water and ground water. in Ship Creek near Anchorage, Alaska, by J. B. Weeks...... Prairie potholes and the water table, by C. E. Sloan.

\section{Erosion and sedimentation}

Hydrologic and biotic effects of grazing versus nongrazing near Grand Junction, Colo., by G. C. Lusby Sandbar development and movement in an alluvial channel, Rio Grande near Bernardo; N. Mex., by J. K. Culbertson and C. H. Scott.

\section{Geochemistry of water}

Spectrochemical determination of microgram quantities of germanium in natural water containing high concentrations of heavy metals, by A. E. Dong

\section{Hydrologic techniques}

Evaluation of a method for estimating sediment yield, by L. M. Shown Dosage requirements for slug injections of Rhodamine BA and WT dyes, by F. A. Kilpatrick . . Comparison of a propeller flowmeter with a hot-film anemometer in measuring turbulence in movable-boundary openchannel flows, by J. P. Bennett and R. S. McQuivey.

INDEXES 


\section{GEOLOGICAL SURVEY RESEARCH 1970}

This collection of 46 short papers is the first published chapter of "Geological Survey Research 1970." The papers report on scientific and economic results of current work by members of the Geologic and Water Resources Divisions of the U.S. Geological Survey.

Chapter A, to be published later in the year, will present a summary of significant results of work done in fiscal year 1970, together with lists of investigations in progress, reports published, cooperating agencies, and Geological Survey offices.

"Geological Survey Research 1970". is the eleventh volume of the annual series Geological Survey Research. The ten volumes already published are listed below, with their series designations.

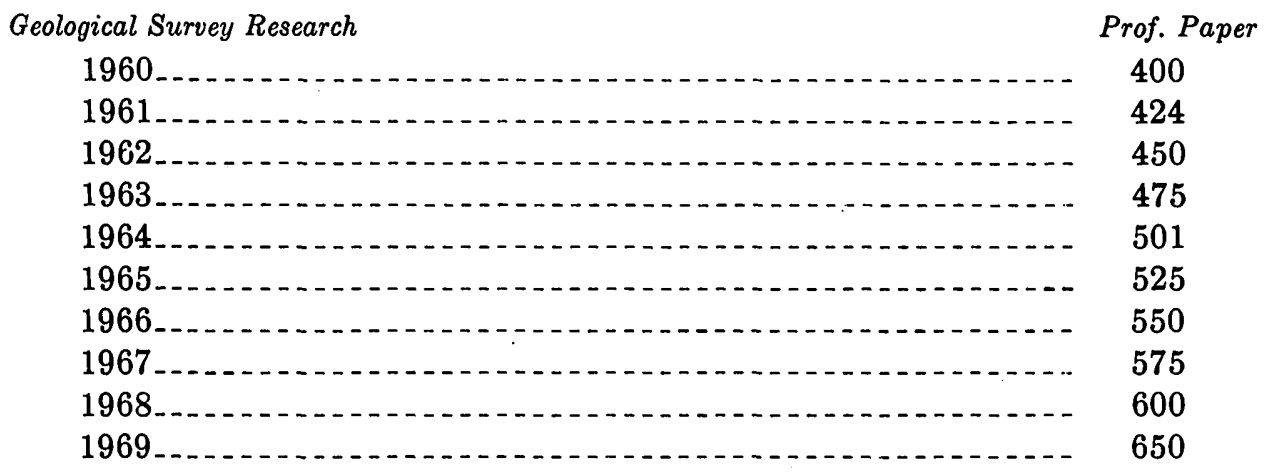


GEOLOGICAL SURVEY RESEARCH 1970

\title{
COPPER IN BIOTITE FROM IGNEOUS ROCKS IN SOUTHERN ARIZONA AS AN ORE INDICATOR
}

\author{
By T. G. LOVERING, J. R. COOPER, HARALD DREWES, \\ and G. C. CONE, Denver, Colo.
}

\begin{abstract}
In the Sierrita and Santa Rita Mountains of southern Arizona, rocks from igneous intrusive bodies that are genetically associated with copper deposits contain as much as 0.03 percent copper; however, biotite separated from these rocks contains as much as 1 percent copper. Rocks from igneous intrusives in the same area that are not associated with copper deposits contain from a few parts to a few tens of parts per million of copper, and the biotites separated from them contain at most $200 \mathrm{ppm}$ copper. The large composite stock on the east side of the Sierrita Mountains shows a well-defined increase in the copper content of biotite, from a few parts per million in the northern part to as much as 1 percent near the copper deposits at its southern end. Copper anomalies in biotite in the rocks in this area provide a more sensitive and extensive indication of associated copper mineralization than do those in the whole-rock samples.
\end{abstract}

Biotite has been separated from samples of four kinds of intrusive rocks, of Precambrian to Paleocene age, in the Santa Rita and Sierrita Mountains of southern Arizona. These separates were analyzed spectrographically to investigate compositional variation among biotite samples from (1) different intrusives of similar ages, (2) similar intrusives of different ages, and (3) a single large ore-related stock.

The greatest variation in trace-element content was found in the copper of these biotites. Copper content ranges from a few parts per million to 1 percent, and the highest copper values are in biotite from rocks that are genetically and spatially related to copper ore deposits. The ore-related biotites consistently contain from one thousand to several thousand parts per million of copper, in contrast to biotites from "barren" intrusives, whose copper content is generally only a few tens of parts per million.

All the biotite samples in which molybdenum was detected $(\geq 10 \mathrm{ppm})$ also contain $>500 \mathrm{ppm}$ (parts per million) copper; however, many of the samples that contain high copper concentrations show no de- tectable molybdenum. None of the other minor elements in the biotite show any consistent relationship to the copper content.

The ability of copper to substitute for iron and magnesium in the biotite lattice and the relatively high concentration of copper in biotites from quartz monzonite stocks in Utah and Nevada that are genetically related to copper ore deposits have been discussed by Parry and Nackowski (1963, p. 1127, 1137, 1140-1141). Putman and Burnham (1963) also reported sporadic, but locally high, concentrations of copper in ferromagnesian mineral concentrates, which consist largely of primary biotite, from their Boriana Granodiorite in the Hualapai Mountains south at Kingman, Ariz. These biotites with high copper content are associated with minor primary chalcopyrite and come from an area that shows copper and molybdenum mineralization (Putman and Burnham, 1963, p. 60, 72, 78-79, 82, 92). However, Bradshaw (1967, p. 143-144) found that the copper content of biotite from ore-related granitic rocks in Cornwall and Wales is consistently less than $50 \mathrm{ppm}$ and that it does not differ significantly from that of biotite from barren granitic intrusives elsewhere in Great Britain.

The biotite in many of the older intrusives of the Santa Rita Mountains shows strong chloritic alteration. Copper analyses are reported here only on those mineral separates that were optically determined to consist of more than 80 percent biotite.

Spectrographic copper analyses had previously been made on some whole-rock samples of the same rocks from which biotite separates had been made. The copper content of ore-associated intrusive rocks is higher than that of barren rocks, but it is more than an order of magnitude lower than the copper content of the biotite.

Samples of the freshest rock obtainable were taken 
for biotite separates; the biotite is a primary mineral in all but one of them (a Precambrian granodiorite from the Santa Rita Mountains which contains secondary biotite of Paleocene age). Many of the pre-Tertiary stocks in the Santa Rita Mountains are not represented in this study because of the intense chloritic alteration of their biotite.

Thirteen biotites were analyzed from the Santa Rita Mountains, and twenty-two from the Sierrita Mountains. Samples from the Santa Rita Mountains comprise three from a large Precambrian stock, two from an Upper Cretaceous stock, four from small barren Paleocene stocks, and four from ore-related Paleocene plugs (fig. 1). All the samples from the Sierrita Mountains were taken from a large composite Paleocene stock that is related to the Esperanza and Sierrita copper deposits of the Pima mining district (fig. 2).

\section{GEOLOGIC SETTING}

The Santa Rita and Sierrita Mountains contain plutonic and closely related hypabyssal rocks. In the Santa Rita Mountains these rocks are of Precambrian, Triassic, Jurassic, Late Cretaceous, Paleocene, and late Oligocene ages. In the Sierrita Mountains they are of Precambrian, Triassic, Jurassic, and Paleocene ages. The larger stocks in both areas are composite bodies whose main phases commonly range in composition from granodiorite to quartz monzonite. The Santa Rita Mountains also are intruded by numerous small homogeneous stocks of granodiorite and quartz monzonite and plugs of quartz latite porphyry. Only the intrusive bodies from which biotite samples were taken for this study are shown on figure 1 .

The copper deposits of the Helvetia, Rosemont, and Greaterville mining districts in the Santa Rita Mountains are associated with Paleocene quartz latite porphyry plugs. Those of the Pima mining district in the Sierrita Mountains are related to Paleocene quartz monzonite porphyry which occurs as plugs and as a facies of Paleocene granodiorite stocks.

\section{METHOD OF MINERAL SEPARATION AND ANALYSIS}

Rock samples were crushed, ground, and sieved. The 60 - to 150 -mesh fraction was used for separation and analysis. The ground sample was then placed in bromoform to float quartz, feldspar, and other light minerals. The heavy-mineral concentrate from the bromoform, including the biotite, was washed, dried, and placed in a methylene iodide solution to float the biotite and sink all heavy minerals of specific gravity greater than 3.3. The biotite concentrate was again washed and dried and was then run through a Frantz magnetic separator at different settings to obtain as pure a bio- tite fraction as possible. Mineral impurities other than chlorite were estimated to constitute less than 5 percent of this fraction. Chlorite, which cannot be removed mechanically by this method of mineral separation, ranged from 1 percent to at least 50 percent. All biotite concentrates were examined optically, and only the analyses of those in which chlorite was less than 20 percent are reported in this paper.

Both whole-rock samples and biotite concentrates were analyzed by a six-step semiquantitative spectrographic method which is similar to the three-step method of Myers, Havens, and Dunton (1961). Results from the six-step method identify geometric intervals that have the boundaries $1.2,0.83,0.56,0.38,0.26,0.18$, $0.12,0.083$, and so forth, and are reported as midpoints of these intervals by the numbers $1,0.7,0.5,0.3,0.2$, $0.15,0.1$, and so forth. The interval identified by the reported midpoint contains the analyst's best estimate of the concentration present. The precision of a reported value is approximately plus or minus one interval at 68-percent confidence, or two intervals at 95percent confidence.

\section{SANTA RITA MOUNTAINS}

\section{Petrography}

Rocks sampled in the Santa Rita Mountains include the Precambrian Continental Granodiorite; the Upper Cretaceous Madera Canyon Granodiorite; the "barren" Paleocene stocks of the Helvetia mining district; and the ore-associated Paleocene plugs of the Greaterville, Rosemont, and Helvetia mining districts (fig. 1). These rocks, mapped by Drewes (1970a, b), are briefly described here; more complete descriptions are planned for future publication.

The Continental Granodiorite forms a large composite stock in the northern part of the Santa Rita Mountains. It is exposed in an eastward-tilted structural block of Precambrian rock that is unconformably overlain by Paleozoic and Mesozoic sedimentary rocks and that is intruded by Paleocene stocks and plugs. The main phase of the stock is a medium-gray to darkgray very coarse grained porphyritic biotite granodiorite that grades to a quartz monzonite. Mafic minerals, chiefly biotite and chlorite, form a meshwork pattern around the felsic minerals. Phenocrysts of light-pinkish-gray microcline or orthoclase as much as $4 \mathrm{~cm}$ long constitute 5-10 percent of the rock. A mode of typical Continental Granodiorite contains, to the nearest percent, quartz, 28 ; plagioclase, 42 ; orthoclase, 18 ; biotite, 9 ; and accessory ilmenitic magnetite, apatite, sphene, and zircon, 3. This rock is isotopically dated as Precambrian (Drewes, 1968). 


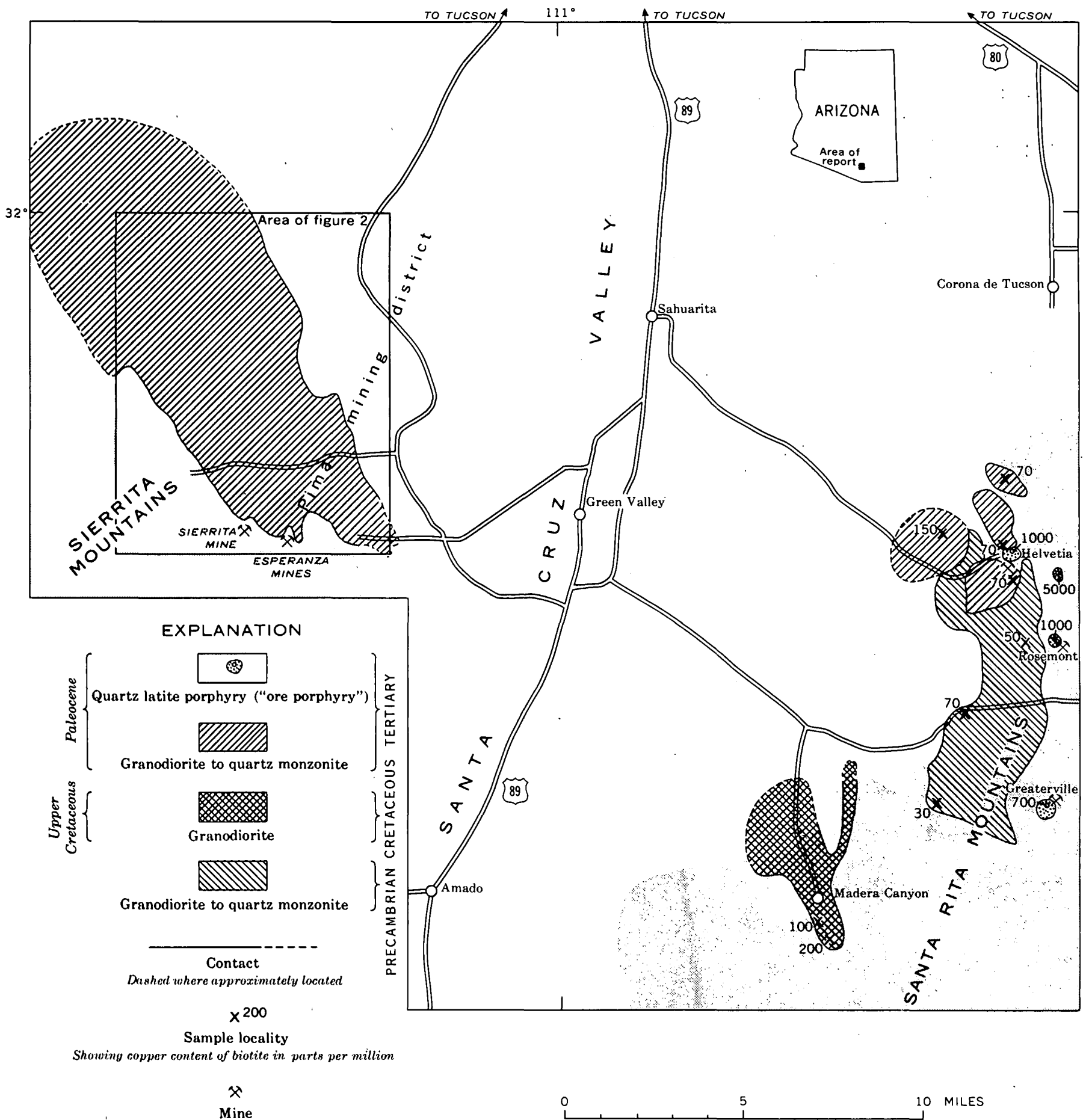

Fraure 1.-Index map showing location of Sierrita and Santa Rita Mountains (light tone), plutons sampled, locality and copper content of biotite samples from the Santa Rita Mountains, and area of flgure 2.

The Madera Canyon Granodiorite is the northernmost of a swarm of stocks of Late Cretaceous age in the southern part of the Santa Rita Mountains. Samples were obtained from a light-gray phase of this rock, which also exhibits porphyritic and melanocratic phases (Drewes, 1970a, b). The light-gray phase is extensively exposed along Madera Canyon, where it has a medium- to coarse-grained hypidiomorphic granular texture. A representative sample contains, to the nearest percent, quartz, 22 ; orthoclase, 26 ; plagioclase, 42 ; hornblende, 5 ; biotite, 4 ; and accessory sphene, ilmenitic magnetite, apatite, and zircon, 1. This rock 
has been dated as about 68 m.y. (million years) (P. E. Damon, written commun., 1964 ; Drewes, 1968, p. C13).

Six small elliptical stocks of Paleocene age, which consist largely of light-gray granodiorite, intrude the structurally complex rocks near Helvetia (Drewes, $1970 \mathrm{~b}$ ). Four of them were sampled for this study (fig. 1). The composition of these stocks is variable, ranging from granodiorite to quartz monzonite. Their inhomogeneity is exemplified by a stock in which the biotite content ranges from 1 to 10 percent. The rocks of these stocks are distinguishable from the Continental Granodiorite by their fresher appearance, the absence of phenocrysts, and the habit of their biotite, which forms discrete books. Modes of these rocks vary widely; that of the sample from the northernmost stock shown on figure 1 , which is fairly representative of the granodiorite, is, to the nearest percent, quartz, 30 ; plagioclase, 45 ; microcline, 13 ; biotite, 10 ; and accessory ilmenitic magnetite, apatite, zircon, and sphene, 1. The stocks of Helvetia are not associated with the mineralization of the district. They have been isotopically dated as about 53 m.y. (Drewes and Finnell, 1968, p. 323 ; R. F. Marvin, written commun., 1968), but geologic field relations indicate that they may be slightly older.

Quartz latite porphyry, locally referred to as the "ore porphyry," forms six small irregular plugs and many dikes in the Greaterville, Rosemont, and Helvetia mining districts. The four plugs sampled are shown on figure 1. The plugs are surrounded by aureoles of low-grade metamorphosed and mineralized rock. Copper, lead, zinc, and silver are the principal metals produced in these districts, but other metals are also present (Schrader 1915; Creasey and Quick, 1955; Drewes, 1970c). The porphyry is typically a grayishorange-pink, closely fractured rock with a saccharoidal groundmass. It contains abundant bipyramidal quartz phenocrysts, sparse small biotite phenocrysts, and traces of disseminated sulfides. Modes of the porphyry are very uniform; the average of the modes of seven specimens, to the nearest percent, is quartz, 26 ; plagioclase, 45; potassium feldspar (largely sanidine), 25; biotite, 3 ; and accessory sphene, apatite, magnetite, zircon, and sulfides, 1 . Biotite from three of these plugs has been isotopically dated as about 56 m.y. (R. F. Marvin, written commun., 1967).

The quartz latite porphyry appears to have been emplaced at a higher temperature than that at which the barren intrusives were emplaced, as indicated by its bypyramidal quartz and sanidine. The extremely irregular shapes of these plugs also suggest that the parent magma of the plugs was highly fluid, a condition that would be favored both by high temperature and by high volatile content. A high metal content of this magma is also indicated by the genetically related ore deposits.

\section{Biotite concentrates and their copper content}

Biotite from the Precambrian Continental Granodiorite is olive green and contains less than 5 percent mineral impurities, which are chiefly chlorite.

Biotite from the Cretaceous Madera Canyon Granodiorite is moderate brown and contains about 10 percent ilmenite and sphene as poikilitic inclusions. Approximately 10 percent each of hornblende and chlorite is present in the mineral concentrates as discrete grains.

Biotite from the Paleocene granodiorite and quartz monzonite porphyry stocks that have no known copper deposits associated with them is dark yellowish brown and contains about 5 percent hematite, apatite, and zircon as inclusions. About 5-10 percent chlorite and minor amounts of sphene and plagioclase are present as accessory minerals in the concentrates.

Four samples were collected from the quartz latite porphyry plugs, which are closely related to copper deposits. These plugs are nearly the same age as the barren monzonite porphyry. Biotite from this "ore porphyry" ranges from light brown to moderate brown, and contains about 5 percent apatite, rutile, and ilmenite as inclusions and 5-10 percent chlorite and sphene as accessory minerals in the concentrate.

Copper concentrations in the biotites of the four rock types in the Santa Rita Mountains that were sampled are summarized in table 1. This table illustrates the marked increase in copper content of biotite samples from the "ore porphyry" relative to such samples from both the unmineralized older granodiorite and the quartz monzonite stocks of approximately the same age as the mineralized quartz latite porphyry plugs.

Copper also increases slightly in whole-rock samples of the ore porphyry, but the copper in biotite separates

\begin{tabular}{|c|c|c|c|}
\hline \multicolumn{4}{|c|}{ [J. L. Finley, analyst] } \\
\hline \multirow[t]{2}{*}{ Rock type } & \multirow{2}{*}{$\begin{array}{l}\text { Number of } \\
\text { samples }\end{array}$} & \multicolumn{2}{|c|}{$\begin{array}{l}\text { Copper content } \\
\text { (ppm) }\end{array}$} \\
\hline & & Range & Mean \\
\hline $\begin{array}{l}\text { Precambrian granodiorite and } \\
\text { quartz monzonite. }\end{array}$ & 3 & $30-70$ & 50 \\
\hline Cretaceous granodiorite & 2 & $100-200$ & 150 \\
\hline $\begin{array}{l}\text { Barren Paleocene quartz } \\
\text { monzonite. }\end{array}$ & 4 & $70-150$ & 90 \\
\hline $\begin{array}{l}\text { Productive Paleocene quartz } \\
\text { latite porphyry. }\end{array}$ & 4 & $700-7,000$ & 3,400 \\
\hline
\end{tabular}


TABLE 2.-Comparison of copper content of whole rock and biotite in sclected samples from the Santa Rita Mountains

\begin{tabular}{|c|c|c|}
\hline \multirow[t]{2}{*}{ Rock type } & \multicolumn{2}{|c|}{$\begin{array}{l}\text { Coppor content } \\
(\mathrm{ppm})\end{array}$} \\
\hline & $\begin{array}{l}\text { Whole } \\
\text { rock }^{1}\end{array}$ & Blotite 2 \\
\hline $\begin{array}{l}\text { Precambrian granodiorite } \\
\text { Cretaceous granodiorite. } \\
\text { Paleocene quartz monzonite } \\
\text { Paleocene quartz latite porphyry }\end{array}$ & $\begin{array}{l}10 \\
20 \\
10 \\
50\end{array}$ & $\begin{array}{r}70 \\
200 \\
70 \\
5,000\end{array}$ \\
\hline
\end{tabular}

1 J. L. Firrls, analyst.

from these samples shows a far greater increase (table 2).

\section{PIMA MINING DISTRICT, SIERRITA MOUNTAINS}

\section{Petrography}

All biotite samples from the Pima mining district came from a large composite stock of Paleocene age, which is genetically related to the Esperanza and Sierrita porphyry copper deposits (fig. 2). This stock and several smaller ones, which are described and shown on a preliminary geologic map by Cooper $\left(1960\right.$, pl. 1), ${ }^{1}$ are mainly granodiorite. The large granodiorite body in the western part of the Pima mining district was named Ruby Star Granodiorite for the Ruby Star Ranch by Livingston, Mauger, and Damon (1968), a name which is here formally adopted. The type area is in parts of Tps. 17 and 18 S., Rs. 12 and 13 E. The granodiorite intrudes intensely deformed rocks of Precambrian to Late Cretaceous age and is overlain unconformably by Quaternary alluvium. The Esperanza and Sierrita ore deposits are near the south end of the large stock, where part of the roof of the stock is exposed.

The composite stock consists of two granodiorite facies and, near the ore deposits, of several quartz monzonite facies not distinguished from one another on figure 2. Modal analyses of four specimens from which the analyzed biotites were obtained are shown in table 3.

The equigranular, border-phase granodiorite (table 3 , analysis 1) is a light-gray medium-grained rock, which is characterized in hand specimen by recognizable quartz, twinned plagioclase, untwinned potassium feldspar, equidimensional books of biotite, hornblende, and small honey-colored crystals of sphene. This rock

1 The "atyplcal granodiorite" of Cooper (1960, p. 70) shown in the southwest corner of this preliminary map is now known to be part of a Triassic or possibly Jurassic intrusive. The granitic rock west of the San Xavier thrust shown near the north edge of the map, which was provisionally assigned to the Precambrian by Cooper $(1960$, p. 68), is now belleved to be slightly younger than the adjacent stock from whlch the blotite samples were obtalned.
TABLE 3.-Modal analyses of rocks in and near the Pima mining district from which biotites were obtained

[Leaders (..) indicate not present]

\begin{tabular}{|c|c|c|c|c|}
\hline & \multicolumn{2}{|c|}{ Granodiorite } & \multicolumn{2}{|c|}{ Quartz monzonite } \\
\hline & 1 & 2 & 3. & 4 \\
\hline $\begin{array}{l}\text { Quartz } \\
\text { Potassium feldspar and }\end{array}$ & 25. 1 & 33. 2 & 27. 4 & 26. 4 \\
\hline perthite & 20. 6 & 19. 2 & 35.4 & 30. 1 \\
\hline Plagioclase & 45. 0 & 42. 8 & 33. 2 & 38. 3 \\
\hline Myrmekite-- & Trace & .3 & 28 & 37 \\
\hline Hornblende....... & $\begin{array}{l}\text { 5. } \\
2.0\end{array}$ & 3. 4 & 2.8 & 3. 7 \\
\hline Opaque minerals . - & .8 & 8 & .8 & 1.0 \\
\hline Sphene___ & .4 & .2 & & .1 \\
\hline Apatite and zircon & .2 & .1 & .2 & Trace \\
\hline Leucoxene, epidote, and & & & & \\
\hline red iron oxid & & & 2 & .4 \\
\hline Total_. & 100. 0 & 100. 0 & 100.0 & 100.0 \\
\hline
\end{tabular}

1. Equigranular granodiorite, average of three specimens from eastern border zone of stock.

2. Porphyritic granodiorite, average of two specimens from core of pluton 2.3 miles northwest of Esperanza mine.

3. Quartz monzonite porphyry, "ore porphyry," average of three specimens from two masses 0.5-0.7 mile north of Esperanza mine.

4. Aplitic quartz monzonite 0.5 mile north of Esperanza mine

has gradational contacts with the porphyritic corephase granodiorite.

The porphyritic core phase (table 3, analysis 2) is much like the border phase, but lacks hornblende and contains from 2 to 10 percent phenocrysts of potassium feldspar which are $1 / 2^{-3}$ inches long. It generally contains less biotite, more quartz, and plagioclase of a less calcic composition than the border phase. Two potassium-argon age dates on the granodiorite facies are $60 \mathrm{~m} . \mathrm{y}$. (Creasey and Kistler, 1962) and $59 \mathrm{m.y}$. (Damon and Mauger, 1966).

The quartz monzonitic part of the stock near the ore deposits (fig. 2) includes rocks distinguishable from the granodiorite only by their mineral proportions, and also finer grained quartz monzonite porphyry and aplitic quartz monzonite phases. The quartz monzonite porphyry has sharp intrusive contacts with the granodiorite at a few places, but gradational contacts at others. The aplitic quartz monzonite phase was called biotite-bearing aplite by Anderson and Kupfer $(1945$, p. 5) and is shown as dacite porphyry on a map by Lynch (1966). It is an intrusive body approximately 1,000 feet wide and 1,800 feet long which is emplaced in quartz monzonite porphyry and granodiorite. It crops out half a mile north of the Esperanza mine, and also forms very small bodies closer to the mine. The quartz monzonite phases are not separately distinguished on figure 2.

The quartz monzonite porphyry (table 3, analysis 3) is light gray to pinkish gray on fresh exposures. Pheno- 
B6

PETROLOGY AND PETROGRAPHY

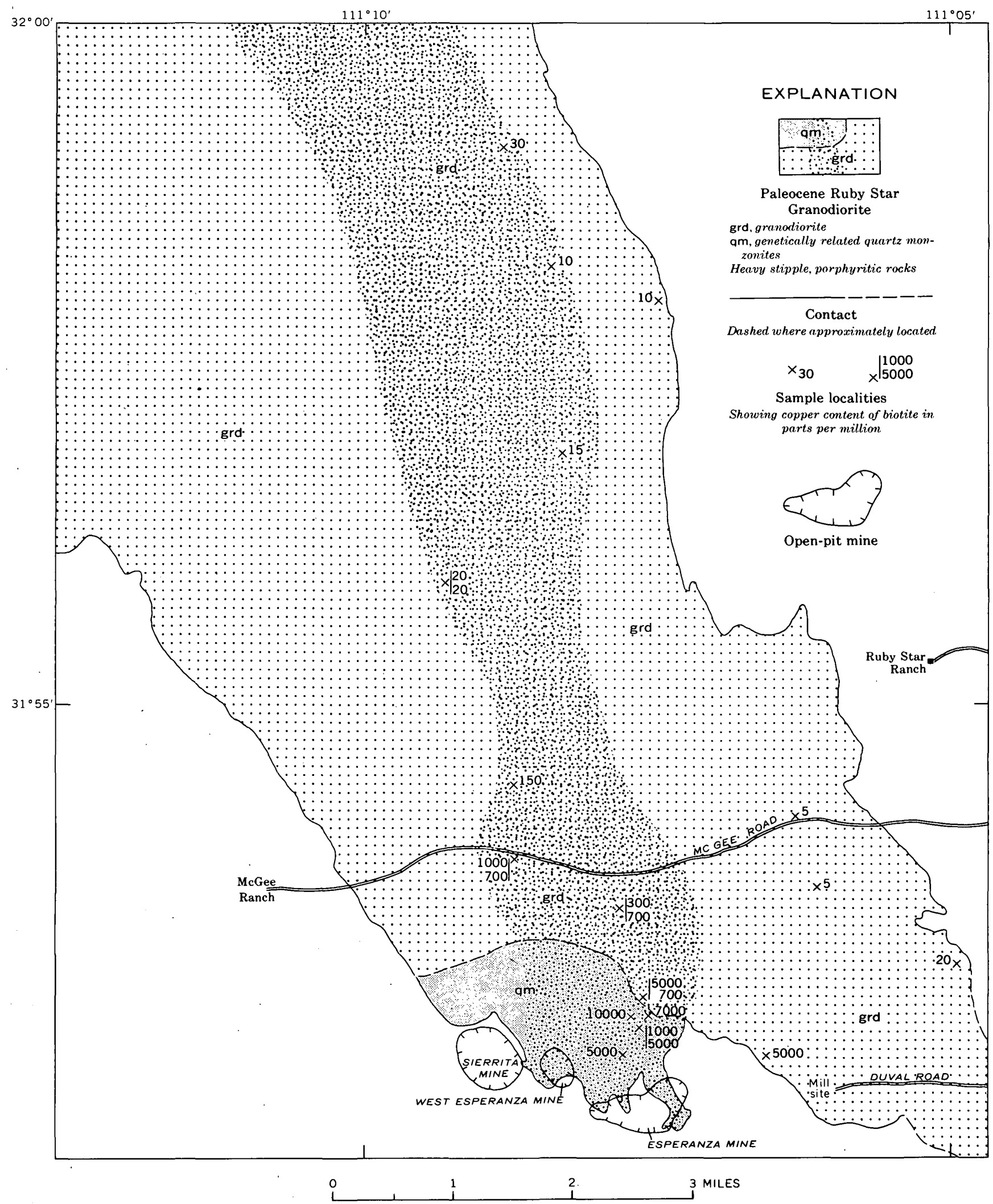

Figure 2.-Generalized map of composite stock and associated ore deposits in the southwestern part of the Pima mining district, east of the Sierrita Mountains, showing sample localities and copper content of biotite. 
crysts of white plagioclase, gray quartz, pink potassium feldspar, and biotite make up about half the rock. The remainder is a fine-grained granular ground-mass of quartz, potassium feldspar, and a little plagioclase. Primary accessory minerals include magnetite, apatite, and zircon.

The aplitic quartz monzonite (table 3 , analysis 4) is a light-gray aplitic rock whose groundmass consists largely of quartz, orthoclase, oligoclase, and biotite in grains less than half a millimeter in diameter. Zoned oligoclase phenocrysts as much as $5 \mathrm{~mm}$ long and biotite books $1-3 \mathrm{~mm}$ in diameter are fairly common, and quartz "eyes" as much as $3 \mathrm{~mm}$ in diameter have been observed but are much less abundant than in the adjacent quartz monzonite porphyry. The accessory minerals include magnetite, apatite, zircon, and sphene.

The quartz monzonite porphyry has been dated by Creasey and Kistler (1962) by the potassium-argon method as 56 m.y. This age may be too young, as the rock is mineralized in the Esperanza mine, and muscovite from a muscovite-quartz-sulfide veinlet in this mine has a potassium-argon age of $61 \mathrm{~m} . \mathrm{y}$. (Damon and Mauger, 1966)-very nearly the same age as the granodiorite.

\section{Biotite concentrates and their copper content}

The sample localities of the rocks from which the 22 biotite separates were made and the copper contents of these separates are shown in figure 2. Two copper values shown for a single locality represent separate samples collected tens of feet apart to test the possibility of sporadic local variation in trace-element content.

The biotite concentrates contain some mineral impurities, both as discrete grains of foreign minerals and as poikilitic inclusions of other minerals within the biotite flakes. The total content of such impurities in the various mineral concentrates ranges from less than 5 percent to nearly 20 percent; however, none of the concentrates contain any visible copper minerals.

The five samples from the equigranular border facies of the granodiorite stock show no consistent features that distinguish them from the 12 samples of porphyritio granodiorite from the central part of the stock. Hornblende is present as an accessory mineral in two of the five concentrates from the border facies but does not appear in any of those from the porphyritic facies. Zircon forms inclusions in biotite in 5 of the 12 concentrates from the porphyritic facies but not in any of the biotite from the equigranular facies.

There is a suggestion of a color change in the biotite of both rock types from north to south in this stock. Most samples near the southern end of the pluton are' moderate brown to dark brown; those from about a mile to about 3 miles north of the southern end tend to be somewhat lighter brown, and those from localities more than 3 miles to the north are olive brown or mixed olive brown and shades of light brown.

Biotite from the porphyritic granodiorite contains a maximum of about 5 percent apatite, rutile, ilmenite, hematite, sphene, and zircon as inclusions. Chlorite, the most common accessory mineral in the concentrates, ranges from 0 to about 10 percent of the sample. Minor amounts of feldspar, hornblende, and sphene are also present as accessory minerals in a few of the concentrates.

Biotite from the quartz monzonite porphyry and aplitic quartz monzonite is moderate brown to dark brown and contains as much as 10 percent of inclusions of apatite, ilmenite, hematite, rutile, and zircon. Chlorite constitutes as much as 10 percent of the mineral concentrate, and minor amounts of sphene occur in two of the samples.

As shown in figure 2, the copper content of the biotites displays a zonal pattern around the copper deposits. The highest copper concentrations are in the biotite nearest the deposits, and anomalous concentrations extend outward for as much as $21 / 2$ miles. These very cupriferous biotites are mostly from quartz monzonite porphyry and aplitic quartz monzonite, but they include biotites from both the porphyritic and the equigranular granodiorite. The lithologic diversity of the samples high in copper content suggests that part or all of this copper may have been introduced by hydrothermal solutions at the time of mineralization, or conceivably could have been introduced by later circulating ground water. However, coarse hydrothermal biotite from veinlets in diorite above the Sierrita ore body contains only $30 \mathrm{ppm}$ copper. This biotite has a potassium-argon age of 60 m.y. (S. S. Goldich, written commun., 1964), the same age as that of the hydrothermal mica from the Esperanza mine.

The zonal pattern of copper concentration in the biotite is also shown by the copper concentration in whole-rock samples, but it is less impressive (table 4). The copper content of whole-rock samples from which biotite was separated for this study is given in table 4 .

\section{CONCLUSIONS}

The copper content of primary biotite in several rock types from southern Arizona ranges from a few parts per million to 1 percent. The concentration of copper in biotite from two different bodies of the same kind of rock differs by more than an order of magnitude, and it varies by three orders of magnitude within a single large ore-related stock of granodiorite in the 
TABLE 4.-Comparison of copper content of whole rock and biotite in selected samples from the Pima mining district

\begin{tabular}{lccc}
\hline Rock type and sample locality & Copper (ppm) & $\begin{array}{c}\text { Percentage of } \\
\text { Whole rock }\end{array}$ & $\begin{array}{c}\text { Biotite }{ }^{2} \\
\text { rock in whole } \\
\text { concentrated in } \\
\text { biotite }\end{array}$ \\
\hline $\begin{array}{c}\text { Equigranular granodiorite, } 2.7 \\
\text { miles northeast of Esperanza }\end{array}$ & 7 & 5 & $<5$ \\
$\begin{array}{c}\text { mine. } \\
\text { Porphyritic granodiorite, 2.9 } \\
\text { miles northwest of Esperanza } \\
\text { mine. }\end{array}$ & 150 & 700 & 15 \\
$\begin{array}{c}\text { Quartz monzonite porphyry, 0.5 } \\
\text { mile northwest of Esperanza } \\
\text { mine. }\end{array}$ & 300 & 5,000 & 50 \\
\hline
\end{tabular}

N.M. Conklin, analyst.

2 R. H. Heidel, analyst.

Pima mining district. Copper anomalies in the rock are magnified in the biotite from that rock, although rocks that are low in copper content contain biotite with equally low copper concentrations. Igneous-rock bodies in the Santa Rita Mountains that are genetically related to copper deposits contain primary biotite with copper concentrations at least an order of magnitude higher than those in biotite from rocks that are not related to copper deposits. The copper anomaly in biotite from the large stock in the Pima district is centered over the mineralized area and extends for more than a mile beyond it.

The copper content of biotite may be useful in recognizing plutons that are genetically related to copper mineralization and as a geochemical guide to copper ore deposits in such plutons.

Although all but one of the biotite samples analyzed are primary, it cannot be conclusively demonstrated that the copper in them is also primary. The lithologic diversity of rocks with high copper content suggests a hydrothermal source; however, a sample of hydrothermal biotite from the mineralized area of the Pima mining district contains only $30 \mathrm{ppm} \mathrm{Cu}$. Putman and Burnham (1963, p. 72, 82) concluded that the copper, present in high concentrations in samples of biotite from their Boriana Granodiorite pluton, is a primary constituent and was not introduced by later hydrothermal activity.

Only the copper content of biotite in the igneous rocks of this area was investigated by the authors, since biotite is the only mafic mineral present in concentratable amounts in all these rocks. If other primary mafic minerals are present in an ore-related igneous rock, they may also concentrate copper. Two samples of hornblende from the Madera Canyon Granodiorite contain about the same amount of copper as the biotite samples from this rock.

\section{REFERENCES}

Anderson, C. A., and Kupfer, D. H., 1945, Report on the properties of the Amargosa Molybdenum and Copper Corporation, Pima County, Arizona: U.S. Geol. Survey open-file report, 20 p., 9 pls.

Bradshaw, P. M. D., 1967, Distribution of selected elements in feldspar, biotite and muscovite from British granites in relation to mineralization: Inst. Mining and Metallurgy Trans., Sec. B, v. 76, p. 187-148.

Cooper, J. R., 1960, Some geologic features of the Pima mining district, Pima County, Arizona: U.S. Geol. Survey Bull. 1112-C, p. 63-103.

Creasey, S. C., and Kistler, R. W., 1962, Age of some copperbearing porphyries and other igneous rocks in southeastern Arizona: Art. 1 in U.S. Geol. Survey Prof. Paper 450-D, p. D1-D5.

Creasey, S. C., and Quick, G. L., 1955, Copper deposits of part of Helvetia mining district, Pima County, Arizona: U.S. Geol. Survey Bull. 1027-F, p. 301-323 [1956].

Damon, P. E., and Mauger, R. L., 1966, Epelrogeny-orogeny viewed from the Basin and Range province: Soc. Mining Engineers Trans., v. 235, no. 1, p. 99-112.

Drewes, Harald, 1968, New and revised stratigraphic names in the Santa Rita Mountains of southeastern Arizona: U.S. Geol. Survey Bull. 1274-C, p. C1-C15.

1970a, Geologic map and sections of the Mount Wrightson quadrangle southeast of Tucson, Santa Cruz and Pima Counties, Arizona: U.S. Geal. Survey Misc. Geol. Inv. Map I-614 [in press].

1970b, Geologic map of the Sahuarita quadrangle, southeast of Tucson, Pima County, Arizona: U.S. Geol. Survey Misc. Geol. Inv. Map I-613 [In press].

1970c, Structural control of geochemical anomalles at Greaterville, southeast of Tucson, Arizona : U.S. Geol. Survey Bull. 1312-A, $49 \mathrm{p}$. [In press].

Drewes, Harald, and Finnell, T. L., 1968, Mesozoic stratigraphy and Laramide tectonics of part of the Santa Rita and Empire Mountains southeast of Tucson, Arizona, Field trip 2 in Titley, S. R., ed., Southern Arizona guidebook 3Geol. Soc. America Cordilleran Sec. 64th Ann. Mtg., Tucson, 1968: Arizona Geol. Soc., p. 315-324.

Livingston, D. E., Mauger, R. L., and Damon, P. E., 1968, Geochronology of the emplacement, enrichment, and preservation of Arizona porphyry copper deposits: Econ. Geology, v. 63 , no. 1, p. $30-36$.

Lynch, D. W., 1966, The economic geology of the Esperanza mine and vicinity, p. 267-279 in Titley, S. R., and Hicks, C. L., eds., Geology of the porphyry copper deposits, southwestern North America : Arizona Univ. Press, Wilson volume, $287 \mathrm{p}$.

Myers, A. T., Havens, R. G., and Dunton, P. J., 1961, A spectrochemical method for the semiquantitative analysis of rocks, minerals, and ores: U.S. Geol. Survey Bull. 1084-I, p. 207229.

Parry, W. T., and Nackowski, M. P., 1963, Copper, lead, and zinc in biotites from Basin and Range quartz monzonltes: Econ. Geology, v. 58, no. 7, p. 1126-1144.

Putman, G. W., and Burnham, C. W., 1963, Trace elements in igneous rocks, northwestern and central Arizona: Geochim. et Cosmochim. Acta, v. 27, no. 1, p. 53-106.

Schrader, F. C., 1915, Mineral deposits of the Santa Rita and Patagonia Mountains, Arizona, with contributions by J. M. Hill: U.S. Geol. Survey Bull. 582, 373 p. 


\title{
RELATION OF CARBON DIOXIDE CONTENT OF APATITE OF THE PHOSPHORIA FORMATION TO REGIONAL FACIES
}

\author{
By R. A. GULBRANDSEN, Menlo Park, Calif.
}

\begin{abstract}
Many recent data provide a well-defined empirical relation between the carbonate content and the $a$-cell dimension of carbonate fluorapatite, the marine variety of apatite. This relationship is used as the basis of an X-ray peak-pair method for estimating the $\mathrm{CO}_{\mathfrak{}}$ content of apatite. An estimate of the average $\mathrm{CO}_{\mathfrak{}}$ content of apatite in the Permian Phosphoria Formation, as determined on a representative group of samples by the peak-pair method, is 1.8 weight percent. Averages for a serles of sections located across major rock facies from southcentral Idaho to central Wyoming indicate an eastward increase in the $\mathrm{CO}_{\mathfrak{a}}$ content of apatite that possibly was due to an increase of water temperature.
\end{abstract}

Carbonate fluorapatite has been recognized as the compositional variety of apatite in marine phosphorites since Altschuler, Cisney, and Barlow (1952) and Silverman, Fuyat, and Weiser (1952) showed that carbonate was an integral component of the mineral and that the a-cell dimension, in particular, distinguishes carbonate fluorapatite from other apatites. The recent outstanding work of Smith and Lehr (1966), Lehr, McClellan, Smith, and Frazier (1968), and McClellan and Lehr (1969) has now shown the approximate range of carbonate substitution likely to occur in apatite and has established an empirical relation of this substitution with the mineral's cell dimensions. These studies of the apatite in a large number of phosphorites from deposits around the world constitute a milestone in the mineralogy of marine apatite. They present many compositional, physical, and structural data, but it is the data on carbonate in apatite that is of interest here. It is now possible to determine semiquantitatively by $\mathrm{X}$-ray measurement the amount of carbonate in marine apatite. Rather than utilize cell dimensions, however, a peak-pair method is described and applied to the apatite in rocks of the Phosphoria Formation in the Western United States.

Acknowledgment.-The development by Ming Ko, U.S. Geological Survey, of a computer program to handle the many and varied calculations utilized here is greatly appreciated.

\section{CORRELATION OF $\mathrm{CO}_{2}$ CONTENT WITH THE a-CELL DIMENSION}

It is to be expected that the cell dimensions of a mineral vary with changes of the mineral's composition, and McClellan and Lehr (1969) show the effect of compositional changes of apatite upon its cell dimensions. Although they found that the changes in the $a$ dimension were correlated best in an expression treating both carbonate and fluorine, the largest effect is due to carbonate. A direct correlation exists therefore between the carbonate content and the $a$ dimension of apatite, as shown in figure 1 using the $\mathrm{CO}_{2}$ content and $a$-cell unit data of McClellan and Lehr $(1969$, p. 1379) for 74 marine apatites from deposits in Africa, Florida, North and South Carolina, and the Western United States. A least-squares line for the expression $y=a+b x$ is shown for these data, where $y$ is $\mathrm{CO}_{2}$ percent by weight and $x$ is the $a$-cell dimension in angstroms. Even though the scatter of points is fairly large, the trend is well defined, and the leastsquares line represents an empirically derived relationship that is useful for semiquantitative determinations of the $\mathrm{CO}_{2}$ content of marine apatites. A method of this kind is desirable because the determination is unaffected by the presence of other carbonate-bearing minerals as well as other impurities so long as the $\mathrm{X}$-ray peaks are defined well enough for accurate measurement. It does require, however, the use of an internal standard for an accurate measurement of the absolute $d$ values, as well as a calculation of the $a$ cell dimension. A simpler method for making the $\mathrm{CO}_{2}$ determinations is utilized here. It requires only the measurement of the angular difference between two $\mathrm{X}$-ray diffraction peaks-the peak-pair method. 


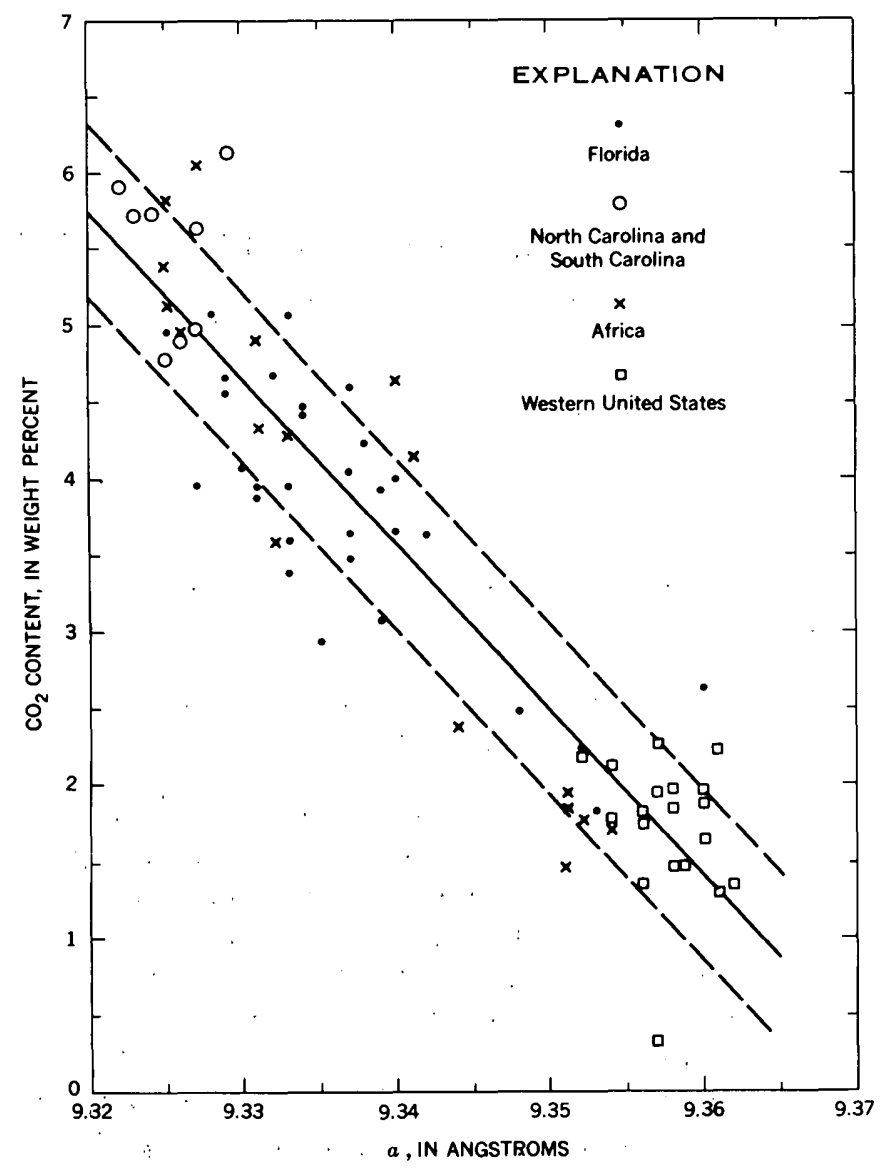

Figure 1.-Plot of $\mathrm{CO}_{2}$ weight percent and $a$-cell dimension of marine apatites. Data from McClellan and Lehr (1969). Equation of line is $y=1014.66-108.253 x$, where $y=\mathrm{CO}_{2}$ in weight percent, and $x=a$-cell dimension in angstroms Standard error of estimate of $y=0.5569$ (shown by dashed lines).

Because the $c$ dimension is much less affected by carbonate substitution than the $a$ dimension, peaks whose indices are of the (001) type change less than other types-(hkl), (hk0), (h00), or $(0 \mathrm{k} 0)$-all of which include a component of the $a$ dimension. A pair of peaks, one of which is an (001) type, therefore shows a difference that is proportional to the amount of carbonate substitution, expressed here as the $\mathrm{CO}_{2}$ content in weight percent. The peak-pair method was used by Silverman, Fuyat, and Weiser (1952) to show that carbonate fluorapatite was different from other apatites. - The pair of peaks selected here are the (410) and the (004), which occur around $51.6^{\circ}$ and $53.1^{\circ} 2 \theta$, respectively, for $\mathrm{Cu}$ radiation. They are close together, of medium intensity, and at angles large enough to provide a useful range of spacing differences, $\Delta 2 \theta$. A $\Delta 2 \theta_{(004) \text {-(410) }}$ value for each of the 74 samples utilized in figure 1 was calculated by computer from the cell dimensions given

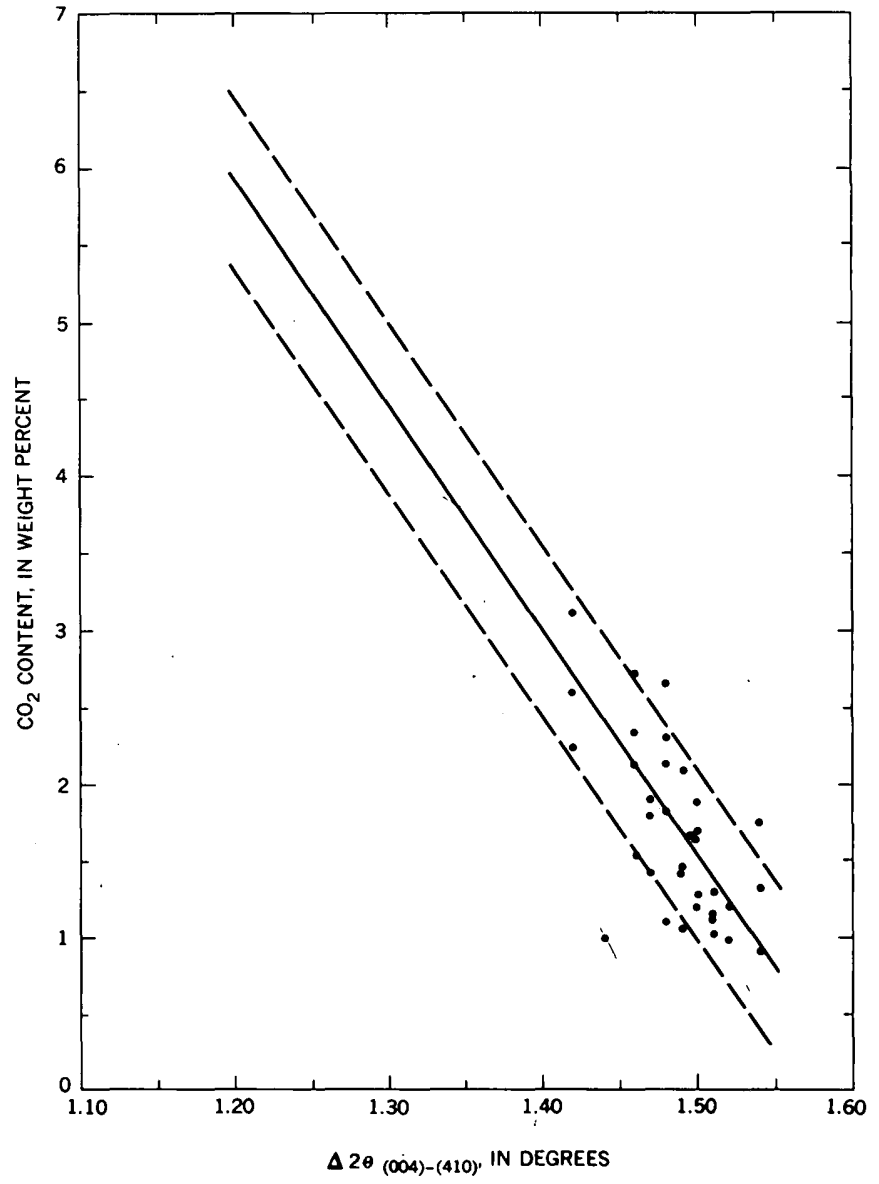

Figure 2.-Plot of $\mathrm{CO}_{2}$ content and $\Delta 2 \theta_{(004)-(410)}$ data of apatite in Phosphoria phosphorites, showing good agreement with least-squares line calculated with the data of McClellan and Lehr (1969) (fig. 1). Equation of line is $y=23.6341-14.7361 x$, where $y=\mathrm{CO}_{3}$ weight percent, and

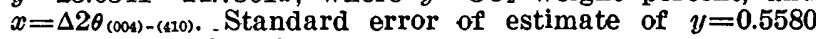
(shown by dashed lines).

by McClellan and Lehr (1969) and was used in place of the $a$ dimension to calculate a new least-squares line. This line, which now shows the relation of $\Delta 2 \theta_{(004)-(410)}$ to $\mathrm{CO}_{2}$ content, is plotted in figure 2 ; the standard error of estimate for $y\left(\mathrm{CO}_{2}\right)$ in this new relationship is 0.5580 .

The points plotted on figure 2 are data of apatites in phosphorites of the Phosphoria Formation that are independently determined and not.part of those of McClellan and Lehr (1969) plotted in figure 1. These new data agree well with those of McClellan and Lehr, which are represented in figure 2 by the least-squares line and standard-error-of-estimate lines, and add additional support to the empirical relation. The new data are from 35 of the 60 phosphorites whose chemical composition was earlier reported by Gulbrandsen (1966), and which do not contain other carbonate-bearing min- 
erals. The reported $\mathrm{CO}_{2}$ content of these samples is adjusted here on the basis of their $\mathrm{CaO}$ content to equivalent pure apatite containing a theoretical 55.56 percent $\mathrm{CaO}$. The adjustment is inexact owing to substituitions for calcium but does satisfy the major correction needed for the variable amounts of impurities present in the rock samples. The $\Delta 2 \theta_{(004) \text {-(410) }}$ measurements were made on chart recordings of $1 / 2^{\circ} \mathrm{rpm}$ traverses through the angular range required to record the peak pair using a Norelco X-ray diffractometer with $\mathrm{Cu}$ radiation.

Another pair of peaks that can be used for the measurement as just described is made up of the two major peaks whose indices are (002) and (300) and that occur with $\mathrm{Cu}$ radiation around $25.9^{\circ}$ and $33.1^{\circ} 2 \theta$, respectively. Because resolution decreases with decreasing $2 \theta$, owing to the nature of the sine function, this pair of peaks is not as good as the (004) and (410) pair for the measurement of $\mathrm{CO}_{2}$ content. The (002) and (300) pair is of value, however, because both peaks are of strong intensity and can be used for $\mathrm{CO}_{2}$ estimates where the (004) and (410) pair of peaks is too weak or too poorly defined to be measured. The least-squares line for this peak-pair relationship is not plotted here, but the equation for the line is

where

$$
y=185.0+25.5740 x
$$

$$
\begin{aligned}
& y=\mathrm{CO}_{2} \text { weight percent and } \\
& x=\Delta 2 \theta^{\circ}{ }_{(300)-(002)} \text {. }
\end{aligned}
$$

The standard error of estimate is 0.5295 . The data used for this calculation are again those of McClellan and Lehr (1969).

Because the 60 phosphorites of Gulbrandsen (1966) make up the best available representation of phosphorites of the Phosphoria Formation, the $\Delta 2 \theta_{(400)-(410)}$ measurements for these samples are listed in table 1 along with the $\mathrm{CO}_{2}$ determinations made from the relationship represented by the least-squares lines of figure 2. The $\mathrm{CO}_{2}$ values shown in parentheses in the table are those adjusted from chemical analyses and used in figure 2. The average $\mathrm{CO}_{2}$ content of the 60 samples, 1.8 weight percent, provides an estimate of the average $\mathrm{CO}_{2}$ content of apatite in the Phosphoria Formation, It is markedly low in comparison with the main mass of values shown in figure 1 for apatite in some of the major phosphate deposits of the world. This indicates a difference in optimum conditions for apatite deposition between those in the Phosphoria and those in other deposits. A possible explanation for this difference is revealed by an examination of the relation of the $\mathrm{CO}_{2}$ content of Phosphoria apatite to regional facies.

\section{RELATION OF $\mathrm{CO}_{2}$ CONTENT OF APATITE TO REGIONAL FACIES}

The Permian rocks of southern Idaho and Wyoming exhibit west-to-east facies changes that McKelvey, Williams, Sheldon, Cressman, Cheney, and Swanson (1959, p. 2-5) consider to represent environmental changes due to an eastward shallowing and warming of sea water. From south-central Idaho to central Wyoming, the dominant lithologies change from chert, mudstone, and phosphorite to carbonate rock. The region of greatest phosphate deposition is in southeastern Idaho near the Wyoming border.

The $\mathrm{CO}_{2}$ content of apatite in 368 samples of phosphorites and phosphatic rocks (generally containing more than 10 percent $\mathrm{P}_{2} \mathrm{O}_{5}$ ) from nine sections located along the west-east facies change has been measured by the $\mathrm{X}$-ray method that utilizes the $\Delta 2 \theta_{(004) \text {-(410) }}$ relation shown in figure 2. These data are summarized in table 2. Figure 3 shows the location and the average $\mathrm{CO}_{2}$ content of apatite in each section.

In the region where the greatest amount of phosphate was deposited, represented by sections 2,3 , and 4 (Trail Canyon, Mabie Canyon, and Montpelier Canyon), the average amount of $\mathrm{CO}_{2}$ in the apatite is 1.7 to 1.8 weight percent, an amount practically the same as the 1.8 weight percent estimated above for the Phosphoria Formation as a whole. Marked changes are evident, however, to both the west and east of this region; the $\mathrm{CO}_{2}$ content is lower to the west and about twice as great to the east in central Wyoming. The greatest contrast is between the westernmost and easternmost sections, and it is emphasized by the range of values in the sections presented in table 2. The Mud Spring section, locality 1 , and the Conant Creek section, locality 9 , do not overlap in their ranges of $\mathrm{CO}_{2}$ content, but both overlap with most in-between sections.

The extremes are especially interesting, because the dominant lithologies or facies of the two regions are also distinctly different. At Mud Spring, locality 1, the principal lithologies are chert, mudstone, and phosphorite. There are no carbonate rocks present, and no carbonate minerals have been detected by $\mathrm{X}$-ray analysis. In contrast, the Conant Creek section, locality 9 , is composed predominantly of carbonate rock, but also contains chert, mudstone, siltstone, sandstone, and phosphorite. Some of the rocks at Conant Creek are glauconitic and some contain appreciable gypsum. Sections 7 and 8 are similar to Conant Creek in their main features. The western sections, intermediate in $\mathrm{CO}_{2}$ content, are also intermediate in the lithologies represented. 


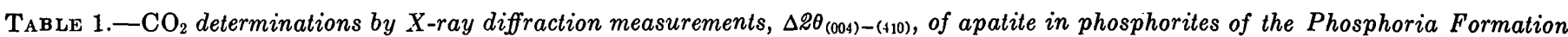
[Samples are those chemically analyzed (Gulbrandsen, 1966, table 1)]

\begin{tabular}{|c|c|c|c|c|c|c|c|}
\hline \multirow{2}{*}{ Measurement No. 1} & \multirow{2}{*}{$\begin{array}{c}\Delta 2 \theta(\cos 4)-(410) \\
(\text { degrees) }\end{array}$} & \multicolumn{2}{|c|}{$\mathrm{CO}_{2}$ (weight percent) } & \multirow{2}{*}{ Measurement No.1 } & \multirow{2}{*}{$\begin{array}{c}\Delta 2 \theta \text { (oos) - (410) } \\
(\text { degrees) }\end{array}$} & \multicolumn{2}{|c|}{$\mathrm{CO}_{2}$ (weight percent) } \\
\hline & & X-ray & Chemical 2 & & & $\mathrm{X}$-ray & Chemical ${ }^{2}$ \\
\hline $\begin{array}{l}12 \\
20\end{array}$ & $\begin{array}{l}\text { 1. } 49 \\
\text { 1. } 46 \\
\text { 1. } 47 \\
\text { 1. } 47 \\
\text { 1. } 51 \\
\text { 1. } 49 \\
\text { 1. } 51 \\
\text { 1. } 50 \\
\text { 1. } 41 \\
\text { 1. } 48 \\
\text { 1. } 46 \\
\text { 1. } 51 \\
\text { 1. } 42 \\
\text { 1. } 48 \\
\text { 1. } 47 \\
\text { 1. } 51 \\
\text { 1. } 46 \\
\text { 1. } 46 \\
\text { 1. } 52 \\
\text { 1. } 48 \\
\text { 1. } 40 \\
\text { 1. } 42 \\
\text { 1. } 44 \\
\text { 1. } 45 \\
1.53 \\
1.50 \\
1.46 \\
1.46 \\
1.51 \\
1.48 \\
1.50\end{array}$ & $\begin{array}{l}\text { 1. } 7 \\
2.1 \\
2.0 \\
2.0 \\
\text { 1. } 4 \\
\text { 1. } \\
\text { 1. } 4 \\
\text { 1. } 5 \\
2.9 \\
\text { 1. } 8 \\
2.1 \\
\text { 1. } 4 \\
2.7 \\
\text { 1. } 8 \\
2.0 \\
\text { 1. } 4 \\
2.1 \\
2.1 \\
\text { 1. } 2 \\
\text { 1. } 8 \\
\text { 3. } 0 \\
2.7 \\
2.4 \\
2.3 \\
1.1 \\
\text { 1. } \\
2.1 \\
2.1 \\
1.4 \\
1.8 \\
1.5\end{array}$ & 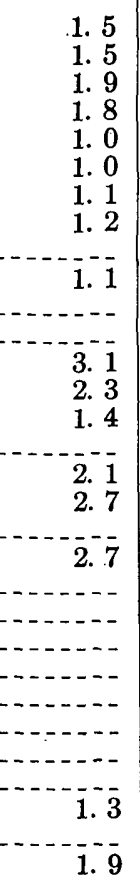 & $\begin{array}{l}3356 \\
356 \\
35 \\
38 \\
39\end{array}$ & $\begin{array}{l}\text { 1. } 50 \\
\text { 1. } 48 \\
\text { 1. } 54 \\
\text { 1. } 54 \\
\text { 1. } 50 \\
\text { 1. } 48 \\
\text { 1. } 47 \\
\text { 1. } 42 \\
\text { 1. } 50 \\
\text { 1. } 46 \\
\text { 1. } 50 \\
\text { 1. } 57 \\
\text { 1. } 52 \\
\text { 1. } 44 \\
\text { 1. } 51 \\
\text { 1. } 42 \\
\text { 1. } 49 \\
\text { 1. } 54 \\
\text { 1. } 52 \\
\text { 1. } 51 \\
\text { 1. } 51 \\
\text { 1. } 53 \\
\text { 1. } 49 \\
\text { 1. } 43 \\
\text { 1. } 45 \\
\text { 1. } 54 \\
\text { 1. } 48 \\
\text { 1. } 48 \\
\text { 1. } 46 \\
-\end{array}$ & 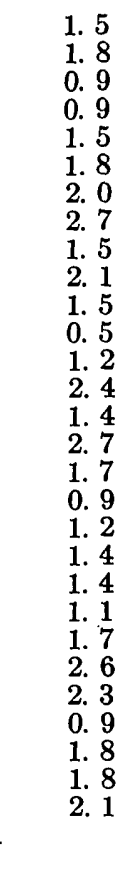 & 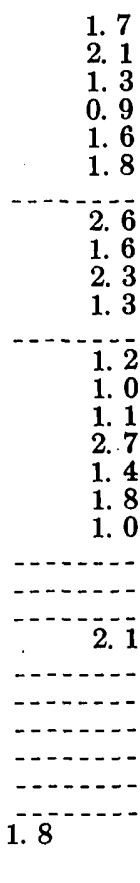 \\
\hline
\end{tabular}

1 Same as analysis number in Gulbrandsen (1966, table 1$)$. ${ }^{2}$ Chemically determined $\mathrm{CO}_{2}$ content adjusted from Gulbrandsen (1966, table 1) to equivalent pure apatite with 55.56 percent CaO for those samples which do not contain calcite or dolomite. Values plotted on figure 2 .

The western region, where carbonate rock is not present, is the region where the $\mathrm{CO}_{2}$ content of apatite is the lowest, and the eastern region, at the other extreme, is where the greatest amount of carbonate rock occurs and the $\mathrm{CO}_{2}$ content of the apatite is highest. If the warming of the sea water from west to east was

TABLE 2.-Average and range of $\mathrm{CO}_{2}$ content of apatite in Permian sections

[Most determinations made by $D$. W. Reeser]

\begin{tabular}{|c|c|c|c|}
\hline \multirow{2}{*}{ Section ${ }^{1}$} & \multirow{2}{*}{$\begin{array}{c}\text { Number of } \\
\text { samples }\end{array}$} & \multicolumn{2}{|c|}{$\mathrm{CO}_{2}$ (weight percent) } \\
\hline & & Average & Range \\
\hline $\begin{array}{l}\text { 1. Mud Spring } \\
\text { 2. Trail Canyon } \\
\text { 3. Mabie Canyon } \\
\text { 4. Montpelier Canyon } \\
\text { 5. Coal Canyon } \\
\text { 6. Lakeridge } \\
\text { 7. Dinwoody Lakes } \\
\text { 8. Bull Lake } \\
\text { 9. Conant Creek }\end{array}$ & $\begin{array}{r}24 \\
87 \\
84 \\
102 \\
44 \\
11 \\
6 \\
5 \\
5\end{array}$ & $\begin{array}{l}\text { 1. } 2 \\
\text { 1. } 7 \\
\text { 1. } 7 \\
\text { 1. } 8 \\
\text { 1. } 7 \\
\text { 2. } 0 \\
\text { 3. } 2 \\
\text { 3. } 3 \\
\text { 3. } 4\end{array}$ & $\begin{array}{l}0.9-1.8 \\
0.8-2.6 \\
0.6-2.3 \\
\text { 1. } 1-2.6 \\
0.8-3.0 \\
0.9-3.6 \\
\text { 2. } 7-3.9 \\
2.6-3.9 \\
\text { 2. } 6-4.2\end{array}$ \\
\hline
\end{tabular}

1 Stratigraphic descriptions of the sections and some analytical data have been reported as follows:

1. Smart, Waring, Cheney, and Sheldon (1954, p. 20-21).

2, 4. McKelvey, Armstrong, Gulbrandesn, and Campbeli (1953, p. 21-31, 50-58).
3. McKelvey, Davidson, O'Malley, and Smith (1953, p. 14-24).

$6,7,8,9$. Sheldon (1963, p. 241-245, 221-224, 229-234, 258-260).

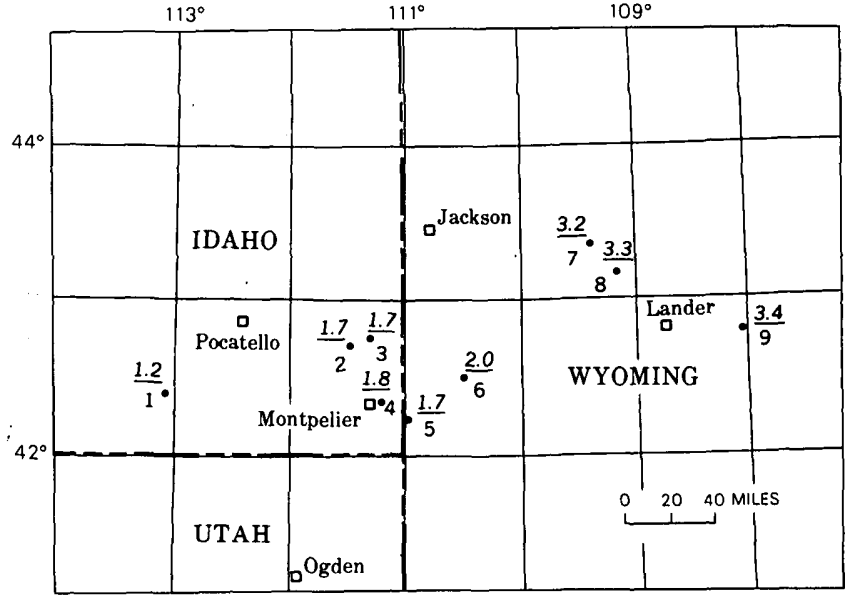

Figure 3.-Location of Permian sections (table 2) in Idaho and Wyoming. Underlined numbers are average $\mathrm{CO}_{3}$ content, in weight percent, of apatite in rocks of these sections.

a major factor in producing these differences, then the $\mathrm{CO}_{2}$ content of apatite may be qualitatively proportional to temperature. This tentative interpretation needs additional investigation and substantiation before it can be accepted. It does represent a beginning, however, in efforts toward understanding the signifi- 
cance of the variable composition of marine apatite and the differences among environments in which the phosphate deposits of different ages and in different parts of the world were formed.

\section{REFERENCES}

Altschuler, Z. S., Cisney, E. A., and Barlow, I. S., 1952, X-ray evidence of the nature of carbonate-apatite [abs.]: Geol. Soc. America Bull., v. 63, no. 12, pt. 2, p. 1230-1231.

Gulbrindsen, R. A., 1960, Petrology of the Meade Peak phosphatic shale member of the Phosphoria Formation at Coal Canyon, Wyoming: U.S. Geol. Survey Bull. 1111-C, p. 71146.

1966, Chemical composition of phosphorites of the Phosphoria Formation: Geochim. et Cosmochim. Acta, v. 30, p. 769-778.

Lehr, I. R., McClellan, G. H., Smith, J. P., and Frazier, A. W., 1968, Charncterization of apatites in commercial phosphate rocks, in Phosphates naturals-Phosphates dans l'agriculture: Colloque international sur les phosphates minéraux solides, Toulouse 16-20 Mai 1967, v. 2, p. 29-44.

McClellan, G. H., and Lehr, J. R., 1969, Crystal-chemical investigation of natural apatites: Am. Mineralogist, $\nabla .54$, nos. 9-10, p. 1374-1391.
McKelvey, V. E., Armstrong, F. C., Gulbrandsen, R. A., and Campbell, R. M., 1953, Stratigraphic sections of the Phosphoria formation in Idaho, 1947-48: U.S. Geol. Survey Circ. 301 , pt. 2, $58 \mathrm{p}$.

McKelvey, V. E., Davidson, D. F., O'Malley, F. W., and Smith, L. E., 1953, Stratigraphic sections of the Phosphoria formation in Idaho, 1947-48: U.S. Geol. Survey Circ. 208, pt. 1, $49 \mathrm{p}$.

McKelvey, V. E., Williams, J. S., Sheldon, R. P., Cressman, E. R., Cheney, T. M., and Swanson, R. W., 1959, The Phosphoria, Park City, and Shedhorn formations in the western phosphate field: U.S. Geol. Survey Prof. Paper 313-A, p. 1-47.

Sheldon, R. P., 1963, Physical stratigraphy and mineral resources of Permian rocks in western Wyoming: U.S. Geol. Survey Prof. Paper 313-B, p. 49-273.

Silverman, S. R., Fuyat, R. K., and Weiser, J. D., 1952, Quantitative determination of calcite associated with carbonatebearing apatites: Am. Mineralogist, v. 37, nos. 3-4, p. 211222.

Smart, R. A., Waring, R. G., Cheney, T. M., and Sheldon, R. P., 1954, Stratigraphic sections of the Phosphoria formation in Idaho, 1950-51: U.S. Geol. Survey Circ. 327, 22 p.

Smith, J. P., and Lehr, J. R., 1966, An X-ray investigation of carbonate apatites: Jour. Agr. and Food Chemistry, v. 14, no. 4 , p. 342-349. 


\title{
EXTENSIVE ZEOLITIZATION ASSOCIATED WITH HOT SPRINGS IN CENTRAL COLORADO
}

\author{
By WILLIAM N. SHARP, Denver, Colo.
}

\begin{abstract}
Extensive zeolitization that accompanied formation of laumontite-leonhardite in shattered quartz monzonite at the base of Mount Princeton in central Colorado is attributed to hot silica- and calcium-bearing alkaline waters reacting with the country rock at depth. The shattered and altered rocks and active thermal springs are related to faults that are part of the upper Arkansas Valley structure system. Apparent zoning of mineral assemblages around the thermal centers seems similar to that in other thermal areas, and is significant in terms of depth of formation, temperature, and pressure.
\end{abstract}

Two masses of shattered quartz monzonite are exposed as conspicuous white, chalky bluffs along Chalk and Cottonwood Creeks at the base of Mount Princeton in Chaffee County, Colo. These bluffs are outstanding mostly because of their color, which is largely a result of abundant leonhardite, a calcium zeolite. Hot springs issue from the base of the cliffs in both creek valleys; the Mount Princeton Hot Springs occur at Chalk Cliffs on Chalk Creek, and the smaller Cottonwood Hot Spring occurs along Cottonwood Creek.

The purpose of this paper is to briefly describe these occurrences of zeolitized rocks, and to give some suggestions as to their possible geologic significance.

Chalk Cliffs at Mount Princeton Hot Springs has been a landmark in central Colorado for many years. The white, rubbly, steep bluffs rise several hundred feet above the hot springs along Chalk Creek, and form the north wall at the entrance of Chalk Creek canyon, which is along the west side of the Arkansas Valley (fig. 1). Mount Princeton, with an altitude of 14,197 feet, towers over these cliffs, which have been well known from the time of legendary Indian visits before white settlement, through the mining and railroad operations in 1880's, the grand hotel-spas in 1920 's, to the present era of modern swimming pools and commercial greenhouses. Indians allegedly used caves formed in the cliffs as steam baths and healing sites. This bit of folklore does not seem to be borne out by the nature of the caves, which are not spring sites; nevertheless, the place has been an attraction for many years. Hortense Hot Spring, one of the Mount Princeton Hot Springs group, is the hottest spring $\left(83^{\circ} \mathrm{C}\right)$ in the State. Its output is used largely as a heat sourse in greenhouses and mountain homes.

Cottonwood Hot Spring, on Cottonwood Creek, a. few miles to the northwest of Chalk Cliffs near the mouth of the narrow creek valley, marks a smaller thermal area than that of the Mount Princeton Hot Springs, but is similarly situated at the edge of a large zeolitized mass exposed for several miles along Cottonwood Creek. The cliff walls of the valley are considerably less spectacular than Chalk Cliffs, and are generally less zeolitized.

\section{GEOLOGIC SETTING}

The regional geology is generalized in figure 1. The structural framework of the upper Arkansas Valley is only partly understood. The elements shown were compiled from field studies and photographic interpretation by the author, from recent mapping by Van Alstine (1966) and Brock and Barker (1966), and from unpublished gravity work of J. E. Case, all of the U.S. Geological Survey.

The upper Arkansas Valley north of Salida is a narrow, north-trending, downdropped trough bounded by a complex of mostly normal, steeply dipping faults. This structural valley is accentuated by a rugged mountain system on the west and rugged but less conspicuous highlands on the east. The east side of the trough is marked generally by a single, narrow fault zone. The boundary faults on the west side appear to be more complex, and the total downward displacement is accumulated along several faults both paralleling and transecting the valley.

The sediments in the Arkansas Valley are river deposits of the Dry Union Formation of Miocene and 


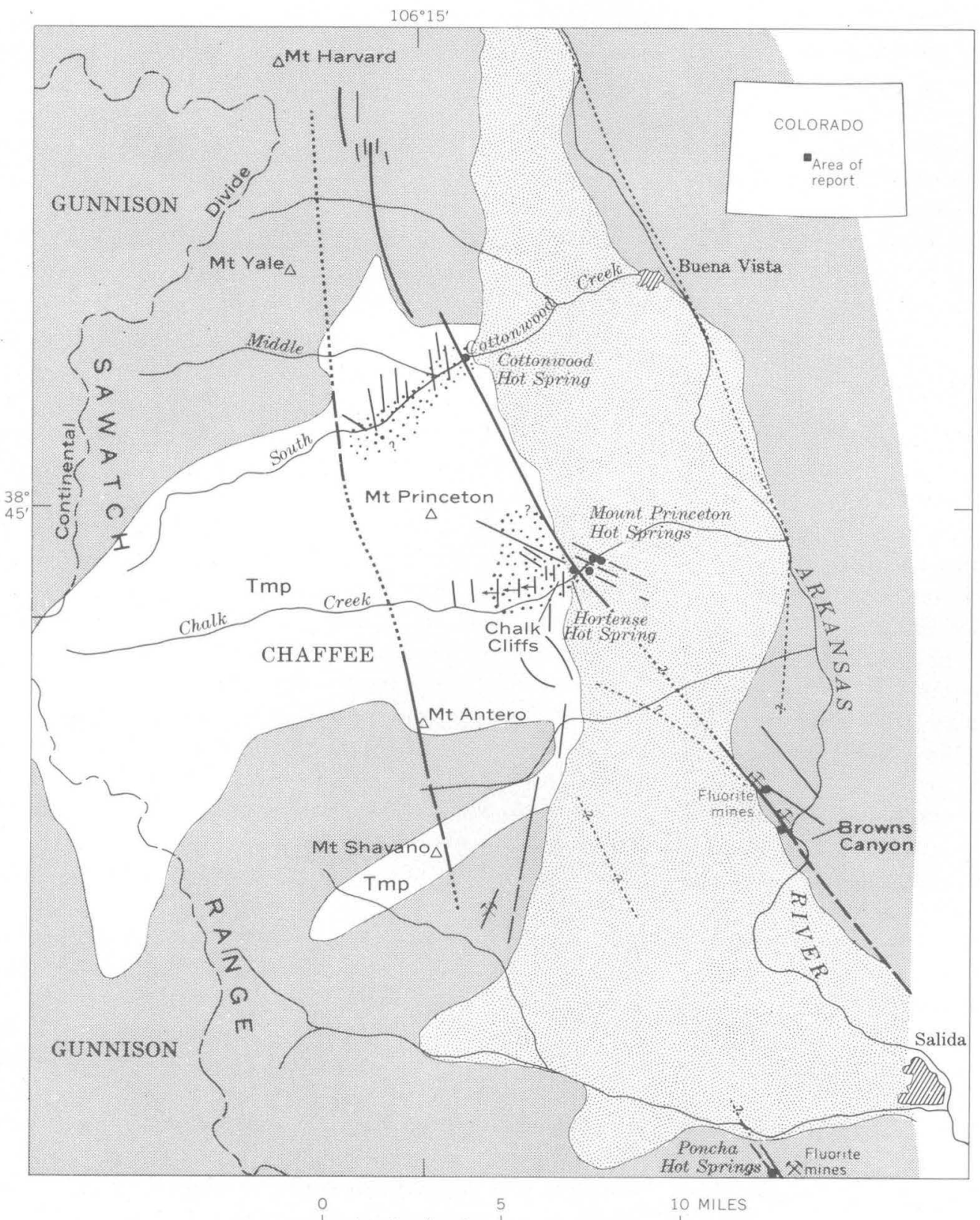

EXPLANATION

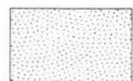

Valley fill materials

Holocene terrace gravels and Pleistocene glacial outwash averlying Pliocene and Miocene Dry Union Formation. Generally marks extent of Arkansas Valley

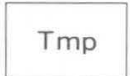

Tertiary Mount Princeton Quartz Monzonite

Generalized outline shown

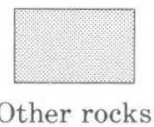

Tertiary quartz monzonite and granite, Paleozoic sedimentary rocks, and Precambrian gneisses

Contact, approximately located

Faults

Dashed where not clearly evident; dotted where covered. Accentuated along boundary of "wedge"

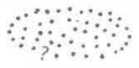

Zone of zeolitized shattered quartz monzonite

Queried where extent not known

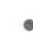

Spring

父

Mine

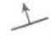

Strike and dip of shear plane

Figure 1.-Part of the upper Arkansas Valley, showing structural features, hot springs, and zeolitized zones.

Pliocene age that are overlain by glacial outwash and moraines of Quaternary age (Tweto, 1961). The trough, therefore, probably formed largely in midTertiary time.

The mountains east of the Arkansas Valley are composed predominantly of Precambrian granitic gneisses, overlain in places by upper Tertiary flows and pyroclastic rocks of rhyolitic to andesitic composition. The Sawatch Range west of the Arkansas Valley consists chiefly of Precambrian batholiths of quartz diorite and granodiorite, and the lower Tertiary batholith of Mount Princeton Quartz Monzonite.
A structural element of special significance to this study is the northwest-trending fault zone that crosses the valley diagonally from near Salida to the Mount Princeton area, where it merges with faults that form the west boundary of the valley northward to the Mount Harvard area (fig. 1). The southern part of this fault zone contains the commercial fluorite deposits at Browns Canyon and also gives rise to warm springs containing more than normal amounts of fluorine (Russell, 1945). Farther to the northwest, in the same fault zone on the west side of the valley, water of the Mount Princeton and Cottonwood Hot 
Springs also contains anomalously large amounts of fluorine. The fault zone, marked by these two hot spring areas, appears to be the east edge of a northpointing wedge of greatly sheared and shattered rocks, mostly Mount Princeton Quartz Monzonite. The wedge is bounded on the west by a less clearly defined shear zone extending from Mount Shavano on the south to Mount Yale and possibly Mount Harvard on the north at a point of the wedge. The shattered rocks of this faulted wedge have been zeolitized in the vicinity of Mount Princeton.

\section{ZEOLITIZED ZONES AND STRUCTURAL CONTROL}

The large bodies of zeolitized quartz monzonite are exposed best in the canyons of Chalk and Cottonwood Creeks that transect the faultbound wedge (fig. 1).

Chalk Cliffs is the most conspicuous outcrop of zeolitized rocks, and leonhardite is abundant in these rocks for a distance of more than a mile along the cliffs. Chalky white leonhardite fills cracks and coats rock fragments in the highly shattered and sheared quartz monzonite to such degree that it imparts a bright white hue to the normally gray host rock. Besides being noticeably white, the zeolitized cliffs are extremely rugged and contain many steep blind canyons. Several shallow, wide-mouth caverns dot the walls of the cliffs and terminate some of the short steep canyons. These caverns characteristically have flat backs and steeply inclined floors and appear to have formed mostly by spalling of fragmental material from beneath flat faults. There is no evidence that these features are solution cavities or sites of recent hot springs.

Chalk Cliffs seems to represent in part a locus of intense alteration and metasomatism. Hortense Hot Spring of the Mount Princeton Hot Springs group near the east end of the cliffs is surrounded by several hundred feet of greenish-gray propylitized fault gouge and brecciated quartz monzonite-a zone that grades outward abruptly into the zeolitized rocks of the cliffs. This zonation probably is significant in accounting for the zeolite bodies. The propylitized material, which is marbled with greenish-gray and white veins, consists largely of a mixture of chlorite, quartz, illite, and epidote with minor amounts of calcite and fluorite. White vein material is mostly calcite with subordinate amounts of quartz and fluorite.

Much of the character of Chalk Cliffs just described and the extent of the cliffs seem due to the intersection here of at least three faults or fault zones. The principal fault, which passes through the east end of the cliffs, extends northwest beyond the Mount Princeton Hot Springs and through the Cottonwood Hot Spring site, and feathers out near Mount Harvard. Joining this fault at Chalk Cliffs is a rather wide zone of faults that extends south to southwest from Mount Princeton Hot Springs along the west edge of the Arkansas Valley. North-striking, west-dipping shear planes in this fault zone are conspicuous in the cliffs west of the springs.

An additional shear zone, oriented N. $60^{\circ}$ to $70^{\circ} \mathrm{W}$., transects the major fault associated with the hot springs at Mount Princeton. This zone is the least extensive and is not traceable outside the area of known zeolitized rocks and hot springs; however, this group of shear planes appears to control the distribution of hot springs for about three-fourths of a mile along the creek at the southeast base of Mount Princeton.

Zeolitized rocks similar to Chalk Cliffs extend along Cottonwood Creek, west of Buena Vista, from the easternmost exposures of crystalline rocks at the mountain front near the hot spring, almost continuously for about 4 miles westward in the valley of South Cottonwood Creek. The zone is near the north end of the structural wedge and extends almost the entire width of the wedge. The zone also is marked by very rugged cliffs particularly along the northwest side of the valley; but, except for the strongly zeolitized fault zone directly above Cottonwood Hot Spring, these cliffs are not as conspicuously mineralized as Chalk Cliffs.

In the zeolitized crystalline rocks along Cottonwood Creek, faults and zones of shearing trend predominantly north to northwest. The prevailing direction of the numerous shear planes near the hot springs is $\mathrm{N}$. $30^{\circ} \mathrm{W}$. to $\mathrm{N} .10^{\circ} \mathrm{W}$. Farther west along the valley, the south-facing slopes of the mountain mass between the South Cottonwood and Middle Cottonwood Creeks are extremely broken and eroded to a rugged topography. Much of this ruggedness is due to several north-trending faults transected by fractures oriented N. $40^{\circ}$ W. to N. $80^{\circ} \mathrm{E}$. White fracture fillings of leonhardite and calcite are obvious in the cliffs for a distance of several hundred feet above the valley. Probably some of these structural features extend southward across South Cottonwood Creek and through the Mount Princeton mass to connect with structures in the Chalk Creek drainage.

Good exposures of fault zones and zeolitized rock also can be seen along a steep vehicle track on the east face of Mount Princeton, about a mile north of Chalk Cliffs. North-trending fault planes and zones in shattered quartz monzonite are filled with leonhardite to such a degree that it seems reasonable to suspect that sparsely zeolitized rocks extend much farther north- 
ward from Chalk Cliffs along the mountain front than indicated on figure 1 , and could be virtually continuous with the zeolitized cliffs in the eastern part of the Cottonwood Creek canyon.

The zones of zeolitization along both Cottonwood Creek and Chalk Creek appear to extend 1,000-2,000 feet above the valley floor, but the exact nature of the rocks high on the valley walls and on Mount Princeton has not been determined.

The Mount Princeton Quartz Monzonite involved in this extensive crushing, thermal alteration, and zeolitization is gray, medium-grained, biotitic quartz monzonite. Locally the rock is porphyritic; phenocrysts of pink $\mathrm{K}$-feldspar are conspicuous in an even-textured, medium-grained groundmass containing much lightgray plagioclase. The quartz monzonite, in all size fragments down to sand-sized material in most of the faults and shattered rocks, is only slightly altered. Biotite is generally converted to chlorite, but feldspars are apparently little changed. Both plagioclase and $\mathrm{K}$ feldspar are at most only clouded; albitization which commonly accompanies formation of Ca-zeolites is not evident.

\section{ZEOLITE}

Leonhardite is virtually the only zeolite found in the area, and it, ranges in appearance from white and yellowish-white pulverulent coatings on weathered surfaces to white and pink, sparkling, matted crystals in newly broken rocks. The material that fills fractures encloses rock chips and sand-sized grains of most minerals of the host rock. The individual leonhardite crystals rarely are more than $1 \mathrm{~mm}$ long and $0.2-0.3 \mathrm{~mm}$ across. The indices of refraction are about $1.50 \alpha$ and $1.51 \gamma$, and measurements of extinction angles in the prism zone range from about $40^{\circ}$ to $65^{\circ}$ with a noticeable change in character from length fast to length slow at about $44^{\circ}$. This change is characteristic of leonhardite and denotes orientation from 010 to 110 position in the prism fragments (Coombs, 1952,p. 812).

$\mathbf{X}$-ray diffraction patterns of air-dried material from throughout the zeolitized zones match closely the data for leonhardite published by Coombs (1952) and Lapham (1963). Some minor shifts in reflections are general from sample to sample and a conspicuous reflection is found at 9.5-9.4 A. This reflection was not reported by Coombs, but it was noted by Lapham (1963).

Leonhardite forms by a slight dehydration of laumontite $\left(\mathrm{Cr}_{0.5} \mathrm{Al} \mathrm{Si}_{2} \mathrm{O}_{0} \cdot 2 \mathrm{H}_{2} \mathrm{O}\right)$, and the dehydration process is readily reversible (Coombs, 1952). It seems reasonable to presume that leonhardite in the exposures in this area grades to dominantly laumontite below the surface. In leonhardite from Chalk Cliffs the potassium content is anomalously high (table 1 ).
TABLE 1.-Semiquantitative spectrographic analysis of leonhardite from Chalk Cliffs

[Analyst, Barbara Tobin. M, major constituent, $>10$ percent]

\begin{tabular}{|c|c|c|}
\hline $\begin{array}{l}\mathrm{Si} \\
\mathrm{Al} \\
\mathrm{Fe} \\
\mathrm{Mg} \\
\mathrm{Ca} \\
\mathrm{Na} \\
\mathrm{K} \\
\mathrm{K} \\
\mathrm{Ti} \\
\mathrm{Mn} \\
\mathrm{Ba} \\
\mathrm{Ba}\end{array}$ & 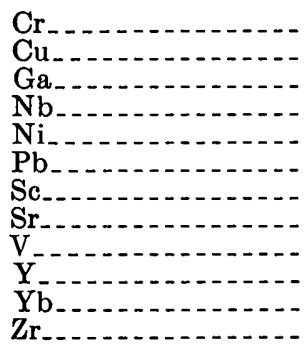 & $\begin{array}{l}0.0007 \\
.0015 \\
.005 \\
.002 \\
.002 \\
.007 \\
.0007 \\
.1 \\
.003 \\
.001 \\
.0001 \\
.002\end{array}$ \\
\hline
\end{tabular}

Results are reported in percent to the nearest number in the series $1,0.7,0.5,0.3,0.2,0.15$ and 0.1 , and so forth, which represent approximate midpoints of group data on a geometric scale. The assigned group for semiquantitative results will include the quantitative value about 30 percent of the time.

\section{HOT SPRINGS}

New analyses of water from Hortense Hot Spring on Chalk Creek and the Cottonwood Hot Spring on Cottonwood Creek are given in table 2, along with three other analyses of water in the region. A comparison of these analyses with the only previously published analyses of this water (George and others, 1920, p. 205, $223,264,373-376)$ indicates that the composition of the hot spring has not changed significantly in about 50 years. The water at Hortense and Cottonwood Hot Springs is alkaline $(\mathrm{pH} 8.7-8.9)$ and contains relatively little dissolved material compared to the water of most other hot springs. Sodium, silica, bicarbonate, and sulfate are the principal components; fluorine content of $13 \mathrm{ppm}$ is uncommonly large. The fluorine concentration in this water is much like that in Poncha Hot Springs and in springs at Browns Canyon, both of which are at large fluorite deposits (table 2). Surprisingly, fluorite is sparse at Chalk Cliffs and has not been found along Cottonwood Creek.

Solid residues from Hortense and Cottonwood Hot Springs water, as shown by spectrographic analyses, contain unusual amounts of molybdenum and gallium (table 2). Molybdenum content of the water is $100 \mathrm{ppb}$ and $50 \mathrm{ppb}$, respectively, determined by a selective analytical technique.

Small amounts of white punky sublimate salt accumulate on rocks and on transfer pipes at the springs. This material is a mixture of opal and a salt containing fluorine that gives a low-amplitude, $\mathrm{X}$-ray powder pattern similar to that of the multiple salt $\mathrm{Na}_{2} \mathrm{SO}_{4} \cdot \mathrm{NaF}$ and the mineral schairerite.

A white mixture of calcite, opal, and phillipsite coats some unconsolidated boulders in recently formed rubble and was deposited from hot spring water flowing over and through surface debris. 
TABLE 2.-Chemical analyses of water from Chalk Creek and hot springs at Mount Princeton, Cottonwood Creek, Poncha Hot Springs, and Browns Canyon, Chaffee County, Colo., and spectrographic analyses of residues

IChemical analyses 1-3, by M. J. Fishman and C. G. Angelo; 4, by H. C. Whitehead; and 5 , by C. S. Howard. Spectrographic analyses, by P. R. Barnett. Leaders (..) indicate not determined]

\begin{tabular}{ccccc}
$\begin{array}{c}1 \\
\text { Hortense } \\
\text { Hot Spring, } \\
\text { Mount, } \\
\text { Princeton }\end{array}$ & $\begin{array}{c}\text { Cottonwood } \\
\text { Hot Spring, } \\
\text { Cottonwood } \\
\text { Creek }\end{array}$ & $\begin{array}{c}\text { Chalk } \\
\text { Creek, } \\
\text { Miount } \\
\text { Princeton }\end{array}$ & $\begin{array}{c}\text { Poncha } \\
\text { Hot } \\
\text { Springs, } \\
\text { main } \\
\text { springs }\end{array}$ & $\begin{array}{c}\text { Spring at } \\
\text { U.S. } \\
\text { Fluorspar } \\
\text { mine, } \\
\text { Browns } \\
\text { Canyon }\end{array}$ \\
\hline
\end{tabular}

\begin{tabular}{ccccccc}
\hline $\begin{array}{c}\text { Temperature, }{ }^{\circ} \mathrm{F} \\
\left({ }^{\circ} \mathrm{C}\right) \ldots \ldots \ldots \ldots \ldots\end{array}$ & $183(83.8)$ & $126(52.2)$ & $52(11)$ & $158(70)$ & $67(19.4)$ \\
\hline pH................. & 8.9 & 8.9 & 7.5 & 7.6 & $\ldots \ldots \ldots \ldots \ldots$ \\
\hline
\end{tabular}

\begin{tabular}{|c|c|c|c|c|c|}
\hline \multicolumn{6}{|c|}{ Chemical analyses (parts per million) } \\
\hline $\mathrm{SiO}_{2} \ldots$ & 72 & 52.08 & 7. 8 & 84 & 38 \\
\hline $\mathbf{F e}$ & .40 & $0^{.00}$ & 0.05 & $\begin{array}{l}.53 \\
.46\end{array}$ & 04 \\
\hline - & 0 & 0 & .02 & 10 & \\
\hline ...... & 3.4 & 6. 3 & 14 & 17 & 7. 9 \\
\hline $\mathrm{Mg} \ldots$ & 0 & .3 & 1 & .2 & 1. 8 \\
\hline $\mathrm{Na}_{\ldots} \ldots \ldots \ldots$ & 94 & 98 & 2 & $190^{\circ}$ & 151 \\
\hline $\mathbf{K}$ & 2. 9 & 2.5 & 8 & 6. 6 & 4. 8 \\
\hline $\mathrm{HCO}_{3-\ldots} \ldots$ & 44 & $5 \overline{5}$ & 33 & 210 & 127 \\
\hline $\mathrm{CO}_{3-\ldots}$ & 19 & 9 & 0 & 0 & 4.9 \\
\hline $\mathrm{SO}_{4-\ldots \ldots} \ldots \ldots$ & 101 & 98 & 19 & 200 & 142 \\
\hline $\mathrm{Cl}_{\ldots} \ldots$ & 9. 5 & 26 & .4 & 54 & 53 \\
\hline $\mathbf{F}_{-}$ & 13. & 13 & 4 & 11 & 13 \\
\hline$-\ldots$ & 2 & .4 & 4 & 0 & 0 \\
\hline & 0 . & & 0 & .02 & \\
\hline
\end{tabular}

Dissolved solids:

Calcu-

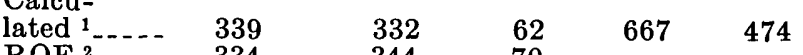

ROE ${ }^{2}-\ldots-334 \quad 344 \quad 70 \quad \ldots+\ldots$

\begin{tabular}{|c|c|c|c|c|}
\hline \multicolumn{4}{|c|}{ Spectrographic analyses (values in $\mu \mathrm{g} / \mathrm{l})^{3}$} & \\
\hline 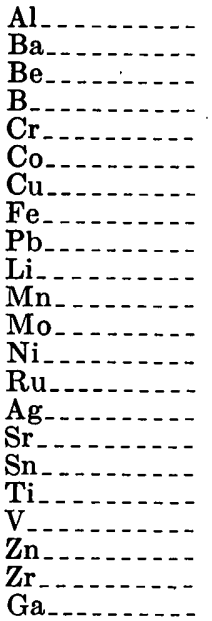 & \begin{tabular}{c}
87. \\
10 \\
$<1$ \\
33 \\
$<5$ \\
$<5$ \\
\multicolumn{1}{c}{${ }^{\circ} .4$} \\
7 \\
$<2$ \\
70 \\
$<2$ \\
56 \\
$<2$ \\
10 \\
$<.3$ \\
250 \\
12 \\
$<2$ \\
$<2$ \\
$<130$ \\
$<5$ \\
$<$ \\
$(4)$
\end{tabular} & $\begin{array}{r}25 \\
10 \\
<1 \\
36 \\
<5 \\
<5 \\
11 \\
<2 \\
<0 \\
<2 \\
30 \\
<2 \\
9 \\
<. \\
220 \\
11 \\
<2 \\
<2 \\
<130 \\
<5 \\
(4)\end{array}$ & $\begin{array}{c}19 \\
11 \\
<.2 \\
12 \\
<.7 \\
<.7 \\
23 \\
23 \\
3.4 \\
33 \\
2.4 \\
.6 \\
.2 \\
<.04 \\
32 \\
<.8 \\
16 \\
<.4 \\
240 \\
<.7 \\
-\ldots . .-\end{array}$ & \\
\hline
\end{tabular}

1 Calculated using procedure described by Rainwater and Thatcher (1960).

2 Residues on evaporation at $180^{\circ} \mathrm{C}$.

Analyses of residues on evaporation at $180^{\circ} \mathrm{C}$

Semiquantitative estimate, in the range of $1-9 \mathrm{mg} / \mathrm{l}$.

\section{ZEOLITE GENESIS AND POSSIBLE SIGNIFICANCE}

Laumontite, the parent mineral of leonhardite, is a high-density, silica-rich, less hydrated zeolite that is associated with environments of greater depth and higher temperatures than most zeolites. It is commonly the product of alteration of calcic plagioclase. This alteration seems to take place readily in tuff, sandstone, and graywacke under conditions of low-grade metamorphism in the presence of abundant saline water, or in zones of crushed rock supplied in some manner with excess silica and calcium. For example, Coombs, Ellis, Fyfe, and Taylor (1959) described laumontite in aquifers in Triassic sedimentary rocks of Taringatura, New Zealand, that appears to be the degradation product of calcic plagioclase. Hoare, Condon, and Patton (1964) described similar formation of zeolites in western Alaska. At Otama, New Zealand, calcium and aluminum, released from plagioclase during albitization, may contribute to the formation of laumontite within joints and crush zones; however, Coombs, Ellis, Fyfe, and Taylor (1959) stated that the evidence is good that this mineral can form from argillic and calcitic cements.

The depth and temperature of the environment in which laumontite occurs have been recorded at two major thermal areas of the world. At Wairakei, New Zealand, laumontite was found at 150-275 meters (490-900 ft) depth where temperatures range from $195^{\circ} \mathrm{C}$ to $220^{\circ} \mathrm{C}$ (Coombs and others, 1959). More recently laumontite-bearing material was penetrated in two deep geothermal drill holes in Iceland. Sigvaldason (1963) reported that laumontite was first found at 160 meters $(525 \mathrm{ft})$ depth in drill holes in thermal areas at Reykjavik and was the most common zeolite to depths of at least 2,000 meters $(6,500 \mathrm{ft})$. Temperatures were as much as about $145^{\circ} \mathrm{C}$. At Hveragerdi, laumontite occurred at depths below 225 meters and was dominant from 250 meters $(820 \mathrm{ft}$ ) to more than 600 meters $(1,970 \mathrm{ft})$. Associated minerals are chlorite, albite, calcite, and epidote.

Coombs' work involving the genesis of zeolites led to the proposal of a zeolite mineral facies-extending Turner's earlier zeolite facies of metamorphism (Turner, in Fyfe and others, 1958)-as intermediate between diagenesis and low-grade regional metamorphism (Coombs and others, 1959; Coombs, 1960). Briefly, the zeolite facies includes mineral assemblages that range in composition from a low-grade heulanditeanalcime-quartz assemblage to a higher grade laumontite-albite-quartz assemblage to a prehnite-pumpellyite stage. In a general sense, a zonation of these assemblages might be present in any thermal environment where proper $\mathrm{pH}$ conditions and chemical activities and components exist.

Zen (1961) suggested, and Hay (1966) later restated, that formation of a zeolite-bearing assemblage or a clay-bearing assemblage during hydrothermal al- 
teration probably depends greatly on the relative chemical activities of the $\mathrm{H}_{2} \mathrm{O}$ and $\mathrm{CO}_{2}$ in the system. At high activities of $\mathrm{H}_{2} \mathrm{O}$ relative to $\mathrm{CO}_{2}$, and other factors being favorable, the zeolite facies forms. These conditions generally prevail in thermal areas where hot water has a $\mathrm{pH}$ of 8 to 9 , a feature pointed out by White and Sigvaldason (1963); $\mathrm{CO}_{2}$ is maintained as bicarbonate, and its activity relative to $\mathrm{H}_{2} \mathrm{O}$ is kept low. Reversing the relative values of the chemical potentials favors formation of calcite and the claybearing (kaolinite-pyrophyllite) assemblage.

White and Sigvaldason (1963) emphasized also the significance of epidote in mineral assemblages in hotspring systems as an indication of conditions of formation. In relating the depth and corresponding temperature to formation of epidote in hot-spring systems, they concluded that if epidote occurs as a hydrothermal product in exposed rocks, erosion of at least 1,300 feet $(390 \mathrm{~m})$ of cover is indicated.

In this framework, it seems likely, therefore, that the less-hydrated zeolite near Mount Princeton was formed, while still deeply buried, by the metasomatic action of hot mineral water on fine-grained debris in the large masses of shattered quartz monzonite. The rock grains and flour, between fragments and in shear zones, may have supplied some of the materials for laumontite, but the generally unaltered condition of the rock fragments strongly suggests that most materials were supplied by ascending hot water. The abundant calcium in the zeolitized zones, in both leonhardite and calcite, seems to be the principal material added to the system, either from a magmatic source or from deeper and more extensively altered and leached quartz monzonite. The lack of albite (or adularia) associated with the zeolite zones argues against a simple in-place leaching process for the supply of components. Fry (1966, p. 105) stated more strongly, after Turner (in Fyfe and others, 1958), that interdependent reactions like this are sensible in zones of zeolite faciescomponents released in a reaction at one place supply materials for minerals like laumontite at another.

At Mount Princeton the temperature during zeolitization was without doubt in excess of the present temperature of issuing water (maximum $83^{\circ} \mathrm{C}$ ). Maximum temperature would depend in part on the depth of zeolitization, which can only be estimated. If late middle Tertiary time was the time of zeolitization, the depth might be roughly the distance between the creek level and the top of Mount Princeton, approximately $1,800 \mathrm{~m}(5,900 \mathrm{ft})$, which is the amount of erosion that has occurred since uplift in late middle Tertiary time. If liberal latitude is permitted in the estimate, the depth of formation probably was at least several hundred meters. These environmental conditions easily fit within the ranges of temperatures $\left(145^{\circ} \mathrm{C}\right.$ to $220^{\circ} \mathrm{C}$ ) and depth $(150 \mathrm{~m}$ to $2,000 \mathrm{~m})$ for formation of laumontite existing at Wairakei, New Zealand, and in Iceland.

At Mount Princeton a "laumontite (leonhardite) stage" and a highly propylitized aureole (chloriteepidote-clay assemblage) around Hortense Hot Spring are known. Perhaps other zeolite mineral assemblages are not present, but the known association, viewed in the framework of the facies concept, invites speculation that a more complex sequence of mineralogical changes extends to deeper levels. Additional study of these zeolitized zones could provide more details concerning the geologic development of the Chalk Cliffs and Cottonwood Creek zeolitized zones themselves and their possible downward change into other mineral assemblages, and also expand the understanding of the geologic evolution of the Arkansas Valley.

\section{REFERENCES}

Brock, M. R., and Barker, Fred, 1966, Geologic map of the Mount Harvard quadrangle, Gunnison and Chaffee Counties, Colorado: U.S. Geol. Survey open-file report.

Coombs, D. S., 1952, Cell size, optical properties and chemical composition of laumontite and leonhardite, with a note on regional occurrences in New Zealand: Am. Mineralogist, v. 37, nos. 9-10, p. 812-830.

1960, Lower grade mineral facies in New Zealand: Internat. Geol. Cong., 21st, Copenhagen 1960, Rept., pt. 13, p. 339-351.

Coombs, D. S., Ellis, A. J., Fyfe, W. S., and Taylor, A. M., 1959, The zeolite facies with comments on the interpretation of hydrothermal syntheses: Geochim. et Cosmochim. Acta, v. 17, nos. 1-2, p. 53-107.

Fyfe, W. S., Turner, F. J., and Verhoogen, John, 1958, Metamorphic reactions and metamorphic facies: Geol. Soc. America Mem. 73, 259 p.

George, R. D., Curtis, H. A., Lester, O. C., Cook, J. K., Yeo, J. B., and others, 1920, Mineral waters of Colorado: Colorado Geol. Survey Bull, 11, 474 p.

Hay, R. L., 1966, Zeolites and zeolitic reactions in sedimentary rocks: Geol. Soc. America Spec. Paper 85, 130 p.

Hoare, J. M., Condon, W. H., and Patton, W. W., Jr., 1964, Occurrence and origin of laumontite in Cretaceous sedimentary rocks in western Alaska, in Geological Survey Research 1964 : U.S. Geol. Survey Prof. Paper 501-C, p. C74C78.

Lapham, D. M., 1963, Leonhardite and laumontite in diabase from Dillsburg, Pennsylvania: Am. Mineralogist, v. 48, nos. 5-6, p. 683-689.

Rainwater, F. H., and Thatcher, L. L., 1960, Methods for collection and analysis of water samples: U.S. Geol. Survey Water-Supply Paper 1454, $301 \mathrm{p}$.

Russell, R. T., 1945, The Poncha fluorspar deposits, Chaffee County, Colorado: U.S. Geol. Survey Strategic Mineral Inv. Prelim. Rept. 3-210, 12 p. 
Sigvaldason, G. E., 1963, Epidote and related minerals in two deep geothermal drill holes, Reykjavik and Hveragerdi, Iceland: Art. 200 in U.S. Geol. Survey Prof. Paper 450-E, p. E77-E79.

Tweto, Ogden, 1961, Late Cenozoic events of the Leadville district and upper Arkansas valley, Colorado: Art. 56 in U.S. Geol. Survey Prof. Paper 424-B, p. B133-B135.

Van Alstine, R. E., 1966, Geologic map of the Poncha Springs
NE quadrangle, Chaffee County, Colorado: U.S. Geol. Survey open-file report.

White, D. E., and Sigvaldason, G. E., 1963, Epidote in hotsprings systems, and depth of formation of propylitic epidote in epithermal ore deposits : Art. 201 in U.S. Geol. Survey Prof. Paper 450-E, p. E80-E84.

Zen, E-an, 1961, The zeolite facies-An interpretation: Am. Jour. Sci., v. 259, no. 6, p. 401-409. 


\title{
MAFIC AND ULTRAMAFIC ROCKS FROM A LAYERED PLUTON AT MOUNT FAIRWEATHER, ALASKA
}

\author{
By GEORGE PLAFKER and E. M. MacKEVETT, JR., \\ Menlo Park, Calif.
}

\begin{abstract}
Reconnaissance mapping in the Fairweather Range of southeastern Alaska has revealed that a layered maflc and ultramafic pluton, the Fairweather pluton, underlies much of the Mount Fairweather area. The maflc rocks, which constitute most of the pluton, are magnetite- and ilmenite-bearing twopyroxene gabbros and clinopyroxene-olivine gabbros. The ultramafic rocks consist mainly of sulfide- and chromite-bearing wehrlite, pyroxenite, and dunite, and locally contain significant concentrations of chromium, cobalt, copper, nickel, and platinum-group elements. The pluton is probably a source for ilmenite, magnetite, platinum, and other heavy minerals that have been found as placer beach deposits along the adjacent Gulf of Alaska coast.
\end{abstract}

During a geochemical sampling program in the Yakutat quadrangle and adjacent areas in 1968, the authors traced float of mafic and ultramafic rocks in glacial moraines to a previously undescribed small layered pluton at Mount Fairweather (fig. 1). The discovery is noteworthy because it extends the known area of a belt of layered mafic plutons in the Fairweather Range some 20 miles northwestward, and because the pluton contains ultramafic rocks with concentrations of chromite, nickel, copper, and platinumgroup metals. Ultramafic rocks have possible economic importance at the one other locality in the Fairweather Range where they have been found. The purpose of this paper is to outline the general setting of the Fairweather pluton, as determined from a brief aerial reconnaissance, and to present the results of petrologic and chemical analyses of some samples of float rock that were derived from the pluton.

The Fairweather pluton is the most northerly of three layered mafic intrusives that lie roughly along the axis of the northwest-trending Fairweather Range (fig. 1). Its existence in the general vicinity of Mount Fairweather was correctly inferred by Rossman (1963, p. F11) from float of gabbroic rocks found in the moraines of Fairweather Glacier. However, the loca- tion of the source pluton was not known, and no ultramafic rocks were reported in the float. The belt of layered intrusives extends southeastward through Yakobi Island and western Chichagof Island where several smaller bodies of gabbroic rock similar in composition to those of the Fairweather Range are exposed (Rossman, 1963, p. F11). Other than at the Fairweather pluton, ultramafic rocks in the range have been found only in small isolated nunataks at the Brady Glacier nickel-copper prospect (fig. 1), which is believed to lie near the margin of the Crillon-La Perouse pluton (Cornwall, 1967).

\section{SETTING}

The Fairweather pluton probably underlies an area of more than 15 square miles along the southwest flank of Mount Fairweather between the trunk stream of Fairweather Glacier and Sea Otter Glacier (fig. 1). Its general configuration and its relation to the adjacent metamorphic and granitic rocks were deduced by close observation from a helicopter. Our knowledge of the lithology of rocks in the pluton and inferences regarding the distribution of ultramafic rocks within it are based entirely on examination of moraines of the glaciers that drain toward the west and southwest from the Mount Fairweather area. The combination of rugged terrain and high altitude precluded landings within the pluton (fig. 2). Technical mountaineering capabilities would be required for a ground study. Virtually all of the pliton, except for the extreme northwestern end, is within the Glacier Bay National Monument.

The Fairweather pluton appears to be at least 6 miles long and $31 / 2$ miles wide, the long axis trending approximately northwestward. It is elongated parallel to the structural grain of the adjacent foliated country rocks, which are mainly steeply dipping amphibolite 


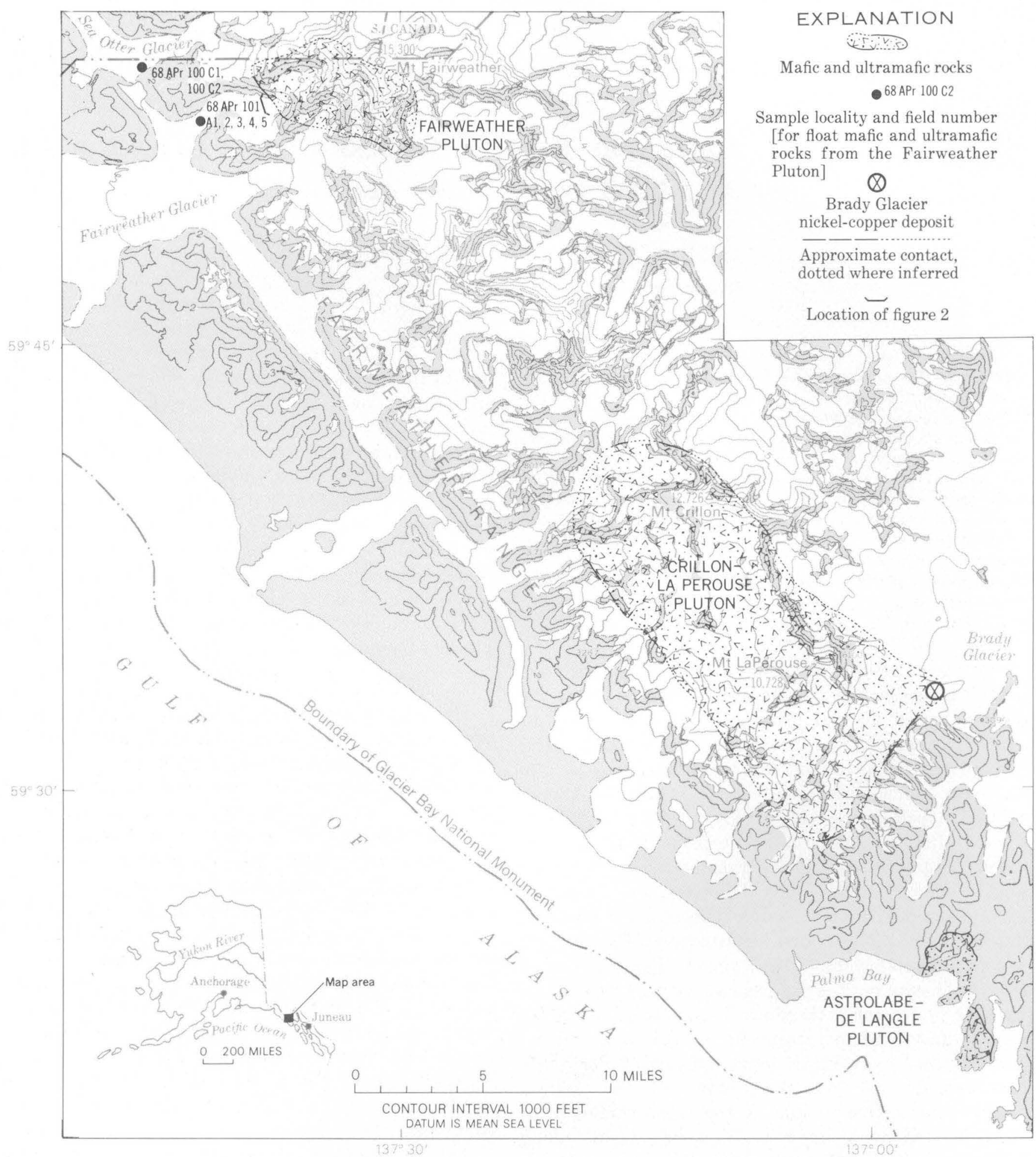

Figure 1.-Index map showing the approximate location of the Fairweather pluton and other layered mafic plutons in the Fairweather Range. Crillon-La Perouse and Astrolabe-De Langle plutons after Rossman (1963). 


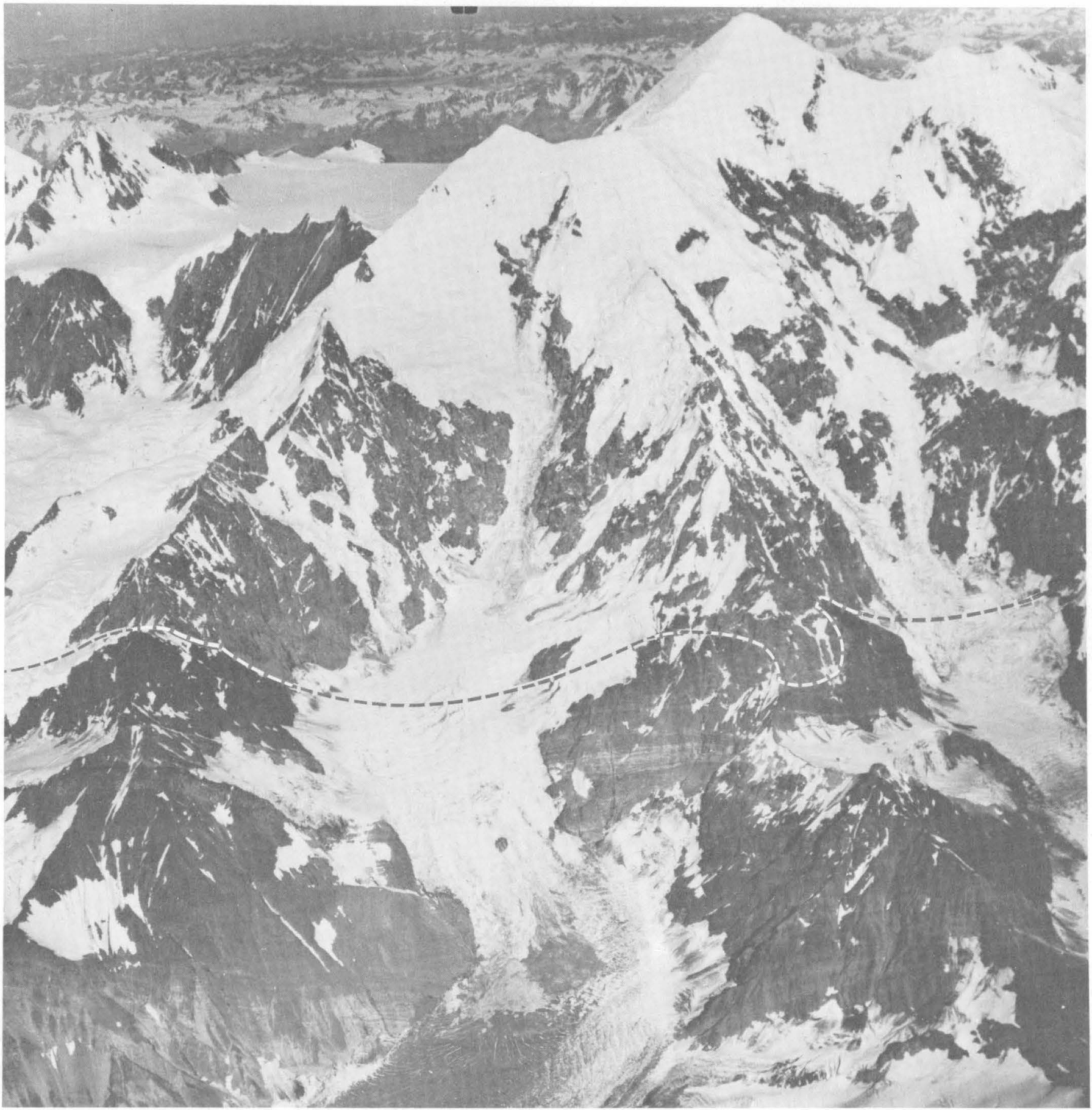

Figure 2.-Aerial view of the western part of the Fairweather pluton (location shown on fig. 1). Dashed line indicates the inferred southwest contact. The conspicuously banded rocks in the foreground are probably intertonguing metavolcanic and metasedimentary country rocks. Photograph by Austin Post.

and mica schist cut by granitic stocks and sills. Dark, layered mafic and ultramafic rocks are exposed in sheer cirque walls and knife-edged arêtes along the southwest margin of the pluton from an altitude between 7,000 and 10,000 feet, to the general vicinity of the summit, which rises 15,300 feet above sea level (fig. 2).
The layered igneous rocks on the southwest flank of Mount Fairweather appear to dip northeast at a moderate angle. The northeastern contact of the pluton is largely concealed beneath the extensive snow and ice cover on the highest part of the mountain; the contact shown on figure 1 is inferred from the distribution of 
schistose country rock at lower elevations. Massive, blocky, light-colored rocks in part border the layered rocks on the southwest in a zone as much as 2 miles wide, and locally seem to crosscut the darker layered rocks. It was not possible to tell from the air whether the light-gray unit represented a felsic granitic intrusive or a relatively nonlayered leucocratic gabbro. However, the general scarcity of felsic rocks in the moraines of glaciers draining this part of the mountain favor the latter alternative, and the light-gray zone was tentatively mapped as part of the pluton.

No data are available on the age of the pluton or of the adjacent foliated rocks. Rossman (1963, p. F10) correlated the schistose rocks of the Fairweather Range with units of Mesozoic age on Chichagof Island. Samples of gabbro from the compositionally and structurally similar Crillon-La Perouse pluton, which have been submitted for radiometric dating (D. A. Brew, oral commun., April 1969), may provide information on the time of intrusion of the layered rocks.

\section{DESCRIPTION OF THE ROCKS}

The compositional layering, textures, and mineralogy of the Fairweather pluton are broadly comparable to those of the layered igneous rocks elsewhere in the Fairweather Range (Rossman, 1957) and in many well-known localities throughout the world such as the Skaergaard, Stillwater, and Bushveld Complexes (Wager and Brown, 1968). Such rocks are generally considered to result from fractional crystallization and crystal settling in a magma originally of basaltic composition.

Ultramafic rocks of the Fairweather pluton are re- stricted to moraines on the south side of Sea Otter Glacier and on the unnamed glacier between Sea Otter and Fairweather Glaciers; gabbroic rocks are abundant in these moraines and in the lateral moraine along the north side of Fairweather Glacier (fig. 1). The distribution of ultramafic float suggests that its source is in the northern part of the pluton in the general area due west of Mount Fairweather.

Samples of float from the Fairweather pluton are composed primarily of virtually unaltered plagioclase, clinopyroxene, olivine, and orthopyroxene. Accessory constituents include sulfides, spinel-group minerals, ilmenite, hornblende, and traces of rutile and apatite. Detailed compositional studies have not been made, but the optical properties suggest that the plagioclase is mostly labradorite $\left(\mathrm{An}_{60-70}\right)$, the clinopyroxene is probably augite, the olivine has a forsterite content of about 80 percent, and the orthopyroxene is magnesian hypersthene $\left(\mathrm{En}_{85}\right)$. Augite characteristically is twinned and exhibits schiller structure; the hypersthene contains rare exsolution lamellae and blebs of clinopyroxene. The rock compositions vary from anorthosite or leucocratic gabbro to pyroxenite, wehrlite, and dunite. Chemical analyses of samples of the various rock types are presented in table 1 .

Gabbroic rocks are by far the most abundant in the moraines, and probably constitute the great bulk of the pluton. They are leucocratic to melanocratic rocks in which the layering results from variations in the proportions of plagioclase and ferromagnesian minerals. Individual layers in float on the moraines range from a fraction of an inch to several feet in thickness. The rocks that were collected are fine- to medium-grained

TABLE 1.-Chemical analyses, in. weight percent, of six rock samples from the Fairweather pluton

[Samples analyzed by methods similar to those described in U.S. Geol. Survey Bull. 1144-A, supplemented by atomic absorption. Analysts, Lowell Artis, G. W. Chloe, P. L. Elmore, John Glenn, James Kelsey, and H. Smith]

\begin{tabular}{|c|c|c|c|c|c|c|}
\hline \multirow{2}{*}{$\begin{array}{l}\text { Rock type } \\
\text { Lab No } \\
\text { Field No }\end{array}$} & \multirow{2}{*}{$\begin{array}{l}\text { Dunite } \\
\text { M106 } \\
872 \mathrm{~W} \\
68 \mathrm{APr} \\
101 \mathrm{Al}\end{array}$} & \multirow{2}{*}{$\begin{array}{l}\text { Wehrlite } \\
\text { M106 } \\
873 W \\
68 \mathrm{APr} \\
100 \mathrm{C} 2\end{array}$} & \multicolumn{2}{|c|}{ Two-pyroxene gabbro } & \multirow{2}{*}{$\begin{array}{l}\text { Clinopyroxene } \\
\text { olivine gabbro } \\
\text { M106 } \\
876 \mathrm{~W} \\
68 \mathrm{APr} \\
101 \mathrm{A4}\end{array}$} & \multirow{2}{*}{$\begin{array}{l}\text { Dunite } \\
\text { (sheared) } \\
\text { M106 } \\
877 W \\
68 \mathrm{APr} \\
101 \mathrm{A5}\end{array}$} \\
\hline & & & $\begin{array}{c}\text { M106 } \\
874 W \\
68 \mathrm{APr} \\
101 \mathrm{~A} 2\end{array}$ & $\begin{array}{c}\text { M106 } \\
875 W \\
68 \mathrm{APr} \\
101 \mathrm{A3}\end{array}$ & & \\
\hline 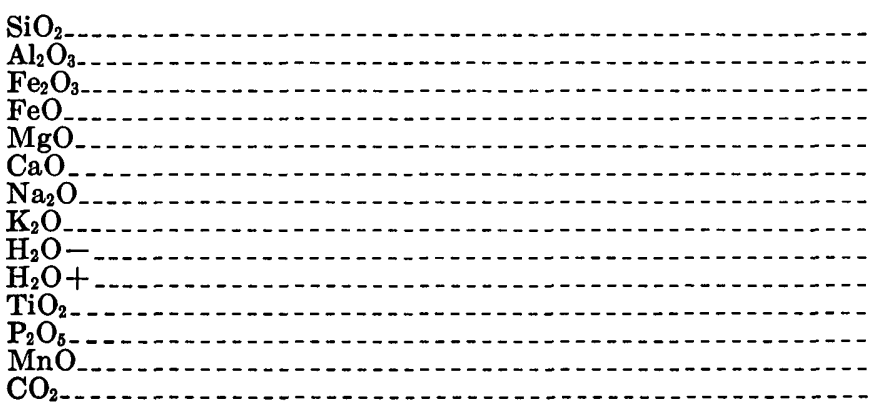 & $\begin{array}{r}40.5 \\
1.3 \\
1.2 \\
9.4 \\
44.4 \\
1.4 \\
.07 \\
.05 \\
.07 \\
.80 \\
.04 \\
.05 \\
.16 \\
.08\end{array}$ & $\begin{array}{r}44.2 \\
3.7 \\
1.7 \\
7.6 \\
29.3 \\
\text { 10. } 6 \\
.32 \\
.08 \\
.08 \\
\text { 1. } 2 \\
.21 \\
.04 \\
.15 \\
<.05\end{array}$ & $\begin{array}{c}44.4 \\
13.0 \\
5.0 \\
11.0 \\
11.3 \\
9.9 \\
1.2 \\
.10 \\
.10 \\
.72 \\
3.2 \\
.06 \\
.21 \\
.05\end{array}$ & $\begin{array}{r}49.5 \\
23.0 \\
1.0 \\
2.8 \\
7.2 \\
13.6 \\
1.5 \\
.10 \\
.07 \\
.56 \\
.13 \\
.02 \\
.20 \\
<.05\end{array}$ & $\begin{array}{r}46.1 \\
8.0 \\
2.2 \\
10.6 \\
18.5 \\
12.4 \\
.63 \\
.08 \\
.05 \\
.65 \\
.73 \\
.05 \\
.21 \\
.08\end{array}$ & $\begin{array}{r}38.8 \\
.81 \\
3.2 \\
7.6 \\
43.8 \\
.70 \\
.04 \\
.10 \\
.24 \\
4.9 \\
.03 \\
.04 \\
.16 \\
.05\end{array}$ \\
\hline Sum & 100 & 99 & 100 & 100 & 100 & 100 \\
\hline
\end{tabular}


two-pyroxene gabbro and clinopyroxene-olivine gabbro with xenomorphic to hypidiomorphic granular textures. Plagioclase in crystals up to $3.5 \mathrm{~mm}$ in length constitutes 10-60 percent of the gabbros analyzed. Rutilated plagioclase makes up an estimated 85 percent of a variant that had a decidedly purplish cast in the hand specimen, and the composition borders on anorthosite. The ferromagnesian minerals are as much as $2.5 \mathrm{~mm}$ in size.

The ratio of clinopyroxene to orthopyroxene in the two-pyroxene gabbro is variable, and either mineral may predominate in a given rock. Irregular masses of magnetite and ilmenite(?) in grains $1.5 \mathrm{~mm}$ or smaller constitute as much as 10 percent of one sample (68 APr $101 \mathrm{~A} 2$ ). The iron ores occur both interstitially and enclosed within the pyroxenes. The clinopyroxeneolivine gabbio (68 APr $101 \mathrm{~A} 4$ ) is composed mainly of clinopyroxene and olivine in grains as much as $2.5 \mathrm{~mm}$ across; the grains contain about 10 percent plagioclase and a few percent interstitial hypersthene. Opaque minerals make up as much as 5 percent of the rock. The predominant ore mineral is interstitial chalcopyrite in grains of less than $0.5 \mathrm{~mm}$. Other accessory minerals in the gabbros are generally less than $0.5 \mathrm{~mm}$ in size and include brown hornblende, green spinel, and rare cubanite, pyrrhotite, magnetite, chromite (?), and pentlandite(?).

The float of the ultramafic rock consists of black, greenish-black, and olivine-green crystal cumulates with a faintly layered structure. One sample of dunite (68 APr $101 \mathrm{~A} 1$ ) consists of more than 90 percent fresh euhedral to anhedral olivine in grains ranging from 0.2 to $4.5 \mathrm{~mm}$ in size. Some of the grains exhibit twinning and protoclastic textures. The remainder of the rock is composed of euhedral to subhedral chromite crystals 0.1 to $0.5 \mathrm{~mm}$ across, a few crystals of pentlandite less than $0.05 \mathrm{~mm}$ in size, and minor amounts of interstitial clinopyroxene and hornblende. One sheared dunite specimen (68 APr 101 A5) was cut by cross-fiber serpentine in closely spaced veinlets less than $0.02 \mathrm{~mm}$ wide that make up as much as 20 percent of the rock. The essential mineral of a pyroxenite sample (68 APr $100 \mathrm{C} 1$ ) is anhedral clinopyroxene in grains 0.5 to $3.0 \mathrm{~mm}$ across with about 25 percent anhedral to subhedral hypersthene that is less than $1.0 \mathrm{~mm}$ in size. A sample of wehrlite (68 APr $100 \mathrm{C} 2$ ) consists of about equal amounts of subhedral and anhedral olivine in grains as much as $2.5 \mathrm{~mm}$ across and anhedral, partially poikilitic clinopyroxene as much as $5.0 \mathrm{~mm}$. The clinopyroxene is commonly altered along grain boundaries and cracks to a mixture of fibrous green actinolite and antigorite. The pyroxenite and wehrlite contain as much as 15 percent interstitial sul- fides and minor scattered crystals of chromite and spinel from a few microns to $1 \mathrm{~mm}$ in size. The sulfide minerals, which occur in irregular scattered masses and microveinlets, are cubanite intergrown with chalcopyrite and pyrrhotite. Some pentlandite is intergrown with chalcopyrite or cubanite, or, more rarely, it occurs in isolated masses.

\section{SPECTROGRAPHIC ANALYSES}

Seven isolated float samples were analyzed for total metals by semiquantitative spectrographic methods, and of these, five ultramafic rocks and one gabbro were analyzed for platinum-group elements by quantitative spectrographic methods (table 2). The rocks analyzed include all the lithologic types described in the preceding section, and some of them had the highest content of disseminated opaque minerals found in the float. With the exception of the pyroxenite (68 APr $100 \mathrm{C} 1$ ), chemical analyses are given for these same rocks in table 2.

The analyses indicate concentrations of titanium (2 percent) and vanadium $(2,000 \mathrm{ppm})$ in the magnetiteand ilmenite-bearing two-pyroxene gabbro that are not unusual for rocks of this type. As much as $5,000 \mathrm{ppm}$ chromium, 5,000 ppm copper, and 5,000 ppm nickel are present in the richest samples of sulfide- and chromitebearing pyroxenite and wehrlite, as much as $5,000 \mathrm{ppm}$ chromium, and 3,000 ppm nickel, in the chromite-bearing dunite. Noteworthy amounts of cobalt and platinumgroup elements were also found in the ultramafic rocks and, to a lesser extent, in the gabbros. The largest amounts of these elements, which were in the sheared dunite (68 APr 101 A5), totaled 200 ppm cobalt and $0.184 \mathrm{ppm}$ palladium, $0.171 \mathrm{ppm}$ platinum, and detectable rhodium (0.004 ppm).

Disseminated opaque minerals occur in all the float collected from the Fairweather pluton. These minerals are mainly magnetite, ilmenite, sulfides, and chromite, which undoubtedly account for the anomalous metal content of these rocks. Combined magnetite and ilmenite constitute as much as 10 percent by volume of some gabbros. The wehrlite and pyroxenite contain up to 15 percent sulfides with minor chromite, and some dunites contain a few percent of chromite with minor sulfides. The sulfides identified in polished section include cubanite, chalcopyrite, pyrrhotite, and pentlandite. No chromitites or massive sulfides were found. The nickel and copper content of the highest grade rocks sampled is about 0.5 percent each. This may be compared with a content of 1.5 percent nickel and 2 percent copper in selected samples of ultramafic rocks from the Brady Glacier prospect which is cur- 
TABLE 2.-Spectrographio analyses of selected float ultramafic and mafic rocks from the Fairweather pluton

[Asterisk indicates quantitative analysis, A. F. Dorrzapf and Marian Schnepfe, analysts; all other analyses are semiquantitative, Chris Heropoulos, analyst. G, major constituents greater than 10 percent; $\mathrm{N}$, not detected. Other elements looked for but not found: As, Au, B, Be, Bi, Cd, La, Mo, Nb, Pb, Sb, Sn, Te, U, W, Zn, Zr, Ce, Ge, Hi, In, Ll, Re, Ta, Th, Tl, Eu]

\begin{tabular}{|c|c|c|c|c|c|c|c|}
\hline $\begin{array}{l}\text { Rock type } \\
\text { Field No No } \\
\text { Laboratory No }\end{array}$ & $\begin{array}{l}\quad \text { Dunite } \\
68 \text { APr } 101 \text { A1 } \\
\text { M4949 } \\
\text { M106892W }\end{array}$ & $\begin{array}{l}\begin{array}{c}\text { Dunite } \\
\text { (sheared) }\end{array} \\
68 \stackrel{\text { APr } 101 \text { A5 }}{ } \\
\text { M106877W }\end{array}$ & $\begin{array}{l}\text { Wehrlite } \\
68 \text { APr } 100 \text { C2 } \\
\text { M4949 } \\
\text { M106873W }\end{array}$ & $\begin{array}{l}\text { Clinopyroxene } \\
\text { olivine gabbro } \\
68 \text { APr } 101 \text { A4 } \\
\text { M106876W }\end{array}$ & $\begin{array}{c}\text { Two-pyroxene } \\
\text { gabbro } \\
68 \mathrm{APr} 101 \mathrm{A3} \\
\text { M106875W }\end{array}$ & $\begin{array}{l}\text { Two-pyroxene } \\
\text { gabbro } \\
68 \text { APr } 101 \text { A2 } \\
\text { M4949 } \\
\text { M106874W }\end{array}$ & $\begin{array}{l}\text { Pyroxenite } \\
68 \text { APr } 100 \mathrm{C} 1 \\
\text { M4949 }\end{array}$ \\
\hline \multicolumn{8}{|c|}{ Weight percent } \\
\hline 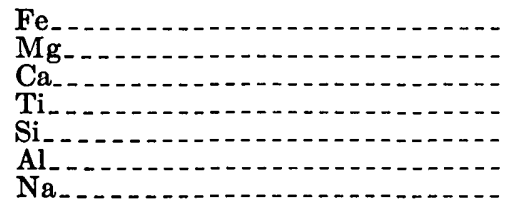 & $\begin{array}{ll}10 & \\
\mathrm{G} & \\
0.7 \\
0 . & 05 \\
\mathrm{G} & \\
1 . & 0 \\
\mathrm{~N} & \end{array}$ & $\begin{array}{ll}10 & \\
\mathrm{G} & \\
0 . & 5 \\
0 . & 02 \\
\mathrm{G} & \\
0 . & 7 \\
0 . & 02\end{array}$ & $\begin{array}{l}10 \\
\text { G } \\
7 \\
0.2 \\
\text { G } \\
2.0 \\
0.2\end{array}$ & $\begin{array}{l}\text { G } \\
10 \\
7 \\
0.5 \\
\text { G } \\
5.0 \\
0.7\end{array}$ & 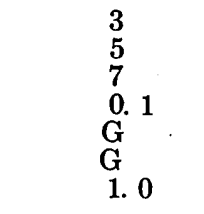 & $\begin{array}{l}\mathrm{G} \\
7 \\
5 \\
2 \\
\mathrm{G} \\
7.0 \\
1.0\end{array}$ & $\begin{array}{l}7 \\
10 \\
7 \\
0.2 \\
\text { G } \\
2 \\
0.15\end{array}$ \\
\hline \multicolumn{8}{|c|}{ Parts per million } \\
\hline 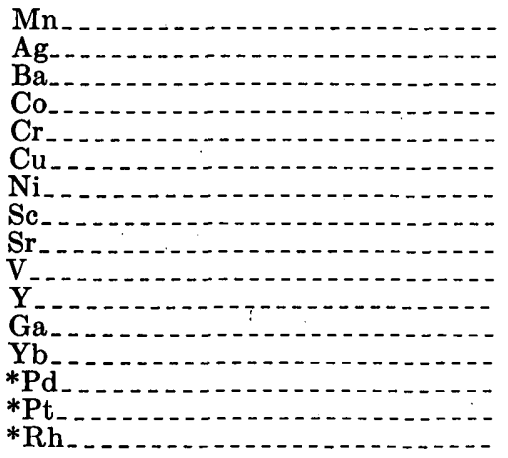 & $\begin{array}{r}1,500 \\
\mathrm{~N} \\
20 \\
150 \\
5,000 \\
50 \\
3,000 \\
15 \\
\mathrm{~N} \\
50 \\
\mathrm{~N} \\
3 \\
1 \\
20.006 \\
20.010 \\
0.002\end{array}$ & $\begin{array}{l}1,500 \\
\mathrm{~N} \\
15 \\
200 \\
3,000 \\
30 \\
2,000 \\
7 \\
\mathrm{~N} \\
30 \\
\mathrm{~N} \\
\mathrm{~N} \\
\mathrm{~N} \\
0.184 \\
0.171 \\
0.004\end{array}$ & $\begin{array}{r}1,000 \\
1 \\
30 \\
150 \\
5,000 \\
3,000 \\
5,000 \\
70 \\
15 \\
150 \\
10 \\
3 \\
1.5 \\
10.056 \\
10.048 \\
10.002\end{array}$ & $\begin{array}{r}3,000 \\
\mathrm{~N} \\
30 \\
100 \\
700 \\
700 \\
500 \\
150 \\
100 \\
500 \\
10 \\
7 \\
1 \\
0.002 \\
0.003 \\
\mathrm{~N}\end{array}$ & $\begin{array}{r}700 \\
\mathrm{~N} \\
50 \\
30 \\
300 \\
100 \\
150 \\
30 \\
500 \\
150 \\
\mathrm{~N} \\
15 \\
\mathrm{~N} \\
\\
\end{array}$ & $\begin{array}{r}3,000 \\
\mathrm{~N} \\
50 \\
70 \\
150 \\
200 \\
100 \\
70 \\
200 \\
2,000 \\
10 \\
15 \\
\mathrm{~N} \\
10.006 \\
10.009 \\
<0.002\end{array}$ & $\begin{array}{r}1,000 \\
2 \\
N \\
150 \\
3,000 \\
5,000 \\
5,000 \\
70 \\
10 \\
300 \\
N \\
N \\
N \\
0.006 \\
0.043 \\
<0.002\end{array}$ \\
\hline
\end{tabular}

1 Average of two analyses. ${ }^{2}$ Average of three analyses.

rently being actively explored by the Newmont Min"ing Co. (Cornwall, 1967, p. 153, table 15).

The Fairweather pluton is probably a major source for magnetite, ilmenite, platinum, and other heavy minerals that occur in association with placer gold in beach deposits along the adjacent Gulf of Alaska coast (Rossman, 1957, 1963; 'Thomas and Berryhill,' 1962).

\section{REFERENCES}

Cornwall, H. R., 1967, Brady Glacier prospect, in MacKevett, E. M., Jr., Brew, D. A., Hawley, C. C., Huff, L. C., and
Smith, J. G., Mineral resources of Glacier Bay National Monument: U.S. Geol. Survey open-file report, July 14, 1967, p. 153-158.

Rossman, D. L., 1957, Ilmenite-bearing beach sands near Lituya Bay, Alaska: U.S. Geol. Survey open-file report, June 29, 1957, 10 p., 1 pl., 2 tables.

- 1963, Geology and petrology of two stocks of layered gabbro in the Fairweather Range, Alaska: U.S. Geol. Survey Bull. 1121-F, p. F1-F50.

Thomas, B. I., and Berryhill, R. V., 1962, Reconnaissance studies of Alaskan beach sands, eastern Gulf of Alaska: U.S. Bur. Mines Rept. Inv. 5986, 40 p.

Wager, L. R., and Brown, G. M., 1968, Layered igneous rocks: Edinburgh and London, Oliver and Boyd, Ltd., 588 p. 


\title{
AUTHIGENIC KAOLINITE IN SAND OF THE WILCOX FORMATION, JACKSON PURCHASE REGION, KENTUCKY
}

\author{
By JOHN D. SIMS, Paducah, Ky.
}

Work done in cooperation with the Kentucky Geological Survey

\begin{abstract}
Authigenic kaolinite occurs as spindle-shaped rods and subhedral vermicular masses in the Wilcox Formation of Eocene nge in Kentucky. The vermicular kaolinite occurs in sand and silt having "sawdust sand" lithology. Lack of disruption or abrasion of the delicate spindle-shaped rods and vermicular masses indicates that the kaolinite is of diagenetic rather than detrital origin. The sediments of the Wilcox Formation are dominantly of fluvial origin derived by erosion and alteration of local detritus from underlying rocks. Thermodynamic considerations suggest postdepositional flushing with fresh water during which preexisting phyllosilicate minerals were altered to kaolinite and an illite-like mineral.
\end{abstract}

The Wilcox Formation has been mapped in the eastern and northern parts of the Jackson Purchase region, Kentucky. Olive and Finch (1969) and Olive and Davis (1968) called attention to the Wilcox as a possible source of high-quality kaolinite. Finch (1964) described subsurface rocks of the Wilcox Formation in the Symsonia quadrangle, Kentucky (fig. 1).

Authigenic kaolinite and illite(?) occur in the Wilcox Formation at the localities shown in figure 1 as well as numerous other localities in the outcrop belt of the Wilcox of the Mississippi embayment region of far westem Kentucky. Kaolinite, the most abundant authigenic mineral, occurs as spindle-shaped rods and subhedral vermicular masses, resulting in the "sawdust sand" lithology described by Whitlatch $(1940$, p. 243). The "sawdust sand" is the most distinctive and dominant lithology in the Wilcox Formation of the Jackson Purchase region.

The authigenic kaolinite in the Wilcox Formation of the Jackson Purchase region was first identified by Charles Milton (written commun., 1963) from samples collected and described by Finch (1964), represented here by sample SYM (fig. 1). Olive and Davis (1968) described rocks of similar lithology in the Oak Level quadrangle, Kentucky, represented here by samples OL and PCR-4C (fig. 1). Similar occurences of authigenic kaolinite have been described in detail by Ross and Kerr (1931), Carozzi (1960, p. 179-185), and Jonas (1964).

\section{PETROLOGY}

The mineral composition of these three samples of the "sawdust sand" was determined by modal analyses of thin sections (table 1). The count interval, based on grain-size estimate, was 200 microns for sample SYM and 300 microns for samples OL and PCR-4C. Quartz uniformly has a first-order white interference color indicating that the thin sections are $\leq 0.03 \mathrm{~mm}$ throughout. Quantitative X-ray mineralogical analyses agree closely with the modal analyses, but result in less detailed identification of components.

The basis for identifying clay minerals in these thin sections is taken from Millot (1963, p. 280-285). Millot shows that kaolinite occurs as low-birefringence (birefringence $=0.006$ ) interstitial masses of vermicular ma-

TABLE 1.-Modal analyses of "sawdust sand," in percentage of total components

[200 grains counted per thin section; Tr., trace]

\begin{tabular}{|c|c|c|c|}
\hline & OL & SYM & PCR-4C \\
\hline $\begin{array}{l}\text { Quartz } \\
\text { Polycrystalline quartz } \\
\text { Vermicular kaolinite. } \\
\text { Illite(?) } \\
\text { Detrital muscovite. } \\
\text { Lithic fragments. } \\
\text { Feldspar } \\
\text { Glauconite } \\
\text { Opaque grains. } \\
\text { Matrix }\end{array}$ & $\begin{array}{r}46 \\
12 \\
18 \\
4 \\
\operatorname{Tr} \\
3 \\
2 \\
2 \\
3\end{array}$ & $\begin{array}{r}31 \\
9 \\
16 \\
4 \\
\operatorname{Tr} . \\
17 \\
2 \\
-- \\
1 \\
20\end{array}$ & $\begin{array}{r}33 \\
7 \\
12 \\
5 \\
1 \\
8 \\
2 \\
2 \\
1 \\
28\end{array}$ \\
\hline , & 100 & 100 & 99 \\
\hline
\end{tabular}




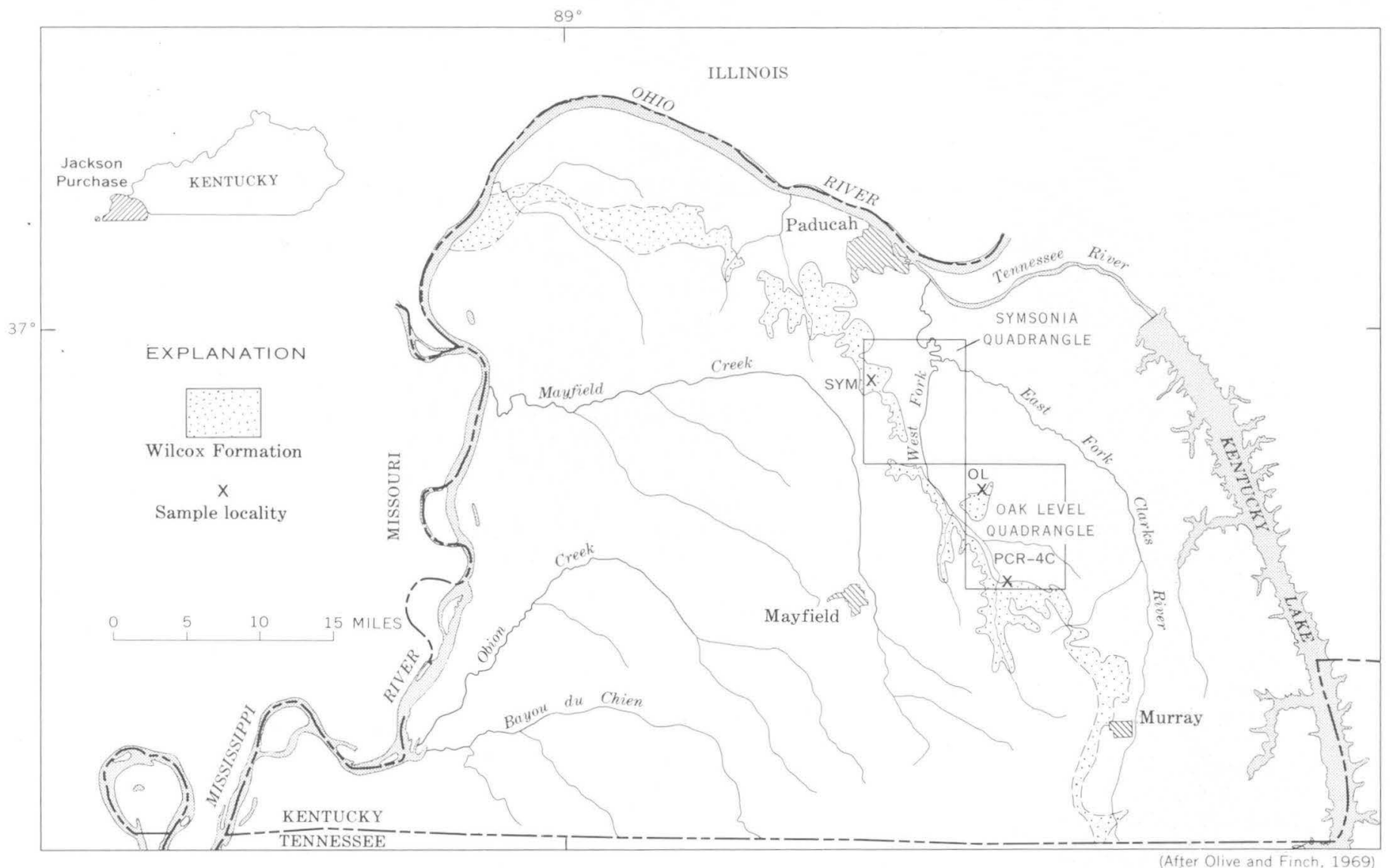

Figure 1.-Outcrop area of the Wilcox Formation in the Jackson Purchase region, Kentucky, and sample localities.

terial, whereas illite is generally highly birefringent (birefringence $\approx 0.03$ ). Deer, Howie, and Zussman (1962, p. 206-207) state that "The kaolinite minerals may occur in compact massive blocks, in vermiform or granular aggregates, as radiating platelets, or as piles of platelets (or "books"), the latter form being particularly common for dickite." Kaolinite may be distinguished from sericite, montmorillonite, and illite. Sericite and montmorillonite have greater birefringence than kaolinite, and montmorillonite has a lower refractive index. Reliable identification can only be achieved by X-ray diffraction.

Illite shows a wide range in index of refraction owing to the various substitutions, the degree of hydration, and interlayering with other minerals, commonly montmorillonite. Indices of refraction of illite are generally slightly below those of muscovite and biotite. Accurate measurement of optical parameters generally cannot be made because of the extremely small size of illite particles. Illite and muscovite are distinguished in X-ray diffractograms only on the basis of basal reflection peak shape because their basal reflections occur at approximately the same $2 \theta$ positions.
Interstitial vermicular kaolinite masses are shown in figure 2. The individual crystallites of kaolinite books,

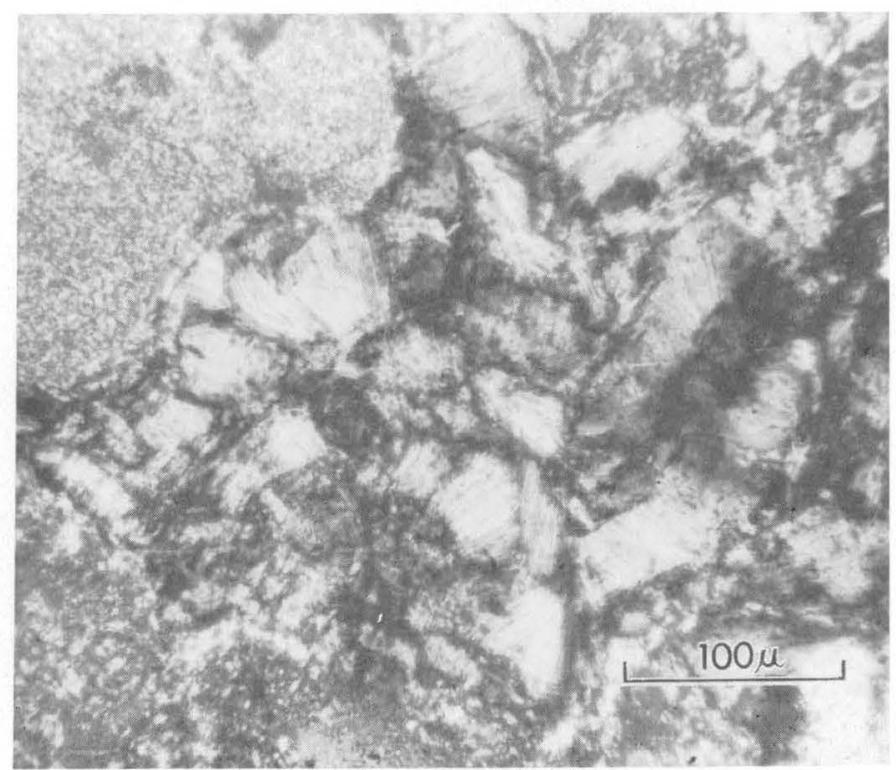

FIGURE 2.-Photomicrograph of interstitial masses of kaolinite books. Crossed polarizers. Sample SYM. 
such as those shown in figure 2 , have a size range of $20-80 \mu$ perpendicular to the basal (001) cleavage. The (001) cleavage is distinct, and grain boundaries between kaolinite books, detrital grains, and matrix are generally sharp. Some wispy kaolinite crystallites appear to be growing on the surface of a few quartz grains, but do not penetrate the surface of the grains.

Larger crystals of vermicular kaolinite ranging in length from $250 \mu$ to $980 \mu$ occur as distinct individual grains and commonly appear to have striae parallel to the length of the grain, which are probably boundaries between crystallites in compound vermicular crystals (Jonas, 1964, p. 203). These larger grains also appear to have grown in place and to have laterally displaced surrounding detrital grains (fig. 3). Distinct differences in birefringence are commonly noted between adjacent crystals of authigenic vermicular minerals (fig. 4). Some of the crystals have a first-order white or gray interference color (birefringence $=0.006$ ), while others exhibit first-order yellow to orange (birefringence $=$ 0.012 to 0.014 ). These crystals with differing birefringence resemble those described by Ross and Kerr (1931) and are identified as authigenic kaolinite (low birefringence) and authigenic illite(?) (higher birefringence) (fig. 4). The identification of illite is queried because substantiating mineralogical data are not available.

The term "authigenic illite(?)", as used here refers to a phyllosilicate of moderate birefringence and little or no pleochroism occurring as vermicular crystals,

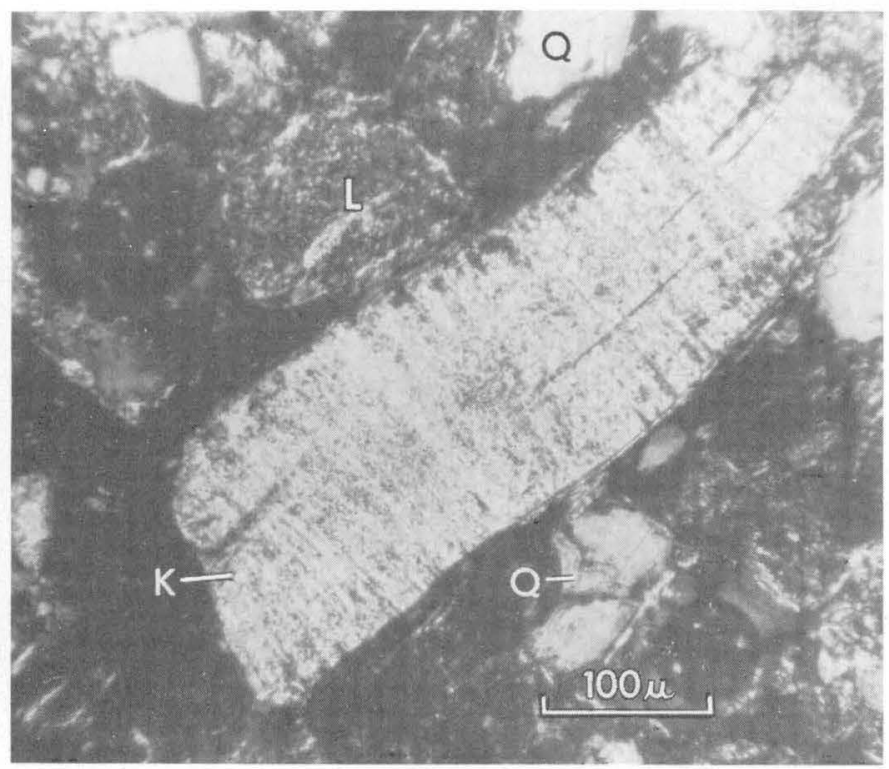

Figure 3.-Photomicrograph of a single crystal of authigenic kaolinite $(K)$ which appears to have laterally displaced surrounding detrital grains. L, lithic fragments; $Q$, quartz grains. Crossed polarizers. Sample SYM.

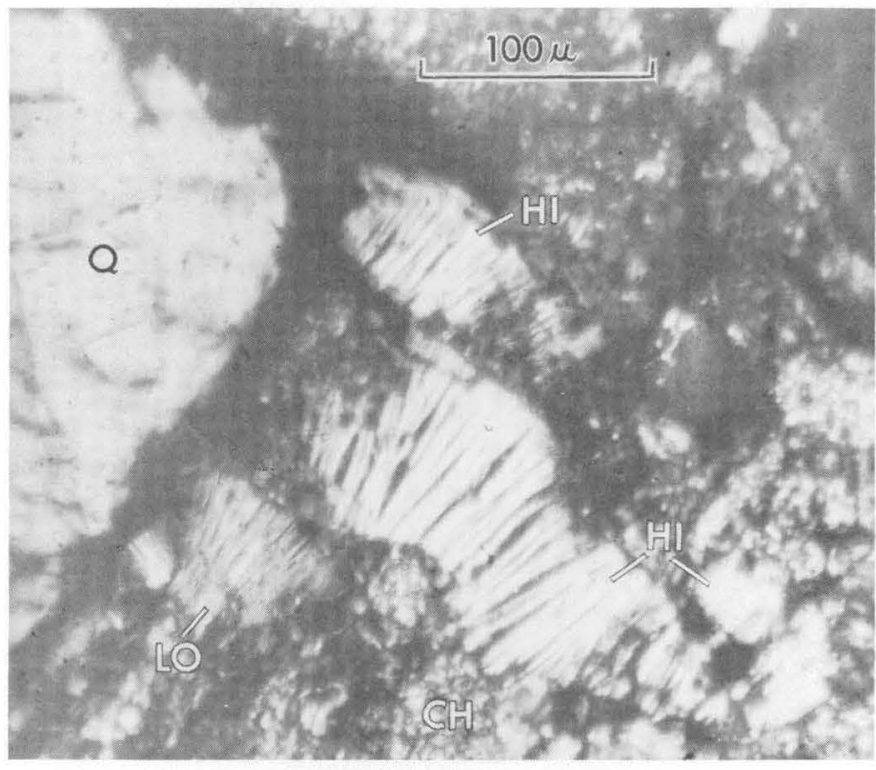

Figure 4.-Photomicrograph showing high- and low-birefringence vermicular minerals. High-birefringence $(\mathrm{HI})$ mineral is probably illite or a highly birefringent kaolinite similar to that described by Ross and Kerr (1931), and the lowbirefringence (LO) vermicular mineral is kaolinite. Note authigenic polycrystalline quartz $(\mathrm{CH}), Q$, detrital quartz. Crossed polarizers. Sample OL.

wispy fragments, and acicular masses. It may include some authigenic muscovite which in thin sections and $\mathrm{X}$-ray diffractograms is difficult to distinguish from illite. Several occurrences of a wispy acicular moderately birefringent mineral closely associated with and penetrating some detrital quartz grains were noted. These minerals are presumably authigenic illite(?). One interstice, formed by bounding quartz grains, is zoned with kaolinite in the outer position and highly birefringent, fine-grained, mica and (or) illite in the inner position of the void. Identification of this material is uncertain because detailed X-ray and chemical data are unavailable.

Quartz is the most abundant mineral in the Wilcox Formation and is angular to subangular. Rarely, grains with overgrowths are noted, and in one grain corrosion of a quartz overgrowth was noted. Some quartz grains have rims of highly birefringent green material, but the rim is not thick enough for optical identification.

Polycrystalline quartz includes both authigenic and detrital types. Grain size ranges from microcrystalline $(\geq 10 \mu)$ to cryptocrystalline $(\leq 2 \mu)$. Much of the polycrystalline quartz is identifiable as detrital because of the easily distinguished irregular boundary and relations with other detrital grains. Where grain boundary relationship with other grains, especially with the matrix, are obscure the polycrystalline mass is assumed to be diagenetic but is not separately tabulated (table 1). 
Detrital muscovite and biotite (fig. 5) are rare. Muscovite does not appear in the modal analyses for SYM and OL (table 1), but these grains were noted in the thin sections. All muscovite fragments are frayed, and the grains are bent and broken. Detrital pleochroic brown biotite was seen in thin section but does not appear in the modal analyses.

Lithic fragments containing highly birefringent tabular minerals are generally rounded to subrounded and show only vague internal structure. Orientation of particles within mudstones and lithic fragments is generally not well developed. Shale fragments are compressed between some quartz grains.

Feldspar fragments are generally rounded to subrounded and are generally extensively altered, particularly along cleavages. One perthite grain with only minor alteration along the edges and cleavages was observed. Other similar grains lack grid twinning but have dustlike inclusions and a cloudy appearance. Some highly altered detrital grains are present in sample SYM $(\approx 2$ percent) and are tentatively identified as K-feldspar.

Opaque grains are rare, and no attempt was made to distinguish organic from inorganic opaque grains. Matrix, as used in this report, is fine-grained material in which the individual grains are not distinguishable using $\times 625$ magnification. The matrix probably includes substantial quantities of authigenic kaolinite, illite(?), and silica.

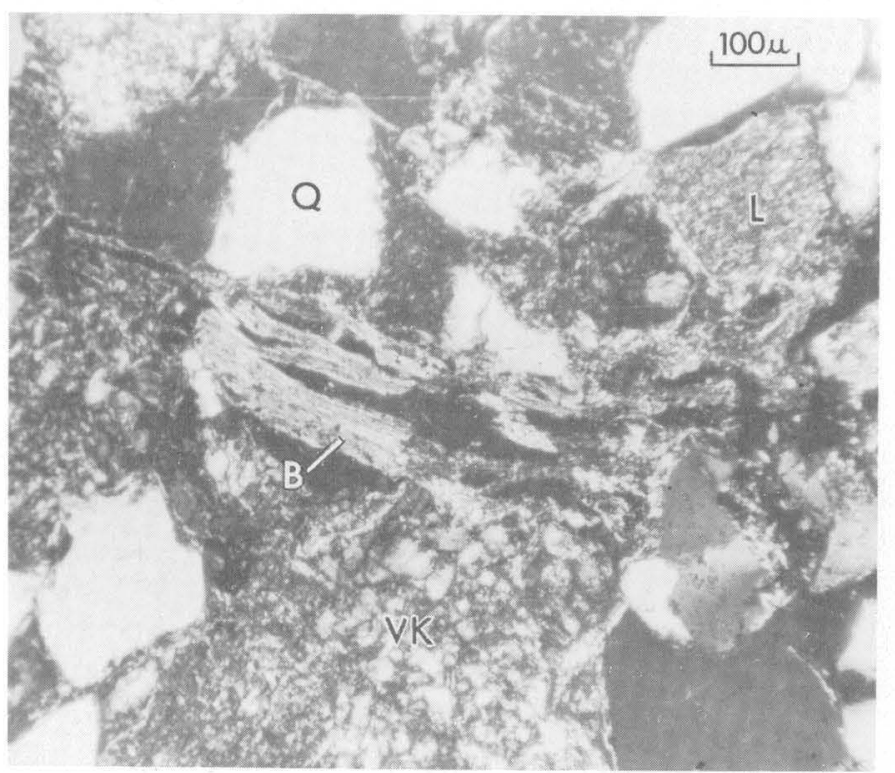

Figure 5.-Detrital biotite (B). Some grains are greatly frayed and expanded, probably owing to hydrolysis. Other biotite grains are rounded and slightly expanded into fan shapes. Q, quartz; L, lithic fragment; VK, interstitial vermicular kaolinite mass. Crossed polarizers. Sample SYM
Green polycrystalline fragments are rounded, contain rodlike opaque inclusions, and occur sparsely in all thin sections. These grains are apparently glauconite as identified by Finch (1964).

Commonly, lithic fragments and quartz grains have a rind of highly birefringent material which appears to coat them. Few mineralogic data are obtained from these coatings because of their thinness.

Chert (polycrystalline quartz), siltstone and mudstone fragments, and kaolinite books commonly have an opaque coating, which is either organic material or manganese oxide. In sample OL an opaque mineral coating was deposited probably in the final stage of diagenesis. Feldspar( ?) grains, surrounded by dark opaque material, are clouded with dustlike inclusions(?). The inclusions(?) may be identical with the late-stage opaque material that coats and obscures grain boundaries and internal detail in other grains.

\section{COMPARISON OF WILCOX FORMATION AND PORTERS CREEK CLAY}

Sample OL does not show as close a mineralogical relation to the underlying Porters Creek Clay as do samples SYM and PCR-4C. The occurrence of glauconite, muscovite, and rare fragments of biotite in samples SYM and PCR-4C and absence of these minerals in sample OL may indicate that sample OL is younger and was receiving less detritus from Porters Creek rocks. X-ray diffractograms show that montmorillonite, an abundant mineral in the Porters Creek Clay, is absent or rare in the Wilcox.

Kaolinite is absent or a minor constituent in the Porters Creek Clay, but authigenic kaolinite is commonly observed to be abundant in rocks of the Porters Creek Clay near the contact with the overlying Wilcox Formation. The montmorillonite-biotite-glauconitemuscovite mineral suite of the Porters Creek Clay contrasts strikingly with the authigenic kaolinite-authigenic illite(?) suite of the Wilcox Formation.

\section{GENESIS OF KAOLINITE}

Ross and Kerr (1931) stated that the alteration of feldspar is the chief process in the formation of authigenic kaolinite, but that in a few places kaolinite has been formed by the alteration of other minerals. A mica-like, vermicular mineral with a birefringence (birefringence $=0.014$ ) nearly that of muscovite occurs in many kaolin deposits, and is especially abundant in the kaolinite near Franklin, N. C. (Ross and Kerr, 1931). Chemical analyses of the kaolinite and mica-like mineral (Ross and Kerr, 1931, p. 172) are similar. This may indicate that authigenic vermicular kaolinite is produced by the hydrolysis and removal 
of the more soluble cations from muscovite. The mineral with a muscovite-like birefringence and a kaolinitelike chemical composition may represent the penultimate stage in the transformation of muscovite to kaolinite. These data may also be interpreted to suggest that illite and (or) muscovite are intermediate phases in the authigenesis of kaolinite from some other silicate mineral-such as $\mathbf{K}$-feldspar.

Jonas (1964) presents data suggesting that wellcrystallized vermicular kaolinite is derived by recrystallization. Jonas further indicates that authigenic kaolinite derived from $\mathrm{K}$-feldspar occurs as wellcrystallized pseudomorphs, and kaolinite derived from muscovite is $b$-axis disordered. The kaolinite in the Wilcox Formation, except for kaolinite in the matrix, is dominantly of the vermicular well-ordered type. $\mathrm{X}$ ray diffractograms show some $b$-axis disorder, but it is not definitely attributable to the vermicular kaolinite.

Mullineaux, Nichols, and Speirer (1964) present a paragenesis of authigenic clay minerals in a Pleistocene paleosol near Seattle, Wash. The clay mineral suites in this paleosol illustrate the destruction of illite and chlorite in the weathering profile of soils to form kaolinite and montmorillonitic mixed-layer minerals. Grim (1968, p. 520-523) presents a further concise treatment of the nature of the alteration of primary minerals to clay minerals. These data support the theoretical considerations of Kittrick (1968), Garrels and Christ (1965), and Mackenzie and Garrels (1966).

Kittrick (1968) presents diagrams that enable visualization of the relative stability of minerals in the system $\mathrm{Al}_{2} \mathrm{O}_{3}-\mathrm{SiO}_{2}-\mathrm{H}_{2} \mathrm{O}$. Solubility studies on soils indicate that the $\mathrm{H}_{4} \mathrm{SiO}_{4}$ activity is controlled, not by equilibrium thermodynamics, but by kinetics of the dissolution of silica. The silica activity in turn seems to determine which secondary minerals will form. Amorphous silica probably limits high silica levels, with montmorillonite forming at slightly lower levels, kaolinite at intermediate levels, and gibbsite at low silica levels.

Rex (1966), Hess (1966), and Mackenzie and Garrels (1966), illustrate the nature of the kaoliniteK-mica-K-feldspar equilibria (fig. 6). The geochemical environment of the Wilcox Formation was estimated by using world averages for the composition of fresh-water rivers and lakes (Livingstone, 1963) and assumed $\mathrm{pH}=7.5$, and is in agreement with Garrels and Christ (1965) and Rex (1966). The data suggest that kaolinite can precipitate from solution when the ion activity product of kaolinite in solution is increased to equal or exceed the equilibrium constant of kaolinite. Kaolinite precipitates only where alkali and alkalineearth metal cations are not present in sufficient quantity

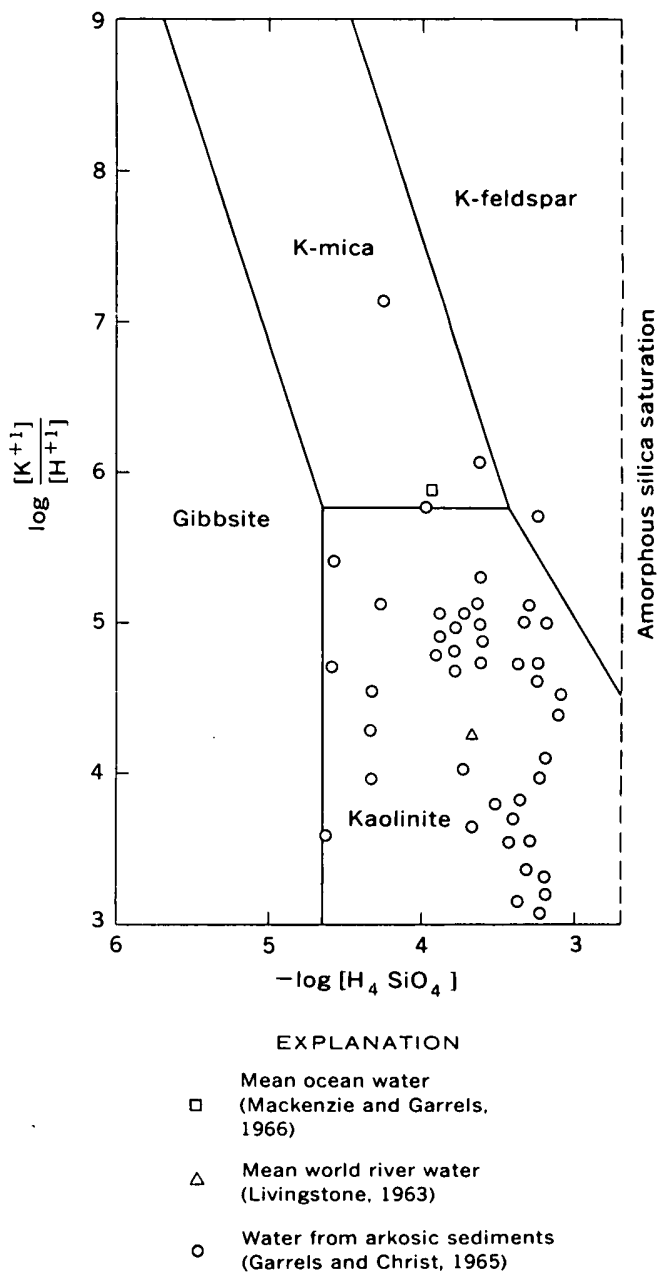

Figure 6.-Stability relations of some phases in the system $\mathrm{K}_{2} \mathrm{O}-\mathrm{Al}_{2} \mathrm{O}_{3}-\mathrm{SiO}_{2}-\mathrm{H}_{2} \mathrm{O}$ at $25^{\circ} \mathrm{C}$ and 1 atmosphere as functions of $\log \left[\mathrm{K}^{+1}\right] /\left[\mathrm{H}^{+1}\right]$ and $-\log \left[\mathrm{H}_{4} \mathrm{SiO}_{4}\right]$ and $\log \left[\mathrm{Na}^{+1}\right] /\left[\mathrm{H}^{+1}\right] \approx 2.0$. The assumed pore-water composition for the Wilcox Formation has the following cation/ hydrogen ion ratios:

$$
\log \frac{\left[\mathrm{K}^{+1}\right]}{\left[\mathrm{H}^{+1}\right]}=4.73, \log \frac{\left[\mathrm{Na}^{+1}\right]}{\left[\mathrm{H}^{+1}\right]}=2.06,
$$

and $-\log \mathrm{H}_{4} \mathrm{SiO}_{4}=4.36$, derived from data of Livingstone (1963, p. 41) and with an assumed $\mathrm{pH}=7.5$.

to produce cation alumino-silicates. Stated conversely in the terms of Kittrick (1968), very low cation concentration at relatively moderate silica values favors crystallization of kaolinite. In order to meet these conditions large quantities of cation-free water are needed to either flush away or greatly dilute the solution products derived from the hydrolysis of unstable minerals. Such a flushing mechanism has been proposed by Hay (1963) to account for the diagenetic mineral assemblages in the middle-Tertiary volcanogenic continental sediments in Oregon.

The data presented indicate that the kaolinite occurring interstitially in the "sawdust sand" crystallized in 
place. Geochemical considerations further indicate that the process occurred in a fresh-water environment (Asquith, 1968).

The original materials from which the kaolinite formed are difficult to identify, but they were probably precursor clay minerals and (or) feldspar. After these minerals were deposited as detritus, the alkali-metal ions were selectively removed by hydrolysis in fresh water that moved through the sediment. The action of the water, however, was not sufficient to lower the concentrations of aluminum and silica in solution below the activity product for kaolinite and illite(?) as is shown by the presence of authigenic polycrystalline quartz. Thus, silica and aluminum concentrations favorable to the subsequent formation of kaolinite were maintained. The dissolution and reorganization processes probably occurred concomitantly with cation removal. Kaolinite was probably derived from clay minerals rather than from feldspar, because the preexisting phyllosilicate structure of clay minerals could be more readily utilized for nucleation.

\section{CONCLUSIONS}

Kaolinite in the thin sections studied represents precursor feldspar and (or) cation-bearing clay minerals that underwent diagenesis in a fresh-water environment. The evidence for nondetrital origin of the kaolinite is large grain size and subhedral to euhedral vermicular form. The vermicular masses of kaolinite would probably not withstand much abrasion or disruption without destroying their structure. The dominant minerals in the thin sections are kaolinite and quartz, indicating a high degree of selective removal of the easily soluble cations of $\mathrm{Ca}, \mathrm{Na}$, and $\mathrm{K}$. The postdepositional environment was probably characterized by large volumes of fresh water flushing through porous sandstones.

\section{REFERENCES}

Asquith, G. B., 1968, Origin of large kaolinite crystals in the lower Almond Formation in southwest Wyoming: Jour. Sed: Petrology, v. 38, p. 948-949.

Carozzi, A. V., 1960, Microscopic sedimentary petrography : New York, John Wiley and Sons, $485 \mathrm{p}$.
Deer, W. A., Howie, R. A., and Zussman, J., 1962, Rock-forming minerals; v. 3, Sheet silicates: New York, John Wiley and Sons, $270 \mathrm{p}$.

Finch, W. I., 1964, Geology of the Symsonia quadrangle, Kentucky: U.S. Geol. Survey Geol. Quad. Map GQ-326.

Garrels, R. M., and Christ, C. L., 1965, Solutions, minerals, and equilibria: New York, Harper and Row, 450 p.

Grim, R. E., 1968, Cla:y mineralogy, 2d ed. : New York, McGrawHill, 596 p.

Hay, R. L., 1963, Stratigraphy and zeolitic diagenesis of the John Day Formation of Oregon: California Univ. Pubs. Geol. Sci., v. 42, p. 199-262.

Hess, P. C., 1966, Phase equilibria of some minerals in the $\mathrm{K}_{2} \mathrm{O}-\mathrm{Na}_{2} \mathrm{O}-\mathrm{Al}_{2} \mathrm{O}_{5}-\mathrm{SiO}_{2}-\mathrm{H}_{2} \mathrm{O}$ system at $25^{\circ} \mathrm{C}$ and 1 atmosphere: Am. Jour. Sci., v. 264, p. 289-309.

Jonas, E. C., 1964, Petrology of the Dry Branch, Georgia, kaolin deposits, in Clays and clay minerals, 12th Natl. Conf., Atlanta, Ga., 1963, Proc. : New York, Pergamon Press, p. 199205.

Kittrick, J. A., 1969, Soil minerals in the $\mathrm{Al}_{2} \mathrm{O}_{3}-\mathrm{SiO}_{2}-\mathrm{H}_{2} \mathrm{O}$ system and a theory of their formation: Clays and Clay Minerals, v. 17, no. 3, p. 157-168.

Livingstone, D. A., 1963, Data of geochemistry, 6th ed.; chap. G, Chemical composition of rivers and lakes: U.S. Geol. Survey Prof. Paper 440-G, 64 p.

Mackenzie, F. T., and Garrels, R. M., 1966, Silica-bicarbonate balance in the ocean and early diagensis : Jour. Sed. Petrology, v. 36, p. 1075-1084.

Millot, Georges, 1963, Géologie des Argiles; Paris, Masson et Cie, $499 \mathrm{p}$.

Mullineaux, D. R., Nichols, T. C., and Speirer, R. A., 1964, A zone of montmorillonitic weathered clay in Pleistocene deposits at Seattle, Washington, in Geological Survey Research, 1964 : U.S. Geol. Survey Prof. Paper 501-D, p. D99D103.

Olive, W. W., and Davis, R. D., 1968, Geologic map of the Oak Level quadrangle, western Kentucky: U.S. Geol. Survey Geol. Quad. Map GQ-744.

Olive, W. W., and Finch, W. I., 1969, Stratigraphic and mineralogic relations and ceramic properties of clay deposits of Eocene age in the Jackson Purchase region, Kentucky, and adjacent parts of Tennessee: U.S. Geol. Survey Bull. 1282, $35 \mathrm{p}$.

Rex, R. W., 1966, Authigenic kaolinite and mica as evidence for phase equilibria at low temperatures, in Clays and clay minerals, 13th Natl. Conf., Madison, Wis., 1966; Proc.: New York, Pergamon Press, p. 95-104.

Ross, C. S., and Kerr, P. F., 1931, The kaolin minerals: U.S. Geol. Survey Prof. Paper 165, p. 151-176.

Whitlatch, G. I., 1940, The clays of west Tennessee : Tennessee Div. Geology Bull. 49, 368 p. 


\title{
BLUESCHIST AND RELATED GREENSCHIST FACIES ROCKS OF THE SEWARD PENINSULA, ALASKA
}

\author{
By C. L. SAINSBURY; R. G. COLEMAN, and REUBEN KACHADOORIAN, \\ Denver, Colo.; Menlo Park, Calif.
}

\begin{abstract}
A.bstract.-Blueschist facies rocks of Precambrian age are exposed in thrust slices over an area of more than 10,000 square miles of the Senward Peninsula, Alaska. Rocks with mineral nssemblages characteristic of high-grade blueschist facies and retrograde blueschist facies occur juxtaposed against low-rank metamorphic pelitic and carbonate rocks, possibly because of thrust faults. From west to enst over the Seward Peninsula, progressive regional metamorphism of Cretaceous(?) age and extensive overthrust faulting of pre-mid-Cretaceous age have complicated the metamorphic assemblages. Field evidence proves that the blueschist rocks represent metavolcanic rocks and metamorphosed mafic rocks of late Precambrian age. Mineral assemblages are strongly influenced by the original chemical composition of the rocks.
\end{abstract}

Glaucophane-bearing rocks have long been known in the south-central Seward Peninsula (Smith, 1910; Moffit, 1913) ; mapping by the senior author from 1960 to 1968 has shown that similar rocks are exposed over much of the central and eastern Seward Peninsula. In view of the intense current interest in such rocks and problems of interpretation of their origin (Essene and others, 1965 ; Ernst, 1963; Coleman, 1967; Miyashiro, 1961), this preliminary report describes the general field relations of the Seward Peninsula rocks, summarizes the tectonic setting, and briefly describes the mineralogy and metamorphic classification of some of the rocks collected at widely scattered localities. Because of the importance of assigning the blueschist rocks to the Precambrian - blueschist rocks are uncommon in Precambrian rocks-the discussion of the stratigraphy and age relations of rocks of the Seward Peninsula is rather complete. The Precambrian rocks are similar to those of the Soviet Arctic (Rabkin and Ravich, 1961).

\section{REGIONAL GEOLOGY}

Except for small areas near Nome, which were mapped in detail by Smith (1910) and Moffit (1913), the geology of Seward Peninsula has been imperfectly known. Since 1960, mapping by the senior author, assisted in 1967-68 by Kachadoorian, has clarified the stratigraphy and structural setting. The stratigraphy is merely summarized here and is depicted in broad outline on figure 1 .

\section{Older Precambrian. rocks}

Rocks of Precambrian age form the cores of the Kigluaik and Bendeleben Mountains and crop out over wide areas elsewhere on the Seward Peninsula. The oldest rocks, exposed in the Kigluaik arch which trends east along the axis of the range, consist of plagioclaseorthoclase-quartz-biotite-hornblende paragneisses with local beds of calc-silicate rock. These paragneisses grade upward into marble gneisses with forsterite, monticellite, and muscovite, which are formed by chemical reconstitution of the impurities. Because of intense flowage and deformation, the marble gneiss varies greatly in thickness; where best exposed in the Kigluaik arch, it locally exceeds 700 feet, but it thins rapidly by tectonic squeezing. The marble gneiss is transitional with the overlying biotite-orthoclaseplagioclase-quartz paragneiss; this paragneiss is several hundred feet thick and is interbedded with thin layers of calc-silicate rocks. These upper gneisses, which have been dated by Carl Hedge (oral commun., 1969) by the whole-rock rubidium-strontium method as 750 m.y. (million years), the probable age of the metamorphism, grade upward into andalusite-garnet schists, locally gneissic, and thence into biotite-garnet schists and intercalated marble and calc-silicate rocks. Rocks equivalent to these upper schists extend continuously from the east end of the Kigluaik Mountains (fig. 1) and form the bedrock of the western and central Bendeleben Mountains. These rocks were in- 

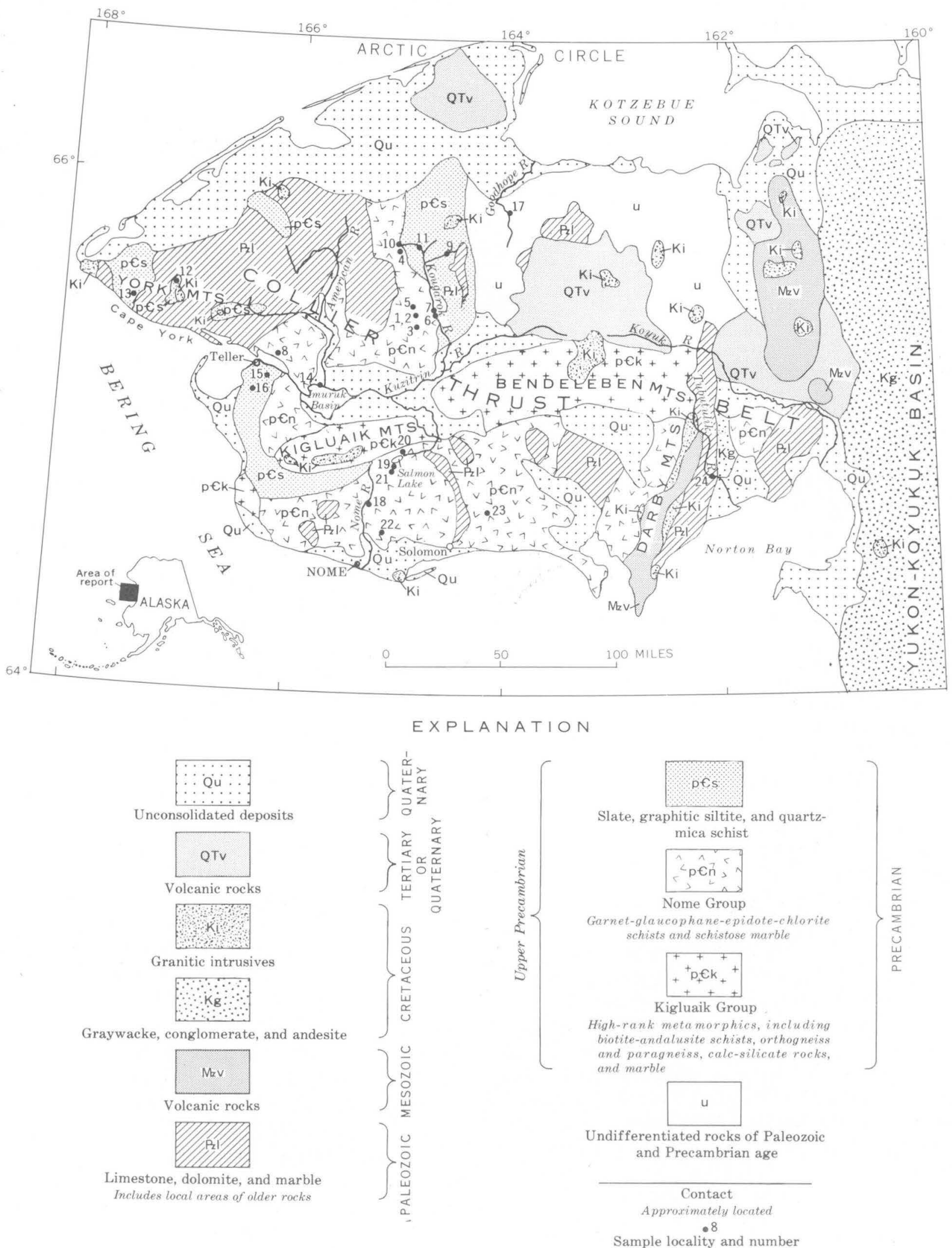

Figure 1.-Generalized geologic map of the Seward Peninsula, Alaska, showing sample localities. Geology modified by C. L. Sainsbury from Dutro and Payne (1957). Geology will be modified further when current work has been completed. 
cluded in the Kigluaik Group by Moffit (1913), and this name is retained in this report.

All the metamorphic rocks described above are intruded by biotite-orthoclase-quartz orthogneiss, which forms extensive masses in the Kigluaik Mountains, and by gneissic biotite granite, which is cataclastic in texture and which is associated with numerous coarsegrained pegmatites. All these intrusive rocks are believed to be of Precambrian age, principally because they are not known to have intruded younger Precambrian rocks.

\section{Younger Precambrian rocks}

Younger rocks which represent metamorphosed volcanic rocks, including tuffaceous sediments and mafic intrusives probably related to the volcanics, and a thick sequence of graphitic pelitic rocks crop out widely over the Seward Peninsula both in thrust slices and as wide expanses of bedrock that exceed hundreds of square miles in area. The older metavolcanic rocks are of principal interest to this report, for they include the blueschist facies rocks; they have been called the Nome Group by Brooks, Richardson, and Collier (1901), by Collier (1902), by Moffit (1913), and by Smith (1910). Although the Nome Group was generally considered to be of Paleozoic age, certain puzzling features of it (principally the wide disparity in metamorphic rank in rocks close to each other) have led some workers (for example, Moffit, 1913, p. 23) to believe that rock of Precambrian age may be included therein.

The younger graphitic rocks have been called the slate of the York region on the western Seward Peninsula by Collier (1902) and by Knopf (1908), and the Kuzitrin Series in the Kigluaik Mountains area by Brooks, Richardson, and Collier (1901); they are probably correlative with the Hurrah SIate and Puckmummie Schist (Smith, 1910) in the Solomon and Casadepaga areas east of Nome. Although several variants are well established, these graphitic or slaty rocks wherever seen exhibit the common characteristic of being composed principally of silt-size quartz grains in a graphitic matrix. The percentages of quartz, graphite, carbonate, and less common albite, chlorite, and muscovite vary from place to place, but in general appearance the rocks are remarkably similar. In contrast to the older Nome Group rocks, which everywhere are intensely deformed into recumbent isoclinal folds, sheared, and completely recrystallized, the graphitic slates not deformed by thrust faulting commonly exhibit a clearly definable clastic texture with angular quartz grains of silt size. Tectonism, thermal metamorphism, and hydrothermal alteration quickly obliterate the sedimentary texture. Nevertheless, the siliceous composition of the slates of the York region is always apparent. Although the normal contact with the Nome Group rocks has not been observed, the disparity in degree of deformation between Nome Group rocks and the slates of the York region suggests that the slates are unconformable above the Nome Group rocks. An unconformable relation is suggested, too, by the fact that Nome Group rocks are intruded by intensely deformed mafic dikes, as well as by the gabbros which alone intrude the slates.

\section{Latest Precambrian rocks}

In the York Mountains of the western Seward Peninsula, detailed mapping by Sainsbury $(1965,1969 \mathrm{~b})$ has demonstrated that the slates of the York region are overlain by more than 2,300 feet of thin-bedded argillaceous and dolomitic limestone, which is completely unmetamorphosed and utterly devoid of fossils. The contact between slate and limestone in at least one locality appears to be gradational and conformable; elsewhere over wide areas it is definitely a thrust-fault contact. These limestones are not delineated separately on the geologic map (fig. 1). At other places on the Seward Peninsula, a thick sequence of thin- to mediumbedded limestones, argillaceous limestone, and dolomitic limestone devoid of fossils overlies the thinbedded dolomitic limestone. All these carbonate rocks are clearly of pre-Ordovician age (Sainsbury, 1965). Because they are not intruded by any of the numerous gabbros that intrude the slate of the York region, they are unquestionably younger than the slates and are, therefore, probably of latest Precambrian age.

\section{Paleozoic rocks}

Detailed and reconnaissance geologic mapping in the Teller, Bendeleben, and Solomon 1:250,000 quadrangles has shown that carbonate rocks of tremendous thickness were deposited on the Seward Peninsula without a major lithologic change from Early Ordovician at least through Mississippian time. The paleostratigraphy has been deciphered from disconnected exposures in thrust plates at widely scattered localities and hence is incomplete. Nevertheless, abundant fossil collections have firmly established that the Ordovician, Silurian, Devonian, and Mississippian Systems are represented by oarbonate rocks throughout the Seward Peninsula. It can be stated emphatically that no fossiliferous noncarbonate rocks of early or middle Paleozoic age are known on the Seward Peninsula and, moreover, that the known stratigraphy allows no appreciable time for deposition of noncarbonate rocks from Ordovician through Mississippian time. No rocks of late Paleozoic age are known on the Seward Peninsula. 


\section{Post-Paleozoic rocks}

Throughout most of the Seward Peninsula, rocks of post-Paleozoic age consist mainly of intrusive rocks, which comprise biotite granites of middle to Late Cretaceous age and granitic and mafic dikes (including lamprophyres) of Late Cretaceous to early Tertiary age. The geologic map of Alaska (Dutro and Payne, 1957) shows rocks of Triassic age on the Seward Peninsula; this age assignment is erroneous, for these rocks are the slates of the York region, which are of pre-Ordovician age. During the Tertiary, small local basins were filled, giving rise to coal-bearing beds; and during the Quaternary, extensive lava fields were formed in the Imuruk Basin and lowlands. East of the Seward Peninsula, volcanic rocks and eugeosynclinal graywackes of Jurassic and Cretaceous age filled the subsiding Yukon-Koyukuk basin (Miller and others, 1959). The Mesozoic rocks extended west only to the Darby Mountains, east of the main Seward Peninsula areas where blueschist facies rocks were studied by the senior author. Some Mesozoic volcanic rocks occur west of the Tubutulik River, where blueschist rocks occur.

\section{Summary of age relations}

The above discussion shows clearly that the rocks of the Nome Group, which contain the glaucophanebearing rocks to be discussed, are intensely deformed and underlie unmetamorphosed pre-Ordovician limestones. The field relations and stratigraphy allow but one conclusion : the Nome Group rocks are considerably older than the slates of the York region, which themselves are older than the pre-Ordovician limestones. Hence, it is concluded that the blueschist facies rocks are of Precambrian age.

\section{STRUCTURE}

Throughout the Seward Peninsula, the geologic structure is dominated by thrust sheets. Thrusting was first inferred by Collier (1902, p. 18), and proved in the Nome area by Moffit (1913) and Smith (1910). Detailed mapping by Sainsbury $(1965,1969 \mathrm{a}, \mathrm{b})$ in the York Mountains showed the great extent of the thrusting and demonstrated the existence of imbricate thrust faults as the dominant structure of the western Seward Peninsula. Reconnaissance mapping to the east for 150 miles and low-level aerial reconnaissance and spot ground checks as far east as Norton Bay have demonstrated that rocks of the entire Seward Peninsula are involved in thrust sheets of tremendous extent and complexity. This thrust belt has been named the Collier thrust belt (Sainsbury, 1969b), to honor A. J. Collier, who first recognized that the limestones of the York
Mountains were not in normal stratigraphic position above the older rocks (Collier, 1902, p. 18).

In the York Mountains of the western Seward Peninsula, the thrusts mainly are horizontal or dip gently south, and the Paleozoic rocks are completely unmetamorphosed. Eastward from the York Mountains, the thrusting becomes more complex, thrusts are folded, and a weak regional metamorphism begins near the American River (fig. 1) and becomes progressively stronger eastward and southward. East of the Kougarok River, imbricate thrust sheets are intricately folded, and the Paleozoic carbonate rocks are recrystallized to sugary-textured marble in which bedding is largely obliterated. In this area, thrust sheets involve the Precambrian rocks as well as the Paleozoic, fold axes generally trend northward, and thrusting was eastward. Mapping in 1969 by Sainsbury has shown that the York Mountains thrust sheets, where thrusting was northward, are succeeded to the west by thrust sheets with intensely folded limestones of Mississippian age. The Mississippian rocks are thrust northeastward. Seemingly, then, two distinct cycles of thrusting are represented; the earlier was characterized by intense folding and eastward transport, the younger was characterized by imbricate thrusting without major folding and by northward transport.

Because the thrust sheets have been intruded by granite stocks of middle to Late Cretaceous age, the thrusting is earlier than middle Cretaceous. As the thrust belt is probably buried by the Cretaceous rocks of the Yukon-Koyukuk basin, the thrusting is apparently of pre-mid-Cretaceous age, for the Jurassic and Lower Cretaceous rocks are intimately folded. No upper Paleozoic or lower Mesozoic rocks being known in the thrust belt, the thrusting cannot be dated more precisely than post-Mississippian and pre-Late Cretaceous, although it most likely is of Early Cretaceous age. The regional thermal metamorphism impressed upon the thrust sheets in the eastern Seward Peninsula is probably related to the intrusion of large batholiths and stocks of granite and related syenites, which have been dated as of mid-Cretaceous age (Miller and others, 1966). Biotite separated from Precambrian schists in the Kougarok River area, where Paleozoic limestones of thrust sheets are metamorphosed to marble, gave a "re-set" age date of 100 m.y., on the basis of the potassium-argon method (J. D. Obradovich, oral commun., 1969). Apparently, regional metamorphism and intrusion of granitic batholiths were related and occurred generally in the Cretaceous. This regional thermal metamorphism probably caused the marked retrograde metamorphism of the blueschist facies rocks. 


\section{BLUESCHIST ROCKS}

The blueschist and related rocks to be described were sampled at widely scattered localities on the Seward Peninsula-all samples, however, came from rocks belonging to the Nome Group (p. B35). Wherever seen, the Nome Group rocks consist of greenish schists and intercalated beds of schistose marble. Locally, dark-green rocks intrude both the limestones and the schists and are themselves locally converted to blueschist rocks. Where exposures are good, color banding and lithologic variations in the Nome Group rocks suggest that the Nome Group represents old volcanic rocks, tuffs, and tuffaceous limestones. Locally, as in the Nome River valley, where samples 68-ASn-566 to $566 \mathrm{H} \mathrm{(p.} \mathrm{B41)} \mathrm{were} \mathrm{collected,} \mathrm{irregular} \mathrm{masses} \mathrm{of}$ rock related to the blueschist facies are isolated within schistose marble (fig. 2), thus showing unquestionable contemporaneity of calcareous muds and material most logically interpreted as tuff or volcanic bombs. Similar relations have been observed in southeastern Alaska (Sainsbury, 1961, p. 315), where pyritized volcanic bombs are encased in unaltered limestone. For comparison with the blueschist rocks, altered mafic intrusive rocks from west of the main blueschist belt are described. All sample localities are shown on figure 1.

\section{Petrography}

For this preliminary report, Coleman has classified rocks collected by Sainsbury in 1967, and determined to be glaucophane-bearing, into four groups that are correlative with types originally defined by Coleman and Lee (1963) in the Cazadero area, California. Rocks collected by F. H. Moffit from the Solomon area and by W. C. Mendenhall from the Darby Mountains on the

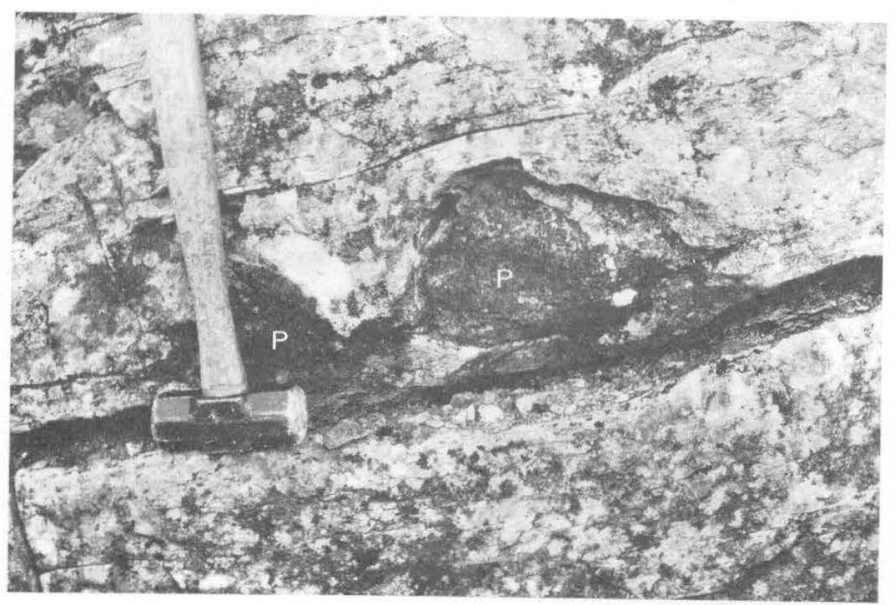

Figure 2.-Pods (P) of rock related to the blueschist facies in schistose marble of the Nome Group. eastern Seward Peninsula are described briefly, and reference is made to probable blueschist rocks discussed by Smith (1910). The suite of related rocks (group 6) from a small area in the Salmon Lake area (fig. 1) was classified by Sainsbury.

Five groups of rocks are recognized: (1) glaucophane schists, (2) retrograde glaucophane schists, (3) metasedimentary rocks, (4) metagabbros not converted to blueschist rocks, and (5) metagabbros or metavolcanic rocks intrusive into Precambrian limestones and belonging to the blueschist facies. The detailed collection localities of all the samples to be described are given in table 1.

Group 1 rocks represent the following mineral assemblages :

\begin{tabular}{|c|c|}
\hline Field No. & Description \\
\hline$-\mathrm{ASN}-264$ & $\begin{array}{l}\text { Glaucophane-actinolite-chlorite-epidote- } \\
\text { garnet-sphene-white mica-quartz. }\end{array}$ \\
\hline 67-ASn-264A. & $\begin{array}{l}\text { Glaucophane-epidote-garnet-sphene- } \\
\text { rutile-chlorite. }\end{array}$ \\
\hline $67-\mathrm{ASn}-50$ & $\begin{array}{l}\text { Glaucophane-epidote-garnet-chlorite- } \\
\text { sphene-white mica-quartz-rutile. }\end{array}$ \\
\hline 67-ASn-595 & $\begin{array}{l}\text { Glaucophane-garnet-sphene-white } \\
\text { mica. }\end{array}$ \\
\hline
\end{tabular}

These rocks are foliated because of orientation of the platy minerals; garnets are euhedral to subhedral porphyroblasts (nonhelical), which contain abundant inclusions of the other minerals that make up the rest of the rock. The blue amphibole was identified as glaucophane on the basis of the following optical constants: $2 V=30-40^{\circ}(-), Z \wedge C$ less than $7^{\circ}, x=$ colorless, $y=$ purple, and $z=$ blue. In sample $67-\mathrm{ASn}-264$, the actinolite coexists with the glaucophane and is not retrograde. The epidote forms anhedral masses, and individual grains have iron-rich cores as deduced by birefringence and color. Sphene is common, generally forming anhedral masses-euhedra are very rare. The rutile occurs within the sphene masses and may be retrograding to sphene. Some of the minor chlorite may be retrograde, but much of it is intergrown with glaucophane and probably is in equilibrium with it. The sparse white mica may be phengitic. The small amount of quartz commonly occurs in the pressure shadows behind garnets. Apatite is a minor accessory; small opaque grains associated with rutile may be ilmenite.

The textures (fig. 3) and mineral assemblages are nearly identical with those of the "high-grade" type IV blueschists from California and New Caledonia (Coleman, 1967). However, these Seward Peninsula glaucophane schists lack omphacite, which is common in type IV blueschists of California (Coleman and Lee, 1963). 
TABLE 1.-Localities and descriptions of samples referred to in this report

\begin{tabular}{|c|c|c|c|c|c|c|}
\hline Group & $\begin{array}{l}\text { Map } \\
\text { No. }\end{array}$ & Field No. & Locality & Latitude (N.) & Longitude (W.) & General description of sampled rock body \\
\hline \multirow[t]{4}{*}{$1 \ldots \ldots$} & 1 & 67-ASn-264 & West of Kougarok River. & $65^{\circ} 26^{\prime} 20^{\prime \prime}$ & $164^{\circ} 55^{\prime} 30^{\prime \prime}$ & $\begin{array}{l}\text { Frost-riven massive boulders on surface of } \\
\text { tundra-covered ridge. }\end{array}$ \\
\hline & 2 & 67-ASn-264A & -.... do & $65^{\circ} 26^{\prime} 20^{\prime \prime}$ & $164^{\circ} 55^{\prime} 30^{\prime \prime}$ & $\begin{array}{l}\text { Schistose frost-riven boulders surrounding } \\
67-\mathrm{ASn}-264 \text {. }\end{array}$ \\
\hline & 3 & 67-ASn-503 & . do & $65^{\circ} 24^{\prime} 20^{\prime \prime}$ & $164^{\circ} 54^{\prime} 30^{\prime \prime}$ & $\begin{array}{l}\text { Frost-riven massive boulders on surfaces } \\
\text { of tundra-covered ridge. }\end{array}$ \\
\hline & 4 & 67-ASn-595 & $\begin{array}{l}\text { West headwaters of } \\
\text { Kougarok River. }\end{array}$ & $65^{\circ} 42^{\prime} 20^{\prime \prime}$ & $164^{\circ} 59^{\prime} 50^{\prime \prime}$ & $\begin{array}{l}\text { Float boulders in creek bed, surrounded by } \\
\text { tundra-covered hills. }\end{array}$ \\
\hline \multirow[t]{3}{*}{$2 \ldots \ldots . . .-1$} & 5 & 67-ASn-373 & West of Kougarok River_ & $65^{\circ} 30^{\prime} 35^{\prime \prime}$ & $164^{\circ} 55^{\prime} 50^{\prime \prime}$ & $\begin{array}{l}\text { Frost-riven boulders on tundra-covered } \\
\text { ridgeline. }\end{array}$ \\
\hline & 6 & $67-\mathrm{ASn}-438$ & Bed of Kougarok River.. & $65^{\circ} 28^{\prime}$ & $164^{\circ} 42^{\prime} 30^{\prime \prime}$ & $\begin{array}{l}\text { Small outcrop on east bank of river, mas- } \\
\text { sive-appearing blueschist. }\end{array}$ \\
\hline & 7 & 67-ASn-439 & $\ldots$ do $_{-}$ & $65^{\circ} 29^{\prime}$ & $164^{\circ} 43^{\prime}$ & $\begin{array}{l}\text { Outcrop on west bank of River, relatively } \\
\text { sheared, pyrrhotite noticeable. }\end{array}$ \\
\hline \multirow[t]{5}{*}{$3 \ldots \ldots$} & 8 & 67-ASn-137 & $\begin{array}{l}\text { North of Grantley } \\
\text { Harbor. }\end{array}$ & $65^{\circ} 19^{\prime}$ & $166^{\circ} 06^{\prime} 30^{\prime \prime}$ & $\begin{array}{l}\text { Graphitic slate band in chloritic schist, } \\
\text { float on ridgeline. }\end{array}$ \\
\hline & 9 & 67-ASn-326 & $\begin{array}{l}\text { East of Kougarok River, } \\
\text { top of Harris Dome. }\end{array}$ & $65^{\circ} 37^{\prime} 30^{\prime \prime}$ & $164^{\circ} 33^{\prime} 40^{\prime \prime}$ & Thrust "xenolith" in marble. \\
\hline & 10 & $67-\mathrm{ASn}-369$ & $\begin{array}{l}\text { West headwaters of } \\
\text { Kougarok River, north } \\
\text { bank of Washington } \\
\text { Creek. }\end{array}$ & $65^{\circ} 44^{\prime}$ & $164^{\circ} 58^{\prime}$ & Outcrop of calcareous, lineated slate. \\
\hline & 11 & $67-\mathrm{ASn}-434$ & $\begin{array}{l}\text { West fork of Kougarok } \\
\text { River, north bank of } \\
\text { Washington Creek. }\end{array}$ & $65^{\circ} 44^{\prime} 20^{\prime \prime}$ & $164^{\circ} 52^{\prime}$ & Outcrop of sheared calcareous slate. \\
\hline & 12 & $62-\mathrm{ASn}-652 \mathrm{D}$ & $\begin{array}{l}\text { t shoulder, } \\
\text { Mountain. }\end{array}$ & $65^{\circ} 33^{\prime}$ & $167^{\circ} 04^{\prime}$ & $\begin{array}{l}\text { Outcrop, siliceous graphitic bed with } \\
\text { numerous quartz pods. }\end{array}$ \\
\hline \multirow[t]{5}{*}{$4 \ldots \ldots$} & 13 & $61-\mathrm{ASn}-477$ & $\begin{array}{l}\text { West bank, Kanauguk } \\
\text { River. }\end{array}$ & $65^{\circ} 32^{\prime}$ & $167^{\circ} 31^{\prime} 30^{\prime \prime}$ & Outcrop in creek bed, graphitic siltite. \\
\hline & 14 & $67-A S n-65$ & $\begin{array}{l}\text { North shore, Imuruk } \\
\text { Basin. }\end{array}$ & $65^{\circ} 11^{\prime} 40^{\prime \prime}$ & $165^{\circ} 46^{\prime} 30^{\prime \prime}$ & $\begin{array}{l}\text { Outcrop at beach level, gray-green mafic } \\
\text { dike, sheared. }\end{array}$ \\
\hline & 15 & 67-ASn-135E & $\begin{array}{l}\text { South of Grantley } \\
\text { Harbor. }\end{array}$ & 6 & 16 & Frost-riven rubble of mafic intrusive. \\
\hline & 16 & 67 & $\begin{array}{l}\text { Southeast of Gantley } \\
\text { Harbor. }\end{array}$ & 6 & $166^{\circ} 2$ & usive into lime- \\
\hline & 17 & 68-ASn-136 & $\begin{array}{l}\text { East bank, Goodhope } \\
\text { River. }\end{array}$ & & $164^{\circ} 03^{\prime}$ & $\begin{array}{l}\text { Altered gabbro dike intrusive into chloritic } \\
\text { schist. }\end{array}$ \\
\hline \multirow[t]{3}{*}{5} & 18 & $67-\mathrm{ASn}-41$ & $\begin{array}{l}\text { Headwaters of Nome } \\
\text { River. }\end{array}$ & $64^{\circ} 50^{\prime} 12^{\prime \prime}$ & $165^{\circ} 12^{\prime} 20^{\prime \prime}$ & Sheared gabbro intruding limestone schist. \\
\hline & 19 & 68-ASn-567 & $\begin{array}{l}\text { Southeast of Salmon } \\
\text { Lake. }\end{array}$ & $64^{\circ} 52^{\prime}$ & $165^{\circ} 10^{\prime}$ & Lenticular body (tuff?) in limestone schist. \\
\hline & 20 & 68-ASn-444 & $\begin{array}{l}\text { Northeast of Salmon } \\
\text { Lake. }\end{array}$ & $64^{\circ} 57^{\prime} 30^{\prime \prime}$ & $164^{\circ} 50^{\prime} 20^{\prime \prime}$ & Mafic inclusion in limestone schist. \\
\hline \multirow[t]{2}{*}{$6 \ldots \ldots$} & 21 & $68-\mathrm{ASn}-566$ & $\begin{array}{l}\text { Southeast of Salmon } \\
\text { Lake. }\end{array}$ & $64^{\circ} 52^{\prime} 04^{\prime \prime}$ & $165^{\circ} 10^{\prime}$ & $\begin{array}{l}\text { Well-exposed outcrop of chloritic schist, } \\
\text { faint color banding. }\end{array}$ \\
\hline & & $\begin{array}{l}\text { 68-ASn-566B } \\
68-\mathrm{ASn}-566 \mathrm{C} \\
68-\mathrm{ASn}-566 \mathrm{D} \\
68-\mathrm{ASn}-566 \mathrm{E} \\
68-\mathrm{ASn}-566 \mathrm{~F} \\
68-\mathrm{ASn}-566 \mathrm{G} \\
68-\mathrm{ASn}-566 \mathrm{H}\end{array}$ & 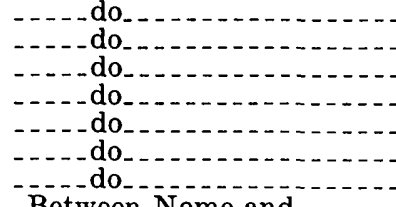 & do & 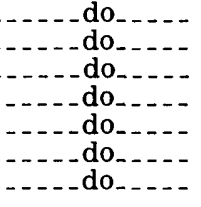 & $\begin{array}{l}\text { Do. } \\
\text { Do. } \\
\text { Do. } \\
\text { Do. } \\
\text { Do. } \\
\text { Do. } \\
\text { Do. }\end{array}$ \\
\hline & 22 & Moffit's (1913) & $\begin{array}{l}\text { Between Nome and } \\
\text { Solomon. }\end{array}$ & & & $\begin{array}{l}\text { Chloritic schist of the Nome Grolip, es- } \\
\text { pecially intrusives in marble. }\end{array}$ \\
\hline & 23 & $\begin{array}{l}\text { Smith's (1910) } \\
\text { area. }\end{array}$ & & & & $\begin{array}{l}\text { "Greenstones" and chloritic schists of the } \\
\text { Nome Group. }\end{array}$ \\
\hline None) - & 24 & $\begin{array}{l}\text { Mendenhall's } \\
\text { (1901)area. }\end{array}$ & $\begin{array}{l}\text { Tubutulik River, eastern } \\
\text { Seward Peninsula. }\end{array}$ & & & $\begin{array}{l}\text { Chloritic schist within or beneath thrust } \\
\text { slices of marble. }\end{array}$ \\
\hline
\end{tabular}

The absence of lawsonite and aragonite in the Alaskan rocks indicates that these rocks are not similar to the lower grade type III rocks of the Cazadero area, where the mineral assemblage is glaucophane-lawsonite-chlorite \pm phengite \pm aragonite \pm jadetic pyroxene-sphene.

Group 2 rocks clearly are retrograde blueschists. Specimens and mineral assemblages are listed below, with the unusual minerals in italic:

\begin{abstract}
Field No.
67-Aisn-373

Description

$67-\mathrm{ASn}-438$

67-ASn-439

Chlorite-actinolite-white mica-albitegarnet-epidote-sphene-(aragonite?). Albite-chlorite-actinolite-garnetepidote-sphene. Albite-chlorite-actinolite-epidote-
garnet-sphene-glaucophane-calcite
\end{abstract}

These rocks clearly show a strong retrogression to greenschist facies under static conditions; some original foliation remains but is not inherited by the retrograde 


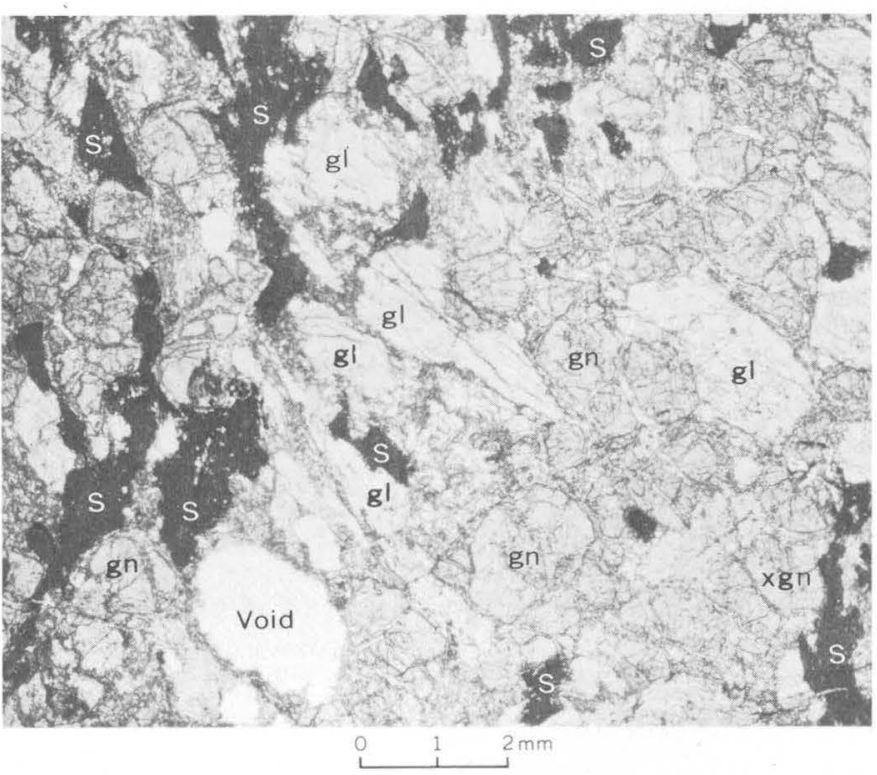

Figure 3.-Photomicrograph of typical coarse-grained garnetglaucophane rock from the Kougarok River drainage; gl, glaucophane; gn, garnet; S, sphene; $x$ gn, garnet with glaucophane in fractures. Plain light. Photomicrograph by Ernest Krier, U.S. Geological Survey.

minerals. The apparent original blueschist minerals are glaucophane-epidote-garnet-sphene; of these, glaucophane and garnet have been most altered, glaucophane being virtually absent. The glaucophane relicts are being replaced and surrounded by a pale-green amphibole, which is set in a matrix of chlorite and albite. The new amphibole looks like actinolite but with detailed study may prove to be common hornblende. A possible reaction for this retrogression is as follows:

$$
\begin{aligned}
& 25\left(\mathrm{H}_{2} \mathrm{Na}_{2} \mathrm{Mg}_{3} \mathrm{Al}_{2} \mathrm{Si}_{8} \mathrm{O}_{24}\right)+6\left(\mathrm{HCa}_{2} \mathrm{Al}_{3} \mathrm{Si}_{3} \mathrm{O}_{13}\right)+7\left(\mathrm{SiO}_{2}\right)+14 \mathrm{H}_{2} \mathrm{O} \rightarrow \\
& \text { glaucophane }+ \text { epidote }+ \text { quartz + water } \\
& 50\left(\mathrm{NaAlSi}_{3} \mathrm{O}_{8}\right)+9\left(\mathrm{H}_{8} \mathrm{Mg}_{5} \mathrm{Al}_{2} \mathrm{Si}_{3} \mathrm{O}_{18}\right)+6\left(\mathrm{H}_{2} \mathrm{Ca}_{2} \mathrm{Mg}_{5} \mathrm{Si}_{8} \mathrm{O}_{24}\right) \text {. } \\
& \text { albite }+ \text { chlorite }+ \text { actinolite }
\end{aligned}
$$

Although chlorite and actinolite occur in rocks of the first group, they are intergrown with glaucophane and are not clearly retrograde as in the second group. Retrograde rocks have been identified at other localities on the Seward Peninsula, and apparently an initial period of blueschist metamorphism was followed by at least one period of static heating or loss of high pressure with concomitant change to greenschist or epidote-amphibolite facies. As will be shown in the final part of this report, the dynamic metamorphism that produced the blueschist rocks was probably of Precambrian age; hence, the blueschists have gone through a major thrust cycle, which produced no regional metamorphism, as well as a younger regional metamorphism in Cretaceous time that made marble of limestone. In addition, local hydrothermal altera- tion has further modified some of the blueschist rocks. The retrograde metamorphism recorded by the rocks of group 2 cannot as yet be definitely correlated with the Cretaceous thermal event, principally because blueschist rocks have not been found outside the zone of regional thermal metamorphism. However, massive garnet-glaucophane rocks of group 1 and retrograde rocks of group 2 occur within a few miles of one another, showing that retrogression was not regional in scope.

Group 3 rocks consist of metapelitic rocks equivalent to the slate of the York region; these rocks are younger than the Nome Group rocks of groups 1 and 2. They were examined principally to see if they contained aragonite, for some contain appreciable carbonate. All are from rocks believed to be younger than the Nome Group, which contain the blueschists here described; and all represent mildly metamorphosed pelitic rocks, which were originally composed principally of silt-size quartz grains, minor clay minerals, carbonaceous matter, and carbonate. The samples studied are glistening black phyllites with veinlets of white quartz. Two distinct S-planes are visible, an S-1 plane which represents the main foliation, and an S-2 plane which

\begin{tabular}{|c|c|}
\hline Field No. & Description \\
\hline$-\mathrm{ASn}-137$ & Quartz-mica-graphite-chlorite-albite. \\
\hline 6 & $\begin{array}{l}\text { Quartz-mica-carbonate-chlorite- } \\
\text { graphite. }\end{array}$ \\
\hline $67-\mathrm{ASn}-369$ & $\begin{array}{l}\text { Quartz-albite-mica-chlorite-- } \\
\text { carbonate-graphite. }\end{array}$ \\
\hline $67-\mathrm{ASn}-434_{--}$ & $\begin{array}{l}\text { Quartz-albite-chlorite-mica- } \\
\text { carbonate-graphite. }\end{array}$ \\
\hline 62-ASn-652D_. & $\begin{array}{l}\text { Quartz-albite-white mica-carbonate- } \\
\text { graphite. }\end{array}$ \\
\hline
\end{tabular}
consists of a strong crinkling of the S-1 planes. Individual samples and their mineral assemblages are as follows :

Present textures of these rocks are metamorphic and markedly schistose. The albite (indices less than for Canada balsam) forms irregular porphyroblasts that contain numerous inclusions of graphite; carbonate occurs as irregular porphyroblasts. The mica is mainly white (phengitic?) and is concentrated along folia; locally, chlorite is interleaved with the white mica. Opaque clots are mostly graphite, but some rutile needles were observed.

These graphitic metapelitic rocks probably belong to the greenschist facies-a classification which agrees with the impression given by field mapping. Although in places the rocks are so completely recrystallized that quartz grains are much larger and graphite is completely clotted, temperatures were so low that quartz 
did not react with calcite to form calc-silicate rocks. There is no hint of blueschist-facies metamorphism in any of the rocks examined.

Group 4 rocks represent selected specimens of metagabbros and related mafic dikes that intruded rocks as young as the slate of the York region at many places throughout the Seward Peninsula. These mafic dikes are compositionally close to volcanic rocks and might have been expected to become blueschists, if they had gone through the blueschist metamorphic event. All have gone through the thrust cycles. Selected specimens were collected progressively from west to east across the Seward Peninsula (fig. 1, table 1), from outside the zone of blueschist facies into the Kougarok River area where blueschist rocks are common. The following is a list of these rocks and their mineral assemblages:

\begin{tabular}{|c|c|}
\hline Field No. & Description \\
\hline $61-\mathrm{ASn}-477$ & $\begin{array}{l}\text { Augite-titaniferous magnetite- } \\
\text { leucoxene-labradorite-serpentine- } \\
\text { sideritic carbonate. }\end{array}$ \\
\hline $67-\mathrm{ASn}-65$ & $\begin{array}{l}\text { Actinolite-epidote-chlorite-albite- } \\
\text { augite (?)-white mica. }\end{array}$ \\
\hline 67-ASn-135E_ & $\begin{array}{l}\text { Titaniferous augite-ilmenite-leucoxene- } \\
\text { white mica-chlorite-actinolite- } \\
\text { epidote. }\end{array}$ \\
\hline $67-\mathrm{ASn}-242$ & $\begin{array}{l}\text { Augite-actinolite-epidote-albite- } \\
\text { leucoxene-titaniferous magnetite(?)- } \\
\text { chlorite. }\end{array}$ \\
\hline 68-ASn-136 & $\begin{array}{l}\text { Augite-actinolite-leucoxene-epidote- } \\
\text { chlorite-plagioclase. }\end{array}$ \\
\hline
\end{tabular}

These rocks, though containing minerals such as epidote, chlorite, and actinolite, which are often found in the retrograde blueschists, differ markedly from the blueschist rocks in several respects: (1) primary augite remains, (2) zoned high-calcic plagioclase remains, (3) opaque iron ores remain and are altering to leucoxene, (4) the relict igneous texture is clearly visible, and (5) none contain garnets. The textures, shearing, and metamorphic minerals are possibly related to the thrust cycles and to the younger regional static thermal metamorphism; clearly, however, none of these rocks have been completely reconstituted and made schistose as has happened to chemically similar blueschist rocks. Nevertheless, the most altered of these rocks resemble the retrograde blueschists somewhat, although they are readily distinguished in thin section. The rocks of this group intruded the upper Precambrian slates, but not the younger carbonate rocks, and are probably of late or latest Precambrian age.

Group 5 rocks represent mafic dikes that cut limestone schists in the Nome Group of Precambrian age, and altered mafic material occurring as lenticular beds (fig. 2) and isolated clots in limestone schists inter- calated in the blueschists of the Nome Group. These rocks and their mineral assemblages are listed below:

Field No.
67-ASn-41_-
68-ASn-567__arnet-quartz-epidote-apatite-sphene-
albite-chlorite-calcite-blue-green
amphibole.
Garnet-white mica-epidote-quartz-
calcite-sphene-apatite-magnetite-
hematite.
Garnet-albite-epidote-chlorite-sphene-
quartz-calcite.

These rocks are unusual in that they contain garnet, are obviously schistose, and lack glaucophane. The mafic material which occurs in the limestone lacks amphibole entirely, whereas it commonly contains white mica. Garnets are subhedral to anhedral, and most contain numerous inclusions. There is no clear evidence that these rocks ever contained glaucophane. The limestone shown in figure 3, which surrounds the material represented by $68-\mathrm{ASn}-567$, is schistose and contains rounded quartz grains and white mica. The quartz grains have not reacted with the carbonate. The schistosity, complete mineralogical reconstitution, and lack of relict igneous textures and minerals show that this group of rocks, though in part definitely intrusive, has passed through a regional metamorphism in a high-stress environment which did not affect the metagabbros of group 4. Hence, it is concluded that the blueschist metamorphism occurred between the intrusion of the two different mafic-dike suites that are represented by rocks of groups 4 and 5 , and must, therefore, be of late Precambrian age.

\section{Petrography of related variants}

A suite of samples (group 6) from a well-exposed outcrop of Nome Group blueschist rocks (fig. 4) was

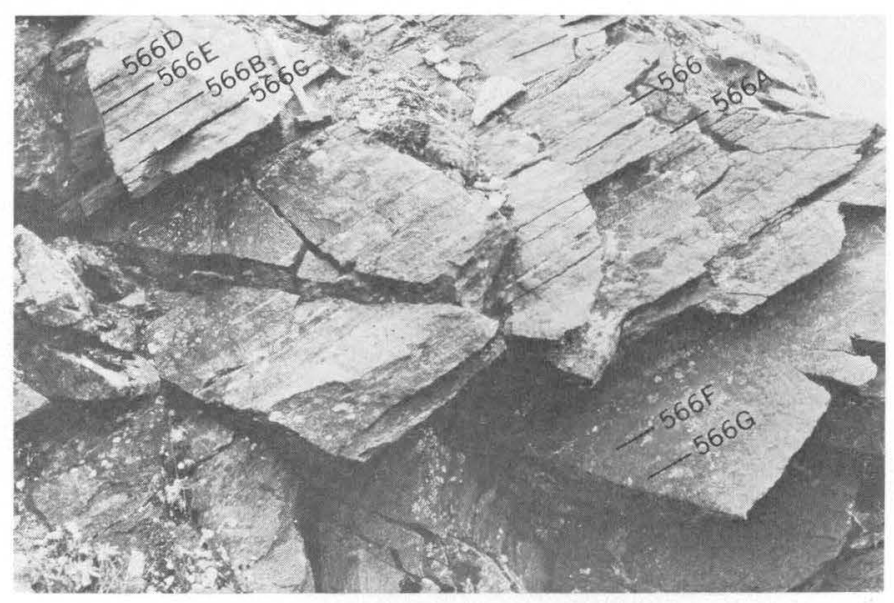

FigURE 4.-Photograph of outerop of retrograde bluechist rocks, showing location of closely spaced samples. All sample numbers are preceded by $68-\mathrm{ASn}$ : 
studied to determine the mineralogical variations within a restricted area. Individual samples and mineral assemblages as determined by Sainsbury are listed below:

\begin{tabular}{|c|c|}
\hline Field No. & Description \\
\hline 68-ASn-566. & $\begin{array}{l}\text { Garnet-white mica-chlorite-sphene- } \\
\text { calcite-quartz-blue-green amphibole- } \\
\text { epidote-pyrite. }\end{array}$ \\
\hline $68-\mathrm{ASn}-566 \mathrm{~B}$ & $\begin{array}{l}\text { Quartz-white mica-garnet-epidote- } \\
\text { sphene-minor blue-green amphibole- } \\
\text { apatite. }\end{array}$ \\
\hline $68-\mathrm{ASn}-566 \mathrm{C}$ & $\begin{array}{l}\text { Quartz-albite-white mica-garnet- } \\
\text { calcite-sphene-epidote-apatite. }\end{array}$ \\
\hline 68-ASn-566D_.- & $\begin{array}{l}\text { Quartz-albite-white mica-chlorite- } \\
\text { garnet. }\end{array}$ \\
\hline 68-ASn-566E... & $\begin{array}{l}\text { Calcite-white mica-quartz-epidote- } \\
\text { sphene-garnet in calcite-rich layer; } \\
\text { and quartz-calcite-white mica- } \\
\text { sphene-chlorite-apatite-pyrrhotite in } \\
\text { quartz-rich part. }\end{array}$ \\
\hline $68-\mathrm{A} \cdot \mathrm{Sn}-566 \mathrm{~F}$ & $\begin{array}{l}\text { Quartz-albite-white mica-chlorite- } \\
\text { garnet-magnetite-biotite-apatite- } \\
\text { biotite. }\end{array}$ \\
\hline 68-ASn-566G_ & $\begin{array}{l}\text { Quartz-albite-white mica-garnet- } \\
\text { chlorite-magnetite-biotite-apatite. }\end{array}$ \\
\hline 68-ASn-566H. & $\begin{array}{l}\text { Quartz-albite-white mica-chlorite- } \\
\text { epidote-magnetite-calcite. }\end{array}$ \\
\hline
\end{tabular}

These rocks are clearly retrograde garnet-bearing rocks, but the mineral assemblages are controlled by the bulk composition of the rock. Where quartz, albite, or calcite predominates, blue amphibole and sphene are virtually absent. In quartz-albite-rich rocks, garnet is poorly developed, forming a net that surrounds quartz and albite grains; in the rock that contains amphibole, garnet is subhedral. Chlorite is retrograde from white mica. The development of bits of biotite in 68-ASn-566F suggests that a thermal event has been impressed upon the retrograde rocks. This event is probably correlative with the intrusion of granite stocks in the Kigluaik Mountains.

\section{Other areas of blueschisł rocks}

Blueschist-facies rocks were reported by Moffit (1913, p. 32-33) east of Nome at Osborn and Buster Creeks (area 22, fig. 1), where they are in part intrusive into schistose limestone of the Nome Group. The mineral assemblage reported by Moffit (1913) is garnet-glaucophane-chlorite-epidote-titanite-albite; locally, iron ores, pyrite, rutile, quartz, and calcite occur. Moffit noted that the rocks intrusive into limestone are less schistose than the surrounded blueschists. Smith (1910, p. 76-83) discussed glaucophane-bearing rocks in the Solomon area (area 23, fig. 1); he stated that some are unquestionably intrusive into limestone (see photograph on p. 76 of Smith, 1910), and that two ages of mafic intrusives are represented:
It should be stated, however, that although some of the feldspathic schists were undoubtedly formed from rocks similar in composition to the greenstones, a part of the greenstones are later than these schists, for they show but slight evidences of having been subjected to the same amount of metamorphism.

Smith did not describe individual mineral assemblages of single rock specimens. He noted, however, that most contain garnet, green to blue soda amphibole, chlorite, sphene, quartz, and albite; this mineralogy relates them to the blueschist facies. The rocks described by Smith belong to the Nome Group.

Mendenhall (1901) collected chloritic rocks in the Darby Mountains of the southeastern Seward Peninsula (area 24, fig. 1). Two thin sections representing two of these rocks were reexamined in 1969 by T. P. Miller (written commun., 1969), who reported that one rock is a glaucophane schist. The mineral assemblage reported by Miller is chlorite-albite-epidotesphene-glaucophane; the rock is foliated. The second sample, collected 500 feet away, has relict clinopyroxene associated with colorless amphibole. The mineral assemblages in these two rocks are similar to those of groups 1 and 4 of this report and are the basis for inference by the senior author that the rock containing clinopyroxene is a later intrusive into blueschist-facies rocks of the Nome Group; such a relationship is common far to the west.

\section{CONCLUSIONS}

All the blueschist rocks herein described are believed to belong to a metamorphosed sequence of Precambrian age-the Nome Group. The original rocks probably contained varying amounts of mafic volcanic material that included lavas, tuffs, and dikes related to the volcanism. Numerous interbedded limestones suggest that the depositional environment was marine: After deposition of the Nome Group rocks, an intense regional dynamic metamorphism was impressed upon Nome Group rocks over thousands of square miles of the Seaward Peninsula, creating blueschist-facies rocks. After the dynamic metamorphism, a carbonaceous siltite was deposited over much of the Seward Peninsula; the siltite was then intruded by numerous dikes, sills, and bosses of gabbro. All these rocks are believed to be of late Precambrian age. In latest Precambrian time, impure thin-bedded limestones were deposited over much of the Seward Peninsula and are completely unmetamorphosed in the area from Teller west. During Cambrian time, the Seward Peninsula probably was a positive area, for no rocks of this age are known. From Early Ordovician through Mississippian time, carbonate rocks were deposited over the Seward Peninsula. After deposition of the Mississippian limestone and prior to the injection of granitic rocks in the mid- 
Cretaceous, rocks of the entire Seward Peninsula were involved in intensive thrust faulting, which juxtaposed Precambrian schists and clastic rocks against Paleozoic carbonate rocks. This juxtaposition led to the puzzling age relations that baffled early workers and led them to conclude that the Nome Group rocks were of Precambrian and Paleozoic age. After the thrusting, granitic rocks were emplaced and formed isolated stocks on the western Seward Peninsula and large batholiths on the eastern Seward Peninsula. The heating associated with the intrusion of granitic rocks probably accounts for the great increase in the metamorphosis of the Paleozoic carbonate of the thrust sheets from west to east. The west-to-east increase in the size of the intrusives-and, concomitantly, in the amount of heat introduced-probably caused the corresponding great increase in the metamorphism of the Paleozoic carbonates of the thrust sheets.

The blueschist rocks are confined to units older than gabbros of latest Precambrian age. Glaucophane-bearing rocks occur near retrograde blueschist rocks because of tectonic transport by thrusting and by local factors, such as hydrothermal alteration, nearness to younger granites, and proximity to thrust faults. The metamorphic fabric of the blueschist rocks clearly shows two periods of deformation, the second of which probably corresponds to the thrust cycle. Blueschist facies rocks often occur in polymetamorphic terranes (Zwart, 1967) or are juxtaposed against lower grade rocks (Coleman, 1967) in a way that leads to enigmatic geologic situations, and the blueschists of the Seward Peninsula conform to that general pattern. However, it should be emphasized that the Seward Peninsula is not part of the circum-Pacific tectonic belt which contains the well-studied blueschist rocks of late Mesozoic age, but rather represents a well-preserved area of Precambrian blueschist rocks.

This preliminary report records the results of studies made as a very minor part of a regional mapping program, and important relations may be glossed over. The blueschist-facies terrane here discussed offers geologic conditions, such as intense thrusting and later progressive metamorphism, which are not every where found. It is hoped that this report will lead to detailed studies by geologists and mineralogists interested in the formation and destruction of blueschist-facies rocks.

\section{REFERENCES}

Brooks, A. H., assisted by Richardson, G. B., and Collier, A. J., 1901, A reconnaissance of the Cape Nome and adjacent $\operatorname{gold}$ fields of Seward Peninsula, Alaska, in 1900, p. 1-185 in Reconnaissances in the Cape Nome and Norton Bay regions, Alaska, in 1900 : U.S. Geol. Survey Spec. Pub., 222 p.

Coleman, R. G., 1967, Glaucophane schists from California and New Caledonia, in Age and nature of the circum-Pacific: Tectonophysics, v. 4, no. 4-6, spec. issue, p. 479-498.

Coleman, R. G., and Lee, D. E., 1963, Glaucophane-bearing metamorphic rock types of the Cazadero area, California: Jour. Petrology, v. 4, no. 2, p. 260-301.

Collier, A. J., 1902, A reconnaissance of the northwestern portion of Seward Peninsula, Alaska: U.S. Geol. Survey Prof. Paper 2, $70 \mathrm{p}$.

Dutro, J. T., Jr., and Payne, T. G., 1957, Geologic map of Alaska : U.S. Geol. Survey.

Ernst, W. G., 1963; Petrogenesis of glaucophane schists : Jour. Petrology, v. 4, no. 1, p. 1-30.

Essene, E. J., Fyfe, W. S., and Turner, F. J., 1965, Petrogenesis of Franciscan glaucophane schists and associated metamorphic rocks, California: Beitr. Mineralogie u. Petrographie, v. 11 , no. 7 , p. $695-704$.

Knopf, Adolph, 1908, Geology of the Seward Peninsula tin deposits, Alaska : U.S. Geol. Survey Bull. 358, 71 p.

Mendenhall, W. C., 1901, A reconnaissance in the Norton Bay region, Alaska, in 1900, p. 187-218 in Reconnaissances in the Cape Nome and Norton Bay regions, Alaska, in 1900: U.S. Geol. Survey Spec. Pub., 222 p.

Miller, D. J., Payne, T. G., and Gryc, George, 1959, Geology of possible petroleum provinces in Alaska, with an Annotated bibliography, by E. H. Cobb : U.S. Geol. Survey Bull. 1904, $131 \mathrm{p}$.

Miller, T. P., Patton, W. W., Jr., and Lanphere, M. A., 1966, Preliminary report on a plutonic belt in west-central Alaska, in Geological Survey Research 1966: U.S. Geol. Survey Prof. Paper 550-D, p. D158-D162.

Miyashiro, A., 1961, Evolution of metamorphic belts: Jour. Petrology, c. 2 , no. 3, p. 277-311.

Moffit, F, H., 1913, Geology of the Nome and Grand Central quadrangles, Alaska: U.S. Geol. Survey Bull. 533, 140 p.

Rabkin, M. I., and Ravich, M. G., 1961, The Precambrian of the Soviet Arctic, p. 18-30 in Raasch, G. O., ed., Geology of the Arctic, v. 1 : Toronto Univ. Press, 732 p.

Sainsbury, C. L., 1961, Geology of part of the Craig C-2 quadrangle and adjoining areas, Prince of Wales Island, southeastern Alaska : U.S. Geol. Survey Bull. 1058-H, p. 299-362.

1965, Geology and ore deposits of the central York Mountains, western Seward Peninsula, Alaska: U.S. Geol. Survey open-file report, 150 p., and Stanford Univ. Ph.D. thesis.

1969a, Geologic map of the Teller $B-4$ and southern part of the Teller $\mathrm{C}-4$ quadrangles, western Seward Peninsula, Alaska : U.S. Geol. Survey Misc. Geol. Inv. Map I-572.

1969b, Geology and ore deposits of the central York Mountains, western Seward Peninsula, Alaska: U.S. Geol. Survey Bull. 1287, 101 p. [1970]

Smith, P. S., 1910, Geology and mineral resources of the Solomon and Casadepage quadrangles, Seward Peninsula, Alaska: U.S. Geol. Survey Bull. 433, 234 p.

Zwart, H. J., 1967, The duality of orogenic belts: Geologie en Mijnbouw, v. 46, no. 8, p. 283-309. 


\title{
ALLOCHTHONOUS PALEOZOIC BLOCKS IN THE TERTIARY SAN LUIS-UPPER ARKANSAS GRABEN, COLORADO
}

\author{
By RALPH E. VAN ALSTINE, Washington, D.C.
}

Work done in cooperation with the Colorado State Mining Industrial

Development Board

\begin{abstract}
Allochthonous breccia blocks of Paleozoic rocks, locnlized within or near a late Tertiary trough between the Sawatch and Sangre de Cristo Ranges of south-central Colorado, evidently were the result of gravitational sliding several miles eastward from the Sawatch Range. Seventeen detached Paleozoic blocks within the Dry Union Formation of Miocene and Pliocene age are exposed in areas of as much as 400 by 800 feet and for heights of about 150 feet. To the west, six remnants of Paleozoic carbonate rocks, some in areas underlain by Precambrian gneiss and others in areas underlain by unconsolidated fll, also may be detached blocks. Similar detached blocks have been reported along the margins of other basins in the Western United States.
\end{abstract}

Geologic investigations, made in cooperation with the Colorado State Mining Industrial Development Board, southwest of Salida in the Southern Rocky Mountains of south-central Colorado (fig. 1), revealed more than 20 detached Paleozoic blocks within and adjacent to a late Tertiary trough (Van Alstine, 1968). This narrow trough between the Sawatch and Sangre de Cristo Ranges is part of the San Luis-Upper Arkansas graben (Tweto, 1968, p. 566, 582) and is the northward continuation of the Rio Grande depression (Bryan and McCann, '1938, p. 2-3; Kelley, 1956), a fault structure typical of the Basin and Range province. The detached blocks (fig. 2), composed mainly of brecciated carbonate rocks, are too large to have been transported by water. They were emplaced at several stratigraphic levels in the Dry Union Formation of Miocene and Pliocene age that fills the trough, evidently by gravitational sliding eastward from a structural high, the Sawatch Range (fig. 3). The trough deposits were derived largely from the same source area that shed the detached blocks. The Paleo-

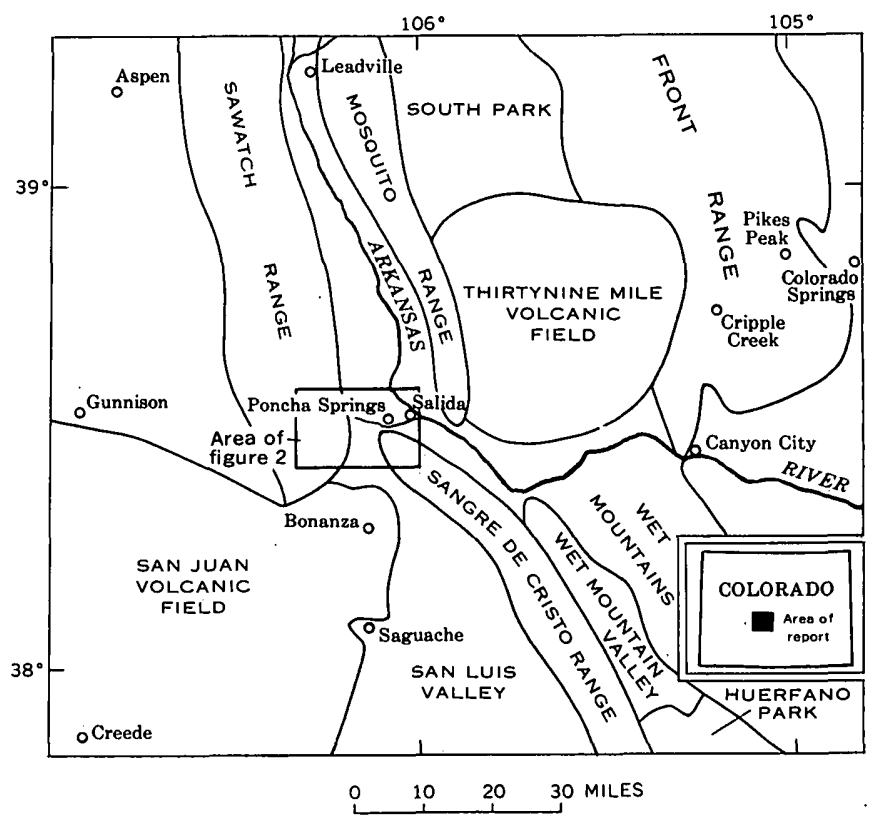

FTGURE 1.-Index map of south-central Colorado.

zoic blocks are now being exposed as the adjacent basin fill is removed by erosion.

Other interpretations have been given to several of the Paleozoic remnants. For example, from the presence of some of the brecciated Paleozoic masses, Russell (1950, pl. 1 and p. 17-18) inferred two steep fault zones and concluded that Paleozoic sedimentary rocks underlie the trough fill here.

\section{DRY UNION FORMATION}

The Dry Union Formation, named and defined by T'weto (1961) in the Leadville area about 45 miles 


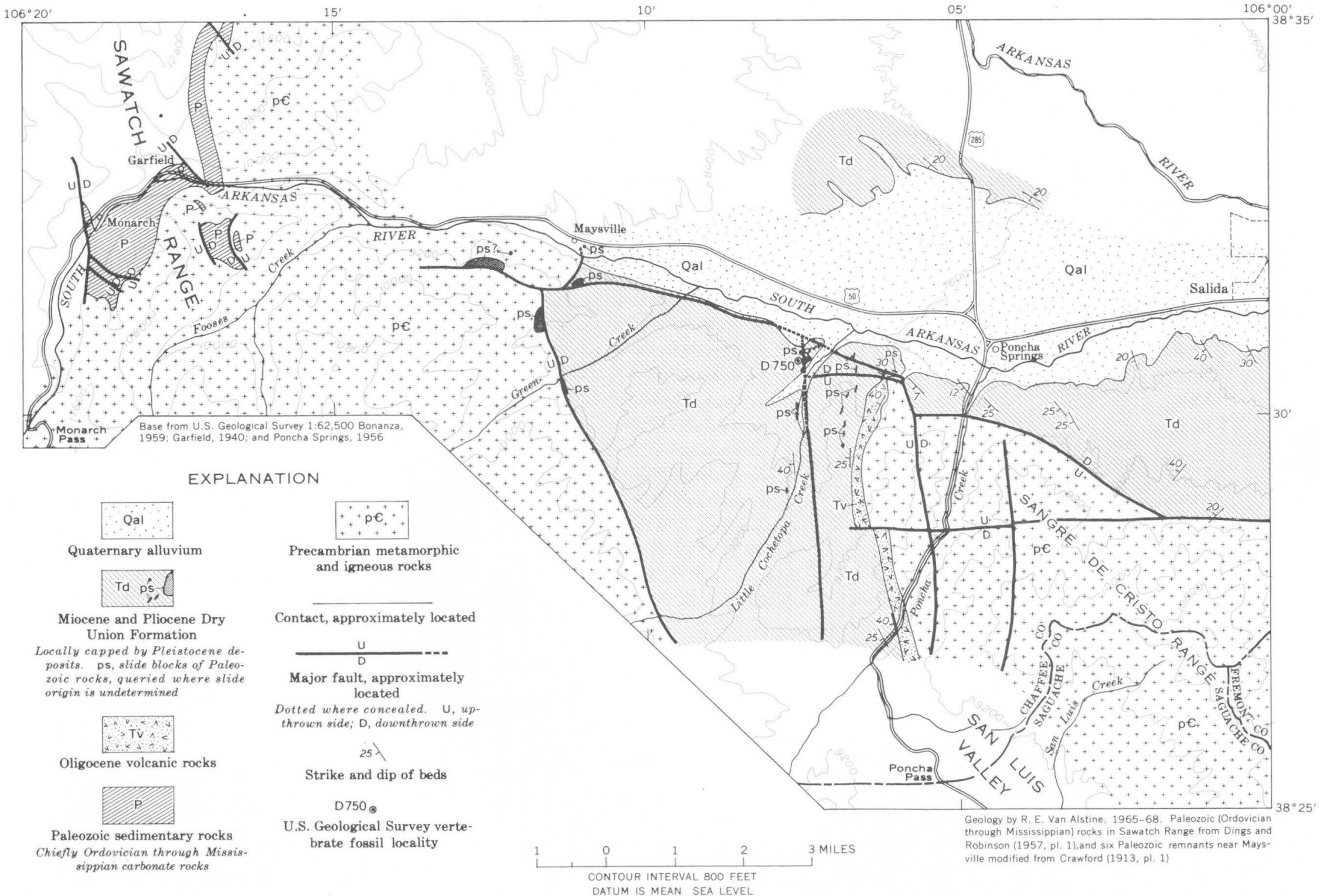




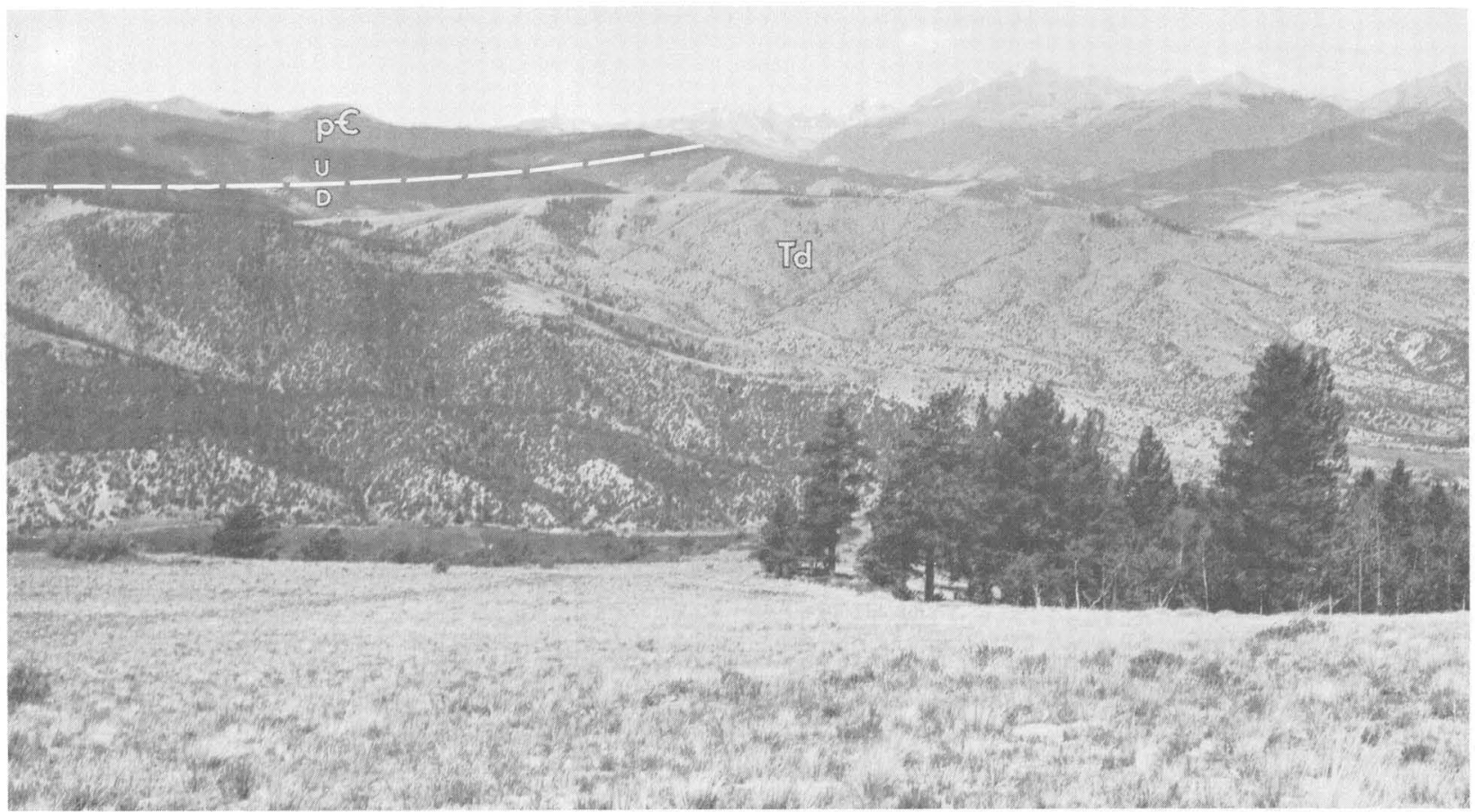

Figure 3.-View west across late Tertiary trough to source area of slide blocks in the Sawatch Range, showing Dry Union sediments (Td) faulted against Precambrian gneisses ( $p €)$.

north of Poncha Springs, records various geologic events that occurred in this area in late Tertiary time. The formation is chiefly composed of unconsolidated gravel, sand, silt, clay, volcanic ash, and limestone deposited in alluvial-fan, mudflow, and pond environments, and it contains the detached Paleozoic blocks (fig. 4). The basal part is largely mudflow material consisting of unstratified gravel containing abundant clasts of vesicular basalt, andesite, and latite derived from lower Oligocene lava flows at the eastern and southwestern edges of the trough. Especially conspicuous at many weathered outcrops are agates and bluegray angular jasperoid fragments of intensely silicified volcanic rocks transported from the Bonanza volcanic center to the southwest (Burbank, 1932, p. 71-77; Cook, 1961, p. 289).

Within the Tertiary sediments above the basal volcanic gravel, clasts of Paleozoic rocks are common among the debris. They have lithologies and ages similar to those of the adjacent detached Paleozoic blocks found at several stratigraphic horizons. On the ridge crest east of Little Cochetopa Creek, blocks of limestone (some fetid and containing black chert) and dolomite (without chert) probably are from the Leadville Limestone of Mississippian age; fossils in similar. limestone clasts in the adjacent debris were identified as (1) fragments of Ovatia cf. O. laevicosta (White), known to occur in the Leadville Limestone, (2) echinoderm debris, and (3) fragments of a syringoporoid coral (J. T. Dutro, Jr., written commun., Feb. 7, 1969). Precambrian debris containing gneiss, granite, and pegmatite boulders as much as 12 feet in diameter is predominant in the upper part of the trough fill. Thus, the stratigraphy of the Dry Union Formation locally reflects, in reverse, the sequence of rocks in the adjoining source areas; debris, first from Tertiary volcanic rocks and then from progressively older Paleozoic and Precambrian formations, was stripped, carried into the trough, and deposited.

Mesozoic rock fragments from the Morrison Formation, Dakota Sandstone, and Mancos Shale were not observed among the clasts in the Dry Union Formation and evidently were not shed eastward into this trough. These three formations are exposed on the west edge of the Sawatch Range. Dings and Robinson (1957, p. 9, 18-19) suggested that possibly several thousand feet of Mesozoic sedimentary rock was removed from the range by erosion. The apparent lack of Mesozoic debris in the Tertiary trough deposits indicates that the three Mesozoic units may not have covered the base- and precious-metal district near Monarch and Garfield in Tertiary time when the mineralization occurred.

In the area near Little Cochetopa Creek, the Dry Union Formation may be more than 10,000 feet thick, if the moderate westward dip persists to the fault at the west edge of the trough. The westward tilting possibly is related to late Pliocene uplift of the Sangre de Cristo Range to the east. 


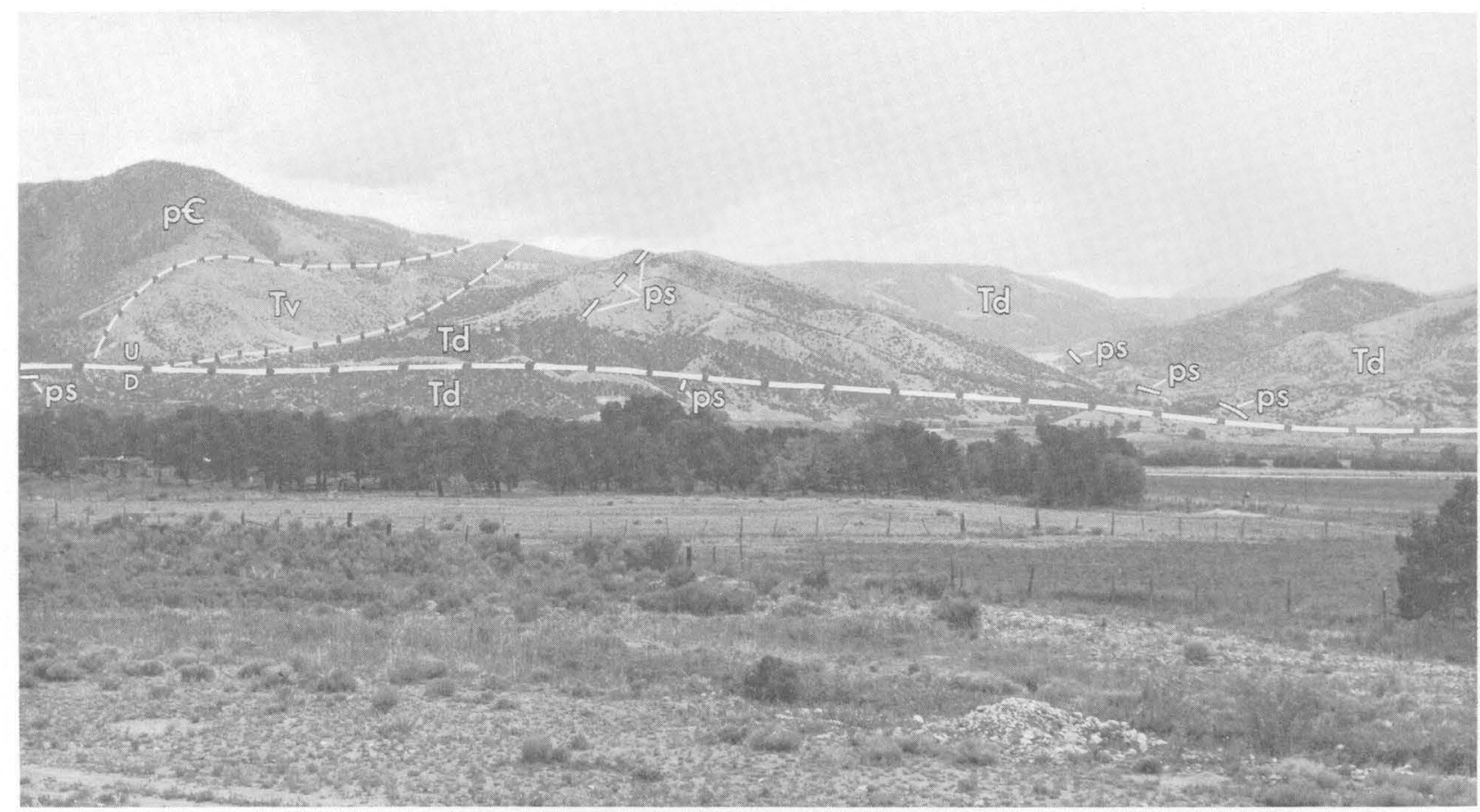

Figure 4.-View south along Little Cochetopa Creek, showing faulted Miocene and Pliocene sediments (Dry Union Formation, Td) containing blocksi of Paleozoic rocks (ps); underlying Oligocene volcanic rocks (Tv) rest on Precambrian gneiss $(p €)$ of Sangre de Cristo Range.

The Pliocene age of some of the trough deposits now assigned to the Dry Union Formation was determined from fossil horse teeth and camel bones found to the east and north in the Arkansas Valley (Powers, 1935, p. 189; Van Alstine and Lewis, 1960). The age, however, is now extended to late Miocene, for at vertebrate fossil locality D750 (fig. 2) several identifiable horse teeth were collected from locally gypsiferous greenish clays and silts. G. E. Lewis (written commun., Dec. 17, 1968 ) reported the fossils to be cheek teeth of Merychippus cf. M. calamarius (Cope) and stated that this species is characteristic of the upper Miocene part of the middle(?) Miocene to lower Pliocene Tesuque Formation of the Santa Fe Group of New Mexico in the southern part of the same structural trough (Spiegel and others, 1963, p. 39-43, 62-63). Possibly, older Miocene fossils could be found in the trough fill below the beds at fossil locality D750 or to the east, nearer the contact of the deposits with the lower Oligocene volcanic rocks. Fossil charophytes, ostracodes, gastropods, and pelecypods were collected from the pond sediments immediately beneath the strata at the vertebrate fossil locality. Specimens of the genus Chara probably are late Tertiary in age (R. E. Peck, written commun., June 6,1967$)$. Some of the ostracodes were identified as Candona spp. and Darwinula? sp., smooth, fresh-water types common in Tertiary sediments (I. G. Sohn, written communs., May 10, 1967, and Mar. 5,
1968). The other invertebrate fossils have not yet been studied.

\section{ALLOCHTHONOUS PALEOZOIC BLOCKS}

Seventeen detached Paleozoic blocks of various sizes are exposed within the Dry Union Formation east and west of Little Cochetopa Creek; similar blocks, mostly larger, are found in Precambrian terrane and trough fill at higher altitudes about 4 miles farther west (fig. 2 ). The blocks near Little Cochetopa Creek crop out at altitudes between 7,830 and 8,880 feet. In outcrop they commonly are longer north-south, are arranged mainly in two north-trending belts, and are oriented approximately parallel to the attitude of the enclosing sediments at several stratigraphic horizons, calculated at 700 to 2,600 feet above the base of the Dry Union Formation. One of the belts of Paleozoic blocks sustains a prominent ridge east of Little Cochetopa Creek.

The Paleozoic formations found in the detached blocks are the Manitou Dolomite, Harding Quartzite, and Fremont Dolomite of Early, Middle, and Late Ordovician ages, respectively; the Chaffee Formation of Late Devonian age; and the Leadville Limestone of Mississippian age. Especially distinctive among the predominantly carbonate rocks are the Harding Quartzite containing conspicuous fossil fish plates, the fossiliferous Fremont Dolomite, and the basal argil- 
laceous part of the Chaffee Formation. Criteria for the recognition of the various Paleozoic formations, as found at higher altitudes in the Sawatch Range to the west, were given by Johnson (1944) and by Dings and Robinson (1957, p. 11-18). Litsey (1958, p. 1150-1161) has also described these units at a locality a few miles to the east at lower altitudes on the northeast flank of the Sangre de Cristo Range.

Although most detached blocks are composed of one or two of the Paleozoic formations, some contain as many as four. Near the west edge of Little Cochetopa Creek valley just below an altitude of 8,000 feet, the largest and most accessible allochthonous block here is exposed in an area of about 400 by 800 feet and for a height of about 150 feet (fig. 5). Remnants of the Manitou, Harding, and Fremont Formations appear along the cliffed east face, and the crest and west slope are occupied by the Chaffee Formation. These brecciated Paleozoic units make up about 300 feet of strata in the exposure; the four units total approximately 540-700 feet in thickness where they are completely exposed in the Sawatch Range about 8 miles to the west (Dings and Robinson, 1957, p. 11-15) and in the Sangre de Cristo Range at a locality about $91 / 2$ miles to the east (Litsey, 1958, p. 1149). The bedding, still recognizable locally in this detached block, dips $25^{\circ}-$ $50^{\circ} \mathrm{W}$., approximately parallel to the dip of the enclosing Tertiary beds; the steeper dips are near late Tertiary faults.

The Paleozoic blocks are made up predominantly of crackled and brecciated dolomite and limestone. Much of the material, especially that near the base, consists of breccia fragments less than 2 inches in diameter. Sharply angular fragments and others rounded by abrasion are set in a highly indurated matrix of

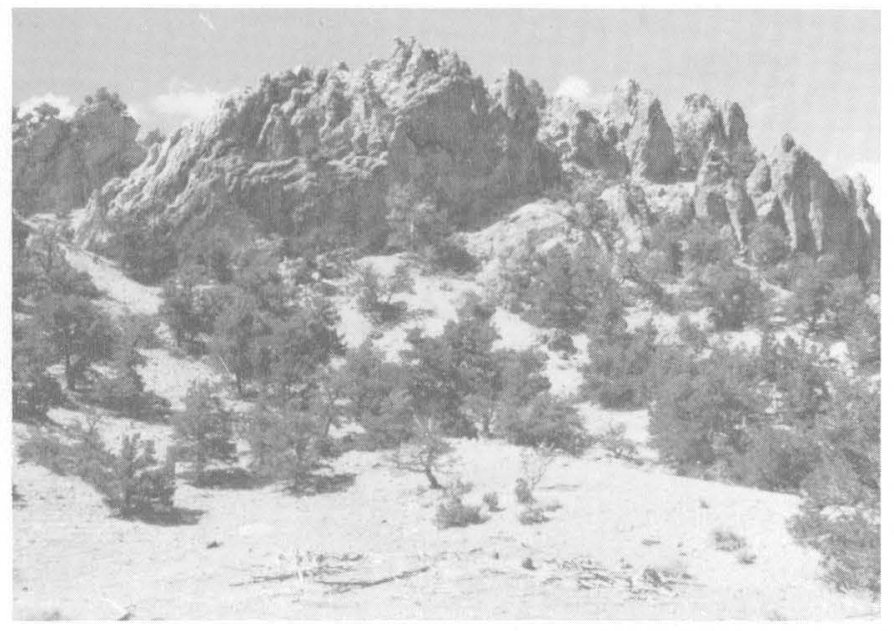

Figure 5.-Allochthonous Paleozoic block in the Dry Union Formation near the west edge of Little Cochetopa Creek valley. View north. crushed carbonate rock cemented by calcite, generally fine grained but locally coarsely crystalline. Bedding is no longer evident in this type of breccia but is discernible in less brecciated parts of blocks. Irregularities of adjacent breccia fragments generally do not correspond in shape, which further suggests relative movement following brecciation. Brecciation occurred before the Paleozoic blocks came to rest within the Tertiary sediments, for fragments of brecciated Paleozoic rocks commonly occur in the immediately overlying and surrounding beds. Miocene ostracodal limestone beds of the Dry Union Formation above the largest Paleozoic block immediately west of Little Cochetopa Creek valley contain small angular and rounded clasts of brecciated Paleozoic rocks (fig. 6).

Three and one-half to 5 miles west of Little Cochetopa Creek (fig. 2), Crawford (1913, pl. 2) mapped six patches of Paleozoic carbonate rocks, ranging in age from Ordovician to Mississippian. Some of these remnants of Paleozoic rock were shown in areas underlain by Precambrian gneiss; others were in areas underlain by unconsolidated fill. The remnants are at altitudes of 8,200 to 9,600 feet, about $3 \frac{1}{2}$ miles east of a large faulted synclinal mass composed of the same formations (fig. 2), which is exposed 2-4 miles east of the Continental Divide and at altitudes of 10,500 to 12,000 feet (Dings and Robinson, 1957, pl. 1). Recent examination of the four Paleozoic remnants along the west edge of the Tertiary trough suggests that they are detached blocks; they are composed of thoroughly brecciated and calcite-cemented material typical of the other slide blocks farther east. Crawford (1913, p. 88, 101 , and pl. 3 , sec. $E-E^{\prime}$ ) regarded two of the six Paleozoic remnants as synclines. Gabelman (1952, p. 1594) similarly interpreted the patches of east-dipping to nearly horizontal Paleozoic rocks as evidence for a synclinal area between the uplifted Sawatch and Sangre de Cristo Ranges. Evidence for the east limb of this proposed syncline, however, is even less convincing, because on the west flank of the Sangre de Cristo Range, at its north end, the rocks that underlie the fill in the trough and overlie the Precambrian basement are not Paleozoic sedimentary rocks but volcanic rocks of Oligocene age (fig. 2).

\section{TERTIARY FAULTING RELATED TO DETACHED BLOCKS}

In this region near the junction of the San Luis and Arkansas Valleys, Tertiary faulting probably occurred before, during, and after emplacement of the detached Paleozoic blocks in the Tertiary sediments. The continuity of the faults in many places is evident on aerial photographs but is not obvious in the field; this is 


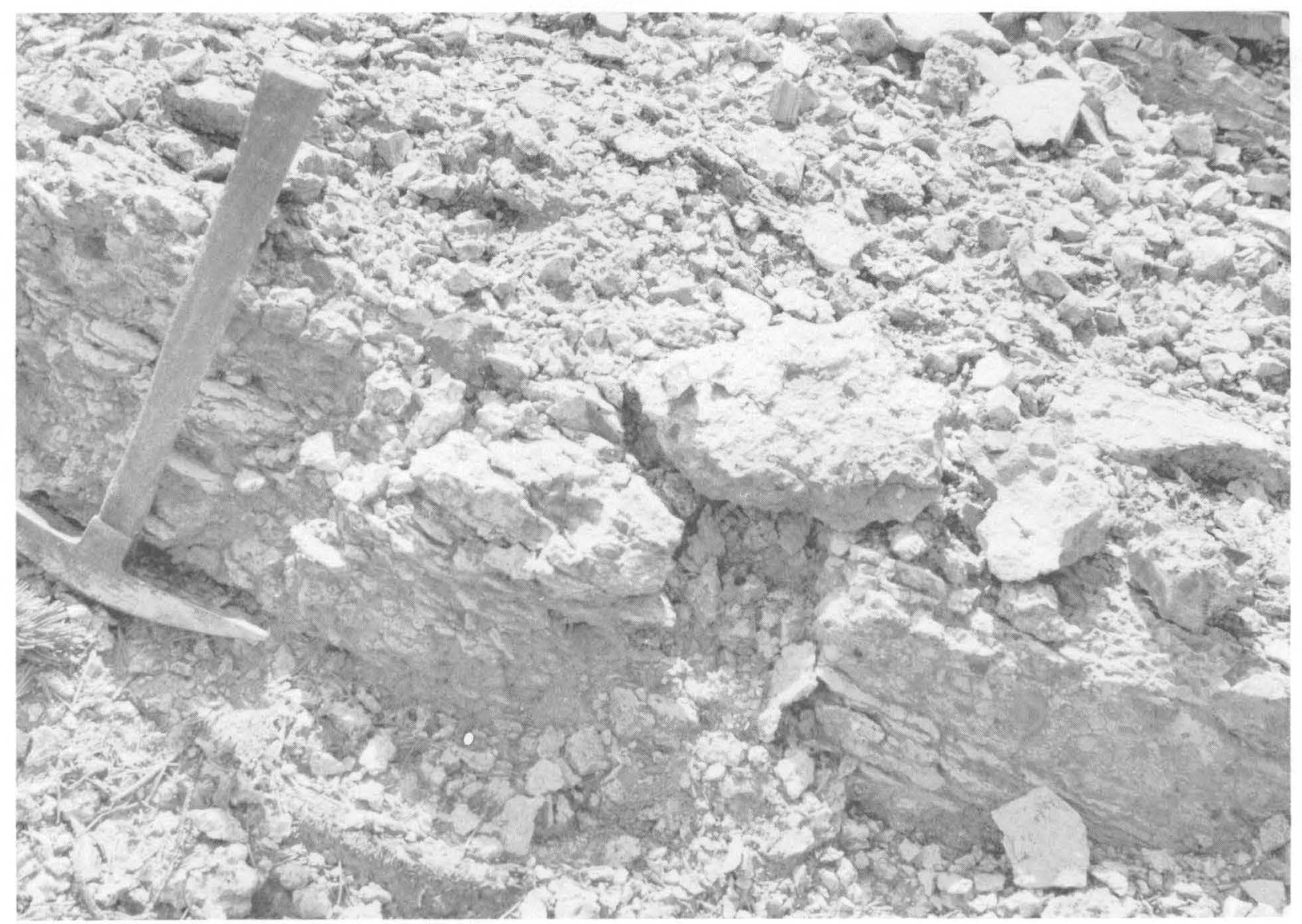

Figure 6.-Angular and rounded clasts of brecciated Paleozoic limestone, dolomite, and chert in Miocene ostracodal limestone of the Dry Union Formation.

especially true of the faults in the unconsolidated Dry Union Formation. The dip of the fault and the amount and direction of displacement commonly are not determinable.

\section{Laramide faults}

Possibly early Tertiary faulting and associated folding initiated the conditions favorable for detachment and transport of the allochthonous Paleozoic blocks in later Tertiary time. In the adjoining quadrangle west of the area of detached breccia blocks, Dings and Robinson (1957, p. 36-40) described various types of Laramide faults, some mineralized with base metals. Their Tincup-Morning Glim fault (1957, p. 36), the mineralized Chester fault of the Marshall Pass uranium district about 10 miles south of Garfield (Wright and Everhart, 1960, p. 357-359), and the Eocene faults in the Bonanza mining district (Burbank, 1932, p. 38-41) about 15 miles south-southwest of Poncha Springs are all reported as thrust faults that displaced Precambrian rocks chiefly northward or westward over Paleozoic rocks. To the north near Aspen, Colo., the Elk Range thrust sheet may have formed in early
Tertiary time by gravity sliding of a thick section of upper Paleozoic and Mesozoic sedimentary rocks off the steep western flank of the Sawatch Range uplift (Bryant, 1966).

\section{Miocene north-trending border faults}

The north end of the San Luis Valley, structurally part of the Rio Grande depression, is bordered on the east by a steep fault that formed chiefly from late Oligocene to the end of Tertiary time, according to Burbank and Goddard (1937, p. 965). More recently, others have reported that downfaulting of this depression began in Miocene time (Gabelman, 1952, p. 1606; Kelley, 1956; Lipman and Mehnert, 1968; Steven and Epis, 1968, p. 248-249). Recent fieldwork in the Poncha Springs and Bonanza quadrangles similarly shows that faults bordering the trough formed at some time between the eruption of Oligocene volcanic rocks and the deposition of sediments of late Miocene age. As suggested below, recurrent movement of the fault at the west border of the trough (fig. 2) may have helped the eastward transfer of the detached Paleozoic blocks 
along their underlying slide surfaces and over the 'Tertiary sediments.

\section{Post-Pliocene faults}

Steep north-trending and east-trending faults cut some of the detached Paleozoic blocks and the adjacent Dry Union sediments of Miocene age near Little Cochetopa Creek (fig. 2), as well as the fossiliferous Pliocene part of the Dry Union Formation farther north and east. West of the creek, a north-trending fault zone dips about $70^{\circ} \mathrm{W}$; argillaceous beds near the base of: the Chaffee Formation of Late Devonian age that are normally pink are locally green and sheared along this fault zone. The east-trending fault cutting the Dry Union Formation south of the South Arkansas River (fig. 2) dips steeply north and offsets the linear belts of detached Paleozoic blocks near Little Cochetopa Creek. Along the fault, the north side has been displaced downward and to the east. The Arkansas Valley is about 1,000 feet lower than the San Luis Valley as a result of downfaulting along the easttrending and north-trending late Tertiary structures and also because of more active erosion in the Arkansas drainage during Pleistocene and Holocene time (Van Alstine, 1970). About 3 miles east of Salida, Rold (1961, p. 116 and fig. 4) also reported right-lateral movement on a probably related east-trending fault zone on the northeast flank of the Sangre de Cristo Range.

\section{EMPLACEMENT OF THE DETACHED BLOCKS}

Detachment of the Paleozoic blocks evidently resulted from recurrent gravitational sliding off the flank of the Sawatch aniticline and off the upthrown side of the fault at the margin of the late Tertiary trough. Emplacement of the blocks within the Dry Union Formation near Little Cochetopa Creek is dated fairly closely, for it occurred after Oligocene volcanism, during Dry Union sedimentation, and before deposition of the beds containing the vertebrate fossils of late Miocene age. At this time the Paleozoic rocks to the west were being very actively eroded, as shown by the abundant clasts from lower, middle, and upper Paleozoic carbonate rocks, lower Paleozoic quartzite, and upper Paleozoic arkosic sandstones found within the Tertiary sediments immediately above and below the blocks. Mudflows associated with the blocks in the Dry Union Formation further indicate that landslides were very active at this time.

The blocks are not overturned, suggesting that the sliding was not accompanied by toppling that occurs during rockfall or flow; the normal stratigraphic section of Paleozoic rocks can be recognized in less brecciated parts of some blocks, as previously described.
The brittle carbonate rocks and quartzite were broken into many detached blocks that moved independently and were emplaced without markedly disturbing the underlying Tertiary sediments. Near the northeast crest of the ridge east of Little Cochetopa Creek, the lower surfaces of itwo blocks strike about N. $20^{\circ} \mathrm{E}$. and dip about $20^{\circ} \mathrm{W}$; t this attitude is approximately parallel to that of the enclosing Tertiary sediments, as shown locally by stratification and by the orientation of boulders and cobbles in the underlying mudflow. The material immediately beneath these Paleozoic blocks is made up of unbrecciated clasts consisting largely of Tertiary volcanic and Paleozoic carbonate rocks in a clayey gouge. The contacts between the underlying sediments and the bases of the breccia blocks obviously were the surfaces along which the blocks slid.

Intrusion of a batholith and stocks northwest of the area and local differential movement may have increased the gravitational potential for sliding. Doming probably accompanied emplacement of the Mount Princeton batholith and other intrusive bodies (Dings and Robinson, 1957, p. 25-27, 31-32); these Tertiary intrusives have not yet been precisely dated. Differential movement caused by uplift of the Sawatch Range or lowering of the Rio Grande trough in Miocene time probably triggered the eastward transfer of Paleozoic blocks over the Precambrian terrane and down the flank of the Sawatch anticline, the major Laramide structure. Some detached blocks came to rest on Precambrian gneiss and on trough fill near the fault at the west edge of the Tertiary depression. Other blocks slid farther east over the well-lubricated mudflows and other unconsolidated sediments of late Tertiary age.

Although a highland source area for the detached blocks is available to the west in the Sawatch Range, the actual bedrock structure or structures that furnished the slide blocks are not definitely known. The downfolded and downfaulted masses of lower and middle Paleozoic bedrock near Monarch and Garfield (fig. 2) are the most probable sources now remaining in this extensively eroded, largely Precambrian terrane. These masses in the Monarch district were locally mineralized with base-metal sulfide minerals in early Tertiary time (Crawford, 1913, p. 195-283; Dings and Robinson, 1957, p. 81-95), but sulfide minerals were not seen in the detached breccia blocks in the trough.

The magnitude of slope of the surface of transport is not definitely known. If the blocks now at an altitude of about 8,800 feet near the fault along the west border of the Tertiary trough slid eastward about $31 / 2$ miles from the nearest large synclinal mass, which is at an altitude of about 10,500 feet (fig. 2), the in- 
clined slide surface would slope east at about $5^{\circ}$; such a slope is well within the range in which mudflows respond to gravity and twice the slope angle of the Wyoming Heart Mountain detachment fault along which Paleozoic masses slid (Pierce, 1963, p. 1234). One cannot estimate the slope angle of the similar inclined surface of transport from the possible source area in the Sawatch Range eastward for $91 / 2$ miles to the Paleozoic blocks beyond Little Cochetopa Creek; this surface would cross the border fault of the Tertiary trough, which probably was active during and has been active since the time of gravitational sliding. A further complication is the fact that the Paleozoic blocks and enclosing Tertiary beds have been tilted westward since emplacement.

Furthermore, no estimate can be made of the attenuation that occurred in individual blocks during gravity sliding, because examination of the detached blocks fails to show precisely when brecciation and thinning of the stratigraphic section took place; an unknown amount perhaps occurred before the masses were freed from the bedrock to slide as isolated blocks. In the probable source area to the west, all Paleozoic formations are separated by erosional unconformities, and reduced thicknesses of the lower Paleozoic rocks also resulted from Laramide faulting and squeezing of the beds (Dings and Robinson, 1957, p. 9, 11).

\section{OTHER EXAMPLES OF GRAVITATIONAL SLIDES IN THE WESTERN UNITED STATES}

Other areas of the Western United States contain excellent, well-documented examples of localities where gravitational sliding is the suggested mechanism for the formation of detached and brecciated blocks. About 50 miles east of the area under investigation, in the Milsap Creek area of Fremont County, Colo., blocks of lower Paleozoic carbonate and Precambrian rocks slid westward, probably in late Cenozoic time, down the flank of the Cripple Creek arch and onto upper Paleozoic rocks in a graben (Gerhard and Wahlstedt, 1965). Along the Front Range west of Fort Collins, Colo., blocks of sandstone of the Dakota Group slid down the dip slopes of hogbacks in Pleistocene time and overrode younger Cretaceous strata (Braddock and Eicher, 1962). South of the Owl Creek Range, Wyo., brecciated Paleozoic blocks moved during early Tertiary time by gravity sliding across a frontal fault zone and onto Triassic redbeds in the Wind River Basin (Wise, 1963).

Even more analogous to the detached blocks southwest of Salida, Colo., are various structures formed when gravity sliding occurred during deposition within Tertiary basins and when the blocks became incor- porated within the sediments. Pierce $(1957,1960,1963)$ has given detailed accounts of detachment faults on the west side of the Bighorn Basin, Wyo., along which allochthonous blocks of brecciated Paleozoic rocks moved 5 to 30 miles basinward; some finally came to rest within Eocene sediments (Pierce and Nelson, 1968).

The Basin and Range province of the southwest similarly contains many gravity slide blocks formed in Cenozoic time. In the Shadow Mountains area, San Bernardino County, Calif., beds or large lenses of brecciated carbonate rocks of early Paleozoic age occur at several horizons in sediments of middle Tertiary age; detached blocks moved laterally and evidently were emplaced under the influence of gravity (Hewett, 1956, p. 88-90, 96, 99). About 100 miles southwest of there, large blocks of brecciated Paleozoic limestone slid northward, possibly on a cushion of trapped air (Shreve, 1968), for several miles beyond the San Bernardino Mountains and onto upper Tertiary sediments of the Mojave Desert (Woodford and Harriss, 1928 , p. 279-283, 287-290). Gravity sliding attenuated the stratigraphic section to one-fourth the normal thickness in allochthonous Paleozoic masses in MiocenePliocene sediments in the Horse Range of east-central Nevada (Moores, 1968, p. 94-96; Moores and others, 1968$, p. 1716,1719$)$. In the San Manuel area, Pinal County, Ariz., a large lens about 500 feet thick and 4,500 feet long, composed chiefly of blocks of Paleozoic limestone and Precambrian diabase, slid laterally about 8 miles from the probable source area to the resting place within upper Tertiary sediments of the basin (Creasey, 1965, p. 20-22). Sheets of Upper Cretaceous sandstone in the Jicarilla Mountains of central New Mexico moved under the influence of gravity from an area domed by intrusion; the blocks rest on the eroded surface of Triassic and Permian rocks and are partly covered by the Ogallala Formation of Pliocene age (Budding, 1963).

Gravity slide blocks may also occur near the east edge of the Rio Grande trough in the Santa Fe area, N. Mexico. Large detached blocks of Pennsylvanian(?) quartzite are arranged in a linear belt parallel to the strike of adjacent strata in the Tesuque Formation (Miocene and Pliocene) of the Santa Fe Group (Spiegel and others, 1963, p. 63, 76-78). The authors suggested that the blocks may represent ancient talus from basement rocks raised to the surface along a fault not yet recognized; the possible origin of the blocks by gravity sliding from reported exposures at greater altitudes several miles to the east seems worthy of further consideration. 


\section{REFERENCES}

Braddock, W. A., and Eicher, D. L., 1962, Block-glide landslides in the Dakota Group of the Front Range foothills, Colorado: Geol. Soc. America Bull., v. 73, no. 3, p. 317-323.

Bryan, Kirk, and McCann, F. T., 1937-38, The Ceja del Rio Puerco, a border fenture of the Basin and Range province in New Mexico: Jour. Geology, v. 45, no. 8, p. 801-828; v. 46 , no. 1 , p. 1-16.

Bryant, Bruce, 1966, Possible window in the Elk Range thrust sheet near Aspen, Colorado, in Geological Survey Research 1966 ; U.S. Geol. Survey Prof. Paper 550-D, p. D1-D8.

Budding, A. J., 1963, Origin and age of superficial structures, Jicarilla Mountains, central New Mexico: Geol. Soc. America Bull., v. 74, no. 2, p. 203-208.

Burbank, W. S., 1932, Geology and ore deposits of the Bonanza mining district, Colorado: U.S. Geol. Survey Prof. Paper $169,166 \mathrm{p}$.

Burbank, W. S., and Goddard, E. N., 1937, Thrusting in Huerfano Park, Colorado, and related problems of orogeny in the Sangre de Cristo Mountains: Geol. Soc. America Bull., v. 48, no. 7, p. 931-976.

Cook, D. R., 1961, Bonanza project, Bear Creek Mining Company : Am. Inst. Mining, Metall. and Petroleum Engineers Trans. 1960 , v. 217 , p. $285-295$.

Crawford, R. D., 1913, Geology and ore deposits of the Monarch and Tomichi districts, Colorado: Colorado Geol. Survey Bull. 4, 317 p.

Crensey, S. C., 1965, Geology of the San Manuel area, Pinal County, Arizona: U.S. Geol. Survey Prof. Paper 471, 64 p.

Dings, M. G., and Robinson, C. S., 1957, Geology and ore deposits of the Garfleld quadrangle, Colorado: U.S. Geol. Survey Prof. Paper 289, $110 \mathrm{p}$.

Gabelman, J. W., 1952, Structure and origin of northern Sangre de Cristo Range, Colorado: Am. Assoc. Petroleum Geologists Bull., v. 36, no. 8, p. 1574-1612.

Gerhard, L. C., and Wahlstedt, W. J., 1965, Milsap Creek fault block, a gravitational structure: Mtn. Geologist, v. 2, no. 4, p. 203-208.

Hewett, D. F., 1956, Geology and mineral resources of the Ivanpah quadrangle, California and Nevada: U.S. Geol. Survey Prof. Paper 275, $172 \mathrm{p}$.

Johnson, J. H., 1944, Paleozoic stratigraphy of the Sawatch Range, Colorado: Geol. Soc. America Bull., v. 55, no. 3, p. 303-378.

Kelley, V. C., 1956, The Rio Grande depression from Taos to Santa Fe, in New Mexico Geol. Soc., Guidebook of southeastern Sangre de Cristo Mountains, New Mexico, 7th field conference, October 19-21, 1956: p. 109-114.

Ijipman, P. W., and Mehnert, H. H., 1968, Structural history of the eastern San Juan Mountains and the San Luis Valley, Colorndo [abs.] : Geol. Soc. America, Cordilleran Sec., 64th Ann. Mtg., 'Tucson, Ariz., 1968, Program, p. 76-77.

Litsey, L. R., 1958, Stratigraphy and structure of the northern Sangre de Cristo Mountains, Colorado: Geol. Soc. America Bull., v. 69, no. 9, p. 1.143-1178.

Moores, 12. M., 1.968, Mio-Pliocene sediments, gravity slides, and their tectonic significance, east-central Nevada: Jour. Geology, v. 76, no. 1, p. $88-98$.

Moores, I. M., Scott, R. B., and Lumsden, W. W., 1968, Tertiary tectonics of the White Pine-Grant Range region, eastcentral Nevada, and some regional implications: Geol. Soc. America Bull., v. 79, no. 12, p. 1703-1726.
Pierce, W. G., 1957, Heart Mountain and South Fork detachment thrusts of Wyoming: Am. Assoc. Petroleum Geologists Bull., v. 41, no. 4, p. 591-626.

- 1960, The "break-away" point of the Heart Mountain detachment fault in northwestern Wyoming: Art. 106 in U.S. Geol. Survey Prof. Paper 400-B, p. B236-B237.

1963, Reef Creek detachment fault, northwestern Wyoming: Geol. Soc. America Bull., v. 74, no. 10, p. 1225-1236.

Pierce, W. G., and Nelson, W. H., 1968, Geologic map of the Pat O'Hara Mountain quadrangle, Park County, Wyoming: U.S. Geol. Survey Geol. Quad. Map GQ-755, scale 1:62,500.

Powers, W. E., 1935, Physiographic history of the upper Arkansas River valley and the Royal Gorge, Colorado: Jour. Geology, v. 43, no. 2, p. 184-199.

Rold, J. W., 1961, The structure and lower and middle Paleozoic stratigraphy of the Wellsville area, Colorado, in Symposium on lower and middle Paleozoic rocks of Colorado, 12th field conference: Denver, Colo., Rocky Mountain Assoc. Geologists, p. 107-117.

Russell, R. T., 1950, The geology of the Poncha fluorspar district, Chaffee County, Colorado: Cincinnati, Ohio, Univ. Cincinnati, unpub. Ph.D. thesis, 70 p.

Shreve, R. L., 1968, The Blackhawk landslide: Geol. Soc. America Spec. Paper 108, $47 \mathrm{p}$.

Spiegel, Zane, Baldwin, Brewster, Kottlowski, F. E., Barrows, E. L., and Winkler, H. A., 1963, Geology and water resources of the Santa Fe area, New Mexico: U.S. Geol. Survey Water-Supply Paper 1525, $258 \mathrm{p}$

Steven, T. A., and Epis, R. C., 1968, Oligocene volcanism in south-central Colorado, in Cenozoic volcanism in the Southern Rocky Mountains : Colorado School Mines Quart., v. 63, no. 3, p. 241-258.

Tweto, Ogden, 1961, Late Cenozoic events of the Leadville district and upper Arkansas Valley, Colorado: Art. 56 in U.S. Geol. Survey Prof. Paper 424-B, p. B133-B135.

- 1968, Geologic setting and interrelationships of mineral deposits in the mountain province of Colorado and southcentral Wyoming, in Ridge, J. D., ed., Ore deposits of the United States, 1933-1967 (Graton-Sales volume): New York, Am. Inst. Mining, Metall., and Petroleum Engineers, v. 1, p. $551-588$

Van Alstine, R. E., 1968, Tertiary trough between the Arkansas and San Luis Valleys, Colorado, in Geological Survey Research 1968: U.S. Geol. Survey Prof. Paper 600-C, p. C158C160.

1970, Geology and mineral deposits of the Poncha Springs NE quadrangle, Chaffee County, Colorado: U.S. Geol. Survey Prof. Paper 626, 52 p. [1970]

Van Alstine, R. E., and Lewis, G. E., 1960, Pliocene sediments near Salida, Chaffee County, Colorado: Art. 111 in U.S. Geol. Survey Prof. Paper 400-B, p. B245.

Wise, D. U., 1963, Keystone faulting and gravity sliding driven by basement uplift of Owl Creek Mountains, Wyoming: Am. Assoc. Petroleum Geologists Bull., v. 47, no. 4, p. 586598.

Woodford, A. O., and Harriss, T. F., 1928, Geology of Blackhawk Canyon, San Bernardino Mountains, California: California Univ., Dept. Geol. Sci. Bull., v. 17, no. 8, p. 265304.

Wright, R. J., and Everhart, D. L., 1960, Uranium, chap. 5 in Del Rio, S. M., comp., and others, Mineral resources of Colorado, 1st sequel : Denver, Colorado Mineral Resources Board, p. 327-365. 


\title{
CALCULATED IN SITU BULK DENSITIES FROM SUBSURFACE GRAVITY OBSERVATIONS AND DENSITY LOGS, NEVADA TEST SITE AND HOT CREEK VALLEY, NYE COUNTY, NEVADA
}

\author{
By D. L. HEALEY, Denver, Colo.
}

Work done in cooperation with the U.S. Atomic Energy. Commission

\begin{abstract}
At the Nevada Test Site and Hot Creek Valley a borehole gravity meter was used to $\log$ four holes, and standard gravity meters were used to $\log$ five 48 -inch-diameter holes and a vertical shaft. Three holes (Ue2y, test well $B$, and UCe-18) and the U5i shaft penetrated alluvium, and six holes penetrated Tertiary volcanic rocks on Pahute Mesa. The weighted average densities determined in the holes and shaft in alluvium are $1.94,1.69,2.22$, and $2.05 \mathrm{~g} / \mathrm{cc}$, respectively; the density determined in five of the six holes in Tertiary volcanic rocks ranged from 1.98 to $2.06 \mathrm{~g} / \mathrm{cc}$. One hole (UE19n) penetrated a thick ashflow tuff that averaged $1.51 \mathrm{~g} / \mathrm{cc}$. Density $\operatorname{logs}$ were taken in 10 additional holes. In Yucca Flat the mean density of more than 7,000 feet of alluvium is $2.01 \mathrm{~g} / \mathrm{cc}$, and in Hot Creek Valley the mean of more than 18,000 feet is $2.18 \mathrm{~g} / \mathrm{cc}$.
\end{abstract}

Accurate in situ bulk densities are very important to exploration geophysics and more specifically to gravity surveys. Gravity surveys, in conjunction with aeromagnetic and seismic surveys and geologic mapping, have been made at the Nevada Test Site and at Hot Creek Valley, northern Nye County, Nev. (fig. 1). The purpose of this work was to assist the underground testing program of the U.S. Atomic Energy Commission by delineating those areas suitable for specifically designed experiments. In this role the gravity data are interpreted to delineate the thickness of the Tertiary (?) and Quaternary alluvium and (or) the Tertiary volcanic rocks. The upper configuration of the underlying pre-Cenozoic surface can be defined if these thicknesses are known, but to interpret thicknesses as accurately as possible, one must know the bulk densities of the adjacent rocks.

In an effort to determine bulk densities, many core, cuttings, and outcrop samples have been analyzed.

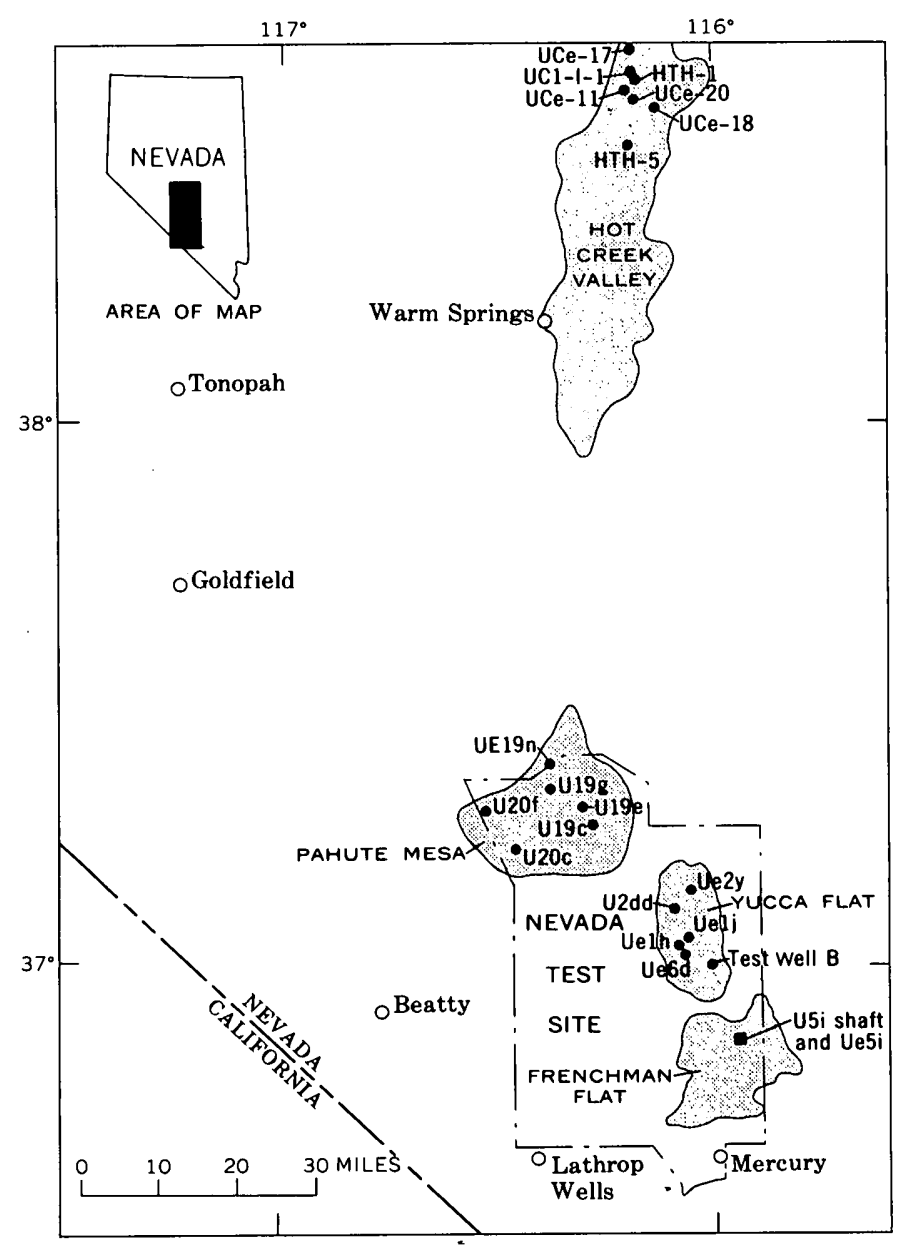

Fiaure 1.-Index map of the Nevada Test Site and Hot Creek Valley, Nev., showing locations where subsurface density data were obtained. 
However, many of the available samples are not representative of the total stratigraphy of an area, and in such areas the real bulk density may still be unknown. Also, reliable alluvium bulk densities are difficult to obtain because laboratory analysis of alluvium often is not feasible.

The search for a fast and reliable method of measuring, in situ, the bulk density of rocks and alluvium has been long and frequently frustrating (Grant and West, 1965, p. 196-200). The present paper describes a method of computing the in situ bulk density of a large volume of rocks and (or) alluvium from subsurface gravity data by use of the IBM System/360, Model 65 computer. Ten sets of subsurface gravity data were obtained: four with the U.S. Geological Survey-Ia Coste and Romberg, Inc., borehole gravity meter and six with standard Worden and La CosteRomberg gravity meters. Of the six data sets, five were obtained in cased 48-inch-diameter drill holes and one was obtained in a vertical shaft.

The borehole gravity meter was used to log four small-diameter drill holes at the Nevada Test Site and in Hot Creek Valley. These observations were made by lowering the steel-housed instrument into drill holes no smaller than $63 / 4$ inches in diameter by means of a multiconductor armored cable. The observations were made at predetermined intervals to coincide, as nenrly as possible, with known lithologic changes. The rendings were recorded graphically at the surface. The logged holes ranged in depth from 1,236 to 6,488 feet.

Each of the five 48-inch-diameter holes had a small chamber excavated at the detonation point near the bottom. These chambers were located between 2,247 and 4,748 feet below the ground surface. The size of these holes plus the size of the chamber at the bottom made it possible for a man to physically transport the gravity meter to the bottom and obtain the gravity readings. Usually, three round trips from the surface to the chamber were made to insure accurate observations.

Nine gravity observations were also made at approximately 100 -foot intervals down a 11 - by 15 -foot vertical shaft whose total depth was 825 feet.

Alluvium densities were determined from gammagamma density logs taken in 10 drill holes in Yucca Flat and Hot Creek Valley. These data, which sampled 18,743 feet of alluvium, supplemented the gravitymeter data and provided a better understanding of the alluvium density.

The sensor of the U.S. Geological Survey-La Coste and Romberg borehole gravity meter consists of a La Coste and Romberg geodetic gravity meter (G-95) that has been modified and fitted into a waterproofed, high-pressure steel housing. Details of construction, electronics, remote reading procedures, precision, and support equipment requirements have been described by McCulloh (1967), McCulloh, LaCoste, Schoellhamer, and Pampeyan (1967), and McCulloh, Schoellhamer, Pampeyan, and Parks (1967).

This instrument evolved from the combined efforts of many people to make precise subsurface gravity observations a reality. Airy (1856) made the first underground measurements of gravity by means of pendulum apparatus. Since then many papers that describe the theory, practice, instrumentation, or results of measurements in vertical shafts, mines, tunnels, or boreholes have been published. Some of the significant papers are those regarding theory and principles of subsurface gravimetry, by Lorenz (1938), Smith (1950), and Domzalski (1955); those regarding instrumentation problems and considerations, by Smith (1950), Gilbert (1952), Dolbear (1959), Lukavchenko (1962), and Goodell and Fay (1964); and those regarding subsurface methods and observational data, by Hammer (1950), Domzalski (1954), and McCulloh (1965). For a more complete bibliography the reader is referred to McCulloh $(1965,1966)$. As a result of all these efforts several workable borehole gravity meters have been developed (Goodell and Fay, 1964; Howell and others, 1965; McCulloh, 1965).

Acknowledgments.-J. E. Schoellhamer, L. A. Beyers, E. A. Barker, and E. H. Pampeyan, of the U.S. Geological Survey, operated the borehole gravity meter and its supporting equipment while the four holes were being logged; F. E. Currey made, or assisted with, all other subsurface gravity observations and the free-air gradient measurements; and C. H. Miller assisted with the gravity observations in U19c. J. R. Hearst, of the Lawrence Radiation Laboratory, Livermore, Calif., provided his computer program, Code Moria. R. R. Wahl, of the U.S. Geological Survey and Metropolitan State College, Denver, Colo., converted Code Moria to the IBM System 360, Model 65 computer, and added several subroutines to make the program more adaptable to our requirements.

\section{DATA REDUCTION}

Subsurface gravity observations are influenced by the in situ bulk densities of the adjacent rocks, the free-air gradient, the borehole or shaft void, the excavated chamber or other underground workings, and the adjacent topography (terrain correction). The general form of these relationships has been given by Hammer 
(1950), Domzalski (1954), and McCulloh (1965) as follows:

$$
\Delta g u=(F-4 \pi \gamma \sigma) \Delta Z+\Delta T+\Delta g c+\Delta b
$$

where $\Delta g u$ is the difference in gravity between two vertically separated points underground; $F$ is the measured or calculated free-air gradient of gravity ; $4 \pi \gamma \sigma$ is twice the normal Bouguer correction, which is necessary to account for the upward and downward attraction of the material above and below the subsurface observation point; $\gamma$ is the gravitational constant; $\sigma$ is the mean density of the rocks separating the two points; $\Delta Z$ is the vertical distance between these two points; $\Delta T$ is the difference in the terrain effect between these points; $\Delta g c$ is the geologic correction due to unlevel or discontinuous strata; and $\Delta b$ is the correction for the drill-hole, shaft, or chamber voids.

The free-air gradient of gravity either was calculated between one or more observation points downhole or was measured between the ground surface and the platform of the headframe over several drill holes. The measured free-air gradients, corrected for the effect of adjacent terrain (Kumagi and others, 1960), range from 0.090253 to 0.095045 milligal per foot and vary from the assumed normal by -4.0 and +1.0 percent. Based on the work of Hearst (1968) the geologic correction is assumed negligible. The correction for the drill-hole void is negligible in the small-diameter holes logged with the borehole gravity meter. However, corrections for voids were applied to the observations made down the shaft and the 48-inch-diameter drill holes. If one assumes that $\Delta g e$ is negligible and that $\Delta b$ is negligible or can be readily calculated and substituted, equation 1 may be solved directly for density $(\sigma)$ giving

$$
\sigma=F / 4 \pi \gamma-(\Delta g-\Delta T) / 4 \pi \gamma \Delta Z \text {. }
$$

The substitution of measured and normal values into equation 2 permits its reduction to the more useful form

$$
\sigma=3.6818-39.1425(\Delta g-\Delta T) / \Delta Z \text {. }
$$

If the measured or computed free-air gradient differs from the normal value of $0.09406 \mathrm{mgal} /$ foot, the first term of equation 3 will be changed accordingly.

A computer program, based on the above relationships, that will make all the necessary calculations to determine the interval in situ bulk density was reported by Hearst (1968). The data reported herein were calculated from a computer program extensively modified by R. R. Wahl (U.S. Geol. Survey) from the one described by Hearst. The modified program accepts as basic data the gravity observations in milligals (previously corrected for instrument drift, earth tides, and the effect of shaft and drift voids) and the depth of the gravity observation. If a free-air measurement was previously made, its value in milligals and the measurement height are also input data. Finally, the average elevation of each terrain correction compartment was determined and entered as input data. The program will accept either Hammer (1939), Hayford-Bowie (Hayford and Bowie, 1912), or arbitrary terrain correction zones.

From these input data the computer determines (1) the terrain correction for each observation point, including the free-air gradient; (2) the interval gravity value; (3) the interval footage between observations; (4) the interval terrain correction; (5) the vertical gradient; and (6) the interval in situ bulk density. These data are printed out in tabular form. One option, if called, will print graphically the interval bulk density yalues versus depth using the line printer on the computer. This printout graph permits a rapid visual inspection of any density changes downhole.

\section{BOREHOLE GRAVITY METER DATA}

The borehole gravity meter was used to $\log$ drill holes Ue2y and test well B in northern and southcentral Yucca Flat, UCe-18 in northern Hot Creek Valley, and UE19n on Pahute Mesa (fig. 1). The data obtained are thought to be accurate to within \pm 0.02 mgal, which is the repeatability of the instrument.

\section{Ue2y}

In drill hole Ue2y, which was logged to a depth of 1,236 feet on May 22, 1967, 16 gravity observations were made at depths previously measured and marked on the logging cable, and 15 interval bulk densities were calculated. These densities, which range from 1.82 to $2.06 \mathrm{~g} / \mathrm{cc}$, together with lithologic and stratigraphic data, are plotted on figure 2.

The weighted average bulk density (weighted relative to thickness) of the alluvium between the surface and 1,090 feet is $1.94 \mathrm{~g} / \mathrm{cc}$. The weighted average density of all rocks logged, including the tuff of the Rainier Mesa Member, is $1.93 \mathrm{~g} / \mathrm{cc}$. The densest interval occurs between 100 and 460 feet, which is apparently. attributable to the high percentage of Paleozoic rock fragments in this zone. Microscopic examination of the Ue2y drill cuttings by M. A. Pistrang (oral commun., 1969) indicates that the rock fragments in this interval are composed largely of limestone and dolomite. These Paleozoic rock fragments are very angular, suggesting that they were broken from large cobbles by the drill bit. Above and below this higher density zone the fragments contain welded tuff and are more rounded.

While drill hole Ue2y was being drilled, three sets of density $\log s$ were taken-one when the hole was dry, one when it was filled with Davis Mix, and one 


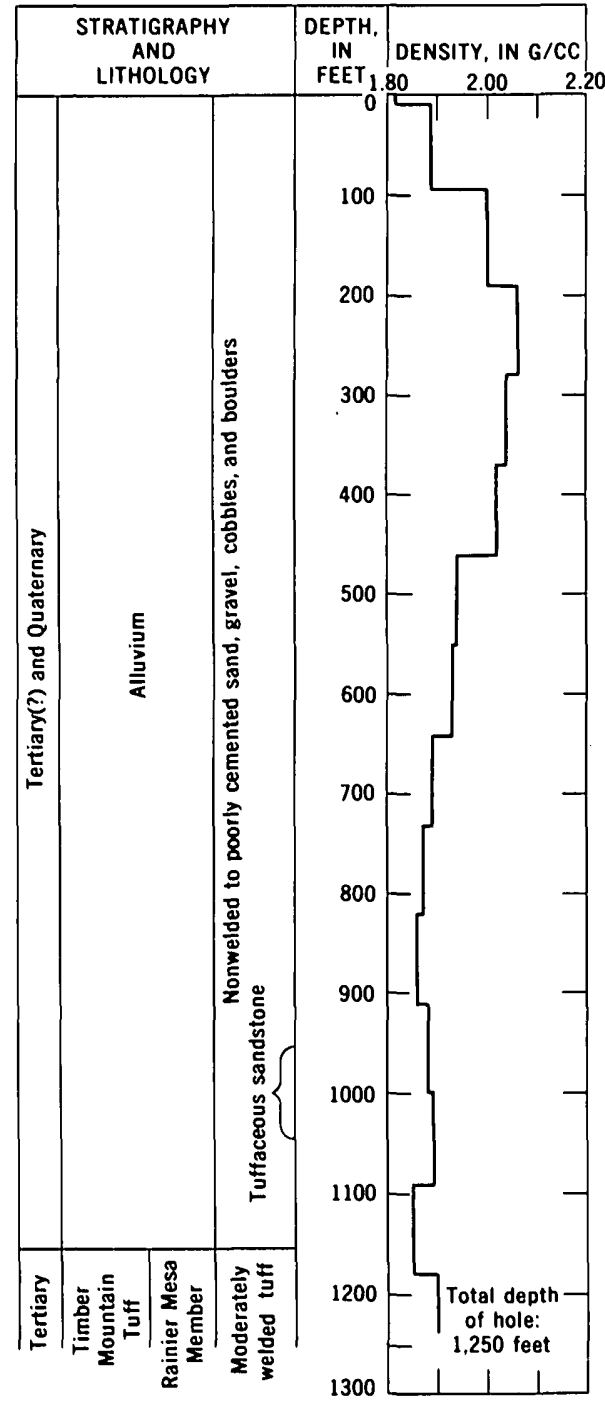

Frgure 2.-In situ interval bulk densities calculated from borehole gravity meter data, drill hole Ue2y.

when it was filled with drilling mud. In 1963, R. D. Carroll (unpub. U.S. Geol. Survey data) suggested that the invasion of drilling fluid in alluvium would increase the measured density significantly above true density. To check this hypothesis these three sets of density $\log \mathrm{s}$ were analyzed in detail by Hearst, Wheeler, and Rambo (1968). They reported that densities measured in the hole when it was filled with Davis Mix or drilling mud were 10-15 percent higher than those measured in the hole when it was dry.

My study of these density logs indicated a somewhat similar result. Generally, the logs in the Davis Mixfilled hole have values intermediate to those of the dry-hole logs (low) and those of the logs taken when the hole was filled with drilling mud (high). How- ever, the interval values of the borehole gravity meter generally plot between the dry-hole values and the Davis Mix values. This suggests that the values from holes filled with Davis Mix and drilling mud are probably too high and that the dry-hole values are probably several percentage points too low. These values may be undercompensated; the erratic and widely fluctuating nature of the dry-hole logs makes it very difficult to correct fully for the proximity effect on the tool because of drill-hole rugosity. The borehole interval values are probably most reliable in drill hole Ue2y.

\section{UCe-18}

Drill hole UCe-18, in northern Hot Creek Valley, was logged to a depth of 6,488 feet on May 27, 1967. Gravity observations were made at 35 stations down the hole, and 34 interval densities were calculated. The in situ rock densities determined from the borehole gravity meter data are compared, on figure 3 , with those from a continuous gamma-gamma density log and with the results of laboratory analysis of core.

The hole penetrated alluvium of Quaternary and Tertiary (?) age from the surface to 4,205 feet, Tertiary (?) lake beds from 4,205 to 4,378 feet, Tertiary rhyolitic lava flows from 4,378 to 6,450 feet, and Tertiary bedded tuff from 6,450 to 6,514 feet (fig. 3). An increase in density with depth is apparent for both the alluvium and volcanic rocks. The increase in density with depth, as determined by the method of least squares, is $0.1045 \mathrm{~g} / \mathrm{cc}$ and $0.1227 \mathrm{~g} / \mathrm{cc}$ for each 1,000 feet of alluvium and rhyolite, respectively. The intervening lake deposits form a distinctive low-density zone having a density of about $2.21 \mathrm{~g} / \mathrm{cc}$, whereas the density of the basal alluvium is $2.35 \mathrm{~g} / \mathrm{cc}$. The weighted average value for the alluvium is $2.22 \mathrm{~g} / \mathrm{cc}$.

The upper part of the rhyolite has a density of 2.26 $\mathrm{g} / \mathrm{cc}$. In the lower part of the hole the density of the rhyolite increases to more than $2.46 \mathrm{~g} / \mathrm{cc}$ and the weighted average density is $2.35 \mathrm{~g} / \mathrm{cc}$. The density of the bedded tuff is not determined inasmuch as only one observation near the upper contact was made.

The density data from the gamma-gamma density $\log$ exhibit a very irregular pattern when compared to the gravity data, but the overall agreement between the two methods is very good. The weighted average density for the alluvium (80-4,202 feet), from the density $\log$, is $2.26 \mathrm{~g} / \mathrm{cc}$. This value differs from the average density determined from the gravity data by $+0.04 \mathrm{~g} / \mathrm{cc}$, which is less than 2 percent. The density $\log$ is subject to all local density variations within the 



Figure 3.-Calculated interval in situ bulk densities from borehole gravity meter and density log data, with laboratory analysis of core, drill hole UCe-18, Hot Creek Valley, Nev. Lithology modified from R. P. Snyder (unpub. data).

penetrated rocks and is also considerably influenced by hole rugosity which affects the positioning of the tool against the side of the hole and, consequently, its precision. None of these factors, however, influence the borehole gravity meter. The density determined from the gravity data is the average value for all the rocks in this interval, out to a radius approximatelv equivalent to five times the interval thickness (McCulloh,
1966, p. 4). This factor tends to average the borehole gravity meter data.

The saturated bulk density data determined by laboratory analysis of core versus depth are plotted on figure 3. These data also exhibit considerable scatter, which is not unexpected because the densities are determined on individual cores from rocks that are not homogeneous. 


\section{Test well B}

Drill hole test well B (TW-B), in southern Yucca Flat, was logged to a depth of 1,510 feet on July 8, 1967. The well is cased to its total depth of 1,675 feet with 103/4-inch steel casing, and therefore no supplementary gamma-gamma density $\operatorname{logs}$ were taken. In the hole, at intervals chosen to coincide with the lithologic breaks reported by Moore and Garber (1962), 16 gravity observations were made, from which 15 interval densities were calculated (fig. 4).

The correlation between the calculated interval densities and the different lithologies is striking. The alluvium density ranges from 1.47 to $1.70 \mathrm{~g} / \mathrm{cc}$, and the weighted average is $1.69 \mathrm{~g} / \mathrm{cc}$. The weighted average for the lake beds is $1.87 \mathrm{~g} / \mathrm{cc}$. The density of the Rainier Mesa Member ranges from $1.61 \mathrm{~g} / \mathrm{cc}$ for the nonwelded tuff to $1.87 \mathrm{~g} / \mathrm{cc}$ for the pumiceous tuff and the underlying incipiently welded tuff. The weighted average value is $1.77 \mathrm{~g} / \mathrm{cc}$. The density of the Tiva Canyon Member of the Paintbrush Tuff ranges from 1.55 to $1.88 \mathrm{~g} / \mathrm{cc}$, and the weighted average value is $1.68 \mathrm{~g} / \mathrm{cc}$. The upper 110 feet of the Topopah Spring Member of the Paintbrush Tuff has a density of 2.25 $\mathrm{g} / \mathrm{cc}$. The weighted average of all the rocks sampled in test well $\mathrm{B}$ is $1.70 \mathrm{~g} / \mathrm{cc}$.

\section{UE19n}

Drill hole UE19n, on Pahute Mesa, was logged to a depth of 1,398 feet on July 9 and 10, 1967. It was drilled with a $97 / 8$-inch bit, but in many places has caved to 20 inches or more.

Fifteen gravity observations were made, at places selected to correspond with lithologic changes, and 14 interval densities were calculated and plotted against depth (fig. 5). UE19n penetrated four separate lithologies, each of which has characteristic density values: Rainier Mesa Member, 2.01-2.19 g/cc, average 2.10 $\mathrm{g} / \mathrm{cc}$; the tuft of Blacktop Buttes of the Paintbrush Tuff, $1.46-1.54 \mathrm{~g} / \mathrm{cc}$, average $1.51 \mathrm{~g} / \mathrm{cc}$, and the tuffs and rhyolites of Area 20,1.63-1.77 g/cc, average 1.70 $\mathrm{g} / \mathrm{cc}$. The density of the rhyolite of Quartet Dome is not defined inasmuch as the density calculations are based on multiple measurements within each unit. The last density shown is accurate for that interval; however, it represents an average value proportionate to the two rock units sampled.

Drill hole UE19n was selected as the site for a specific experiment having very stringent density requirements; therefore, the physical properties of the penetrated rocks, specifically the Paintbrush Tuff, were examined in detail by Stearns and Hearst (1967), Sterrett (1968), and Hearst and Carlson (1968). The

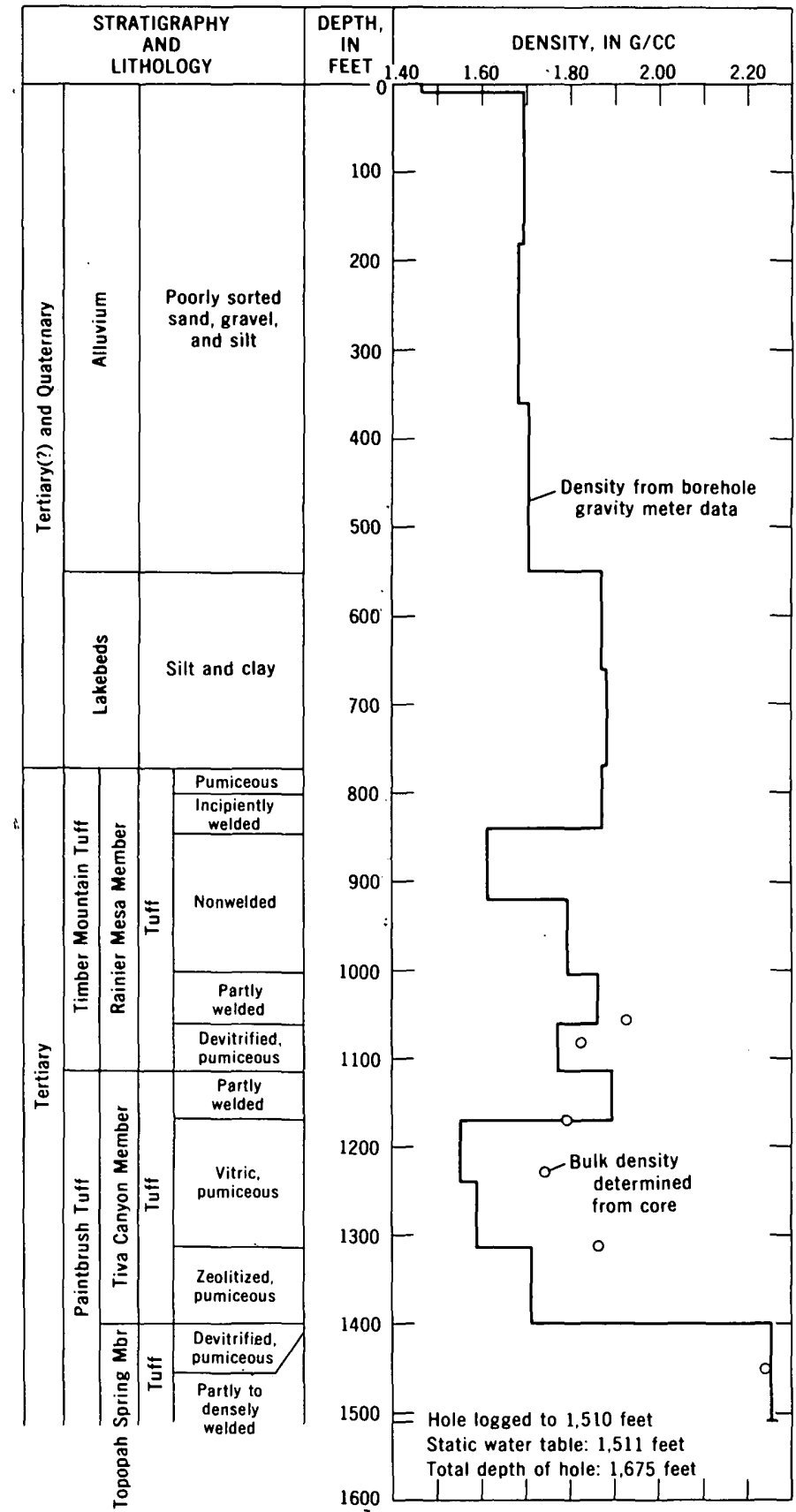

FigURe 4-Calculated in situ interval bulk densities from borehole gravity meter data in drill hole test well B (TW-B). Stratigraphy from Orkild (1965); lithology modified from Moore and Garber (1962).

summary results of their work are also plotted. on figure 5 .

In the most critical zone-the nonwelded ash-flow tuff between 500 and 970 feet-usable results came only from the borehole gravity meter and the Rugosity Insensitive Density System (RIDS), recently developed by the Lawrence Radiation Laboratory (Hearst and Carlson, 1969), which was formerly named Rugos- 


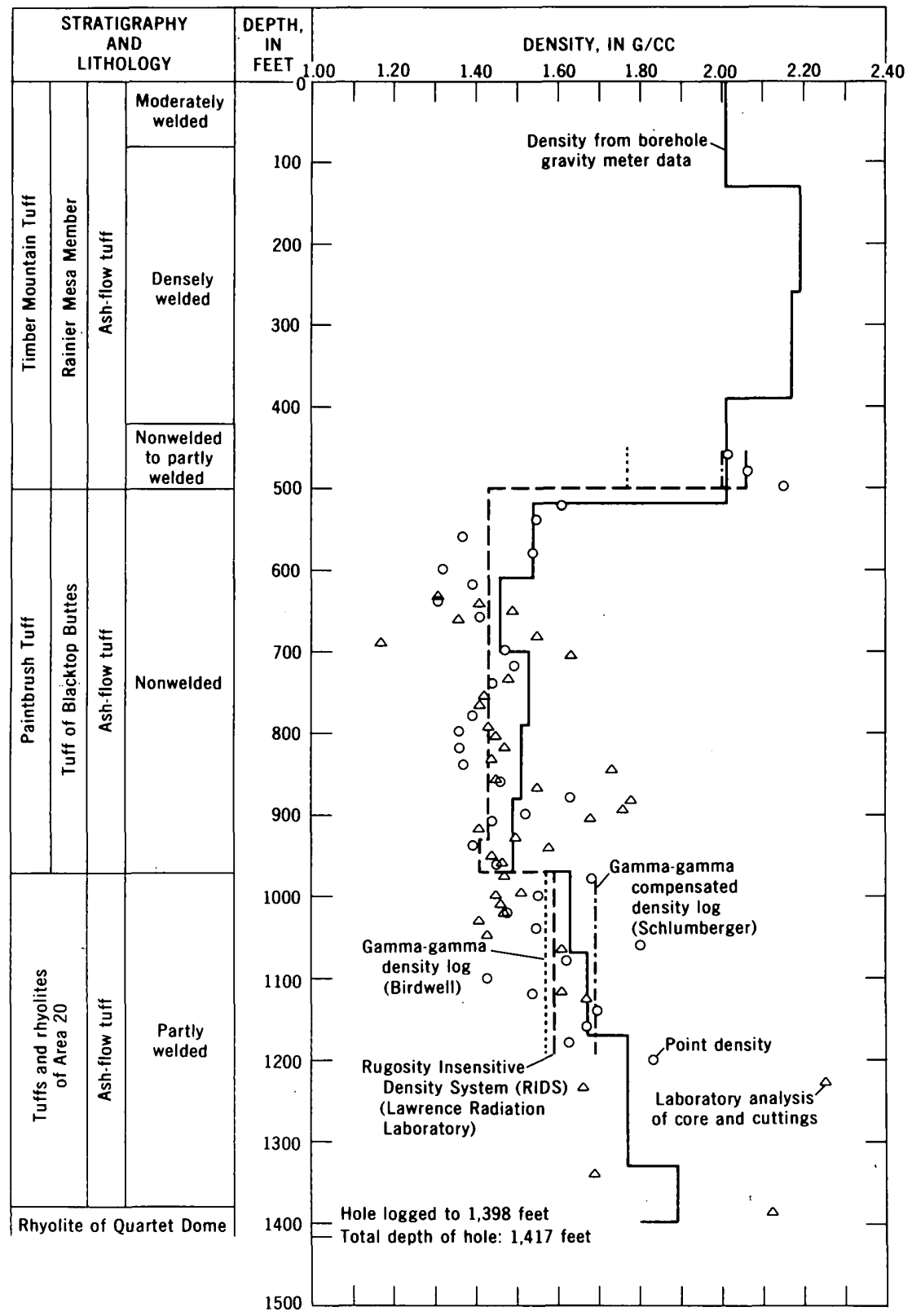

Figure 5.-Graph comparing in situ density data determined by borehole gravity meter, density $\mathrm{log}$, and laboratory analysis of cuttings of Tertiary rocks, drill hole UE19n, Pahute Mesa. Point density (LRL) from Stearns and Hearst (1967, p. 25) ; laboratory analysis of core and cuttings (Core Laboratories, Inc.) from Sterrett $(1968$, p. 20$)$.

ity Insensitive Density $\log$ (RIDL). These values, based on the average differences in the calculated densities, agree within 5.3 percent of each other. However, the RIDS values may be low by as much as 3 percent (Hearst and Carlson, 1968, p. 16) because of uncompensated background radiation. Both the Birdwell and Schlumberger gamma-gamma density $\operatorname{logs}$ were unusable because of hole rugosity and caving in this zone. The point readings, taken about 20 feet apart with the RIDS tool in UE19n and plotted as circles on figure
5 , and the average densities for each interval, determined from these point readings and shown as long dashes, are from Stearns and Hearst (1967, p. .25, table 6, p. 11).

Core Laboratories, Inc. determined the bulk (natural-state) density values of cuttings from several depths; these are plotted as triangles on figure 5. Inasmuch as adequate core samples could not be obtained from these very incompetent rocks, the density determinations were made on powdered cuttings. The density 
values determined in the laboratory exhibit considerable scatter and, because they are determined from powdered samples, are not given much credence.

As a result of this detailed study the physical properties of the rocks penetrated by UE19n are probably better known than those at any other place at the Nevada Test Site. The absolute in situ bulk density of these rocks may not be known; however, the densities determined from the gravity data should certainly be within 5 percent and probably within 3 percent of the true value.

\section{OTHER SUBSURFACE GRAVITY DATA}

Standard gravity meters were used to $\log$ the U5i shaft in Frenchman Flat and five 48-inch-diameter drill holes on Pahute Mesa.

\section{U5i shaft}

The U5i shaft was sunk in northern Frenchman Flat, and its dimensions were $11 \times 15 \times 825$ feet. The shaft penetrated alluvium to total depth.

On August 4, 1966, a total of nine gravity observations were made: one on the surface, one on the bottom, and one in each of seven small alcoves spaced about 100 feet apart down the shaft. The alcoves were places where alluvium samples had been removed from one side of the shaft, which provided vibration-free places to set the gravity meter. This set of observations was made with a Worden Master gravity meter having a scale constant of $0.0756 \pm 0.0001 \mathrm{mgal}$ per scale division. The corrections for the open vertical shaft, as well as those for the 545 -foot horizontal drift at the base of the shaft, were determined and included with the observed gravity values before submitting the data to the computer.

The calculated in situ interval densities from the U5i shaft, together with values from a continuous gamma-gamma density log taken in an adjacent drill hole are plotted on figure 6 . The density values from the gravity data range from 1.97 to $2.17 \mathrm{~g} / \mathrm{cc}$, and the weighted average density is $2.05 \mathrm{~g} / \mathrm{cc}$.

A continuous gamma-gamma density $\log$ was taken in drill hole Ue5i, which was drilled 648 feet north and 131 feet west of the U5i shaft. Similar lithologies were found in both holes. Above 332 feet the density $\log$ was unusable because of caving; however, in the interval between 332 and 844 feet a weighted average bulk density of $2.04 \mathrm{~g} / \mathrm{cc}$ was determined. This value is $0.04 \mathrm{~g} / \mathrm{cc}$ lower and differs by less than 2 percent from the $2.08 \mathrm{~g} / \mathrm{cc}$ determined from the gravity data for the interval 291 to 825 feet.

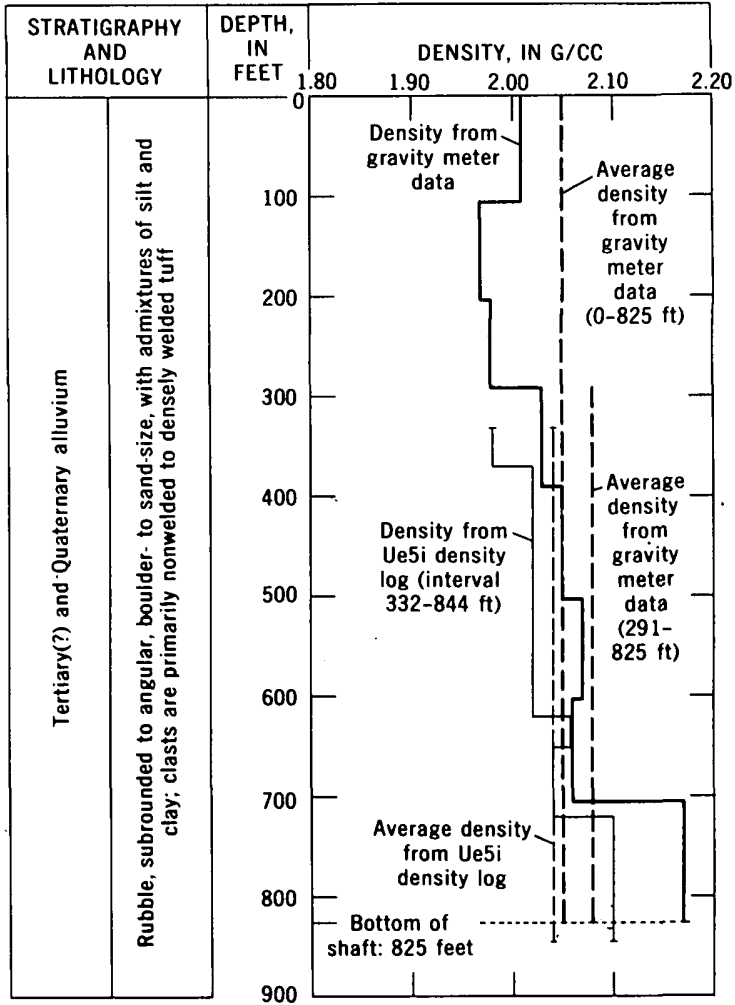

Figure 6.-Interval in situ bulk density values calculated from gravity data and density logs, U5i shaft and Uesi drill hole, Frenchman Flat, Nev.

\section{Pahute Mesa 48-inch holes}

A total of five 48 -inch cased holes were logged with standard gravity meters between December 1966 and December 1967. These holes were drilled on Pahute Mesa and were equipped with hoists and cages which permitted the physical transportation of a gravity meter to the bottom. Three round trips to the bottom of each hole were made to insure the accuracy of the observations made on the ground surface and on the chamber floor.

The surface observations were set back several feet from the open holes to minimize the void corrections. The chamber observations were corrected for the chamber voids but no correction for the hole voids were necessary inasmuch as each hole was overdrilled below the chamber. The correction for the open hole below the observation is positive, whereas the correction for the hole above is negative. These corrections cancel when $Z>10 R$ (Domzalski, 1954, p. 436), where $Z$ is depth of hole and $R$ is the radius of the hole.

Free-air gradient measurements were made between the surface and the headframe over three of the five holes. These values, corrected for the effect of adjacent terrain, ranged from 0.090253 to $0.095045 \mathrm{mgal} / \mathrm{foot}$, and -4 and +1 percent below and above the normal 
value. A normal free-air gradient of $0.094061 \mathrm{mgal} /$ foot was assumed for the other two holes which did not have either headframes or adjacent high structures upon which to measure the free-air gradients.

The generalized geology of each of these five holes is presented graphically on figure 7 .

The depths at which the gravity observations were made range from 2,247 feet in drill hole U19c to 4,748 feet in U19e. The resulting data from these five holes are summarized in table 1 . The calculated in situ bulk density varies by only $0.08 \mathrm{~g} / \mathrm{cc}$ even though the wells are widely distributed over Pahute Mesa. All five holes are in the Silent Canyon caldera (Healey, 1968, fig. 3, p. 152). For a detailed description of the subsurface geology of the Silent Canyon caldera see Orkild, Byers, Hoover, and Sargent (1968). Drill holes U20f and U19c are near the edge of the caldera on the west and east, respectively. Each hole is drilled on a gravity gradient that outlines the caldera boundary.
An increase in density toward this boundary, based on the gravity anomaly, is to be expected.

Calculations in table 1 were substantiated by analyzing laboratory-determined bulk density values for core samples from each hole and also by assigning bulk density values to the varying lithologies penetrated by the hole where no core was taken. The bulk density values assigned are determined in several ways. The very detailed, but unpublished, graphic lithologic log of each hole was consulted to determine the rock type. Then, known values from similar lithologies within the hole, or from adjacent holes, or elsewhere on Pahute Mesa were assigned to these intervals.

In drill hole U20f, the mean value of the dry and saturated bulk density values for 22 core samples is $1.98 \mathrm{~g} / \mathrm{cc}$. When density values are assigned to those lithologic units not cored, the weighted value becomes $2.02 \mathrm{~g} / \mathrm{cc}$. These weighted values agree to within -3.9

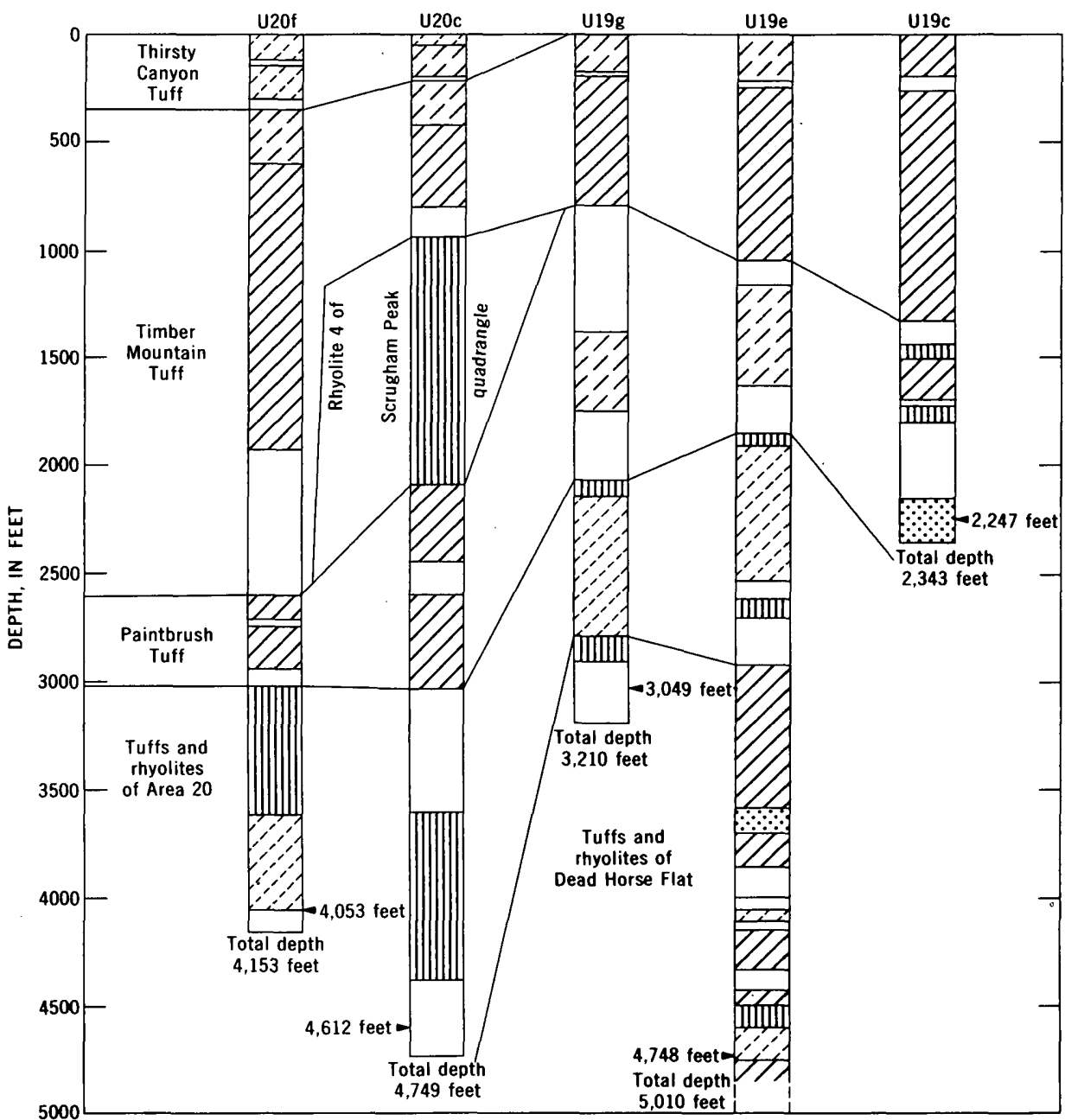

EXPLANATION

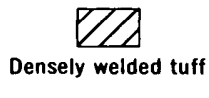

[Z3

Moderately welded tuff

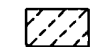

Nonwelded to slightly welded tuff

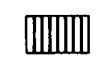

Lava flow

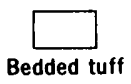

.

Silty or sandy rock

$-2,247$ feet

Depth of gravity observation

FIGURE 7.-Generalized graphic lithologic logs of Tertiary rocks in five 48-inch-diameter drill holes in which gravity observations were made, Nevada Test Site. (Geology from unpub. report by P. P. Orkild, U.S. Geol. Survey.) 
TABLE 1.-Summation of data resulting from gravity observations in five 48-inch-diameter drill holes in Pahute Mesa, Nevada Test Site

\begin{tabular}{|c|c|c|c|c|c|c|c|}
\hline Drill hole & $\begin{array}{l}\text { Total hole } \\
\text { depth (feet) }\end{array}$ & $\begin{array}{l}\text { Observation } \\
\text { depth (feet) }\end{array}$ & $\underset{\text { (mgal/ft) }}{\text { Free-air }}$ & $\begin{array}{l}\text { Interval } \\
\text { gravity } \\
\text { (mgal) }\end{array}$ & $\begin{array}{l}\text { Interval } \\
\text { terrain } \\
\text { correction } \\
\text { (mgal) }\end{array}$ & $\begin{array}{c}\text { Vertical } \\
\text { gradient } \\
\text { (mgal/ft) }\end{array}$ & $\begin{array}{l}\text { Calculated } \\
\text { density } \\
(\mathrm{g} / \mathrm{cc})\end{array}$ \\
\hline U20f & 4,153 & 4,053 & $\begin{array}{l}0.094061 \\
\text { (assumed) }\end{array}$ & 167.62 & -0.3278 & 0.0414 & 2. 060 \\
\hline 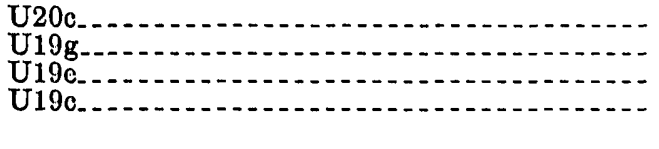 & $\begin{array}{l}4,749 \\
3,210 \\
5,010 \\
2,343\end{array}$ & $\begin{array}{l}4,612 \\
3,049 \\
4,748 \\
2,247\end{array}$ & $\begin{array}{c}.093139 \\
.095045 \\
.090253 \\
.094061 \\
\text { (assumed) }\end{array}$ & $\begin{array}{r}195.75 \\
137.55 \\
191.85 \\
97.57\end{array}$ & $\begin{array}{l}\text { 2. } 4112 \\
\text { 1. } 7337 \\
\text { 3. } 9968 \\
\text { 3. } 1401\end{array}$ & $\begin{array}{l}.0419 \\
.0445 \\
.0396 \\
.0420\end{array}$ & $\begin{array}{l}\text { 2. } 005 \\
\text { 1. } 977 \\
\text { 1. } 984 \\
\text { 2. } 037\end{array}$ \\
\hline
\end{tabular}

and -1.9 percent of the calculated values. An analysis of density $\log$ in the interval $735-4,053$ feet by R. D. Carroll (unpub. data, 1966) gives a value of $2.02 \mathrm{~g} / \mathrm{cc}$, which also agrees to within 1.9 percent of the calculated value. In drill hole U20c, the mean of $25 \mathrm{un}$ weighted samples yields a density of $2.01 \mathrm{~g} / \mathrm{cc}$, but 2.02 $\mathrm{g} / \mathrm{cc}$ is determined when densities are assigned to those lithologies not cored. These values agree to within +0.0 and +0.5 percent of the calculated value of 2.01 $\mathrm{g} / \mathrm{cc}$. In drill hole U19g, the mean of eight unweighted samples yields a value of $1.95 \mathrm{~g} / \mathrm{cc}$. To obtain a value weighted by lithology, bulk densities had to be assigned to 1,841 feet of rock, or 60 percent of the measured interval. The weighted value thus determined was $2.03 \mathrm{~g} / \mathrm{cc}$. These values agree to within -1.5 and +2.5 percent of the calculated value. In drill hole $\mathrm{U} 19 \mathrm{e}$, the mean of 15 unweighted samples yields a value of $2.04 \mathrm{~g} / \mathrm{cc}$. To obtain a value weighted for the uncored rock types, values were assigned to 1,232 feet of rock, or 26 percent of the measured interval. The value thus determined was $2.11 \mathrm{~g} / \mathrm{cc}$. The agreement between these values and the calculated value of 1.98 $\mathrm{g} / \mathrm{cc}$ is +3.0 and +6.6 percent. Finally, the mean of six unweighted core values in drill hole U19c yields a value of $1.98 \mathrm{~g} / \mathrm{cc}$. A value of $2.05 \mathrm{~g} / \mathrm{cc}$ was determined by assigning bulk densities to 461 feet of rock or 20.5 percent of the measured interval. These values agree to within -2.9 and +0.5 percent of the calculated value of $2.04 \mathrm{~g} / \mathrm{cc}$.

\section{GAMMA-GAMMA DENSITY LOGS}

The accurate bulk density data determined from the gravity observations provide an opportunity to evaluate the accuracy and applicability of the gamma-gamma density logs taken in the many drill holes at the Nevada Test Site and in Hot Creek Valley.

The accuracy of the density logs in or adjacent to those holes logged by gravity meter has been discussed earlier in the text. From the level of accuracy so far obtained, it was concluded that density logs in other holes could be profitably used to extend knowledge of the bulk density of the alluvium in other parts of Yucca Flat and Hot Creek Valley. Such values should be accurate to within \pm 5.0 percent in the dry and rugose holes, and probably within \pm 2.5 percent in the wet and (or) more smooth holes after corrections for hole size and proximity. With this accuracy in mind, I studied gamma-gamma density logs from five holes in Yucca Flat (fig. 1) which penetrated a total of almost 6,000 feet of alluvium. The data thus obtained were combined with the gravity meter data for statistical analysis. In all, more than 7,300 feet of alluvium was studied, and the mean density is $2.012 \pm 0.007 \mathrm{~g} / \mathrm{cc}$, the variance $\left(\sigma^{2}\right)$ is $0.037 \mathrm{~g} / \mathrm{cc}$, the standard deviation $(\sigma)$ is 0.192 $\mathrm{g} / \mathrm{cc}$, and the standard error $\left(\sigma_{m}\right)$ is $0.007 \mathrm{~g} / \mathrm{cc}$.

In Hot Creek Valley, density log data from six holes (fig. 1) which penetrated a total of almost 14,000 feet of alluvium were combined with data for the 4,202 feet of alluvium logged by gravity meter in UCe-18. The statistical analysis of these data yielded a mean density $(\bar{x})$ of $2.184 \pm 0.004 \mathrm{~g} / \mathrm{cc}$, a variance $\left(\sigma^{2}\right)$ of $0.026 \mathrm{~g} / \mathrm{cc}$, a standard deviation $(\sigma)$ of $0.163 \mathrm{~g} / \mathrm{cc}$, and a standard error $\left(\sigma_{m}\right)$ of $0.004 \mathrm{~g} / \mathrm{cc}$.

\section{REFERENCES}

Airy, G. B., 1856, Account of pendulum experiments undertaken in the Harton Colliery for the purpose of determining the mean density of the earth: Royal Soc. London Philos. Trans,. v. 146, nos. 14, 15, p. 297-356.

Dolbear, D. W. N., 1959, Design considerations of a bore-hole gravimeter: Geophys. Prosp. [Netherlands] v. 7, no. 2, p. 196-201.

Domzalski, W., 1954, Gravity measurements in a vertical shaft: Inst. Mining and Metallurgy Trans., Bull. 63, no. 9, p. 429445.

- 1955, Relative determination of the density of surface rocks and the mean density of the earth from vertical gravity measurements: Geophys. Prosp. [Netherlands] v. 3, no. 3 , p. $212-227$.

Gilbert, R. L. G., 1952, Gravity observations in a borehole: Nature, v. 170 , no. 4523 , p. $424-425$.

Goodell, R. R., and Fay, C. H., 1964, Borehole gravity and its application : Geophysics, v. 29, no. 5, p. 774-782.

Grant, F. S., and West, G. F., 1965, Interpretation theory in applied geophysics: New York, McGraw-Hill Book Co., Inc., $583 \mathrm{p}$. 
Hammer, Sigmund, 1939, Terrain corrections for gravimeter stations: Geophysics, v. 4, no. 3, p. 184-194.

- 1950, Density determinations by underground gravity measurements: Geophysics, v. 15 , no. 4, p. 637-652.

Hayford, J. F., and Bowie, William, 1912, The effect of topography and isostatic compensation upon the intensity of gravity: U.S. Coast and Geod. Survey Spec. Pub. 10, 132 p.

Healey, D. L., 1968, Application of gravity data to geologic problems at Nevada Test Site: Geol. Soc. America Mem. 110, p. 147-156.

Hearst, J. R., 1968, Terrain corrections for borehole gravimetry : Geophysics, v. 33, no. 2, p. 361-362.

Hearst, J. R., and Carlson, R. C., 1968, The rugosity insensitive density $\log$ : California Univ., Lawrence Radiation Lab. Rept. UCRL-70962.

1969, The RIDS-A density logger for rough holes: Geophysics, v. 34, no. 2, p. 222-234.

Hearst, J. R., Wheeler, V. E., and Rambo, J. T., 1968, On the effect of drilling fluid on measured density in alluvium: California Univ., Lawrence Radiation Lab. Rept. UCID15313.

Howell, L. G., Heintz, K. O., and Barry, A., 1965, The development and use of a high-precision downhole gravity meter: Geophysics, v. 31, no. 4, p. 764-772.

Kumagi, Naoiti, Abe, E., and Yoshimura, Y., 1960, Measurements of the vertical gradient of gravity and its significance: Boll. Geofisica Teor. ed Appl., v. 2, no. 8, p. 607-630.

Lorenz, H., 1938, Beiträge zur Theorie des Erdaufbaus: Zeitschr. Geophysik, v. 14, p. 142-152.

Lukavchenko, P. I., 1962, Observations with gravity meters in wells and mine shafts [in Russian]: Razved. i Promyslovaya Geofizika, no. 43 , p. 52-64.

McCulloh, T. H., 1965, A confirmation by gravity measurements of an underground density profile based on core densities: Geophysics, v. 30, no. 6, p. 1108-1132.

- 1966, The promise of precise borehole gravimetry in petroleum exploration and exploitation: U.S. Geol. Survey Circ. 531, $12 \mathrm{p}$.
1967, Borehole gravimetry-New developments and applications, in Origin of oil, geology and geophysics: World Petroleum Cong., 7th, Mexico, 1967, Proc., v. 2, London, Elsevier Publishing Co., p. 735-744.

McCulloh, T. H., LaCoste, L. J: B., Schoellhamer, J. E., and Pampeyan, E. H., 1967, The U.S. Geological Survey-LaCoste and Romberg precise borehole gravimeter system-Instrumentation and support equipment, in Geological Survey Research 1967: U.S. Geol. Survey Prof. Paper 575-D, p. D92-D100.

McCulloh, T. H., Schoellhamer, J. E., Pampeyan, E. H., and Parks, H. B., 1967, The U.S. Geological Survey-LaCoste and Romberg precise borehole gravimeter system-Test results, in Geological Survey Research 1967: U.S. Geol. Survey Paper 575-D, p. D101-D112.

Moore, J. E., and Garber, M. S., 1962, Ground-water test well B, Nevada Test Site, Nye County, Nevada: U.S. Geol. Survey TWI-S08, issued by the U.S. Atomic Energy Comm. Tech. Inf. Service, Oak Ridge, Tenn., $39 \mathrm{p}$.

Orkild, P. P., 1965, Paintbrush Tuff and Timber Mountain Tuff of Nye County, Nevada, in Cohee, G. V., and West, W. S., Changes in stratigraphic nomenclature by the U.S. Geological Survey, 1964: U.S. Geol. Survey Bull. 1224-A, p. A44-A51.

Orkild, P. P., Byers, F. M., Jr., Hoover, D. L., and Sargent, K. A., 1968, Subsurface geology of Silent Canyon caldera, Nevada Test Site, Nevada: Geol. Soc. American Mem. 110, p. 77-86.

Smith, N. J., 1950, The case for gravity data from boreholes: Geophysics, v. 15, no. 4, p. 605-635.

Stearns, R. T., and Hearst, J. R., 1967, Geophysical measurements in a low-density medium at the Scroll site: California Univ., Lawrence Radiation Lab. Rept. UCID-15233, 38 p.

Sterrett, T. S., 1968, Summary of the UE19n Scroll exploratory drill hole: California Univ., Lawrence Radiation Lab. Rept. UCID-15245, $44 \mathrm{p}$. 


\title{
GEOLOGIC AND GRAVITY EVIDENCE FOR A BURIED PLUTON, LITTLE BELT MOUNTAINS, CENTRAL MONTANA
}

\author{
By I. J. WITKIND, M. D. KLEINKOPF, and W. R. KEEFER, \\ Denver, Colo.
}

\begin{abstract}
Gravity contours delineate a buried pluton that has domed Precambrian metamorphic crystalline rocks exposed in the core of the Little Belt Mountains, central Montana. The pluton, probably of Tertiary age, appears to be a northeastwardtrending ovoid body 3 miles wide and possibly as much as 7 miles long.
\end{abstract}

The Little Belt Mountains are one of several laccolithic mountain groups that rise above the plains of central Montana (fig. 1). The core of the range is composed of Precambrian crystalline metamorphic rocks that have been intruded and uplifted by a compound rhyolitic pluton of Tertiary age. Part of the pluton is exposed, but most of it is still concealed beneath the Precambrian rocks. Deposits of silver, lead, and zinc have been mined from the exposed part, and similar deposits may be within the buried part.

The gross shape and size of the pluton have been suggested by detailed geologic mapping and gravity

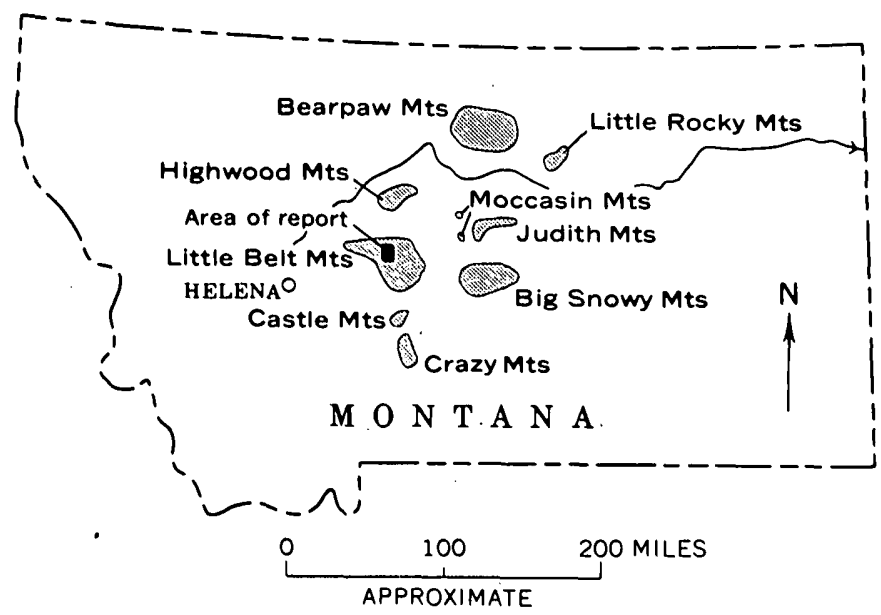

Froure 1.-Index map of Montana, showing the major laccolithic and volcanic mountain groups (stippled areas) in central Montana. studies. Maps resulting from the geologic investigations have been placed on open file by the U.S. Geological Survey (Witkind, 1969; Keefer, 1969).

The Precambrian complex crops out in about 50 square miles in the southern third of the Barker $71 / 2$ minute quadrangle and the northern third of the Neihart 71/2-minute quadrangle, Cascade and Judith Basin Counties, central Montana (fig. 2). It consists of both paragneisses and orthogneisses which have undergone two episodes of metamorphism (Catanzaro and Kulp, 1964). The complex is overlain by Paleozoic rocks along its northern margin and by rocks of the Precambrian Belt Supergroup to the south.

The pluton, composed of several quartz rhyolite porphyries grouped as the Snow Creek Porphyry, was intruded into the Precambrian basement during the early Tertiary as indicated by preliminary $\mathrm{K}$-Ar data (R. F. Marvin, written commun., 1969). Although the pluton is exposed only in an area of about $1 \frac{1}{2}$ square miles (fig. 2), several lines of geologic evidence suggest that it underlies a much larger part of the Precambrian crystalline terrane: (1) sharp doming of the Precambrian basement as reflected by moderate to steep dips in the flanking sedimentary rocks; (2) geographic distribution, in the Precambrian complex, of small quartz rhyolite porphyry dikes that are mineralogically and chemically similar to the Snow Creek Porphyry; (3) prograde contact metamorphism in some Precambrian metamorphic rocks (microcline incompletely converted to orthoclase, actinolite grains with hormblende rims, fig. 3), and (4) local areas where the pluton can be seen to intrude and pass beneath the metamorphic rocks.

Gravity data were collected at 146 stations across the buried pluton (fig. 2). The data were referenced to the absolute value determined by Woollard and Rose (1963) for station WA 124, Great Falls, Mont., air- 


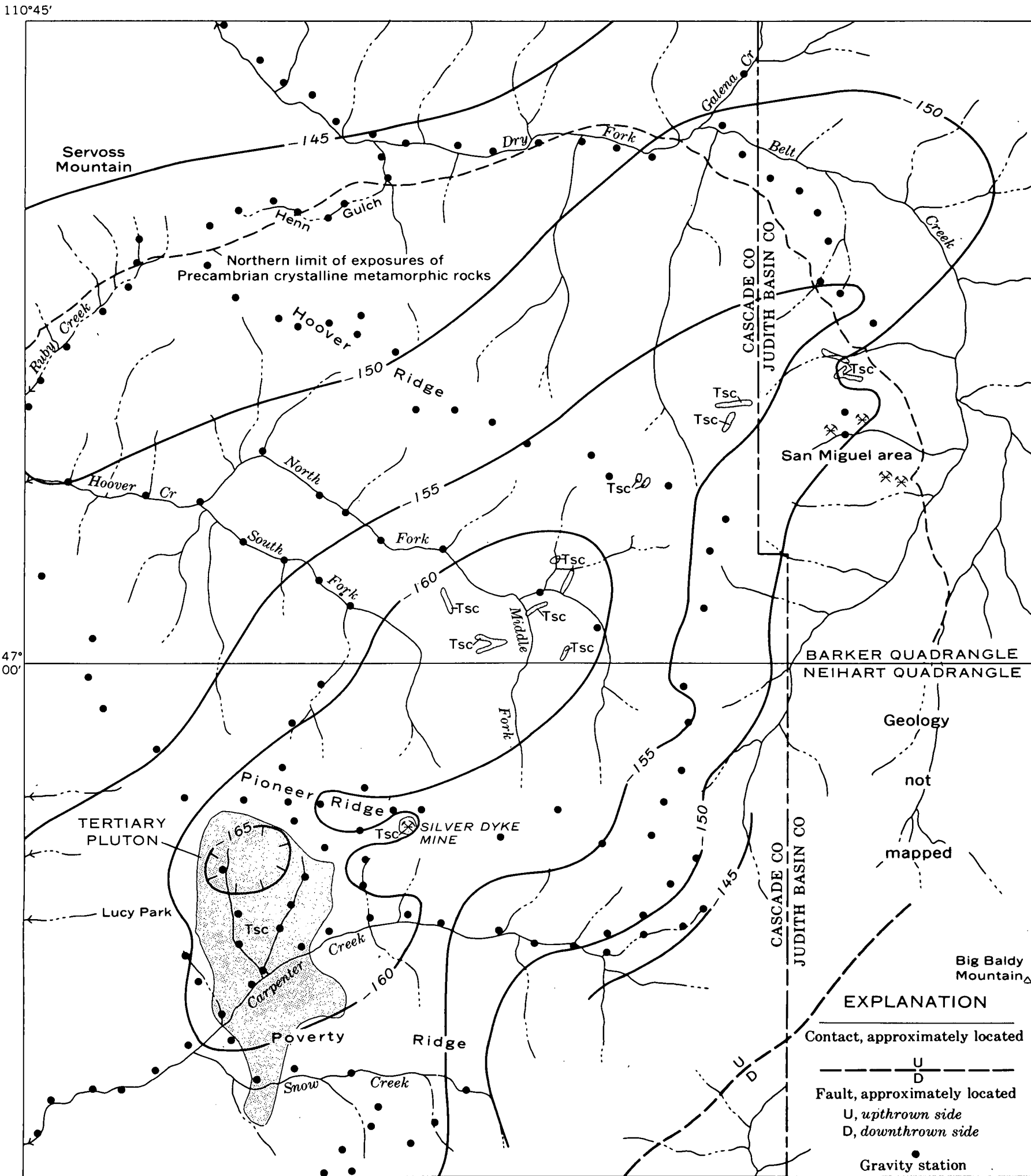

2 MILES

F.GURE 2.-Complete Bouguer gravity and geologic sketch map. Gravity contoured by M. D. Kleinkopf; gravity contour interval is 5 milligals. Geology morth of lat $47^{\circ} 00^{\prime} \mathrm{N}$. by I. J. Witkind in 1967 ; south of it by W. R. Keefer in 1965. Base from U.S. Geological Survey 1961. Tsc, Snow Creek Porphyry of Tertiary age. All mines shown are abandoned. 


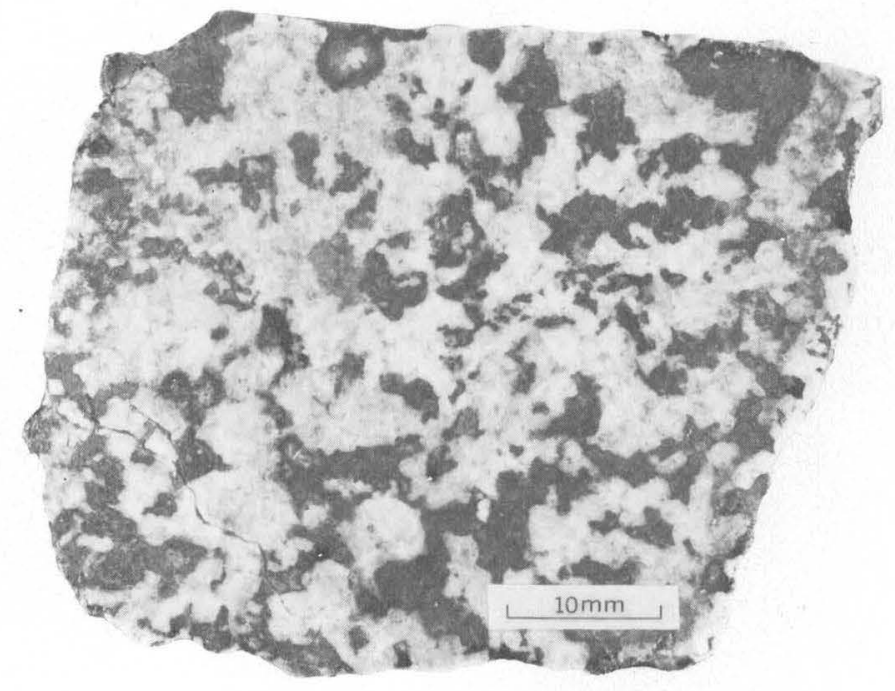

A

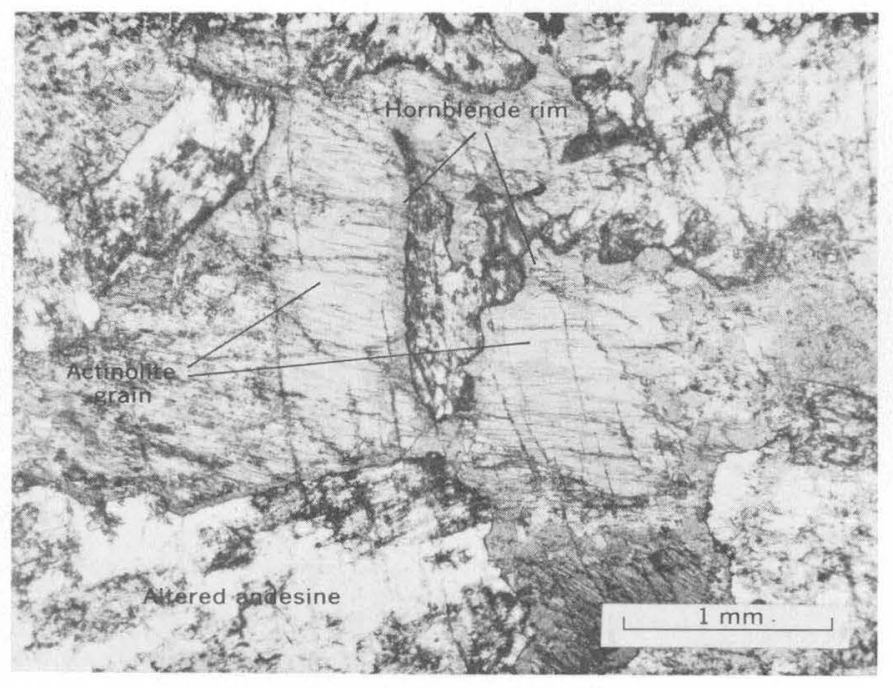

$B$

Figure 3.-Pinto Diorite, a typical orthogneiss from the Precambrian complex, Little Belt Monntains, $A$, hand specimen showing characteristic mottled appearance. Dark areas are clusters of hornblende grains; light areas are clusters of andesine grains. $B$, actinolite grains rimmed by hornblende. Photographs by Richard B. Taylor and Sandra Brennan, U.S. Geological Survey.

port. Corrections were made for drift, latitude, elevation, and terrain effects. Terrain corrections were computed out to a distance of 167 kilometers. An elevation factor of $0.06 \mathrm{mgal}$ per $\mathrm{ft}$ (milligal per foot), based on an assumed density of $2.67 \mathrm{~g} / \mathrm{cm}^{3}$, was used in the calculations of elevation and terrain corrections. Vertical and horizontal positions for the stations were determined from bench-mark data and topographic controls shown on the $71 / 2$-minute quadrangle maps of the U.S. Geological Survey. The accuracy of the Bouguer gravity data is estimated to be $1 \mathrm{mgal}$.

Complete Bouguer gravity data across the buried pluton show a striking gravity-minimum anomaly of about $15 \mathrm{mgal}$. The anomaly appears to define the lateral extent of the pluton, but little can be said about the depth configuration without detailed model studies of the gravity data.

The gravity-minimum anomaly suggests that the pluton may be about 3 miles wide and extend 4 to 6 miles northeastward from the outcrop along Carpenter Creek. It also may extend at least 1 mile southwest of the outcrop. The minimum anomaly is distorted at the northeastern end probably by high densities of the intensely deformed and altered metamorphic rocks in the San Miguel area.

Two additional lines of evidence substantiate the definition of the buried pluton by gravity data. First, the axis of the gravity-minimum anomaly correlates with a zone of quartz porphyry dikes and plugs which are probably apophyses of the concealed pluton (fig. 2 ). Second, the association of a gravity-minimum anomaly with the Snow Creek Porphyry is predictable from rock density studies. Results from three determinations of Snow Creek Porphyry and 10 determinations of Precambrian metamorphic rocks showed a lower density for the porphyry of about $0.2 \mathrm{~g} / \mathrm{cm}^{3}$. The lowest gravity values in the area are defined by the -165-mgal contour closure whch is over the north part of the porphyry outcrop along Carpenter Creek.

\section{REFERENCES}

Catanzaro, E. J., and Kulp, J. L., 1964, Discordant zircons from the Little Belt (Montana), Beartooth (Montana), and Santa Catalina (Arizona) Mountains: Geochim. et Cos. mochim. Acta, v. 28, no. 4, p. 87-124.

Keefer, W. R., 1969, Preliminary geologic map of the Neihart $\left(71^{\prime} 2^{\prime}\right)$ quadrangle, Cascade and Judith Basin Counties, Montana: U.S. Geol. Survey open-file map.

Witkind, I. J., 1969, Preliminary geologic map of the Barker ( 7 1/2') quadrangle, Judith Basin and Cascade Counties, Montana: U.S. Geol. Survey open-file map.

Woollard, G. P., and Rose, J. C., 1963, International gravity measurements: Wisconsin Univ. Geophys. and Polar Research Center, 518 p. 


\title{
AEROMAGNETIC AND GRAVITY FEATURES OF THE WESTERN FRANCISCAN AND SALINIAN BASEMENT TERRANES BETWEEN CAPE SAN MARTIN AND SAN LUIS OBISPO, CALIFORNIA
}

\author{
By W. F. HANNA, Menlo Park, Calif.
}

\begin{abstract}
Aeromagnetic and gravity data covering a 30- by 65-mile area along the southwest coast of California help delineate the occurrence of subsurface serpentinites, plutonic and metamorphic rocks, and sedimentary basin fill within the eugeosynclinal Franciscan and the plutonic and metamorphic Salinian basement complexes. The magnetic data suggest that the buried contact between basement tracts forms a broad arc, convex toward "the northeast, between the exposed basement contacts in the northern and southern parts of the area. Gravity data conspicuously reflect thick sedimentary rock accumulations within each of the basement terranes.
\end{abstract}

A regional study of aeromagnetic and gravity data was made to add a vertical dimension to geologic mapping along the southwest coast of California between Cape San Martin and San Luis Obispo (fig. 1). The area, a 30 - by 65 -mile rectangle, trends $\mathrm{N} .40^{\circ} \mathrm{W}$. and contains two strikingly different basement complexes, each extensively covered by sedimentary rocks and other deposits. These complexes are: (1) a eugeosynclinal assemblage called the Franciscan (Reed, 1933; Taliaferro, 1943; Bailey and others, 1964), restricted to the southwest part of the area, and (2) a plutonic and metamorphic rock assemblage of the Salinian block (Compton, 1966; Page, 1966), confined to the northeast part of the area.

Geologic mapping has provided much information about general lithologic and structural characteristics of Franciscan and Salinian rocks exposed at the surface. As an aid to understanding gross lithologic and structural features of the basement rocks deeper in the earth's crust, the aeromagnetic and gravity data were interpreted in light of the geologic mapping. The combination of geologic and geophysical data provides some insight into the subsurface distribution of basement rocks, the contact between contrasting basement

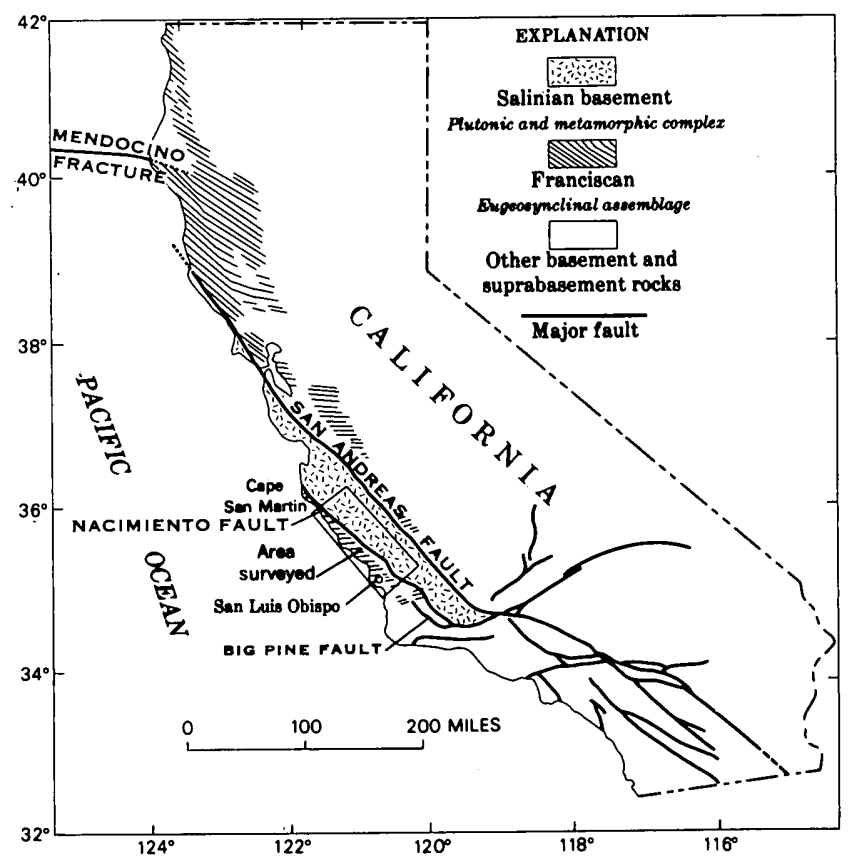

Figure 1.-Index map showing regional geologic setting and area surveyed. Geology from Bailey and others (1964).

terranes, and local geologic features within the basement terranes.

\section{GEOLOGIC SETTING}

The area investigated forms part of the southwest margin of a 300 - by 40 -mile block of late Mesozoic plutonic and metamorphic rocks, the Salinian block, in lateral contact with late Mesozoic eugeosynclinal rocks, the Franciscan assemblage, at its northeast and southwest boundaries, extending under the Pacific Ocean at its northwest boundary, and covered by Cenozoic sedimentary rocks at its southeast boundary (fig. 1). This crystalline block appears to be bounded by 
four major fault systems: (1) the San Andreas fault on the northeast, (2) the Sur-Nacimiento fault system on the southwest (known as the Nacimiento fault in the area studied), (3) the Mendocino fracture zone on the northwest, and (4) the Big Pine fault on the southeast (Chesterman, 1952 ; Hanna, 1952 ; Hill and Dibblee, 1953; Menard, 1955; Bailey and others, 1964; Page, 1966 ; Compton, 1966; Vedder and Brown, 1968). Upper Mesozoic and Cenozoic sedimentary rocks cover extensive areas of both basement terranes.

The Salinian basement complex in the area studied consists of outcropping metamorphic rocks of the Sur Series of Trask (1926) northeast of Cape San Martin, a wedge of exposed plutonic rocks northwest of Paso Robles, and a broad area of exposed plutonic rocks northeast of Santa Margarita (fig. 2). Except for these rock exposures and for a limited number of basement drill-hole data, the exact location and extent of Salinian basement is not well known, especially in areas of sedimentary rock cover between Cape San Martin and Santa Margarita.

Salinian basement rocks northeast of Cape San Martin generally consist of high-grade metamorphic rocks including quartzites, granofelses, and gneisses, interlayered with amphibolites, schists, and marbles and cut by granitic veins and dikes. Diorite veins and dikes intrude a number of mafic and ultramafic bodies that occur in the otherwise predominantly granitic igneous complex (Compton, 1966). Potassium-argon ages of basement rocks in this area, determined by John Obradovich, are 69.6 and 75 m.y. (million years). Salinian basement outcrops northeast of Santa Margarita consist primarily of adamellite with inclusions of diorite, gabbro, marble, schist, and quartzite (Compton, 1966). A potassium-argon age of granitic rocks in this area, determined by Curtis, Evernden, and Lipson (1958) is $80.2 \mathrm{~m} . \mathrm{y}$. The oldest date yet obtained for Salinian rocks is 106 m.y., determined by C. O. Hutton (1959) for granitic rocks north of the study area by use of $(\mathrm{U}+\mathrm{Th}): \mathrm{Pb}$ ratios in detrital monazite. Densities determined for a limited number of schists within the Salinian block range from about 2.8 to $3.1 \mathrm{~g} / \mathrm{cm}^{3}$ (Compton, 1966).

Franciscan rocks in the area investigated consist largely of clastic sedimentary rocks including graywackes, siltstones, shales, and conglomerates, intermixed with patches of somewhat altered mafic volcanic rocks (Bailey and others, 1964). Although intrusive feeders for the volcanic rocks have not generally been found, Taliaferro (1943) reported an occurrence of vent agglomerates east of Cape San Martin. Ultramafic rocks, chiefly serpentinites, are an integral part of the eugeosynclinal assemblage, having intruded
Franciscan sedimentary and volcanic rocks as dikes, sills, and plugs (Bailey and others, 1964). Fossiliferous parts of Franciscan rocks range in age from Late Jurassic to Late Cretaceous. Densities of all Franciscan rocks in the study area average about $2.6 \mathrm{~g} / \mathrm{cm},{ }^{3}$ densities of the graywackes alone about $2.7 \mathrm{~g} / \mathrm{cm}^{3}$ (Bailey and others, 1964).

Of considerable interest is the fact that rocks of the Salinian block have not been observed to intrude or metamorphose Franciscan rocks. Further, no Salinian detritus has been found in Franciscan rocks. Also noteworthy is the conspicuous lack of serpentinites within Salinian rock exposures in the study area. These geologic relations clearly indicate that one of the outstanding geologic problems in the area is the tectonic relationship between the tracts of Franciscan rocks and Salinian basement rocks.

Perhaps the most important structural feature is the contact between Franciscan rocks and rocks of the Salinian block, generally believed to be the Nacimiento fault on the basis of geologic mapping. This basement. discontinuity may be a distantly displaced part of the contact between metamorphic and plutonic rocks of the Sierra Nevada and oceanic Franciscan rocks of the San Joaquin Valley (Hill and Dibblee, 1953; King, 1959. Page, 1966). In contrast to the nearly straight, steeply dipping, considerably active strike-slip character of the San Andreas fault to the northeast, the Nacimiento fault is, in general, discontinuous, curved, cross faulted and relatively inactive; the nature of apparent movement is not well understood (Vedder and Brown, 1968).

\section{AEROMAGNETIC DATA}

An aeromagnetic map (fig. 2) was prepared from data of the U.S. Geological Survey obtained at a barometric elevation of 6,500 feet along northeast-southwest flight lines spaced 1 mile apart. The magnetic data are digitally recorded output from an ASQ-10 fluxgate magnetometer. Flight paths were controlled using an APN-147 Doppler system and were checked with a gyrostabilized strip-film camera. A regional magnetic field gradient of 9 gammas per mile in the direction N. $16^{\circ}$ E. was removed from the original data.

Aeromagnetic features over exposed Franciscan rocks contrast sharply in shape and extent with features over exposed Salinian basement rocks. The area of Franciscan rocks is characterized by a discontinuous, somewhat sinuous train of narrow northwesttrending anomalies associated mainly with steeply dipping serpentinite sheets. The northwest segment of this train of anomalies extends from Cape San Martin to just south of San Simeon Point. Most of the anoma- 


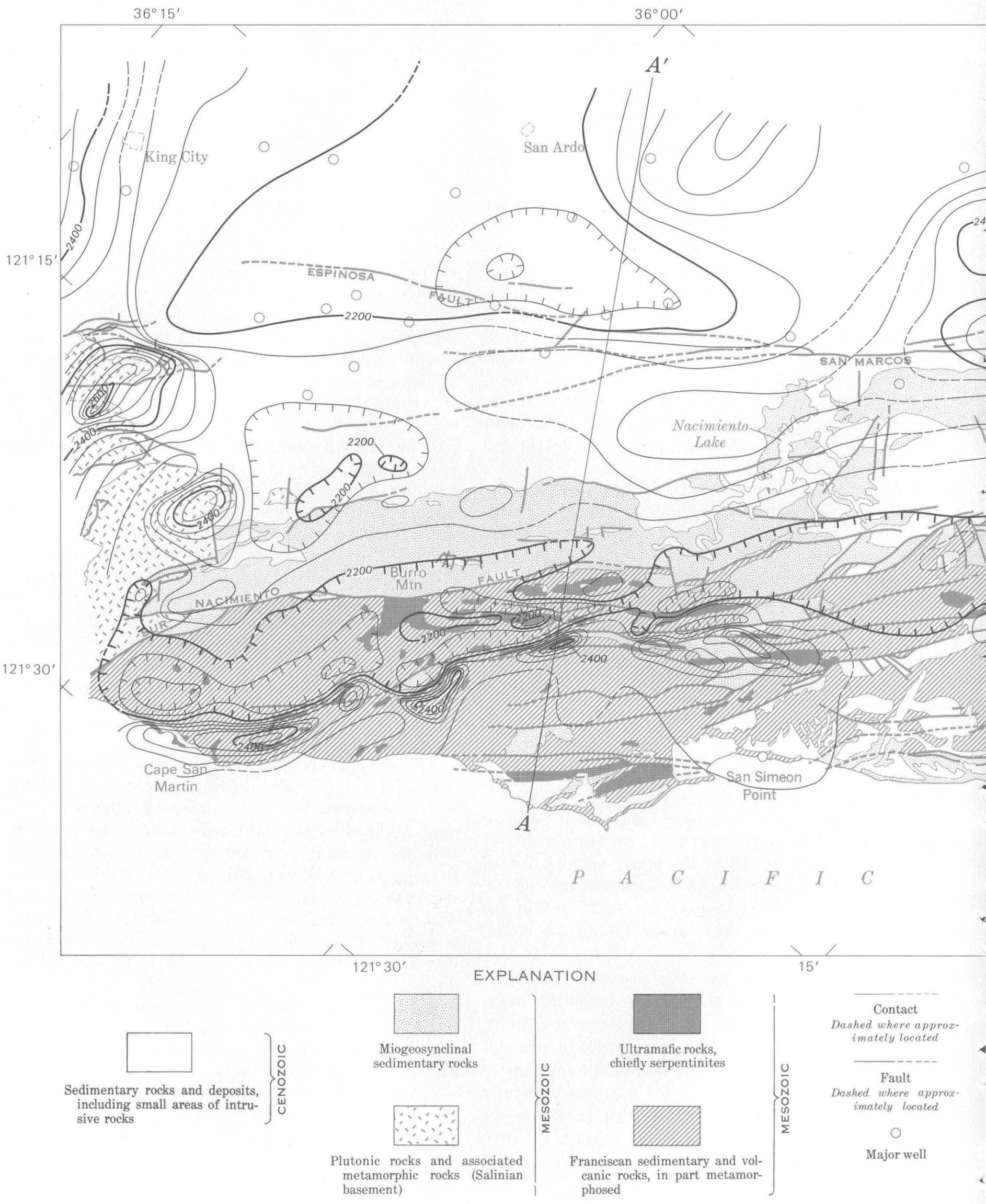




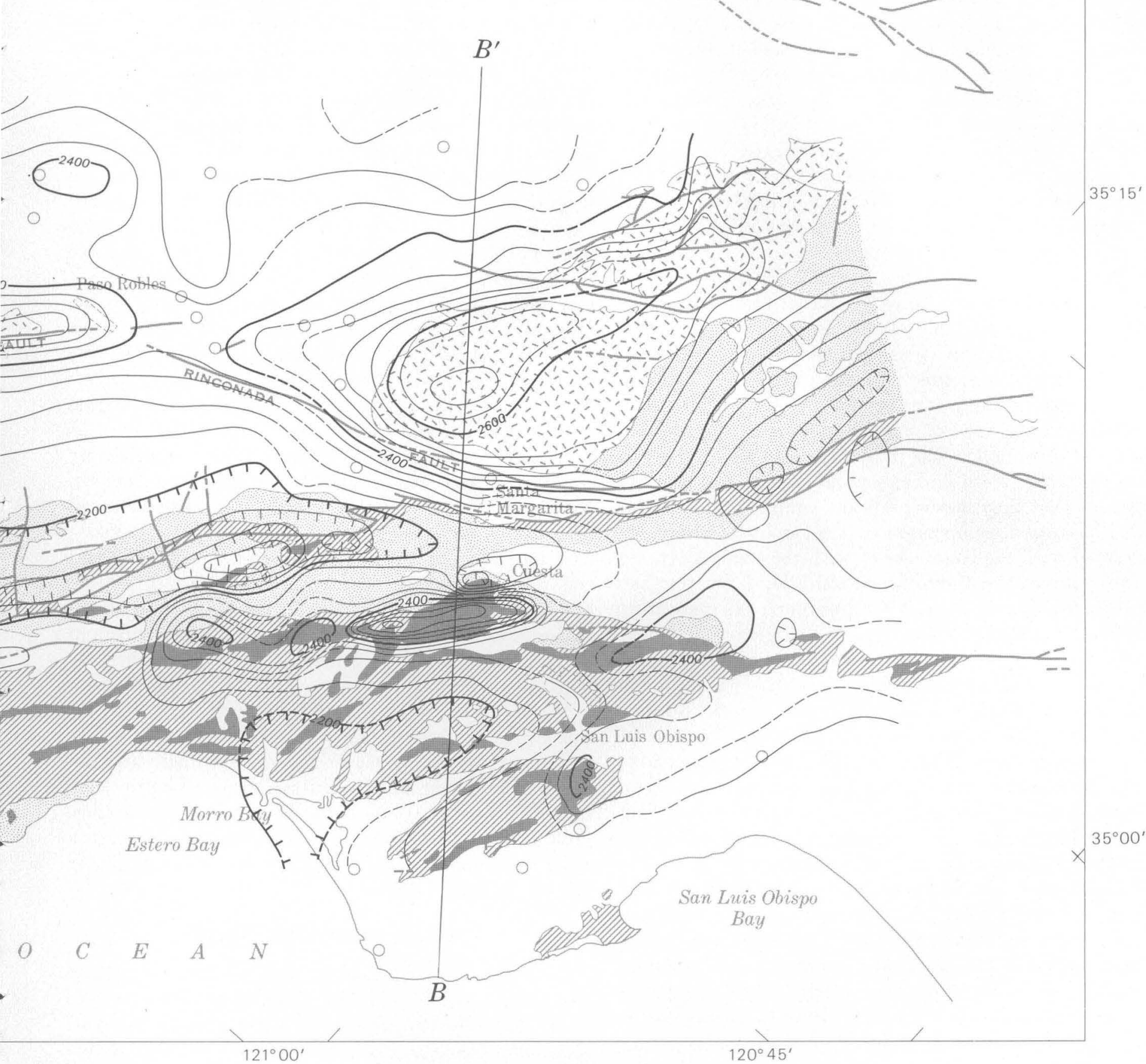

Figure 2.-Generalized geologic and aeromagnetic map of the Cape San Martin-San Luis Obispo area. Geology from San Luis Obispo and Santa Cruz sheets of the geologic map of California (Jernings, 1958; Jennings and Strand, 1959). Well data from Smith (1964). Magnetic contours show total-intensity magnetic field of the earth relative to arbitrary datum. Contour interval, 40 gammas. Flight elevation, 6,500 feet barometric. A regional field of 9 gammas in the direction $\mathrm{N} .16^{\circ} \mathrm{E}$. has been removed. 
lies occur over relatively small outcrops of serpentinite, many of which extend several miles deep in the earth's crust. Larger ultramafic bodies, such as Burro Mountain (Burch, 1968), 11 miles east-southeast of Cape San Martin, have little or no magnetic expression. The southeast segment of the anomaly train extends from Estero Bay to just south of San Luis Obispo. Here the most conspicuous single anomaly is associated with a major serpentinite body at Cuesta, 5 miles north of San Luis Obispo. The inferred subsurface extent of the Cuesta body exceeds that of all other serpentinite bodies in the map area.

The occurrence of positive anomalies over the terrane of Franciscan rocks suggests that most ultramafic rocks are expressed largely by their intensity of induced magnetization; these positive features serve as indicators of the degree of serpentinization of ultramafic rocks as well as the amount of these rocks in the subsurface. Absence of magnetic expression over outcrops of ultramafic rocks indicates either that the rocks are relatively fresh and unserpentinized or, if serpentinized, that they lack significant volume at depth. As an illustration, comparison of the strong anomaly associated with the Cuesta body with the weak magnetic expression of the Burro Mountain body indicates that the Burro Mountain mass contains much less serpentinite than the Cuesta mass.

Positive magnetic features over Salinian terrane are associated with metamorphic rocks 12 and 18 miles northeast of Cape San Martin, plutonic rocks 3 miles northwest of Paso Robles, and plutonic rocks 2 to 16 miles east of Santa Margarita. In contrast to anomalies over Franciscan rocks, these magnetic features have lower gradients and are greater in areal extent. The two isolated anomalies northeast of Cape San Martin may reflect the presence of mafic intrusive rocks within the metamorphic rock complex or perhaps a more highly mafic part of the metamorphic rock assemblage. The areally restricted, elliptical anomaly northwest of Paso Robles is almost totally confined to the plutonic rock exposure; however, weak extensions of this anomaly 8 miles to the northeast and 20 miles to the northwest define areas of near-surface plutonic rocks buried by less than half a mile of sedimentary cover. The broad magnetic high east of Santa Margarita is maximum over the northwest part of the igneous rock massif, indicating that the greatest subsurface distribution of mafic plutonic rocks is concentrated in this part of the massif. A single magnetic high, incompletely defined by the magnetic data, occurs over Cenozoic sedimentary rocks 11 miles southeast of San Ardo, suggesting a major topographic rise of mafic Salinian basement, generally supported by basement well data.
The location and configuration of the unexposed boundary between Salinian and Franciscan rocks south of the exposed contact near Cape San Martin and north of the well-defined contact near Santa Margarita is reflected to some extent in the magnetic data. A distinct northwest-trending magnetic trough extends for nearly the entire length of the map area near the northeast edge of the anomaly train within Franciscan rocks. Just northeast of the magnetic trough, the magnetic field increases with varying slope toward exposures of Salinian basement, except where the field is depressed by thick Cenozoic rock cover between Cape San Martin and San Ardo. Although there is much ambiguity in determining the exact location of the magnetic basement barrier on the basis of the weak magnetic gradient, an approximate estimate of the shallow subsurface contact is between the heavy " 2200 " contour line defining the northeast edge of the elongate negative trough and the adjacent light " 2240 " contour line to the northeast. The contact between magnetically contrasting basement rocks is deeply buried between Nacimiento Lake and Santa Margarita, as evidenced by a flattening of the magnetic gradient.

A more definite contact between magnetically contrasting rocks is the Rinconada-San Marcos fault system, which outlines the southwestern extents of plutonic rock exposures east of Santa Margarita and northwest of Paso Robles. This contact, marked by high magnetic gradients, appears to be steeply dipping at the margins of exposed plutonic rocks, although the subsurface extension of the feature is probably shallower than the major crustal contact between Salinian basement and Franciscan rocks. The gradients suggest a continuation of the Rinconada-San Marcos fault contact along the Espinosa fault to a point 8 miles west-southwest of San Ardo where the magnetic pattern becomes diffuse.

\section{BOUGUER GRAVITY DATA}

Complete Bouguer gravity data in the rectangular study area (fig. 3 ) have been compiled from surveys by the U.S. Geological Survey, California Division of Mines and Geology, University of California at Riverside, and Stanford University. Gravity coverage north of lat $36^{\circ} \mathrm{N}$., representing about 10 percent of the area, consists of a compilation made by Bishop and Chapman (1967). Coverage south of lat $36^{\circ} \mathrm{N}$., representing the remaining 90 percent of the area, was compiled from surveys of Burch, Grannell, and Hanna (1970) together with local gravity control of Thompson (1963) in the Burro Mountain area. Most of the gravity stations were established with LaCoste-Romberg geodetic gravity meters at a spacing of 1 to 2 
miles, and all observed gravity values are referenced to the datum of the California Division of Mines and Geology gravity base station network (Chapman, 1966). All stations have been terrain corrected to a standard radius of $166.7 \mathrm{~km}$ (outer radius of HayfordBowie zone $\mathrm{O}$ ), using a standard density of $2.67 \mathrm{~g} / \mathrm{cm}^{3}$.

The regional gravity expression within the study area is a northwest-trending gradient of about 2 milligals per mile negative toward the northeast. The orientation of this gradient is $20^{\circ}$ to $30^{\circ}$ northeast of the alinement of the regional magnetic gradient. This gravity gradient may be attributed to a combination of a northeastward thickening and a northeastward decrease in density of the continental crust. The gradient is apparently controlled by relatively deep crustal features, as suggested by Thompson and Talwani (1964) for an area to the north, rather than by the configuration of the contact between the two basement terranes. The oblique trend of the gravity gradient relative to the Nacimiento fault trace indicates that there is no systematic average density difference between Franciscan and Salinian basement rocks in this area. The gradient conspicuously steepens where low-density crustal features such as major sedimentary basins occur within either type of basement terrane. The gradient broadens between Nacimiento Lake and Santa Margarita, where the location of the contact between basement tracts becomes obscure.

The main gravity features of the Franciscan terrane are a weak elongate high about 8 miles north-northeast of Cape San Martin, a weak elliptical high about 4 miles southeast of Morro Bay, and a strong elliptical low about 12 miles southeast of San Luis Obispo. The positive anomalies are associated with outcrops of Franciscan rocks, mainly graywackes; the negative anomaly is associated with low-density Cenozoic sedimentary rocks.

The high north-northeast of Cape San Martin, which extends northwestward out of the map area, includes exposed Salinian rocks and may be caused by a moderately dense part of the Salinian metamorphic rocks in contact with less dense Franciscan sedimentary rocks. Burch (1970) has suggested that the weak positive anomally is due entirely to the topographic mass of this part of the Santa Lucia Range rather than to a buried anomaly source. A gravity low indicated by a notch in the southeastern extremity of the anomaly may express the contact between basement types; if so, this may be the only gravity expression of the basement contact in the study area.

The weak high southeast of Morro Bay is probably associated with normal-density Franciscan rocks in lateral contact with low-density Cenozoic rocks and deposits to the east and south. The northeastern flank of this anomaly, which is partly developed over outcropping Franciscan rocks, is probably an expression of low-density serpentinites (interpreted from magnetic data) and Cenozoic sedimentary cover rather than post-Franciscan Cretaceous sedimentary rocks cropping out to the northeast.

'The major gravity low east of San Luis Obispo Bay, which extends southeastward out of the map area, is associated with a great thickness of Cenozoic sedimentary rocks within a major syncline described by Hall and Corbató (1967). If an average density contrast between basement and Cenozoic rocks of 0.5 to $0.8 \mathrm{~g} /$ $\mathrm{cm}^{3}$ is assumed, which is consistent with density determinations for similar rocks to the north (Byerly, 1966), the Cenozoic rock cover is over 2 miles thick (Burch and others, 1970).

Local gravity features over Salinian basement are restricted to negative anomalies associated with Cenozoic sedimentary rocks and positive anomalies associated with outcropping or near-surface plutonic rocks. The most conspicuous negative anomalies occur about 10 miles northeast of Nacimiento Lake and 18 miles northwest; smaller negative anomalies occur 7 miles south of King City and at Santa Margarita. Positive anomalies occur 8 miles northwest of San Ardo, 10 miles and 21 miles north of Nacimiento Lake, 3 miles northwest of Paso Robles, and 5 miles northeast of Santa Margarita.

The major gravity lows northeast and northwest of Nacimiento Lake represent accumulations of lowdensity Cenozoic sedimentary rocks and deposits as much as 2 miles and 1 mile thick, respectively. The minor gravity low south of King City is associated with a greater than 1,000-foot thickening of basin fill. The weak gravity trough between the Rinconada and Nacimiento fault traces at Santa Margarita is probably attributable to a wedge-shaped accumulation of low-density Cenozoic sedimentary rocks.

Gravity highs north of Nacimiento Lake and northwest of San Ardo are probably produced by plutonic or metamorphic rocks buried beneath a relatively thin sedimentary, cover ranging in thickness from about 300 to 1,000 feet. The conspicuous high northwest of Paso Robles is associated with outcrops of plutonic rocks which are estimated to rise at least 1 mile above nearby mean basement topography. The broad gravity high northeast of Santa Margarita is associated with an extensive plutonic rock massif which is overlain by thin sedimentary cover along its northern border and deeper sedimentary cover along its northeast margin. The gravity data support the interpretation made from magnetic data that the predominant mass of the 


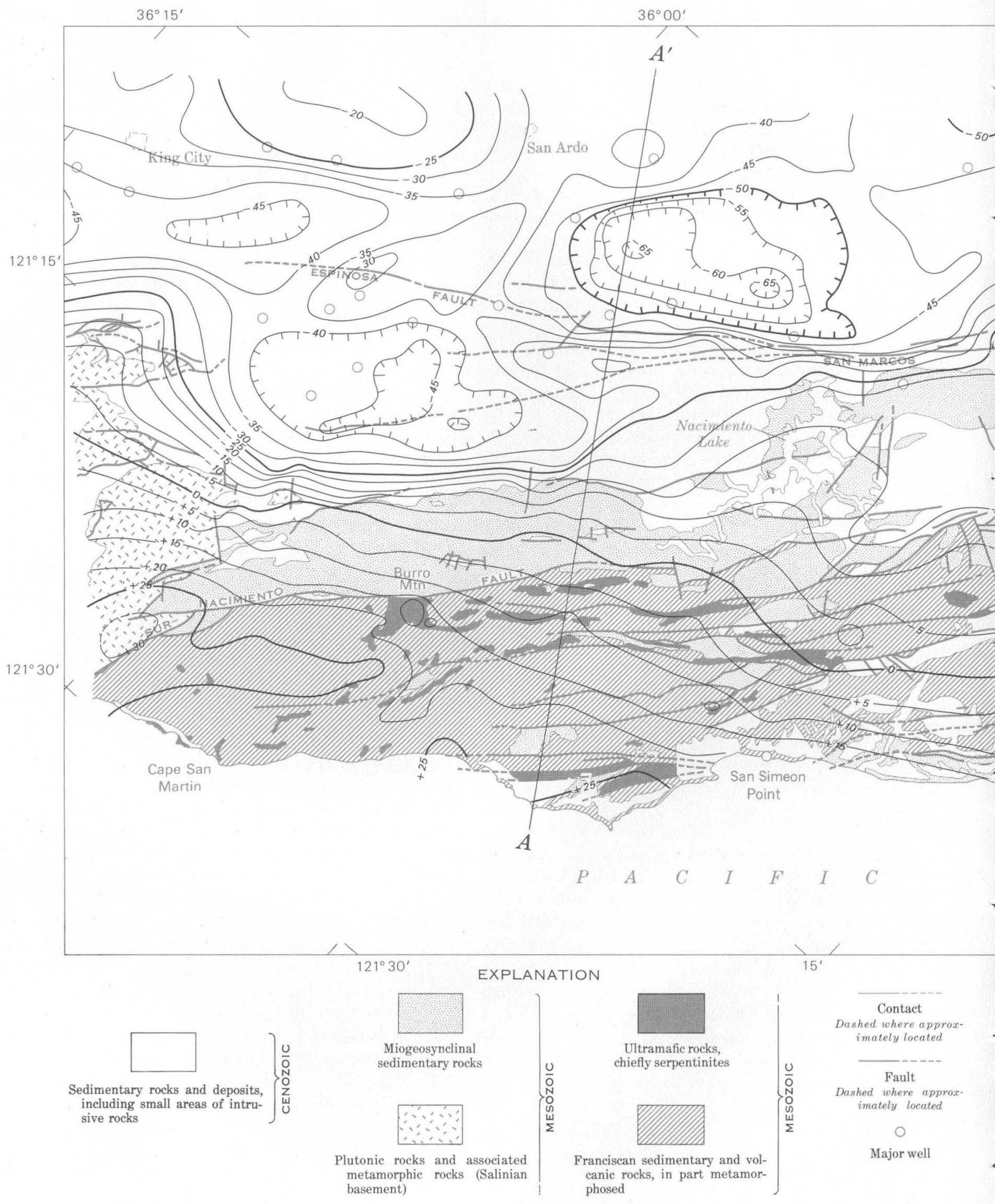




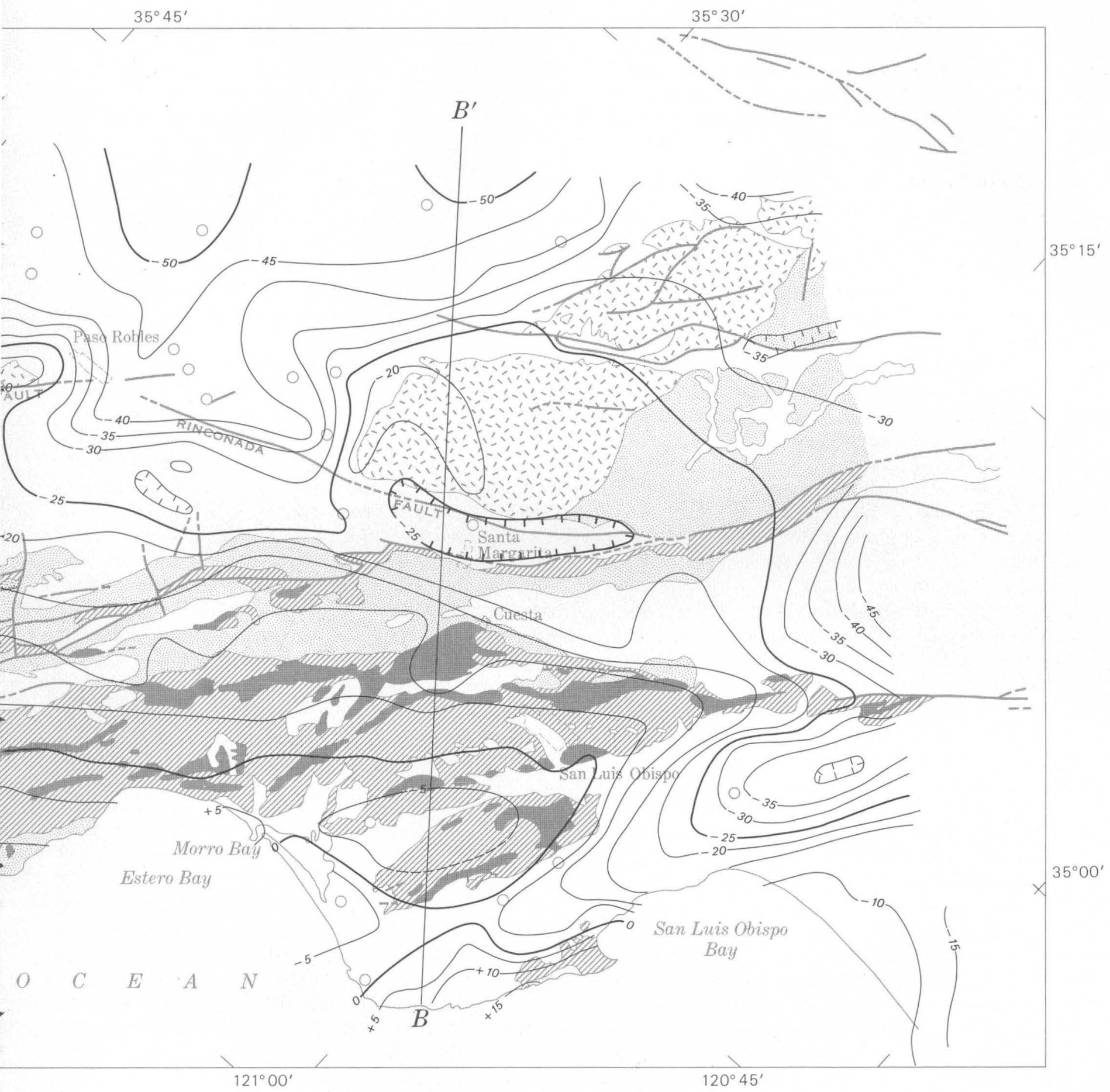

Figure 3.-Complete Bouguer gravity map of the Cape San Martin-San Luis Obispo area (after Burch and others, 1970 ; Bishop and Chapman, 1967). Contour interval, 5 milligals, Geology same as in figure 2. 
igneous massif is concentrated in the northwest part of the outcrop area. Uniform gravity values to the south indicate that post-Franciscan Cretaceous sedimentary rocks at the southeast margin of the outcrop area have an average density similar to that of nearby Salinian basement and Franciscan rocks.

\section{IMPLICATIONS OF GEOPHYSICAL DATA}

Although the aeromagnetic and gravity surveys have limited value as precise indicators of both the subsurface distribution of the basement complexes and the contact between complexes, many important inferences may be drawn from the data.

The train of narrow magnetic anomalies within the Franciscan terrane suggests that serpentinites have intruded a roughly linear, somewhat discontinuous zone of weakness in former oceanic crust. The locus of these extensive serpentinite dikes or sheets may be an ancient fault surface that at the present time is nearly vertical or steeply dipping toward the northeast. The presence of major serpentinite intrusions suggests that at least part of the tract of Franciscan rocks may rest directly on a serpentine-rich substratum.

Seismic-refraction profiles of Healy (1963), Eaton (1963), and Stewart (1968) perpendicular and parallel to the coast of California indicate that the Salinian basement complex is about 13 to 16 miles thick, depending upon assumptions about the geometry and the velocity distribution of the crustal model. The possibilities that Salinian basement rests directly on buried Franciscan rocks, a serpentine-rich substratum, or a basaltic substratum cannot be deduced by the magnetic method, as unpublished heat-flow data suggest that the Curie isotherm may be less than 13 miles deep. This isotherm sets the lower limit of detectable ferromagnetism within crustal rocks. The seismic data thus indicate that the Salinian basement complex has no deep root similar to that of the Sierra Nevada (Byerly, 1938; Eaton, 1963, 1966 ; Bateman and Eaton, 1967.) to the northeast.

The location and configuration of the contact between basement terranes are expressed to some extent by the magnetic data but are nearly everywhere ambiguous in the gravi data. Average magnetization contrasts between basement terranes appear to be small but detectable; average density contrasts appear to be generally undetectable. Geophysical data show no expression of buried Franciscan rocks northeast of presently mapped contacts. It should be noted, however, that serpentinite-deficient Franciscan rocks would not produce appreciable magnetic or gravity anomalies if they were present in the subsurface. Geophysical features and well-hole data indicate an extension of buried
Salinian rocks northwest of mapped contacts. Gravity, magnetic, and well-hole data between Nacimiento Lake and the northwest extremity of the Espinosa fault define a northwest-trending ridge about 20 miles long covered by sedimentary rocks probably less than half a mile thick.

The geophysical data indicate that the trace of the concealed fault between basement complexes lies within a continuous zone about 5 miles wide along the margin of the northeasternmost exposed Franciscan rocks. The magnetic data suggest that the buried basement contact approximately follows the " 2240 " contour line (fig. 3) from the exposed basement contact in the northwestern corner of the study area, through exposed Mesozoic and Cenozoic sedimentary rocks, to the intersection of the Nacimiento and Rinconada faults near Santa Margarita. Thus the basement contact trace, if interpreted to be a continuous curve, forms a broad arc, convex toward the northeast, in the central part of the map area. The magnetic gradient in the central part of the area is consistent with that produced by weakly contrasting magnetic basement rocks separated by a steeply dipping contact. The magnetic and gravity data suggest that the contact may dip from $75^{\circ}$ to $45^{\circ}$ toward the northeast near the northwest corner and southern edge of the map area and that it may be nearly vertical to steeply northeast dipping in the center of the area.

The most pronounced physical discontinuities within the basement tracts are major density contacts of Cenozoic sedimentary rock basins with Franciscan, Salinian, or post-Franciscan Cretaceous sedimentary rocks. The steepest gravity gradients in the map area form the southwest flanks of two major gravity lows between Nacimiento Lake and King City. It is believed that these gradients reflect nearly vertical density boundaries which may also be significant fault surfaces in the upper crust. The southwest gradient flanking the gravity low 20 miles northwest of Paso Robles coincides with the San Marcos-Espinosa fault system. The southwest gradient flanking the gravity low about 6 miles northwest of Burro Mountain does not coincide with a major surface fault. This gradient is interpreted to reflect a major crustal contact, perhaps a subsurface fault, about half a mile northeast of the northeasternmost exposures of post-Franciscan Cretaceous sedimentary rocks.

Regarding the proposed klippe origin of an allochthonous Franciscan "mélange" derived from considerable distance to the northeast (Hsu, 1966, 1967, 1968), the magnetic data indicate that, with few exceptions, major serpentinite bodies within Franciscan rocks exhibit a definite alinement and extend to considerable depths within the crust. It is believed that these ser- 
pentinites were emplaced within zones of weakness produced by stress patterns related to broad areas of folding and faulting throughout much of the present California Coast Ranges. The geophysical data do not directly bear on other questions of the proposed klippe origin.

In summary, generalized interpretations of shallow subsurface rocks are shown in figure 4 (p. B76-B77) as profiles $A-A^{\prime}$ and $B-B^{\prime}$ across the northern and southern parts of the area, respectively. Crustal features shown in the cross sections satisfy the residual gravity anomaly and aeromagnetic anomaly profiles to a good approximation, although only a small part of some geologic features occur in the sections. For example, the ultramafic serpentinite bodies producing major magnetic anomalies may, on the basis of modeling results, extend to depths of more than 10 miles, although physicochemical conditions not considered here may impose restrictions on these depths.

Construction of the idealized geologic sections was controlled by known surface geology, a limited number of well data, and assumed values for density and magnetization contrasts of subsurface rocks. The average density contrast between Cenozoic rocks and Mesozoic miogeosynclinal rocks, Franciscan rocks, or Salinian basement was assumed to be $0.5 \mathrm{~g} / \mathrm{cm}^{3}$, whereas that between serpentinites and Mesozoic rocks was taken to be about $0.1 \mathrm{~g} / \mathrm{cm}^{3}$. The total magnetization of serpentinites relative to nonmagnetic rocks was assumed to be $0.0025 \mathrm{emu} / \mathrm{cm}^{3}$, whereas that of Salinian basement rocks was taken to be half that of the serpentinites, or $0.00125 \mathrm{emu} / \mathrm{cm}^{3}$. Total magnetization was everywhere assumed to be parallel to the earth's present field direction. Subsurface interpretations using these assumed values of density and magnetization contrast are intended to provide a basis for refinement using more detailed geophysical and geologic information as it becomes available.

\section{REFERENCES}

Bailey, E. H., Irwin, W. P., and Jones, D. L., 1964, Franciscan and related rocks, and their significance in the geology of western California: California Div. Mines and Geology Bull. 183, 177 p.

Bateman, P. C., and Eaton, J. P., 1967, Sierra Nevada batholith: Science, v. 158, no. 3807, p. 1407-1417.

13ishop, C. C., and Chapman, R. H., 1967, Bouguer gravity map of California, Santa Cruz sheet: California Div. Mines and Geology, scale $1: 250,000$.

Burch, S. H., 1968, Tectonic emplacement of the Burro Mountain ultramafic body, Santa Lucia Range, California: Geol. Soc. America Bull., v. 79, no. 5, p. 527-544.

- 1970, Complete Bouguer gravity and general geology of the Cape San Martin, Bryson, Piedras Blancas, and San Simeon quadrangles, California: U.S. Geol. Survey Prof. Paper 646-A [In Press].
Burch, S. H., Grannell, R. B., and Hanna, W. F., 1970, Bouguer gravity map of California, San Luis Obispo sheet: California Div. Mines and Geology, scale $1: 250,000$ [In Press].

Byerly, Perry, 1938, Comment on "The Sierra Nevada in the light of isostasy, by Andrew C. Lawson": Geol. Soc. America Bull., v. 48 , no. 12 , p. 2025-2031.

Byerly, P. E., 1966, Interpretations of gravity data from the central Coast Ranges and San Joaquin Valley, California : Geol. Soc. America Bull., v. 77, no. 11, p. 83-94.

Chapman, R. H., 1966, The California Division of Mines and Geology gravity base station network: California Div. Mines and Geology Spec. Rept. 90, 49 p.

Chesterman, C. W., 1952, Descriptive petrography of rocks dredged off the coast of central California : California Acad. Sci. Proc., 4th ser., v. 27, p. 359-374.

Compton, R. R., 1966, Granitic and metamorphic rocks of the Salinian block, California Coast Ranges in Bailey, E. H., ed., Geology of northern California: Califoruia Div. Mines and Geology Bull. 190, p. 277-287.

Curtis, G. H., Evernden, J. F., and Lipson, J., 1958, Age determination of some grantic rocks in California by the potassium-argon method: California Div. Mines Spec. Rept. 54, $16 \mathrm{p}$.

Eaton, J. P., 1963, Crustal structure from San Francisco, California, to Eureka, Nevada, from seismic-refraction measurements: Jour. Geophys. Research, v. 68, no. 20, p. 5789-5806.

1966, Crustal structure in northern and central California from seismic evidence, in Bailey, E. H., ed., Geology of northern California: California Div. Mines and Geology Bull. 190, p. 419-426.

Hall, C. A., and Corbató, C. E., 1967, Stratigraphy and structure of Mesozoic and Cenozoic rocks, Nipomo quadrangle, southern Coast Ranges, California: Geol. Soc. America Bull., v. 78 , no. 5 , p. 559-582.

Hanna, G. D., 1952, Geology of the continental slope off central California : California Acad. Sci. Proc., 4th ser., v. 27, no. 9, p. 325-358.

Healy, J. H., 1963, Crustal structure along the coast of California from seismic-refraction measurements: Jour. Geophys. Research, v. 68 , no. 20 , p. 5777-5787.

Hill, M. L., and Dibblee, T. W., Jr., 1953, San Andreas, Garlock, and Big Pine faults, California-A Study of the character, history, and tectonic significance of their displacements: Geol. Soc. America Bull., v. 64, no. 4, p. 443-458.

Hsu, K. J., 1966, On the klippe origin of the Franciscan rocks of Santa Lucia Range, California-A working hypothesis: Geol. Soc. America Spec. Paper 87, p. 82-83.

- 1967, Mesozoic geology of the California Coast RangesA new working hypothesis, in litages tectoniques. Colloque de Neuchâtel, Neuchâtel Univ. Inst. Geol., 1966 : Neuchâtel, Switzerland, La Baconnière, p. 279-296.

1968, Principles of mélanges and their bearing on the Franciscan-Knoxville paradox: Geol. Soc. America Bull., v. 79 , no. 8 , p. $1063-1074$.

Hutton, C. O., 1959, Mineralogy of beach sands between Halfmoon and Monterey Bays, California : California Div. Mines Spec. Rept. 59, 32 p.

Jennings, C. W., 1958, Geologic map of California, Olaf P. Jenkins edition, San Luis Obispo sheet: California Div. Mines, scale $1: 250,000$.

Jennings, C. W., and Strand, R. G., 1959, Geologic map of California, Olaf P. Jenkins edition, Santa Cruz sheet: California Div. Mines, scale $1: 250,000$. 

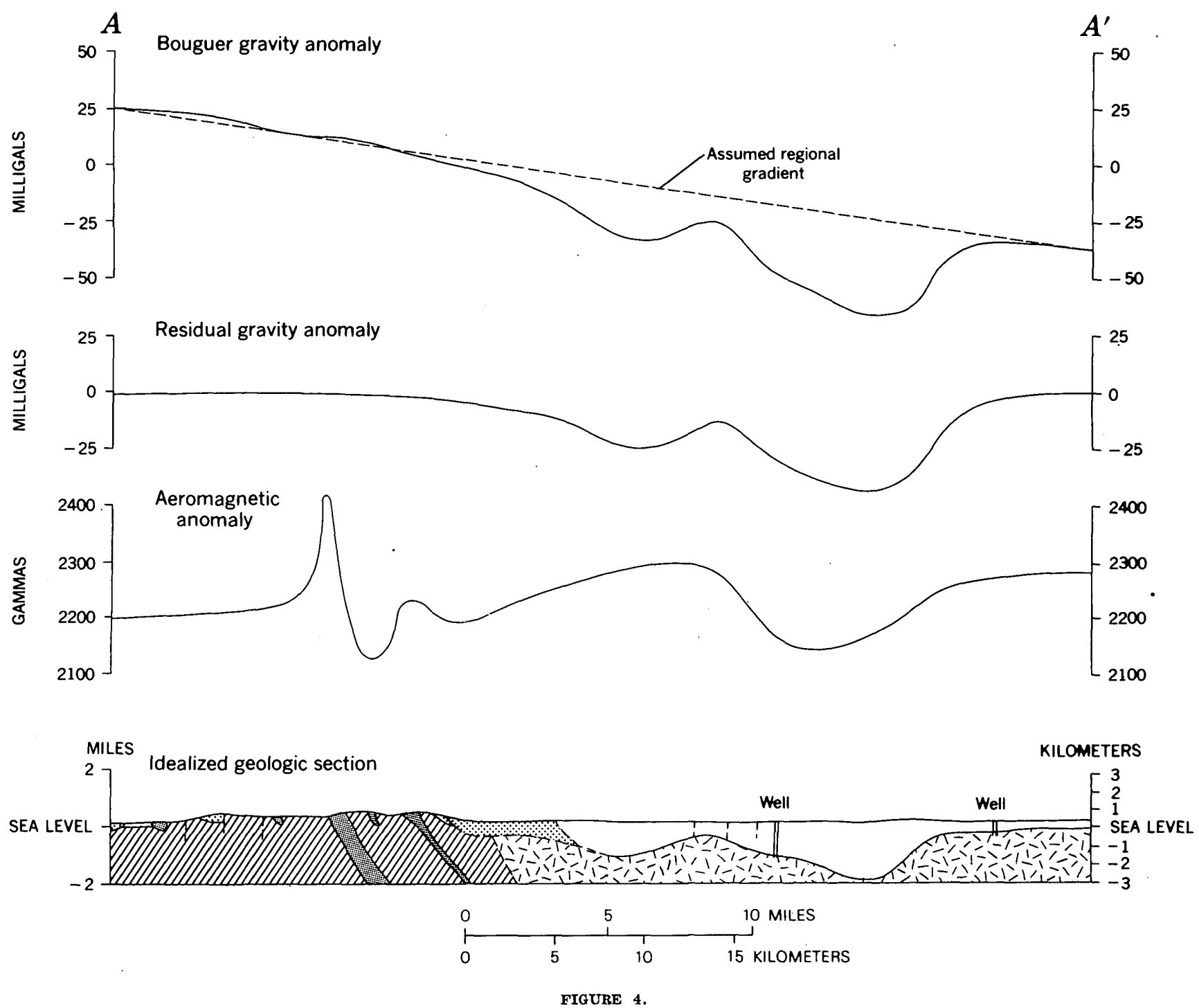

King, P. B., 1959, The evolution of North America : Princeton, N.J., Princeton Univ. Press, 190 p.

Menard, H. W., 1955, Deformation of the northeastern Pacific basin and the west coast of North America: Geol. Soc. America Bull., v. 66, no. 9, p. 1149-119̂8.

Page, B. M., 1966, Geology of the Coast Ranges of California, in Bailey, E. H., ed., Geology of northern California : California Div. Mines and Geology Bull. 190, p. 255-276.

Reed, R. D., 1933, Geology of California: Tulsa, Okla., Am. Assoc. Petroleum Geologists, 355 p.
Smith, M. B., 1964, Map showing distribution and configuration of basement rocks in California : U.S. Geol. Survey Oil and Gas Inv. Map OM-215, scale $1: 500,000$.

Stewart, S. W., 1968, Preliminary comparison of seismic traveltime and inferred crustal structure adjacent to the San Andreas fault in the Diablo and Gabilan Ranges of central California, in Dickinson, W. R., and Grantz, Arthur, eds., Proceedings of conference on geologic problems of San Andreas fault system: Stanford Univ. Pubs. Geol. Sci., v. 11, p. 218-230. 

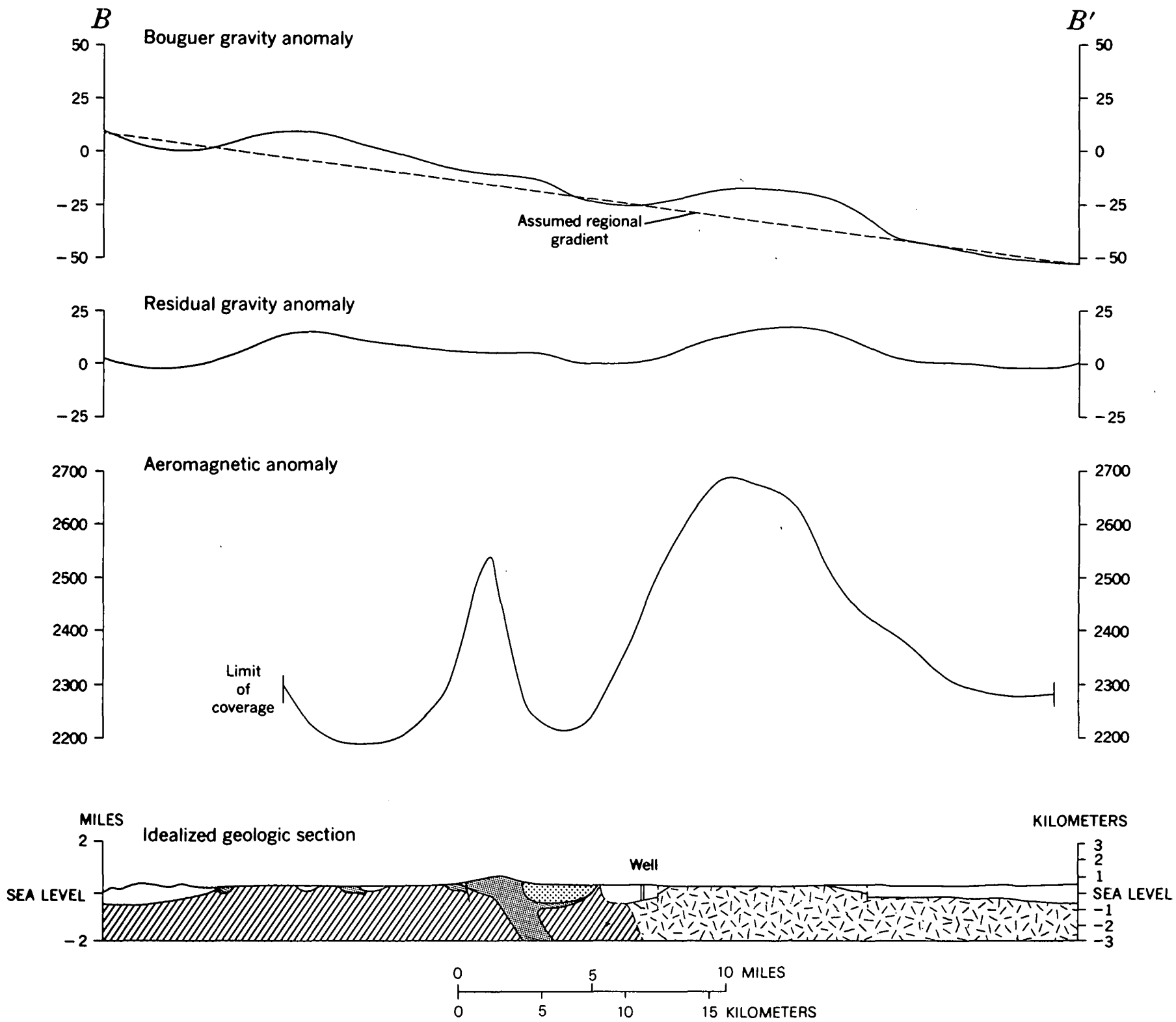

Froure 4.-Bouguer gravity anomaly, residual gravity anomaly, aeromagnetic anomaly, and idealized geologic cross sections $A-A{ }^{\prime}$, northern part of area, and $B-B^{\prime}$, southern part of area. Profile traces are shown on fiigures 2 and 3 . Geologic symbols siame as in figure 2 .

Inlinferro, N. I., 1943, Geologic history and structure of the centrinl Const Ranges of California: California Div. Mines Bull. 118, p. 119-163.

Thompson, G. A., 1963, Geophysical investigation of the dunite at Twin Sisters, Washington [abs.]: Geol. Soc. America Spec. Paper 76, p. 227-228.

Thompson, G. A., and Talwani, Manik, 1964, Crustal structure from Pacific basin to central Nevada: Jour. Geophys. Research, v. 69 , no. 22, p. $4813-4837$.
Trask, P. D., 1926, Geology of the Point Sur quadrangle, California: California Univ. Pubs., Dept. Geology Bull., v. 16, no. 6, p. 119-186.

Vedder, J. G., and Brown, R. D., 1968, Structural and stratigraphic relations along the Nacimiento fault in the southern Santa Lucia Range and San Rafael Mountains, California, in Dickinson, w. R., and Grantz, Arthur, eds., Proceedings of conference on geologic problems of the San Andreas fault system: Stanford Univ. Pubs. Geol. Sci., v. 11, p. 242-259. 


\title{
RECONNAISSANCE GEOPHYSICAL STUDIES OF THE TRINIDAD QUADRANGLE, SOUTH-CENTRAL COLORADO
}

\author{
By M. DEAN KLEINKOPF, DONALD L. PETERSON, \\ and ROSS B. JOHNSON, Denver, Colo.
}

\begin{abstract}
In the Trinidad quadrangle, Colorado, major gravity and magnetic anomalies correlate with the large geological features. The most conspicuous gravity anomaly in the quadrangle is a 30-milligal minimum along the east edge of the San Luis Valley. The anomaly may be caused by $20,000-30,000$ feet of Tertiary and Quaternary sediments. Regional northeasterly trends in the geophysical data are interpreted as fault trends or shear zones in the crystalline basement. A large positive magnetic anomaly of about 700 gammas amplitude and correlative gravity maximum in the northeast part of the quadrangle may indicate a buried intrabasement crystalline mass of intermediate to basic composition. This proposed intrabasement body lies along the axis of the Apishapa arch.
\end{abstract}

As part of the U.S. Geological Survey's contribution to the Upper Mantle Project a gravity map (Peterson and others, 1968) and a geologic map (Johnson, 1968b) of the Trinidad quadrangle were prepared. The quadrangle was also shown on the magnetic map of a transcontinental geophysical survey (Zietz and Kirby, 1968). This report presents an interpretation of the geophysical data as they relate to the regional geology. The gravity data in the western third of the quadrangle have been studied by Gaca and Karig (1966), and the regional gravity data of the State of Colorado have been studied by Holmer (1954) and Qureshy (1960). To the south in the Sangre de Cristo Mountains of New Mexico, isostatic compensation has been studied by Andreasen and Kane (1961).

'The dominant geologic features of the area are the Apishapa arch, Raton basin, Spanish Peaks, Raton Mesas, Wet Mountains, Huerfano Park, Sangre de Cristo Mountains, end San Luis Valley. Hills (1900) described granites and gneisses, hornblende-, mica-, and chlorite-schist rocks of the Wet Mountains. Burbank and Goddard (1937) described Precambrian hornblende gneiss highly injected by granite and peg- matite in the Sangre de Cristo Mountains near Huerfano Park. Many types of metamorphic and igneous rocks of Precambrian age in previously unexplored areas of the Sangre de Cristo Mountains have been mapped recently by M. R. Brock (in Johnson, 1968b), and are believed to be representative of Precambrian rocks underlying the quadrangle.

A Bouguer gravity-anomaly and generalized geologic map of the Trinidad quadrangle (fig. 1) was prepared from published sources (Peterson and others, 1968; Gaca and Karig, 1966; Johnson, 1968b). Most of the gravity stations are located at bench marks and other points of known elevation. About 20 percent of the station elevations were determined by altimeter surveys. The gravity stations are corrected for terrain out to a distance of $167 \mathrm{~km}$. The accuracy of the gravity data is estimated to be about 2 milligals. Some of the mountain stations with altimeter elevations may have an accuracy of only $5 \mathrm{mgal}$. The geology is generalized from a recent map of the Trinidad quadrangle.

The total intensity aeromagnetic map. (fig. 2) is adapted from the transcontinental geophysical survey (Zietz and Kirby, 1968). An additional magnetic traverse, $A-A^{\prime}$, was flown across the Sangre de Cristo and Wet Mountains, an area of poor control on the magnetic map (fig. 2).

Two-dimensional models were computed for two profiles. Residual anomalies were obtained by removing an assumed smoothed regional magnetic and gravity anomaly. Most of the larger gravity anomalies were assumed to be produced by density contrasts between the Precambrian basement rock and overlying sedimentary rock. Locally, volcanic rock with an intermediate density is also reflected in the gravity data. Magnetic anomalies are attributed to relief on the basement rock, the presence of volcanic rock, and the presence of lithologic units in the basement rock. 
The east side of the San Luis Valley shows a large gravity minimum of some $30 \mathrm{mgal}$ which centers about 10 miles northwest of the Great Sand Dunes National Monument (fig. 1). Gaca and Karig (1966) concluded that this anomaly was produced by a graben containing a maximum of 30,000 feet of sediment based on a density contrast of $-0.33 \mathrm{~g} / \mathrm{cm}^{3}$. A sedimentary rock density of $2.37 \mathrm{~g} / \mathrm{cm}^{3}$ is assumed contrasted to the Precambrian gneiss, schist, and igneous basement of 2.70 $\mathrm{g} / \mathrm{cm}^{3}$. To the south, smaller horsts and grabens of San Luis Valley, which form the north end of the Rio Grande depression (Kelley, 1956), are expressed in the gravity data as a series of closed maxima and minima (fig. 1). The magnetic reconnaissance data show a large north-trending magnetic negative anomaly over the eastern San Luis Valley (fig. 2). The most negative values at the north end correspond to the closure of the $-285 \mathrm{mgal}$ contour in the center of the gravity minimum.

From an analysis of the gravity gradients near the western end of section $A-A^{\prime}$, the sedimentary rocks were computed to be approximately 8,000 feet thick at a location about 10 miles south of the center of the major minimum. A density contrast of $0.4 \mathrm{~g} / \mathrm{cm}^{3}$ was assumed in the calculations. To the south the 5- to 10 mgal minimum over the San Luis Valley along $B-B^{\prime}$ indicates about 6,000 feet of buried sedimentary and volcanic rocks. A density contrast of $0.2 \mathrm{~g} / \mathrm{cm}^{3}$ was assumed here because of the greater amount of volcanic material in the sedimentary debris filling the depression. On profile $A-A^{\prime}$, the magnetic data suggest that the large San Luis Valley graben indicated by the gravity minimum is flanked on the west by a buried volcanic mass or Precambrian high. At the west end of both profiles $A-A^{\prime}$ and $B-B^{\prime}$, high susceptibility masses were required to approximate the observed magnetic anomalies (figs. 3 and 4 ).

No major magnetic anomalies were observed over the Sangre de Cristo Mountains (figs. 2, 3, 4). In general, the gravity field over the range is high. Gaca and Karig (1966) reported a positive free-air anomaly of about 80 mgal. Andreasen and Kane (1961) found a positive free-air anomaly of about the same magnitude over the Sangre de Cristo Mountains of New Mexico. The additional gravity data shown here tend to confirm the conclusions of Gaca and Karig (1966) that the Sangre de Cristo Mountains are locally uncompensated and hence the mountains are an excess mass supported by the crust. The small graben filled with Tertiary and Quaternary gravels and sands and lava flows north of Sierra Blanca shows a 10-mgal gravity minimum which may indicate a thickness of at least 10,000 feet of less dense section.
At Huerfano Park the 10-mgal gravity minimum probably is caused by 10,000-15,000 feet of highly contorted Paleozoic, Mesozoic, and Cenozoic sedimentary rocks. A density contrast of $0.2 \mathrm{~g} / \mathrm{cm}^{3}$ is assumed: $2.50 \mathrm{~g} / \mathrm{cm}^{3}$. for the sedimentary rocks and $2.70 \mathrm{~g} / \mathrm{cm}^{3}$ for the Precambrian gneiss and schist.

The complex in the Wet Mountains, which is composed of vertically uplifted blocks of Precambrian metamorphic and igneous rocks, is flanked on both sides by large positive magnetic anomalies (fig. 3). The anomaly sources may be related to the outcropping crystalline rocks of intermediate composition in the Wet Mountains. The gravity data show a maximum of about 10 mgal (fig. 1) over the Wet Mountains.

Along the east side of the Sangre de Cristo Mountains, a series of gravity minima denotes the structural deep of the $\mathrm{La}$ Veta syncline which extends from Huerfano Park south into the Raton structural basin. The La Veta synclinal axis may be the control of several intermediate intrusives such as the stocks and associated dikes at West Spanish Peak and Dike Mountains (Johnson, 1968a, p. G37). On profile $B-B^{\prime}$, the 100 -gamma anomaly over the axis of the Raton basin may represent a buried crystalline mass of intermediate composition (fig. 3). The Raton structural basin appears to have an axis bending to the north and east as shown by the gravity minimum axis which trends northeast through Hoehne.

The large magnetic positive anomaly of about 700 gammas amplitude in the northeast part of the quadrangle may represent a buried intrabasement crystalline mass of intermediate or basic composition (fig. 2). The magnetic profile $A-A^{\prime}$ crosses the north edge of the anomaly. A magnetic susceptibility value of 0.003 electromagnetic unit was used in the modeling to approximate the observed anomaly. The correlative residual gravity maximum on the west side of the major gravity high which is defined by the -175 -mgal closure also suggests the presence of a discrete mass in the crystalline basement. The 700 -gamma magnetic anomaly may denote a general characteristic of the Rocky Mountain Front. At about the same relative location in western Montana, isolated magnetic positive anomalies suggest that intermediate to basic intrabasement crystalline masses occur along the east edge of the disturbed belt (anomaly 14, Mudge and others, 1968).

The proposed intrabasement body may lie along the Apishapa arch. The arch axis, as defined from structure contours on top of the Dakota Sandstone (Johnson, $1968 \mathrm{~b})$, can be traced to the southeast where the gravity expression is a 10-mgal maximum trend. A correlative positive magnetic anomaly suggests a second intrabase- 


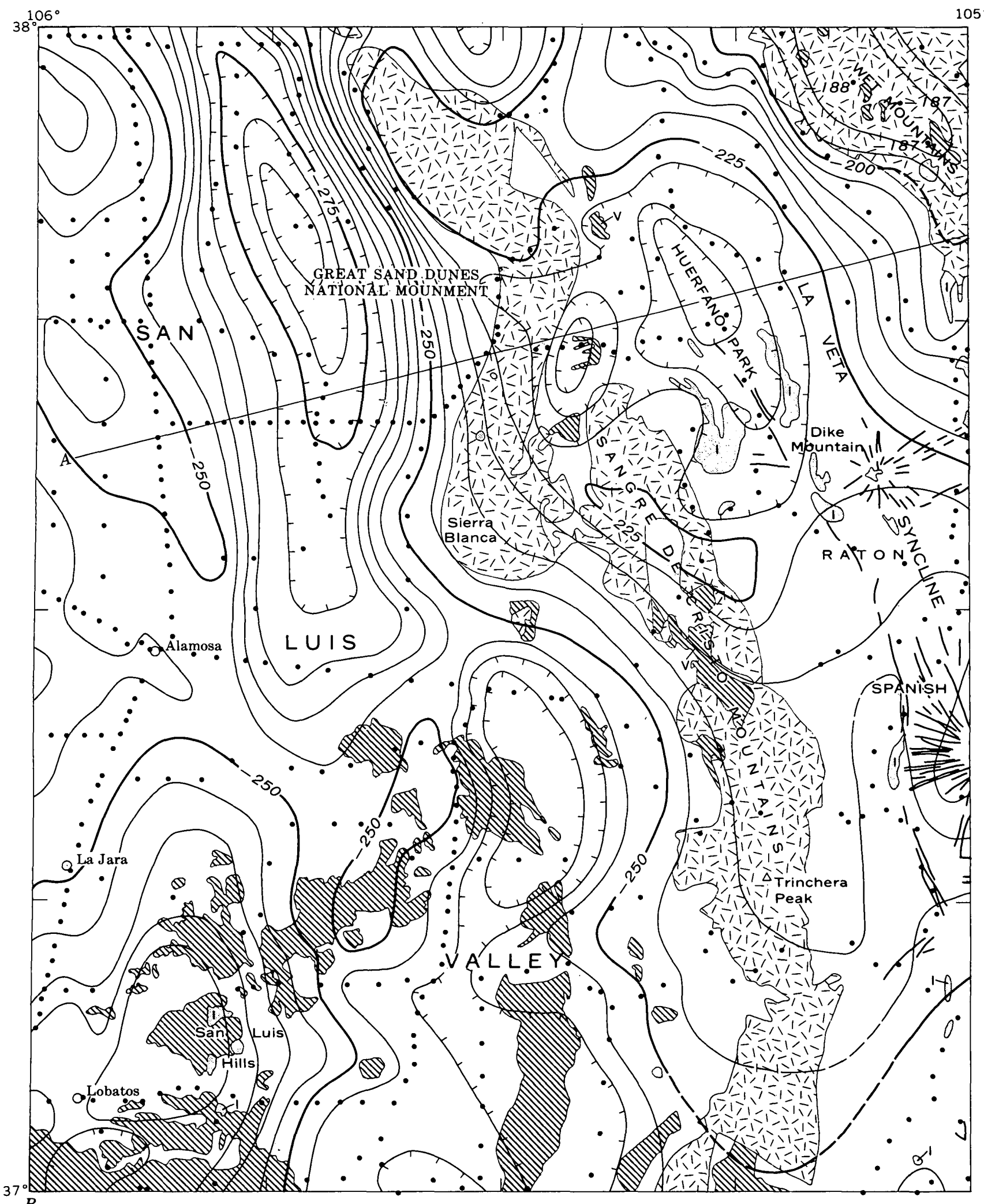

FIgURE 1.-Bouguer gravity and generalized geologic map of the Trinidad quadrangle. Hachured contours indicate closed gravity low; interval 5 milligals. Dots indicate gravity' stations. $A-A^{\prime}$ (near top of map) and $B-B^{\prime}$ (at bottom of map), locations of models shown on figures 3 and 4. Gravity data from Peterson, Popenoe, Gaca, and Karig (1968) ; geology generalized from Johnson (1968b). 


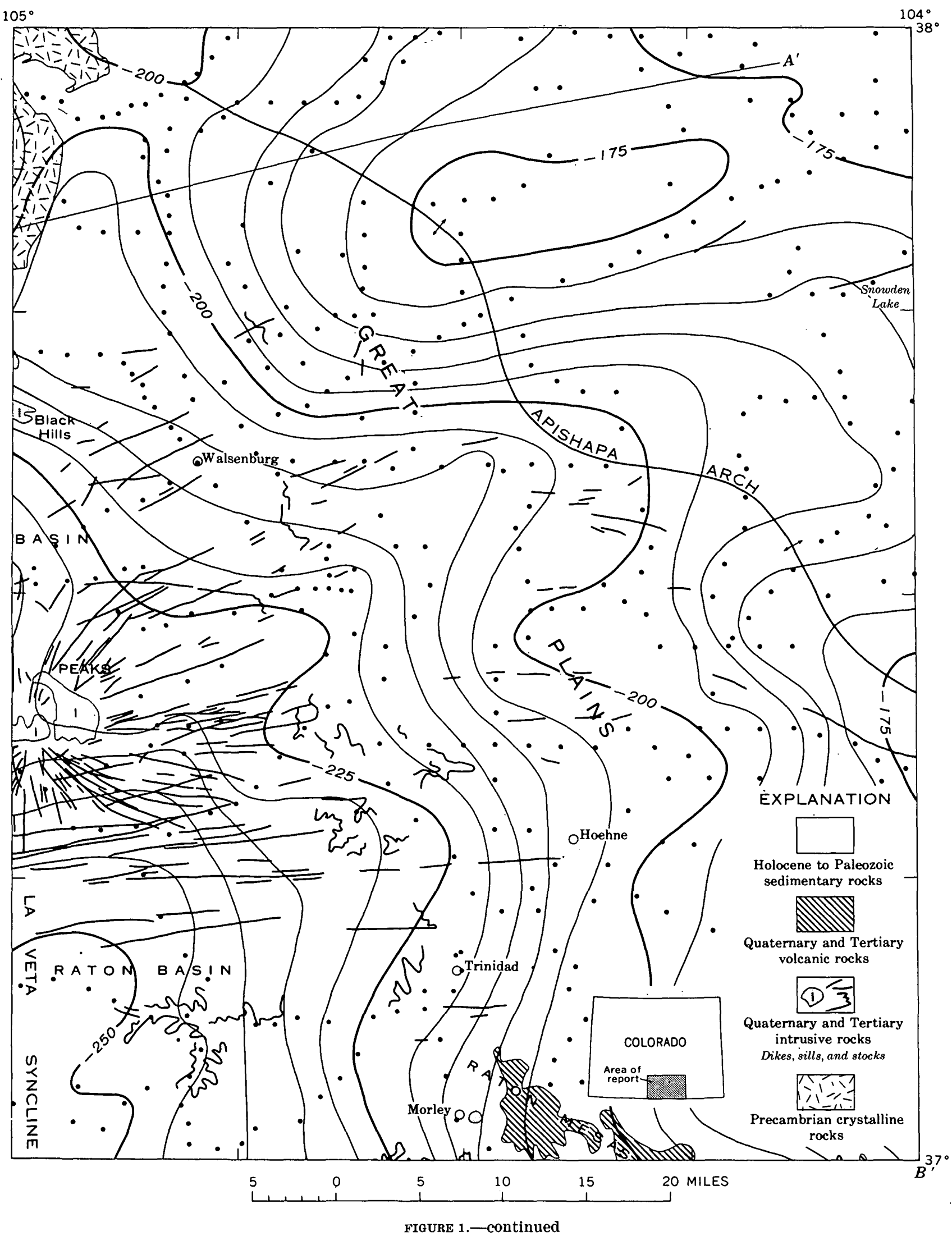



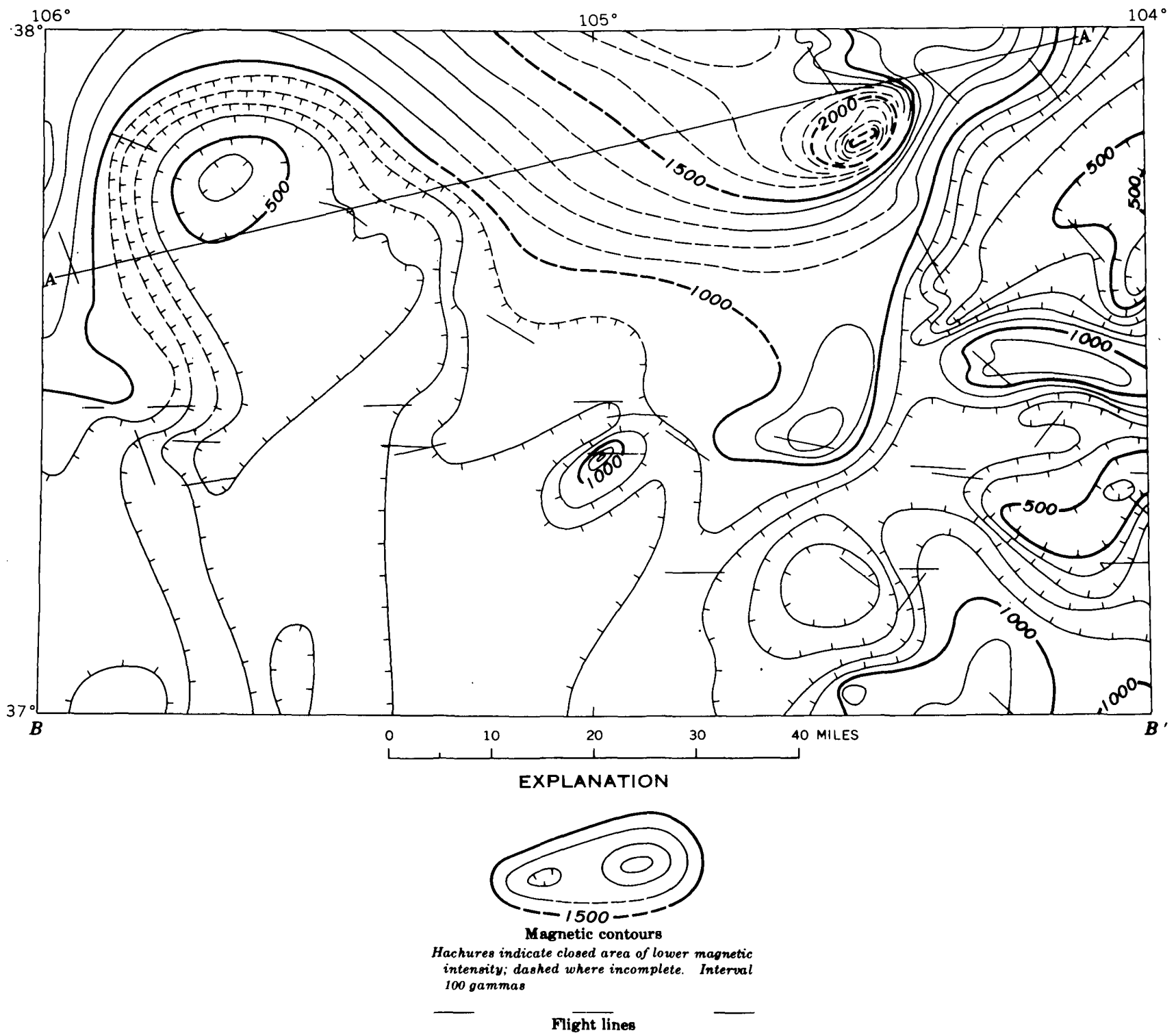

FigURe 2-Reconnaissance aeromagnetic map of the Trinidad quadrangle (Zietz and Kirby, 1968). Values are total magnetic intensity relative to an arbitrary datum. Main magnetic field of the earth, supplied by the U.S. Coast and Geodetic Survey and based on Epoch 1955, has been removed. Aeromagnetic survey flown between 7,000- and 16,000foot barometric elevation. $A-A^{\prime}$ (near top of map) and $B-B^{\prime}$ (at bottom of map), location of models shown on figures 3 and 4.

ment mass of high density and magnetic susceptibility along the arch.

Near the east end of $B-B^{\prime}$, the magnetic profile shows a 350-gamma positive anomaly over the volcanic flows of the Raton Mesas (fig. 4). However, the model studies and configuration of the observed magnetic anomaly suggest that the source is an intrabasement body of intermediate composition and perhaps is a source of the basaltic flow rocks. The plug shown on the geologic map near Morley may be an apophysis of the body thought to cause the anomaly (fig. 1). The 20 -gamma positive anomaly superimposed on the 350 gamma anomaly correlates with the surface volcanic exposures. Inasmuch as the volcanic. flow rocks are olivine basalts, which generally are highly magnetic, we examined the possibility that the 350 -gamma magnetic anomaly was caused by the surface volcanics of finite thickness. The calculated anomaly, which was a typical plate configuration, did not fit the observed anomaly. In addition, the flow thickness of about 2,000 feet that is required to produce the amplitude of the observed profile is considerably greater than known thicknesses of flows in the area.

Regional northeasterly trends in the gravity and magnetic data may represent faults or shear zones in the crystalline basement. One trend extends from La 

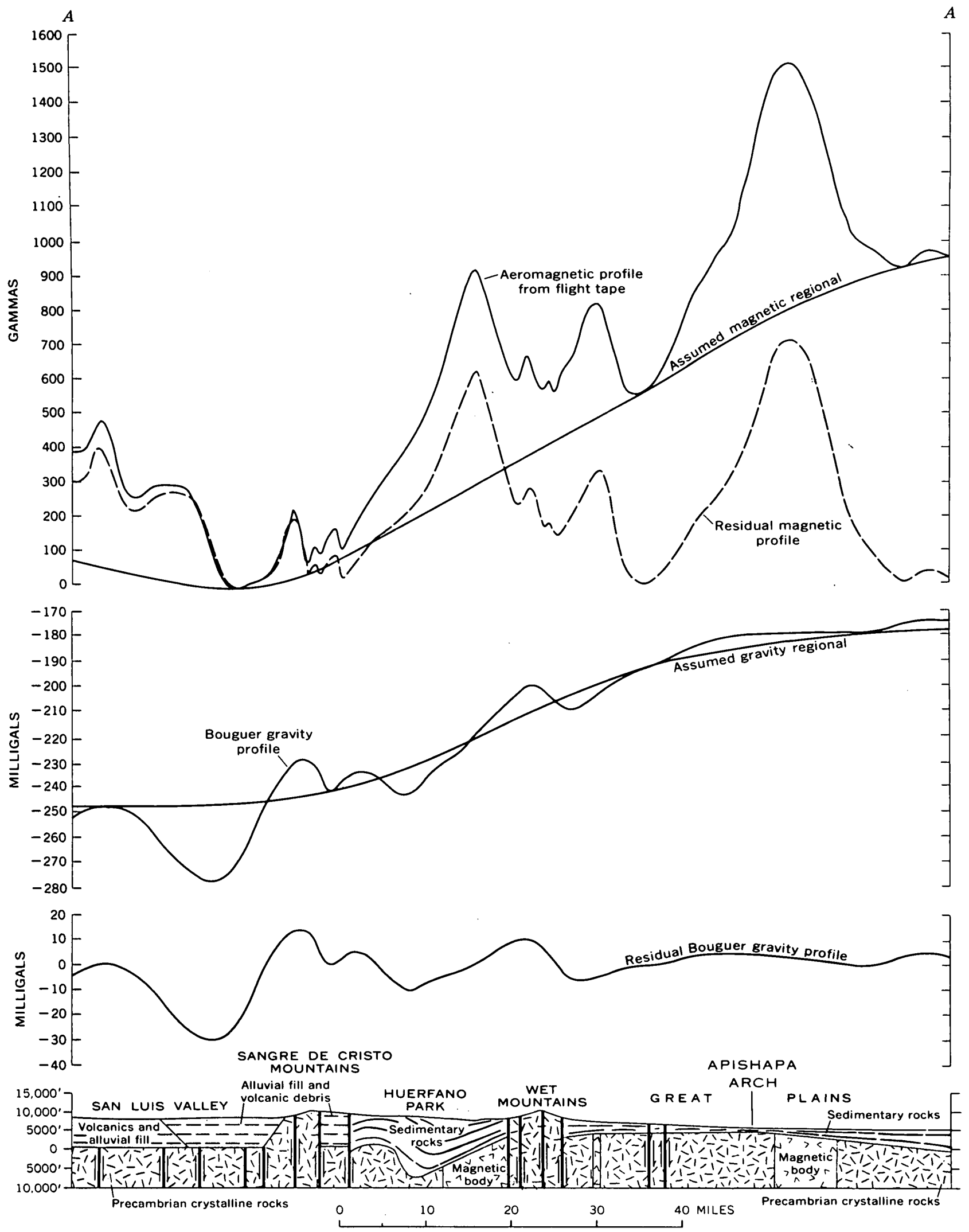

Froure 3.-Gravity and magnetic profiles and computed geologic model along section $A-A^{\prime}$. Model location shown on figures 1 and 2 . The flight level for the aeromagnetic profile was 11,000 feet barometric elevation. The aeromagnetic profile is from unpublished U.S. Geological Survey data. 

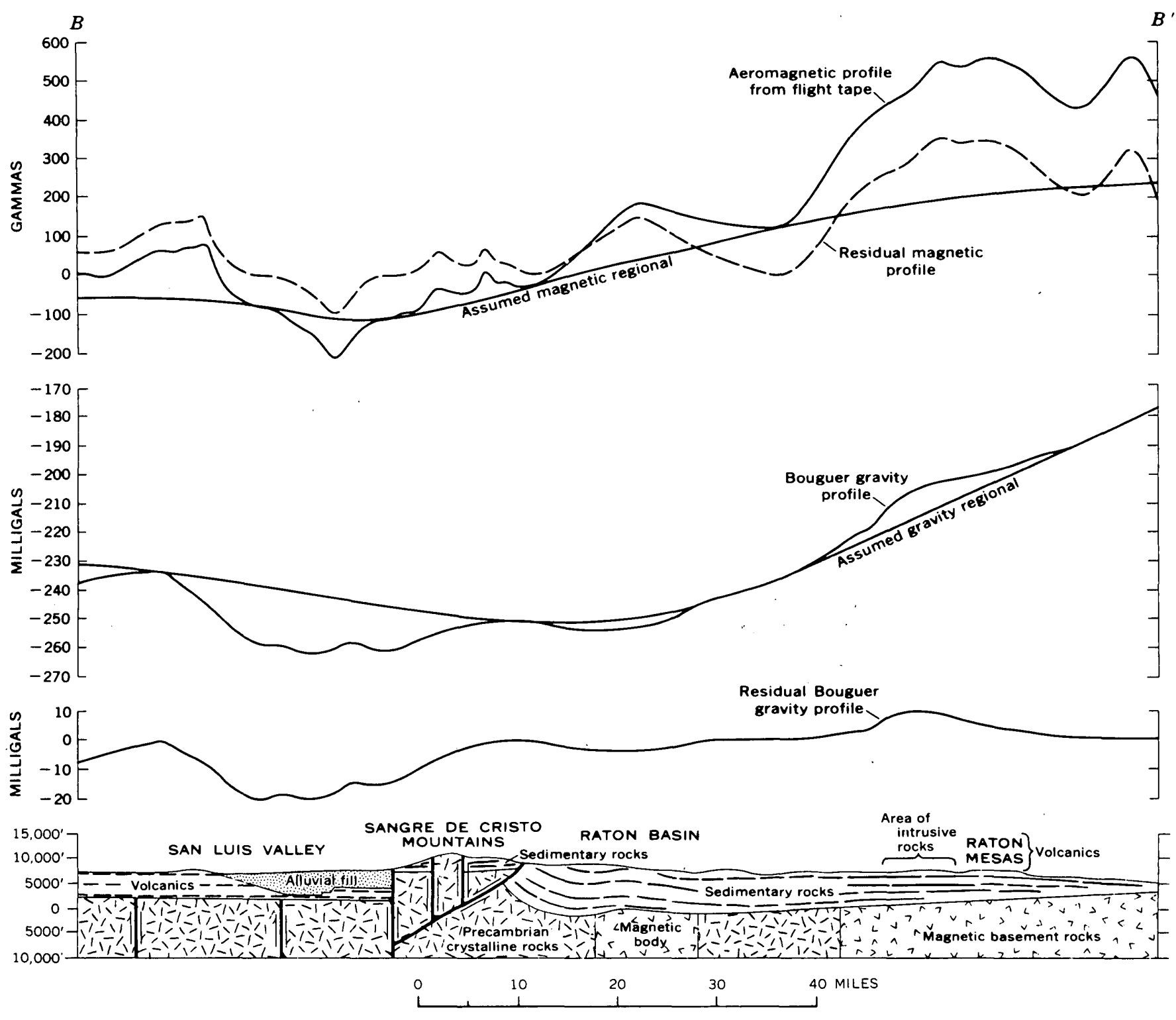

FigURE 4.-Gravity and magnetic profiles and computed geologic model along section $B-B^{\prime}$. Model location shown. on figures 1 and 2 . The flight level of the aeromagnetic profile was 14,500 feet barometric elevation.

Jara to the northeast corner of the quadrangle. The trend goes along the north edge of the San Luis Hills volcanic fields and near the south termination of the major gravity minimum over the northeast part of the valley and the large reentrant of the Sangre de Cristo Mountains southwest of Sierra Blanca. It passes near the south end of the Huerfano Park gravity minimum. It includes the stock and dike swarm of Dike Mountain (Silver Mountain) (Johnson, 1961, p. 586588 ) and the laccolith of the Black Hills (Johnson, 1968a, p. G16-G35). The large gravity and magnetic positive anomalies that probably represent an intrabasement source are on the trend.
A parallel trend can be traced across the quadrangle from Lobatos northeastward through the Spanish Peaks to Snowden Lake. Along the trend a buried westward protrusion of the Sangre de Cristo Mountains is indicated by a gravity nose. In the main mountain range just southwest of Trinchera Peak there is a strong northeast-trending valley at the north fork of Culebra Creek. The high-density igneous rocks near the Spanish Peaks (Knopf, 1936; Johnson, 1968a, p. G16-G35) produce another gravity maximum along the trend. To the northeast the axis of a gravity minimum is parallel to several surface faults and dike swarms (fig. 1). The parallelism of the magnetic gradient zones (fig. 2) further suggests that the major 
northeast gravity trends are produced by a series of faults or shear zones in the crystalline basement.

\section{REFERENCES}

Andrensen, G. E., and Kinne, M. F., 1961, Isostatic compensation in the Sangre de Cristo Mountains, New Mexico: Art. 391 in U.S. Geol. Survey Prof. Paper 424-D, p. D277-D281.

lBurbank, W. S., and Goddard, E. N., 1937, Thrusting in Huerfuno Park, Colorado, and related problems of orogeny in the Sangre de Cristo Mountains: Geol. Soc. America Bull., v. 48 , no. 7 , p. $931-976$.

Gaca, J. R., and Karig, J. E., 1966, Gravity survey in the San luis valley area, Colorado: U.S. Geol. Survey open-file report, $22 \mathrm{p}$.

Hills, R. C., 1900, Description of the Walsenburg quadrangle [Colorado]: U.S. Geol. Survey Geol. Atlas, Folio 68, 6 p.

Holmer, R. C., 1954, A regional gravity survey of Colorado: Colorado School Mines. D. Sc. thesis S01, 94 p.

Tohnson, R. 13., 1961, Patterns and origin of radial dike swarms associated with West Spanish Peak and Dike Mountains, south-central Colorado: Geol. Soc. America Bull., v. 72, no. 4, p. 579-590.

1968 , Geology of the igneous rocks of the Spanish Peaks region, Colorado: U.S. Geol. Survey Prof. Paper 594-G, p. G1-G47. 1968b, Geologic map of the Trinidad quadrangle, southcentral Colorado: U.S. Geol. Survey Misc. Geol. Inv. Map I-558.

Kelley, V. C., 1956, The Rio Grande depression from Taos to Santa Fe, in New Mexico Geol. Soc. Guidebook 7th Field Conf., 1956 : p. 109-114.

Knopf, Adolph, 1936, Igneous geology of the Spanish Peaks region, Colorado: Geol. Soc. America Bull., v. 47, no. 11, p. 1727-1784.

Mudge, M. R., Erickson, R. L., and Kleinkopf, Dean, 1968, Reconnaissance geology, geophysics, and geochemistry of the southeastern part of the Lewis and Clark Range, Montana, with a scction on Isotopic composition of lead, by $\mathbf{R}$. $\mathbf{E}$. Zartman: U.S. Geol. Surrey Bull. 1252-E, p. E1-E35.

Peterson, D. L., Popenoe, Peter, Gaca, J. R., and Karig, D. E., 1968, Gravity map of the Trinidad quadrangle, Colorado: U.S. Geol. Survey Geophys. Inv. Map GP-638.

Qureshy, M. N., 1960, Airy-Heiskanen anomaly map of Colorado, in Rocky Mountain Assoc. Geologists Guide to the geology of Colorado: Denver, p. S-9.

Zietz, Isidore, and Kirby, J. R., 1968, Transcontinental geophysical survey $\left(35^{\circ}-39^{\circ} \mathrm{N}\right)$ magnetic map from $100^{\circ}$ to $112^{\circ} \mathrm{W}$ longitude: U.S. Geol. Survey Misc. Geol. Inv. Map I-533-A, scale $1: 1,000,000$. 


\title{
WHOLE-ROCK Rb-Sr AGE OF THE PIKES PEAK BATHOLITH, COLORADO
}

\author{
By C. E. HEDGE, Denver, Colo.
}

\begin{abstract}
Ten whole-rock samples from the Pikes Peak batholith and 3 from the satellite Rosalie lobe yield a $\mathbf{R b}-\mathbf{S r}$ age for the time of batholith emplacement of $1,041 \pm 13$ million years. All the major lithological variants were probably intruded within less than 20 m.y. The Pikes Peak batholith represents the youngest major Precambrian granitic intrusion in the Front Range.
\end{abstract}

The Pikes Peak batholith is the largest single mass of granite in the Front Range of Colorado (fig. 1). It is exposed as an approximately 1,200-square-mile body, somewhat elongate in a north-south direction, in the southern part of the Front Range. A significant satellite mass, locally known as the Rosalie lobe (Hutchinson, 1960), occurs just north of the batholith, and several small bodies of probable Pikes Peak Granite crop out on the east slope of Mount Evans to the northwest of the Rosalie lobe. Other granite bodies of similar lithology are known in the region, but no other major bodies of igneous rocks of an equivalent age are known in the immediate area or elsewhere in Colorado.

The Pikes Peak Granite was first named by Cross in 1894 and has since been the object of many studies. The batholith is complex and contains mappable variants. Gross and Heinrich (1965) discussed the characteristics of some of the rocks of the southern part of the batholith. In this area some of the variants have been given local names. Hutchinson (1960) has mapped and subdivided the northern part of the batholith, using petrologic names for the respective subdivisions. The samples in the present study include most of the recognized variants and two late dike rocks which are common throughout the batholith.

Several studies of mineral ages from the batholith have been published. Most notable of these are by Aldrich, Wetherill, Davis, and Tilton (1958), Hutchinson (1960), and Giffin and Kulp (1960). The published ages are summarized in table 1 . The total spread in
TABLE 1.-Published mineral ages from the Pikes Peak batholith

\begin{tabular}{|c|c|c|c|c|}
\hline Sample locality & Mineral & $\begin{array}{l}\text { Source } \\
\text { of data } 1\end{array}$ & Method & $\begin{array}{c}\text { Age } \\
\text { (m.y.) }\end{array}$ \\
\hline \multirow[t]{2}{*}{ Manitou Springs area } & Biotite & 1 & $\mathrm{~K}-\mathrm{Ar}$ & $\begin{array}{r}980 \\
020\end{array}$ \\
\hline & Zircol & $\begin{array}{l}1 \\
1\end{array}$ & $\mathrm{~Pb}^{207}-\mathrm{Pb}^{206}$ & $\begin{array}{r}1,020 \\
980\end{array}$ \\
\hline \multirow[t]{3}{*}{ Summit of Pikes Peak } & Biotite & 1 & $\mathrm{~K}-\mathrm{Ar}$ & 1,060 \\
\hline & $\ldots d c$ & 1 & $\mathrm{Rb}-\mathrm{Sr}$ & 1,080 \\
\hline & & & $\mathrm{K}-\mathrm{Ar}$ & 980 \\
\hline $\begin{array}{l}\text { Ute Pass } \\
\text { Gold Camp Road. }\end{array}$ & - do & $\begin{array}{l}2 \\
2\end{array}$ & $\underset{\mathbf{K}-\mathrm{Ar}}{\mathrm{K}-\mathrm{Ar}}$ & 1,030 \\
\hline Pikes Peak Toll Road & 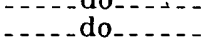 & $\begin{array}{l}2 \\
2\end{array}$ & $\mathbf{K}-\mathbf{A r}$ & 1,020 \\
\hline Near Foxter & do_ & 3 & $\overline{\mathrm{K}}-\mathrm{Ar}$ & 1,080 \\
\hline Buffalo & $-\mathrm{do}_{-}$ & 3 & $\mathrm{~K}-\mathrm{Ar}$ & 1,050 \\
\hline $\begin{array}{l}\text { Wellington Reservoir } \\
\text { area. }\end{array}$ & & 3 & $\mathrm{~K}$-Ar & 1,050 \\
\hline Mount Rosa & Rieb & 4 & $\mathrm{~K}$-Ar & 1,040 \\
\hline Redskin stock & iot & 5 & $\overline{\mathbf{K}}-\mathbf{A r}$ & 980 \\
\hline & & 5 & $\mathrm{Rb}-\mathrm{Sr}$ & 980 \\
\hline $\begin{array}{l}\text { Redskin stock greisen } \\
\text { Boomer cupola_ }\end{array}$ & $\begin{array}{l}\text { Iuscovite_-_- } \\
\text { L_-_do_._- }\end{array}$ & $\begin{array}{l}5 \\
5\end{array}$ & $\begin{array}{l}\mathrm{K}-\mathbf{A r} \\
\mathbf{K}-\mathbf{A r}\end{array}$ & $\begin{array}{r}1,020 \\
990\end{array}$ \\
\hline Boomer cupola greisen & & 5 & $\mathrm{Rb}-\mathrm{Sr}$ & 1,010 \\
\hline Doomer cupora gre & & & & 1,000 \\
\hline
\end{tabular}

\footnotetext{
1 Sources of data:

1. Aldrich, Wetherill, Davis, and Tilton (1958)

2. Giffin and Kulp (1969)

3. Hutchinson (1960)

4. Gross and Heinrich (1966).

5. Hawley, Huffman, Hamilton, and Rader (1966).
}

mica ages, by both K-Ar and Rb-Sr methods, is from 980 to 1,080 million years. The mean mica age is 1,030 m.y., and, considering the normal analytical uncertainties, the data are consistent with analytical scatter around a single number. $\mathrm{K}$-Ar analysis of a riebeckite from a pegmatite gave a similar result of 1,040 m.y. (Gross and Heinrich, 1965). One zircon from the Pikes Peak batholith has been isotopically dated (Aldrich and others, 1958), and, although discordant, the $\mathrm{Pb}^{207}-\mathrm{Pb}^{206}$ age of 980 m.y. is compatible with the mica ages.

Hawley, Huffman, Hamilton, and Rader (1966) have reported $\mathrm{K}$-Ar mica ages for two small satellite masses on the western edge of the batholith. These ages and two $\mathrm{Rb}$-Sr ages of microclines from the same area are also given in table 1. 

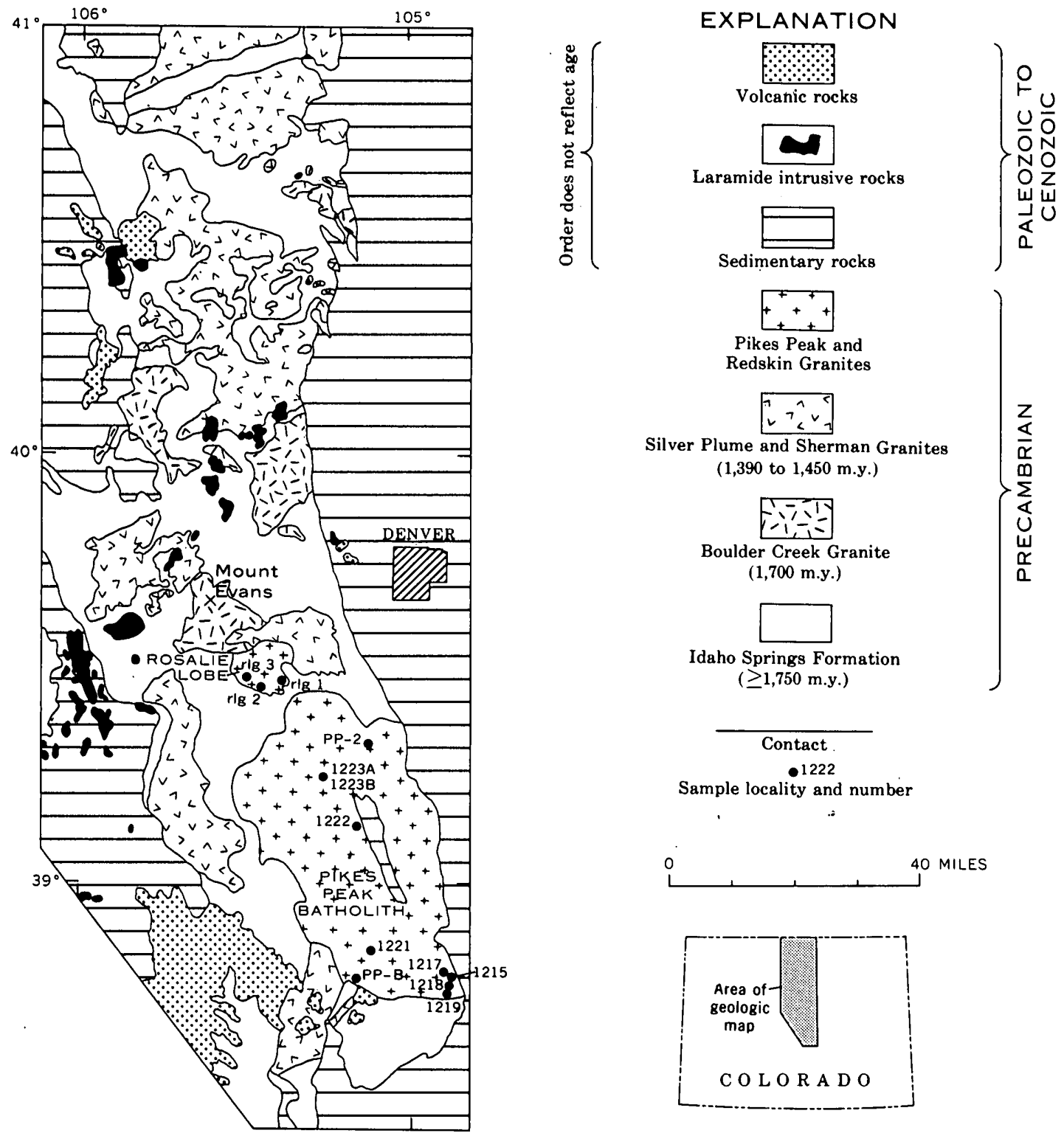

Frours 1.-Generalized geologic map of the Front Range, showing localities for samples listed in table 2 (geology compiled from Lovering and Goddard, 1950; Osterwald and Dean, 1958; Tweto and Sims, 1963; and Hutchinson and Hedge, 1967).

Numerous $\mathrm{Pb}-\alpha$ ages of zircon have also been reported by Gross and Feinrich (1966), but inasmuch as the precision of these $\mathrm{Pb}-\alpha$ ages is not. comparable to that of ages determined by other methods, the $\mathrm{Pb}-\alpha$ ages are not discussed further here.

\section{DATA}

Exact sample locations (shown in fig. 1) are given in table 2, and the analytical data are presented in table 3 , as are the individually calculated ages for all samples. The ages range from 1,013 to $1,108 \mathrm{~m}$.y. The sample yielding the greatest apparent age (PP-2) has a very unfavorable $\mathrm{Rb} / \mathrm{Sr}$ ratio and hence a large correction for nonradiogenic $\mathrm{Sr}^{\mathrm{s}}$ and a large analytical uncertainty of about $90 \mathrm{~m} . \mathrm{y}$. It can, therefore, not be interpreted as being significantly older than the other samples. Individual analytical uncertainties for the other samples are in the range of 20 to $30 \mathrm{~m} . \mathrm{y}$. The data are thus consistent with the interpretation that all the samples are of one age and the apparent age differences are due only to analytical uncertainties.

The data (excluding those for the two dike rocks 1218 and 1223B) are also plotted on an isochron diagram in figure 2. Such a plot has the inherent assump- 
TABLe 2.-Sample localities and descriptions [Samplo localities shown on fig. 1]

\begin{tabular}{|c|c|c|c|}
\hline Sample No. & Latitude (N.) & Longitude (W.) & Rock type sampled \\
\hline 1215 & $38^{\circ} 47$ & $104^{\circ} 52^{\prime} 35^{\prime \prime}$ & \multirow{4}{*}{$\begin{array}{l}\text { Biotite granite. } \\
\text { Fayalite granite (Gross } \\
\text { and Heinrich, 1965). } \\
\text { Porphyry dike. } \\
\text { Fayalite granite (Gross } \\
\text { and Heinrich, 1965). }\end{array}$} \\
\hline 121 & $38^{\circ} 47^{\prime} 22^{\prime \prime}$ & $104^{\circ} 54^{\prime} 11^{\prime \prime}$ & \\
\hline 1218 & $38^{\circ} 47^{\prime} 08^{\prime \prime}$ & $104^{\circ} 54^{\prime} 16^{\prime \prime}$ & \\
\hline 12 & & $104^{\circ} 54^{\prime} 46^{\prime \prime}$ & \\
\hline 1221 . & $38^{\circ} 50^{\prime} 23^{\prime \prime}$ & $105^{\circ} 08^{\prime} 17^{\prime \prime}$ & \multirow{5}{*}{$\begin{array}{l}\text { Hornblende granite. } \\
\text { Hornblende syenite. } \\
\text { Biotite granite. } \\
\text { Aplite dike. } \\
\text { Border facies (shown on } \\
\text { fig. } 1 \text { as Pikes Peak } \\
\text { Granite). }\end{array}$} \\
\hline 1222 & $39^{\circ} 10^{\prime} 08^{\prime \prime}$ & $105^{\circ} 09^{\prime} 53^{\prime \prime}$ & \\
\hline $1223 \mathrm{~A}$ & $39^{\circ} 15^{\prime} 18^{\prime \prime}$ & $105^{\circ} 15^{\prime} 48^{\prime \prime}$ & \\
\hline $1223 \mathrm{~B}$ & $39^{\circ} 15^{\prime} 18^{\prime \prime}$ & $105^{\circ} 15^{\prime} 48^{\prime \prime}$ & \\
\hline $\mathrm{PP}-\mathrm{B}_{-}$ & $38^{\circ} 46^{\prime} 57^{\prime \prime}$ & $105^{\circ} 12^{\prime} 07^{\prime \prime}$ & \\
\hline $\mathrm{PP}-$ & $39^{\circ} 19^{\prime} 28^{\prime \prime}$ & $105^{\circ} 07^{\prime} 33^{\prime \prime}$ & \multirow{3}{*}{$\begin{array}{l}\text { Porphyritic granite } \\
\text { (Hutchinson, 1960). } \\
\text { Biotite granite of } \\
\text { Rosalie lobe. } \\
\text { Do. } \\
\text { Do. }\end{array}$} \\
\hline $\mathrm{rlg}-1$ & $39^{\circ} 27^{\prime} 03^{\prime \prime}$ & $105^{\circ} 26^{\prime} 25^{\prime \prime}$ & \\
\hline $\begin{array}{l}\text { rlg-2 } \ldots \ldots \\
\text { rlg-3... }\end{array}$ & $\begin{array}{l}39^{\circ} 27^{\prime} 52^{\prime \prime} \\
39^{\circ} 29^{\prime} 01^{\prime \prime}\end{array}$ & $\begin{array}{l}105^{\circ} 28^{\prime} 25^{\prime \prime} \\
105^{\circ} 29^{\prime} 16^{\prime \prime}\end{array}$ & \\
\hline
\end{tabular}

TABLE 3.-Analytical data on samples from localities in figure 1 and table 2

\begin{tabular}{|c|c|c|c|c|c|}
\hline Sample No. & $\underset{(\mathrm{ppm})}{\mathrm{Rb}}$ & $\mathrm{Sr}^{1}(\mathrm{ppm})$ & $\mathrm{Rb}^{37} / \mathrm{Sr}^{86} 2$ & $\mathrm{Sr}^{87} / \mathrm{Sr}^{86} 3$ & $\underset{(\text { m.y.) }}{\text { Apparent age }}$ \\
\hline 21 & 215 & 95.4 & 6. 327 & 0. 7979 & 1,023 \\
\hline & 258 & 51. & 14. & & \\
\hline & 240 & 4. 91 & 179.0 & 3. 364 & 1., 060 \\
\hline & 289 & 45.2 & 19. 0 & .9864 & 1,048 \\
\hline 12 & 221 & 144 & 4. & .7 & 1,081 \\
\hline 12 & 157 & 15. 8 & 29. 91 & 1. 1452 & 1 , \\
\hline 122 & 220 & 63.4 & 10. 17 & .8545 & 1,033 \\
\hline 122 & 541 & 4. 78 & 621.5 & 9.8 & \\
\hline $\mathrm{P}$ & 199 & 160 & 3. 61 & .7 & 1,053 \\
\hline $\mathbf{P P}-$ & 160 & 249 & & & 1,108 \\
\hline g- & 160 & 55.4 & 7. 904 & .8380 & 1,048 \\
\hline & 16 & 58. & 8. & .8 & 1,052 \\
\hline rlg & 144 & 56.4 & 8. 483 & .8176 & 1,053 \\
\hline
\end{tabular}

1 Normal Sr.

$2 \mathrm{Rb}$ and Sr concentrations determined by isotope dilution.

Constants: $\mathrm{Rb}^{87} \lambda \beta=1.39 \times 10^{-11} \mathrm{yr}^{-1}$

${ }^{3}$ Fractionation effects corrected for by normalizing observed $\mathrm{Sr}^{88} / \mathrm{Sr}^{83}$ ratios to 0.1194

tion that all the samples are the same age and began with the same $\mathrm{Sr}$ isotopic composition. All the points fit the line within their respective analytical uncertainties and are, therefore, consistent with the singleage interpretation. This best age would be 1,041 m.y. with an apparent uncertainty of $13 \mathrm{~m} . \mathrm{y}$. If the time of emplacement of these samples diverged by more than about 20 m.y., some of the points would deviate from the line.

\section{DISCUSSION}

Although the Pikes Peak batholith is generally believed to represent the youngest major period of Precambrian igneous activity in the Front Range, some discrepancies, which need to be clarified, still exist. The Pikes Peak batholith has often been correlated, on the

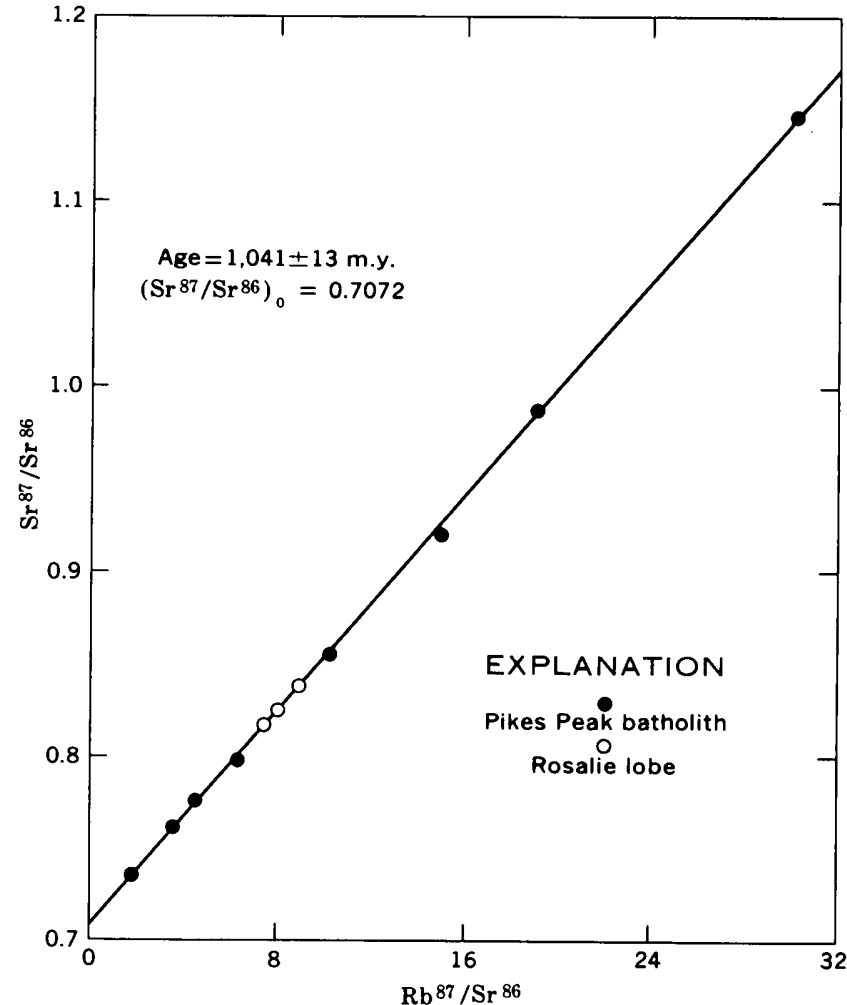

Figure 2.-Isochron plot for total-rock samples from the Pikes Peak batholith and Rosalie lobe. The two most radiogenic samples (1218 and 1223B) are not plotted, but they lie on the projection of this isochron.

basis of lithology, with the Sherman Granite of the Colorado-Wyoming border area. This correlation is erroneous, as the age of the Sherman Granite is 1,410 m.y. (Peterman and others, 1968). The Sherman Granite is intruded by the Log Cabin batholith, which is composed of Silver Plume Granite. This relationship, together with an interpretation of the contact between the Rosalie lobe and other bodies of Silver Plume-like granite (Boos and Aberdeen, 1940), has led some to the belief that the Pikes Peak batholith is older than the Silver Plume Granite. The various bodies of Silver Plume Granite, in the Front Range, are all 1,400-1,450 m.y. old (Peterman and others, 1968; Hedge, 1968). Included in these are the Cripple Creek Granite and the Indian Creek Granite of Boos and Aberdeen (1940), both of which have been interpreted as being younger than the Pikes Peak. Enough data are now available to say with certainty that the emplacement of the Pikes Peak batholith, 1,040 m.y. ago, was the last major Precambrian igneous event in the Front Range.

Though attempts can be made to decipher the emplacement history of a complex batholith such as the Pikes Peak batholith on the basis of radiometric dat- 
ing, the unraveling of the sequence must depend, ultimately, on determining the geological relationships. The time involved is so small that it is lost in the analytical uncertainties of the radiometric dating techniques. The 20-m.y. uncertainty of the age of the batholith is the approximate limit on the total time of emplacement.

\section{REFERENCES}

Aldrich, L. T., Wetherill, G. W., Davis, G. L., and Tilton, G. R., 1958, Radionctive ages of micas from granitic rocks by $\mathbf{R b}$ Sr and K-A methods: Am. Geophys. Union Trans., v. 39, no. 6, p. 1124-1134.

Boos, M. F., and Aberdeen, E. J., 1940, Granites of the Front Range, Colorado; The Indian Creek plutons: Geol. Soc. America Bull., v. 51, no. 5, p. 695-730.

Cross, Whitman, 1894, Pikes Peak, Colorado: U.S. Geol. Survey Geol. Atlas, Folio 7, 8 p.

Giffin, C. E., and Kulp, J. L., 1960, Potassium-argon ages in the Precambrian basement of Colorado: Geol. Soc. America Bull., v. 71, no. 2, p. 219-222.

Gross, E. B., and Heinrich, E. W., 1965, Petrology and mineralogy of the Mount Rosa area, El Paso and Teller Counties, Colorado, [pt.] 1, The granites: Am. Mineralogist, v. 50, no. 9, p. 1273-1295.

Gross, E. B., and Heinrich, E. W., 1966, Petrology and mineralogy of the Mount Rosa area, El Paso and Teller Counties, Colorado, [pt.] 2, Pegmatites: Am. Mineralogist, v. 51, nos. $3-4$, p. $299-323$.
Hawley, C. C., Huffman, Claude, Jr., Hamilton, J. C., and Rader, L. F., 1966, Geologic and geochemical features of the Redskin Granite and associated rocks, Lake George beryllium area, Colorado, in Geological Survey Research 1966: U.S. Geol. Survey Prof. Paper 550-C, p. C138-C147.

Hedge, C. E., 1968, Precambrian geochronology of the central Front Range, Colorado, in Abstracts for 1967: Geol. Soc. America Spec. Paper 115, p. 423.

Hutchinson, R. M., 1960, Structure and petrology of the north end of Pikes Peak batholith, Colorado, in Weimer, $\mathbf{R}$.J., and Haun, J. D., eds., Guide to the geology of Colorado: Rocky Mountain Assoc. Geologists, p. 170-180.

Hutchinson, R. M., and Hedge, C. E., 1967, Precambrian basement rocks of the central Colorado Front Range and its 700 million year history, in Geol. Soc. America Rocky Mountain Sec. Guidebook : p. 51.

Lovering, T. S., and Goddard, E. N., 1950, Geology and ore deposits of the Front Range, Colorado: U.S. Geol. Survey Prof. Paper 223, 319 p. [1951].

Osterwald, F. W., and Dean, B. G., compilers, 1958, Preliminary tectonic map of northern Colorado and northeastern Utah, showing the distribution of uranium deposits: U.S. Geol. Survey Mineral Inv. Field Studies Map MF-130, scale $1: 500,000,2$ sheets.

Peterman, Z. E., Hedge, C. E., and Braddock, W. A., 1968, Age of Precambrian events in the northeastern Front Range, Colorado: Jour. Geophys. Research, v. 73, no. 6, p. 22772296.

Tweto, Ogden, and Sims, P. K., 1963, Precambrian ancestry of the Colorado mineral belt: Geol. Soc. America Bull., v. 74, no. 8, p. 991-1014. 


\title{
DISTRIBUTION OF URANIUM IN URANIUM-SERIES DATED FOSSIL SHELLS AND BONES SHOWN BY FISSION TRACKS
}

\author{
By B. J. SZABO, J. R. DOOLEY, JR., R. B. TAYLOR, \\ and J. N. ROSHOLT, Denver, Colo.
}

\begin{abstract}
Fission tracks show that uranium is dispersed throughout fossil shells and bones. However, a white layer of a shell may contain only half as much uranium as the darker organic-stained layer, and the surface layer of bone can be depleted in uranium. The distribution of uranium appears to be independent of age, uranium content, or departure from the ideal closed-system requirements.
\end{abstract}

Mathematical models for uranium-series dating of crystallographically unaltered shells and bones by measurements of accumulated ${ }^{230} \mathrm{Th}$ and ${ }^{231} \mathrm{~Pa}$ isotopes assume that these products of uranium decay are entirely retained and that the uranium is either immobile (the "closed system") or partly mobile, moving through the sample in a mathematically predictable way (the "open system"). Because knowledge of uranium distribution is required to evaluate models for dating samples that do not conform with the ideal closed system, we discuss here a method and results of determining uranium distribution in dated fossil materials.

Uranium-series dating by measuring the growth of ${ }^{230} \mathrm{Th}$ was applied first to coral limestone cuttings (Barnes and others, 1956). Subsequent reports showed that corals have virtually no initial thorium, that these animals assimilate uranium in their skeletons during life, and that such material is therefore suitable for dating (Sackett and Potratz, 1963; Broecker and Thurber, 1965; Thurber and others, 1965; Veeh, 1966 ; $\mathrm{Ku}, 1968)$. The feasibility of dating fossil marine mollusks was similarly demonstrated by the discovery that the largely secondary uranium was assimilated soon after death (Broecker, 1963; Kaufman and Broecker, 1965; Thurber and others, 1965). Thus, by assuming a closed system with respect to uranium and thorium isotopes through time, fossil shells were dated from various places (Thurber, 1965; Stearns and
Thurber, 1965; Blanchard and others, 1967; Veeh and Valentine, 1967). When the activity ratios of both ${ }^{230} \mathrm{Th} /{ }^{234} \mathrm{U}$ and ${ }^{231} \mathrm{~Pa} /{ }^{235} \mathrm{U}$ were measured, however, excess ${ }^{231} \mathrm{~Pa}$ relative to ${ }^{230} \mathrm{Th}$ and ${ }^{235} \mathrm{U}$ was found which was attributed to migrating uranium, and an "open system" model was accordingly proposed to account for this effect (Rosholt, 1967; Szabo and Rosholt, 1969). In addition to mollusks, some fossil bones have been dated with this model, together with related bones that satisfy the more restricted closed system (Szabo and others, 1969).

In order to study the migration of uranium in fossil shells and bones, we have used the fission-track method to determine the uranium distribution in dated samples. Our approach resembles a study of contemporary mollusk shells (Lahoud and others, 1966), which found that internal and external surfaces contained more uranium than did the interior. Table 1 lists the samples studied and their calculated dates and uranium contents (determined by isotope dilution and mass spectrometry). X-ray diffraction analysis indicated that the shells are composed of aragonite and the bones composed of apatite, with minor calcite as open-space fillings.

By the fission-track method, the fission of ${ }^{235} \mathrm{U}$ under thermal neutron bombardment is recorded on adjacent Lexan plastic, and the resulting tracks are then studied under an optical microscope after etching (Price and Walker, 1962; Fleischer and others, 1965; Hamilton, 1966; Kleeman and Lovering, 1967; Fleischer, 1968). Thin sections of the shells and bones about $500 \mu$ thick were cleaned in an ultrasonic bath, superimposed with Lexan plastic plates, and then irradiated by a total flux ranging from $1 \times 10^{15}$ to $2 \times 10^{16}$ neutrons $/ \mathrm{cm}^{2}$, depending on uranium content. The induced fission tracks in the Lexan were developed in $6 \mathrm{~N} \mathrm{KOH}$ for 5-6 minutes at $60^{\circ} \mathrm{C}$. For orienting the developed Lexan 
TABLE 1.-Sample descriptions, uranium content, and calculated ages of fossil shells and bones



1 Calculated from measured ${ }^{230} \mathrm{Th} / 234 \mathrm{U}$ and ${ }^{231} \mathrm{~Pa} / 235 \mathrm{U}$ (Szabo and Rosholt, 1969). 2 Calculated from measured ${ }^{230} \mathrm{Th} / 234 \mathrm{U}$ activity ratios.

3 Szabo and Rosholt (1969).

plates with respect to the samples, the thin sections were marked with ink or aluminum containing trace amounts of uranium which, in turn, produced a fissiontrack duplication of the mark on the Lexan. A sufficient number of tracks (over 100 per unit area) were counted so that the counting error did not exceed \pm 10 percent.

Examination of the etched Lexan plates showed no single uranium-rich grains even on a microscopic scale. Images from the fossil shells revealed that some dark layers rich in organic material have twice as much uranium as adjacent white layers. In the fossil bones, a thin layer at the surface and around open centers of Haversian canals had as little as one-tenth the amount of uranium elsewhere within the sample (fig. 1). In general, uranium was dispersed rather uniformly in the bulk of shell and bone samples independently of age, uranium content, or the departure from closed system as revealed by discordant closed- and opensystem dates.

\section{REFERENCES}

Barnes, J. W., Lang, E. J., and Potratz, H. A., 1956, Ratio of ionium to uranium in eoral limestone: Science, v. 124, no. 3213 , p. $175-176$.

Blanchard, R. L., Cheng, M. H., and Potratz, H. A., 1967, Uranium and thorium series disequilibria in recent and fossil marine molluscan shells: Jour. Geophys. Research, v. 72, no. 18 , p. $4745-4757$.

Broecker, W. S., 1963, Preliminary evaluation of uranium series inequilibrium as a tool for absolute age measurement on marine carbonates: Jour. Geophys. Research, v. 68, no. 9, p. $2817-2834$.

Broecker, W. S., and Thurber, D. L., 1965, Uranium-series dating of corals and oolites from Bahaman and Florida Key limestones: Science, v. 149, no. 3679, p. 58-90.

Fanale, E. P., and Schaeffer, O. A., 1965, Helium-uranium ratios for Pleistocene and Tertiary fossil aragonites: Science, v. 149 , no. 3681 , p. $312-317$.
${ }_{5}^{4}$ After Fanale and Schaeffer (1965).

5 Calculated from measured $231 \mathrm{~Pa} / 235 \mathrm{U}$ activity ratio.

6 Szabo, Malde, and Irwin-Williams (1969).
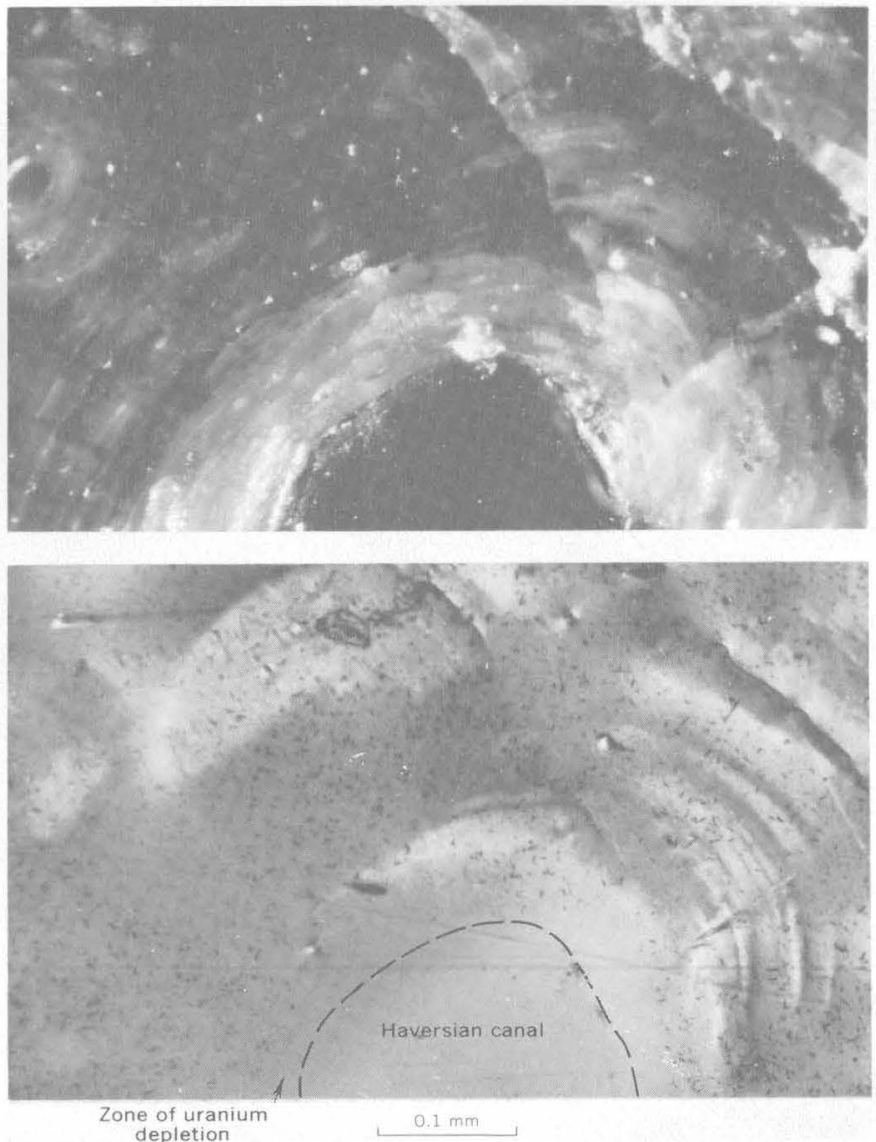

Figure 1.-Photomicrographs of a thin section of camel bone (top) and of Lexan plastic (bottom) with induced fission tracks. A zone with lower track density, and hence lower uranium concentration, around the open center of the Haversian canal shown in bottom photograph coincides with the lighter area around the canal in top. The top photomicrograph was taken with oblique top lighting; the bottom was taken with transmitted light using crossed polarizers, as the replication of the bone structure was primarily a variation in the birefringence of the Lexan. 
Fleischer, R. I., 1968, Uranium distribution in stone meteorites by the fission track technique : Geochim. et Cosmochim. Acta, v. 32 , no. 9, p. 989-998.

Fleischer, R. L., Price, P. B., and Walker, R. M., 1965, Tracks of charged particles in solids: Science, v. 149, no. 3682, p. 383-393.

Hamilton, E. I., 1966, Distribution of uranium in some natural minerals: Science, v. 151, no. 3710, p. 570-571.

Kaufman, Aaron, and Broecker, W. S., 1965, Comparison of $\mathrm{Th}^{230}$ and $\mathrm{C}^{14}$ ages for carbonate materials from Lakes Lahontan and Bonneville: Jour. Geophys. Research, v. 70, no. 16 , p. $4039-4054$.

Kleeman, J. D., and Lovering, J. F., 1967, Uranium distribution in rocks by fission-track registration in Lexan plastic: Science, v. 156 , no. 3774 , p. $512-513$.

Ku, Teh-Lung, 1968, Protactinium 231 method of dating coral from Barbados Island: Jour. Geophys. Research, v. 73, no. 6, p. 2271-2276.

Lahoud, J. A., Miller, D. S., and Friedman, G. M., 1966, Relationship between depositional environment and uranium concentration of molluscan shells: Jour. Sed. Petrology, v. 36 , no. 2 , p. 541-547.

Price, P. B., and Walker, R. M., 1962, Observations of charged particle tracks in solids: Jour. Appl. Physics, v. 33, p. 34003406.

Rosholt, J. N., 1967, Open system model for uranium-series dating of Pleistocene samples, in Radioactive dating and methods of low-level counting: Internat. Atomic Energy Agency, Vienna, Proc. Ser., Pub. SM-87/50, p. 299-311.
Sackett, W. M., and Potratz, H. A., 1963, Dating of carbonate rocks by ionium-uranium ratios, in Schlanger, S. O., Subsurface geology of Eniwetok Atoll: U.S. Geol. Survey Prof. Paper 260-BB, p. 1053-1066.

Stearns, C. E., and Thurber, D. L., 1965, $T^{230}-U^{234}$ dates of late Pleistocene marine fossils from the Mediterranean and Moroccan littorals: Quaternaria, v. 7, p. 29-42.

Szabo, B. J., Malde, H. E., and Irwin-Williams, Cynthia, 1969, Dilemma posed by uranium-series dates on archaeologically significant bones from Valsequillo, Puebla, Mexico: Earth and Planetary Sci. Letters, v. 6, no. 4, p. 237-244.

Szabo, B. J., and Rosholt, J. N., 1969, Uranium-series dating of Pleistocene molluscan shells from southern California-An open system model: Jour. Geophys. Research, v. 74, no. 12, p. 3253-3260.

Thurber, D. L., 1965, The dating of molluscs from raised marine terraces by the $\mathrm{Th}^{230} / \mathrm{U}^{234}$ method, in Symposium on marine geochemistry, Proc., 1964 : Rhode Island Univ. Narragansett Marine Lab. Occasional Pub. 3, p. 1-27.

Thurber, D. L., Broecker, W. S., and Kaufman, Aaron, 1965, 'The comparison of radiocarbon ages of carbonates with uranium series ages, in Sixth Internat. Conf. Radiocarbon and Tritium Dating, Washington State Univ., 1965, Proc.: AEC conf. 650652, p. 367-3S2.

Veeh, H. H., 1966, $\mathrm{Th}^{230} / \mathrm{U}^{238}$ and $\mathrm{U}^{234} / \mathrm{U}^{238}$ ages of Pleistocene high sea level stand: Jour. Geophys. Research, v. 71, no. 14, p. 3379-3386.

Veeh, H. H., and Valentine, J. W., 1967, Radiometric ages of Pleistocene fossils from Cayucos, California: Geol. Soc. America Bull., v. 78, no. 4, p. 547-549. 


\title{
IRON DEPOSITS OF THE ESTES CREEK AREA, LAWRENCE COUNTY, SOUTH DAKOTA
}

\author{
By RICHARD W. BAYLEY, Menlo Park, Calif.
}

\begin{abstract}
The Estes Creek iron deposits underlie a hilltop nrea in excess of 2 million square feet. Tightly folded Precambrian sedimentary iron-formation (taconite), about 29 percent iron, makes up the deposit. Laboratory tests by the U.S. Bureau of Mines show that the iron-formation is amenable to concentration. It is estimated that this deposit plus smaller deposits nearby could sustain a nominal mining venture.
\end{abstract}

This report presents the results of a recent (1967) field examination of some iron deposits near Estes Creek in Lawrence County, S. Dak. The Estes Creek area is ane of many in the Nemo district of the northeastern Black Hills which contain iron deposits (Harrer, 1966). It was selected for special examination because it seemed to contain the largest single iron deposit in the district. Figure 1 shows the location of the district and the Estes Creek area; figures 2 and 3 show the geology of the area and a magnetic survey of the iron-bearing portions. Siliceous hematite-magnetite iron-formation of Precambrian age makes up the iron deposits. The iron-formation is mainly in the SE $1 / 4$ sec. 33 (figs. 2 and 4), and mainly on a group of mineral claims called "B \& O". The principal deposit location is a relatively flat hilltop 400-500 feet above Estes Creek; it is easily accessible, and the topography (fig. 4) seems naturally suited to open-pit mine development.

\section{FIELD METHODS}

Most of the area of figure 2 was mapped by paceand-compass methods on topographic base maps. The small area which includes the iron deposits (fig. 3) was given special attention. The directions of survey lines were controlled by sundial compass, and distances along the lines were measured by steel tape and corrected approximately for slope. The origin of the detailed survey, point $A$ on figures 2 and 3 , represents a small hill showing one closed contour, the center point

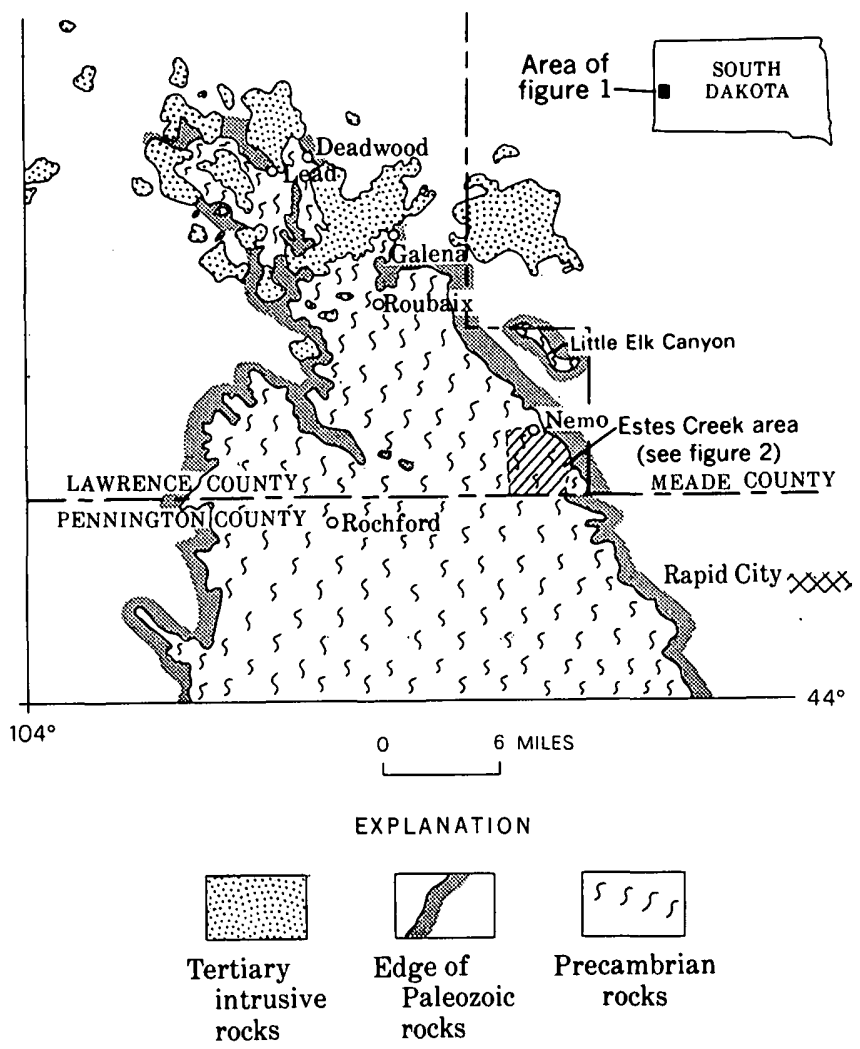

Figure 1.-Generalized geologic map of the northern Black Hills, showing location of the. Estes Creek iron area.

of which was determined as closely as possible by inspection on the ground. This point of origin could be mislocated slightly (10-25 feet) in any direction, and each other point of the survey net could be similarly shifted. Beyond the survey net, points are less well located, and errors of location of 50 feet or more may be expected. However, it is not expected that errors in location of the order mentioned in any way affect the final geologic picture. 


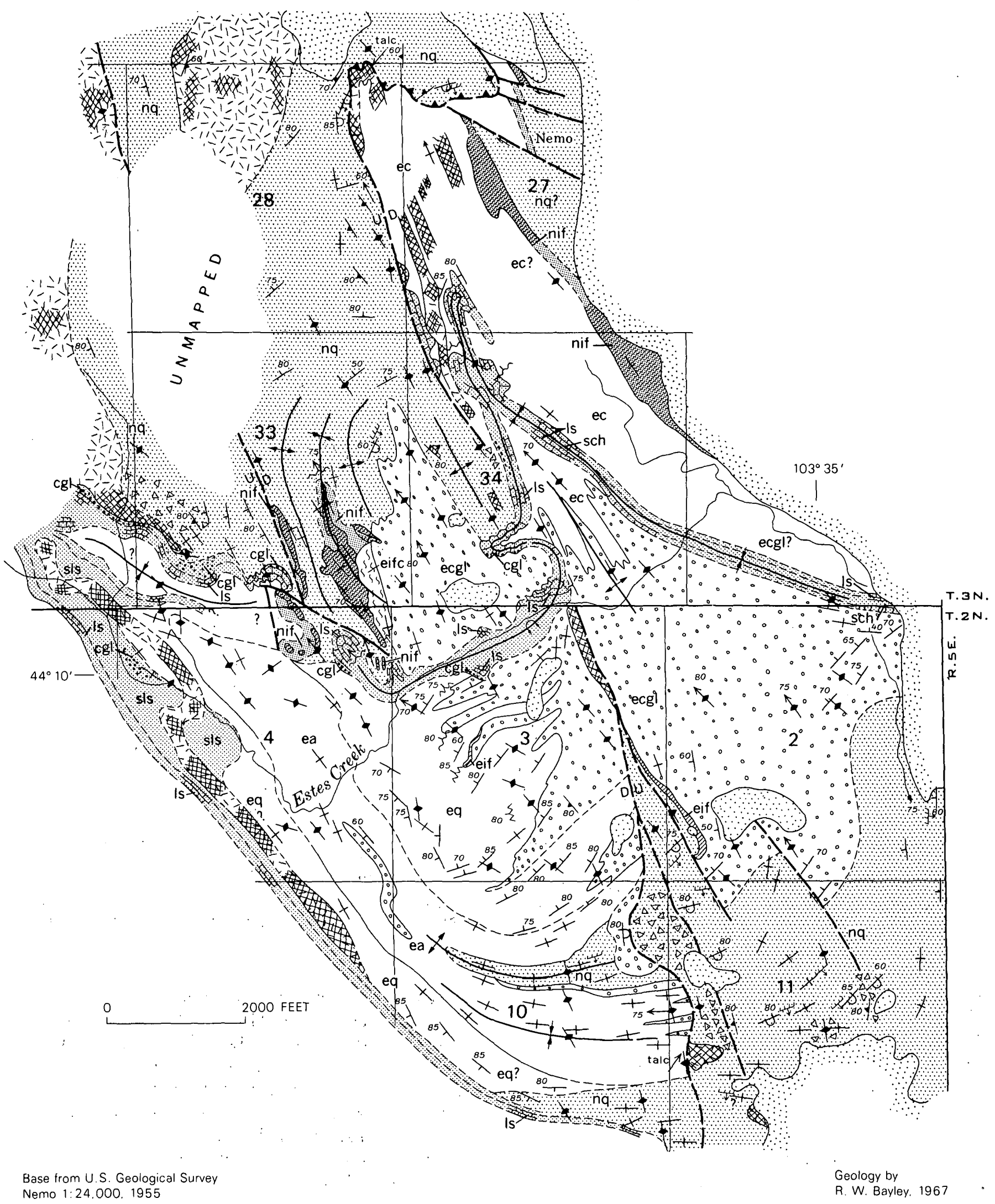




\section{EXPLANATION}

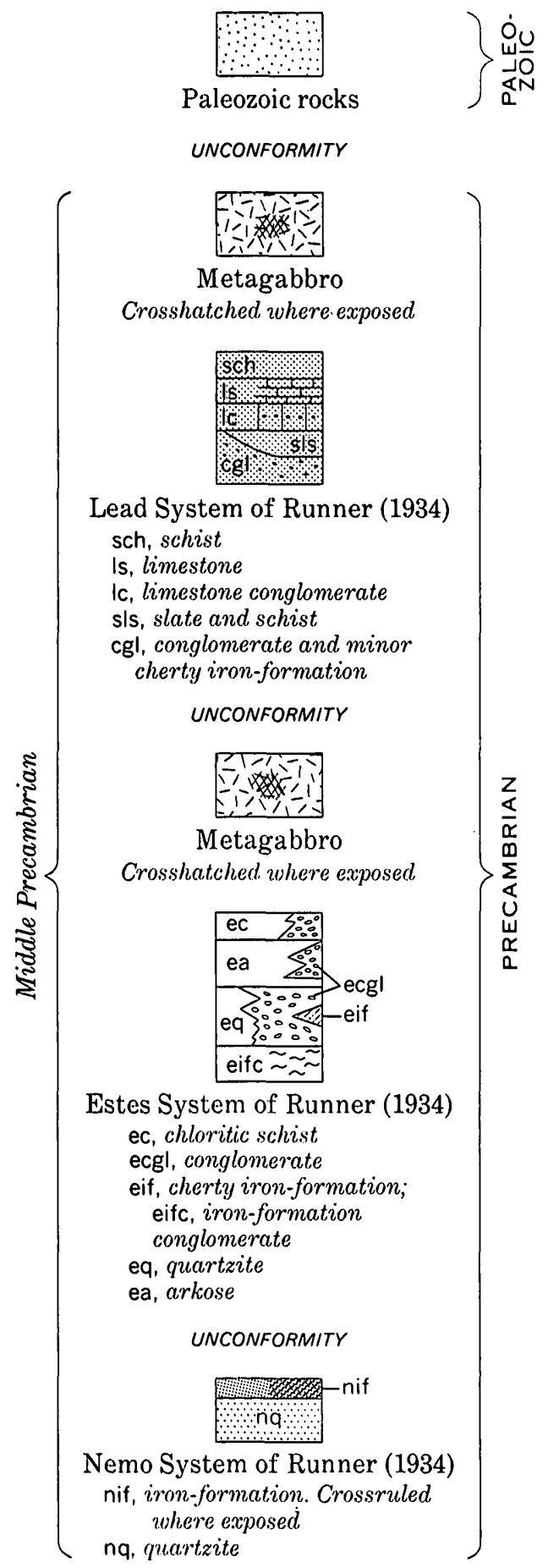
Contact
Da.shed where approximately located or inferred.

$$
\frac{U}{D}-\rightleftharpoons
$$

Normal or wrench fault, approximately located

U, upthrown side; D, downthrown side. Arrows indicate relative horizontal movement

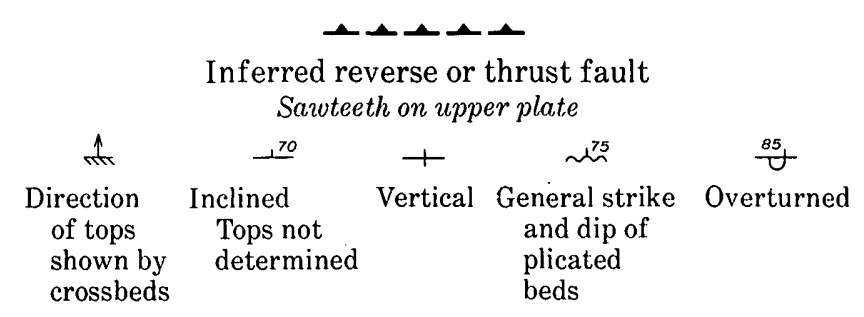

Strike and dip of beds

$$
\stackrel{60}{\text { Inclined }} \stackrel{-}{-}
$$

Strike and dip of foliation

May be combined with other symbols

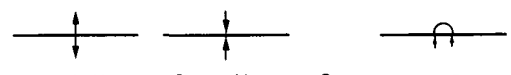

Anticline Syncline Overturned syncline Fold axes

Arrouss show direction of dip of limbs

$$
\text { Bearing and plunge } \quad \stackrel{4}{85}^{60} \quad \text { Plunge of minor folds }
$$
of lineation

$$
\begin{aligned}
& \Delta \Delta \Delta_{\nabla} \Delta \Delta \Delta \Delta \\
& \text { Breccia zone }
\end{aligned}
$$

Frgure 2.-Preliminary geologic map of the Estes Creek area. 


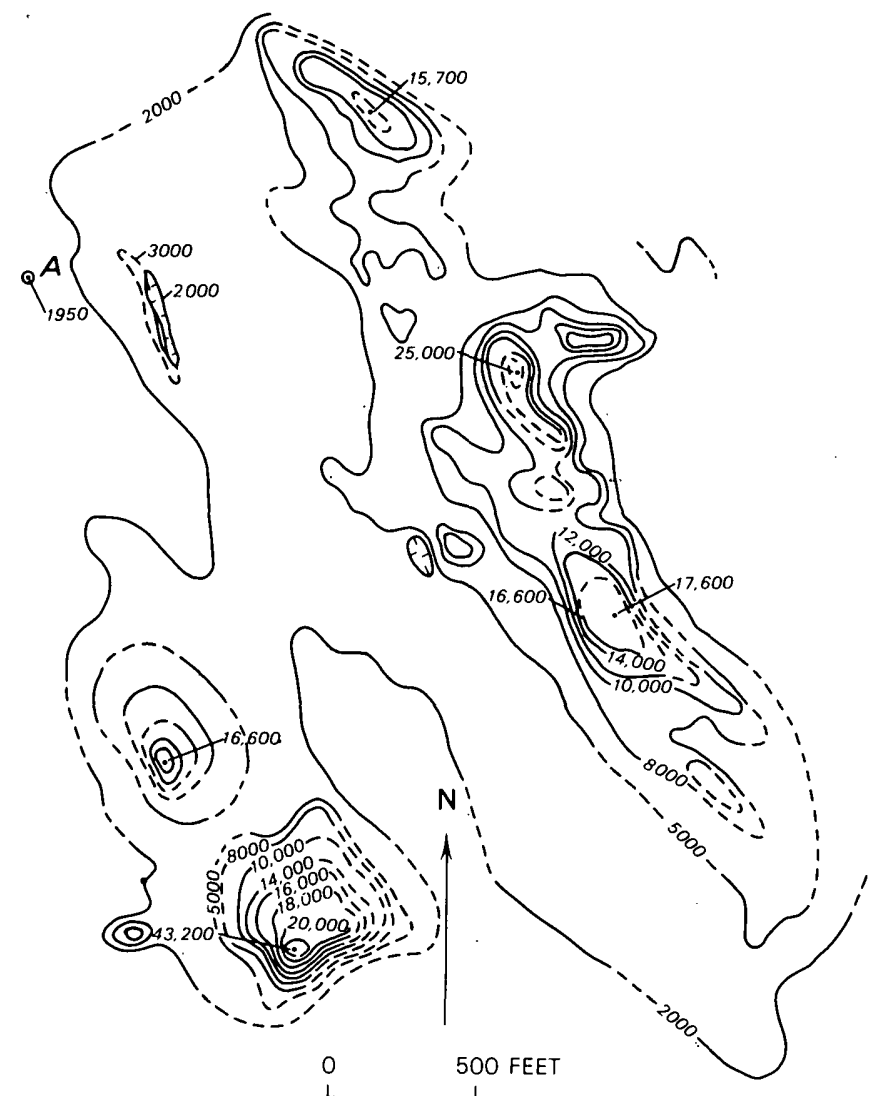

Magnetic survey by $\mathrm{S}$. Ludington and R. W. Bayley, assisted by J. G. Dudley. 1967

Figure 3.-Magnetic survey of iron deposits near Estes Creek, Lawrence County, S. Dak. Contours in gammas above arbitrary datum. Point $A$ is origin of survey (see fig. 4).

The magnetic survey was made with a hand-carried vertical-intensity fluxgate magnetometer with a sensitivity of about 10 gammas. The datum is local and arbitrary. A base station was used to determine the constancy of the instrument, but, because of the steep gradients, diurnal changes of the ambient magnetic field were not recorded or used to correct station values. This omission is considered to have caused a permissible error of plus or minus 25-50 gammas.

\section{GENERAL GEOLOGY}

To put the Estes Creek geology in context, it is necessary to explain that, despite the present gentle anticlinal configuration of the Black Hills uplift, the basic Precambrian structure of the hills is probably that of a synclinorium. The synclinorium area is composed chiefly of tightly folded sedimentary rocks of various kinds which rest unconformably on a granitic gneiss basement (Bayley and Meuhlberger, 1968). This old basement is exposed in the Nemo district on
Little Elk Creek (Zartman and Stern, 1967). As might be anticipated, the Precambrian formations closest to the basement show evidences of a complicated structural history which preceded the deposition of the younger formations of the synclinorium, though all formations are complexly folded, and all are metamorphosed.

The Estes Creek area is underlain by Precambrian formations which lie closest to the basement gneiss. These were probably twice folded before the last Precambrian deformation, during which they were folded again and collectively domed as a complex basement. The nature of these complexities will be described in a later section.

\section{STRATIGRAPHY}

The Precambrian rocks of the Estes Creek area comprise three distinct groups of formations separated by unconformities. The oldest group, called the Nemo System by Runner (1934), is composed chiefly of quartzite, quartz-mica schist, and iron-formation. The second group of rocks, called the Estes System by Runner, is composed of boulder conglomerate, quartzite, quartz-mica schist, meta-arkose, and minor ironformation. The third and youngest group of rocks, which apparently represents the lowest part of Runner's Lead System, is composed of conglomerate, limestone, minor iron-formation, and schist and slate of several kinds. Runner's pioneer summary of the Nemo district stratigraphy, and the stratigraphic summary for the Estes Creek area based on the findings of the present investigation are shown in table 1 . The stratigraphic revisions embodied in the column for the Estes Creek area involve the numbered units on the table, as explained in the footnotes accompanying the table. However, it should be noted in passing that not all revisions necessitated by the findings of the present investigation are indicated on the table. The omitted changes have to do mainly with the Lead System and are beyond the scope of this report.

\section{Rocks of the Estes Creek area}

Nemo System ${ }^{1}$ of Runner (1934).-The Nemo System consists of quartzite, a little quartz-mica schist, and the only important iron-formation. The quartzite is light-colored ordinary orthoquartzite. Beds are commonly a few feet thick, most are strongly sheared, and some show crossbedding. The quartzite is exposed mainly in section 33 beneath the iron-formation and in the southeast part of the area; its thickness cannot

\footnotetext{
1 The term "system" is here retained as used by Runner (1934) and credited to Runner. He intended that the systemic names be viewed as informal terms of local significance reflecting his conclusion that several periods of geologic time elapsed during the deposition and upheaval of the several rock groups.
} 


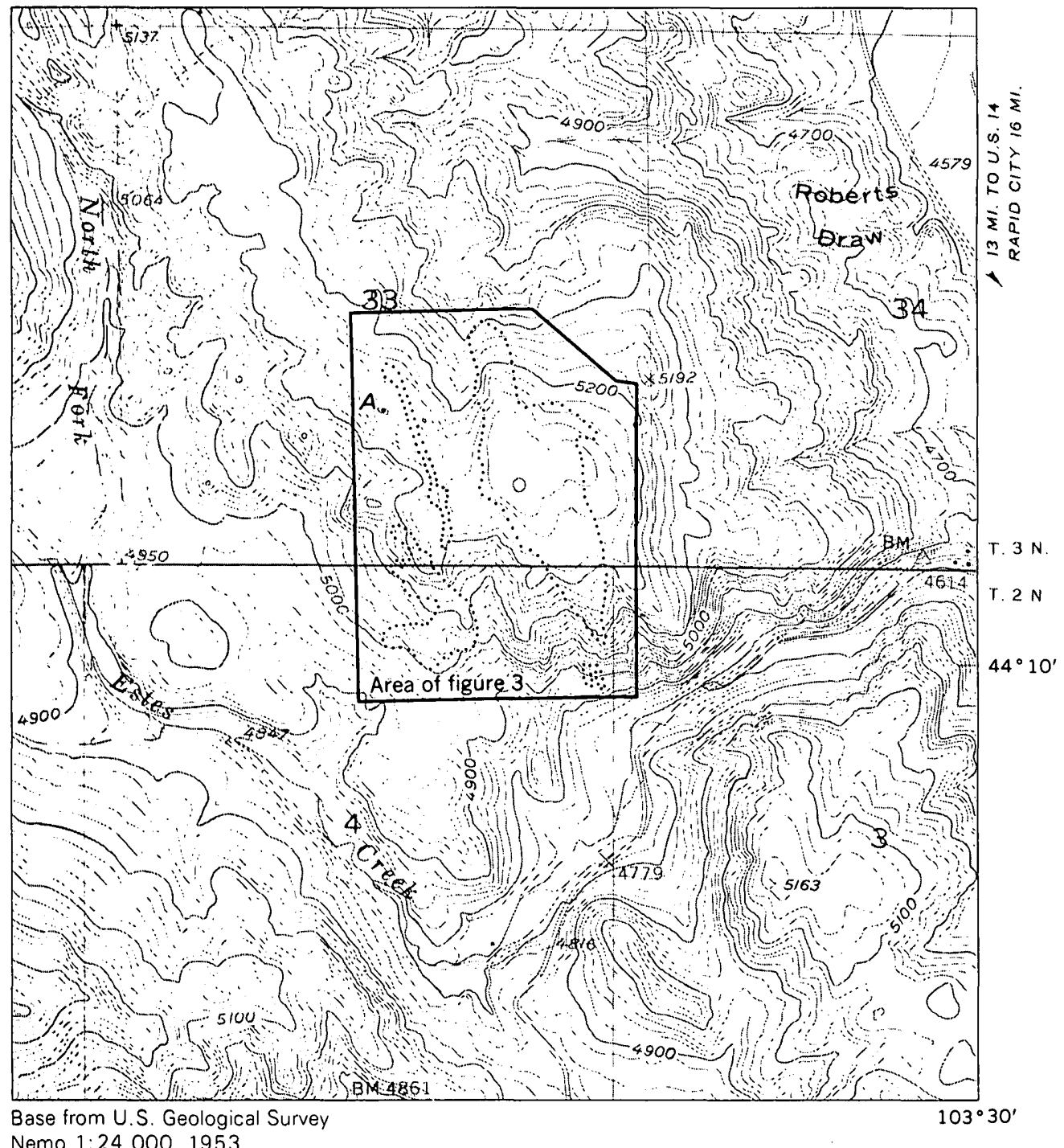

Nemo $1: 24.000 .1953$

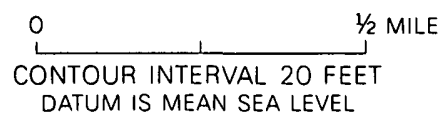

Fugure 4.-Map showing topography of the Estes Creek area. Dots outline areas underlain by iron-formation. Point $A$, origin of magnetic survey (see fig. 3 ).

be determined but must exceed several thousand feet. The iron-formation is a conspicuously banded reddishblack to silvery-gray rock. It is composed of approximately equal parts of thin layers of metachert and thin layers of specular hematite, magnetite, and quartz. The iron content is reported to be $29.6-37.2$ percent (Harrer, 1966).

Estes System of Runner (1934).-The Estes System, here revised to exclude the overlying limestone, is primarily a boulder conglomerate formation, which changes laterally, by interfingering, to three distinctly different facies : quartzite and quartz-mica schist, meta- arkose, and pebbly chlorite schist. The main body of the conglomerate and each of the several facies rest unconformably on the Nemo System at different places -each facies is basal in its own area-which probably indicates that the pre-Estes topography had considerable relief.

The conglomerate is composed mostly of pebbles and boulders derived from quartzite and iron-formation of the Nemo System. Quartzite cobbles a few inches in diameter are most common, but boulders a few feet in diameter occur near the base of the unit. The iron-formation pebbles tend to be concentrated in certain layers 
TABLE 1.-Summary of Nemo district statigraphy (Runner, 1934) and summary of Estes Creek area from present investigation

Lead System:

[Granite] 1

Amphibolite; basic intrusive. ${ }^{2}$

Garfield Formation; ferruginous quartzite.

Northwestern Formation; mica schist and phyllite.

Ellison Formation; slate and quartzite.

Homestake Formation; ferruginous carbonate rocks.

Poorman Formation; calcareous slate and limestone. ${ }^{3}$

POSSIBLE UNCONFORMITY

Estes System:

Very thick quartzite, slate. iron-formation, and arkose grit. Conglomerate, quartzite, [limestone ${ }^{3}$ and slate].

Nemo System:

UNCONFORMITY

Quartzites.

Some iron-formation.

1 This granite, belleved by Runner to be intrusive and the youngest Precambrian unit, is the granitic gneiss of Little Elk Canyon, referred to the Precambrian strata of this district. 'The reasoning behind the change in stratigraphic order has been reviewed by Zartman and Stern $(1967, p$. D159). In brief, no evidence of intrusion, such as dikes, crosscutting relationships, contact metamorphism, or the like, could be found. On the other hand, four different ines of evidence indicate that the gneiss is basement to Runner's Nemo System: (1) iron-formation, in the Nemo System which strikes parallel to the gneiss front, is succeeded away from the gneiss by conglomerates within the Estes System, this order indicating that the neiss lies stratigraphically below the Nemo 'System; (2) Runner's istes System includes abundant meta-arkose, which necessitates the and that both (U-Pb) a

in the conglomerate and at the base. One such basal concentration, mapped separately, rests on the main iron deposit in sections 33 and 4. This conglomerate lens is virtually pure iron-formation and, for practical purposes, should be considered a part of the iron deposit. The conglomerate matrix is predominantly quartzite except in the easternmost exposure where it is predominantly chlorite and other micaceous minerals. The northeasternmost exposures represent the pebbly chlorite schist facies. At a few localities, in sections 2 and 3 , there are thin lenses of banded cherty iron-formation within the Estes System.

The quartzite facies is interlayered with conglomerate in section 3 ; it is very thick and entirely quartzite in the west part of section 3 , but very thin and mostly quartz-mica schist in the NE1/4 sec. 4 . The quartzite is most commonly reddish brown, in beds $1-5$ feet thick. Obvious primary features such as ripple marks, and graded bedding, and, fortunately, crossbedding are lacking. If crossbedded, this quartzite could not be distinguished from the underlying Nemo quartzite. The interfingering of the quartzite with the conglomerate in section 3 is the only substantial clue to its relationship to the conglomerate.

The meta-arkose facies forms a broad northeast-
Metagabbro. ${ }^{2}$

(Not exposed in Estes Creek area).

Lead System of Runner (1934):

Limestone, ${ }^{3}$ conglomerate, schist, minor ironformation.

UNCONFORMITY

Metagabbro. ${ }^{2}$

Estes System of Runner (1934)

Conglomerate, quartzite, meta-arkose, schist, and minor iron-formation.

UNCONFORMITY

Nemo System of Runner (1934):

Quartzite, quartz-mica schist, and iron-formation.

$\mathrm{Rb}-\mathrm{Sr}$ age is only about 1.8 billion years, which probably means that the gneiss was metamorphosed at approximately the same time as the instrusion of the Harney Peak Granite in the southern Black Hills and the contemporaneous regional metamorphism 1.7 to 1.8 billion years ago (Zartman and Stern, 1967, p. D162)

There are apparently intrusive metagabbro bodies of two ages in the Estes Creek area, and the large bodies which have Invaded quartzite of the Nemo System in the northwest part of the map area are oldest. Pebbles and boulders of metagabbro occur in the conglomera te which lies adjacent to the metagabbro in the SW $1 / 4$ sec. 33. All other metagabbro odies belong to a swarm that is much younger than the limestone.

${ }^{3}$ The limestones of Runner's Poorman Formation and Estes System, so far as it is possible to tell from careful geologic mapping, are now units to represent the same stratigraphic unit and not two different and a r inot a part of the Lstes system. Whether or not the limestone not determinable.

trending belt in section 4 . The belt pinches off to the north; to the south, it bends, in a broad bow, eastward then northeastward, following the curvature of the conglomerate and quartzite. The meta-arkose is interbedded with quartzite and flanked by similar quartzite and quartz-mica schist in section 4 . In the south part of the bow, in section 10, it is interbedded with quartzite and conglomerate. Also in that section, the south edge of the meta-arkose rests on Nemo quartzite, and the meta-arkose belt is pierced by an irregular anticline of the same quartzite. Boulder conglomerates mark the base of the meta-arkose at the contact with the older quartzite of the latter anticline. The metaarkose is dark, nearly black; it is composed of coarse angular fragments of feldspar set in a matrix of quartz grains. The quartz grains are mostly millky blue and opalescent, and these characteristic grains are also found eastward in the main conglomerate facies of the Estes System. The meta-arkose also includes a few thin interbeds of black argillite which also extend into the conglomerate. Doubtless the feldspar clasts also occurred in the eastern conglomerate, but this is so thoroughly sheared and the matrix so thoroughly altered to micaceous minerals that the feldspar has never been observed. 
Limestone and conglomerate.-A limestone formation and its basal conglomerate rest unconformably on both the Nemo and Estes Systems. The basal conglomerate is exceedingly varied in composition and thickness from one place to another. In the southwest part of section 33, it rests on quartzite and ironformation and is composed mainly of highly magnetic iron-formation pebbles. The iron-formation between the older quartzite and the conglomerate is a thin bed of banded magnetite-quartz rock which may represent fine-grained debris from the underlying Nemo System iron-formation. On the south side of Estes Creek, in section 3, only a thin quartz-pebble conglomerate marks the base of the limestone; in section 34 most exposures show no conglomerate, but along one short stretch the basal limestone bed contains quartzite boulders as much as 3 feet in diameter. Slate and slaty conglomerate occur below the limestone in section 4, but do not continue on strike to the southeast.

The limestone itself is fairly uniform in appearance in most places. It is covered by a buff to brown weathering rind that can easily be recognized from a distance. However, the fresh rock is gray, fine grained, siliceous, and very hard. Acid tests indicate that some of it is dolomitic. Bedding planes are indistinct. A few beds of limestone-pebble conglomerate occur in this unit but not in the Estes Creek area. In two places, one in section 4 and one in section 34 , the unit is badly sheared and converted to white marble. The thickness of the formation is about 200 feet. The overlying rocks, shown only in the syncline in secs. 34 and 35, are fissile, gray, sericitic schist.

\section{STRUCTURE}

A workable tentative interpretation of the structure of the Estes Creek area is shown on figure 2. Broadly speaking, the general area is anticlinal. The anticlinal core reveals a structural complex involving folded Nemo and Estes rocks, which long predates the anticlino itself. To be more precise, the complex rests on the west flank of a basement gneiss anticline, which lies under Paleozoic rocks east of the Estes Creek area. The complex thus exposes the oldest sedimentary formations deposited on the gneiss, and these older formations, Rumner's (1934) Nemo and Estes Systems, show two periods of deformation that predate the deposition of the limestone of the Estes Creek area. The deformation after the limestone deposition reoriented most older structures and further complicated the general structure to the extent that much of the older record has been obliterated.

The oldest fold structures involve only the Nemo System. Refolding has largely obscured the nature of these old folds, but remnants of folds throughout the Nemo district suggest that the axial trend of the fold structures was northwesterly, roughly parallel to the present west edge of the underlying gneiss. The main iron-formation exposure, in the $\mathrm{SE} 1 / 4$ sec. 33 (fig. 2), appears to be the keel of a syncline which was downfolded into the quartzite well below the erosion surface upon which conglomerates of the Estes System lie. The other iron-formation exposures in sections 33 and 4, also appear to be parts of a syncline, but no satisfactory reconstruction seems possible. A northwest-trending septum of vertically dipping bedded quartzite lies between the two main exposures of ironformation and is assumed to be an anticline. The conclusion that the quartzite is older than the iron-formation, implicit in the above interpretation, is based on a district-wide analysis. Reference to figure 2 will show that the iron-formation beds are vertical and that the plunge of minor plications is about $75^{\circ} \mathrm{NW}$. For a syncline, this is a reversed plunge but is easily explained by slight rotation during a subsequent folding. Erosion of the Nemo System after folding resulted in a rough hill-and-basin foreland topography which gave rise to the overlying Estes System. Most of that system is probably fanglomerate and continental, but the finer grained facies, the quartzite, quartz-mica schist, chlorite schist, and meta-arkose, were deposited in a marine or lacustrine environment.

The second fold system involves both the Nemo and Estes Systems. The extent and magnitude of this folding is not at all clear. The great conglomerate reentrant in sections 33 and 34 would seem to be a syncline from this period; the flanking areas of Nemo quartzite and iron-formation are probably anticlines, but there is considerable uncertainty about this interpretation. However, the fact that the overlying limestone rests unconformably on the Nemo rocks and the Estes conglomerate indicates that it blanketed a diverse terrane, though, as indicated by the small amount of basal conglomerate beneath the limestone, not a very rough one. The most obvious effect of the post-Estes folding is the deformation of the post-Nemo erosion surface. This surface, where it crosses main iron deposits, must have warped down southeastward, thereby rotating the iron deposit en masse. The present attitude of the old surface is impossible to determine exactly because it is difficult to see any bedding in the coarse basal part of the conglomerate, but all beds away from the base are vertical or $\operatorname{dip} 75^{\circ}$ to $80^{\circ} \mathrm{N}$., and the elongated boulders in the conglomerate plunge about $80^{\circ} \mathrm{N}$.; thus, there is a strong indication that the erosion surface is overturned and dips north. This conclusion about the attitude of the post-Nemo erosion 
surface seems to be borne out by the magnetic survey (fig. 3), which shows a sharp truncation of the ironformation anomalies on the east side.

The third fold system involves the Nemo and Estes System and all younger Precambrian rocks, although only the basal part of the younger system, the limestone and so forth, can be seen in the Estes Creek area. Because this is the youngest Precambrian folding, the results are widespread over the region in the youngest rocks and consequently well documented, though not wholly understood. The late folding seems to have taken place in two distinct stages: (1) the production of very tight isoclinal folds with roughly a northwest trend, probably caused by a north-south compression, and (2) local refolding of the isoclinal folds by massive lateral translations between very large northwesttrending blocks, the movement of which apparently reflects a continuation of the original north-south compression. Several such zones of translation lie just beyond the west margin of the Estes Creek area; the closest one is probably in a heavily silicified belt just above the westernmost exposures of limestone; however, the location of that fault zone is uncertain in the latitude of the Estes Creek area. The faults to the west of the Estes Creek area are demonstrably right lateral, whereas some within the area, in the east, seem to have moved in the opposite sense.

The folded limestone of the Estes Creek area provides the only clues to the nature of the third folding. In general it seems that previous anticlines of old Nemo quartzite and the gneiss basement moved upward again, thus compressing further the synclines of Estes conglomerate and infolding the overlying limestone and conglomerate. Secondarily, continued compression, after maximum folding, caused differential movements between major blocks-left lateral east of the main quartzite block in sections 28 and 33 , and right lateral to the west of that block-which caused bending of the Estes rocks to the present oxbow configuration and refolding of the overlying infolded limestone. The present strong regional cleavage and north-plunging lineation relate to this last deformation and are unrelated to any previous deformation.

The faults shown on the Estes Creek area map have been inferred; none are actually exposed. Of principal interest is the fault zone which passes northwestward through sections $11,3,34$, and 28 . The dislocations in sections 2 and 11 suggest normal or lateral faulting. Limy quartzite breccia marks the southwest edge of the fault zone. The location of the fault in the south part of section 34 is uncertain, but it is thought to be continuous. Northwest of Nemo, in sections 27 and 28, the fault apparently turns abruptly east along the con- tact of an inverted arm of Nemo quartzite. This east segment of the fault appears to be a reverse fault or underthrust, with only north-plunging, talcose metagabbro exposed on the south side. Only two possible explanations for the peculiar behavior of this fault come to mind: (1) the fault changes from left lateral to a reverse or underthrust fault against a quartzite buttress which was a feature on the pre-Estes System topography; and (2) the quartzite arm and the fault were drag folded because of right-lateral movements between the Estes rocks and the gneiss basement to the east, the edge of which is represented at Nemo by the Nemo iron-formation and quartzite (?) which show offsets possibly caused by right-lateral faulting.

\section{QUANTITY AND QUALITY OF IRON-FORMATION}

The area underlain by iron-formation of the Nemo System is approximately $2,710,000$ square feet, $2,000,000$ square feet of which are in the area of the main, easternmost, iron-formation body in section 33 . When 10 cubic feet per short ton is used as a rule of thumb, the eastern deposit alone should produce 200,000 short tons of iron-formation for every foot of depth. Exploration by drilling is needed to determine the total recoverable tonnage. On the basis of the belief that the main deposit is synclinal and in consideration of the attitude of the beds and appearance of the magnetic survey, the minimum depth of the deposit is estimated to be about 1,000 feet. The total tonnage will probably prove too little to sustain a long term (30 years) beneficiation project; however, other nearby deposits, within 2 miles hauling distance (secs. 27 and 34), could easily provide iron-formation enough for a nominal project.

The chemical quality of the main iron-formation at Estes Creek is indicated by the following average of partial analyses by the U.S. Bureau of Mines (Harrer, 1966 , p. 44-45).

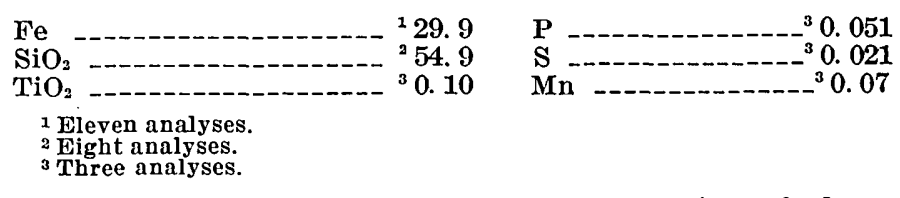

A spectrographic analysis of a composite of three of the samples shows: as much as 1.0 percent $\mathrm{Al}$; as much as 0.1 percent $\mathrm{Ca}, \mathrm{K}, \mathrm{Na}, \mathrm{Mg}, \mathrm{Ni}$, Se, and $\mathrm{Ti}$; as much as 0.01 percent $\mathrm{Ba}, \mathrm{Cr}, \mathrm{Cu}$, and $\mathrm{Zr}$; and as much as 0.001 percent $\mathrm{Ga}, \mathrm{Li}$, and $\mathrm{Rb}$.

\section{CONCENTRATABILITY}

The iron-formation is very fine grained, and the minerals are intricately interlocked but not more so than some iron-formation now being successfully beneficiated. Laboratory concentration tests carried out by 
the U.S. Bureau of Mines show that 85 percent of the minus 325-mesh heads may be concentrated satisfactorily by several methods. Of these, anionic flotation using locked batches resulted in a concentrate averaging 65 percent $\mathrm{Fe}$ and 4.9 percent silica, with a recovery of 89.5 percent of the $\mathrm{Fe}$; and Davis Tube magnetic separations on minus 325 -mesh heads, reduced by roasting, resulted in a concentrate containing 64.8 percent Fe and 9.8 percent silica with recovery of 98.2 percent of the Fe (Harrer, 1966, p. 80-81). The analysis of one concentrate indicates that the percentage of $P$ may be reduced fivefold as a result of the concentration. Weight distribution is about $40-45$ percent concentrate and 55-60 percent tailings. The minimal ratio, tons of heads to ton of concentrate, is 2.5 to 1 . The tests show only $a^{3}$ general amenability of the iron-formation to treatment. Harrer (1966, p. 84) concludes that the proof must await pilot-plant testing and design, which, among other important considerations, will determine economic feasibility.

\section{REFERENCES}

Bayley, R. W., and Meuhlberger, W. R., 1968, Basement rock map of the United States, exclusive of Alaska and Hawaii; U.S. Geol. Survey, 2 sheets, scale $1: 2,500,000$.

Harrer, C. M., 1968, Iron resources of South Dakota : U.S. Bur. Mines Inf. Circ. $8278,160 \mathrm{p}$.

Runner, J. J., 1934, Pre-Cambrian geology of the Nemo district, Black Hills, South Dakota: Am. Jour. Sci., 5th ser., v. 28, no. 167 , p. $353-372$.

Zartman, R. E., and Stern, T. W., 1967, Isotopic age and geologic relationships of the Little Elk Granite, northern Black Hills, South Dakota, in Geological Survey Research, 1967: U.S. Geol. Survey Prof. Paper 575-D, p. D157-D163. 


\title{
HIGH-CALCIUM LIMESTONE DEPOSITS IN LANCASTER COUNTY, SOUTHEASTERN PENNSYLVANIA
}

\author{
By ALBERT E. BECHER and HAROLD MEISLER, \\ Harrisburg, Pa., Trenton, N.J.
}

Work done in cooperation with the Pennsylvania Geological Survey

\begin{abstract}
Geologic mapping in the Lititz $71 / 2$-minute quadrangle, Lancaster County, revealed the presence of the Annville Limestone in the Piedmont province of southeastern Pennsylvania. The Annville is a commercially valuable high-calcium limestone that was reported previously only in the Great Valley of the Valley and Ridge province. Chemical analyses of composite samples from each of four stations in the Lititz quadrangle indicate that the $\mathrm{CaCO}_{3}$ content ranges from 94.2 to 96.5 percent, the $\mathrm{MgCO}_{3}$ content ranges from 1.3 to 3.7 percent, and the silica-alumina content is less than 2 percent. These analyses indicate that the Annville Limestone is a potential source of high-calcium limestone in the Lititz $71 \frac{1}{2}$-minute quadrangle.
\end{abstract}

During a hydrogeologic study in southeastern Pennsylvania (Meisler and Becher, 1966, 1969), a limestone unit was mapped that seemed to have an unusually high calcite content. The unit was correlated with the Annville Limestone of Ordovician age described by Gray (1951) and Prouty (1959) in that part of the Great Valley that lies in Dauphin, Lebanon, and Berks Counties. In the Great Valley, the Annville is quarried for high-calcium limestone. The areal extent of the Lancaster County deposits (as indicated by surface exposures of the Annville) and their apparent purity suggested that they might be of commercial value. Therefore, samples were collected and submitted for chemical analysis.

Commercially valuable limestone used in the manufacture of high-calcium products should contain at least 97 percent calcium carbonate and no more than 3 percent silica and alumina (Swain, 1946). High-calcium limestone is used mostly for metallurgical lime and flux stone in the iron and steel industry, chemical lime in the chemical industry and in the production of paper, and for other uses in agriculture and construction.

\section{GEOLOGIC SETTING}

Exposures of the Annville Limestone in the Conestoga Valley of the Piedmont physiographic province occur in the northeastern part of the Lititz 71/2-minute quadrangle in Lancaster County (fig. 1). The Annville Limestone, of Middle Ordovician age, occurs near the top of a thick stratigraphic sequence of carbonate rocks of Cambrian and Ordovician age described by Meisler and Becher (1968). It lies between the older Ontelaunee Formation, a dolomite unit, and the younger Myerstown Limestone. Outcrops of the Annville occur on each flank of a large eastward-plunging anticline that is overturned, past recumbency, to the north. The northern outcrop of Annville (fig. 1), in the normal limb of the fold, strikes northeastward and dips steeply northwestward, whereas the southern outcrop of Annville, in the overturned limb of the fold, strikes northwestward and dips gently to moderately northeastward. The estimated maximum stratigraphic thickness of the Annville is about 200 feet.

\section{DESCRIPTION OF SAMPLE STATIONS}

Rock samples were collected from all major exposures of the Annville Limestone in the Lititz quadrangle. The location of the sample stations are shown in figure 1. Stations 1885 and 1889 are small abandoned quarries in which about 60 feet and 20 feet, respectively, of section is exposed. Limestone was formerly extracted from these quarries and burned by local farmers for agricultural lime. About 25 feet of the Annville Limestone section is exposed at station 

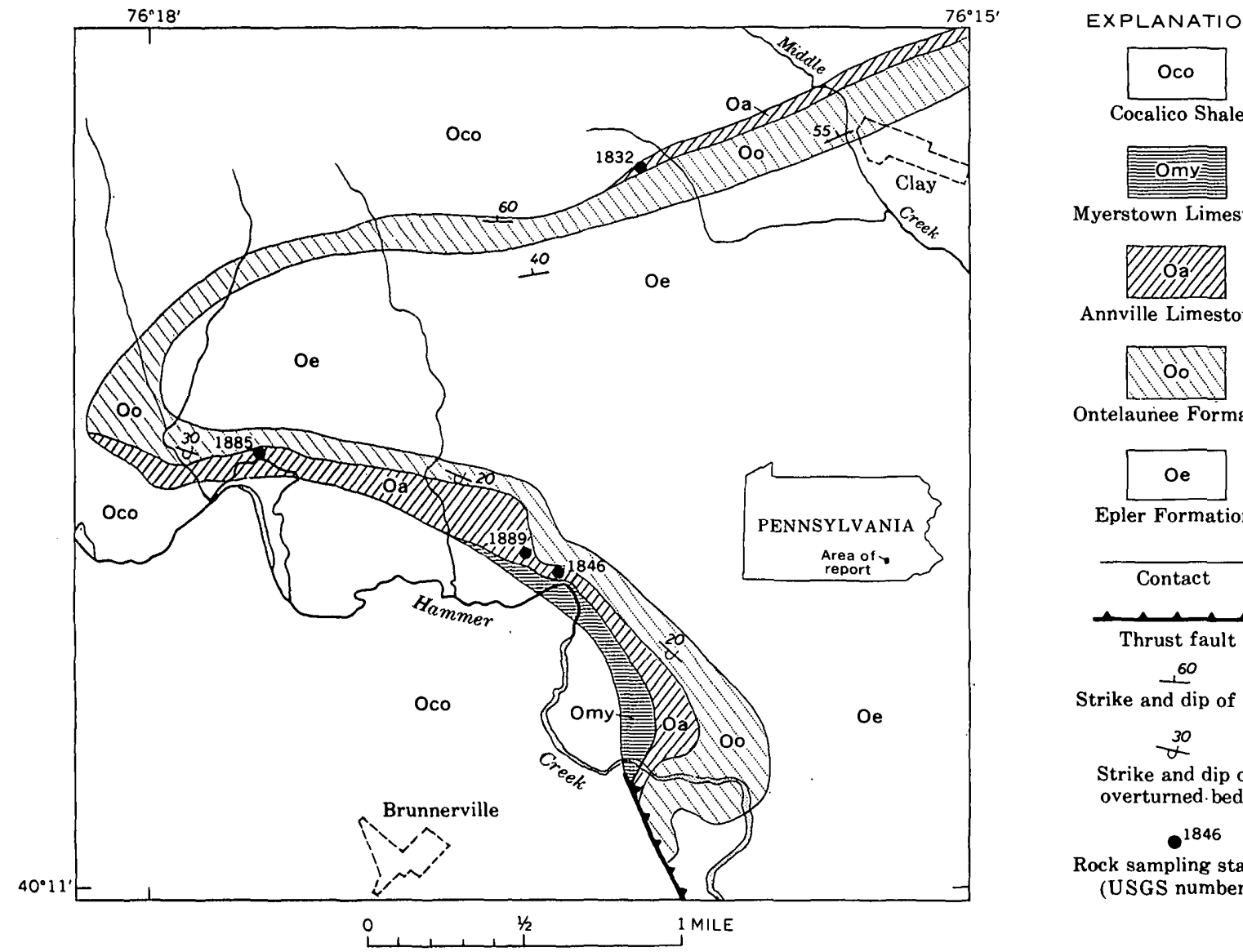

Myerstown Limestone

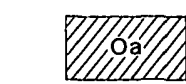

Annville Limestone

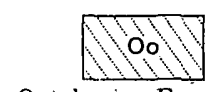

Ontelaunee Formation

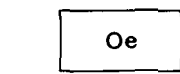

Epler Formation

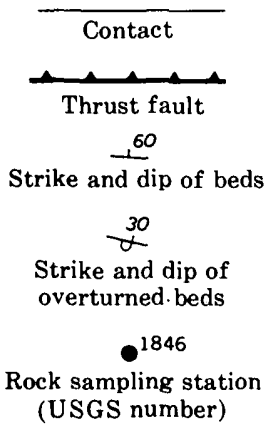

Frgure 1.--Generalized geologic map of part of the Lititz 71/2-minute quadrangle, Pennsylvania, showing the Aunville Limestone sample stations.

1832. About 15 feet of section is exposed in discontinuous hillside outcrops at station 1846. The stratigraphic section of station 1885 is representative of the formation in the Lititz quadrangle and its description follows:

Section of the Annville Limestone at station 1885

$$
\text { Dcscription }
$$

Thickness $\underline{(f e e t)}$

Limestone, medium-dark-gray to dark-gray and darkgray, very finely crystalline; weathers light gray to medium gray and light olive gray to medium gray; parting into 1- to 2.5 -foot layers; upper 0.5 foot lamlnated

Limestone, light-gray, medium-gray, and medium-darkgray, rery finely crystalline; weathers light gray to medium gray; massive; well laminated; some lightgray distupted laminae as much as 0.25 -inch thick; laminae weather out into ribs in upper 2 feet

Limestone, light-gray, medium-gray, and medium-darkgray, very finely crystalline; weathers light gray to medium gray; parting into 1.5 - to 10-inch layers; well laminated; beds isoclinally folded.
Limestone, medium-dark-gray and medium-dark-gray to dark gray, very finely crystalline; veathers medium light gray and medium gray; massive; laminae weather into ribs on some beds; moderately folded; calcite veins -...--

Limestone, medium-dark-gray, very finely crystalline; weathers medium light gray and medium gray; parting into 2- to 7-inch layers; laminated; laminae weather fluted or ribbed on some beds; silty laminae as much as 0.5-inch thick in upper 0.5 foot; moder-

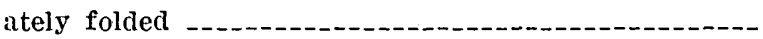

Limestone, light-gray, medium-gray, and medium-darkgray, very finely crystalline; weathers light gray, medium gray, and very light gray to pale orange; laminated; fluted and ribbed on some weathered surfaces. 12.5

Total $57 . \overline{5-61.5}$

\section{SAMPLE COLLECTION, PREPARATION, AND ANALYSIS}

Random samples, each containing from 4 to 13 rock 6 specimens, were collected at each station by Paul R. Seaber, U.S. Geological Survey. All specimens from each station were combined, crushed, ground, and split by personnel of the Pennsylvania Geological Survey. 
Each of the four samples was analyzed to determine its chemical composition. The nonvolatile oxides were determined by spectrographic analysis. Total volatiles and $\mathrm{H}_{2} \mathrm{O}$ fractions were gravimetrically determined. The remaining components were volumetrically determined. The results of these analyses are shown in table 1 , and determination of the calcium and magnesium carbonates as calculated from their respective oxides are shown in table 2. Trace amounts of barium, titanium, sodium, strontium, and manganese were found in all samples.

TABLE 1.-Analyses, in weight percent, of samples from the Annville Limestone

[Tr., trace]

\begin{tabular}{|c|c|c|c|c|}
\hline & \multicolumn{4}{|c|}{ Station } \\
\hline & 1832 & 1546 & 1885 & 1889 \\
\hline $\mathrm{SiO}_{2-}$ & 1. 00 & 1. 06 & 0.72 & 1. 12 \\
\hline $\mathrm{Fe}_{2} \mathrm{O}_{3}$ & 12 & .12 & .09 & .10 \\
\hline $\mathrm{FeO}$. & Tr. & Tr. & Tr. & $\mathrm{Tr}$ \\
\hline $\mathrm{P}_{2} \mathrm{O}_{5}$. & & .01 & .02 & \\
\hline $\mathrm{Al}_{2} \mathrm{O}_{3}$. & & .97 & .53 & 91 \\
\hline $\mathrm{CaO}$. & 54.01 & 52.76 & 54.06 & 54.01 \\
\hline $\mathrm{MgO}_{--}$ & .81 & 1. 77 & .63 & .64 \\
\hline S (total) . & & .04 & & \\
\hline $\mathrm{CO}_{2} \ldots \ldots$ & 42.78 & 43. 00 & 43. 06 & 42.94 \\
\hline C (organic) & & .30 & & \\
\hline $\mathrm{H}_{2} \mathrm{O} \cdots \ldots$ & & 07 & 07 & \\
\hline $\mathrm{H}_{2} \mathrm{O}+\ldots$ & 59 & 13 & & 16 \\
\hline $\begin{array}{l}\text { Loss on ignition }\left(\mathrm{N}_{2} \text { atmos- }\right. \\
\left.\text { phere at } 1,000^{\circ} \mathrm{C}\right) \text {. }\end{array}$ & 43.11 & 43.33 & 43.63 & 43. 03 \\
\hline
\end{tabular}

TABLE 2.-Calculation of the calcium and magnesium oxides as carbonates, in weight percent, of samples from the Annville Limestone

Station

1832

1846

1885

1889

$$
\begin{aligned}
& \mathrm{C} \\
& \hline 96 \\
& 9 \\
& 9
\end{aligned}
$$$$
\begin{aligned}
& \mathrm{CaCO} \\
& 96 . \\
& 94 . \\
& 96 .
\end{aligned}
$$

$\underline{\mathrm{MgCO}_{3}}$

1. 7

3. 7

1. 3

1. 3

\section{CONCLUSIONS}

Analyses of the composite samples from the Annville Limestone indicate an average $\mathrm{CaCO}_{3}$ content very close to the desired composition of commercial grade high-calcium limestone. The samples from stations 1832,1885 , and 1889 contain almost identical amounts of $\mathrm{CaCO}_{3}$, suggesting that the Annville has a $\mathrm{CaCO}_{3}$ composition that is relatively constant throughout the section. Samples from station 1846 were collected from outcrops very close to dolomite beds belonging to the underlying Ontelaunee Formation. It is possible that a specimen from the Ontelaunee was inadvertently included in the sample, thereby reducing the apparent $\mathrm{CaCO}_{3}$ content of the limestone. The compositions of the composite samples indicate that the Annville is a potential source of high-calcium limestone.

\section{REFERENCES}

Gray, Carlyle, 1951, Preliminary report on certain limestones and dolomites of Berks County, Pennsylvania : Pennsylvania Geol. Survey, 4th ser., Prog. Rept. 136, 85 p.

Meisler, Harold, and Becher, A. E., 1966, Hydrology of the carbonate rocks of the Lancaster 15-minute quadrangle, Pennsyltania : Pennsylvania Geol. Survey, 4th ser., Prog. Rept. 171, 36 p.

1968, Carbonate rocks of Cambrian and Ordovician age in the Lancaster quadrangle, Pennsylvania : U.S. Geol. Survey Bull. 1254-G, $14 \mathrm{p}$.

- 1969, Hydrogeology of the carbonate rocks of the Lancaster 15-minute quadrangle, southeastern Pennsylvania: Pennsylvania Geol. Survey, 4th ser., Bull. W-26. [In press]

Prouty, C. E., 1959, The Annville, Myerstown, and Hershey Formations of Pennsylvania: Pennsylvania Geol. Survey, 4th ser., Bull. G-31, 47 p.

Swain, F. M., 1946, Geology and economic aspects of the more important high-calcium limestone deposits in Pennsylvania : Pennsylvania State Coll. Mineral Industries Expt. Sta. Bull. 43, 29 p. 


\title{
GEOLOGY AND MINERAL POTENTIAL OF THE ADOBE RANGE, ELKO HILLS, AND ADJACENT AREAS, ELKO COUNTY, NEVADA
}

\author{
By KEITH B. KETNER, Denver, Colo.
}

\begin{abstract}
A.bstract.-Ordovician to Triassic sedimentary rocks in the Adobe Range and neighboring hills are tightly folded and broken by thrust faults. At least one episode of thrusting is of Paleozoic nge. The folding and a younger episode of thrusting took place in Mesozoic or very early Tertiary time. Although Paleozoic rocks have been intruded by two sizable stocks, metallic inineral deposits like those commonly associated with similar stocks in other parts of Nevada have not yet been found. Rocks adjacent to thrust faults and some steep faults are silicified and iron stained. Some of these altered rocks are slightly enriched in lead and yinc. The Permian System contains many weakly phosphatic beds and a few beds of moderately rich phosphate rock. The lower part of the 'Tertiary sequence includes extensive beds of oil shale similar to the well-known occurrence on the south edge of Dlko.
\end{abstract}

Reconnaissance mapping of central Elko County was begun in 1966 in an effort to assess the mineral potential of the area as part of the U.S. Geological Survey's heavy-metals program. In particular, stratigraphic and structural conditions similar to those of the Carlin mine area (Hardie, 1966), Cortez (Gilluly and Masursky, 1965), and the Gold Acres mine (Ketner, 1965) were sought. Similar conditions found in the Swales Mountain area have been described (Ketner and others, 1968).

The present report outlines the geology of a large part of central Elko County adjacent to the Swales Mountain area (figs. 1, 2). J. G. Evans assisted in mapping the Elko Hills and Peko Hills. Geochemical tests for metals were made under the direction of $\mathbf{A}$. P. Marranzino, and $\mathrm{P}_{2} \mathrm{O}_{5}$ analyses were made by G. D. Shipley. Helpful paleontologic data, to be discussed in a later report, were provided by a large number of paleontologists.

\section{STRATIGRAPHY}

Oldest rocks exposed in the area are a complexly faulted sequence known as western-facies rocks because they are thought to have been carried on thrust faults from a more westerly site of deposition. They are com-

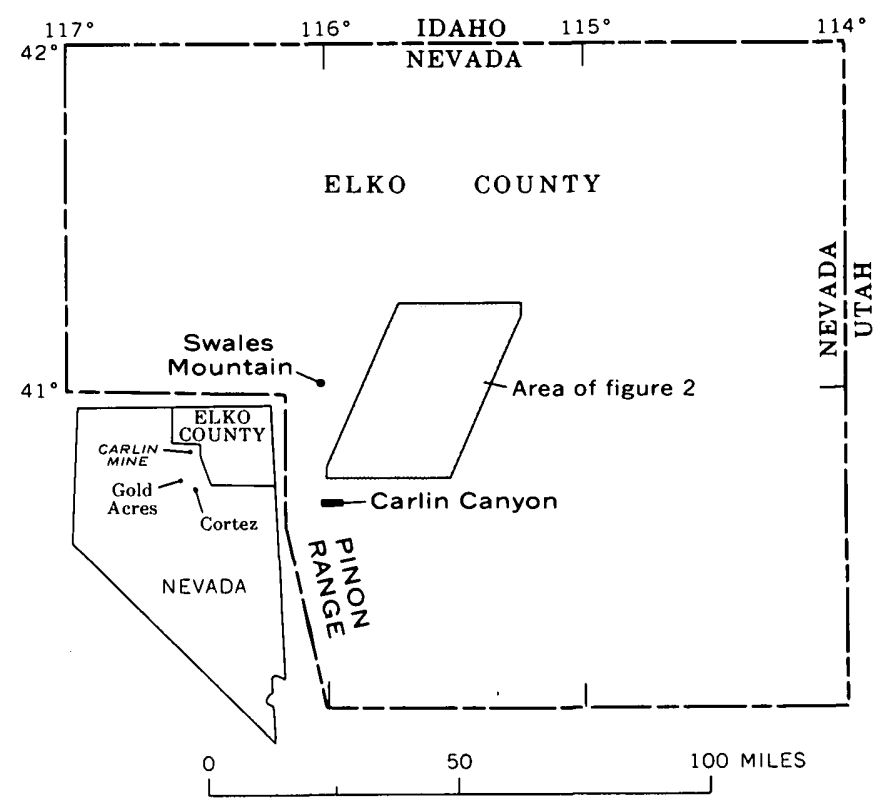

Figure 1.-Index map of Elko County, Nev., showing localities referred to in text and the area of figure 2 .

posed principally of chert, shale, siltstone, and limestone. The normal stratigraphic sequence and thickness of these beds cannot be determined owing to their complex structure, but the sequence ranges in age from Early Ordovician to Late Devonian.

The next younger rocks are assigned to the Chainman Shale. Exposures of the Chainman in the neighboring Pinon Range (fig. 1) were recently described by Smith and Ketner (1968). In the area of the present report the Chainman is composed largely of chertgrain sandstone and black siliceous shale. Its thickness, estimated from the width and attitude of the outcrop, is at least 5,000 feet; and its age, according to correlation with dated beds of similar lithology in the Pinon Range, is Mississippian.

The Diamond Peak Formation, which conformably 


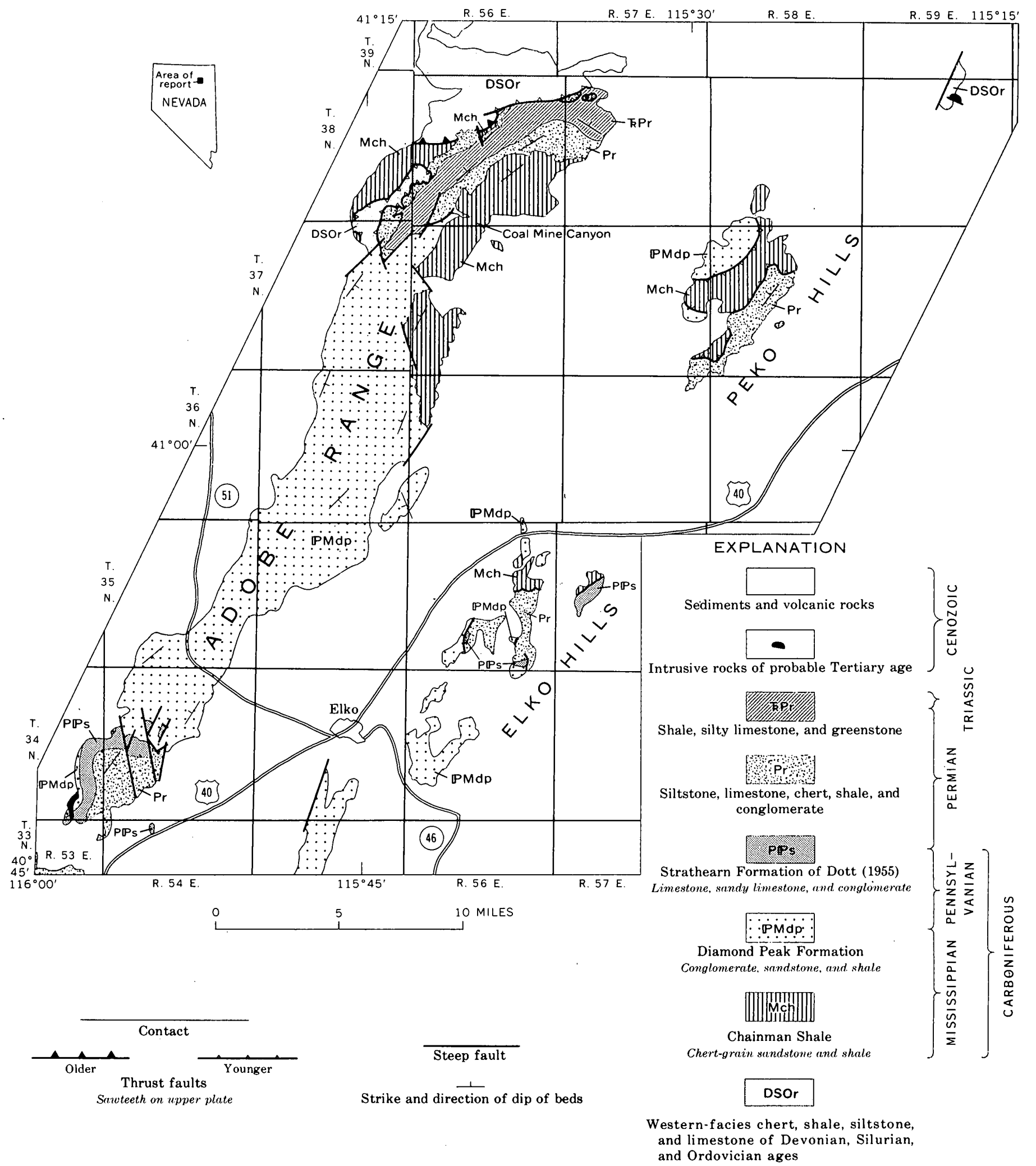

Frgure 2.-Geologic sketch map of the Adobe Range, Peko Hills, and Elko Hills, Elko County, Nev. Geology by K. B. Ketner and J. G. Evans, 1966-69. 
overlies the Chainman Shale, is composed almost entirely of conglomerate but contains some thin red beds, black shale, sandstone, and limestone. Pebbles and larger particles in the conglomerate are composed mainly of chert and quartzite and are about 1 foot in maximum diameter. The conglomerate is composed entirely of material derived from western-facies rocks. The contact with the Chainman Shale is conformable and abrupt. The thickness of the Diamond Peak is estimated to be 5,000 feet or more, and its age, determined from marine fossils, is Mississippian and Pennsylvanian.

The Strathearn Formation of Dott (1955) unconformably overlies the Diamond Peak Formation. Exposures of the Strathearn in the southern Adobe Range and in the Elko Hills are similar to those in the Carlin Canyon area which were fully described by Dott. The formation consists mostly of limestone, but locally contains sandy, conglomeratic, and cherty beds. The Strathearn is estimated to be about 1,200 feet thick. Its age is Late Pennsylvanian and Early Permian.

An unnamed sequence of Permian age overlies the Strathearn Formation. In the Carlin Canyon area this sequence was divided into three formations by T. G. Fails (1960). These proposed formations are not accepted in the present report because, owing to lateral changes in lithology, they could not be certainly identified beyond their type areas. The unnamed Permian sequence is composed principally of siltstone, limestone, chert, shale, and conglomerate. Nearly all beds in the upper half of this unit are abnormally phosphatic, and the phosphate resembles that of the Phosphoria Formation. This sequence lies conformably on the Strathearn Formation in the southern part of the area of this report but is more extensive than the Strathearn, and extends northward, overlapping Mississippian rocks in the northern Adobe Range. The age of the sequence is Early to Late Permian. Among the many fossil collections on which this age designation is based are two collections of the bivalve Atomodesma, rarely recorded from North America. In the southern Adobe Range, where the sequence is thickest, it is estimated to be at least 5,000 feet thick.

Overlying this sequence of Permian rocks in the northern Adobe Range is an unnamed formation resembling, in some respects, the Dinwoody Formation of southern Idaho. It is composed largely of soft dark shale that weathers greenish gray; platy, silty limestone; and a small amount of greenstone. The internal stratigraphic sequence of these lithic types has not been determined owing to complex structure and poor exposures. Its age, as determined from collections of brachiopods and ammonoids, is Late Permian and Early Triassic.

Overlying all older rocks with profound unconformity is a sequence of rocks probably entirely of Cenozoic age. In the northern Adobe Range, where it is best exposed, the basal unit is composed of very coarse conglomerate similar in appearance to the Diamond Peak Formation but much more coarse and containing boulders of conglomerate and sandstone derived from the Chainman and Diamond Peak Formations. Above the boulder conglomerate is a sequence several hundred feet thick of sandstone, limestone, and oil shale. The upper part of the Cenozoic sequence is composed of ash deposits, lava flows, and alluvial sand and gravel.

Two bodies of intrusive rock are exposed in the area of this report. One, a coarse-grained quartz monzonite, intruded shale of Ordovician age (fig. $2 ;$ T. 38 N., R. 59 E.). The other, a quartz porphyry, intruded the Diamond Peak and Strathearn Formations (fig. 2; T. 34 N., R. 53 E.). The ages of these intrusives are as yet unknown.

\section{STRUCTURE}

Structural relations in the area of this report indicate two episodes of thrust faulting and a period of folding. The oldest thrust exposed in the area carried Ordovician, Silurian, and Devonian rocks over the Mississippian Chainman Shale. Overlap of this fault by Permian rocks proves a Paleozoic age.

In a second stage of deformation, Paleozoic and Mesozoic rocks were compressed into northeast-trending folds. The best developed of these folds is a syncline that can be traced along the entire length of the Adobe Range.

Relatively young thrusts carried rocks ranging in age from Ordovician to Permian over the previously folded Permian and Permian to Triassic sequences. These thrusts probably resulted from a continuation of the forces that produced the Adobe Range syncline. This episode of folding and thrusting is clearly of post-Early Triassic age and represents forces acting from the northwest toward the southeast.

\section{MINERAL POTENTIAL AND SUGGESTIONS FOR PROSPECTING}

Although ore deposits in the region are commonly associated with stocks of acidic rocks, no minerals of economic importance were found in or near the two stocks exposed in the area of this report. However, aeromagnetic lines (U.S. Geol. Survey, 1967a, b) in the vicinity of one of them (T. 34 N., R. 53 E.) indicate the exposed part of this intrusive to be part of a much larger intrusive that extends westward from the 
outcrop under a cover of Tertiary sediments. The concealed part of this intrusive and associated rocks should be further investigated by geophysical methods and drilling.

Belts of silicified, iron-stained rock extend along some thrust faults in the northern Adobe Range ( $T$. 38 N., R. 56 E.), in the Peko Hills (T. 37 N., Rs. 57, 58 E.), and along steep faults in the Elko Hills (T. 35 N., R. 56 E.). Some of these bands of altered rock are slightly mineralized. Spectrographic analyses of 100 samples of altered rock along thrusts in the Adobe Range indicated that there has been some enrichment in lead and zinc. However, the silver content of these samples averaged less than 1 part per million (ppm), and the gold content, determined by atomic absorption, averaged less than $0.02 \mathrm{ppm}$. Additional geochemical prospecting of these zones is warranted.

In the southern Adobe Range (secs. 3, 5, 8, and 10, T. 34 N., R. 54 E.), parts of the Diamond Peak Formation seem to be somewhat mineralized. Altered material from this area is slightly enriched in copper and silver. Although aeromagnetic lines give no indication of a concealed intrusive there and alteration is not intense, further geochemical prospecting is advisable in this area.

Permian rocks in the southern and northern Adobe Range and in the Peko Hills are significantly phosphatic. Outcrops of chert, siltstone, and limestone in these areas contain small percentages of phosphate, and concealed thin beds of very phosphatic rock are indicated by loose pieces scattered on the surface. Analyzed selected samples from the southern Adobe Range contained as much as 13 percent $\mathrm{P}_{2} \mathrm{O}_{5}$, and some samples from the Peko Hills contained about 20 percent. Because the richly phosphatic beds fail to crop out, their extent and thickness can be determined only after exploratory trenching in areas where loose pieces are found.

Oil shale in the Tertiary deposits is exposed in places along the east side of the Adobe Range and around the Elko Hills. The "coal mine" for which Coal Mine Canyon is named was a prospect opening in an exposure of oil shale about a quarter of a mile north of the Coal Mine Canyon road at the east edge of the Adobe Range (T. 38 N., R. 56 E.; see King, 1876 , map IV). Because oil shale quickly disintegrates on exposure to air, outcrops are scarce and exploration is best done by trenching where loose pieces of oil shale or associated rocks are found at the surface. These have been found in the area of this report among the Elko Hills and along the east edge of the Adobe Range. Exposures of oil shale along the east edge of the Pinon Range (fig. 1) (J. Fred Smith, Jr., and Ketner, unpub. data) indicate a total north-south extent of at least 45 miles. It is very likely that the shale underlies nearly all the major valleys in the area of this report, but in most places the shale is deeply buried, approaching the surface only near the hills and mountain ranges.

\section{REFERENCES}

Dott, R. H., Jr., 1955, Pennsylvanian stratigraphy of Elko and northern Diamond Ranges, northeastern Nevada: Am. Assoc. Petroleum Geologists Bull., v. 39, no. 11, p. 2211-2305.

Fails, T. G., 1960, Permian stratigraphy at Carlin Canyon, Nevada: Am. Assoc. Petroleum Geologists Bull., v. 44, no. 10, p. 1692-1703.

Gilluly, James, and Masursky, Harold, 1965, Geology of the Cortez quadrangle, Nerada, with a section on Gravity and aeromagnetic surveys, by D. R. Mabey: U.S. Geol. Survey Bull. 1175, $117 \mathrm{p}$.

Hardie, B. S., 1966, Carlin gold mine, Lynn district, Nevada: Nevada Bur. Mines Rept. 13, pt. A, p. 73-83.

Ketner, K. B., 1965, Economic geology, in Gilluly, James, and Gates, Olcott, Tectonic and igneous geology of the northern Shoshone Range, Nevada: U.S. Geol. Survey Prof. Paper 465, p. 129-144.

Ketner, K. B., Evans, J. G., and Hessin, T. D., 1968, Geochemical anomalies in the Swales Mountain area, Elko County, Nevada: U.S. Geol. Survey Circ. 588, 13 p.

King, Clarence, 1876, Geological and topographical atlas accompanying the report of the geological exploration of the fortieth parallel: U.S. Geol. Explor. 40th Parallel.

Smith, J. F., Jr., and Ketner, K. B., 1968, Devonian and Mississippian rocks and the date of the Roberts Mountains thrust in the Carlin-Pinon Range area, Nevada: U.S. Geol. Survey Bull. 1251-I, p. I1-I18.

U.S. Geological Survey, 1967a, Aeromagnetic map of the Dixie Flats and Elko 2 quadrangles, Elko County, Nevada, scale $1: 62,500$ : U.S. Geol. Survey open-file report.

1967b, Aeromagnetic map of the Palisade 1 and Palisade 2 quadrangles, Eureka and Elko Counties, Nevada, scale $1: 62,500$ : U.S. Geol. Survey open-file report. 
GEOLOGICAL SURVEY RESEARCH 1970

\title{
EARLY PERMIAN PLANTS FROM THE CUTLER FORMATION IN MONUMENT VALLEY, UTAH
}

\author{
By SERGIUS H. MAMAY and WILLIAM J. BREED, ${ }^{1}$ \\ Washington, D.C., Flagstaff, Ariz.
}

\begin{abstract}
A small assemblage of fossil plants was found in the Organ Rock Tongue of the Cutler Formation in Monument Valley, Utah. This florn is related to that of the Hermit Shale of Arizona, through the presence of Supaia rigida White; the Utah assemblage represents the most northerly known occurrence of the Supaia flora. Presence of the genus Protoblechnum Lesquereux in the florn ( $P$. bradyi, n. sp.) suggests Asiatic relationships for the Cutler flora.
\end{abstract}

Although the Permian red beds of the southwestern United States are generally poor in plant fossils, our knowledge of the Permian floras of that area increases steadily. Paleobotanical assemblages have recently been reported from several important Permian units, particularly in north-central Texas (see Mamay, 1967, p. C120). A significant picture of floristic diversity emerges from these assemblages, lending the impression of rapid botanical evolution during Early Permian time. Thus it is important that each newly discovered assemblage, no matter how limited taxonomically, be reported promptly and interpreted in terms of its relationships to the others.

The Cutler Formation is a thick sequence of predominantly red Permian shales, sandstones, and siltstones that are exposed in large parts of the Four Corners area of Colorado, Utah, Arizona, and New Mexico. These sediments are mainly regarded as continental deposits, and as such, they represent the physical remains of the environment of a considerable segment of the Permian terrestrial biota of the United States. However, fossils are disappointingly scarce in the Cutler Formation, and the only substantial paleontological information derived from these beds chiefly involves vertebrates. Langston's (1953) study of Permian amphibians from New Mexico included several forms from the Cutler Formation. Lewis and Vaughn

\footnotetext{
${ }^{1}$ Muscum of Northern Arizonn, Flngstaff, Ariz.
}

(1965) summarized the history of fossil vertebrate discoveries in the Cutler Formation and described a tetrapod fauna consisting of nine genera from the Cutler Formation of Colorado.

Paleobotanical records from the Cutler Formation have been even less satisfactory, for to the best of our knowledge, only three occurrences of fossil plants have been reported from that formation, and only one from Utah. Baker (1933, p. 33) reported two specimens of Pecopteris tenuinervis? from the lower part of the Cutler Formation in Indian Creek Valley, San Juan County, Utah. Baker (1936, p. 35) also reported Walchia piniformis and Yakia heterophylla in the Organ Rock Tongue of the Cutler Formation from Copper Canyon, Ariz.; all of Baker's specimens were identified by David White. Langston $(1953$, p. 358, 410) reported a florule from the Cutler Formation in northern New Mexico, in association with amphibian remains. Identified by W. C. Darrah, the florule contained Pecopteris arborescens, $P$. bredovi, Odontopteris genuina, Taeniopteris sp., Daubreeia sp., Calamites, Lobatannularia sp., Dicranophyllum or Cordaites, and Cardiocarpus (?). None of the foregoing plants was either described or illustrated.

\section{SOURCE OF MATERIAL}

The material upon which this report is based consists of eight specimens collected from the Organ Rock Tongue of the Cutler Formation in Monument Valley, San Juan County, Utah. The specimens were uncovered in 1963, during the course of excavation for the construction of the Seventh-Day Adventist Monument Valley Mission and Hospital. The fossils were collected by $\mathrm{Mr}$. Daniel Walter, of the hospital, and Mr. Harry Goulding, of Goulding's Trading Post. Mr. Goulding subsequently loaned the specimens to the late Major L. F. 
Brady, of the Museum of Northern Arizona. Major Brady prepared the specimens, which are now on deposit in the Museum of Northern Arizona.

The stratigraphic position of the fossiliferous beds was determined by Breed, who in February 1967, measured a stratigraphic section near the hospital site. The section and geographic references follow; the fossils originated from unit 3 of this section.

Stratigraphic section in Clay Hills $4 \mathrm{SW}$ quadrangle, Utah, sec. 36, T. 43 S., R. 15 E., 1/4 mile northwest of Goulding's Trading Post at eastern tip of Oljeto Mesa

\section{Permian}

Cutler Formation (part) :

De Chelly Sandstone Member (part):

11. Sandstone, light-brown $(5 Y R 6 / 4)$, very fine grained, well-sorted; composed of subangular stained quartz; well cemented, siliceous ; highto low-angle, large-scale to very large scale cross beds ; forms cliff ; base is gradational._-

Organ Rock Tongue (part) :

10. Siltstone, grayish-red (10R 4/2); fair sorting; stained quartz; well cemented, argillaceous; thick bedded ( $1-4 \mathrm{ft})$; some shaly partings; forms cliff; base is sharp and flat.

9. Silty sandstone, moderate-reddish-brown (10R $4 / 6$ ) ; silt to fine-grained sand ; poorly sorted; composed of subangular, stained quartz; firmly cemented, calcareous and argillaceous; splits shaly; flat, thin bedded; forms slope; base is gradational.

8. Conglomerate, same as unit 4........-...

7. Siltstone, moderate-reddish-brown (10R 4/4); fair sorting; composed of subangular stained quartz; weakly cemented, argillaceous and slightly calcareous; thin bedded; weathers hackly ; forms slope.

6. Siltstone, moderate-reddish-brown (10R 4/4), poorly sorted, weakly cemented, argillaceous, flat, thick-bedded, massive; some bleached zones; weathers massive to blocky; forms ledge -.-....--

5. Siltstone, moderate-reddish-brown (10R 4/4), flat, thin-bedded; weathers hackly; forms slope

4. Conglomerate; similar to unit 2 ; interbedded with siltstone; moderate-reddish-brown ( $10 R$ 4/4) ; small-scale crossbedding; thin-bedded; cement slightly calcareous; contains plant fragments ; forms cliff

3. Siltstone, moderate-reddish-brown (10R 4/4), flat, medium-bedded; weathers rounded; some bleached zones; cement slightly calcareous; contains plant material; forms slope

2 . Conglomerate; matrix, very pale orange $(10 Y R$ $8 / 2$ ) limestone, and moderate-reddish-brown (10YR 4/4) siltstone; pebbles, mainly siltstone and limestone; forms cliff
1. Siltstone, moderate-reddish-brown (10R 4/4); massive, with bleached spots; cement slightly calcareous; forms alternate slopes (90 percent) and ledges (10 percent); base is concealed 55.50

Incomplete thickness of the Organ Rock Tongue Member 278. 75

\section{PRESERVATION OF THE SPECIMENS}

The plant fossils are not well preserved, and some of the critical details are not observable. Cuticular material is totally absent, and the only evidence of organic remnants in the matrix is present in a darkbrown stain delineating outlines of some of the specimens. Only one specimen (Taeniopteris sp.) shows any trace of the ultimate venation, and therefore only gross morphologic features are available upon which to base identifications. Fortunately, such characteristics as size and shape of pinnules are sufficiently diagnostic in this florule to render identifications reasonably significant.

\section{DESCRIPTION OF THE FLORULE}

The assemblage is small, with only four, possibly five taxa; in aggregate, the fossils are reminiscent of the Hermit Shale flora of the Grand Canyon. Taeniopteris sp., Supaia rigida White, Protoblechnum bradyi, new species, Callipteris (?) sp., and an indeterminable specimen constitute the assemblage. Taxonomic affinities of the plants are largely conjectural. Taeniopteris is presumably a pteridosperm, but Supaia, Protoblechnum, and Callipteris (?) may be either ferns or pteridosperms; the indeterminable specimen is possibly a conifer. No lycopods or arthrophytes are present.

\section{Genus PROTOBLECHNUM Lesquereux}

The name Protoblechnum was originally applied to an alethopteroid plant from strata of Pennsylvanian age in Ohio. Halle (1927) published a detailed review of the history of the name, with considerable discussion of morphological similarities between Protoblechnum, Glenopteris, Danaeopsis, and other genera. $\mathrm{He}$ ultimately decided to apply Lesquereux's name to some large fronds from the Lower Permian Shihhotse Series of Shansi, China, and we herein follow Halle's choice of name in reference to one of the Cutler specimens. Halle (1927, p. 135) summarized the feature of Protoblechnum as follows:

Frond large, simply pinnate, sometimes bifurcating once. Pinnae large, except in the lowermost part of the frond decurrent on the rachis, often almost to the next lower pinna, the decurrent wings broad and ending rather abruptly, sometimes auriculate. Venation consisting of a strong midrib persisting to near the apex, and arching secondary veins, dividing once or trice, 4. 00 some veins occasionally simple; decurrent part of the pinna re- 
ceiving veins, similar to the secondary veins, direct from the main rachis.

$P$. wongii Halle is the best known of the few species attributed to Protoblechnum. It has been reported from several localities in China and Korea, but Halle's (1927) account is the most complete; his work was the major influence in our assigning the Cutler specimen to Protoblechnum.

\section{Profoblechnum bradyi Mamay and Breed, new species}

Figure 1

Specific diagnosis.-Frond large, symmetrically developed, probably several decimeters or more long, 20 $\mathrm{cm}$ or more wide. Rachis stout, $1.0 \mathrm{~cm}$ or more wide, ventrally flattened or channeled, with minor ridges. Pinnules straight or slightly falcate, oppositely paired, closely spaced, some overlapping, inserted at nearly right angles; pinnules $11.0 \mathrm{~cm}$ or more long, narrowly lanceolate with deeply constricted, slightly auriculate bases and proximal lamina decurrent on rachis; pinnules broadest (to $2.0 \mathrm{~cm}$ ) near base, with rachial attachment approximately half as broad. Midveins broad, complete, departing at sharp angles. Subsidiary venation unknown.

Holotype.-Specimen P4.150.

Description.-This account is based on one large, incomplete specimen, shown slightly reduced in figure 1 ; in spite of imperfections in its preservation, it is a remarkable specimen on the basis of its clearcut identity with the Asiatic genus Protoblechnum. To judge from the size of the fragment, it represents a small part of a very large frond, probably 10 decimeters or more long; if it was bifurcate, as Protoblechnum was in some instances, then it was an impressive structure.

The fragment is $23 \mathrm{~cm}$ long, measured between the broken ends of the rachis; the greatest width of the specimen is $19.0 \mathrm{~cm}$, measured across the broken tips of two opposite pinnae. The stout rachis constitutes one of the more conspicuous features of this frond, principally because its lack of tapering from one broken end to the other distinctly suggests a great overall original length for the frond; the rachis may have reached a width of considerably more than that shown by this fragmentary specimen. The upper, exposed surface is flat or shallowly channeled, with a low ridge along each side and one along the middle. The specimen is preserved in substantial relief, so that $2.0 \mathrm{~mm}$ or slightly more of the thickness of the rachis is exposed between pinnules. This condition suggests that little if any compressional distortion took place during burial of the frond, and the rachis was originally very stout, flattened, and ventrally ridged. There are no traces of rachial indument or other accessory features.

Twenty pinnules are attached, ten on each side of the rachis; most of these are nearly complete. At the base of the specimen the pinnules are inserted in opposite pairs, while the uppermost two pairs appear to be slightly alternate; the latter arrangement is probably an illusion resulting from minor preservational distortion. The pinnules are closely spaced, with intervals of about $2.0 \mathrm{~cm}$ between the midveins of adjacent pinnules; the spacing is sufficiently close that some of the pinnules slightly overlap each other. The pinnules are inserted at broad angles $\left(60^{\circ}-75^{\circ}\right)$ to the rachis, with no significant variation.

The pinnules are very large, the longest ones measuring $11.0 \mathrm{~cm}$ in length; they are equally developed on both sides of the frond. The pinnules are straight or slightly falcate, and narrowly lanceolate, with their greatest expansion at or within 1.0 to $1.5 \mathrm{~cm}$ of their points of attachment to the rachis. At these broadest, basal points, the pinnules reach $2.0 \mathrm{~cm}$ in width. Their actual bases, however, are deeply constricted, with the points of attachment to the rachis measuring 1.0 to 1.5 $\mathrm{cm}$ in width; some of the pinnules have weakly developed auricles. There is a slight decurrence of the lamina, forming a narrow, tapered wing on the rachis between adjacent pinnules; this is relatively broad at the proximal edge of each pinnule base, but it narrows to the point of disappearance just above the next proximally adjacent pinnule. Beyond the basal laminar enlargements, the laminae taper gradually and evenly, terminating in bluntly rounded tips about $5.0 \mathrm{~mm}$ wide.

The pinnules seem to have been preserved in substantially their original shapes, inasmuch as the impressions show a natural-ap'pearing, ventrally convex curvature. This is especially noticeable at the basal constrictions of the pinnules, where the laminar tissue is rather abruptly curled downward into the matrix, or toward the dorsal side of the frond. The curling is best seen in the pinnules at the bottom left of figure 1 .

The pinnules were provided with strong midribs, as evidenced by a wide (as much as $2.0 \mathrm{~mm}$ ) shallow median groove in each pinnule. The midribs depart sharply, showing no decurrence, and extend to the tips of the pinnules. The specimen contains no evidence of subsidiary venation.

Remarks.-The only similarly large fronds known from the upper Paleozoic of North America are found in Supaia or Glenopteris, the latter an Early Permian genus described by Sellards (1900) from a small area in Dickinson County, Kans. The first described species 




FIGURE 1.-Protoblechnum bradyi Mamay and Breed, new species. Notice thick, flattened and channeled rachis, constricted pinnule bases, decurrent laminae, and heavy midribs. Holotype, slightly reduced. Specimen P4.150. 
of Glenopteris show considerable variation in size, pinnule characteristics, and other morphological details. Only G. splendens, with frond widths of $20 \mathrm{~cm}$ or more, approximates the Cutler specimen in size, but the pinnules of the Kansas species are strongly auricled and have midribs only two-thirds as long as the pinnules. These and other contrasting features render it unlikely that the Cutler specimen is conspecific with Glenopteris splendens.

In anticipation of any suggestion that the Cutler specimen is a new species of Glenopteris, it should be remarked that Glenopteris apparently inhabited a restricted geographic area in Kansas, its limited range probably a function of environmental control; this circumstance was discussed by Read and Mamay (1964, p. K16-K18) in delimiting three Early Permian floral provinces. Glenopteris has not yet been recognized in the province of Gigantopteris, which contains a rich flora and is geographically interposed between the provinces of Supaia and Glenopteris; this fact would seem to emphasize the morphological evidence against assignment of the Cutler specimen to Glenopteris.

While some of the species of Supaia approach the Cutler specimen in size of pinnules, none possesses the combination of such features as the channeled rachis, abruptly tapering pinnules, and deeply constricted pinnule bases; thus we reject Supaia as a generic repository for the Cutler specimen.

The resemblances between the Cutler specimen and the material of Protoblechnum wongii illustrated by Halle (1927, pls. 35-36) outweigh by far any other comparisons that might be made. The Chinese material possesses the same type of constricted or auriculate pinnule bases, decurrent laminae, strong midribs, channeled rachises and other morphological features of the Cutler specimen. The frond of Protoblechnum bradyi as demonstrated by the holotype has a particularly close resemblance to the specimen of $P$. wongii shown in Halle's figure 2, plate 36. The frond of the Cutler specimen, however, is somewhat more compact, with more closely spaced pinnules than the Chinese material; $P$. wongii is diagnosed by Falle $(1927$, p. 135$)$ as having "distant pinnae", while those of $P$. bradyi tend to overlap. It is also possible that there are differences in details of the venation between the two species, but unfortunately this feature is not preserved in $P$. bradyi.

Protoblechnum bradyi is named for the late Major L. F. Brady, of the Museum of Northern Arizona, in recognition of his interest in this study and his preparation of the specimens.

\section{Genus SUPAIA White}

The assignment to Supaia of incomplete fronds such as that in the Cutler collection is necessarily based largely on characters of secondary importance, because this specimen is lacking in what White regarded as the main distinguishing generic feature-a dichotomously forked rachis. White $(1929$, p. 54) defined Supaia as having an equally bifurcate frond with once-pinnate or pinnatifid lamina; each side of the divided frond was supposedly asymmetrical, with the outer pinnules much longer than the inner. While the dichotomous division of the rachis is observable on several of White's specimens and may constitute a reliable generic feature, the degree of asymmetrical pinnule development, as shown in White's (1929, fig. 1) reconstruction of a frond of Supaia linearifolia, is not convincingly borne out by the original specimens. Some of the specimens are too fragmentary to determine size relationships between pinnules on opposite sides of the same rachis; some specimens show a slight degree of asymmetry, while others apparently had equally developed pinnules. For this reason we are inclined to minimize the importance of laminar asymmetry and base our identifications on other characteristics, chiefly size, shape, and distribution of pinnules.

\section{Supaia rigida D. White}

Figure $2 D$ (cf. White, 1929, pl. 17, fig. 1, 2)

Description.-One specimen of this taxon is present in the collection; it consists of what appears to be the terminal part of a frond or the terminal part of one of the dichotomous divisions of the lamina. There is no evidence of asymmetrical development of the frond, however, as the pinnules to either side of the rachis are virtually of equal length.

The rachis is $10.0 \mathrm{~cm}$ long between its broken ends and about $3.0 \mathrm{~mm}$ wide at its broadest point; it is perfectly straight and gives the impression of considerable rigidity in life. There is nothing distinctive about the rachis, as it is completely lacking in surface ornamentation or indument.

Fourteen pinnules, mostly complete, are attached to the rachis. The basal pinnules are inserted oppositely, while those toward the apex of the specimen are subopposite or alternate. They are widely spaced, with intervals of $1.0 \mathrm{~cm}$ or more between adjacent pinnules. The basal ones are inserted at very broad angles to the rachis (approximately $75^{\circ}-80^{\circ}$ ), but distally the angles of insertion decrease so that the terminal pinnules create angles of about $45^{\circ}$. 

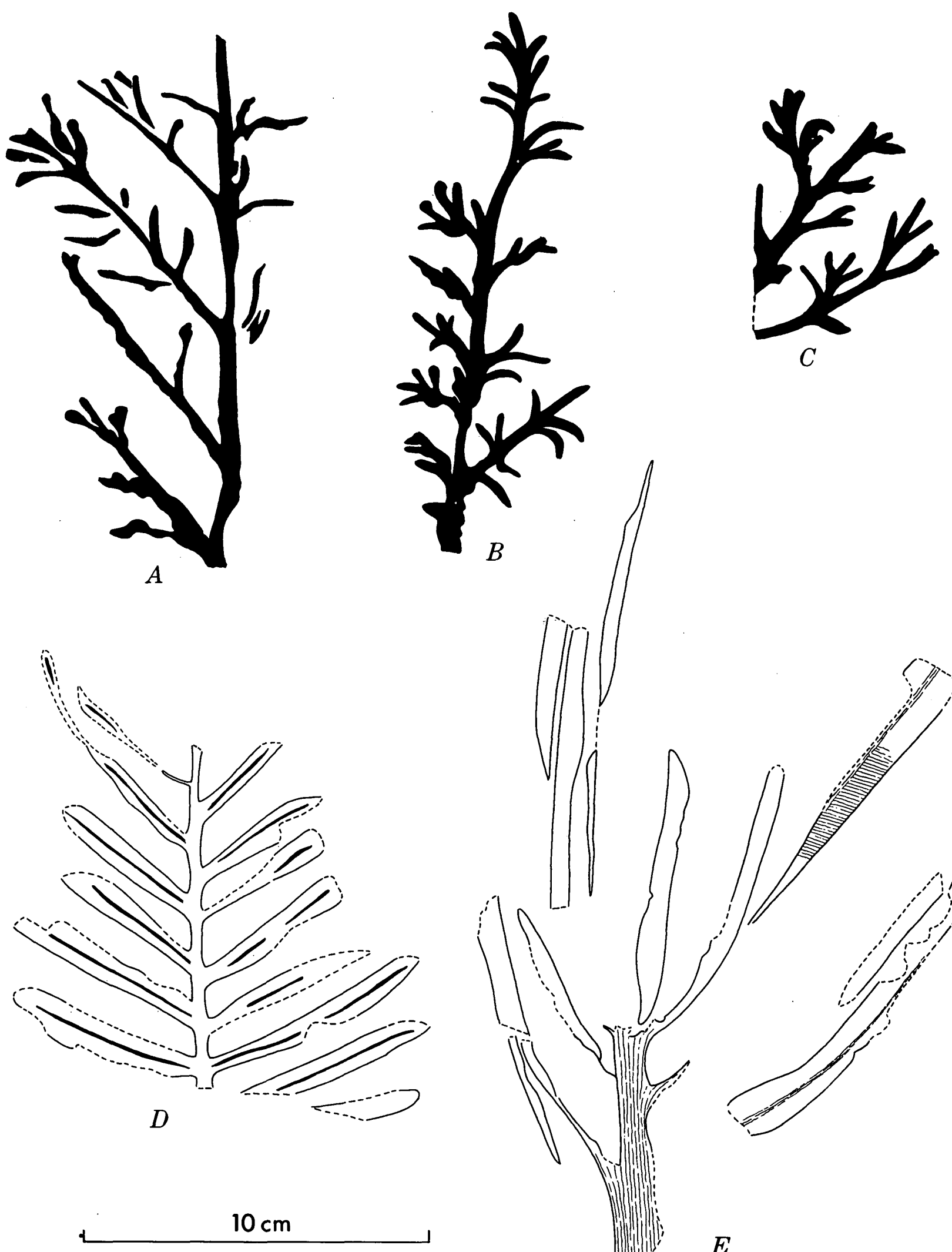

$$
\text { C }
$$

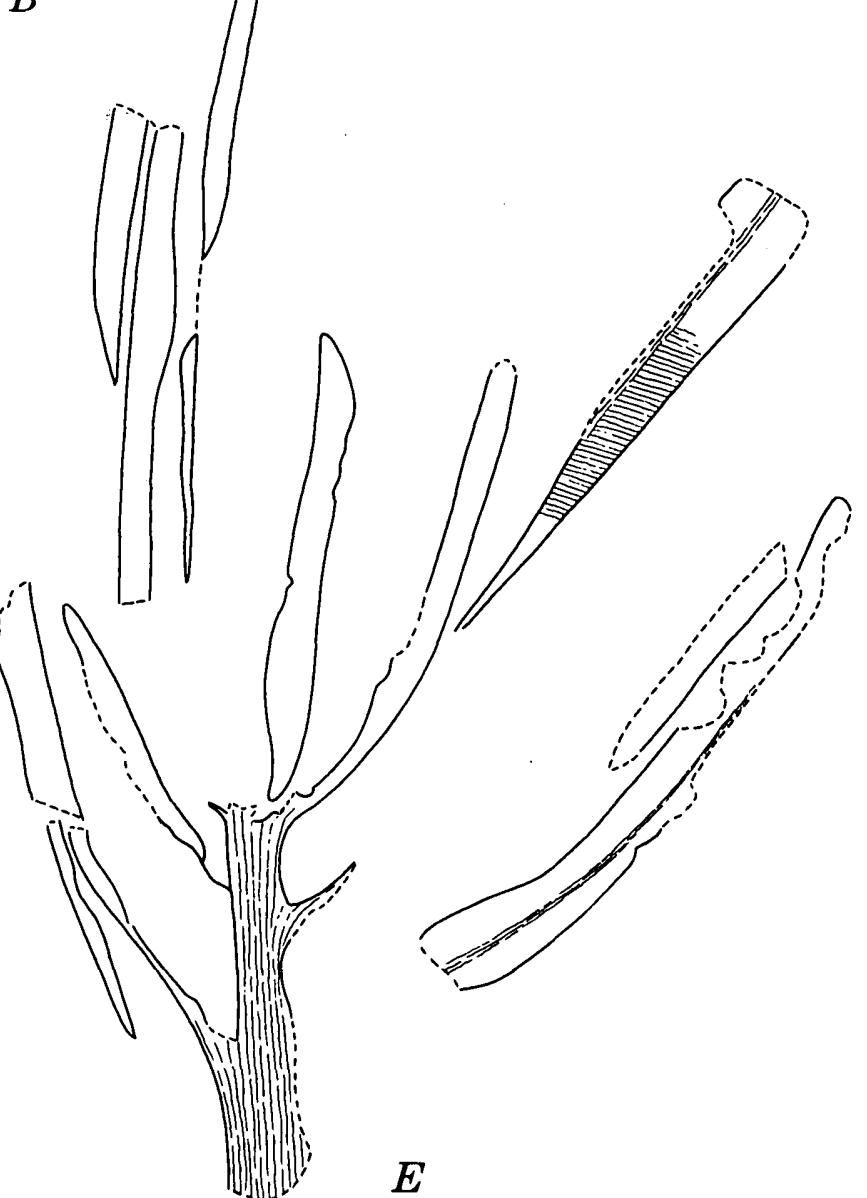

FIgure 2.-Early Permian plant fossils from the Cutler Formation in Monument Valley, Utah; $A-C$, natural size; scale at bottom of plate applies only to $D$ and $E$.

$A$. Undetermined plant fragment, possibly coniferous, specimen $\mathbf{P 4 . 1 5 5}$.

B, C. Callipteris (?) sp. Fragments showing deeply lobed pinnules; $B$, specimen P4.153; $C$, specimen P4.154.

D. Supaia rigida White. Heary black lines indicate pinnule midribs; specimen P4.151.

$E$. 'Specimen of Taeniopteris sp., showing fragmentary shoot at bottom, with several leaf fragments either attached or oriented as though they were part of the same specimen. Ultimate venation indicated at upper right; specimen P4.152. 
The pinnules are long and narrow; the longest is $8.0 \mathrm{~cm}$ long, and the widest is $7.0 \mathrm{~mm}$ wide. At their points of attachment, the pinnules average about 5.0 $\mathrm{mm}$ in width, and the width increases very gradually so that the widest parts of the pinnules occur at about the middle; beyond that their widths decrease very gradually. White $(1929$, p. 65) described the pinnule apices of $S$. rigida as acutely pointed, but incomplete preservation of the Cutler specimen precludes observation of that feature. The pinnule bases are neither constricted nor expanded, and the rachis shows no evidence of a laminar. wing between pinnules.

Pronounced median furrows on most of the pinnules indicate the presence of a strong midrib, $1.0 \mathrm{~mm}$ or more wide. There is no indication of the nature of the ultimate venation.

Remarks.-The Cutler specimen closely resembles the specimen of Supaia rigida illustrated by White (1929) on plate 17 , figure 1 . The distant spacing of the pinnules, their almost complete lack of decurrence, and, as aptly put by White (1929, p. 152), the "skeletal" aspect of the frond are points in which the Hermit and Cutler specimens may be favorably compared. The Cutler specimen is slightly larger than any of White's specimens, and its pinnules are somewhat broader, relative to their length. These differences, however, probably reflect overall size differences between individual fronds and are of doubtful taxonomic significince. The fact that the Cutler specimen shows nearly symmetrical foliar development need not militate against its identification with White's species. Since the specimen probably represents part of a frond considerably larger than White's, the basal part of the frond may have been asymmetrically developed, with the foliar divisions assuming symmetrical outlines toward their tips.

Figured specimen.-P4.151.

\section{Form-genus TAENIOPTERIS Brongniart Taeniopteris sp.}

Figure $2 E$

Description.-The one specimen on hand consists of what is presumably the terminal part of a leafy shoot with remnants of about ten leaves preserved; positions of the leaves suggest preservation in their natural attitudes, relative to the shoot axis. Overall length of the specimen is $25.0 \mathrm{~cm}$. Approximately $5.0 \mathrm{~cm}$ of the axis is exposed at the lower end of the specimen, above which it is buried in the matrix; the shoot is about 1.0 $\mathrm{cm}$ wide at its broadest point.

The actual attachment of two leaf petioles is evident, one at the left side of the shoot and one at the right; the attachment of three others is suggested by their orientation and proximity to the axis. The attached leaves create angles of about $45^{\circ}$ with the axis, and positions and spacing of the remaining leaves suggest a rather loose phyllotactic spiral, with all the leaves decurrently inclined at narrow angles of departure.

As preserved here, the leaves lend the impression of having been fairly rigid in life. The leaves are all fragmentary; the longest measurable specimen is 9.0 $\mathrm{cm}$ long, and another, whose length may be inferred from a series of interrupted traces, is $19.0 \mathrm{~cm}$ long. As far as ascertainable, the leaves have very short petioles of $2.0 \mathrm{~cm}$ or less. The laminae are very narrow, not exceeding $2.0 \mathrm{~cm}$ in total width. The midribs are broad $(1.5-2.0 \mathrm{~mm})$ and in some of the leaves the lamina appears to have split away from one side or the other of the midrib.

The foliar venation is totally obscure in most of the laminar fragments. Strongly oblique lighting, however, shows the faint impressions of the lateral veins in three of the leaves; the clearest of these are indicated at the upper right of figure $1 E$. The veins are apparently simple or only rarely forked, very closely spaced (25-30 per $\mathrm{cm})$ and depart at very broad angles $\left(70^{\circ}-\right.$ $80^{\circ}$ ) to the midrib.

Remarks.-The gross shape and venation of this specimen are sufficiently characteristic to identify the form-genus Taeniopteris, but the available information is insufficient to venture a specific identification. Nonetheless, certain features of this specimen deserve mention here.

The presence in the Cutler Formation of Taeniopteris emphasizes the ubiquity of this form-genus. It appears in nearly all the late Paleozoic floras known on this continent, and to judge from paleoecologic implications of the various kinds of sedimentary rocks in which it has been found, Taeniopteris was one of the most versatile of Permian taxa in terms of ecologic tolerance.

The Cutler specimen is also one of the few North American specimens in which relationships between leaves and stem are demonstrable. Leafy shoots of these plants are relatively rare, but the Cutler specimen distinctly suggests a growth habit in which the terminal portions of the shoots were fairly densely clothed with simple leaves.

Figured specimen.-P4.152.

\section{Genus CALLIPTERIS Brongniart Callipteris(?) sp.}

Figure $2 B$ and $C$

Description.-This provisional identification of $\mathrm{Cal}$ lipteris is based on four poorly preserved frond frag- 
ments, the largest of which is shown as figure $2 B$. It consists of a pinna fragment with a rachis $9.0 \mathrm{~cm}$ long and $3.0 \mathrm{~mm}$ in greatest width; it bears several deeply pinnatifid pinnules. The pinnules reach $2.3 \mathrm{~cm}$ in length, and are distantly inserted $(1.0 \mathrm{~cm}$ or more apart) in oblique $\left(40^{\circ}-60^{\circ}\right)$, alternate positions. The pinnules are deeply incised into as many as seven lobes each, the lobes reaching $7.0 \mathrm{~mm}$ in length but no more than $1.5 \mathrm{~mm}$ in width. The larger of the two figured specimens appears to have been shriveled and somewhat distorted in shape before preservation, but the pinnate-pinnatifid architecture is nonetheless apparent. The smaller figured specimen (fig. $2 C$ ) was apparently in better condition at the time of preservation, and shows a more symmetrical outline on one of its pinnules.

Remarks.-The general aspect of these specimens is definitely callipteroid, but the unsatisfactory state of preservation prevents the determination of the presence of the subsidiary or rachial pinnules that are critical to positive identification of Callipteris. Were the generic determination more definite, one might confidently compare the Cutler specimens with the finely divided species of Callipteris, particularly $C$. raymondi Zeiller or C. strigosa Zeiller. White (1929, p. 52 and pl. 12, fig. 2) reported $C$. raymondi, along with two other species of Callipteris in the Hermit Shale flora.

Except for the facts that the proportions of the Cutler specimens are considerably larger and have fewer lobes per pinnule, one might be tempted to identify the Cutler material with the Hermit Shale specimens. These differences, however, weigh more favorably with a comparison with the closely related Callipteris strigosa, which has larger pinnules with fewer, more distantly spaced lobes.

Figured specimens.-P4.153, P4.154.

\section{Undefermined plant fragment}

Figure $2 A$

Description.-This specimen consists of a sparsely branched axial fragment, $9.0 \mathrm{~cm}$ long and 2.0 to 3.0 $\mathrm{mm}$ thick, with parts of nine lateral branches attached, mostly to the left side of the axis. The main axis is almost perfectly straight and gives the impression of having been very rigid in life. The lateral branches are evenly spaced at intervals of about $2.0 \mathrm{~cm}$, are oppositely arranged at the top of the specimen, and depart at angles of about $45^{\circ}$ to the main axis; these, too, have the appearance of original rigidity.

The lateral branches in turn produce a number of long, slender ultimate appendages, which attain maximum lengths of $12.0 \mathrm{~mm}$ and widths of $2.0 \mathrm{~mm}$. These are distantly spaced, and also create broadly oblique angles of approximately $45^{\circ}$ with their supporting appendages. Some of the ultimate appendages, such as seen at the lower left of figure $2 A$, show undulating outlines slightly suggestive of the alternating bulges that might have been produced by imbricated scalelike coniferous leaves. Others, particularly those shown at the upper left of the figure, assume somewhat clubshaped outlines with enlarged or swollen tips, reminiscent to a certain extent of small, terminal coniferous buds.

Remarks.-It is impossible to be certain as to even the broad affinities of this specimen. The straight, parallel attitudes of the lateral branches give the appearance of a planated, rather than spirally arranged architecture, but this feature in itself is not sufficient basis for determining that the specimen represents a pteridophyll rather than a conifer. Only the clavate tips of some of the ultimate divisions and the undulate outlines of others give a slight clue in the direction of a coniferous alliance for the specimen.

The chief significance of this specimen lies in its resemblance to some of the specimens described by White (1929) as Yakia heterophylla, from the Hermit Shale. The Cutler specimen, on the basis of spacing and attitudes of appendages, is very similar to the specimen of Yakia illustrated by White (1929) on plate 39 , figure 5 . The ultimate mmebers of the Cutler specimen do not show the lobation shown in White's retouched figures; on the other hand, White's original specimens do not convincingly demonstrate lobate margins on the ultimate ramifications, but rather appear to have linear appendages like those of the Cutler specimen. Thus, it is likely that the Cutler specimen is closely allied with White's Yakia and thereby constitutes an additional genetic link between the floras of the Organ Rock Tongue and Hermit Shale.

Figured specimen.-P4.155.

\section{DISCUSSION}

Although a limited taxonomic spectrum is contained in the Cutler collection, the assemblage is significant in that it represents a new fossil plant locality in a stratigraphic unit and geographic area where fossils are rare. The florule also entails interest on the basis of floristic relationships, both provincial and cosmopolitan.

The specimen of Supaia rigida is important in that it identifies the Cutler assemblage with the flora of the Hermit Shale. Among the species of Supaia described by White (1912), S. rigida is probably the most distinctive by virtue of its "skeletal" appearance, and the Cutler specimen is sufficiently similar to the Hermit 
Shale material that the recognition of the Supaia flora in the Monument Valley plant beds rests on a firm basis; the common occurrences of Taeniopteris and Callipteris in both assemblages support this conclusion.

The Supaia flora is known to occur in the Hermit Shale of Arizona (Read and Mamay, 1964, p. K17) and in the upper part of the Abo Formation at several localities in west-central New Mexico (Read in King, 1942 , p. 690). Aside from Baker's (1936, p. 35) report of Yalia in the Organ Rock Tongue in Copper Canyon, Ariz., no representatives of the Supaia flora have previously been reported from the Cutler Formation. Furthermore, the Monument Valley occurrence is the first known in Utah; it thus constitutes the northernmost occurrence of the Supaia flora and increases slightly the geographic extent of the Supaia province, as described by Read and Mamay (1964, p. K17).

The broader implications of the Cutler collection revolve about the presence therein of Protoblechnum bradyi. Although only one specimen is available, it is evident that $P$. bradyi does not compare closely with any North American contemporaneous plant, but, instead, is remarkably similar to the Early Permian $P$. wongii, known from just a few occurrences in East Asia. White (1912) brought attention to the presence of a strong Asiatic element in the Permian flora of North America, and Mamay (1967) introduced additional supporting evidence. Protoblechnum bradyi may be interpreted as a further important Permian link between the American and Asiatic floras. Its discovery in the red beds of the Cutler Formation emphasizes the potential of those strata as a source of important paleofloristic material.

\section{REFERENCES}

Baker, A. A., 1933, Geology and oil possibilities of the Moab district, Grand and San Juan Counties, Utah: U.S. Geol. Survey Bull. 841, 95 p.

1936, Geology of the Monument Valley-Navajo Mountain region, San Juan County, Utah: U.S. Geol. Survey Bull. $865,106 \mathrm{p}$.

Halle, T: G., 1927, Paleozoic plants from Central Shansi: Palaeontologia Sinica, ser. A, v. 2, pt. 1, 316 p., 64 pls.

King, P. B., 1942, Permian of west Texas and southeastern New Mexico, pt. 2 of DeFord, R. K., and Lloyd, E. R., eds., West Texas-New Mexico symposium : Am. Assoc. Petroleum Geologists Bull., v. 26, no. 4, p. 535-763, illus.

Langston, Wann, Jr., 1953, Permian amphibians from New Mexico: California Univ. Pubs. Geol. Sci., v. 29, no. 7, p. $349-416$.

Lewis, G. E., and Vaughn, P. P., 1965, Early Permian vertebrates from the Cutler Formation of the Placerville area, Colorado, with a section on Footprints from the Cutler Formation, by Donald Baird: U.S. Geol. Survey Prof. Paper 503-C, p. C1-C50.

Mamay, S. H., 1967, Lower Permian plants from the Arroyo Formation in Baylor County, north-central Texas, in Geological Survey Research 1967: U.S. Geol. Survey Prof. Paper 575-C, p. C120-C126.

Read, C. B., and Mamay, S. H., 1964, Upper Paleozoic floral zones and floral provinces of the United States: U.S. Geol. Survey Prof. Paper 454-K, p. K1-K35, pls. 1-19.

Sellards, E. H., 1900, A new genus of ferns from the Permian of Kansas: Kansas Univ. Quart., v. 9, p. 179-189, pls. 37-42.

White, David, 1912, The characters of the fossil plant Gigantopteris Schenk and its occurrence in North America : U.S. Nat. Museum Proc., v. 41, p. 493-516, pls. 43-49.

1929, Flora of the Hermit Shale, Grand Canyon, Arizona : Carnegie Inst. Washington Pub. 405, 221 p., 51 pls. 


\title{
STRATIGRAPHIC MICROPALEONTOLOGY OF THE TYPE LOCALITY OF THE WHITE KNOB LIMESTONE (MISSISSIPPIAN), CUSTER COUNTY, IDAHO
}

\author{
By BETTY SKIPP and B. L. MAMET, \\ Denver, Colo., Montreal, Canada
}

\begin{abstract}
Restudy of interbedded limestone, conglomerate, and sandstone of the White Knob Limestone at its type locality near Cabin Creek, Custer County, Idaho, has shown that the entire sequence has a minimum thickness of 5,500 feet and is, on the basis of calcareous Foraminifera, of Visean and of early Namurian (Late Mississippian) age. Foraminiferal Zones $\mathbf{1 6}_{\mathrm{i}}$ through 18 (Chester) are identified with certainty. The beds below Zone $16_{i}$ are known to be at least as young as Zone 13 (middle Meramec). Chert and quartzite pebble conglomerates present in Zones $16_{\mathrm{s}}$ and 17 (Chester) represent orogenic pulses of the same age as that of some of the pulses recorded by conglomerates of the Diamond Peak Formation of east-central Nevada. The type White Knob is the time-stratigraphic equivalent of Huh's (1967) Middle Canyon, Scott Peak, and South Creek Formations and part of his Surrett Canyon Formation described in south-central Idaho, and the equivalent of the Chesterfield Range Group of southeastern Idaho. It is also equivalent to parts of the Mount Head and Etherington Formations of southwestern Alberta.
\end{abstract}

Interbedded limestone, conglomerate, sandstone, and siltstone, which overlie the Milligen Formation near Cabin Creek, Custer County, Idaho (fig. 1), were designated the type locality of the White Knob Limestone by Ross (1962, p. 385), who cited the senior author's lithologic descriptions and age determinations (Skipp, 1961a, b). Since that time more accurate and refined microfaunal zones based on the smaller calcareous Foraminifera have been developed (Mamet, 1968; Mamet and Skipp, 1970; Skipp, 1969), and the Cabin Creek section has been reexamined. The new work in the Cabin Creek area has shown that the measured section illustrated by Skipp (1961a, p. 382-386) is faulted near the base. The 1,950 feet of beds originally assigned to units $\mathrm{v}$ and $\mathrm{w}$ (Skipp, 1961a, p. 380)

\footnotetext{
1 Université de Montréal.
}

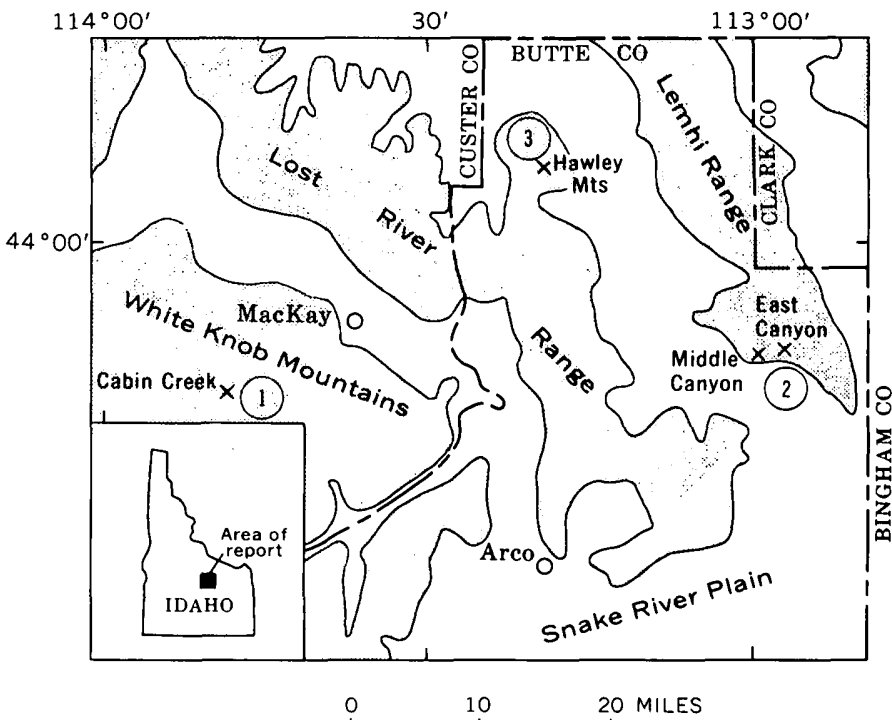

FIGURE 1.-Location of the type locality of the White Knob Limestone at Cabin Creek in the White Knob Mountains, Idaho, in relation to other key sections in the Lemhi and Lost River Ranges in Idaho. 1, Cabin Creek (Skipp, 1961a, b); 2, type sections of the Middle Canyon, Scott Peak, South Creek, and Surrett Canyon Formations of Huh $(1967,1968)$ in the Lemhi Range; 3 , measured sections of the Middle Canyon, Scott Peak, South Creek, and Surrett Canyon Formations of Huh in the Lost Rirer Range (W. J. Mapel, written commun., 1969).

constitutes a wide fault zone of strata that for the most part are repeated from units $s, t$, and $u$. The revised estimate of total thickness of the section without repeated beds is a minimum of about 5,500 feet (fig. 2). Units a through $\mathbf{x}$ are lithologic units described in detail by Skipp (1961a, p. 377-380).

A reevaluation of the fauna, part of which was illustrated in 1961 (Skipp, 1961b, p. C242), indicates that the section is entirely Mississippian, as suggested in 1961 , but that probably no rocks of Osage age are pres- 


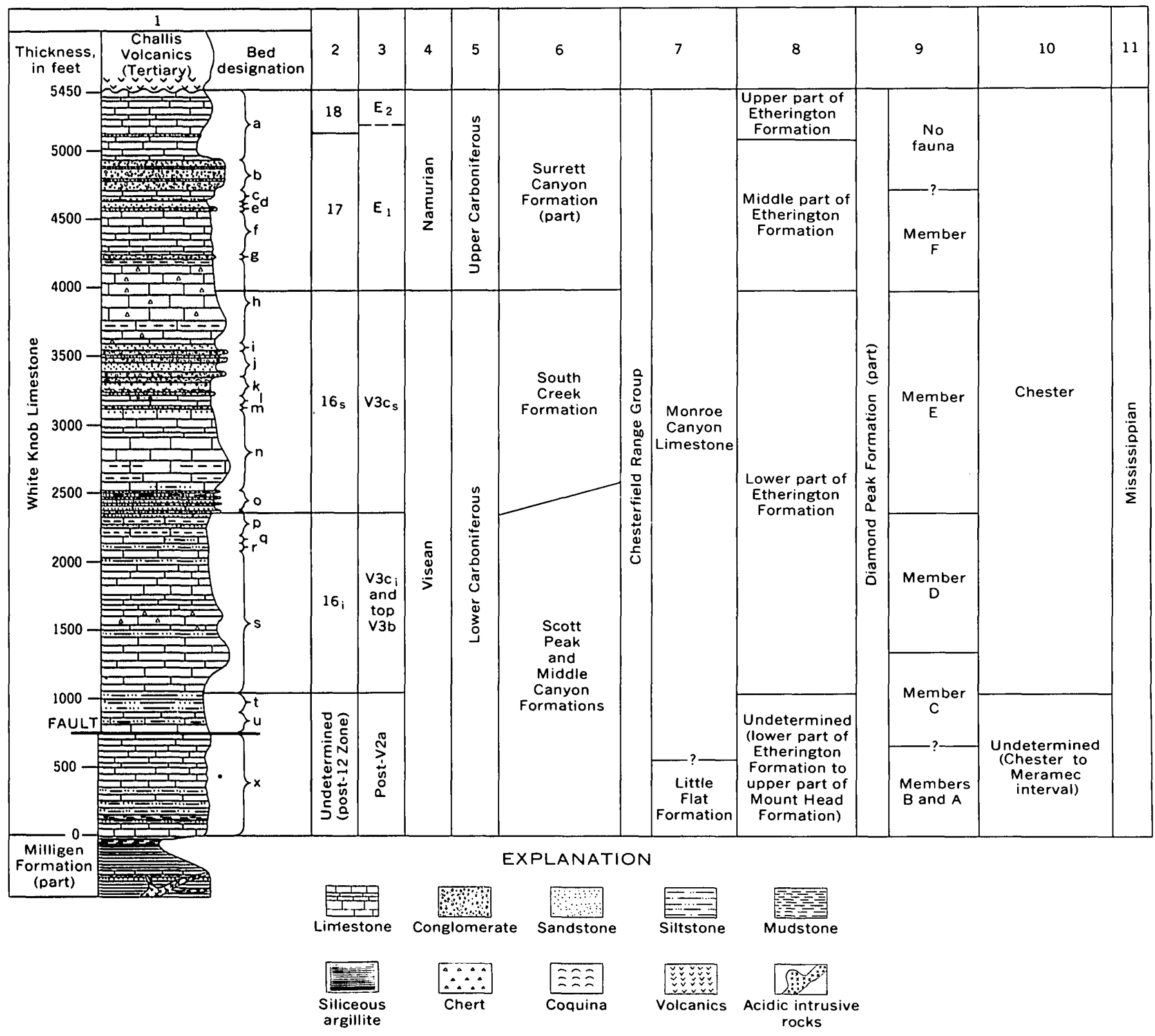

Funure 2.-Columnar diagram of the type locality of the White Knob Limestone in Custer County, Idaho, showing foraminiferal zones, relations to European and North American systems and series, and relations to other rock units in Idaho, Nevada, and Canada: 1, Cabin Creek section modified from Skipp (1961a); 2, microfaunal assemblage zones (Mamet and others, 1.066 ; Namet, 1968; Mamet and Slkipp, 1969) ; 3, European zones of the original Visean and Namurian Stages; 4, European stages (part) ; 5, Duropean systems (part) ; 6 , age ranges of Middle Canyon, Scott Peak, South Creek, and Surrett Canyon (part) Formations of Fuh $(1967,1968)$ in the Lemhi and Lost River Ranges, south-central Idaho; 7 , age range of the Ohesterfield Range Group, southeastern Idaho (Sando and others, 1969); $S$, age ranges of parts of the Mount Head and litherington Formations of southwestern Alberta, Canada (Mamet, 1968) ; 9, age of a part of the Diamond Peak Formation in its type section in Nevada as determined from Foraminifera by Skipp and megafauna by Mackenzie Gordon, Jr. (in Brew, $1970) ; 10$, Midcontinent provincial series ; and 11 , system.

ent. Instead, Foraminiferal Zones 13 ? through 18 defined in Europe and Africa by Mamet (Mamet and others, 1966) and applied to the North American Cordillera (Mamet and Mason, 1968; Mamet and Skipp, 1970) are present, with an attendant age range from middle Meramec (middle Visean) through late Chester (early
Namurian). Conglomerate and sandstone in the section are Chester (latest Visean and early Namurian) and represent orogenic pulses of the same age as those recorded by conglomerates of the type Diamond Peak Formation (fig. 3) of east-central Nevada (Brew, 1964; Mackenzie Gordon, Jr., in Brew, 1970) . (Also see fig. 2.) 


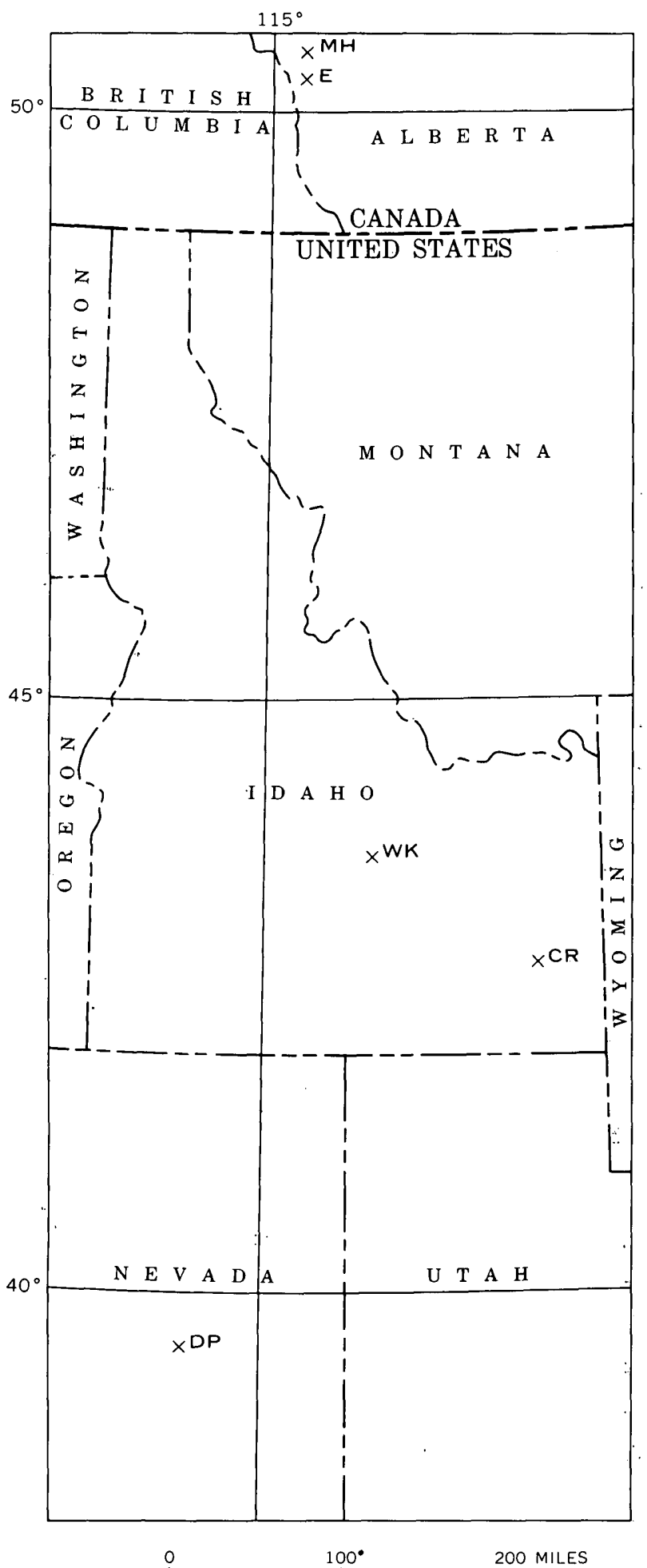

Frgure 3.-Location of the type locality of the White Knob Limestone (WK) in Idaho in relation to the location of the type locality of the Chesterfield Range Group (CR) in southeastern Idaho, the type section of the Mount Head Formation $(\mathrm{MH})$ in Alberta, the type section of the Etherington Formation (E) in Alberta, and the type section of the Diamond Peak Formation (DP) in Nevada.

\section{MICROFAUNA AND LITHOLOGY}

The lower 1,150 feet of the Cabin Creek section is recrystallized micrite and spiculite lithologically very similar to the Middle Canyon Formation and the basal part of the Scott Peak Formation in the Lemhi and Lost River Ranges, Idaho (Huh, 1967, p. 37-41). Thin sections of these rock types from the Cabin Creek section were illustrated by the senior author (Skipp, 1961a, fig. 2, Se-34 and Se-36). The textures are indicative of nonturbulent shallow water, which apparently was not favorable for the development of foraminifers. The sparse fauna present in the upper 300 feet (units $t$ and $u$ ) above the fault is composed of the following genera and species:

\author{
Archaediscus sp. \\ Archaediscus of the group A. krestovnikovi. (Rau- \\ zer-Chernoussova) \\ Brunsia sp. \\ Endothyra sp. \\ Eostaffella? sp. \\ Tuberitina sp.
}

The assemblage is younger than that of the midVisean Zone 12, because it includes Archaediscus krestovnikovi and Eostaffella?; both of these forms are very sparse below Zone 13 in most of the North American Cordillera (Mamet and Skipp, 1970). Absence of Eoendothyranopsis and Endothyranopsis, however, precludes a more precise zonation.

The overlying 1,300 feet of carbonate rocks, which make up units $\mathrm{p}, \mathrm{q}, \mathrm{r}$, and $\mathrm{s}$ below the lowest conglomerate lens, is recrystallized, medium-to coarse-grained bioclastic limestones and reefoid accumulations, which are indicative of open circulation on a shallow marine carbonate shelf. The foraminiferal assemblage, even though extensively recrystallized, contains the following taxa :

Archaediscus sp.

Archaediscus of the group A. chernoussovensis Mamet

Archaediscus of the group A. krestovnikovi Rauzer-Chernoussova

Archaediscus of the group A. moelleri RauzerChernoussova

Brunsia sp.

Calcisphaera sp.

Climacammina sp.

Earlandia sp.

Endothyrasp.

Endothyra of the group A. bowmani Phillips in Brown emend Brady 
Endothyra excellens (Zeller)

Endothyra torquida (Zeller)

Endothyra of the group E. similis Rauzer-Chernoussova and Reitlinger

Globoendothyra sp.

Globoendothyra of the group G. globulus (d'Eichwald emend von Möller)

Palaeotextularia sp.

Stacheoides sp.

Tetrataxis sp.

Tuberitina sp.

The assemblage is much like that observed in the lower part of the Etherington Formation of Alberta (Mamet, 1968, p. 171-177) and is assigned to Zone $16_{1}$ (early Chester or early late late Visean). A similar microfaunal assemblage is present in member $D$ and the upper part of member $\mathrm{C}$ of the Diamond Peak Formation in its type section in Nevada. The 1,300 feet of limestones representing this zone in the White Knob Limestone of the Cabin Creek section is the timestratigraphic equivalent of the upper part of the Scott Peak Formation in the Lemhi and Lost River Ranges, south-central Idaho, and of the lower part of the Monroe Canyon Limestone in the Chesterfield Range, southeastern Idaho (fig. 2).

The overlying 1,600 feet of interbedded limestone, conglomerate, and sandstone, units $h$ (part) through $o$, contains a fairly large foraminiferal assemblage that consists of the following elements:

Archaediscus sp.

Archaediscus of the group A. krestovnikovi Rauzer-Chernoussova

Archaediscus of the group A. moelleri RauzerChernoussova

Calcisphaera sp.

Earlandia sp.

Endothyra sp.

Endothyra of the group E. bowmani Phillips in Brown emend Brady

E'ndothyra excellens (Zeller)

Endothyra of the group E. prisca (Rauzer-Chernoussova and Reitlinger)

Eostaffella sp.

"Eostaffella"(?) discoidea (Girty)

Neoarchaediscus sp.

Neoarchaediscus of the group $N$. incertus (Grozdilova and Lebedeva)

Parathurammina sp.

Planospirodiscus sp.

Pseudoendothyra sp.

$P$ seudoendothyra of the group $P$. kremenskensis Rosovskaia

T'uberitina sp.
Abundant Neoarchaediscus mixed with Planospirodiscus indicate a latest Visean age (Chester, Zone 16 The unit is the time-stratigraphic equivalent of the South Creek Formation and the uppermost beds of the Scott Peak Formation in the Lemhi and Lost River Ranges, and the middle part of the Monroe Canyon Limestone in the Chesterfield Range (fig. 2). It is also the time-stratigraphic equivalent of the upper part of the lower part of the Etherington Formation in southwestern Alberta and member $E$ of the Diamond Peak Formation in the Diamond Peak type section, Nevada. Studies of the interbedded chert- and quartzite-pebble conglomerate and limestone in this part of the section (Skipp, 1961a, p. 381-388) indicate a beach-gravel origin for most of the conglomerate and a shallow-water, turbulent, normal marine environment of deposition for the interbedded limestone.

The upper 1,150 feet of interbedded limestone, conglomerate, and sandstone, units a (part) through $\mathrm{h}$ (part), contains the following faunal assemblage:

Archaediscus sp.

Archaediscus of the group A. krestovnikovi Rauzer- Chernoussova

Asteroarchaediscus sp.

Asteroarchaediscus of the group A. baschkiricus (Krestovnikov and Teodorovitch)

Brunsia sp.

Calcisphaera sp.

Calcisphaera laevis Williamson

Calcitornella? sp.

Climacammina sp.

Diplosphaerina sp.

Earlandia sp.

Endothyra sp.

Endothyra of the group E. bowmani Phillips in Brown emend Brady

Endothyra excellens (Zeller)

Endothyra of the group .E. prisca (Rauzer-Chernoussova and Reitlinger)

Eostaffella sp.

"Eostaffella"(?) discoidea (Girty)

Koskinobigenerina sp.

Neoarchaediscus sp.

Neoarchaediscus of the group $N$. incertus (Grozdilova and Lebedeva)

Palaeotextularia sp.

Pseudoendothyra sp.

Pseudoendothyra of the group P. circuli (Thompson)

Pseudoendothyra of the group P. kremenskensis Rozovskaia.

Planospirodiscus sp.

Stacheoides sp. 
Tetrataxis sp.

Tetrataxis of the group T. eominima Rauzer-Chernoussova

Tuberitina sp.

The appearance of abundant Asteroarchaediscus mixed with Neoarchaediscus and Planospirodiscus indicates an early Namurian age (Chester, Zone 17) for the assemblage. The interval is about the same age as that of the basal part of the Surrett Canyon Formation in the Lemhi (Huh, 1967, 1968) and Lost River Ranges, and the middle part of the Etherington Formation of southwestern Alberta (Mamet, 1968). It is also the time-stratigraphic equivalent of some of the upper part of the Monroe Canyon Limestone of southeastern Idaho and member $F$ of the Diamond Peak Formation of east-central Nevada. The mode of origin of the interbedded quartzose clastic rocks and the bioclastic limestone is the same as that described for the underlying beds of Zone $16_{\mathrm{s}}$.

The uppermost 300 feet of limestone, unit a (part), exposed in the Cabin Creek section is rich in microfauna. The microfauna consists of the following genera and species:

Asteroarchaediscus sp.

Asteroarchaediscus of the group $A$. baschkiricus

(Krestovnikov and Teodorovich)

Calcisphaera sp.

Calcisphaera laevis Williamson

Climacammina sp.

Earlandia sp.

Endothyra sp.

Endothyra of the group E. bowmani Phillips in Brown emend Brady

Endothyra excellens (Zeller)

Endothyranopsis sphaerica (Rauzer-Chernoussova and Reitlinger)

Eostaffella sp.

Globivalvulina? sp.

Globivalvulina? parva Chernysheva

Koskinobigenerina sp.

Neoarchaediscus sp.

Neoarchaediscus incertus (Grozdilova and Lebedeva)

cf. Millerella? sp.

Palaeotextularia sp.

Planospirodiscus sp.

Pseudoendothyra sp.

Pseudoendothyra of the group $P$. circuli (Thompson)

Pseudoendothyra of the group $P$. kremenskensis Rozovskaia

Tuberitina sp.
The first appearance of abundant Globivalvulina? parva mixed with Asteroarchaediscus indicates a late early Namurian age (Chester, Zone 18). The succession is the time-stratigraphic equivalent of part of the Surrett Canyon Formation in the Lemhi and Lost River Ranges, south-central Idaho (fig. 2), and the uppermost part of the Monroe Canyon Limestone in the Chesterfield Range, Idaho. It is also equivalent to the upper part of the Etherington Formation of Alberta (Mamet, 1968).

The top of the White Knob succession at the type locality is eroded, and no equivalent of the Eosigmoilina? Zone 19 fauna, which is present at the top of the Surrett Canyon Formation in the Lost River Range, has been found. Tertiary Challis Volcanics lie with angular unconformity on the eroded carbonate sequence.

\section{CONCLUSIONS}

Reexamination in the field and reevaluation of the microfauna of the Cabin Creek section, the type locality of the White Knob Limestone designated by Ross (1962) in south-central Idaho, have shown that a minimum of 5,500 feet of interbedded limestone, sandstone, and conglomerate is present above the Milligen Formation and that the age range of the succession is Visean and early Namurian (Late Mississippian). Foraminiferal Zones $16_{i}$ through 18 (Chester), as used by Mamet (1968) in the Canadian Cordillera, are present and well developed. Strata in the White Knob below Zone $16_{1}$ are known to be Zone 13 (middle Meramec) or a younger zone. Chert- and quartzite-pebble conglomerates in the section, which first appear in Zone $16_{\mathrm{s}}$ (Chester, latest Visean), extend through Zone 17 (Chester, early Namurian) and are the time-stratigraphic equivalents of a part of the Diamond Peak Formation in east-central Nevada (Brew, 1970).

Lithologies of the lower part of the type White Knob Limestone above the argillites of the Milligen Formation are very similar to those of the Middle Canyon Formation and the lower part of the Scott Peak Formation in the Lemhi and Lost River Ranges of Idaho. The overlying beds are lithologically dissimilar to the formations of $\mathrm{Huh}$, in that they contain interbedded conglomerate and sandstone; but they are the temporal equivalents of the upper strata of the Scott Peak Formation, the entire South Creek Formation, and most of the Surrett Canyon Formation of Huh as exposed in the Lost River and Lemhi Ranges, Idaho (Huh, 1967, 1968). The White Knob beds above the fault zone in the type locality are also probably equivalent to the entire Monroe Canyon Limestone of the Chesterfield Range Group in southeastern Idaho (Sando and others, 1969). 


\section{REFERENCES}

Brew, D. A., 1964, Synorogenic sedimentation of Mississippian age, Eureka quadrangle, Nevada: U.S. Geol. Survey openfile report, $296 \mathrm{p}$.

1970, Mississippian stratigraphy of the Diamond Peak area, Eureka County, Nevada: U.S. Geol. Survey Prof. Paper 661. [In press]

Huh, O. K., 1967, The Mississippian System across the Wasatch line, east central Idaho, extreme southwestern Montana, in Centennial basin of southwest Montana-Montana Geol. Soc. Guidebook 1Sth Ann. Field Conf., 1967 : p. 31-62.

1968, Mississippian stratigraphy and sedimentology, ucross the Wasatch Line, east-central Idaho and extreme southwestern Montana: Pennsylvania State Univ. Ph.D. thesis (Geology), $\mathbf{1 7 5}$ p. (available on microfilm from Univ. Microfilms, Inc., Ann Arbor, Mich.).

Mamet, B. I., 1968, Foraminifera, Etherington Formation (Carboniferous), Alberta, Canada: Bull. Canadian Petroleum Geology, v. 16, no. 2, p. 167-179.

Mamet, B. I., Choubert, G., and Hottinger, L., 1966, Notes sur le carbonifere du jebel Ouarkziz-etude du passage du Viséen an Namurien d'après les foraminifères: Serv. Géol., Maroc, Notes Mém. 19S, p. 6-21.

Mamet, B. L., and Mason, David, 196S, The Foraminiferal zona- tion of the Lower Carboniferous Connor Lakes section, British Columbia: Bull. Canadian Petroleum Geology, v. 16 , no. 2 , p. $147-166$.

Mamet, B. L., and Skipp, Betty, 1970, Lower Carboniferous calcareous Foraminifera-Preliminary zonation and stratigraphic implications for the Mississippian of North America, in 6th Internat. Cong. Carboniferous Stratigraphy and Geology Proc., Sheffield, 1967: [In press]

Ross, C. P., 1962, Upper Paleozoic rocks in central Idaho: Am. Assoc. Petroleum Geologists Bull., v. 46, no. 3, p. 384-387.

Sando, W. J., Mamet, B. L., and Dutro, J. T., Jr., 1969, Mississippian megafaunal and Carboniferous microfaunal zonation in the northern Cordillera of the United States: U.S. Geol. Survey Prof. Paper 613-E, p. E1-E29.

Skipp, Betty, 1961a, Interpretation of sedimentary features in Brazer Limestone (Mississippian) near Mackay, Custer County, Idaho: Am. Assoc. Petroleum Geologists Bull., v. 45 , no. 3 , p. 376-3S9.

1961b, Stratigraphic distribution of endothyrid Foraminifera in Carboniferous rocks of the Mackay quadrangle, Idaho: Art. 236 in U.S. Geol. Survey Prof. Paper 424-C, p. C239-C244.

1969, Foraminifera, in McKee, E. D., and Gutschick, R. C., History of the Redwall Limestone: Geol. Soc. America Mem. 114, p. 173-257. 


\title{
TRIASSIC CONODONTS FROM ISRAEL
}

\author{
By JOHN W. HUDDLE, Washington, D.C.
}

\begin{abstract}
A conodont fauna, dated as Carnian by ostracodes from the Sa'haronim Formation at Makhtesh Ramon in southern Israel contains species characteristic of the so-called Cretaceous conodont fauna of the Cameroons, Africa. Elements of the same fauna are found in upper Middle (or lower Upper?) Triassic rocks in Sardinia, Spain, and Nevada. These occurrences suggest a third Middle Triassic conodont faunal province to the south of the Alpine province and central European Muschelkalk province. This conodont fauna suggests a late Ladinian rather than early Carnian Age for the lower part of the limestonegypsum member of the Sa'haronim Formation, but the Carnian Age as determined by ostracodes is tentatively accepted. Fish remains described by Cherchi in 1967 as conodonts and one holothuroid sclerite are illustrated.
\end{abstract}

Triassic conodonts from Israel were first reported by Sohn and Reiss (1964), but earlier, Eicher (1946) reported Triassic conodonts from a nearby locality in the Sinai Peninsula at approximately the same horizon. Eicher's report was greeted with skepticism by Branson and Mehl (Eicher, 1946, p. 616). Since then, large Triassic conodont faunas have been described in Europe, Asia, and North America, as a result of which Triassic conodonts are well enough known to be useful in correlation. The conodonts reported by Sohn and Reiss (1964) were collected by I. G. Sohn, supported by National Science Foundation grant G-24305, and by Nathan Schulman, of the Department of Geology of the Hebrew University of Jerusalem. The specimens were given to me for study and description by $\mathbf{I}$. G. Sohn, U.S. Geological Survey. Permission to publish was graciously granted by Prof. Y. K. Bentor when he was Director of the Geological Survey of Israel. Nathan Schulman provided the sections used in figure 1.

\section{COLLECTING LOCALITIES}

The conodonts described here were collected in the eastern part of the Makhtesh Ramon in southern Israel. The localities are shown in figure 1 of Sohn (1968), and the stratigraphic position of the collection from USGS Mesozoic locality 29183A is shown in figure 2 of Sohn (1968). The coordinates given are those on the grid map of Israel. The stratigraphic position of the collections made by Nathan Schulman are shown in figure 1 of this paper.

USGS Mesozoic locality 29183A.-Platy red limestone, $0.5 \mathrm{~m}$ thick, in the lower part of the limestone-
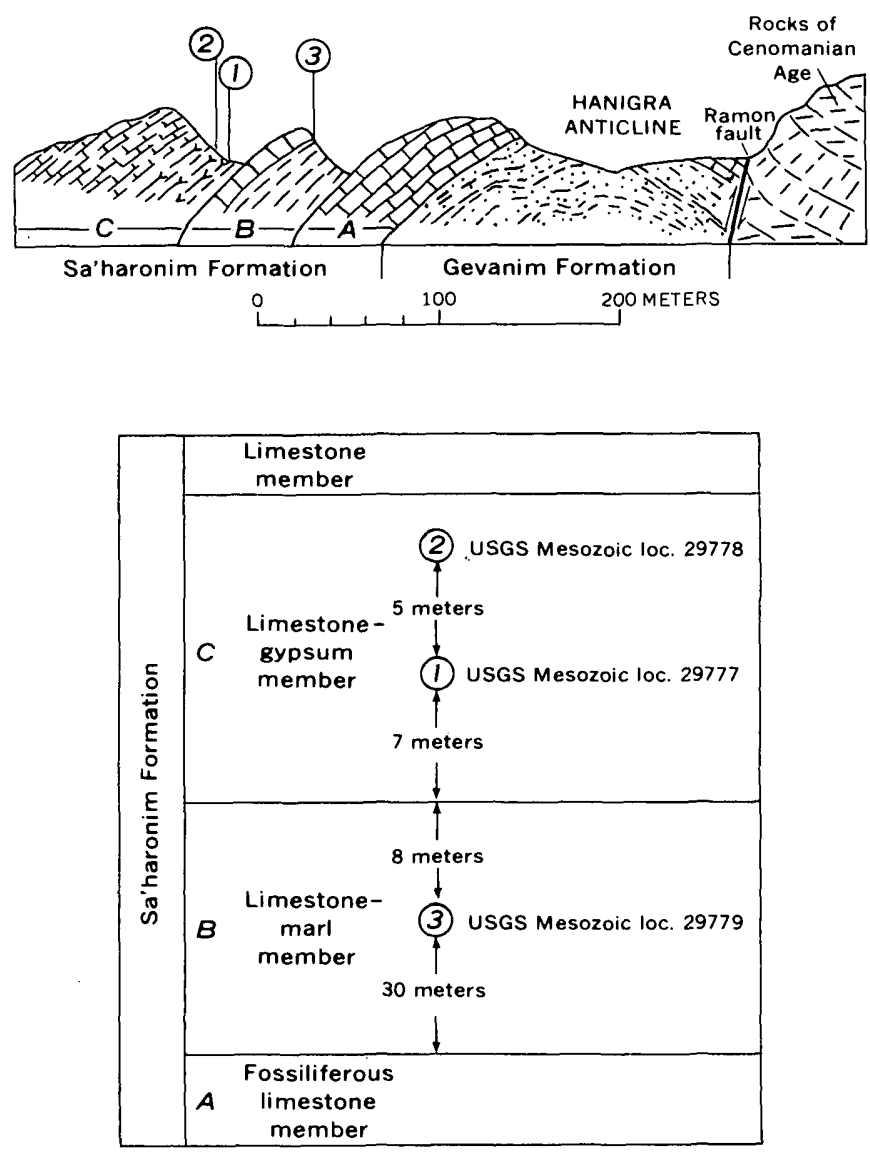

Gevanim Formation

FIGURE 1.-Geologic section and stratigraphic column showing collecting localities (courtesy of Nathan Schulman, Department Geology, Hebrew University of Jerusalem). 
gypsum member of the Sa'haronim Formation, Carnian Stage, Late Triassic, in road at locality A (see fig. 1, Sohn, 1968); coordinates 13766/00003. Collectors: I. G. Sohn and M. I. Price, January 22, 1963. Field No. 1/22/4/63.

USGS Mesozoic locality 297\%"y. - Tan limestone marl immediately below the first gypsum bank at the base of the escarpment slope of the third cuesta $100 \mathrm{~m}$ east of the main wadi in the Hanigra anticline. Ramat Sa'haronim (loc. B of Sohn, 1968; loc. 1, fig. 1, this report). Limestone-gypsum member of Sa'haronim Formation, Carnian Stage, Late Triassic. Collector: Nathan Schulman, February 2, 1963. Field No. 1.

USGS Mesozoic locality 29'1"8. - Gray marl within the second gypsum bank, $5 \mathrm{~m}$ above USGS Mesozoic locality 29777 (loc. 2, fig. 1). Collector : Nathan Schulman, February 2, 1963. Field No. 2.

USGS Mesozoic locality 297'y9.-Tan marly limestone and marl, $30 \mathrm{~m}$ above base of limestone-marl member and $15 \mathrm{~m}$ below USGS Mesozoic locality 29777 (loc. 3, fig. 1), Sa'haronim Formation, Carnian Stage, Late Triassic. Collector: Nathan Schulman, February 2, 1963. Field No. 3.

Conodonts are probably confined to thin layers of limestone, and the forms reported here may not all occur in the same layers. The sample from USGS Mesozoic locality 29183A was a grab sample and was processed in 4 or 5 splits. One split yielded abundant specimens of Pseudofumishius murcianus; another split yielded most of the bar-type conodonts reported from this locality; and another split yielded no bar forms and just a few $P$. murcianus. Still another split yielded Epigondolella mungoensis and a few bar-type conodonts. Apparently the conodonts came from only a few pieces of limestone in the sample and not all the conodonts occurred in the same layers.

\section{SIGNIFICANCE OF THE CONODONT FAUNA}

The conodont fauna of the Sa'haronim Formation is listed in table 1 , and the occurrence of similar faunas is also shown. Table 2 gives the known ranges of the species listed. Table 2 shows that the conodonts indicate a late Ladinian age for the fauna, which conflicts slightly with the age determined by ostracodes (Sohn, 1968). The conodont age determination is based primarily on the known ranges of Pseudofumishins murcianus and Epigondolella mungoensis. These are the only platform-type conodonts present in the fauna. In general, the bar-type conodonts have longer stratigraphic ranges than the platform conodonts and are, therefore, less useful in age determinations.

The conodont fauna of the Sa'haronim Formation is quite similar to the fauna described by Diebel (1956) from the Cameroons and the Muschelkalk fauna described by Cherchi (1967) from Sardinia (see table 1). Pseudofumishius murcianus has also been reported by Boogaard (1966) from upper Middle Triassic (or lower Upper Triassic?) rocks of southeast Spain. Epi-

TABLE 1.-Number of each species of conodonts and other fossils from localities in Israel and occurrence of these species in other localities [X, species present; cf., compared with]

\begin{tabular}{|c|c|c|c|c|c|c|c|c|c|}
\hline & \multicolumn{5}{|c|}{ Localities in Isracl } & \multicolumn{4}{|c|}{ Other localities } \\
\hline & 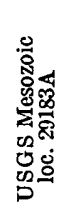 & 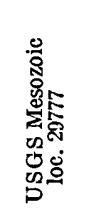 & 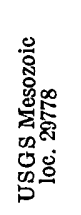 & 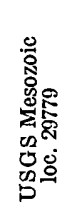 & 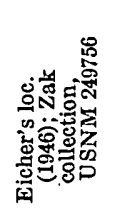 & 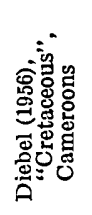 & 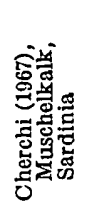 & 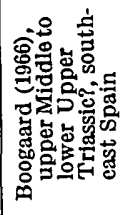 & 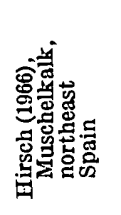 \\
\hline $\begin{array}{l}\text { Conodonts: } \\
\text { Cypridodella spengleri (Huckriede) } \\
\text { Enantiognathus zicgleri (Diebel) } \\
\text { Epigondolclla mungoensis (Diebel) } \\
\text { Hibbardella n. sp. A (Diebel) } \\
\text { Hindeodella? sp. } \\
\text { Ozarkodina toria (Mosher) } \\
\text { "Prioniodella" decrescens Tatge } \\
\text { Prioniodina sp. } \\
\text { Pscudofurnishius mutrcianus Boogaard } \\
\text { Fish remains: } \\
\text { "Acodina" triassica Cherchi. } \\
\text { Nurrella maccagnoac Cherchi. } \\
\text { Iolothuroid sclerite: } \\
\text { Theelia sp. D.? Zankl (1965) }\end{array}$ & $\begin{array}{r}1 \\
3 \\
21 \\
2 \\
3 \\
1 \\
1 \\
1 \\
48 \\
7 \\
1 \\
1\end{array}$ & 45 & $\begin{array}{l}1 \\
2 \\
1\end{array}$ & 3 & - & $\begin{array}{r}x \\
x \\
x \\
x \\
x \\
\text { cf. } \\
x\end{array}$ & $\begin{array}{r}\begin{array}{r}X \\
X\end{array} \\
X \\
X \\
X \\
X\end{array}$ & $\begin{array}{l}-- \\
-- \\
-\cdots \\
-- \\
--\end{array}$ & X \\
\hline
\end{tabular}


TABLE 2.-Ranges of conodont species found in Israel

Anisian Ladinian Carnian Norian

Cypridodella spengleri (Huckriede)

Enantiognathus ziegleri (Diebel)

Epigondolella mungoensis (Diebel)

"Prioniodella" decrescens Tatge

Pseudofurnishius murcianus Boogaard

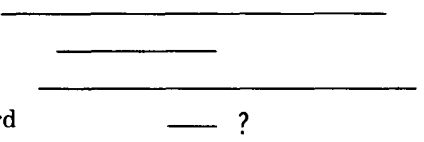

gondolella mungoensis has been reported from the Muschelkalk of Sardinia (Cherchi, 1967), the upper Muschelkalk of Spain (Hirsch, 1966), the late Ladinian of Nevada, and the early Ladinian at Schnann, Austria (Mosher, 1968). Epigondolella mungoensis and Pseudofumishius murcianus have been found in rock dated as Carnian only in Israel, and this may represent an extension of their range. The occurrence of much of the conodont fauna and some of the fish remains in the Muschelkalk, probably Ladinian, in Sardinia, however, suggests a Ladinian age for the lowest part of the limestone-gypsum member of the Sa'haronim Formation.

The close correspondence of the fauna from the Sa'haronim Formation to that reported from the "Cretaceous" of the Cameroons by Diebel (1956) is obvious in table 1, but puzzling. Mosher (1967) has shown that there are several reasons for believing that the fauna reported by Diebel is not Cretaceous. I concur with his analysis. This opinion is reinforced by the presence of the "Cretaceous" fauna in the Triassic of Israel, Sardinia, and Spain, but the interpretation of the "Cameroon" fauna is complicated. It is hard to see how a late Middle (or early Late?) Triassic fauna could be reworked into Cretaceous rocks without the addition of some conodonts of other ages. Perhaps the "Cretaceous" conodonts are from a Triassic pebble or boulder in the Cretaceous rocks of the Cameroons, or perhaps the Cameroon conodonts come from Triassic rocks rather than Cretaceous rocks as reported. Additional data for the Cameroon conodont occurrence is necessary.

Triassic conodont faunas are not yet well enough known to distinguish late Ladinian from early Carnian faunas. Neither Pseudofurnishius murcianus nor Epigondolella mungoensis have been found in rocks of known Carnian Age. However, these forms may have survived into the early Carnian. Therefore the Carnian Age as determined by ostracodes (Sohn, 1968) is accepted here tentatively.

A collection made by Israel Zak, Geological Survey of Israel, at Eicher's locality (1946); Gebel Araif el Naga, Sinai (U.S. National Museum accession No.
249756), contains Epigondolella mungoensis and "Prioniodella" decrescens Tatge. These fossils suggest that Eicher collected from about the same horizon as the collections from the Sa'haronim Formation.

\section{OTHER MICROFOSSILS}

Fish remains and holothuroid sclerites occur in these collections together with conodonts (described herein) and ostracodes (described by Sohn, 1968). Some of the fish remains have been described as conodonts by Cherchi (1967). Two of the forms she described as "Acodina" triassica and Nurrella maccagnoae occur in these collections. The specimens called "Acodina" triassica probably are fish teeth and those called Nurrella maccagnoae are probably dermal denticles or scales. These fish remains are long ranging and not especially helpful in age determination.

\section{TRIASSIC CONODONT PROVINCES}

Huckriede (1958) and Mosher (1968) have recognized a central European Muschelkalk and an Alpine Middle Triassic conodont faunal province, and Mosher (1968) recognized a North American Middle Triassic faunal province. The North American faunal province of Mosher is represented in Spain, Sardinia, Israel, and the Cameroons. It seems to form a faunal province south of the Alpine province. The continuation of the North American faunal province with the Mediterranean is indicated by the common occurrence of Epigondolella mungoensis in the upper Ladinian rocks of both areas. Probably Pseudofumishius murcianus will be found in rocks of late Middle or early Late Triassic age of North Africa, if this speculation proves to be correct. Additional studies of Triassic faunas in the Mediterranean are needed to verify this suggestion.

\section{SYSTEMATIC PALEONTOLOGY}

\section{Conodonta}

\section{Cypridodella spengleri (Huckriede)}

Remarks.-The species is figured and a synonomy is given in Mosher (1968, p. 922). Only one specimen was found in these collections.

\section{Enantiognathus ziegleri (Diebel)}

Figure $2 q$

Remarks.-This well-known species is figured, and its synonomy is given by Mosher (1968, p. 925). It ranges through most of the Triassic and occurs in the Permian. 


\section{Epigondolella mungoensis (Diebel)}

Figure $2 a-h$

1956. Polygnathus mungoensis Diebel, Geologie, v. 5, no. 4-5, p. $431-432$, pl. 1 , flgs. $1-20$, pl. 2 , figs. $1-4$, pl. 3 , fig. 1 , pl. 4 , fig. 1; Huckriede, 1958, Pnlïiont. Zeitschr., v. 32, pl. 14, fig. 23a, b, 24a, b; ?Cherchi, 1967, Riv. Italiana Paleontologiae Stratigrafia, v. 73 , no. 1, p. 220 , pl. 16, figs. 5-17.

1966. Gondolella catalana Hirsch, España Inst. Geol. y Minero Notas y Comun., no. 90, p. 87-90, pl. 1, figs. 1-4.

1968. Epigondolella mungoensis (Diebel). Mosher, Jour. Paleontology, v. 42, no. 4, p. 936-937, pl. 116, flgs. 16-19.

Description.-Plate thin, asymmetrical, bowed laterally, with a variable outline and a tendency to form a second posterior lobe. Oral surface of platform marked by deep troughs flanking the carina, sharp nodes at the outer edges of the anterior part of the plate. Some of the nodes may be high and pointed like denticles. Carina composed of a broken row of nodes, one of which may be larger than the rest and similar to the azygous node of Palmatolepis. The oral surface of the plate appears smooth but often is very finely pustulose especially on the posterior rim. The free blade is highest in the middle and has 3-5 denticles.

Aboral side has a large thick-walled escutcheon filling the area inside the crimp and extending from the free blade to near the posterior tip. Pit beneath the principal node of the carina. A secondary keel is developed on the posterior lobe in a few specimens.

Remarks.-Kurt Diebel kindly sent me topotype specimens of his species Polygnathus mungoensis. A comparison of these specimens with those from Israel shows that they all belong to the same species. The specimens figured by Cherchi (1967, pl. 16, figs. 5-17) appear to lack strong nodes, as pointed out by Mosher $(1968$, p. 937$)$, and therefore are questionably referred to $E$. mungoensis. However, several specimens in my collections also lack the strong pointed nodes, and I am inclined to think that her identification is correct.

Firsch (1966) distinguished Gondolella catalana by its smaller size and less-conspicuous denticles on the margins of the plate. In the latter respect it is like the specimens described by Cherchi. Hirsch's figures are quite similar to topotypes of Polygnathus mungoensis and the specimens from Israel, and I regard $G$. catalana as a junior synonym.

Epigondolella abneptis (Huckriede) is smaller, more symmetrical, and has fewer nodes on the plate margins than E. mungoensis.

Occurrence.-Epigondolella mungoensis has been described from: the "Cretaceous" of the Cameroons (Diebel, 1956); the Middle Triassic, Muschelkalk of Sardinia (Cherchi, 1967) and Spain (Hirsch, 1966); the Middle Triassic, Ladinian, at Schnann, Austria (Mosher, 1968); and the Middle Triassic, Augusta Mountain Formation, New Pass, Nevada (Mosher, 1968).
Mirauta (1963) figured Polygnathus sf. P. mungoensis from rocks of Anisian to Carnian Age at Hagigniol Dobrogea, Roumania. The figure is poor, and the specimen may belong in Epigondolella abneptis. Bender and others (1960) listed Polygnathus aff. P. mungoensis from the Triassic, Anisian to Carnian Age at Theokafta, Greece.

\section{Hibbardella n. sp. A (Diebel)}

Remarks.-This species is probably the same as the one figured by Diebel (1956, pl. 3, figs. 2-3).

\section{Hindeodella? sp.}

Remarks.-Three specimens from USGS Mesozoic loc. $29183 \mathrm{~A}$ are very similar to the specimens figured by Diebel (pl. 6, figs. 3-4). All the specimens are broken, including those figured by Diebel, and the generic assignment is questionable because the anterior bar and cusp are not preserved.

\section{Ozarkodina torta (Mosher)}

1968. Hindeodella torta Mosher, Jour. Paleontology, v. 42, no. 4, p. 929, pl. 114, figs. 11, 12.

Remarks.-The specimens described by Mosher (1968) seem to belong in the same species as the specimens figured by Diebel (1956, pl. 6, figs. 6-10) and the specimen reported herein. The specimens I have studied, including the types of Hindeodella torta, lack the characteristic anterior cusp and incurved anterior bar of Hindeodella. The laterally compressed bar and the subcentral cusp are typical of Ozarkodina, and the species is here referred to this genus.

\section{"Prioniodella" decrescens Tatge}

Figure $2 p$

1968. Prioniodella decrescens Tatge. Mosher, Jour. Paleontology, v. 42 , no. 4 , p. 933, pl. 114, fig. 27 [gives synonomy].

Remarks.-The specimen figured here corresponds very well to the specimen figured by Mosher (1968). Prioniodella is a junior synonym (Huddle, 1968, p. 43) of Prioniodina, and "Prioniodella" decrescens needs a new generic name. I do not have large enough collections to rename the genus and intelligently choose a type species. Some of the Triassic species referred to Prioniodella seem to be broken specimens belonging to species of already named genera.

\section{Prioniodina sp.}

Figure $2 r$

Remarks.-This specimen is broken, but it probably belongs in the genus Prioniodina. 



troses
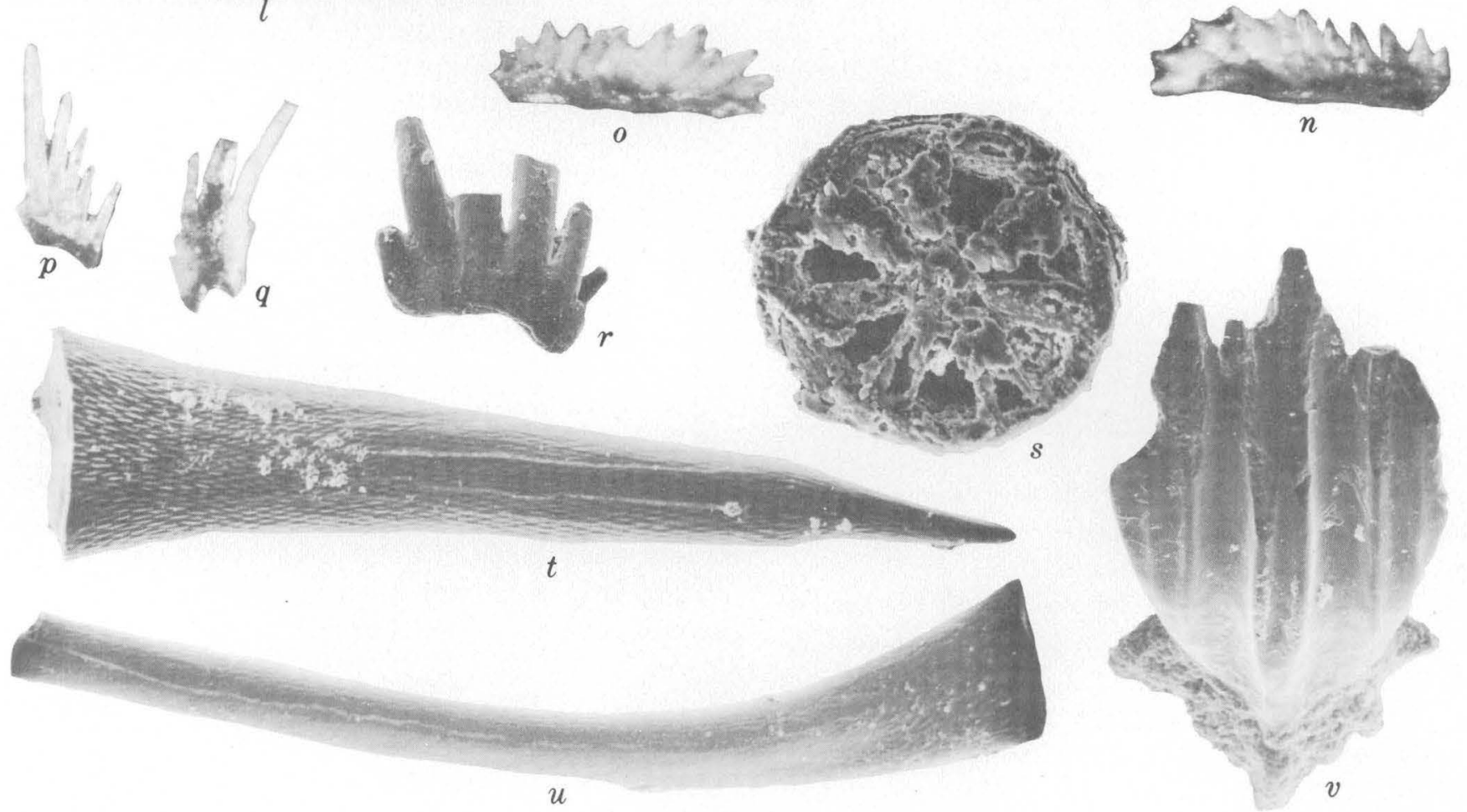


\section{Pseudofurnishius Boogaard}

1966. Pscudofurnishius Boogaard, Koninkl. Nedrlandse Akad. Wetensch. Proc., ser. B, v. 69, no. 5, p. 5-6.

T'ype species.-Pseudofumistius murcianus Boogaard.

Description.-Blade-type conodont, laterally compresed, nearly straight aborally or slightly arched and bowed. Cusp inconspicous, anterior to the platform, denticles flattened, appressed and inclined anteriorly. Posterior inner and outer platforms bearing denticles developed to varying degrees forming a full or partial posterior plate. Base of the platform narrow, and neirly flat. Boogaard oriented the genus with the platform posterior in spite of the inclination of the denticles which suggest the opposite orientation. Diebel (1956) regarded the plate as anterior. Orientation is arbitrary and the plate is here regarded as posterior because Boogaard described the genus with that orientation.

Remarks.-Pseudofumishines differs from Bryantodina (= Spathognathodus) and Bispathodus in the presence of a cusp and in the lack of an expanded escutcheon bearing nodes or denticles on the oral side. Ozarkodina and Bryantodus are similar in appearance to the young specimens of Pseudofurmishine. Polygnathellus differs from Pseudofumishines in having a nondenticulated platform on the inner side only, whereas Nothognathella tends to have the platform de-

Fraune 2.-Triassic microfossils from the Sa'haronim Formation, Isracl, and one "Cretaceous" conodont from the Cameroons. ( $a-d, i-m$, and $r-v$ are electron scan photographs, $\times 120 ; c-h$ and $n-q$ are light photographs of uncoated specimens, $\times 60$.)

$a-h$. Epigondolella mungoensis (Diebel). $a-d, f$, from USGS Mesozoic loc. 29777. $a, f$, oral views of the same hypotype USNM 145913. $b$, oblique view of hypotype USNM 145925. c, aboral view of hypotype, USNM 165204. $d, h$, aboral views of the same hypotype, USNM 165205. c, oblique oral view, USNM 165206, from "Cretaceous", Cameroons: specimen provided by Kurt Diebel. g, oral view, USNM 165207.

i-o. Pseudofurnishius murcianus Boogaard. USGS Mesozoic loc. $29183 \mathrm{~A} . i-k, m$, oral views of hypotypes, USNM 165208-10 and 165212, respectively. $l$, aboral view, hypotype, USNM 165211. n, o, lateral views of hypotypes, USNM 165213 and 165208 (same specimen shown in i).

p. "Prioniodella" decrescens Tatge. Lateral view, hypotype, USNM 165214, USGS Mesozoic loc. 29183A.

q. Enantiognathus ziegleri (Diebel). Lateral view, hypotype, USNM 165215, USGS Mesozoic loc. 29183A

r. Prioniodina sp. Lateral view, USNM 165216, USGS Mesozoic loc. 29183A.

s. Theclia sp. D? Zankl (1965). Holothuroid sclerite, USNM 165217, USGS Mesozoic loc. 29183A

ı,u. "Acodina" triassica Cherchi. USNM 165218, 165219, USGS Mesozoic loc. 29183A. Fish teeth. Note the scaly surfacc texturc.

v. Nurrella maccagnoac Cherchi. USNM 165220, USGS Mesozoic loc. 29183A. Probably the dermal denticle or plate of some fish. veloped the full length of the bar on one or both sides and the denticles are vertical in the carina.

\section{Pseudofurnishius murcianus Boogaard}

Figure 2i-o

1956. Spathognathodus? sp. Diebel, Geologie, v. 5, no. 4-5, p. 432-433, pl. 4, figs. $6,7$.

1966. Pseudofurnishius murcianus Boogaard, Koninkl. Nederlandse Akad. Wetensch., Proc., ser. B, v. 69, no. 5, p. $6-7$, pl. 1, figs. $6-8$, pl. 2 , figs. 1-5.

Description.-Blade-type conodonts with a partly developed posterior plate bearing rounded denticles. Bar straight or slightly arched and laterally bowed. Denticles laterally compressed, closely appressed with the larger and more strongly inclined denticles in the anterior part of the blade. The anterior denticle may be horizontal. Cusp in the anterior third of the blade is slightly longer and broader than other denticles or it may be indistinguishable. The posterior plate ranges in development from a slight oral thickening of the inside of the blade to distinct platforms inside and outside of the bar-bearing rounded denticles which range from half as long to as long as the adjacent blade denticles. The platforms are generally only partly developed, but some extend to the posterior tip on one or both sides of the blade. The platforms develop at the top of the blade at the base of the denticles. The inner platform forms first and the outer develops later; the size of the platforms is partly dependent on the growth stage. On some specimens, two or three denticles are developed in front of the platforms.

The specimens studied ranged in length from 0.47 to $0.64 \mathrm{~mm}$, in height from 0.16 to $0.26 \mathrm{~mm}$, and the platform ranges in width from 0.0 to $0.11 \mathrm{~mm}$. Apparently the bar quickly grows to adult length and later growth increases the height and develops the platforms. The smallest specimens found show a thickening of the blade along the oral edge.

Aboral surface consists of a thick-walled elongate escutcheon extending the length of the blade and deepest below the cusp.

Right- and left-hand forms are present in the collections. The collection from USGS Mesozoic loc. $29183 \mathrm{~A}$ contained 23 specimens with two platforms, 19 with the platform only on the inside, and six with only a thickening at the top of the blade. The collection from USGS Mesozoic loc. 29777 contained 19 specimens with two platforms, 21 with an inner platform, and three with no platform. No difference in the length or height correlates with the presence of one or two platforms. This suggests that during growth, the mature length and height are almost reached before the platforms start to develop. 
Occurrence.- $P$. murcianus has been reported from the "Cretaceous" of the Cameroons, rocks of Ladinian or Carnian Age in southeastern Spain, and the Sa'haronim Formation of Israel.

\section{FISH REMAINS}

\section{"Acodina" triassica Cherchi}

Figure $2 t, u$

1967. Acodina triassica Cherchi, Riv. Italiana Paleontologia e Stratigrafia, v. 73 , no. 1, p. 214, pl. 14, figs. 9-18, pl. 18, figs. $1-12$, pl. 19 , figs. $1-14$, pl. 20 , figs. $1-7$, pl. 25 , fig. $1($ ?).

Remarks.-Two types of fish teeth are included, as conodonts, in this species by Cherchi (1967). The first type is illustrated here and by her on plate 14, figures 9,10 , and 14 , plate 18 , figures 9 and 10 , and plate 20 , figures 1-6. The second type has clear material in the tips and is shown by her on plate 14, figures 11-13, 15, 17 , and 18 , plate 18 , figures $1-8,11$, and 12 , plate 19 , figures 1-14, and plate 20, figure 7 . These two types both have a very fine scaly textured surface, common on fish teeth, and have the internal structure of teeth rather than laminated conodont structure. These forms have a long range and are not well enough known to be useful in dating.

\section{Nurrella maccagnoae Cherchi}

Figure $2 v$

1967. Nurrella maccagnoae Cherchi, Riv. Italiana Paleontologia e Stratigrafia, v. 73 , no. 1 , p. $238-239$, pl. 13, fig. 7 , pl. 23, figs. 17-22.

Remarks.-The specimens from Israel agree well with the specimens shown by Cherchi (1967). This species also lacks the laminated structure of true conodonts. It probably represents the dermal denticle of some fish, rather than conodonts.

\section{REFERENCES}

Bender, Hans, Hirschberg, K., Leuteritz, K., and Mänz, H., 1960, Zur Geologie der Olonos-Pindos und der Parnass-Kionazone im Tal des Asklepieion (Argolis) : Annales Géol. Pay Helléniques, v. 11, p. 201-213.

Boogaard, Marinus, van den, 1966, Post-Carboniferous conodonts from southeastern Spain: Koninkl Nederlandse Akad. Wetensch. Proc., ser. B, v. 69, no. 5, p. 1-8, 2 pls., 1 table.

Cherchi, A. P., 1967, I conodonti del Muschelkalk della Nurra (Sardegna nord-occidentale): Riv. Italiana Paleontologia e Stratigrafia, v. 73, no. 1, p. 205-272, pls. 12-25.

Diebel, Kurt, 1956, Conodonten in der oberkriede von Kameron: Geologie, v. 5 , no. $4-5$, p. $424-450$, pls. 1-6.

Eicher, D. B., 1946, Conodonts from the Triassic of Sinai (Egypt) : Am. Assoc. Petroleum Geologists Bull., v. 30, no. 4, p. 613-616.

Hirsch, Francis, 1966, Sobre la presencia de conodontes en el Muschelkalk Superior de los Catalanides: España Inst. Geol. y Minero Notas y Comun., no. 90, p. 85-92, 1 pl.

Huckriede, Reinhold, 1958, Die Conodonten der mediterranen Trias und ihr stratigraphischer Wert: Paläont. Zeitschr., v. 32 , no. $3-4$, p. 141-175, tables 10-14.

Huddle, J. W., 1968, Redescription of Upper Devonian Conodont genera and species proposed by Ulrich and Bassler in 1926: U.S. Geol. Survey Prof. Paper 578, 55 p., 17 pls.

Mirauta, Elena, 1963, Asupra prezentei uncor conodonte in triasicul de la Hugighiol (Dobrogea) : Acad. Romine Studii şi Cercetari Geologie, Geofizica Geografie, Ser. Geologie, v. 8, no. 4, p. 489-498, 10 figs.

Mosher, L. C., 1967, Are there post-Triassic conodonts?: Jour. Paleontology, v. 41 , no. 6 , p. 1554-1555.

- 1968, Triassic conodonts from western North America and Europe and their correlation: Jour. Paleontology, v. 42 , no. 4 , p. $895-946,5$ pls.

Sohn, I. G., 1968, Triassic ostracodes from Makhtest Ramon, Israel : Israel Geol. Surrey Bull. 44, 71 p., 4 pls.

Sohn, I. G., and Reiss, Zeev, 1964, Conodonts and foraminifera from the Triassic of Israel: Nature, v. 201, no. 4925, p. 1209.

Tatge, Ursula, 1956, Conodonten aus dem germanischen Muschelkalk: Paläont. Zeitschr., v. 30, p. 108-127, 129-147, pls. 5,6 .

Zankl, Heinrich, 1965, Zur mikrofaunistischen Charakteristik des Dachsteinkalkes (Nor/Rät) mit Hilfe einor Lösung. stechnik: Geol. Bundesanst. Verh., Sonderheft G, p. 293$311,3 \mathrm{pls}$ 


\title{
MIDDLE PLEISTOCENE LEPORIDAE FROM THE SAN PEDRO VALLEY, ARIZONA
}

\author{
By JOE S. DOWNEY, Grand Forks, N. Dak.
}

\begin{abstract}
The Curtis Ranch local fauna from near the town of St. David, Ariz, in the San Pedro valley, contains fossil leporid material assignable to the genera Aluralagus and Lepus. A new species is described that appears to be related to Aluralagus bensonensis of the Benson local fauna.
\end{abstract}

The Pliocene and Pleistocene nonmarine sedimentary sequence in the San Pedro River valley of southern Arizona (fig. 1) has been the source of a large number of fossil vertebrate specimens for many years. The fossil assemblages collected there by field parties

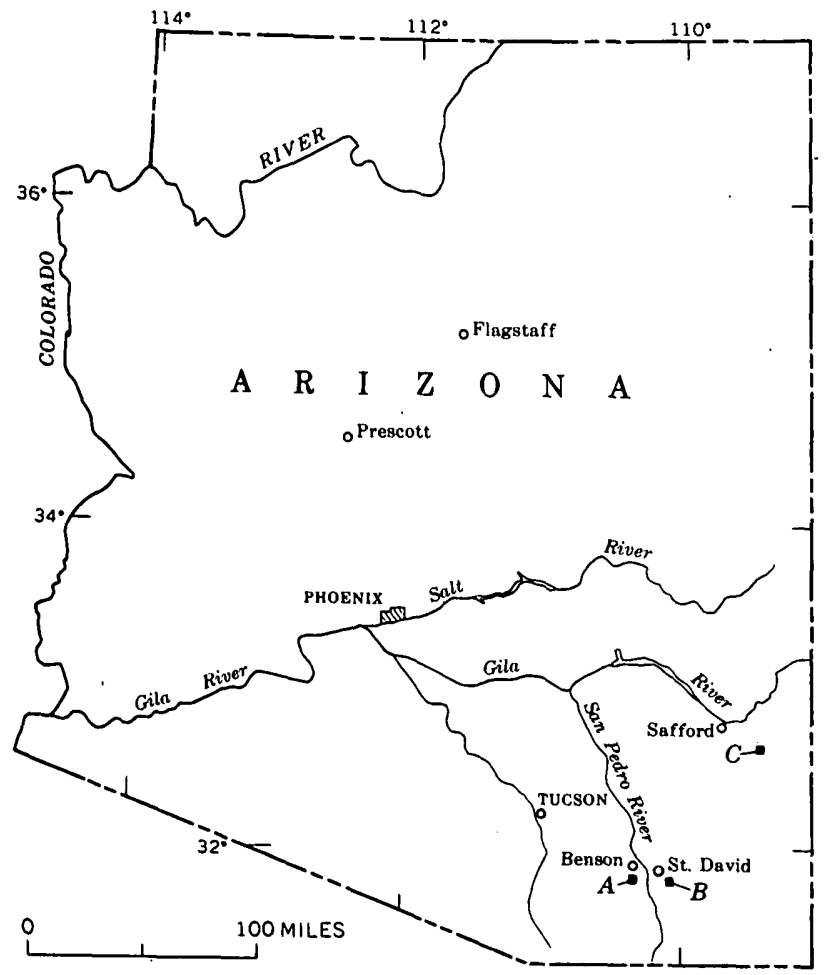

Fraure 1.-Index map of Arizona, showing fossil lagomorph localities. $A$, Benson; $B$, Curtis Ranch; and $C$, Tusker. from various institutions throughout the United States have come to be of considerable significance to biostratigraphers and vertebrate paleontologists working with Pleistocene faunas (Gazin, 1942; Hibbard, 1949). During the past several years these deposits have yielded a large quantity of fossil material to collectors from the University of Arizona at Tucson.

Previous studies in the San Pedro valley have dealt with the physiography and geomorphology (Bryan, 1926; Gilluly, 1956 ; Melton, 1960), vertebrate paleontology (Gidley, 1922, 1926; Gazin, 1942; Downey, 1968), and plant ecology (Zimmermann, 1969). Zimmermann's paper contains a recent list of references to the literature on the geology of the San Pedro valley.

Recent work by Gray (1967) in the valley has shown that the exposed deposits are a continuous succession of lacustrine and fluviatile sediments deposited by a large, low-velocity stream that spread the sediments upon an aggrading flood plain. The vertebrate fauna collected from the sediments suggests that a savanna-grasslands environment existed in the San Pedro valley during the period of deposition.

This succession of fine-grained sediments-composed mainly of silt, clay, fine sand, and fresh-water limestone with minor interbedded pyroclastic units-constitutes a distinct lithologic unit, and the name St. David Formation was proposed by Gray (1967). His work also indicated that the known fossil-producing sites in the San Pedro valley are near the top of the sedimentary sequence.

Two general areas, both near the south end of the San Pedro valley, have been particularly productive in regard to fossil material, and the one near the town of St. David, Ariz., is the source of the fossil specimens described in this report.

This locality, termed the Curtis Ranch locality by Gazin (1942) is on the east side of the valley and ap- 
proximately 5.7 miles southeast of the town of St. David, Ariz., in the NW1/4 sec. 25, T. 18 S., R. 21 E., Gila and Salt River base line and meridian. Several sites within this area yield fossil material, and most of these sites have been worked in the past (Gazin, 1942; Lance, 1960).

The other fossil-producing site in the San Pedro valley is located on the west side of the valley approximately 2 miles south of the town of Benson in the SE $1 / 4$ sec. 21, T. 17 S., R. 20 E. This area has also produced a large quantity of fossil material (Gidley, 1922; Gazin, 1942). The fossil leporid material recovered from the Benson locality was the subject of an earlier report by the author (Downey, 1968).

A full description of both fossil localities, as well as photographs of the Curtis Ranch site, is given by Gazin (1942). Additional information and a brief description of both localities, together with data concerning the geology of the area, are given in Gray's (1967) work.

Two genera of fossil leporids are recognized in this new material from the Curtis Ranch locality-one of which is referred to the genus Aluralagus Downey (1968). The genus Lepus is present in the fauna.

The genus Lepus does not occur in faunas older than late Blancan (Hibbard, 1958; Dawson, 1958). The occurrence of Lepus in the fauna suggests a late Blancan or later age for the Curtis Ranch local fauna.

In general, the fossil leporid material from the Curtis Ranch local fauna consists of isolated teeth and fragmentary maxillary specimens. The material is well preserved and easily cleaned for study.

Except as noted, all material referred to in this report is a part of the paleontological collection of the University of Arizona at Tucson. A full description and the location, keyed to locality numbers, of each known fossil-producing site in the San Pedro valley are given in the paleontological records of the University of Arizona.

Drawings and a photograph of the fossil material described are shown in figures 3 and 4 and the dimensions are given in table 1 . Terms used to describe features found on the occlusal surface of the lower third premolar of leporids are shown in figure 2.

Acknowledgments.-I am indebted to Dr. John F. Lance for loan (Contribution 188 in the program in geochronology of the Geochronology Laboratory, University of Arizona, Tucson) of the fossil leporid material described in this report and for his encouragement and help in my study of fossil leporids. I would also like to thank Dr. Claude W. Hibbard, of the Museum of Paleontology, University of Michigan; Dr. George Lammers, of the Manitoba Museum of Man and
TABLE 1.-Dimensions of the cheek teeth of fossil leporids from the Curtis Ranch local fauna, San Pedro valley, Arizona

\begin{tabular}{|c|c|c|c|c|}
\hline \multirow{2}{*}{ Specimen a } & \multirow{2}{*}{$\begin{array}{l}\text { Tooth } \\
\text { type }\end{array}$} & \multirow[b]{2}{*}{ Species } & \multicolumn{2}{|c|}{$\begin{array}{c}\text { Dimensions (milli- } \\
\text { meters) }\end{array}$} \\
\hline & & & $\begin{array}{l}\text { Antero- } \\
\text { posterior }\end{array}$ & $\begin{array}{c}\text { Trans- } \\
\text { verse }\end{array}$ \\
\hline UA $1372 \ldots$ & $\mathrm{LP}_{3}$ & Aluralagus virginiae & 2. 75 & 2. 48 \\
\hline UA 1373. & $\mathrm{LLI}_{1}$ & -...-. do_ & 2. 74 & 2. 25 \\
\hline & $\mathrm{LP}_{3}$ & -.....do_- & 3. 10 & 2. 50 \\
\hline UA 1374_. & $\begin{array}{l}\mathrm{LP}_{4} \\
\mathrm{RP}^{2}\end{array}$ & Lepus near L. californicus.- & $\begin{array}{l}2.50 \\
2.00\end{array}$ & $\begin{array}{l}2.80 \\
3.60\end{array}$ \\
\hline B 100 & $\mathrm{RP}^{3}$ & . . & 2. 40 & 4. 20 \\
\hline & $\mathrm{RP}^{4}$ & ...... do_. & 2. 40 & 4. 10 \\
\hline & $\mathrm{RM}^{1}$ & -...- do & 2. 30 & 4. 00 \\
\hline & $\mathrm{RM}^{2}$ & $\ldots$. do_. $_{-}$ & 2. 20 & 3. 90 \\
\hline UA $1375 .$. & $\mathrm{LP}_{3}$ & do_ & 3. 50 & 3. 15 \\
\hline & $\mathrm{LP}_{4}$ & - do & 3. 25 & 3. 50 \\
\hline UA $1376 \ldots$ & $\mathrm{RP}_{2}$ & Aluralagus? virginiae & 1. 10 & 2.51 \\
\hline & $\begin{array}{l}\mathrm{RP}_{3} \\
\mathrm{RP}_{4}\end{array}$ & (..... do do & $\begin{array}{l}\text { 1. } 50 \\
1.51\end{array}$ & $\begin{array}{l}\text { 3. } 00 \\
\text { 3. } 00\end{array}$ \\
\hline & $\mathrm{RM}_{1}$ & - ndo do & 1. 51 & 3. 00 \\
\hline & $\mathrm{RM}^{2}$ & do & 1. 50 & 3.45 \\
\hline UA 1377_- & $\mathrm{LP}_{3}$ & Lepus near $L$. californicus_-- & 1. 50 & 1. 50 \\
\hline & $\mathrm{LP}_{3}{ }^{\mathrm{a}}$ & . do & $\begin{array}{l}2.75 \\
1.75\end{array}$ & 2. 00 \\
\hline & $\mathrm{LM}$ & - & 1. 73 & 1. 60 \\
\hline UA 1378 & $\mathrm{LP}_{3}$ & Aluralagus virginiae & 2. 50 & 2. 10 \\
\hline UA 1379.. & $\mathrm{RP}_{3}$ & ar L. californicu & 2. 60 & 2. 48 \\
\hline UA 1382.. & LP & Aluralagus virginiae & 2. 60 & 2. 75 \\
\hline UA 1583 & $\mathrm{RP}_{3}$ & dond & 2. 30 & 2.00 \\
\hline
\end{tabular}

a University of Arizona specimen numbers.

$\mathrm{b}$ Measurement at base of tooth.

Nature, Winnipeg; Dr. Mary R. Dawson, Carnegie Museum, Pittsburgh; and Dr. G. Edward Lewis, U.S. Geological Survey, for reading the manuscript and offering valuable suggestions.

\section{SYSTEMATIC DESCRIPTIONS}

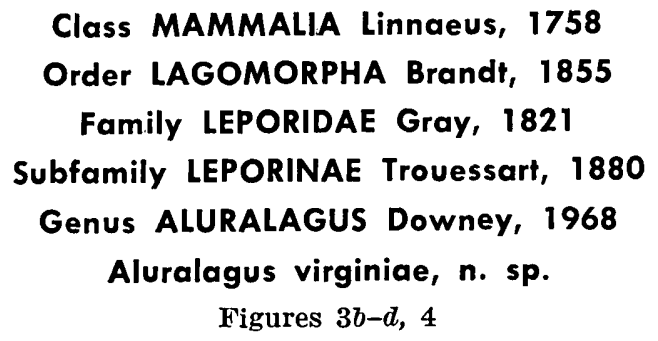

Holotype.-Incomplete left lower jaw with $\mathrm{P}_{3}$, specimen UA 1382 from locality 25-2. Curtis Ranch local fauna.

Paratypes.-Incomplete left lower jaw with $\mathrm{P}_{3}$ and $\mathrm{P}_{4}$, UA 1372. An isolated left $\mathrm{P}_{3}$, UA 1378. Both from UA locality 25-2.

Geologic age and distribution.-Curtis Ranch local fauna. Middle Pleistocene of southern Arizona.

Specific characters.-Lower $\mathrm{P}_{3}$ with deep and complex : posterior external enamel reentrant extending almost to the lingual wall of the tooth. Anterior external reentrant of lower $P_{3}$ crenulated and crosses almost one-fourth of the occlusal surface. The posterior external enamel reentrant of lower $\mathrm{P}_{3}$ displays two folds on 


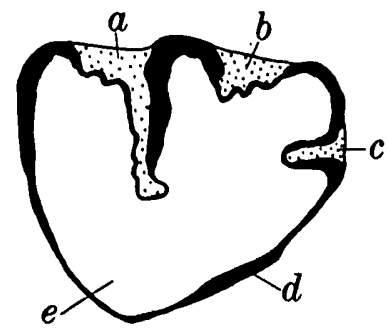

\begin{abstract}
Fiaure 2.-Principal features of the occlusal surface of the lower third premolar of leporids. $a$, posterior external enamel reentrant; $b$, anterior external enamel reentrant; $c$, anterior fold ; $d$, enamel wall of tooth; and $c$, dentine. Dotted area is cement. Lower left premolar used for illustration.
\end{abstract}

the anterior border that extend into the anterior column of the tooth. Anterior enamel fold absent on lower $P_{3}$. Two mental foramina are present on the anterior portion of the lower jaw. One mental foramen is located directly in front of $\mathrm{P}_{3}$ on the dorsal surface of the jaw, and the second mental foramen is located on the dorsal-lateral surface slightly to the anterior of lower $P_{3}$. All reentrants on $P_{3}$ and $P_{4}$ are cement filled. Swelling of the bone over the incisor extends on the medial surface of the lower jaw to below the trigonid of $\mathbf{P}_{3}$. Size near that of Aluralagus bensonensis.

Comparison.-Aluralagus virginiae differs from the species of Lepus, Sylvilagus, and Nekrolagus in that the lower $\mathrm{P}_{3}$ of $A$. virginiae does not display the anterior enamel reentrant on lower $P_{3}$ that is characteristic of the lower $P_{3}$ of these genera. The posterior external enamel reentrant of lower $P_{3}$ is directed more anteriorly in $A$. virginiae than in the same tooth of Lepus, Sylvilagus, or Nekrolagus. In addition, the anterior external enamel reentrant on lower $\mathrm{P}_{3}$ of $A$. virginiae is deeper and more complex than that in Lepus, Sylvilagus, or Nekrolagus.

Aluralagus virginiae differs from $A$. bensonensis (Gazin) of the late Pliocene Benson local fauna (Gazin, 1942; Downey, 1968) and Pratilepus kansasensis Hibbard $(1939,1941)$ of the Pliocene Rexroad local fauna by not showing on lower $\mathrm{P}_{3}$ an internal enamel lake or fold. In addition, the anterior and posterior external enamel reentrants of lower $\mathrm{P}_{3}$ in $A$. virginiae are not as complex as found in $A$. bensonensis or $P$. kansasensis.

Aluralagus virginiae displays a well-developed secondary mental foramen ( $b$, in fig. 4 ) located on the lower jaw in front of and at the base of lower $\mathrm{P}_{3}$ that is not present on the lower jaws of Lepus, Sylvilagus, and Nekrolagus. This foramen is not present on the lower jaws of $A$. bensonensis.

Aluralagus virginiae differs from Brachylagus idahoensis, the Pygmy rabbit of the Western United States, in that the posterior external enamel reentrant of lower $\mathrm{P}_{3}$ in $A$. virginiae extends almost across the occlusal surface to the interior enamel wall, but does not join with the enamel wall to form an anterior and posterior enamel column separated by a cement tract as does the posterior enamel reentrant on the lower $P_{3}$ in B. idahoensis.

Romerolagus diazi, the Volcano rabbit, which occurs today as an isolated population in the highlands of central Mexico, displays features on lower $\mathrm{P}_{3}$ that are similar in many respects to what is found on the same tooth of $A$. virginiae, such as the continuous anterior enamel wall of the anterior column. $R$. diazi differs from $A$. virginiae in that the lower $\mathrm{P}_{3}$ of $R$. diazi shows a persistent enamel lake on the occlusal surface that does not occur on the same tooth of $A$. virginiae. In addition, the anterior external enamel reentrant of lower $\mathrm{P}_{3}$ in $A$. virginiae is deeper and more complex than that displayed by specimens of $R$. diazi.

Discussion.-The affinities of $A$. virginiae appear to be with the group of leporids within the subfamily Leporinae that are characterized by the absence of an anterior enamel fold and the presence of a deep posterior external enamel reentrant on lower $P_{3}$. The presence or absence of an anterior enamel fold on lower $\mathrm{P}_{3}$ appears to be a valid taxonomic character in Pliocene and Pleistocene leporids and may be used to differentiate fossil specimens of Lepus, Sylvilagus, and Nekrolagus from the genera Aluralagus and Pratilepus.

A. virginiae must have been derived from an earlier stock that displayed structures on lower $\mathrm{P}_{3}$ that could produce the deep, complex posterior external enamel reentrant and the shallower crenulated anterior external enamel reentrant.

The lower $\mathrm{P}_{3}$ of $A$. bensonensis (Gazin) from the late Pliocene Benson fauna shows features on the occlusal surface from which the pattern on $\mathrm{P}_{3}$ displayed by $A$. virginiae could have been derived, such as a deep complex posterior enamel reentrant and a crenulated anterior external reentrant. $A$. bensonensis is considered to have been the ancestral stock from which the population of $A$. virginiae was derived.

Aluralagus bensonensis is considered to be an advanced form of Pratilepus kansasensis Hibbard (Downey, 1968, p. D172), a fossil leporid found in the Pliocene Rexroad local fauna of Kansas. The differences between the two genera are similar to those that have been noted to have occurred in the Nekrolagus-Lepus 


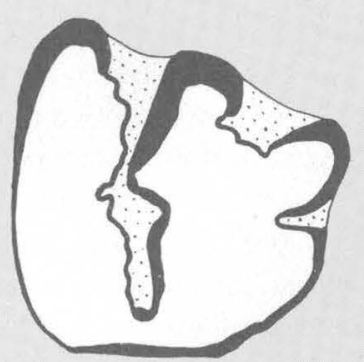

$a$

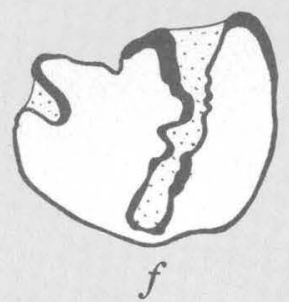

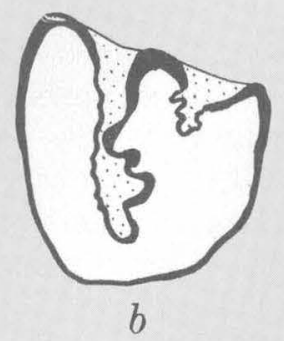
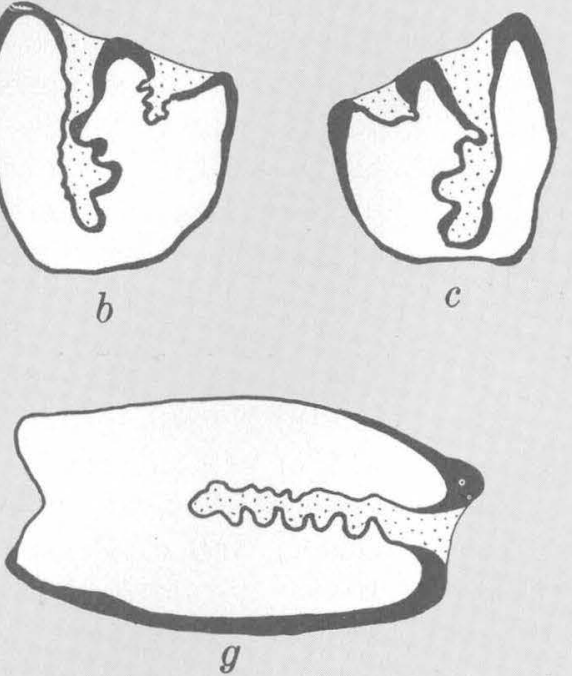

EXPLANATION

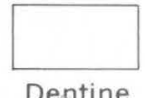

Dentine

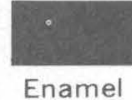

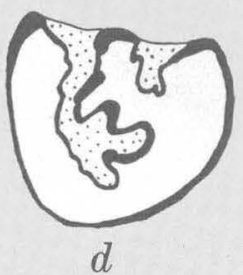

d

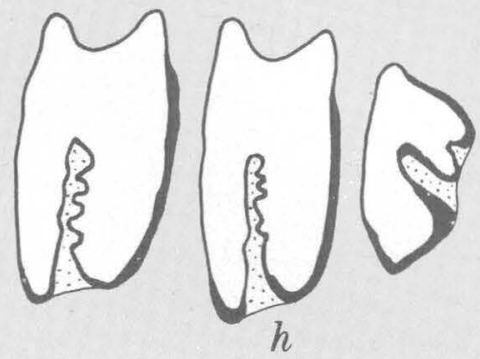

RE 3.-Enamel patterns of the cheek teeth of the various genera and species of lagomorphs from the Curtis Ranch local fauna, $a$, Lepus near L. californicus, $\mathrm{LP}_{3}$, University of Arizona specimen UA 1375 ; $b$, Aluralagus virginiae, LP, type specimen, UA 1382 ; c, Aluralagus virginiae, $\mathrm{LP}_{3}, \mathrm{UA} 1372$, enamel pattern at base of tooth; d, Aluralagus virginiae, $\mathrm{LP}_{3}$, UA 1378; $e$, Lepus near $L$. californicus, $\mathrm{RP}^{2}$, UA $1374 ; f$, Lepus near $L$. californicus, RP. UA 1379 , juvenile; g, Lepus near L. californicus, $\mathrm{RP}^{4}$, UA 1374 ; and $h$ Aluralagus? virginiae, $\mathrm{RP}^{2}, \mathrm{RP}^{3}$, $\mathrm{RP}^{4}$, UA 1376 . Enamel patterns are approximately $\times 10$.

line of descent (Downey, 1968; Hibbard, 1963), namely, the joining of the posterior external enamel reentrant on lower $\mathrm{P}_{3}$ with an internal enamel lake or fold, thus forming a deep enamel reentrant that crosses nearly the entire occlusal surface of the tooth. The lower $\mathrm{P}_{3}$ of $A$. virginiae appears to display features indicating the continued development of this process through time.

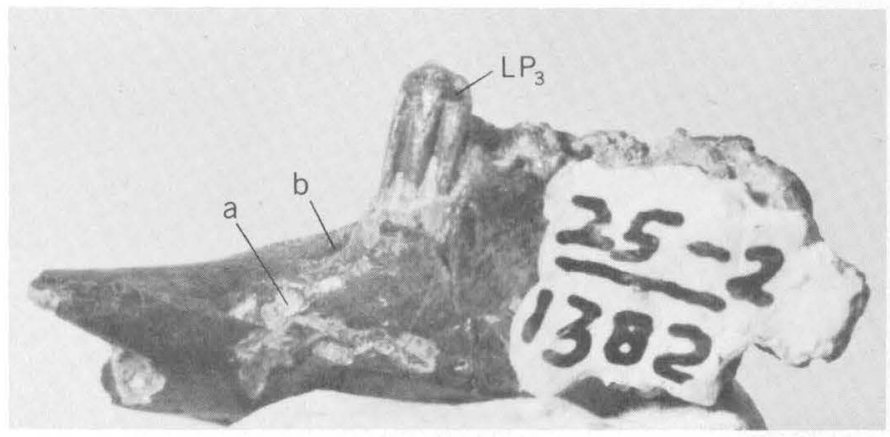

Figure 4,-Lower left jaw of Aluralagus virginiae from the Curtis Ranch local fauna. Type specimen, University of Arizona UA 1382. $a$, mental foramen; and $b$, secondary mental foramen described in text. Approximately $\times 3.9$.
In A. virginiae the posterior enamel wall of the posterior external reentrant of the lower $\mathrm{P}_{3}$ has become less complex when compared with the same feature of $A$. bensonensis, and the anterior enamel wall of the posterior reentrant of lower $\mathrm{P}_{3}$ developed two broad folds into the anterior column of the tooth.

\section{Genus ALURALAGUS?}

\section{Aluralagus? virginiae}

Figure $3 h$

One specimen, an upper right jaw fragment with $\mathrm{P}^{2}, \mathrm{P}^{3}$, and $\mathrm{P}^{4}$, UA 1376, from the Curtis Ranch local fauna is tentatively assigned to the genus Aluralagus. This assignment is based on the enamel pattern of the upper $\mathrm{P}^{2}$, which displays one well-developed anterior enamel reentrant and a shallow anterior enamel groove on the occlusal surface. The upper $\mathrm{P}^{2}$ from the Curtis Ranch fauna resembles in general shape the upper $\mathrm{P}^{2}$ of Pratilepus vagus from the Hagerman local fauna of Idaho (Hibbard, 1969, fig. 3e).

When first described the genus Pratilepus was thought to display three anterior enamel folds on the 
anterior face of upper $\mathrm{P}^{2}$ (Hibbard, 1939, p. 506); however, recent work by Hibbard (1969) has shown that Pratilepus vagus from the Hagerman local fauna displays only one anterior enamel fold on the anterior face of upper $\mathrm{P}^{2}$. It is quite possible that this feature is characteristic of all species of the genus Pratilepus.

The genus Pratilepus is considered to be the ancestral stock from which the genus Aluralagus was derived (Downey, 1968). In view of this derivation, the genus Aluralagus would be expected to display features on the occlusal surface of the upper $\mathrm{P}^{2}$ that are similar to those found on the same tooth of the genus Pratilepus, and the upper $\mathrm{P}^{2}$ originally assigned to the genus Aluralagus (Downey, 1968, fig. 2c) may be from a species of Nekrolagus.

It should be noted that the genus Hypolagus also has an upper $\mathrm{P}^{2}$ with one enamel reentrant on the occlusal surface, and separation of isolated $\mathrm{P}^{2}$ 's of Pratilepus and Aluralagus from Hypolagus is somewhat difficult where they occur together in the same fauna. Lower $P_{3}$ 's with an enamel pattern similar to that displayed by the genus Hypolagus are absent in material collected from the Curtis Ranch area; however, Hypolagus does occur in the nearby middle Pleistocene Tusker local fauna from the Safford valley (Downey, 1962; Wood, 1963).

The upper second premolar assigned to the genus Aluralagus from the Curtis Ranch local fauna is similar in size to the upper $\mathrm{P}^{2}$ 's assigned to Hypolagus from the Tusker fauna; however, the $\mathrm{P}^{2}$. from the Curtis Ranch fauna displays a deeper anterior enamel fold on the anterior surface than what is found in the Tusker Hypolagus. In addition, the enamel reentrants of premolars $\mathrm{P}^{3}$ and $\mathrm{P}^{4}$ are crenulated in the Curtis Ranch material, whereas the material assigned to Hypolagus collected from the Tusker site (Downey, 1962, fig. $1 n$ ) did not show crenulations at any stage of wear.

\section{Genus LEPUS Linnaeus, 1758}

\section{Lepus near L. californicus Gray \\ Figures $3 a, e-g$}

A portion of the fossil material collected at the Curtis Ranch locality represents a large hare similar to the modern form Lepus californicus common in the Southwest.

The specimens, a left $\mathrm{P}_{3}$, UA 1375 ; right $\mathrm{P}_{3}$, UA 1379 ; an upper right jaw fragment with $\mathrm{P}^{2}-\mathrm{M}^{2}$, UA 137.4; and a lower left jaw fragment with $\mathrm{P}_{3}-\mathrm{M}_{1}$ UA 1377 , were collected from the sediments in which $A$. virginiae occurs. From the general structure and enamel pattern of the cheek teeth, a form very close to $L$. califormicus is suggested.
The posteroexternal enamel reentrant of lower $P_{3}$ in both specimens crosses the occlusal surface of the tooth almost to the lingual wall. Both specimens also show a persistent anterior enamel fold on lower $P_{3}$.

A species near Lepus californicus occurs in the middle Pleistocene Tusker local fauna (fig. 1) from near Safford, Ariz. (Downey, 1962; Wood, 1963). The Tusker Lepus is similar in many respects to the material assigned to Lepus from the Curtis Ranch fauna; however, the posterior external reentrant on lower $\mathrm{P}_{3}$ of the Tusker form is somewhat more complex. The forward projecting enamel fold on the posteroexternal reentrant of lower $P_{3}$ is less pronounced on the material assigned to Lepus from the Curtis Ranch fauna.

Comparison of the Curtis Ranch specimens with specimens of Lepus califomicus shows the Curtis Ranch form to be in the same size range, and the configuration of the enamel patterns displayed by both the lower $\mathrm{P}_{3}$ 's and the upper $\mathrm{P}^{2}$ assigned to Lepus definitely verifies the generic assignment of this material.

\section{REFERENCES}

Bryan, Kirk, 1926, San Pedro Valley, Arizona, and the geographic cycle [abs.]: Geol. Soc. America Bull., v. 37, p. 169-170.

Dawson, M. R., 1958, Later Tertiary Leporidae of North America: Univ. Kansas Paleont. Contr., Vertebrata, art. 6, p. 1-75.

Downey, J. S., 1962, Leporidae of the Tusker local fauna from southeastern Arizona: Jour. Paleontology, v. 36, no. 5, p. 1112-1115.

1968, Late Pliocene Lagomorphs of the San Pedro valley, Arizona, in Geological Survey Research 1968: U.S. Geol. Survey Prof. Paper 600-D, p. D169-D173.

Gazin, C. L., 1942, The late. Cenozoic vertebrate faunas from the San Pedro valley, Arizona: U.S. Natl: Mus., Proc., v. 92, no. 3155, p. 475-517.

Gidley, J. W., 1922, Preliminary report on fossil vertebrates of the San Pedro valley, Arizona, with descriptions of new species of Rodentia and Lagomorpha: U.S. Geol. Survey Prof. Paper 131-E, p. 119-131.

1926, Fossil Proboscidea and Edentata of the San Pedro valley, Arizona: U.S. Geol. Survey Prof. Paper 140-B, p. 83-94.

Gilluly, James, 1956, General geology of central Cochise County, Arizona: U.S. Geol. Survey Prof. Paper 281, 169 p.

Gray, R. S., 1967, Petrography of the upper Cenozoic nonmarine sediments in the San Pedro valley, Arizona: Jour. Sed. Petrology, v. 37, no. 3, p. 774-789.

Hibbard, C. W., 1939, Four new rabbits from the upper Pliocene of Kansas: Am. Midland Naturalist, v. 21, no. 2, p. 506-513.

- 1941, Mammals of the Rexroad fauna from the upper Pliocene of southwestern Kansas: Kansas Acad. Sci. Trans., v. 44, p. $265-313$.

1949, Pleistocene vertebrate paleontology in North Amer. ica : Geol. Soc. America Bull., v. 60, p. 1417-1428.

- 1958, Summary of North American Pleistocene mammalian local faunas :: Michigan Acad. Sci. Papers, v. 44, p. 332. 
1963. The origin of the $P_{3}$ pattern of Sylvilagus, Caprolagus, Oryctolagus, and Lepus: Jour. Mammalogy, v. 44, no. 1, p. 1-15.

1969, The rabbits (Hypolagus and Pratilepus) from the upper Pliocene, Hagerman local fauna of Idaho: Michigan Academician, v. 1, nos. 1 and 2, p. 81-97.

Lance, J. F., 1960, Stratigraphic and structural position of Cenozoic fossil localities in Arizona: Arizona Geol. Soc. Digest, v. 3, p. 155-159.
Melton, M. A., 1960, Origin of the drainage and geomorphic history of southeastern Arizona: Arizona Univ., Arid Lands Colloquia, p. 8-16.

Wood, P. A., 1963, Pleistocene fauna from the 111 Ranch area, Graham County, Arizona: Univ. Arizona, unpub. Ph.D. thesis, $121 \mathrm{p}$.

Zimmermann, R. C., 1969, Plant ecology of an arid basin, Tres Alamos-Redington area southeastern Arizona: U.S. Geol. Survey Prof. Paper 485-D, 51 p. 


\title{
NEW DISCOVERIES OF PLEISTOCENE BISONS AND PECCARIES IN COLORADO
}

\author{
By G. EDWARD LEWIS, Denver, Colo.
}

\begin{abstract}
Three taxa of mammals are recorded from Colorado: Bison (Gigantobison) latifrons from Sangamon deposits of the Cunon City area; Bison (Simobison) ? alleni? from lower Wisconsin deposits of the Denver area; and Platygonus comprcssus from upper Wisconsin deposits in Denver.
\end{abstract}

O. P. Fay in 1924 (p. 275) published the thenknown Pleistocene fauna of Colorado: "Mylodon harlani, Elephas columbi, E. imiperator, Mammut americanum, Equus complicatus, E. laurentius, Camelops huerfanensis, Ovibos? sp. indet., Bison bison?, B. sp. extinct, Naemorhedus palmeri." This last genus and species, from Cragin (1900), should be removed from the list. Cragin based the species on an incomplete humerus and an incomplete metacarpus, both immature, from a cave near Colorado Springs. Cragin's figure, without scale, suggests domestic goat or sheep, but he made no comparisons with Capra or Ovis, and gave no measurements.

Few additions to Hay's list have been recorded since that time. Cook (1930, p. 68) reported seeing a a molar tooth of a very large fossil bison, of the size found in the immense B. latifrons $*$ in association with Elcphas ef. columbi * [from] the mountains between Gunnison and Montrose, Colorado $"$ ". The father of the young man who " discovered the bones assured the writer that the large bison horns le found there were longer than, but not quite so robust as, an immense set of Bison latifrons horns now in the Colorado Museum of Natural History, Denver, which were found in the early Pleistocene of Nebraska.

Neither illustrations nor measurements were published because Cook himself had not seen the "horns" (he meant horn cores). In their work on Bison, Skinner and Kaisen (1947) did not record these specimens.

Now, two fragmentary horn cores of giant bison have been found in Colorado. They confirm, in documented form, Cook's reported occurrences of giant bison in Colorado. Another new discovery adds the genus
Platygonus, an extinct peccary, to the known Pleistocene fauna of Colorado.

\section{BISON (GIGANTOBISON) LATIFRONS (Harlan), 1825}

In 1967, Glenn R. Scott, of the U.S. Geological Survey, visited the Canon City Museum, where he saw a specimen, until then believed to be a mammoth tusk, but which he suspected would prove to be a bison horn core. Through the courtesy of H. O. Wood, Curator, and D. I. Duncan, Assistant Curator of the museum, the specimen was sent to me on July 28, 1967.

My report of August 23, 1967, confirmed Scott's tentative conclusion that the specimen is from a bison. The two fragments of bone from the gravel pit in SW1/4 NE1/4 sec. 26, T. 18 S., R. 70 W., Fremont County, Colo., have been studied and identified. The tip of the horn core is missing, and the proximal end was broken off some distance from the burr at its base, so the present chord length of $812 \mathrm{~mm}$ (straight line across the curve from proximal tip to distal tip on the joined fragments preserved) and the present tip-to-tip length along the lower curve of the core of $842 \mathrm{~mm}$ are less than the original total lengths from original distal tip to proximal burr at the base of the core (compare Skinner and Kaisen, 1947, measurements 4 and 5, fig. 1, p. 144-145). Because of the fragmentary nature of the core, the maximum diameter at the burr is unknown. The transverse diameter is $123 \mathrm{~mm}, 460 \mathrm{~mm}$ from the distal end.

Skinner and Kaisen (1947, tables 10-19) list the minimum, average, and maximum lengths of horn cores along the lower curve (measurement 4) and chord (measurement 5) of complete horn cores of the several subgenera and species of Bison. Only the complete horn cores of $B$. (Gigantobison) latifrons attain the minimum size calculated for the original, unbroken Canon City specimen : at least $60 \mathrm{~mm}$ of the distal end and at least $135 \mathrm{~mm}$ of the proximal end of its horn 
core are missing, so the original lower curve length must have been 1,007 mm or more. Thus, B. (Gigantobison) latifrons horn cores (measurement 4 , minimum $800 \mathrm{~mm}$, average $934 \mathrm{~mm}$, maximum $1,156 \mathrm{~mm}$; measurement 5, minimum $680 \mathrm{~mm}$, average $810 \mathrm{~mm}$, maximum $1,020 \mathrm{~mm}$ ), alone of all known species of Bison, reach the size of the Canon City specimen, which I refer without question to Harlan's species.

Through the good offices of Curator Wood and Secretary-Treasurer G. D. Custer, the Board of the Canon City Museum Association decided unanimously to present this important specimen to the U.S. Geological Survey for deposit in the U.S. National Museum, Smithsonian Institution, where it was assigned Catalogue No. 25912. Both organizations are very grateful for this gift. It has been given U.S. Geological Survey/P\&S/Denver/fossil vertebrate locality No. D720, and is illustrated in figure $1 A$.

The geologic age of $B .(G$.) latifrons is a moot question. When the Canon City specimen was first found, G. R. Scott thought the gravels containing it could be of either Illinoian or Kansan age, but he and R. M. Lindvall (Scott and Lindvall, 1970) (p. B144, this chapter) have concluded, after long and careful study, that the gravels and the present specimen of $B$. $(G$.) latifrons are of Sangamon age. The extreme points of view in the past have been those of Schultz and Frankforter (1946, p. 4), who assigned a late Kansan or early Yarmouth age, and that of Miller $(1968$, p. 4), who assigned a late Wisconsin age to $B$. (G.) latifrons. Skinner and Kaisen (1947, p. 155-203) gave the age as "middle Pleistocene."

\section{BISON (SIMOBISON)? ALLENI? (Marsh), 1877}

On August 15, 1966, M. G. Gienau, of Denver, gave the U.S. Geological Survey a fragment of another giant bison horn core, for deposit in the U.S. National Museum, Smithsonian Institution, where it was assigned Catalogue No. 25913. It has been given U.S. Geological Survey/P\&S/Denver/fossil vertebrate locality No. D707, and is illustrated in figure $1 B$. Thanks are due Mr. Gienau for the gift of this specimen, which he

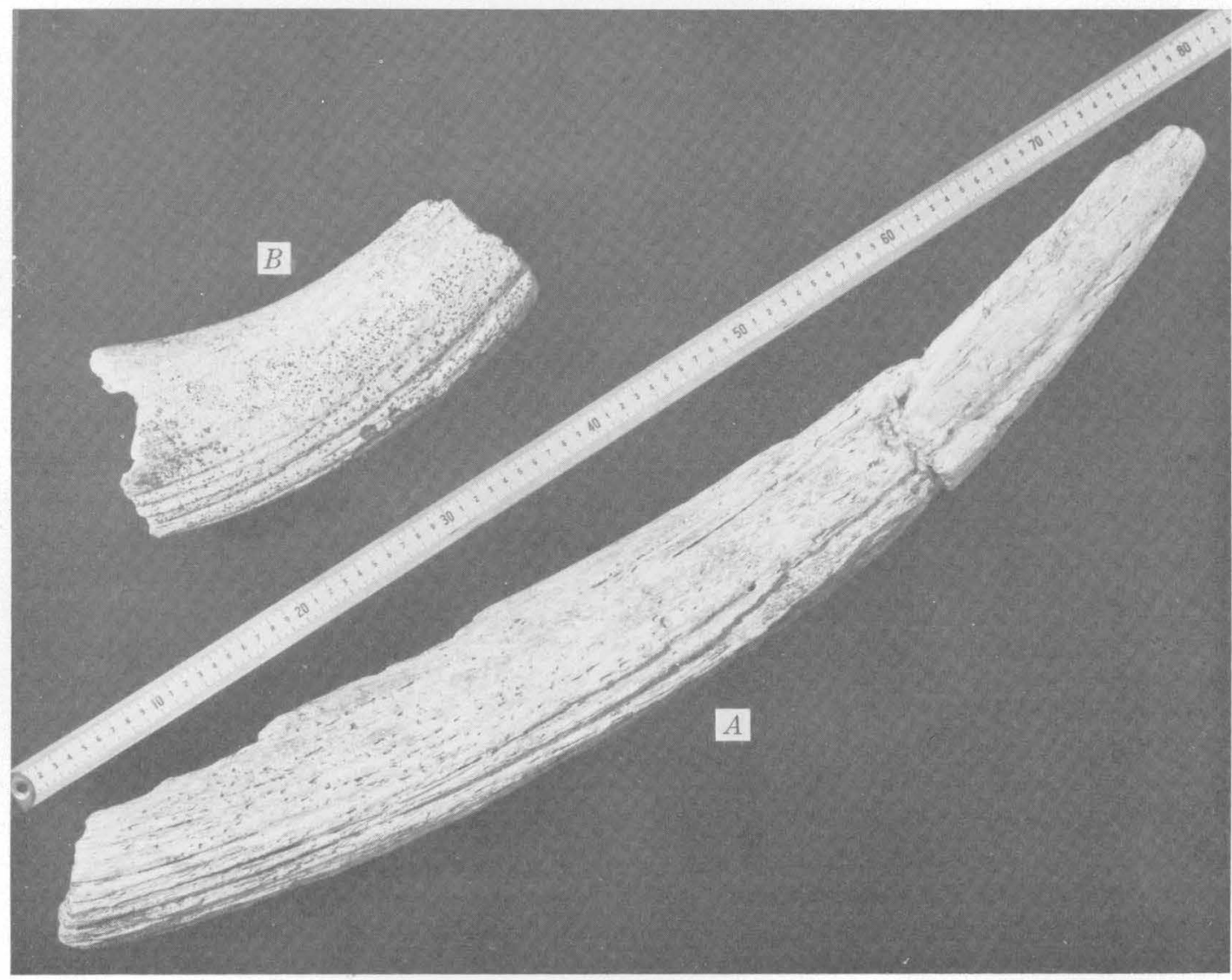

FIgure 1.-Two fragments of horn cores of Pleistocene Bison. Meter stick, numbered in centimeters, included for scale which is about one-fifth natural size.

$A$, specimen identified as B. (Gigantobison) Zatifrons, U.S. National Museum No. 25912.

$B$, specimen questionably referred to $B$. (Simobison)? alleni?, U.S. National Museum No. 25913. 
found in the west bank of Cherry Creek in NE1/4 sec. 30 , T. 5 S., R. $66 \mathrm{~W} ., 53 / 4$ miles north-northwest of Parker and 14 miles south-southeast of Denver.

The specimen is $300 \mathrm{~mm}$ long from the proximal broken end along the lower curve to the distal broken end. Cancellous tissue that connected with the diploë of the skull extends for $240 \mathrm{~mm}$ from the broken proximal end to within $15 \mathrm{~mm}$ of the broken distal end. The length along the lower curve is $300 \mathrm{~mm}$; along the upper curve it is $215 \mathrm{~mm}$. The circumference at the proximal broken end is $418 \mathrm{~mm}$, the transverse diameter there is $145 \mathrm{~mm}$, and the vertical diameter is 117 $\mathrm{mm}$; these dimensions make the index of core compression 80.7 (vertical diameter/transverse diameter $\times$ $100)$. Such a large, flattened, relatively proximal portion of horn core, with these dimensions and curvature, conforms to Skinner and Kaisen's (1947, p. 197, 198) applicable criteria for determination of the subgenus Platycerobison, especially in that, " $" * * *$ proximally, the cores are prominently dorsoventrally flattened as opposed to all other subgenera of Bison." This prominent dorsoventral flattening, "as opposed to all other subgenera," explicitly implies that Platycerobison has a uniquely low index of core compression among the several subgenera of Bison; it is 78 according to Skinner and Kaisen (1947, p. 198). But Skimner and Kaisen themselves, in this same report $(1947$, p. 184), recorded indices of compression for B. (Simobison) alleni that ringe down to 72 . We might agree with Schultz and Frankforter $(1946$, p. 6$)$ that $B .(P$.$) chaneyi appears$ to be synonymous with $B$. $(S$.$) alleni.$

Because of these considerations, and the uncertainties inherent in identification of very incomplete specimens, I refer the Parker Bison questionably to the subgenus and species Bison (Simobison)? alleni? and assign an early Wisconsin age to it. Scott and Lindvall (1970) (p. B145, this chapter) discuss the stratigraphy of the occurrence in detail.

\section{PLATYGONUS COMPRESSUS Leconte, 1848}

In May 1967, during excavation for an addition to the Denver courts' Juvenile Hall at 2844 Downing Street in Denver, Colo., F. R. Weber found a peccary skull that was sent to me for study and identification. "Thanks are due Mr. Weber for his discovery and careful excavation of this specimen, and I welcome the opportunity to study it.

I have identified it as the well-known species Platygonus compressus. The specimen consists of a young adult male skull and mandible with complete dentition except for the left second upper incisor. The right cranial and zygomatic region of the skull was slightly damaged during excavation. The basal length of the skull is $279 \mathrm{~mm}$; width at postorbital processes, 115 $\mathrm{mm}$; diastema behind canine, $48 \mathrm{~mm}$; length of upper cheek tooth series, $77 \mathrm{~mm}$; and length of lower cheek tooth series, $83 \mathrm{~mm}$. These and other measurements are close to those given by Hay $(1914$, p. 219) for $P$. compressus.

The specimen's morphologic features are typical. The remarkable feature of this discovery is that Hay (1924) did not list any occurrence of Platygonus in Colorado. I have not found any such records listed in publications since Hay's compilation. It seems, therefore, that the Denver specimen is the first found in this State.

Hay (1930, v. 2, p. 771-774) recorded Platygonus from Florida, Maryland, Pennsylvania, and New York, west to Mexico, California, and Oregon; he recorded $P$. compressus (including $P$. leptorhinus as a synonym, with which I agree) from New York, Ohio, Kentucky, Indiana, Illinois, Missouri, Iowa, and Kansas.

Our interest aroused by this find, R. M. Lindvall, R. W. O'Donnell, G. R. Scott, and I, all of the U.S. Geological Survey, decided to investigate the occurrence. M. F. Hull, Superintendent of the Juvenile Hall Division, Denver Juvenile Court, kindly gave us permission to search for and collect additional specimens. Scott and Lindvall (1970) (p. B148, this chapter) have described the stratigraphic situation at the site. By early June 1967, O'Donnell had collected most of the new material we found. It includes a second adult male skull, an adult female skull, a juvenile mandible $\left(\mathrm{M}_{2}\right.$ just coming into occlusion, $\mathbf{M}_{3}$ unerupted), and a 70 mm-long newborn or fetal ramus (incisors, canine, and $\mathrm{DP}_{2-4}$ in bud, unerupted), with scattered axial and appendicular skeletal elements that were associated with all the skulls.

The skull found by Mr. Weber had been embedded with scattered bone fragments in old fill or slump around an old sewer line, at a depth of 8 feet 9 inches below the pavement of the .Juvenile Hall parking lot. All other specimens were found in undisturbed eolian sand and silt at a depth of 6 feet 2 inches below the pavement. This locality has been given U.S. Geological Survey/P\&S/Denver/fossil vertebrate locality No. D714; I assign a late Wisconsin age to it.

Some occurrences of Platygonus compressus have included several individual skeletons lying in a preferred orientation in eolian deposits. Modern peccaries commonly travel in droves, and it is not strange to find death assemblages oriented with tails or snouts directed toward the wind on the windward or leeward slopes of sand dunes where they may have died during severe storms. The Denver Juvenile Hall occurrence is not one of these cxamples of preferred orientation in a 
death assemblage: the five individuals were found pointing toward true north bearings of $010^{\circ}, 055^{\circ}, 090^{\circ}$, $120^{\circ}$, and $270^{\circ}$.

\section{REFERENCES}

Cook, H. J., 1930, Occurrence of mammoth and giant bison in glacial moraines in the high mountains of Colorado: Science, v. 72, p. 68.

Cragin, F. W., 1900, Goat-antelope from the cave fauna of Pikes Peak region: Geol. Soc. America Bull., v. 11, p. 610612.

Hay, O. P., 1914, The Pleistocene mammals of Iowa: Iowa Geol. Survey, v. 23, 662 p.

1924, The Pleistocene of the middle region of North America and its vertebrated animals : Carnegie Inst. Washington Pub. 322A, 385 p.
1930, Second bibliography and catalogue of the fossil Vertebrata of North America: Carnegie Inst. Washington Pub. 390, v. 2, 1074 p.

Miller, W. E., 1968, Occurrence of a giant bison, Bison latifrons, and a slender-limbed camel, Tanupolama, at Rancho La Brea: Los Angeles County Mus. Contr. Sci.; no. 147, 9 p. Schultz, C. B., and Frankforter, W. D., 1946, The geologic history of the bison in the Great Plains: Nebraska Univ. State Mus. Bull., v. 3, no. 1, p. 1-10.

Scott, G. R., and Lindvall, R. M., 1970, Geology of new occurrences of Pleistocene bisons and peccaries in Colorado; in Geological Survey Research 1970: U.S. Geol. Survey Prof. Paper 700-B, p. B141-B149.

Skinner, M. F., and Kaisen, O. C., 1947, The fossil Bison of Alaska and preliminary revision of the genus: Am. Mus. Nat. History Bull., v. 89, p. 123-256. 
GEOLOGICAL SURVEY RESEARCH 1970

\title{
GEOLOGY OF NEW OCCURRENCES OF PLEISTOCENE BISONS AND PECCARIES IN COLORADO
}

\author{
By GLENN R. SCOTT and ROBERT M. LINDVALL, \\ Denver, Colo.
}

\begin{abstract}
A.bstract.-New occurrences of Quaternary mammals in Colorado, including Bison (Gigantobison) latifrons in Slocum Alluvium of Sangamon age; Bison (Simobison)? alleni? in Louviers Alluvium of early Bull Lake age; and Platygonus compressus in colian sand of Pinedale and early Holocene age, permit a more definite assignment of age to these vertebrate species than has been possible in the past.
\end{abstract}

Two new occurrences of Pleistocene bison, Bison (Gigantobison) latifrons and Bison (Simobison)? alleni?, and one of peccary, Platygonus compressus, are stratigraphically well documented and permit a more definite assignment of age to these vertebrate species than has been possible in the past. All occur in deposits that are part of a well-established Quaternary sequence along the Rocky Mountains front (Scott, 1960).

This sequence of deposits consists of alluvium on a series of pediments and terraces that range in elevation from nearly 500 feet above present stream level for the oldest to only a few feet above stream level for the youngest. Difterences in degree of weathering and soil profiles imposed on the deposits, as well as in height above stream level, are useful in determining stratigraphic position. The deposits, their ages, and their heights above modern streams are from oldest to youngest: Nussbaum Alluvium of Pleistocene age, 470 feet; Rocky Flats Alluvium of Nebraskan or Aftonian age, 360 feet; Verdos Alluvium of Kansan or Yarmouth age, two levels at 220 feet and 290 feet (a level intermediate between Rocky Flats and typical Verdos); Slocum Alluvium of Illinoian or Sangamon age, two levels at 120 feet and 180 feet (a level intermediate between Verdos and typical Slocum); Louviers Alluvium of Bull Lake age, 80 feet; Broadway Alluvium of Pinedale age, 40 feet; and Piney Creek Alluvium and post-Piney Creek alluvium of late Holocene age, respectively 25 and 5 feet (and the flood plain).

\section{GIANT BISON FROM CANON CITY}

A horn core on display in the municipal museum in Canon City, Colo., was recognized as that of a giant bison by Scott in July 1967. This horn core, which had been found near Canon City a year earlier (fig. 1), was identified by G. Edward Lewis as Bison (Gigantobison) latifrons Harlan and was described by him (Iewis, 1970) (p. B137, this chapter).

The horn core is from a skull found in gravel about 5 feet above the floor of a pit leased by the Fremont County Highway Department in sec. 26, T. 18 S., R. 70 W., Fremont County, Colo. This gravel is part of the Slocum Alluvium along Fourmile Creek, a tributary of the Arkansas River near Canon City. The Slocum Alluvium here consists chiefly of 11-25 feet of yellowish-red well-stratified gravel that contains pebbles, cobbles, and boulders generally in lenses (fig. 2). Large lumps and layers of olive-gray shale reworked from the underlying Pierre Shale are abundant. The gravel is cross-stratified in a manner typical of stream deposits; it also contains channels filled with coarse gravel. The upper part of the Slocum Alluvium consists of about 4 feet of clayey pebbly sand and silt that conformably overlies the lower part. This division of the Slocum into a thick gravel and a thin overlying pebbly sand and silt is typical of the Slocum and of most pediment alluvium. The Slocum, except for the lower bouldery part, is slightly cemented by clay throughout and by calcium carbonate in the upper part where a pre-Bull Lake soil is developed; the lower bouldery part of the gravel is uncemented.

Near Canon City, alluvium in two terraces at 120 and 180 feet above the Arkansas River is placed in the 



Pre-Quaternary bedrock

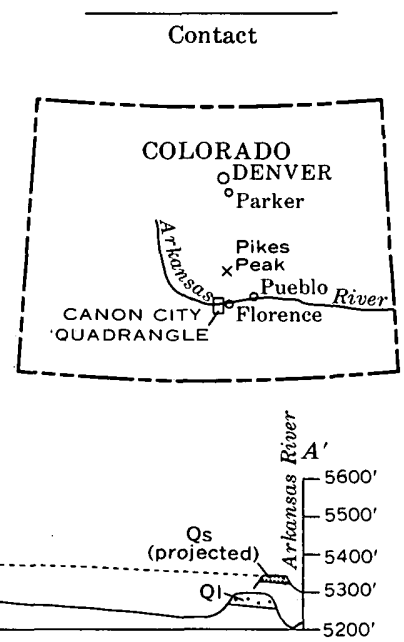

FIGURE 1.-Generalized. surficial geologic map and section of part of the Canon City quadrangle, Colorado. Geology by G. R. Scott, 1967. 


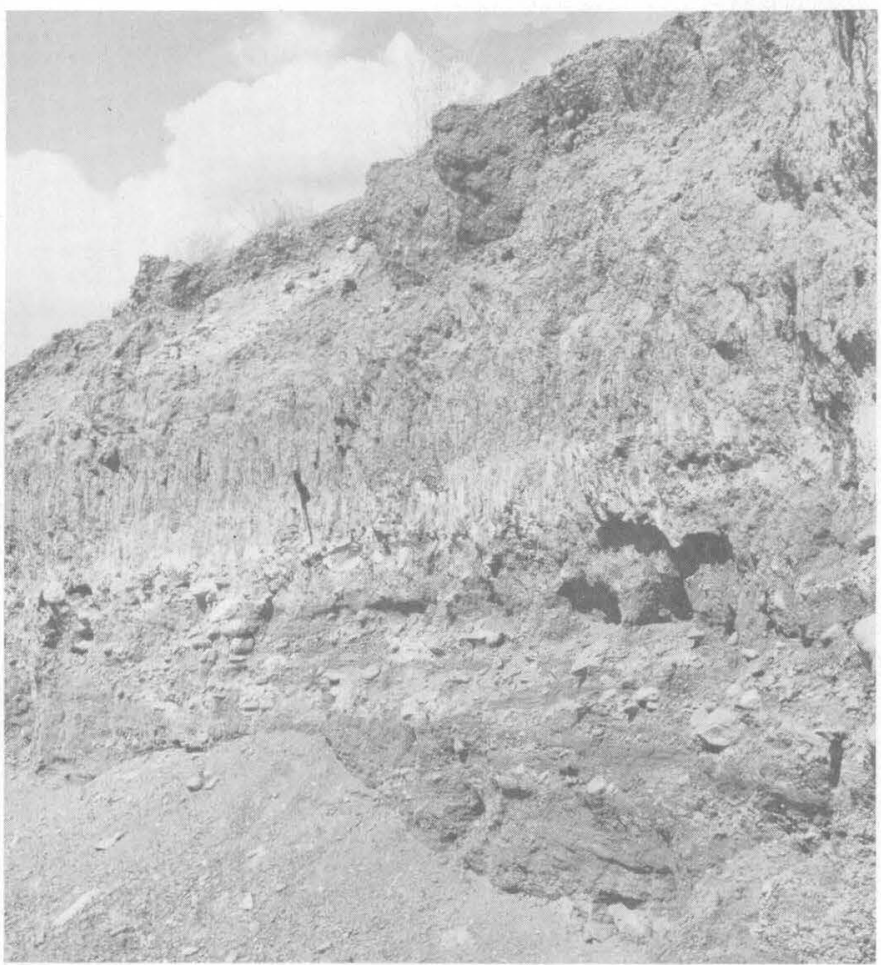

Figure 2.--Slocum Alluvium in gravel pit near Canon City where giant bison was found.

Slocum Alluvium. At Florence, only alluvium at 120 feet (Henry Kane, oral commun., 1964) and at Pueblo only alluvium at 110-120 feet are included in the Slocum (Scott, 1964). The two alluvial terraces at Canon City appear to result from two episodes of alluviation in Illinoian and Sangamon time. The highest deposits, which are intermediate between typical Verdos and typical Slocum, are in the higher of two terraces along the main streams. The lower terrace is considered to be typical Slocum Alluvium, and the giant bison was found in this lower terrace. Slocum Alluvium in the high terrace contains a greater amount of fragments of sedimentary rocks and is not as well washed or reworked as in the low terrace, which suggests that the stream in the low position had a stable base level for a longer time than the stream in the high position.

The following stratigraphic section was measured in the gravel pit where the giant bison horn core was found :

\section{Canon City section}

Section measured in a gravel pit east of Canon City in center N1/2 sec. 26, T. 18 S., R. 70 W., Fremont County, Colo., near location of giant bison skull, May 5, 1968, by Glenn R. Scott
Colluvium (soil on colluvium probably is the Altithermal soil of early Holocene age)

Slocum Alluvium (soil on Slocum Alluvium is a pre-Bull Lake soil) :

Sand, pale-brown, $10 Y R 6 / 3$, fine, clayey, silty, pebbly; weak coarse columnar structure; slightly sticky, plastic; slightly hard when dry $-A$

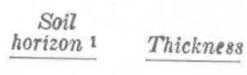

Silt, very pale brown, sandy, clayey; weak medium prismatic structure; slightly sticky, plastic; medium hard when dry. Contains spots of calcium carbonate $1 / 4-1 / 2$ in. in diameter ilt, very pale brown, clayey; contains
a few pebbles; medium-fine columnar structure; slightly sticky, plastic; slightly hard when dry. Contains some calcium carbonate on faces of columns_- Bca 18 in.

Silt, mottled white, pale-brown, and very pale brown, sandy, clayey, pebbly; weak fine columnar structure; slightly sticky, plastic; slightly hard when dry. Contains dense concentration of calcium carbonate on column faces and around pebbles. Interiors of columns are slightly calcareous pink; contains pebbles, cobbles, and houlders as large as $5 \mathrm{ft}$ in long dimension. Large fragments are predominantly granitic, but some are pegmatitic, metamorphic, volcanic, and sedimentary rocks. Sand is predominantly feldspar, quartz, and magnetite. Well stratified, and at places cross-stratified. Contains layers and lenses that are predominantly sand. Skull of Bison latifrons was found in a sand lens $5 \mathrm{ft}$ above the base. Another bone found $12 \mathrm{ft}$ below top was not preservable. Calcium carbonate concentrated on bottoms of stones and in horizontal streaks in upper $5 \mathrm{ft}$. Rind of calcium carbonate on stones is $1 / 8$ in. thick. Most stones are relatively unweathered. Only gneiss and schist ean be broken by the hands

Cea $11-25 \mathrm{ft}$

1 Letter symbols: A, gray humic layer leached of iron, aluminum, and clay; B, yellowish-brown layer having columnar structure and enriched in clay, iron, and aluminum; C, parent material. The addition of "ea" shows concentration of ealcium earbonate.

As shown in the stratigraphic section, a soil is strongly developed on the sand and silt. This soil has a B horizon that is less red, that contains less clay, and that has a weaker structure than a typical preBull Lake soil on the Slocum Alluvium near Den- 
ver. We do not interpret these differences to mean that the soil at Canon City is younger than the pre-Bull Lake soil. Rather, we believe they are the result of a much warmer, drier climate along the Arkansas River valley. All soils along the Arkansas River valley are less well developed than those near Denver, having thin, weakly developed B horizons. The climate of the Arkansas River valley, as shown by the flora and fauna, was warmer and drier than the climate near Denver. The ages of the soils in the two areas must be assessed on the basis of the relative strengths of development of all the soils in the entire sequence in each area. A comparison of the two sequences shows that in each there is a sharp decrease in strength of development after formation of the strongly developed pre-Bull Lake soil. The strength of the soil developed on the alluvium that contains the giant bison plus the height of the alluvium above Fourmile Creek indicates that it is part of the Slocum Alluvium.

Bison latifrons on the Great Plains has been considered as old as Kansan (Schultz and others, 1951) and as young as Sangamon (Hibbard, 1955 ; 1958; Hibbard and Taylor, 1960; Slaughter and Ritchie, 1963; Cheatum and Allen, 1963). Occurrences of B. latifrons near American Falls, Idaho, are considered to be probably of Illinoian age (Carr and Trimble, 1963; Hopkins and others, 1969). The Slocum Alluvium now is assigned an age of Illinoian or Sangamon (Scott, 1960). We believe the topographically lower deposits of Slocum Alluvium at Canon City, which contained the B. latifrons, probably are Sangamon in age. These deposits, now thought to be Sangamon, we formerly believed to be Bull Lake (early Wisconsin) in age (U.S. Geological Survey, 1968, p. A119) because the strength of the soil developed on them was similar to that of the soil developed on the Louviers Alluvium near Denver and because a longitudinal profile drawn across the deposit seemed to project to a remnant of the Louviers Alluvium along the Arkansas River. Reevaluation of the soil development in terms of its strength relative to other soils in the area, however, together with the height of the deposits above the modern streams indicates that they should be assigned to the Slocum Alluvium and therefore are pre-Bull Lake in age.

B. J. Szabo, U.S. Geological Survey (oral commun., 1968 ), recently obtained an age of 160,000 years on the bison horn core by a new method of radiogenic dating using protactinium. Because of the newness of the method, this date must be considered tentative.

\section{BISON FROM PARKER}

In August 1966, Mr. M. G. Gienau found part of a horn core of a large bison near Parker along the west side of Cherry Creek south of Cherry Creek Reservoir in the NE1/4 sec. 30, T. 5 S., R. 66 W. (fig. 3). Edward Lewis identified the specimen as a giant bison, and pointed out that the measurements fall within the ranges of Bison (Gigantobison), B. (Simobison), and B. (Platycerobison). He concluded (Lewis, 1970) (p. B139, this chapter) that it comes closest to Platycerobison chaneyi as defined, but that this subgenus and species are probably synonyms of $B$. (S.) alleni, to which he questionably refers the specimen. C. B. Schultz agrees with this (oral commun., October 1966). The horn core was found at the base of a slope composed, in the upper part, of sand, silt, and clay, and, in the lower part, of iron-stained sandy gravel (fig. 4). Cavities in the horn core contain iron-stained sandy gravel, showing that the core came from the lower part of the exposure. The deposits are assigned by us to the Louviers Alluvium (fig. 5).

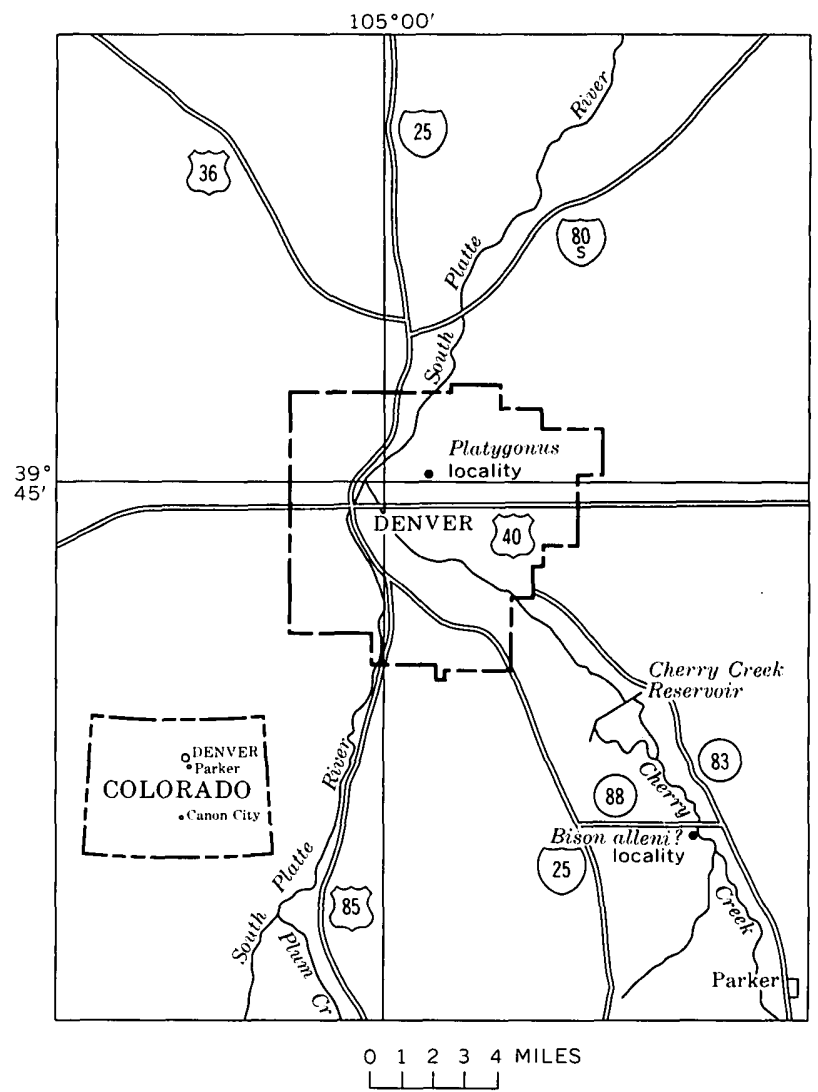

Frgure 3.-Index map of Colorado and the Denver area, showing Platygonus and Bison alleni? fossil localities. 

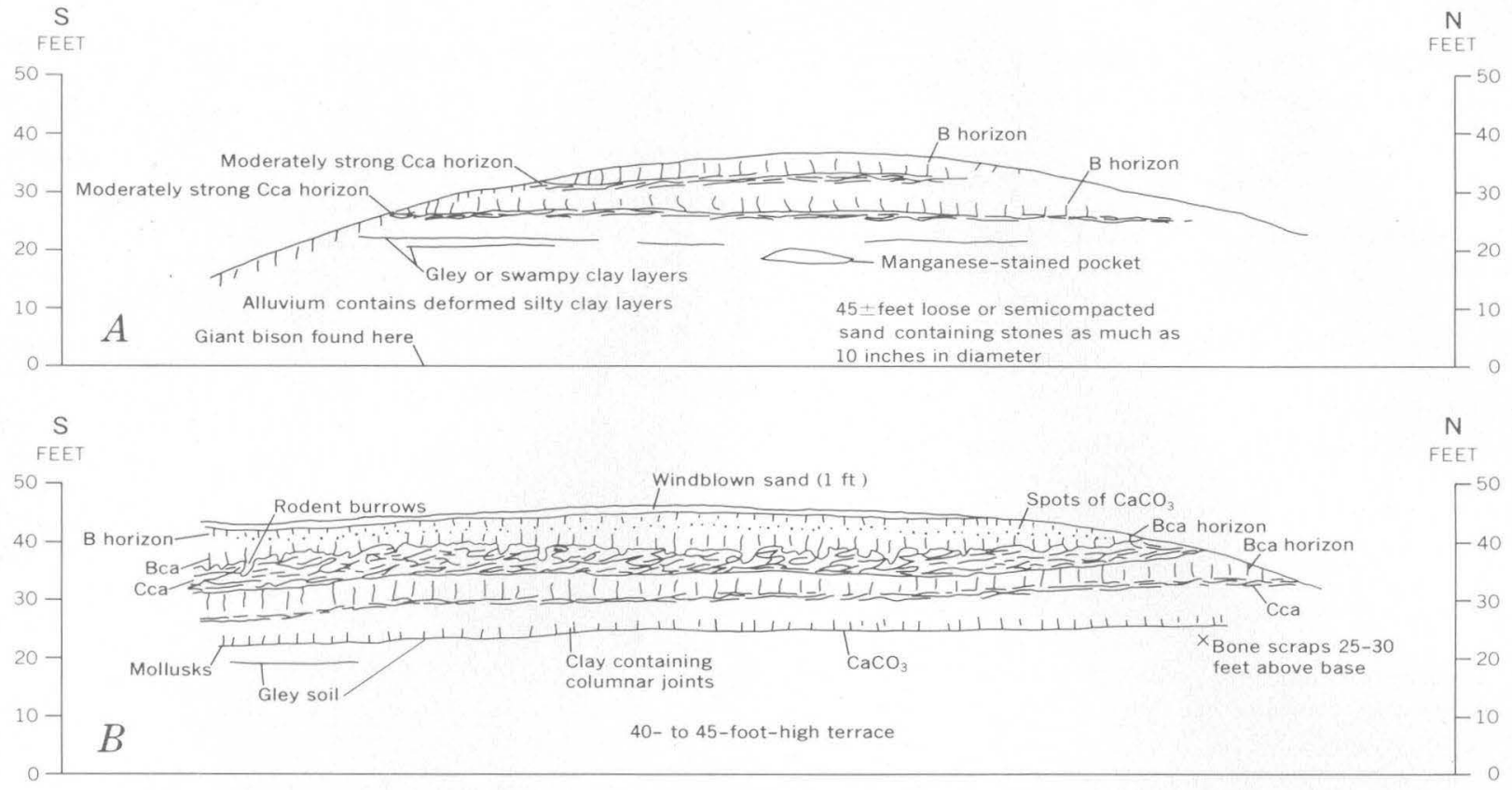

Frgure 4.-Diagrams showing stratigraphy of Louviers Alluvium at Parker bison locality. A, Northern cut along west side of Cherry Creek south of Arapahoe Road (Colorado Highway 88) and south of Cherry Creek Reservoir. $B$, Southern cut along west side of Cherry Creek.

The Louviers Alluvium (Scott, 1960) near Parker, Colo., consists of two parts. The lower part, 34 feet thick, is composed mainly of stratified coarse sand containing pebbles, cobbles, and boulders (fig. 6), the upper 4 feet of which is yellowish-brown to brown pebbly silty sand. The upper part, 8 feet thick, con-

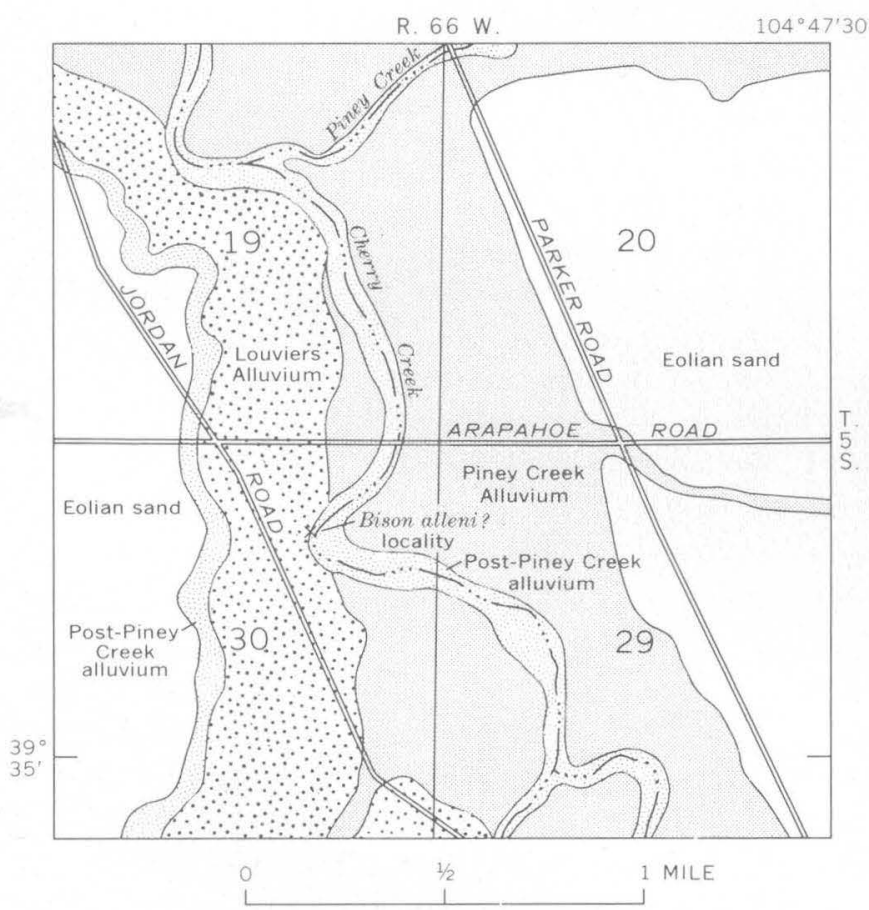

Figure 5.-Generalized geologic map of Parker bison locality. sists of pale- to dark-brown thick-bedded silty sand. The lower part is characterized by abundant pieces of opalized wood from the Dawson Formation of Cretaceous and Paleocene age and ash-flow tuff of Oligocene

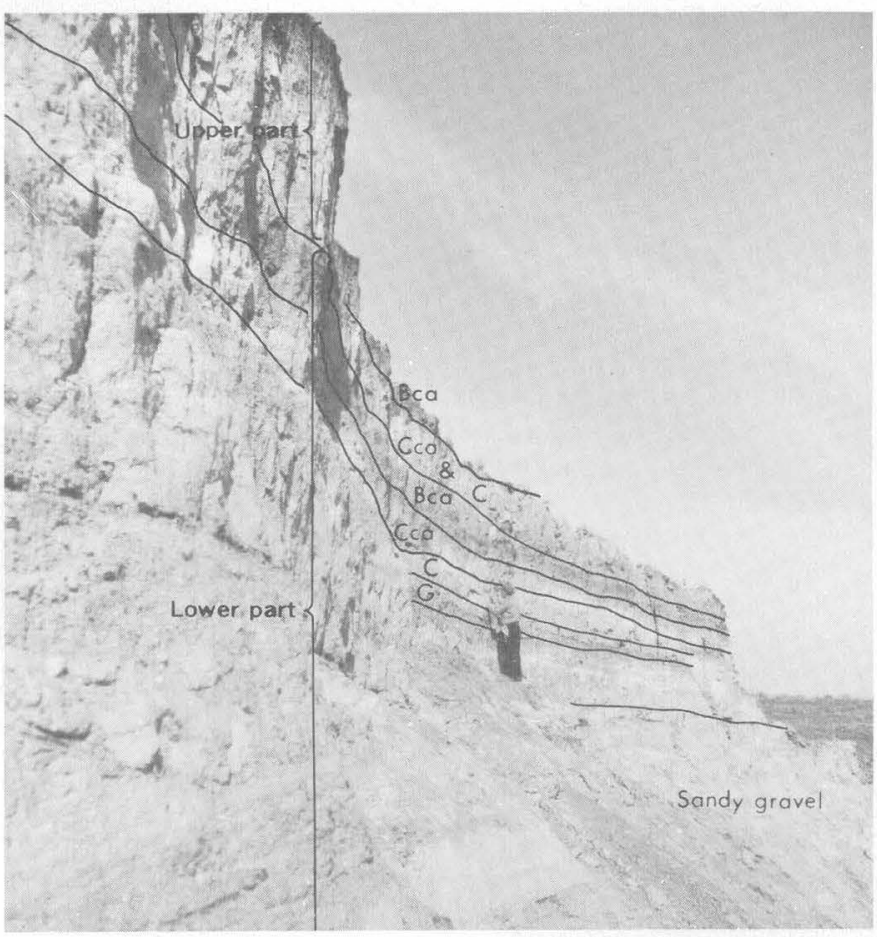

FIGURE 6.- Southern part of eroded terrace, showing Louviers Alluvium at Parker bison locality. C, Cea, and Bca, soil horizons; G, gley soil. Loess and underlyine A horizon are not designated. 
age. A stratigraphic section measured at the site of the bison horn core is as follows:

\section{Parker section}

Section measured in NE1/4 sec. 30 , T. 5 S., R. 66 W., Arapahoe County, Colo., by Glenn R. Scott and Robert M. Lindvall.

Unit and description

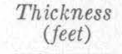

Modern loess (no soil):

11. Sand, clayey, light-yellowish-brown, loose ....... Louviers Alluvium (upper part-late Bull Lake) :

(Contains a composite of Bull Lake-Pinedale, Brady(?), Altithermal, and late Holocene soils developed in upper part; fig. 7.)

10. A horizon: Sand, silty, clayey, dark-brown (10YR $4 / 3)$

9. Bca horizon: Sand, silty, clayey; coarse prismatic structure; contains calcium carbonate along column faces

8. Cea horizon: Sand, silty, very pale brown; columnar structure; dense concentration of calcium carbonate in upper part.

Louviers Alluvium (lower part early Bull Lake) :

(Contains interstadial Bull Lake soil in upper part; fig. 7.)

7. Bca horizon: Sand, silty, brown (10YR 5/3), moderate prismatic structure

6. Cca horizon: Sand, silty, pebbly, light-yellowishbrown; coarse columnar structure; contains concentration of calcium carbonate.

5. C horizon: Sand, coarse, very pale brown, pebbly - -

4. G (gley) horizon: Clay, silty, very pale brown; strong prismatic structure (fig. 8); contains mollusks. Bones found $2 \mathrm{ft}$ above to $1.3 \mathrm{ft}$ below unit 4

3. C horizon: Sand, coarse, very pale brown, layered; blocky structure; locally calcareous .............

2. G horizon: Clay, silty, very pale brown; moderate prismatic structure; locally calcareous because of

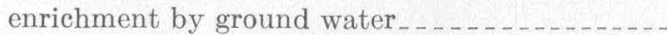

1. G horizon: Sand, coarse to fine; contains pebbles, cobbles, and boulders as much as $18 \mathrm{in}$. in diameter. Sand is mostly composed of quartz, but contains some feldspar. Contains streaks of limonite and podlike areas stained by manganese oxide. Torrential crossbedding. Contains bones, including horn core of giant bison in coarser middle part of deposit; also more rarely in upper part. Upper $4 \mathrm{ft}$ locally calcareous because of enrichment by ground water.

Denver Formation (Paleocene and Cretaceous)

Our interpretation of the soils in this section is that the lower part of the Louviers is early Bull Lake in age and the upper part is late Bull Lake in age and separated from the lower part by an interstadial Bull Lake soil. The soil developed on the upper part formed chiefly between Bull Lake and Pinedale times (fig. 7).

Fossils were found only in the lower part of the

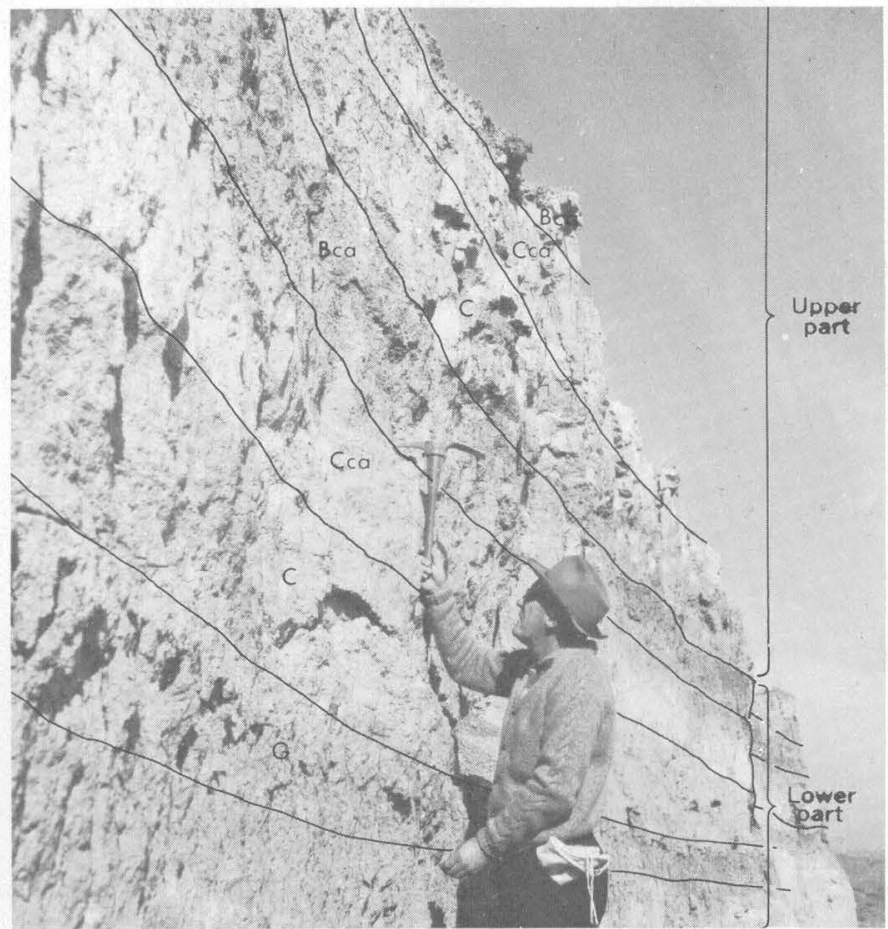

Figure 7-Close view of soils developed on lower and upper parts of the Louviers Alluvium at Parker bison locality, C, Cca, and Bca, soil horizons; G, gley.

Louviers and include bones of mammals and shells of mollusks. All the bones except the bison horn core were nondiagnostic. The mollusks were first collected from the upper of two gley soils (fig. 8) in 1952 by M. R. Mudge, Richard Van Horn, and G. R. Scott. Mudge sent them to A. Byron Leonard, University of Kansas, who identified 10 species as follows:

Discus cronkhitei Newcomb, Gyraulus parvus (Say), Hawaiia minuscula (Binney), Lymncea cf. caperata Say,

L. parva Lea, Retinella electrina (Gould), Vallonia cyclophorella Sterki, V. gracilicosta Reinhardt, Pupilla blandi Morse, and P. muscorum (Linnæus).

About the age of these mollusks, Leonard stated, "I am uncertain about the age of this faunule, although tentatively I judge it to be early Wisconsinan." The fauna is the same as the Louviers fauna of the Kassler quadrangle (Scott, 1963) except for Pupilla blandi which was not found in the Kassler quadrangle or elsewhere in Louviers Alluvium. Pupilla blandi is common in the Slocum Alluvium, where it is with other species that suggest a much warmer climate than that 


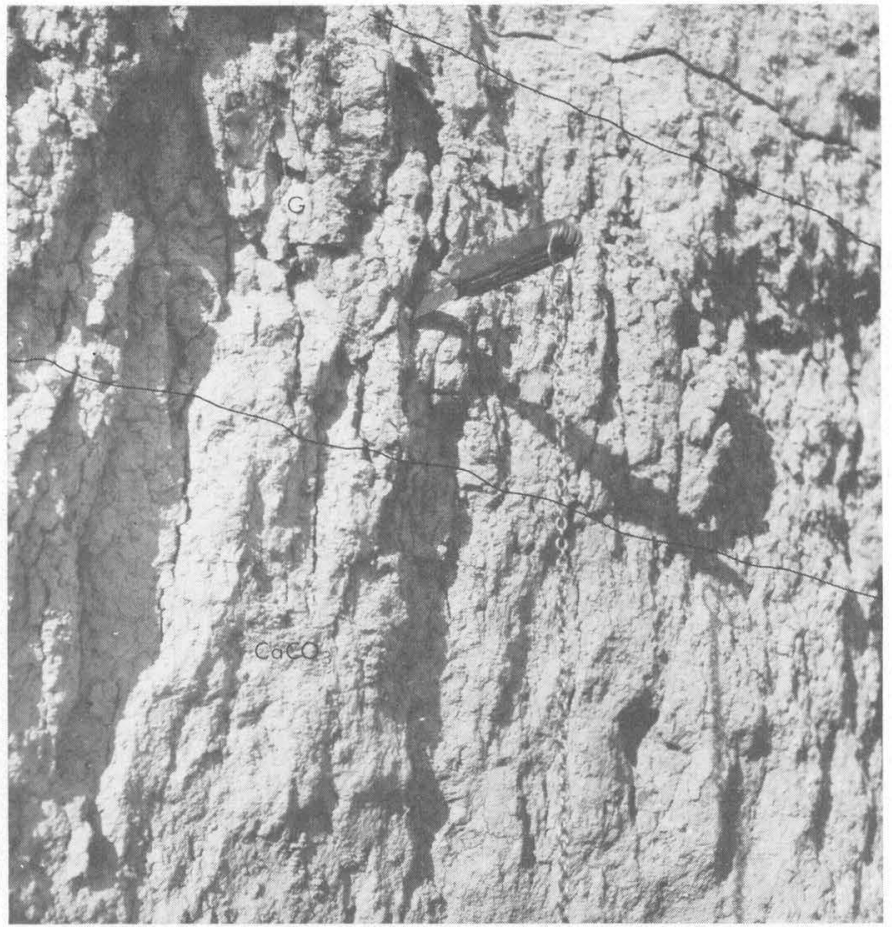

Figure 8.-Close view of gley soil at Parker bison locality from which mollusks were collected. G, gley soil containing mollusks; $\mathrm{CaCO}_{3}$, calcium-carbonate enrichment.

suggested by the other mollusks in the Louviers fauna at Parker. Perhaps most of the previous mollusk collections from Louviers were from the upper (late Bull Lake) part of the Louviers; the lower part possibly was deposited during a slightly warmer time than the upper part.

Louviers Alluvium here is a fill deposited by ancient Cherry Creek in a channel deeper than that of the modern creek. Cherry Creek has cut a deep modern trench into the Louviers Alluvium. The top of the Louviers terrace is about 45 feet above Cherry Creek. This height is 20-35 feet lower than the height of Louviers at most places. For some reason Cherry Creek has not cut the alluvium as deeply as have other streams.

The Louviers is younger than the Slocum and has recently been correlated with Bull Lake Glaciation (Gardner, 1967, p. 84, 85, and table 6). Richmond (1965, table 2) estimated that the earliest part of the Bull Lake Glaciation began more than 70,000 years ago and ended after Bull Lake-Pinedale soil formation about 25,000 years ago.

At Parker, as at Canon City, the giant bison horn core was the only identifiable vertebrate fossil in the Louviers, although several other bones were found. Bison alleni has been found at many places in the conterminous United States between Kansas and Cali- fornia. Schultz, Lueninghoener, and Frankforter (1951, table 1) have assigned a Yarmouth age to $B$. alleni? We believe that the specimen of $B$. alleni from Parker is early Bull Lake in age.

\section{PECCARY FROM DENVER}

In the spring of 1967, a well-preserved skull of an extinct peccary was found by Fred R. Weber about 9 feet below the top of a foundation excavation for an addition to the Denver court's Juvenile Hall, 2844 Downing Street, Denver, Colo. (fig. 3), and identified as Platygonus compressus LeConte by Edward Lewis. Later, more skulls, jaws, and other bones of peccaries were found about 6 feet below the top of the excavation. All the bones were in eolian sand (fig. 9), which extends far below the depth of the foundation excavation. The eolian sand overlies alluvium of the Broadway terrace and has been incised by small drainageways that contain Piney Creek Alluvium (fig. 9).

The Broadway Alluvium, which is of Pinedale age, was sampled by augering 20 feet below the foundation of Juvenile Hall. About 7 feet of Broadway Alluvium was penetrated, and it contains four different lithologies as shown in figure 10. The silty sand in the upper

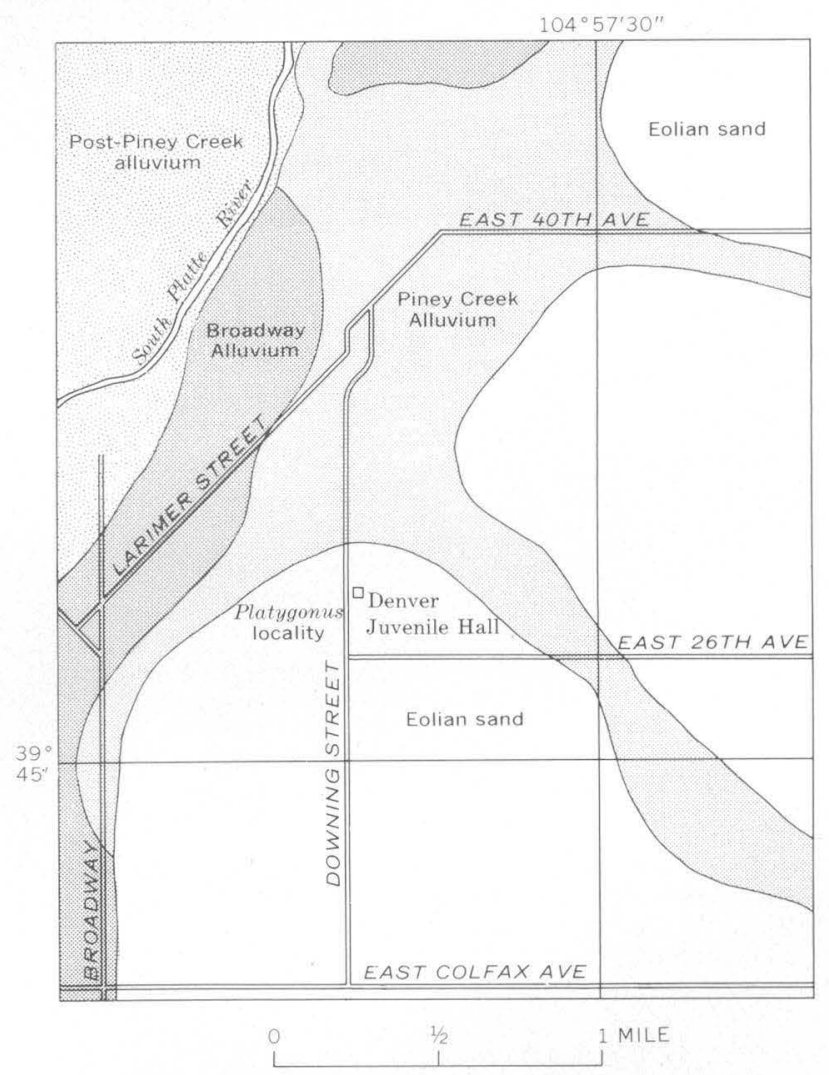

Figure 9.-Generalized geologic map of northeast Denver, showing peccary locality at Juvenile Hall. 


\section{B148}

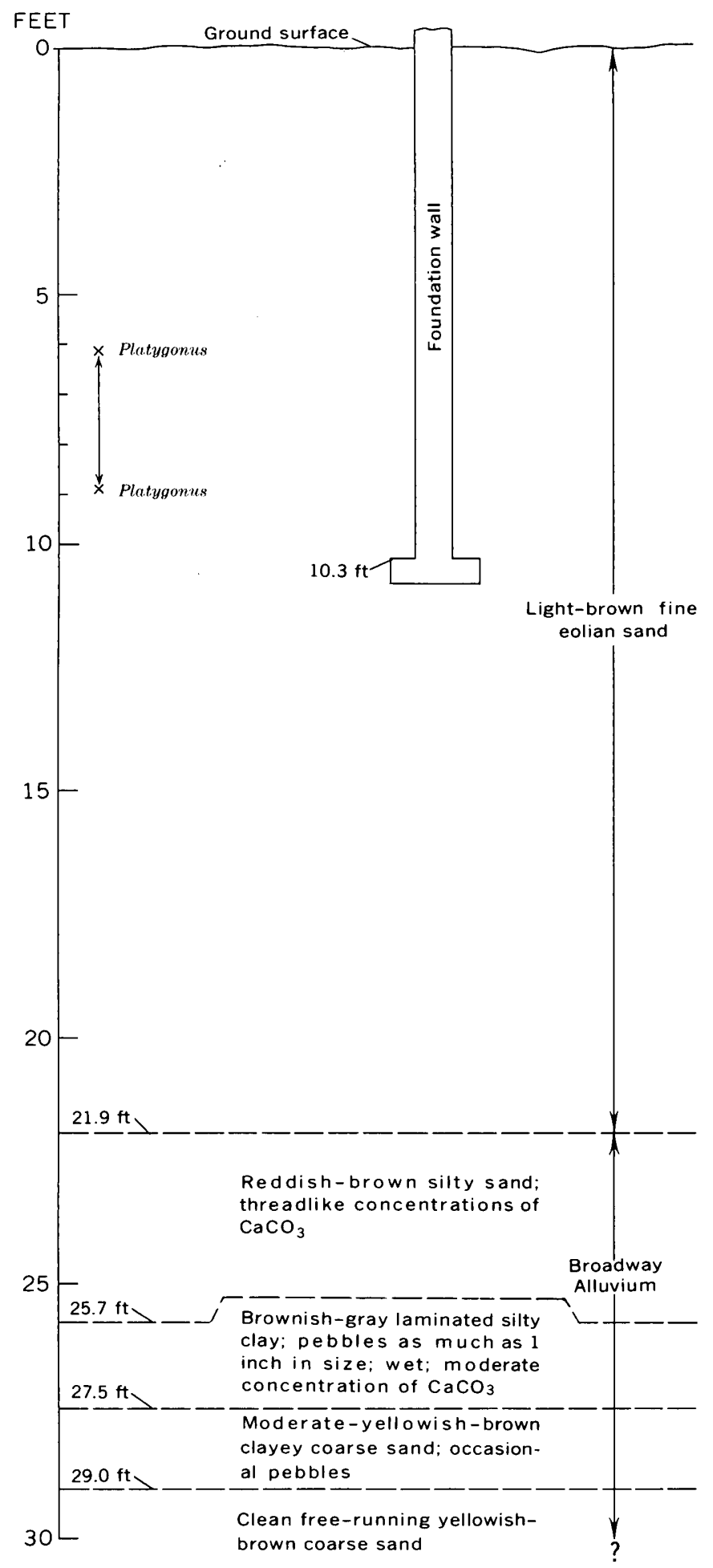

FraURE 10.-Cross-sectional columnar section of eolian sand and Broadway Alluvium at Juvenile Hall. Section measured June 6, 1967, by G. R. Scott, R. M. Lindvall, and R. W. O'Donnell.

part possibly is an overbank late flood deposit such as is observed on most terraces near Denver. The other three lithologies are typical of Broadway Alluvium and demonstrate conclusively that the eolian sand at Juvenile Hall deeply covers the Broadway terrace.

The eolian sand, shown in cross section in figure 10, is composed of light-brown, fine, well-sorted, slightly rounded sand. Generally, either it is not stratified or it shows the sweeping curves of cross-stratification that characterize most sand dunes. Most of the sand is uncemented and only slightly consolidated, but in the upper part it is slightly to firmly cemented by secondary clay and calcium carbonate as a result of soil formation. It is 22 feet thick at Juvenile Hall (fig. 10), but may be twice as thick at other places. A moderately well developed Altithermal soil is formed in the upper part of the eolian sand.

The eolian sand was blown chiefly out of the valley of the South Platte River. Strong winds from the northwest deflated alluvium in the valley and possibly also carried away silt from outcrops of loose Denver Formation and deposited the sand and silt many miles downwind. Lack of vegetation on the newly deposited outwash of the Broadway Alluvium of Pinedale age made the fine part of the outwash readily available to wind erosion. In general, eolian sand lies immediately downwind and loess farther downwind from the valley.

Peccary is one of the few fossils found in the eolian sand in the Denver area. Ages assigned to Platygonus compressus are Sangamon (Schultz and others, 1951, table 1; Hibbard and Taylor, 1960, p. 27 and 32; Slaughter and Ritchie, 1963, p. 126, 128) and Wisconsin (Hibbard, 1958, table 1).

The eolian sand has previously been called late Wisconsin and early Holocene in age (Hunt, 1954, p. 112113; Scott, 1962, p. 32; Scott, 1963, p. 41). We believe that it was deposited starting in Pinedale time and ending when the "Altithermal" soil was formed about 4,500 years ago.

\section{REFERENCES}

Carr, W. J., and Trimble, D. E., 1963, Geology of the American Falls quadrangle, Idaho: U.S. Geol. Survey Bull. 1121-G, $44 \mathrm{p}$.

Cheatum, E. P., and Allen, Don, 1963, An ecological comparison of the Ben Franklin and Clear Creek local molluscan faunas in Texas: Graduate Research Center Jour., v. 31, no. 3, p. 174-179, 1 table.

Gardner, M. E., 1967, Quaternary and engineering geology of the Orchard, Weldona, and Fort Morgan quadrangles, Morgan County, Colorado: Colorado School Mines Ph. D. thesis, $283 \mathrm{p}$.

Hibbard, C. W., 1955, The Jinglebob interglacial (Sangamon?) fauna from Kansas and its climatic significance: Michigan Univ. Mus. Paleontology Contr., v. 12, no. 10, p. 179-228, 2 pls., 8 figs., 1 chart.

1958, Summary of North American Pleistocene mammalian local faunas : Michigan Acad. Sci., Arts, and Letters Papers, v. 43, p. 3-32, 1 table. 
Hibbard, C. W., and Taylor, D. W., 1960, Two late Pleistocene faunas from southwestern Kansas: Michigan Univ. Mus. Paleontology Contr., v. 16, no. 1, p. 1-223, 16 pls., 18 figs.

Hopkins, M. I., Bonnichsen, Robson, and Fortsch, David, 1969, The stratigraphic position and faunal associates of Bison (Gigantobison) latifrons in southeastern Idaho, a progress report: Tebiwa, v. 12 , no. 1 , p. 1-8.

Hunt, C. B., 1954, Pleistocene and Recent deposits in the Denver area, Colorado: U.S. Geol. Survey Bull. 996-C, p. 91-140.

Lewis, G. E., 1970, New discoveries of Pleistocene bisons and peccaries in Colorado, in Geological Survey Research 1970 : U.S. Geol. Survey Prof. Paper 700-B, p. B137-B140.

Richmond, G. M., 1965, Glaciation of the Rocky Mountains, in Wright, H. I., Jr., and Frey, D. G., eds., The Quaternary of the United States: Princeton Univ. Press, p. 217-230.

Schultz, C. B., Lueninghoener, G. C., and Frankforter, W. D., 1951, A graphic résumé of the Pleistocene of Nebraska (with notes on the fossil mammalian remains): Nebraska Univ. State Mus. Bull., v. 3, no. 6, 41 p., 11 figs., 1 table.
Scott, G. R., 1960, Subdivision of the Quaternary alluvium east of the Front Range near Denver, Colorado: Geol. Soc. America Bull., v. 71 , no. 10 , p. 1541-1543.

1962, Geology of the Littleton quadrangle, Jefferson, Douglas, and Arapahoe Counties, Colorado: U.S. Geol. Survey Bull. 1121-L, $53 \mathrm{p}$.

1963, Quaternary geology and geomorphic history of the Kassler quadrangle, Colorado: U.S. Geol. Survey Prof. Paper 421-A, p. 1-70.

1964, Geology of the Northwest and Northeast Pueblo quadrangles, Colorado: U.S. Geol. Survey Misc. Geol. Inv. Map I-408.

Slaughter, B. H., and Ritchie, Ronald, 1963, Pleistocene mammals of the Clear Creek local fauna, Denton County, Texas: Graduate Research Center Jour., v. 31, no. 3, p. 117-131, $1 \mathrm{pl} ., 2$ figs.

U.S. Geological Survey, 1968, Geological Survey Research 1968: U.S. Geol. Survey Prof. Paper 600-A, 371 p. 


\title{
CLAY MINERALOGY OF SELECTED SAMPLES FROM THE MIDDLE MIOCENE FORMATIONS OF SOUTHERN MARYLAND
}

\author{
By KARL STEFANSSON and JAMES P. OWENS, Beltsville, Md.
}

\begin{abstract}
The relative proportions of clay minerals in about 130 samples from the core of a 338 -foot hole drilled by the Baltimore Gas and Electric Co. in Calvert County, Md., in 1967 were calculated from $\mathrm{X}$-ray diffraction patterns, using the ratio of peak area over peak height. Kaolinite, illite, and montmorillonite constitute most of the clay fraction. The illite proportion is nearly constant throughout the core, but the proportions of montmorillonite and kaolinite vary. The results obtained substantiate the hypothesis that montmorillonite increases and kaolinite decreases seaward, away from the source area.
\end{abstract}

In September 1967, the Baltimore Gas and Electric Co. drilled a hole to a depth of 338.0 feet at its atomic reactor site at Calvert Cliffs, southeast of Calvert Beach on Chesapeake Bay, Calvert County, Md. (see BG \& E No. 1 on fig. 1). Ground elevation at the drill site was 112.0 feet above sea level. The hole was cored continuously from a depth of 12.6 feet, and core recovery was almost complete. In the first 109.2 feet cored (from 12.6 to 121.8 feet), there were six intervals, totaling 23.3 feet in thickness, from which no cohesive samples were obtained, but from 121.8 feet to 338 feet the core was continuous. The Baltimore Gas and Electric Co. has made the entire core available to the U.S. Geological Survey and others, for investigation. Data on the clay mineralogy of the core were obtained by X-ray diffraction analyses of about 130 selected samples and are summarized below.

\section{GEOLOGY}

In southern Maryland, strata ranging in age from Early Cretaceous through Holocene crop out. These strata are predominantly poorly consolidated or unconsolidated gravel, sand, silt, and clay. Regional strike is north to northeast, and the dip is east to southeast at a very low angle $\left(1^{\circ}\right.$ or less). The oldest sediments, of Cretaceous age, lie on the Precambrian(?) crystalline rock complex to the west; the younger sediments are exposed progressively to the east and southeast.
Near the core hole the exposed sediments are middle Miocene to Holocene in age (fig. 1). The core hole was spudded in a relatively thin veneer of gravel, silt, and sand, which formerly was believed to be a marine terrace, but is now considered to be part of the "upland deposits" that Hack (1955) has demonstrated to be of fluviatile origin.

The stratigraphic section exposed in a recent excavation near the drill hole is described as follows (modified after Loose, in Glaser, 1968, p. 51-52) :

Undifferentiated Pliocene and Pleistocene and leached Miocene: 26 feet of sand.

Undifferentiated Miocene: 31 feet of sand and clay.

Choptank Formation: 42 feet of clay and sand.

The top of the measured section is approximately the same as the ground elevation at the core hole, and the measured section would therefore be the equivalent of the first 100 feet of the core (fig. 2). In this area the expected section would be the upland deposits, underlain by the middle Miocene St. Marys, Choptank, and Calvert Formations. In the measured section (Loose, in Glaser, 1968, p. 51-52), the uppermost 26 feet of sediments are described as undifferentiated Pliocene and Pleistocene and leached Miocene sands. This section may be equivalent to the Brandywine Formation (upland deposits), of Pliocene(?) age (Hack, 1955). The lack of core recovery from the interval 17.1-24.9 feet in the core hole suggests that the presumed unconformable contact of the Miocene St. Marys Formation with the overlying sediments may be in this interval. If this is true, then Loose's (Loose, in Glaser, 1968, p. 52) "leached Miocene" should be the youngest sediments of St. Marys age present in the core. This, however, does not mean that the entire St. Marys Formation is present. The maximum thickness of the St. Marys Formation, measured in outcrop in the Calvert Cliffs, is 45 feet (Glaser, 1968). If the top of the underlying Choptank formation is correctly picked

U.S. GEOL. SURVEY PROF. PAPER 700-B, PAGES B150-B156 


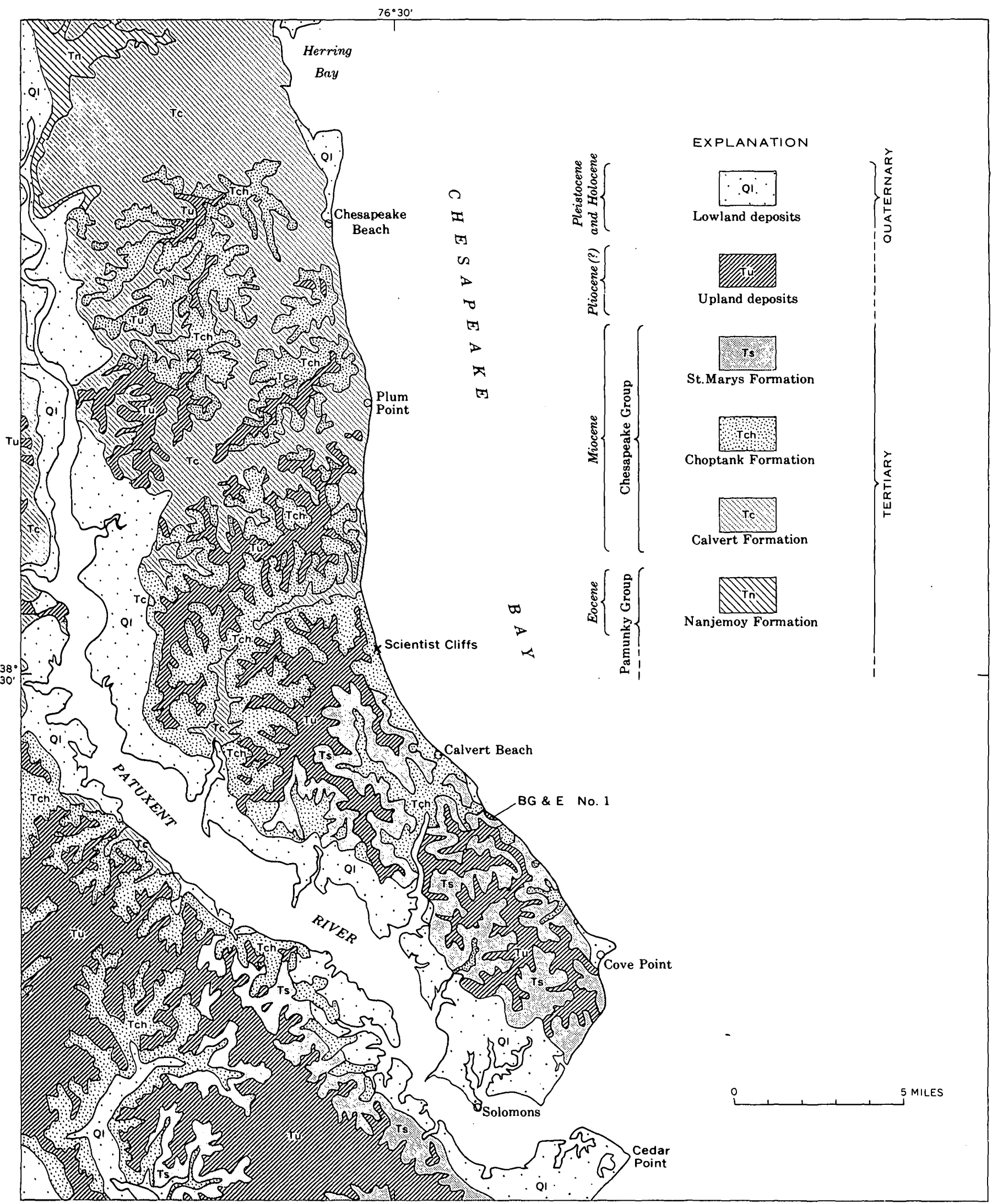

Froure 1.-Generalized geologic map of part of southern Maryland, showing the distribution of Eocene to Holocene formations. (Modified after Glaser, 1968.) 
at a depth of 58 feet in the core hole (see below), and if the contact of the St. Marys Formation with the overlying sediments is somewhere in the interval 17.124.9 feet, then the total thickness of the St. Marys formation in the core hole is less than 45 feet.

The top of the Choptank Formation is placed, on the basis of fossil evidence, at 57 feet below the top of the section measured by Loose (in Glaser, 1968, p. 51-52). In the core, an abundance of fossil shells was noted at a depth of 58 feet, and the top of the Choptank Formation in the core is therefore considered to be at this depth. The total thickness of the measured section is 99 feet, and therefore only the upper part of the Choptank could be measured (57-99 feet). In nearby exposures, the Choptank Formation has a maximum thickness of about 60 feet (Glaser, 1968). If the maximum thickness of the Choptank Formation is present in the core, then the ChoptankCalvert contact should be at a depth of approximately 118 feet. Significantly, there was no core recovery from the interval 113.6-121.8 feet. It may be that the lack of core recovery in this interval is due to physical changes at the contact between the two formations. If so, the placing of the Choptank-Calvert contact at a depth of approximately 118 feet is valid.

The maximum known thickness in outcrop of the Calvert Formation is about 180 feet (Glaser, 1968), but in the core it seems to be considerably greater. At a depth of 329.3 feet there is a 0.3 -foot bed of glauconite with some carbonaceous fragments. Below this, the core is sandy and glauconitic. Just above the glauconite bed the section is sandy, silty, and clayey for a few feet and contains a few grains of glauconite, probably reworked; above this, the section is clayey. The top of the glauconite bed is considered the top of the Nanjemoy Formation of Eocene age. On the basis of the above inferences, that is, that the top of the Calvert is at a depth of approximately 118 feet and the top of the Nanjemoy at about 329 feet, the thickness of the Calvert Formation in the core hole is approximately 211 feet.

\section{SAMPLES}

About 130 samples were selected from the core wherever obvious physical changes, such as changes in lithology, compaction, and color, occurred. The clay fractions from these samples, therefore, represent not only clay but other lithologic types found in the core.

The samples were disaggregated in distilled water. Rapid flocculation took place in nearly all samples and was inhibited by adding sodium hexametaphosphate to the disaggregated samples. This extreme flocculation of the Miocene clays of southern Maryland has been noted before (J. W. Hosterman, oral commun., 1968). An oriented tile for X-ray diffraction analyses was then prepared from the $<4$-micron fraction of each sample. Three diffraction patterns were obtained from each tile: first from the untreated tile, then after heating the tile to $350^{\circ} \mathrm{C}$, and finally after glycolating the tile. Heating to $550^{\circ} \mathrm{C}$ was not necessary because chlorite is absent or very sparse in all samples analyzed.

The X-ray diffraction patterns indicate that the main constituents of the clay fractions are montmorillonite, illite, and kaolinite. To obtain the relative proportions of these three mineral groups, the ratio of peak area over peak height was calculated (Schultz, 1964). The fractions were then adjusted to parts in 10 (for example: montmorillonite, 5 ; illite, 3 ; kaolinite, 2). Many of the samples from the uppermost 145 feet of the core contain large amounts of gypsum. Examination of the excavation near the drill site showed that the gypsum is not a primary deposit; it was formed later along fractures in the sediments and is therefore not pertinent.

\section{DISCUSSION AND CONCLUSIONS}

A generalized stratigraphic section of the core, and the relative proportions of the three principal clay minerals (kaolinite, illite, montmorillonite) in the samples from the core, are shown in figure 2. The columns show that montmorillonite is the major clay constituent in all the samples, except in those from the first 26 feet, where kaolinite predominates. The illite fraction is large and shows remarkably little variation throughout the entire section, leaving the kaolinite and montmorillonite as the varying components of the clay fraction. These results are in substantial agreement with the results obtained by Knechtel, Hamlin, and Hosterman (1966). The ratios of kaolinite and montmorillonite reported by them are, however, somewhat at variance with the results obtained from the study of the core samples, but both studies show an almost identical and invariable relative amount of illite present. According to Knechtel, Hamlin, and Hosterman the clay fractions of materials from the Choptank and Calvert Formations contain little or no kaolinite and are composed mainly of montmorillonite and illite, approximately in a $2: 1$ ratio; 
the clay fractions from the St. Marys Formation contain kaolinite, illite, and montmorillonite in a $1: 1: 1$ ratio. That is, the illite fraction in their samples and in the core samples from the Baltimore Gas and Electric Co. core hole 1 , is almost invariable and amounts to about one-third of the total clay fraction.

The distribution of clay-mineral assemblages in both recent and ancient sediments has been discussed in many papers in recent years. From the existing literature, Parham (1966) tabulated and summarized data relating to this problem. He showed that most workers in this field agree that there is a definite relationship between kaolinite and montmorillonite with regard to the direction of sediment transport. The generally accepted hypothesis is that the amount of kaolinite decreases seaward, away from the source area, and that, conversely, the amount of montmorillonite increases in the same direction. This general agreement, however, is partly contradicted by Brown and Ingram (1954), who note that in sediments of the Neuse River, N.C., both kaolinite and montmorillonite decrease seaward.

A recent study by Porrenga (1966) on the clay mincrals in recent sediments of the Niger Delta (Africa), shows that the main constituents of the clays are kaolinite, illite, and montmorillonite, as is also the case in the Maryland core samples. The main difference between the Niger Delta clays and the clays in the Maryland cores is the relative amount of illite. In the Niger Delta clays, illite is a minor constituent, but in the Maryland clays, it is relatively abundant. In both areas, however, the illite fraction is remarkably constant, and the kaolinite and montmorillonite are the varying components of the clay fraction. Furthermore, according to Porrenga (1966), there is a definite zonal arrangement of the clay fractions, which shows that montmorillonite increases seaward.

Whitehouse, Jeffrey, and Debbrecht (1960) concluded that kaolinite and illite flocculate and settle faster than montmorillonite when they come in contact with salt water. To check this conclusion, Porrenga (1966) performed experiments on Holocene sediments. His experiments confirm the hypothesis (Whitehouse and others, 1960) that each clay mineral has a different rate of floccule formation. Floccules of kaolinite and illite form and settle faster than montmorillonite floccules, which form more slowly and are smaller and will, therefore, be transported farther in moving water. This differential flocculation, then, influences the rate of settling and the distance of transport of the clay minerals, and is, therefore, probably the most important single factor in zonation and lateral mineralogical differentiation in clay sedimentation. Of the three clay minerals discussed, kaolinite and montmorillonite seem to be the two extremes of flocculation and sedimentation behavior. Illite seems to be less affected.

The analyses of the clay fractions in the core from Calvert Cliffs, Md., seem to confirm, at least in part, the theory that montmorillonite increases seaward and that kaolinite decreases in the same direction, away from the source area. The samples from the core show predominance of kaolinite in the top 26 feet; below that, montmorillonite is the major clay constituent. The illite fraction shows little variation throughout the entire core. The upper 26 feet of the core is fluviatile material ("upland deposits") and perhaps the youngest sediments of the emergent St. Marys Formation. That is, the sediments are fluviatile and (or) nearshore deposits, and kaolinite, therefore, should be the major constituent in the clay assemblage.

Near-shore and nonmarine sedimentary equivalents of the marine formations penetrated at Calvert Cliffs by the core drill, crop out to the west, but no data are available on the clay-mineral assemblages in these sediments; the validity of the kaolinite-montmorillonite relationship, therefore, cannot be verified here. To the north, however, in New Jersey, the Kirkwood Formation is considered to be the near-shore equivalent of the marine middle Miocene (St. Marys, Choptank, Calvert) formations of Maryland. Owens and Minard (1962), and particularly Owens and Sohl (1969), have shown that the quartz-rich, sandy, near-shore Kirkwood Formation contains very little or no montmorillonite. The dominant clay mineral is kaolinite, and illite is present in considerable amounts.

Sediments from different source areas will undoubtedly have different mineral assemblages, as is shown by the great abundance of quartz in the clay fractions of the Kirkwood Formation (Owens and Sohl, 1969). If, however, only the relative ratios of kaolinite, illite, and montmorillonite in the near-shore and marine equivalents of the middle Miocene of New Jersey, Delaware, and Maryland are considered, then one must conclude that the interrelationship of these minerals is not determined by diagenesis, but is a function of differential flocculation. This, in turn, determines rate of settling and distance of transportation of these minerals. 


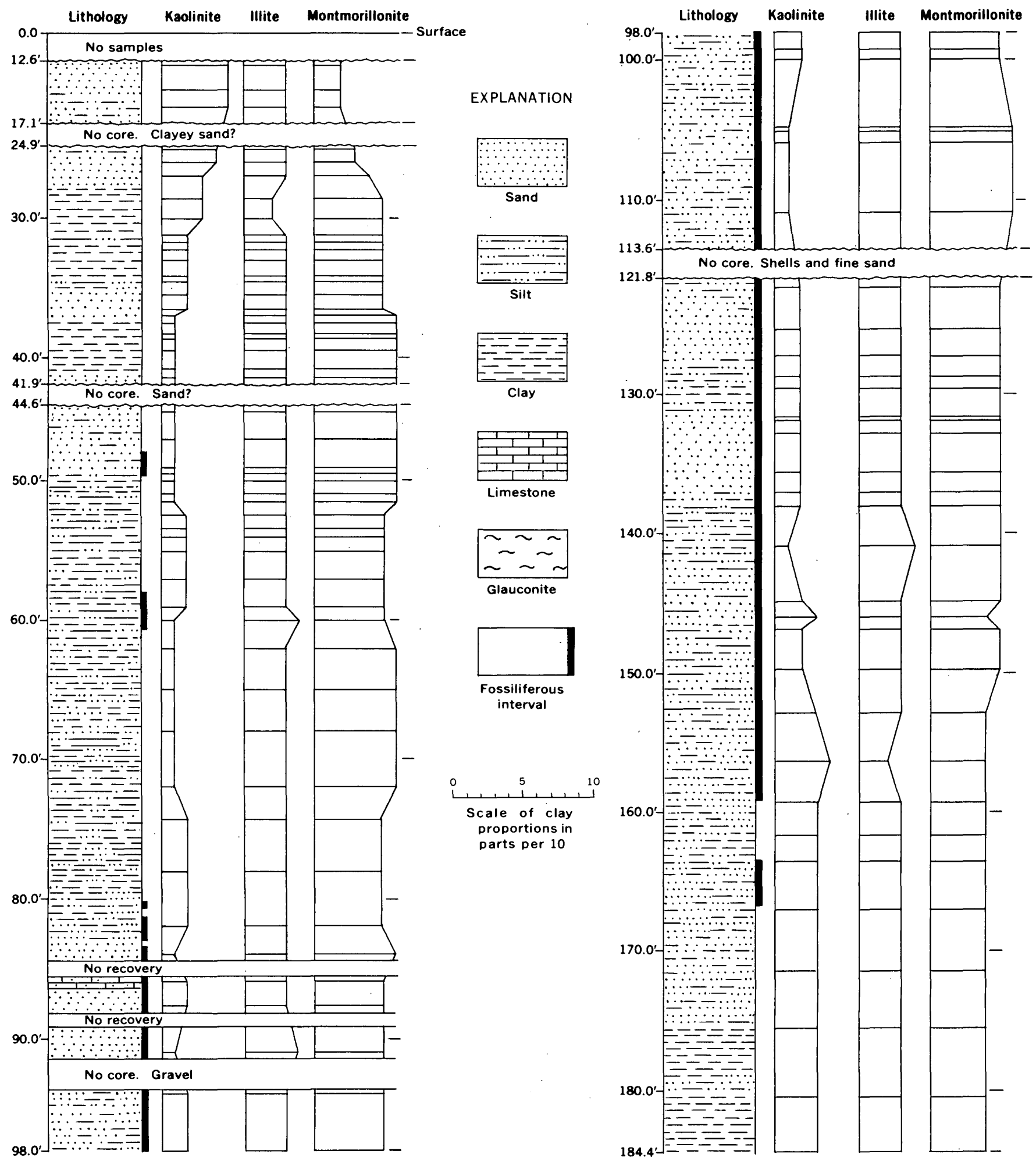

FIgURE 2.-Generalized stratigraphic section, and relative proportions, in parts per 10, of kaolinite, illite, and montmorillonite from selected samples in Balitimore Gas and Electric Co. core hole 1, Calvert County, Md. 

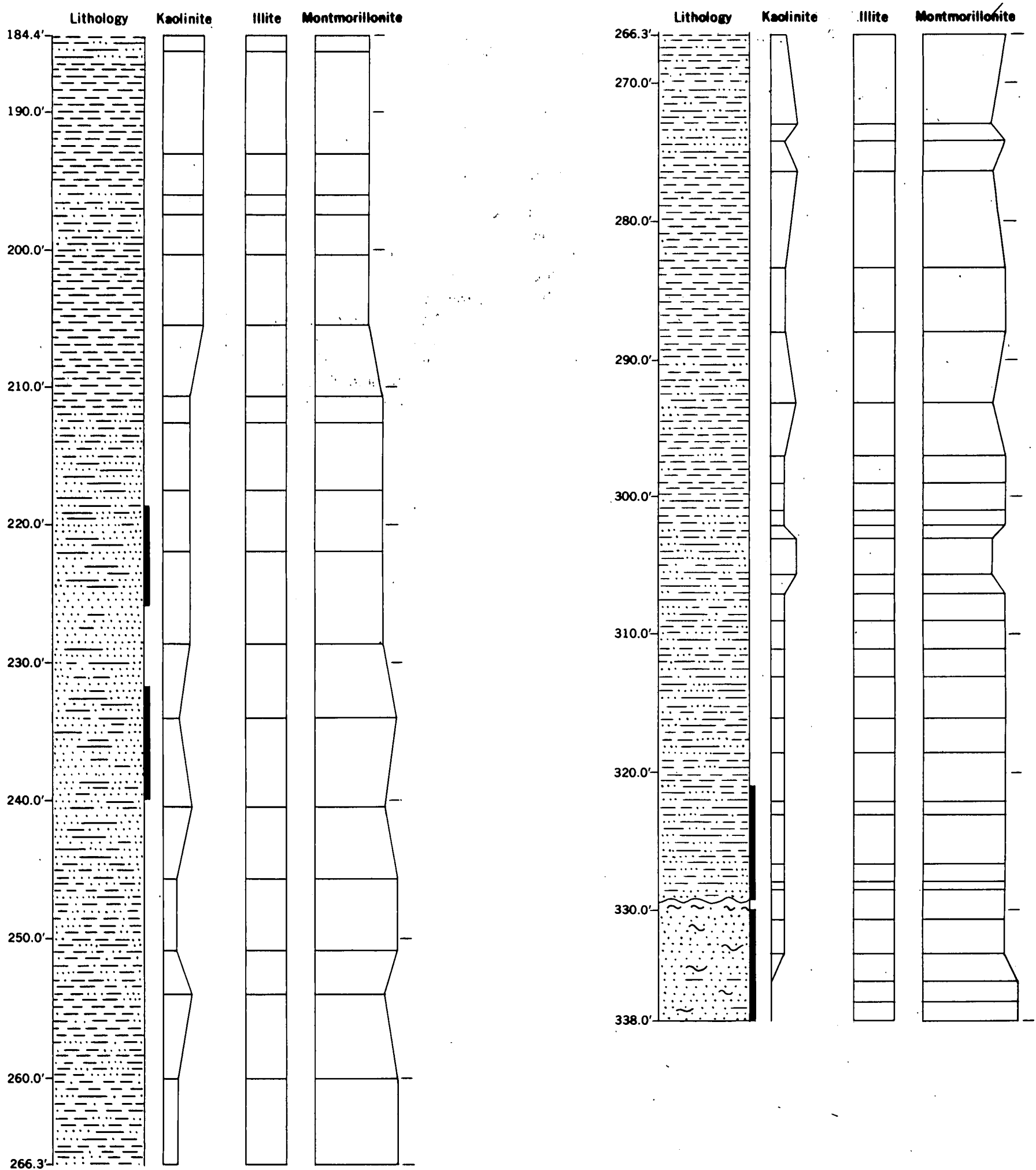

Figure 2. (con.) 


\section{REFERENCES}

Brown, C. Q., and Ingram, R. L., 1954, The clay minerals of the Neuse River sediments [N.C.] : Jour. Sed. Petrology, v. 24, no. 3, p. 196-199.

Glaser, J. D., 1968, Coastal Plain geology of southern Maryland : Maryland Geol. Survey, Guidebook 1, p. 1-56.

Hack, J. T., 1955, Geology of the Brandywine area and origin of the upland of southern Maryland: U.S. Geol. Survey Prof. Paper 267-A, p. 1-43.

Knechtel, M. M., Hamlin, H. P., and Hosterman, J. W., 1966, Expandable clay in St. Marys Formation of southern. Maryland: Maryland Geol. Survey Rept. Inv. 4, $17 \mathrm{p}$.

Owens, J. P., and Minard, J. P., 1962, Pre-Quaternary geology of the Columbus quadrangle, New Jersey: U.S. Geol. Survey Geol. Quad. Map GQ-160.

Owens, J. P., and Sohl, N. F., 1969, Shelf and deltaic paleoenvironments in the Cretaceous-Tertiary formations of the New Jersey Coastal Plain, in Subitzky, Seymour, ed., Geology of selected areas in New Jersey and eastern Penn- sylvania and guidebook of excursions: New Brunswick, N. J., Rutgers Univ. Press, p. 235-278.

Parham, W. E., 1966, Lateral variations of clay mineral assemblages in modern and ancient sediments: Internat. Clay Conf., Jerusalem, Israel, 1966, Proc., v. 1, p. 135-145.

Porrenga, D. H., 1966, Clay minerals in Recent sediments of the Niger Delta, in Bailey, S. W., ed., 1966, Clays and clay minerals-Proceedings of the 14th National Conference, Berkeley, California, [1965] conducted by the Clay Minerals Society: New York, Pergamon Press, p. 221-233.

Schultz, L. G., 1964, Quantitative interpretation of mineralogical composition from $X$-ray and chemical data for the Pierre Shale: U.S. Geol. Survey Prof. Paper 391-C, p. C1-31.

Whitehouse, U. G., Jeffrey, L. M., and Debbrecht, J. D., 1960, Differential settling tendencies of clay minerals in saline waters, in Swineford, Ada, ed., Clays and clay mineralsProceedings of the 7th National Conference on Clays and Clay Minerals, Washington, D. C., Oct. 20-23, 1958: New York, Pergamon Press, p. 1-79. 
GEOLOGICAL SURVEY RESEARCH 1970

\title{
THE GARDINERS CLAY OF EASTERN LONG ISLAND, NEW YORK- A REEXAMINATION
}

\author{
By JOSEPH E. UPSON, Washington, D.C.
}

\begin{abstract}
Certain nonfossiliferous bodies of clay and fine sand exposed in the Mattituck quadrangle, north shore of Long Island, N.Y., identifled by Fuller as Gardiners Clay and Jacob Sand, are interbedded with the Herod Gravel Member of the Manhasset Formation, advance outwash of ice that deposited the Montauk Till Member of the Manhasset Formation. The clay beds may be equivalent to the type Gardiners Clay, but are higher in the stratigraphic sequence than Fuller placed the unit. They are evidently also stratigraphically higher than fossiliferous clays penetrated in wells in central and western Long Island and called Gardiners. The writer believes that the term Gardiners Clay either needs to be redefined, or restricted in usage.
\end{abstract}

Is the Gardiners Clay the Gardiners Clay?

For many years the Gardiners Clay, of late Pleistocene age, has been considered a rather distinctive widespread unit among the glacial deposits of coastal New York and New England-a key horizon. It was named by Fuller (1905, p. 375) from exposures on Gardiners Island, which lies between the forks of eastern Long Island. It was identified by Fuller on Fishers Island and other islands to the east, in a number of exposures along the north shore of eastern and central Long Island, and from well records in western Long Island. It has been thought to be, at least in part, the equivalent of the Cape May Formation of New Jersey (MacClintock and Richards, 1936, p. 335).

However, a number of geologists working on the ground-water resources of Long Island have doubted the widespread nature of the Gardiners Clay, and have questioned specifically whether the formation, as exposed along the sea cliffs of the north shore, really is the same as the clays reported in wells in the western and southwestern parts of the island. The Gardiners Clay may not be wholly, or even at all, equivalent to the Cape May Formation. Also, Kaye (1964) has described two sets of deposits on Martha's Vineyard, evidently separated by a major ice advance. Super- ficially both of these sets appear to be similar to the Gardiners Clay.

In October 1964, the writer began field mapping in eastern Long Island (fig. 1) for the purpose of learning more about the Gardiners Clay. He hoped to determine its relationship to the Wisconsin tills of the area, and to uncover evidence as to whether or not the formation, as exposed, did continue west and south to coincide with what has been called Gardiners Clay in well records. Work was started in the Mattituck quadrangle and, hopefully, will be extended in time to adjoining quadrangles on the west and south. The cliff exposures along the north shore of the Mattituck quadrangle have been examined. This paper presents some of the preliminary findings from this examination. The purpose is also to bring together in one place some of the other dissident ideas about the Gardiners Clay on Long Island.

In this work it has been found meaningless to try to isolate the Gardiners Clay from a unit that immediately overlies it in most places, namely, the Jacob Sand.

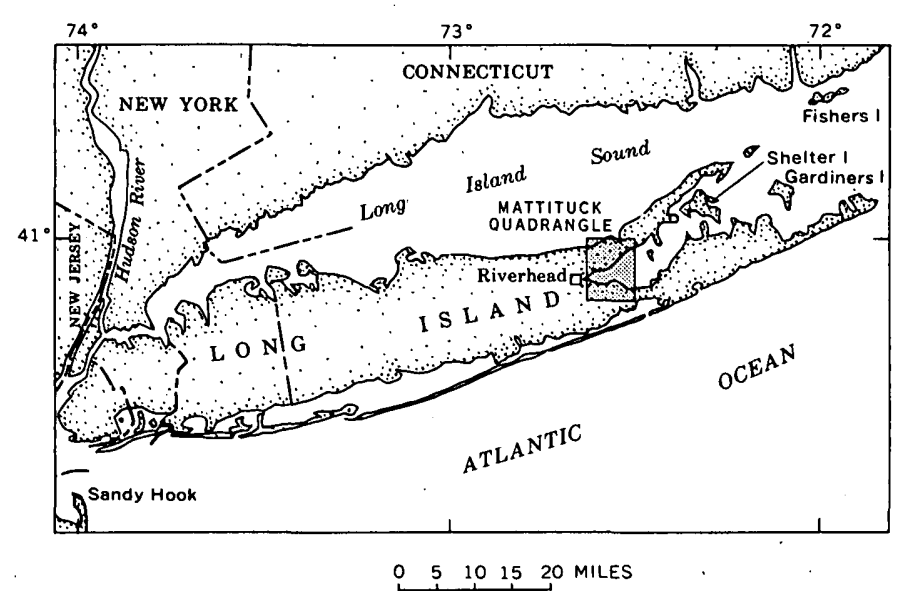

Fiaure 1.-Outline map of Long Island, N.Y., showing location of area studied, and other places mentioned in text. 
In what follows, the Gardiners Clay and Jacob Sand will be treated together.

\section{GARDINERS CLAY AND JACOB SAND}

The Gardiners Clay was described by Fúller (1914, p. 100) from exposures on Gardiners Island "where it consists of black, greenish (fossiliferous), and red clays merging upward into Jacob sand * * *." At other localities farther west the clay is more brown, or chocolate colored, as at Jacob Hill (in the Mattituck quadrangle), "**** where several pinnacles of contorted reddish or chocolate-colored sandy clays stand out prominently just back of the beach ***" (1914, p. 98). (See also Fuller, 1905, p. 375-378.) As seen by this writer, the typical Gardiners is tough clay in massive beds 10 or more feet thick and is nearly always deformed, with distortions ranging from broad folds to minute contortions. The clay is nearly always overlain. by the Jacob Sand through a transitional phase; that is, where the sequence is well exposed, the Gardiners Clay becomes less tough in the upper part and is laminated with seams of fine sand and silt. Upward these seams become thicker and coarser, and the clay laminæ become thinner and farther apart until the whole interlaminated zone gives way to massive, or finely bedded fine to medium sand. This is the Jacob Sand.

This transition and relationship were recognized by Fuller (1914, p. 106), who named the Jacob Sand (p. 107) from Jacob Hill in the Mattituck quadrangle: the Jacob Sand "consists of exceedingly fine sands, mainly quartz flour, but with many grains of white mica and some of.dark-colored minerals. In color $* * *$ very light gray to yellowish and buff tints, but where laminæ of true clay are present they may be stained red externally." (See also Fuller, 1905, p. 378-381.)

\section{STRATIGRAPHIC SEQUENCE IN THE CLIFFS OF THE MATTITUCK QUADRANGLE}

The overall stratigraphic sequence exposed in the cliffs of the Mattituck quadrangle and the eastern part of the adjoining Riverhead quadrangle consists from bottom to top of (1) dark, ordinarily red clay, ordinarily near the bottom of the exposures and visible only in places, (2) fine to medium, massive to faintly stratified sand and silt, gray or faintly yellowish, and characterized by more or less abundant white mica in tiny flakes, (3) thick and rather uniform coarse sand and pebble gravel, light gray to yellowish, and (4) compact gray till. The clay grades upward through interlamination with the fine sand and silt, these two representing the Gardiners Clay and Jacob Sand. Bedding of both these units is distorted to a greater or lesser degree. Except where strongly distorted the sand and silt pass upward through a gradual transition into the coarse sand and gravel. This unit is most conspicuous in the higher cliffs, where it is several tens of feet thick, and represents the Herod Gravel of Fuller. The overlying till is the Montauk Till of Fuller (1914, pl. I). The contact is sharp at some places and gradational at others. Some still younger deposits, present locally, are thought to represent the Harbor Hill Moraine and post-Harbor Hill outwash, but these are not discussed here.

The sequence observed, clay, sand, gravel, and till, is similar to that seen in the cliffs of Fishers Island; parts of the sequence can be seen on Shelter Island and at other localities on the north shore of Long Island.

In the Mattituck quadrangle the sequence indicates glacial conditions. The few pebbles of appreciable size occurring randomly in both the clay and the fine sand suggest ice rafting. The overall sequence is clearly a transitional one culminating in till, and in general the grain size increases upward. However, at two localities the clay appears to be of local extent. At the west end of the cliffs below Jacob Hill, where the Jacob Sand overlies the clay, gravel occurs beneath the clay which, contrary to Fuller's identification as overturned Herod Gravel, appears to lie in normal position stratigraphically below the clay. In the large cliff about a quarter of a mile from the northern edge of the quadrangle, the clay clearly interfingers with the sand and gravel that lies beneath the Montauk Till.

\section{RELATIONSHIPS OF GARDINERS CLAY AND JACOB SAND TO ENCLOSING DEPOSITS}

\section{Jacobs Hill locality}

The first exposure is in the cliff face on the flank of Jacobs Hill and almost due north of Hallocks Pond on the Mattituck quadrangle (see sketch made from photograph, fig. 2). This is a fairly large exposure, the top being 75-80 feet above the beach. At the west end is a sharp pinnacle composed mostly of compact fine sand, Jacob Sand, having a steep dip. It is likely that this pinnacle is the one illustrated by Fuller (1914, fig. 72, p. 98). If so, the interpretation of the structure as here given differs from Fuller's.

In the main part of the cliff the deposits consist of laminated chocolate-brown clay above ( $A$ in fig. 2), light-gray to light-yellowish gray fine sand and silt in the middle. $(B)$, and again brown clay near the bottom $(C)$. This rests on white, pebbly, coarse sand $(D)$ which extends down to the beach. All these strata are distorted in some degree. In particular, the clays are minutely distorted. The upper clay strikes about N. $50^{\circ} \mathrm{W}$., and dips to the northeast. The fine sand is light buff to cream, and contains abundant tiny flakes 


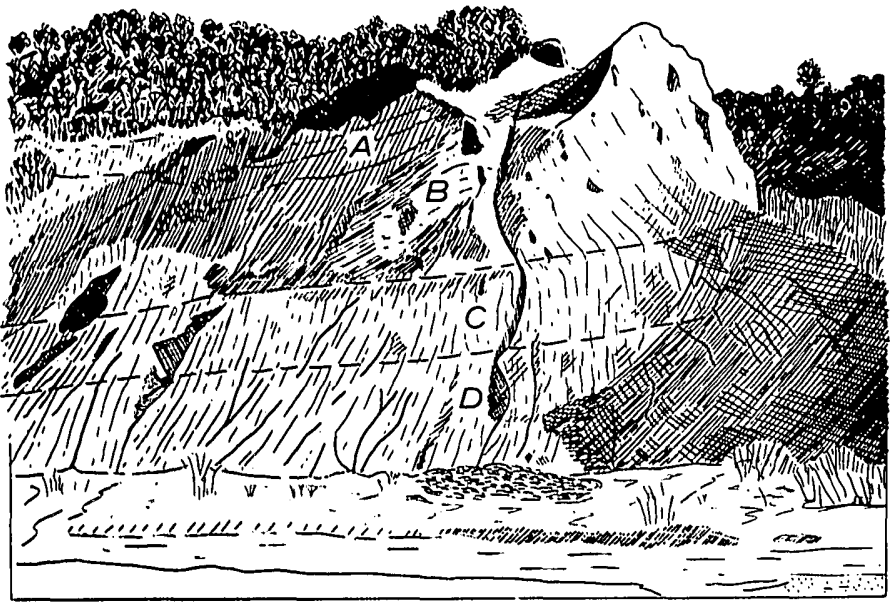

Froure 2.-Exposure of Gardiners Clay and Jacob Sand in sea cliff below Jacobs Hill. $A$, chocolate-brown clay; $B$, very fine sand and silt (Jacob Sand); $C$, brown clay, becoming silty and sandy above (Gardiners Clay); and $D$, coarse pebbly sand, white, mostly covered by wash.

of white mica. Near its base, clayey beds strike N. $80^{\circ}$ E., and dip about $30^{\circ} \mathrm{N}$., slightly less steeply than the slope of the cliff face. Below this, and just above the lower clay, is an isolated body of gravel that resembles till. This probably was rafted by ice into the water body in which the fine sand and silt were being deposited. The fine sand rests in turn on the lower chocolate-brown clay, whose laminations generally strike $\mathrm{N}$. $45^{\circ} \mathrm{E}$. and dip about $50^{\circ} \mathrm{NW}$., again less steeply than the slope of the cliff face. This clay is $20-30$ feet thick and rests with sharp but conformable depositional contact on white, coarse, pebbly sand. A maximum of about 30 feet of this coarse sand is in the base of the clift, though at the time of visit it was not fully exposed.

The upper clay pinches out to the east, and rides up over the fine sand to the west. The fine sand is evidently the Jacob Sand, the lower clay is the Gardiners Clay, both of Fuller. The coarse, pebbly sand which underlies the Gardiners Clay occupies the position of the Jameco Gravel (see table 1). However, the writer considers this coarse sand to be part of the outwash associated with the Montauk Till Member of the Manhasset Formation in which the clay and the sand are interbedded. The stratigraphy at the second locality supports this interpretation.

\section{Aldrich Lane locality}

The second locality is about 0.45 mile east of where the Southold town line meets the beach, and about 0.15 mile east of Aldrich Lane extended where the sea cliff becomes noticeably lower. For a distance of 0.3 mile along the beach west of this place, the general sequence is from bottom to top: (1) compact dark red clay exposed at two places at the base of the cliff (evidently the Gardiners Clay), (2) brown silty clay, (3) medium to fine sand and silt typical of the Jacob Sand, and (4) coarse sand and gravel of the Herod Gravel member of the Manhasset Formation. The silty clay and the overlying fine sand and silt are exposed discontinuously in the lower 25 to 75 feet of the cliff over the distance of about 0.3 mile. At the locality $(0.15$ mile east of Aldrich Lane extended) the fine sand and silt and clay rest on cream to tan coarse sand and pebble gravel which in exposure is about 30 feet thick. The clay and fine sand and silt pinch out a short distance to the east, where the whole cliff is composed of coarse sand and gravel. Thus, the clay and sand, comprising the Gardiners and Jacob units, constitute a lens in the Herod Gravel unit.

Thus, at two places in the Mattituck quadrangle the Gardiners Clay, as defined by Fuller, is seen to rest on light-colored coarse sand and gravel. The grains and pebbles are almost 100 percent quartz, and the larger sized fragments are on the order of 1 inch in diameter. At one of these localities the Gardiners-Jacob is clearly a lens in an otherwise continuous body of gravel. This gravel is transitional with the overlying Montauk Till. It is therefore considered to be the advance outwash from the encroaching ice associated with that till. The Gardiners Clay and Jacob Sand identified by Fuller in the Mattituck quadrangle are then interpreted as a lens or lenses in the outwash preceding the advance of ice that deposited the Montauk Till.

\section{STRATIGRAPHIC RELATIONSHIPS}

Table 1 shows the simplified stratigraphy for Long Island, according to Fuller, and part of the stratigraphy as exposed in sea cliffs of the Mattituck quadrangle and as interpreted in the course of this field study. Note that this interpretation makes a significant change in the stratigraphic position of the material formerly identified as Gardiners Clay in the Mattituck quadrangle.

As Fuller described it, the Gardiners Clay included deposits ranging from exposures on Gardiners Island (the type locality) to clays penetrated by wells in western Long Island at 100 feet or more below sea level (Fuller, 1914, p. 102-103). Students of Long Island geology, working mainly on ground-water resources investigations since the early thirties, have questioned the equivalence of all these exposed bodies and undergiround occurrences. The lenticular units in the Mattituck quadrangle appear to be part of the advance outwash from what has been called Montauk Till and lately considered to be of Wisconsin age. The deposits that occur below sea level in western Long Island were considered to be Sangamon in age, and equivalent to 


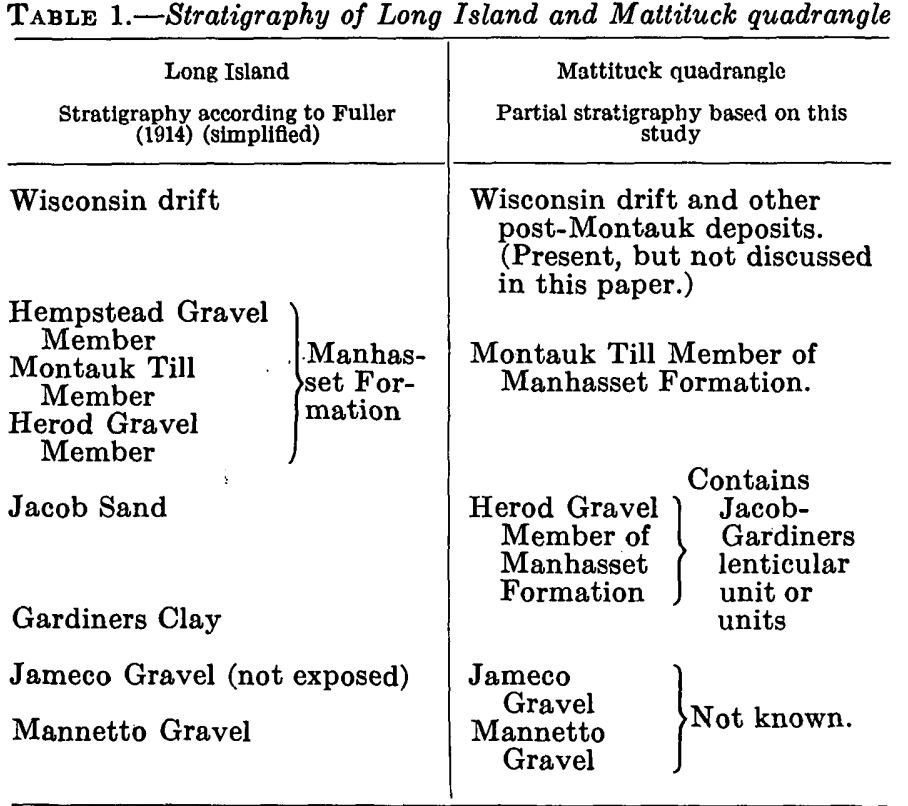

the Cape May Formation in New Jersey (MacClintock and Richards, 1936, p. 335). It seems unlikely that these are the same.

Fuller's determination of age of the Gardiners Clay was based in part on the presence of fossils reported or found almost entirely in wells, indicating an interglacial time; and in part on its position below the Montauk Till, which was thought to be Illinoian. At one locality near Red Spring Point in Nassau County, now (1965) covered by slumped material, beds of darkgray to black, organic-rich clay were observed to contain shells. A collection was made from this locality about 1955 and dated by carbon-14 methods as older than 38,000 years B.P. (Swarzenski, 1959, p. 1084). These deposits are strongly deformed, and probably have been elevated by glacial pressures, or even actual bulk transport. Also, Weiss (1954, p. 155-156) found Foraminifera in supposed Gardiners Clay at a position about 100 feet below sea level in certain wells drilled at the Brookhaven National Laboratory. Weiss further reported (p. 148) that he did not find Foraminifera in the deposits of silt and clay exposed on the north shore of Suffolk County (Long Island). The present writer has examined a good many exposures of supposed Gardiners Clay and Jacob Sand in eastern Long Island, and has seen no macrofossils. Samples collected by J. P. Minard in the fall of 1965 from localities described in this report have been examined by Ruth Todd, of the U.S. Geological Survey, and found to contain no organic material. Records of some wells that penetrate clay called Gardiners in western Long Island indicate some sands that might represent Jacob Sand. At many exposures, the Jacob is 30 feet or more thick, and of distinctive very fine grained lithology. This unit is so pronounced that it ought to be a clearly recognizable layer in well cuttings or samples.

The writer therefore concludes that the Gardiners Clay, as identified on the north shore of Long Island, is not the same as the Gardiners so named from well records in western Long Island. Weiss (1954, p. 148) concluded the same from purely paleontologic evidence. The clay may not even be the same as that at the type locality on Gardiners Island. It, together with the Jacob Sand (whose type locality is within the Mattituck quadrangle), was deposited in shallow depressions on the surface of outwash from advancing ice of probable Wisconsin age. These bodies are of local occurrence stratigraphically, and of limited extent geographically. If this is true, the Gardiners Clay cannot be regarded as a marker bed in Pleistocene stratigraphy, even within Long Island. There may be several units of similar lithology, but of different ages. Just as the exposed beds identified as Gardiners are related to advancing Montauk ice, the clays penetrated in wells in western Long Island may be related to an earlier ice advance.

In summary, the following possibilities present themselves: (1) the deposits in the Mattituck quadrangle which were identified by Fuller as part of the Gardiners Clay are the equivalent of the deposits on Gardiners Island and, hence, really are Gardiners Clay, whereas the subsurface deposits in western Long Island are not; (2) the subsurface deposits are equivalent to the Gardiners of Gardiners Island, and the Mattituck quadrangle deposits are something else; or (3) all the deposits are different. At present, the writer considers that the first possibility is more likely to be correct. If so, the name Gardiners Clay should be retained for these probable Wisconsin deposits, and a different designation sought for the probably older subsurface deposits of western Long Island.

\section{REFERENCES}

Fuller, M. L., 1905, Pleistocene geology of Fishers Island : Geol. Soc. America Bull., v. 16, p. 367-390.

1914, The geology of Long Island, New York: U.S. Geol. Survey Prof. Paper 82, 231 p.

Kaye, C. A., 1964, Outline of Pleistocene geology of Martha's Vineyard, Massachusetts, in Geological Survey Research 1964: U.S. Geol. Survey Prof. Paper 501-C, p. C134-C139.

MacClintock, Paul, and Richards, H. G., 1936, Correlation of late Pleistocene marine and glacial deposits of New Jersey and New York: Geol. Soc. America Bull. v. 47, No. 3, p. 289-338.

Swarzenski, W. V., 1959, Ground-water supplies in Pleistocene and Cretaceous deposits of northwestern Nassau County, N.Y.: New York Acad. Sci. Annals, v. 80, art. 4, p. 10771091.

Weiss, Lawrence, 1954, Foraminifera and origin of the Gardiners Clay (Pleistocene), eastern Long Island, New York: U.S. Geol. Survey Prof. Paper 254-G, p. 143-163. 


\title{
SETTLING VELOCITY OF GRAINS OF QUARTZ AND OTHER MINERALS IN SEA WATER VERSUS PURE WATER
}

\author{
By CHARLES I. WINEGARD, Menlo Park, Calif.
}

\begin{abstract}
The settling velocities of particles in sea water differ signiflcantly from those in fresh water. For example, a 1.0-micron-diameter quartz sphere in sea water will settle 4,000 meters in 882 days. The same particle in fresh water will settle to that depth in 824 days, 6.58 percent less time. Velocities in sea water can be calculated for a spherical particle of given size and composition if the viscosity and specific gravity of the water are known.
\end{abstract}

The settling or terminal velocity of particles is -a significant parameter in sedimentation studies. Settling velocities in sea water are commonly calculated from velocities in fresh water, especially in the laboratory. Velocities can be derived by the following formula (Stokes' law):

$$
V=\frac{g}{18} \times \frac{\left(P_{1}-P_{2}\right) d^{2}}{\eta},
$$

where

$V=$ terminal settling velocity, in centimeters per second,

$g=$ acceleration due to gravity $\left(981 \mathrm{~cm} / \mathrm{sec}^{2}\right)$

$P_{1}=$ specific gravity of particle,

$P_{2}=$ specific gravity of fluid,

$\eta=$ fluid viscosity in poises, and

$d=$ diameter of particle in centimeters.

If settling velocities in sea water are compared with those in fresh water, three of the foregoing parameters are independent of the fluid and, for a given mineral particle, are constant: (1) acceleration due to gravity at a given locality, (2) specific gravity of the particle, and (3) diameter of the particle. Two variable parameters, ones that depend on the medium, are the viscosity and specific gravity of the fluid.

\section{FLUID VISCOSITY}

Fluid viscosity determines, in large degree, the settling velocity of a particle. Slight changes in fluid viscosity cause pronounced changes in the fluid drag on the particle.
The viscosity of sea water decreases markedly with increasing temperature (fig. $1 \mathrm{~A}$ ) and increases slightly
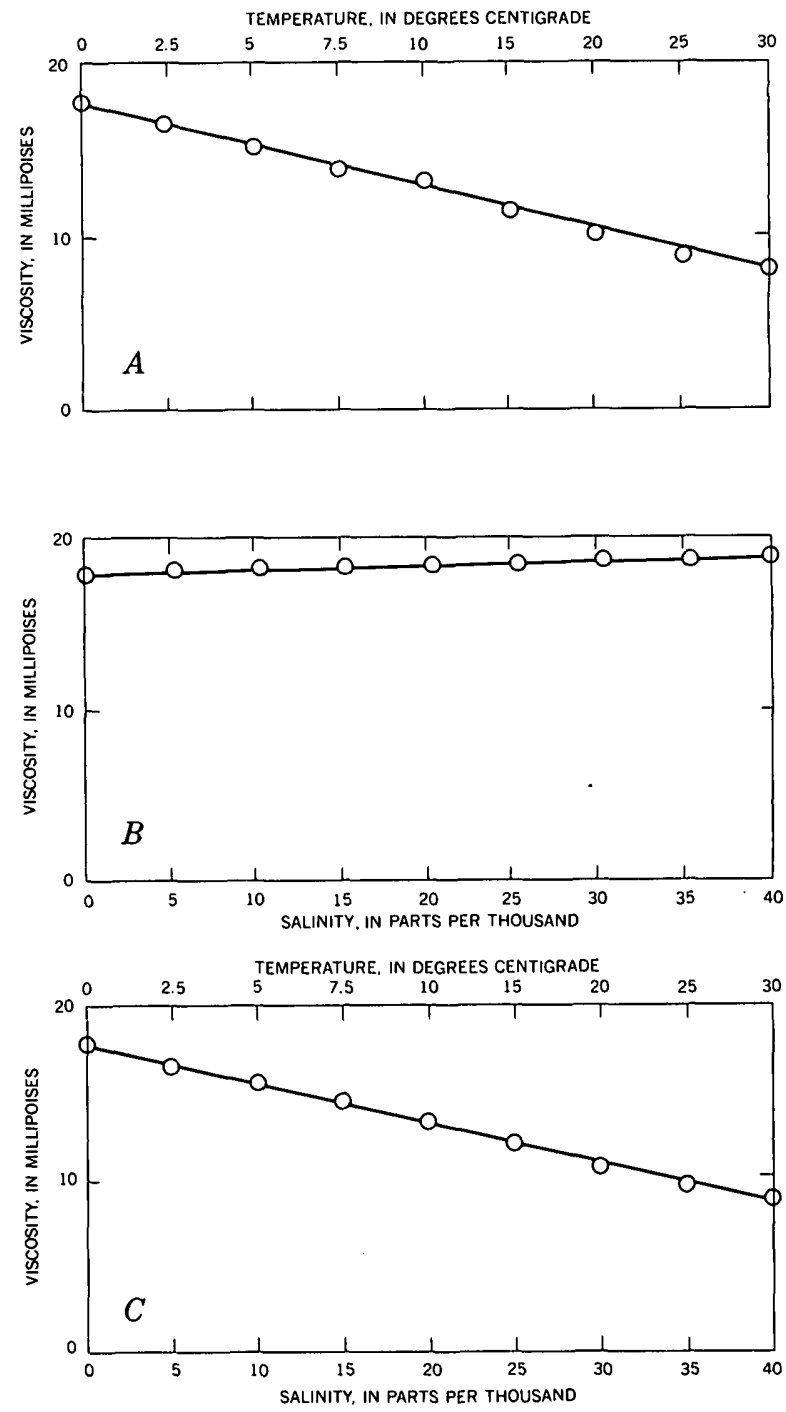

Figure 1.-Relation of temperature and salinity to viscosity of sea water. Data from table 1.

U.S. GEOL. SURVEY PROF. PAPER 700-B, PAGES B161-B166 
with increasing salinity (fig. $1 B$ ). Inasmuch as the effect of temperature is more pronounced than that of salinity, the interaction of the two causes a slightly higher viscosity than that caused by the temperature alone (compare fig. $1 C$ with fig. $1 A$ ). Pressure has a negligible effect on viscosity and thus can be ignored.

The only comprehensive study of the viscosity of sea water was done by Krümmel and Ruppin (1906), who determined a limited number of relative values of internal friction over a temperature range of $0^{\circ}$ to $30^{\circ} \mathrm{C}$ and salinity range of 0 to 40 parts per thousand. Internal friction can be multiplied by the absolute viscosity of pure water at $0^{\circ} \mathrm{C}$ to obtain absolute values of the viscosity of sea water. Table 1 shows viscosities computed in this manner by the author. The values of internal friction that were used in the calculations are for North Sea water and were experimentally determined by Krümmel and Ruppin (1906). Variations in the composition of sea water make it highly probable that no two samples of equal salinity from different areas will have the same viscosity; hence, table 1 should be used only as a guide. Absolute viscosity values can be determined only at the time of the experiment, for a particular sample of sea water.

\section{SPECIFIC GRAVITY}

The specific gravity of sea water can be determined from its density (U.S. Navy Hydrographic Office, 1952): Sp $\mathrm{gr}=($ density $/ 1,000)+1$. Table 2 lists the specific gravity of sea water from 0 to 40 parts per thousand of salinity and from $0^{\circ}$ to $30^{\circ} \mathrm{C}$, calculated by the author.

\section{SETTLING VELOCITIES IN SEA WATER VERSUS PURE WATER}

Settling-velocity data can be used to determine how long it takes a particular mineral particle to settle in undisturbed water. A 10-micron-diameter quartz sphere was used for computing the settling times shown in table 3. For example, this particle will settle 4,000 meters in a normal column of motionless sea water ${ }^{1}$ in approximately 882 days, in the absence of a net upward component of turbulence. The settling time of the sample particle in undisturbed pure water (table 3 ) is approximately 824 days -6.58 percent less time than in sea water.

\footnotetext{
1 The parameters of a normal column of motionless sea water were presented by Mathews (1939, p. 38).
}

TABLE 1.-Viscosity of

\begin{tabular}{|c|c|c|c|c|c|c|c|c|c|c|c|c|c|c|c|c|c|c|c|c|c|}
\hline \multirow{2}{*}{$\begin{array}{l}\text { Temper- } \\
\text { ature } \\
\left({ }^{\circ} \mathrm{C}\right)\end{array}$} & \multicolumn{21}{|c|}{ Salinity (parts } \\
\hline & 01 & 1 & 2 & 3 & 4 & 5 & 6 & 7 & 8 & 9 & 10 & 11 & 12 & 13 & 14 & 15 & 16 & 17 & 18 & 19 & 20 \\
\hline $\begin{array}{l}0 \\
1 \\
2 \\
3 \\
4 \\
5\end{array}$ & $\begin{array}{l}17.92 \\
17.31 \\
16.73 \\
16.19 \\
15.67 \\
15.19\end{array}$ & $\begin{array}{l}17.95 \\
17.32 \\
16.74 \\
16.20 \\
15.69 \\
15.22\end{array}$ & $\begin{array}{l}17.98 \\
17.33 \\
16.74 \\
16.21 \\
15.71 \\
15.24\end{array}$ & $\begin{array}{l}18.02 \\
17.33 \\
16.75 \\
16.22 \\
15.74 \\
15.27\end{array}$ & $\begin{array}{l}18.05 \\
17.34 \\
16.75 \\
16.23 \\
15.76 \\
15.29\end{array}$ & $\begin{array}{l}18.08 \\
17.35 \\
16.76 \\
16.24 \\
15.78 \\
15.32\end{array}$ & $\begin{array}{l}18.11 \\
17.38 \\
16.79 \\
16.27 \\
15.81 \\
15.35\end{array}$ & $\begin{array}{l}18.14 \\
17.41 \\
16.82 \\
16.30 \\
15.84 \\
15.38\end{array}$ & $\begin{array}{l}18.17 \\
17.43 \\
16.84 \\
16.32 \\
15.87 \\
15.41\end{array}$ & $\begin{array}{l}18.20 \\
17.46 \\
16.87 \\
16.35 \\
15.90 \\
15.44\end{array}$ & $\begin{array}{l}18.23 \\
17.49 \\
16.90 \\
16.38 \\
15.93 \\
15.47\end{array}$ & $\begin{array}{l}18.26 \\
17.52 \\
16.93 \\
16.41 \\
15.96 \\
15.49\end{array}$ & $\begin{array}{l}18.29 \\
17.54 \\
16.96 \\
16.44 \\
15.98 \\
15.52\end{array}$ & $\begin{array}{l}18.31 \\
17.57 \\
16.98 \\
16.46 \\
16.01 \\
15.54\end{array}$ & $\begin{array}{l}18.34 \\
17.59 \\
17.01 \\
16.49 \\
16.03 \\
15.57\end{array}$ & $\begin{array}{l}18.37 \\
17.62 \\
17.04 \\
16.52 \\
16.06 \\
15.59\end{array}$ & $\begin{array}{l}18.40 \\
17.64 \\
17.07 \\
16.55 \\
16.09 \\
15.62\end{array}$ & $\begin{array}{l}18.42 \\
17.67 \\
17.10 \\
16.57 \\
16.11 \\
15.64\end{array}$ & $\begin{array}{l}18.45 \\
17.69 \\
17.13 \\
16.60 \\
16.14 \\
15.67\end{array}$ & $\begin{array}{l}18.47 \\
17.72 \\
17.16 \\
16.62 \\
16.16 \\
15.69\end{array}$ & $\begin{array}{l}18.50 \\
17.74 \\
17.19 \\
16.65 \\
16.19 \\
15.72\end{array}$ \\
\hline $\begin{array}{r}6 \\
7 \\
8 \\
9 \\
10\end{array}$ & $\begin{array}{l}14.73 \\
14.28 \\
13.86 \\
13.46 \\
13.08\end{array}$ & $\begin{array}{l}14.76 \\
14.32 \\
13.90 \\
13.50 \\
13.11\end{array}$ & $\begin{array}{l}14.80 \\
14.36 \\
13.94 \\
13.54 \\
13.14\end{array}$ & $\begin{array}{l}14.83 \\
14.40 \\
13.99 \\
13.57 \\
13.17\end{array}$ & $\begin{array}{l}14.87 \\
14.44 \\
14.03 \\
13.61 \\
13.20\end{array}$ & $\begin{array}{l}14.90 \\
14.48 \\
14.07 \\
13.65 \\
13.23\end{array}$ & $\begin{array}{l}14.93 \\
14.51 \\
14.10 \\
13.67 \\
13.25\end{array}$ & $\begin{array}{l}14.96 \\
14.54 \\
14.12 \\
13.70 \\
13.28\end{array}$ & $\begin{array}{l}14.99 \\
14.56 \\
14.15 \\
13.72 \\
13.30\end{array}$ & $\begin{array}{l}15.02 \\
14.59 \\
14.17 \\
13.75 \\
13.33\end{array}$ & $\begin{array}{l}15.05 \\
14.62 \\
14.20 \\
13.77 \\
13.35\end{array}$ & $\begin{array}{l}15.07 \\
14.65 \\
14.22 \\
13.80 \\
13.38\end{array}$ & $\begin{array}{l}15.10 \\
14.67 \\
14.25 \\
13.82 \\
13.40\end{array}$ & $\begin{array}{l}15.12 \\
14.70 \\
14.27 \\
13.85 \\
13.43\end{array}$ & $\begin{array}{l}15.15 \\
14.72 \\
14.30 \\
13.87 \\
13.45\end{array}$ & $\begin{array}{l}15.17 \\
14.75 \\
14.32 \\
13.90 \\
13.48\end{array}$ & $\begin{array}{l}15.19 \\
14.77 \\
14.34 \\
13.92 \\
13.50\end{array}$ & $\begin{array}{l}15.22 \\
14.79 \\
14.37 \\
13.94 \\
13.52\end{array}$ & $\begin{array}{l}15.24 \\
14.82 \\
14.39 \\
13.97 \\
13.54\end{array}$ & $\begin{array}{l}15.27 \\
14.84 \\
14.42 \\
13.99 \\
13.56\end{array}$ & $\begin{array}{l}15.29 \\
14.86 \\
14.44 \\
14.01 \\
13.58\end{array}$ \\
\hline $\begin{array}{l}11 \\
12 \\
13 \\
14 \\
15\end{array}$ & $\begin{array}{l}\text { 12. } 71 \\
12.36 \\
12.03 \\
11.71 \\
11.40\end{array}$ & $\begin{array}{l}12.75 \\
12.40 \\
12.06 \\
11.74 \\
11.42\end{array}$ & $\begin{array}{l}12.78 \\
12.44 \\
12.10 \\
11.77 \\
11.45\end{array}$ & $\begin{array}{l}12.82 \\
12.47 \\
12.13 \\
11.80 \\
11.47\end{array}$ & $\begin{array}{l}12.85 \\
12.51 \\
12.17 \\
11.83 \\
11.50\end{array}$ & $\begin{array}{l}12.89 \\
12.55 \\
12.20 \\
11.86 \\
11.52\end{array}$ & $\begin{array}{l}12.91 \\
12.57 \\
12.22 \\
11.88 \\
11.54\end{array}$ & $\begin{array}{l}12.94 \\
12.59 \\
12.25 \\
11.90 \\
11.56\end{array}$ & $\begin{array}{l}12.96 \\
12.62 \\
12.27 \\
11.93 \\
11.59\end{array}$ & $\begin{array}{l}12.99 \\
12.64 \\
12.30 \\
11.95 \\
11.61\end{array}$ & $\begin{array}{l}13.01 \\
12.66 \\
12.32 \\
11.97 \\
11.62\end{array}$ & $\begin{array}{l}13.04 \\
12.69 \\
12.35 \\
12.00 \\
11.66\end{array}$ & $\begin{array}{l}13.06 \\
12.71 \\
12.37 \\
12.02 \\
11.68\end{array}$ & $\begin{array}{l}13.09 \\
12.74 \\
12.40 \\
12.05 \\
11.71\end{array}$ & $\begin{array}{l}13.11 \\
12.76 \\
12.42 \\
12.07 \\
11.73\end{array}$ & $\begin{array}{l}13.14 \\
12.79 \\
12.45 \\
12.10 \\
11.76\end{array}$ & $\begin{array}{l}13.16 \\
12.81 \\
12.47 \\
12.12 \\
11.78\end{array}$ & $\begin{array}{l}13.18 \\
12.83 \\
12.49 \\
12.14 \\
11.80\end{array}$ & $\begin{array}{l}13.20 \\
12.85 \\
12.51 \\
12.16 \\
11.82\end{array}$ & $\begin{array}{l}13.22 \\
12.87 \\
12.53 \\
12.18 \\
11.84\end{array}$ & $\begin{array}{l}13.24 \\
12.89 \\
12.55 \\
12.20 \\
11.86\end{array}$ \\
\hline $\begin{array}{l}16 \\
17 \\
18 \\
19 \\
20\end{array}$ & $\begin{array}{l}11.11 \\
10.83 \\
10.56 \\
10.30 \\
10.05\end{array}$ & $\begin{array}{l}11.14 \\
10.86 \\
10.59 \\
10.33 \\
10.08\end{array}$ & $\begin{array}{l}11.17 \\
10.89 \\
10.62 \\
10.36 \\
10.10\end{array}$ & $\begin{array}{l}11.19 \\
10.92 \\
10.66 \\
10.39 \\
10.13\end{array}$ & $\begin{array}{l}11.22 \\
10.95 \\
10.69 \\
10.42 \\
10.15\end{array}$ & $\begin{array}{l}11.25 \\
10.98 \\
10.72 \\
10.45 \\
10.18\end{array}$ & $\begin{array}{l}11.27 \\
11.00 \\
10.74 \\
10.47 \\
10.20\end{array}$ & $\begin{array}{l}11.29 \\
11.02 \\
10.76 \\
10.49 \\
10.22\end{array}$ & $\begin{array}{l}11.32 \\
11.05 \\
10.79 \\
10.52 \\
10.25\end{array}$ & $\begin{array}{l}11.34 \\
11.07 \\
10.81 \\
10.54 \\
10.27\end{array}$ & $\begin{array}{l}11.36 \\
11.09 \\
10.83 \\
10.56 \\
10.29\end{array}$ & $\begin{array}{l}11.39 \\
11.11 \\
10.85 \\
10.58 \\
10.31\end{array}$ & $\begin{array}{l}11.41 \\
11.14 \\
10.87 \\
10.60 \\
10.33\end{array}$ & $\begin{array}{l}11.44 \\
11.16 \\
10.90 \\
10.62 \\
10.35\end{array}$ & $\begin{array}{l}11.46 \\
11.19 \\
10.92 \\
10.64 \\
10.37\end{array}$ & $\begin{array}{l}11.49 \\
11.21 \\
10.94 \\
10.66 \\
10.39\end{array}$ & $\begin{array}{l}11.51 \\
11.23 \\
10.96 \\
10.68 \\
10.41\end{array}$ & $\begin{array}{l}11.53 \\
11.25 \\
10.98 \\
10.70 \\
10.43\end{array}$ & $\begin{array}{l}11.55 \\
11.28 \\
11.00 \\
10.73 \\
10.46\end{array}$ & $\begin{array}{l}11.57 \\
11.30 \\
11.02 \\
10.75 \\
10.48\end{array}$ & $\begin{array}{l}11.59 \\
11.32 \\
11.04 \\
10.77 \\
10.50\end{array}$ \\
\hline $\begin{array}{l}21 \\
22 \\
23 \\
24 \\
25\end{array}$ & $\begin{array}{l}9.81 \\
9.58 \\
9.36 \\
9.14 \\
8.94\end{array}$ & $\begin{array}{l}9.84 \\
9.61 \\
9.39 \\
9.16 \\
8.96\end{array}$ & $\begin{array}{l}9.87 \\
9.64 \\
9.41 \\
9.19 \\
8.98\end{array}$ & $\begin{array}{l}9.89 \\
9.66 \\
9.44 \\
9.21 \\
8.99\end{array}$ & $\begin{array}{l}9.92 \\
9.69 \\
9.46 \\
9.24 \\
9.01\end{array}$ & $\begin{array}{l}9.95 \\
9.72 \\
9.49 \\
9.26 \\
9.03\end{array}$ & $\begin{array}{l}9.97 \\
9.74 \\
9.51 \\
9.28 \\
9.05\end{array}$ & $\begin{array}{l}9.99 \\
9.76 \\
9.53 \\
9.30 \\
9.07\end{array}$ & $\begin{array}{r}10.02 \\
9.79 \\
9.56 \\
9.33 \\
9.10\end{array}$ & $\begin{array}{r}10.04 \\
9.81 \\
9.58 \\
9.35 \\
9.12\end{array}$ & $\begin{array}{r}10.06 \\
9.83 \\
9.60 \\
9.37 \\
9.14\end{array}$ & $\begin{array}{r}10.08 \\
9.85 \\
9.62 \\
9.39 \\
9.16\end{array}$ & $\begin{array}{r}10.10 \\
9.87 \\
9.64 \\
9.41 \\
9.18\end{array}$ & $\begin{array}{r}10.12 \\
9.89 \\
9.67 \\
9.44 \\
9.21\end{array}$ & $\begin{array}{r}10.14 \\
9.91 \\
9.69 \\
9.46 \\
9.23\end{array}$ & $\begin{array}{r}10.16 \\
9.93 \\
9.71 \\
9.48 \\
9.25\end{array}$ & $\begin{array}{r}10.18 \\
9.95 \\
9.73 \\
9.50 \\
9.27\end{array}$ & $\begin{array}{r}10.20 \\
9.97 \\
9.75 \\
9.52 \\
9.29\end{array}$ & $\begin{array}{r}10.23 \\
10.00 \\
9.76 \\
9.53 \\
9.30\end{array}$ & \begin{tabular}{|r|}
10.25 \\
10.02 \\
9.78 \\
9.55 \\
9.32
\end{tabular} & $\begin{array}{r}10.27 \\
10.04 \\
9.80 \\
9.57 \\
9.34\end{array}$ \\
\hline $\begin{array}{l}26 \\
27 \\
28 \\
29 \\
30\end{array}$ & $\begin{array}{l}8.74 \\
8.55 \\
8.36 \\
8.18 \\
8.01\end{array}$ & $\begin{array}{l}8.76 \\
8.57 \\
8.39 \\
8.21 \\
8.04\end{array}$ & $\begin{array}{l}8.78 \\
8.60 \\
8.42 \\
8.24 \\
8.06\end{array}$ & $\begin{array}{l}8.81 \\
8.62 \\
8.44 \\
8.26 \\
8.09\end{array}$ & $\begin{array}{l}8.83 \\
8.65 \\
8.47 \\
8.29 \\
8.11\end{array}$ & $\begin{array}{l}8.85 \\
8.67 \\
8.50 \\
8.32 \\
8.14\end{array}$ & $\begin{array}{l}8.87 \\
8.69 \\
8.52 \\
8.34 \\
8.16\end{array}$ & $\begin{array}{l}8.89 \\
8.71 \\
8.54 \\
8.36 \\
8.18\end{array}$ & $\begin{array}{l}8.92 \\
8.74 \\
8.56 \\
8.38 \\
8.20\end{array}$ & $\begin{array}{l}8.94 \\
8.76 \\
8.58 \\
8.40 \\
8.22\end{array}$ & $\begin{array}{l}8.96 \\
8.78 \\
8.60 \\
8.42 \\
8.24\end{array}$ & $\begin{array}{l}8.98 \\
8.80 \\
8.62 \\
8.44 \\
8.26\end{array}$ & $\begin{array}{l}9.00 \\
8.82 \\
8.64 \\
8.46 \\
8.28\end{array}$ & $\begin{array}{l}9.03 \\
8.84 \\
8.66 \\
8.47 \\
8.29\end{array}$ & $\begin{array}{l}9.05 \\
8.86 \\
8.68 \\
8.49 \\
8.31\end{array}$ & $\begin{array}{l}9.07 \\
8.88 \\
8.70 \\
8.51 \\
8.33\end{array}$ & $\begin{array}{l}9.09 \\
8.90 \\
8.72 \\
8.53 \\
8.35\end{array}$ & $\begin{array}{l}9.11 \\
8.92 \\
8.75 \\
8.55 \\
8.37\end{array}$ & $\begin{array}{l}9.12 \\
8.93 \\
8.75 \\
8.56 \\
8.38\end{array}$ & $\begin{array}{l}9.14 \\
8.95 \\
8.77 \\
8.58 \\
8.40\end{array}$ & $\begin{array}{l}9.16 \\
8.97 \\
8.79 \\
8.60 \\
8.42\end{array}$ \\
\hline
\end{tabular}

\footnotetext{
1 Values in this column were obtained from the "Handbook of Chemistry and Note: Viscosity must be converted to poises to be used in Stokes' law.

Physics" (Hodgman, 1960). The viscosity at $0^{\circ} \mathrm{C}$ and 0 parts per thousand sa

linity is more accurate than that presented by Krümmel and Ruppin (1906).
} 
At sea, upwelling and turbulent flow may locally exceed the settling velocity of minute particles. Velocities of vertical flow are generally very small. ${ }^{2}$ However, turbulence might suffice to keep a particle in transport for considerable time.

Figure 2 shows the settling velocity of a quartz sphere in sea water and in pure water over the temperature and salinity ranges covered by tables 1 and 2. The difference is similar for other minerals. For instance, a 10-micron-diameter silver sphere will settle 4,000 meters through a column of pure water in 142.55 days and through a column of sea water in 151.02 days -5.60 percent faster in pure water. A 10-microndiameter gold sphere will settle 5.09 percent faster in pure water than in sea water.

In the foregoing discussion, Stokes' law was used for the sake of simplicity. This law, however, is limited in its application. Aside from the viscosity and specific gravity of the fluid, the major influences on the settling velocity of one particle in a group of particles are its size, shape, and composition (mineralogical or

a Hidaka (1054) estimated that net upwelling in the California current was $80 \mathrm{~m} /$ month, which corresponds to a vertical current of $0.0031 \mathrm{~cm} / \mathrm{sec}$.

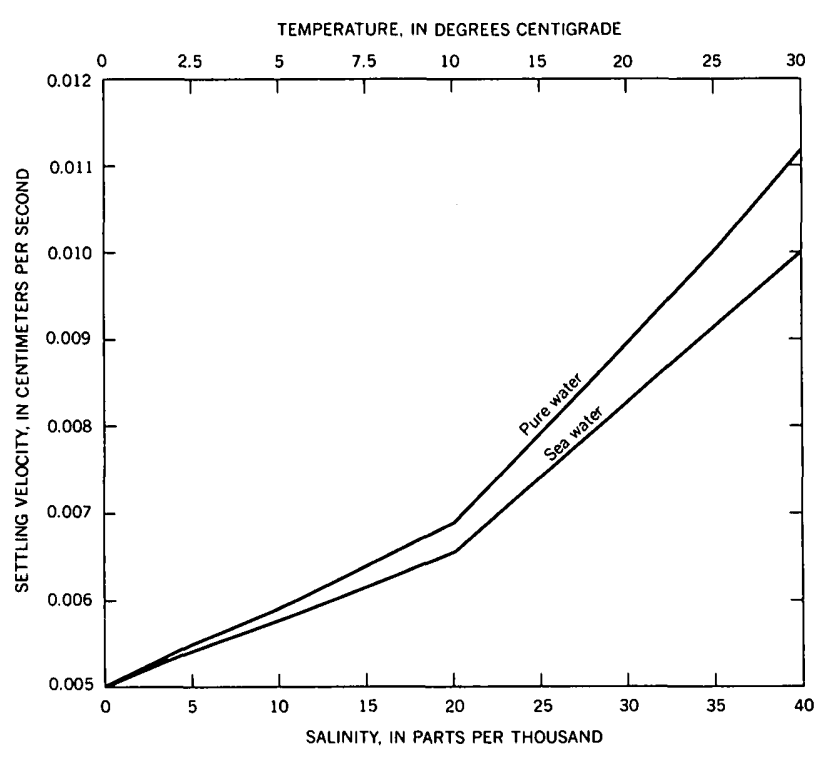

Figure 2.-Settling velocities of a 10-micron-diameter quartz sphere in pure water and in sea water.

biological), the proximity of boundaries, and particle concentration. These determine the Reynolds number, the drag coefficient, and the shape factor of a grain.

sea water, in millipoises

\begin{tabular}{|c|c|c|c|c|c|c|c|c|c|c|c|c|c|c|c|c|c|c|c|c|}
\hline \multicolumn{20}{|c|}{ per thousand) } & \multirow{2}{*}{$\begin{array}{c}\text { Temper } \\
\text { ature } \\
\left({ }^{\circ} \mathrm{C}\right)\end{array}$} \\
\hline 21 & 22 & 23 & 24 & 25 & 26 & 27 & 28 & 29 & 30 & 31 & 32 & 33 & 34 & 35 & 36 & 37 & 38 & 39 & 40 & \\
\hline \begin{tabular}{|l}
18.52 \\
17.77 \\
17.21 \\
16.67 \\
16.21 \\
15.74
\end{tabular} & $\begin{array}{l}18.55 \\
17.70 \\
17.24 \\
16.70 \\
16.24 \\
15.77\end{array}$ & $\begin{array}{l}18.87 \\
17.82 \\
17.26 \\
16.72 \\
18.26 \\
15.70\end{array}$ & \begin{tabular}{|l|}
18.60 \\
17.84 \\
17.29 \\
16.75 \\
16.29 \\
15.82
\end{tabular} & $\begin{array}{l}18.62 \\
17.87 \\
17.31 \\
16.77 \\
16.31 \\
15.84\end{array}$ & $\begin{array}{l}18.64 \\
17.89 \\
17.34 \\
16.80 \\
18.34 \\
15.87\end{array}$ & $\begin{array}{l}18.66 \\
17.92 \\
17.36 \\
16.82 \\
16.36 \\
15.89\end{array}$ & \begin{tabular}{|l|}
18.69 \\
17.94 \\
17.39 \\
16.85 \\
16.39 \\
15.92
\end{tabular} & \begin{tabular}{|l}
18.71 \\
17.97 \\
17.41 \\
16.87 \\
16.41 \\
15.94
\end{tabular} & $\begin{array}{l}18.73 \\
17.99 \\
17.44 \\
16.90 \\
16.44 \\
15.97\end{array}$ & \begin{tabular}{|l|}
18.75 \\
18.02 \\
17.46 \\
16.93 \\
16.46 \\
15.99
\end{tabular} & $\begin{array}{l}18.78 \\
18.04 \\
17.49 \\
16.95 \\
16.49 \\
16.02\end{array}$ & $\begin{array}{l}18.80 \\
18.07 \\
17.51 \\
16.98 \\
16.51 \\
16.04\end{array}$ & $\begin{array}{l}18.83 \\
18.09 \\
17.54 \\
17.00 \\
16.54 \\
16.07\end{array}$ & $\begin{array}{l}18.85 \\
18.12 \\
17.56 \\
17.03 \\
16.56 \\
16.09\end{array}$ & $\begin{array}{l}18.88 \\
18.14 \\
17.59 \\
17.05 \\
16.59 \\
16.12\end{array}$ & $\begin{array}{l}18.90 \\
18.17 \\
17.61 \\
17.08 \\
16.61 \\
16.14\end{array}$ & $\begin{array}{l}18.93 \\
18.19 \\
17.64 \\
17.10 \\
16.64 \\
16.17\end{array}$ & $\begin{array}{l}18.95 \\
18.22 \\
17.66 \\
17.13 \\
16.66 \\
16.19\end{array}$ & $\begin{array}{l}18.98 \\
18.24 \\
17.69 \\
17.15 \\
16.69 \\
16.22\end{array}$ & $\begin{array}{l}0 \\
1 \\
2 \\
3 \\
4 \\
5\end{array}$ \\
\hline $\begin{array}{l}15.31 \\
14.89 \\
14.46 \\
14.04 \\
13.61\end{array}$ & $\begin{array}{l}15.34 \\
114.91 \\
14.40 \\
14.06 \\
13.63\end{array}$ & $\begin{array}{l}15.36 \\
14.94 \\
14.51 \\
14.09 \\
13.68\end{array}$ & \begin{tabular}{|l|}
15.39 \\
14.96 \\
14.64 \\
14.11 \\
13.68
\end{tabular} & $\begin{array}{l}15.41 \\
14.90 \\
14.56 \\
14.14 \\
13.71\end{array}$ & $\begin{array}{l}15.44 \\
15.02 \\
14.59 \\
14.17 \\
13.74\end{array}$ & $\begin{array}{l}15.46 \\
15.04 \\
14.61 \\
14.19 \\
13.76\end{array}$ & $\begin{array}{l}15.49 \\
15.07 \\
14.64 \\
14.22 \\
13.79\end{array}$ & \begin{tabular}{|l|}
15.51 \\
15.09 \\
14.66 \\
14.24 \\
13.81 \\
\end{tabular} & \begin{tabular}{|l|}
15.54 \\
15.12 \\
14.69 \\
14.27 \\
13.84
\end{tabular} & \begin{tabular}{|l|}
15.56 \\
15.14 \\
14.71 \\
14.29 \\
13.86
\end{tabular} & $\begin{array}{l}15.59 \\
15.16 \\
14.73 \\
14.31 \\
13.88\end{array}$ & $\begin{array}{l}15.61 \\
15.19 \\
14.76 \\
14.33 \\
13.90\end{array}$ & & & & & & & & $\begin{array}{r}6 \\
7 \\
8 \\
9 \\
10\end{array}$ \\
\hline $\begin{array}{l}13.27 \\
12.92 \\
12.58 \\
12.23 \\
11.80\end{array}$ & $\begin{array}{l}13.20 \\
12.04 \\
12.60 \\
12.25 \\
11.01\end{array}$ & $\begin{array}{l}13.32 \\
12.07 \\
12.63 \\
12.28 \\
11.94\end{array}$ & \begin{tabular}{|l|}
13.34 \\
12.99 \\
12.65 \\
12.30 \\
11.96
\end{tabular} & $\begin{array}{l}13.37 \\
13.02 \\
12.68 \\
12.33 \\
11.80\end{array}$ & \begin{tabular}{|l|}
3.39 \\
13.04 \\
12.70 \\
12.35 \\
12.01 \\
\end{tabular} & $\begin{array}{l}13.42 \\
13.07 \\
12.73 \\
12.38 \\
12.03\end{array}$ & $\begin{array}{l}13.44 \\
13.09 \\
12.75 \\
12.40 \\
12.06\end{array}$ & \begin{tabular}{|l|}
13.47 \\
13.12 \\
12.78 \\
12.43 \\
12.08
\end{tabular} & \begin{tabular}{|l|}
13.49 \\
13.14 \\
12.80 \\
12.45 \\
12.10
\end{tabular} & \begin{tabular}{|l}
13.51 \\
13.16 \\
12.82 \\
12.47 \\
12.12
\end{tabular} & $\begin{array}{l}13.53 \\
13.18 \\
12.84 \\
12.49 \\
12.15\end{array}$ & $\begin{array}{l}13.56 \\
13.21 \\
12.87 \\
12.52 \\
12.17\end{array}$ & & & & & & & $\begin{array}{l}13.72 \\
13.37 \\
13.03 \\
12.68 \\
12.33\end{array}$ & $\begin{array}{l}11 \\
12 \\
13 \\
14 \\
15\end{array}$ \\
\hline \begin{tabular}{|l|}
11.62 \\
11.85 \\
11.07 \\
10.80 \\
10.63
\end{tabular} & $\begin{array}{l}11.64 \\
11.37 \\
11.09 \\
10.82 \\
10.65\end{array}$ & $\begin{array}{l}11.67 \\
11.40 \\
11.12 \\
10.85 \\
10.88\end{array}$ & $\begin{array}{l}11.69 \\
11.42 \\
11.14 \\
10.87 \\
10.60\end{array}$ & $\begin{array}{l}11.72 \\
11.45 \\
11.17 \\
10.90 \\
10.63\end{array}$ & $\begin{array}{l}11.74 \\
11.47 \\
11.19 \\
10.92 \\
10.65\end{array}$ & $\begin{array}{l}11.76 \\
11.49 \\
11.21 \\
10.94 \\
10.67\end{array}$ & $\begin{array}{l}11.79 \\
11.52 \\
11.24 \\
10.97 \\
10.70\end{array}$ & $\begin{array}{l}11.81 \\
11.54 \\
11.26 \\
10.99 \\
10.72\end{array}$ & \begin{tabular}{|l}
11.83 \\
11.56 \\
11.28 \\
11.01 \\
10.74
\end{tabular} & \begin{tabular}{|l|}
11.85 \\
11.58 \\
11.30 \\
11.03 \\
10.76
\end{tabular} & $\begin{array}{l}11.87 \\
11.60 \\
11.32 \\
11.05 \\
10.78\end{array}$ & $\begin{array}{l}11.90 \\
11.63 \\
11.35 \\
11.08 \\
10.80\end{array}$ & $\begin{array}{l}11.92 \\
11.65 \\
11.37 \\
11.10 \\
10.82\end{array}$ & $\begin{array}{l}11.39 \\
11.12 \\
10.84\end{array}$ & $\begin{array}{l}11.41 \\
11.14 \\
10.86\end{array}$ & & $\begin{array}{l}11.19 \\
10.91\end{array}$ & $\begin{array}{l}11.21 \\
10.93\end{array}$ & $\begin{array}{l}12.05 \\
11.78 \\
11.50 \\
11.23 \\
10.95\end{array}$ & $\begin{array}{l}16 \\
17 \\
18 \\
19 \\
20\end{array}$ \\
\hline $\begin{array}{r}10.29 \\
10.06 \\
0.82 \\
0.59 \\
0.30\end{array}$ & $\begin{array}{r}10.32 \\
10.08 \\
0.86 \\
9.61 \\
0.38\end{array}$ & $\begin{array}{r}10.34 \\
10.11 \\
0.87 \\
0.64 \\
0.40\end{array}$ & $\begin{array}{r}10.37 \\
10.13 \\
0.00 \\
0.66 \\
0.42\end{array}$ & $\begin{array}{c}10.39 \\
10.15 \\
0.92 \\
0.68 \\
0.44\end{array}$ & $\begin{array}{c}10.41 \\
10.17 \\
0.94 \\
0.70 \\
0.46\end{array}$ & $\begin{array}{r}10.43 \\
10.19 \\
9.96 \\
9.72 \\
0.48\end{array}$ & \begin{tabular}{|r|}
10.46 \\
10.22 \\
9.99 \\
9.75 \\
9.51
\end{tabular} & $\begin{array}{r}10.48 \\
10.24 \\
10.01 \\
9.77 \\
9.53\end{array}$ & $\begin{array}{r}10.50 \\
10.26 \\
10.03 \\
9.79 \\
9.55\end{array}$ & \begin{tabular}{|r|}
10.52 \\
10.28 \\
10.05 \\
9.81 \\
9.57
\end{tabular} & $\begin{array}{r}10.54 \\
10.30 \\
10.07 \\
9.83 \\
9.59\end{array}$ & $\begin{array}{r}10.56 \\
10.33 \\
10.09 \\
9.86 \\
9.62\end{array}$ & $\begin{array}{r}10.58 \\
10.35 \\
10.11 \\
9.88 \\
9.64\end{array}$ & $\begin{array}{r}10.60 \\
10.37 \\
10.13 \\
9.90 \\
9.66\end{array}$ & $\begin{array}{r}10.15 \\
9.92 \\
9.68\end{array}$ & $\begin{array}{r}10.17 \\
9.94 \\
9.70\end{array}$ & & & $\begin{array}{r}10.71 \\
10.48 \\
10.24 \\
10.01 \\
9.77\end{array}$ & $\begin{array}{l}21 \\
22 \\
23 \\
24 \\
25\end{array}$ \\
\hline $\begin{array}{l}0.18 \\
8.00 \\
8.81 \\
8.62 \\
8.44\end{array}$ & $\begin{array}{l}0.20 \\
0.01 \\
8.83 \\
8.04 \\
8.46\end{array}$ & $\begin{array}{l}0.21 \\
0.03 \\
8.84 \\
8.06 \\
8.47\end{array}$ & $\begin{array}{l}0.23 \\
0.05 \\
8.86 \\
8.68 \\
8.40\end{array}$ & $\begin{array}{l}9.25 \\
0.07 \\
8.88 \\
8.70 \\
8.81\end{array}$ & $\begin{array}{l}9.27 \\
0.09 \\
8.00 \\
8.72 \\
8.53\end{array}$ & $\begin{array}{l}9.29 \\
9.11 \\
8.92 \\
8.74 \\
\text { 8. } 55\end{array}$ & $\begin{array}{l}9.32 \\
9.14 \\
8.95 \\
8.77 \\
8.58\end{array}$ & $\begin{array}{l}9.34 \\
9.16 \\
8.97 \\
8.79 \\
8.60\end{array}$ & $\begin{array}{l}9.36 \\
9.18 \\
8.99 \\
8.81 \\
8.62\end{array}$ & $\begin{array}{l}9.38 \\
9.20 \\
9.01 \\
8.83 \\
8.64\end{array}$ & $\begin{array}{l}9.40 \\
9.22 \\
9.03 \\
8.85 \\
8.66\end{array}$ & $\begin{array}{l}9.43 \\
9.24 \\
9.05 \\
8.86 \\
8.67\end{array}$ & $\begin{array}{l}9.45 \\
9.26 \\
9.07 \\
8.88 \\
8.69\end{array}$ & $\begin{array}{l}9.47 \\
9.28 \\
9.09 \\
8.90 \\
8.71\end{array}$ & $\begin{array}{l}9.49 \\
9.30 \\
9.11 \\
8.92 \\
8.73\end{array}$ & $\begin{array}{l}9.32 \\
9.13 \\
8.94 \\
8.75\end{array}$ & $\begin{array}{l}9.34 \\
9.15 \\
8.95 \\
8.76\end{array}$ & $\begin{array}{l}9.36 \\
9.17 \\
8.97 \\
8.78\end{array}$ & $\begin{array}{l}9.58 \\
9.38 \\
9.19 \\
8.99 \\
8.80\end{array}$ & $\begin{array}{l}27 \\
28 \\
29 \\
30\end{array}$ \\
\hline
\end{tabular}


TABLE 2.-Specific gravity of sea water

[Calculated on the basis of density data published by U.S. Navy Hydrographic Office (1952)]

\begin{tabular}{|c|c|c|c|c|c|c|c|c|c|c|c|c|c|c|c|c|c|c|c|c|c|}
\hline \multirow{2}{*}{$\begin{array}{c}\text { Temper- } \\
\text { ature } \\
\left({ }^{\circ} \mathrm{C}\right)\end{array}$} & \multicolumn{21}{|c|}{ Salinity (parts per thousand) } \\
\hline & 0 & 1 & 2 & 3 & 4 & 5 & 6 & 7 & 8 & 9 & 10 & 11 & 12 & 13 & 14 & 15 & 16 & 17 & 18 & 19 & 20 \\
\hline $\begin{array}{l}0 \\
1 \\
2 \\
3 \\
4 \\
5\end{array}$ & $\begin{array}{c}0.999868 \\
.99997 \\
.999968 \\
.99992 \\
.000000 \\
: 999992\end{array}$ & $\begin{array}{l}1.000721 \\
1.000776 \\
1.000813 \\
1.000834 \\
1.000338 \\
1.000827\end{array}$ & $\begin{array}{l}1.001534 \\
1.001586 \\
1.001620 \\
1.001637 \\
1.001638 \\
1.001623\end{array}$ & $\begin{array}{l}1.002347 \\
1.002395 \\
1.002425 \\
1.002438 \\
1.002436 \\
1.002418\end{array}$ & $\begin{array}{l}1.003159 \\
1.003203 \\
1.003229 \\
1.003239 \\
1.003234 \\
1.003213\end{array}$ & $\begin{array}{l}1.003970 \\
1.004010 \\
1.004033 \\
1.004040 \\
1.00431 \\
1.004006\end{array}$ & $\begin{array}{l}1.004780 \\
1.004816 \\
1.004836 \\
1.004839 \\
1.004827 \\
1.004800\end{array}$ & $\begin{array}{l}1.005589 \\
1.005622 \\
1.005638 \\
1.005638 \\
1.005623 \\
1.005592\end{array}$ & $\begin{array}{l}1.006398 \\
1.006427 \\
1.006440 \\
1.006437 \\
1.006418 \\
1.006384\end{array}$ & $\begin{array}{l}1.007206 \\
1.007232 \\
1.007241 \\
1.007234 \\
1.007212 \\
1.007176\end{array}$ & $\begin{array}{l}1.008014 \\
1.008036 \\
1.008041 \\
1.008031 \\
1.008006 \\
1.007967\end{array}$ & $\begin{array}{l}1.008821 \\
1.008839 \\
1.008341 \\
1.008882 \\
1.008800 \\
1.008757\end{array}$ & $\begin{array}{l}1.009627 \\
1.009642 \\
1.009641 \\
1.009624 \\
1.009593 \\
1.009547\end{array}$ & $\begin{array}{l}1.010433 \\
1.010445 \\
1.010440 \\
1.010420 \\
1.010386 \\
1.010337\end{array}$ & $\begin{array}{l}1.011239 \\
1.011247 \\
1.011239 \\
1.011216 \\
1.011178 \\
1.011126\end{array}$ & \begin{tabular}{|l|}
1.012044 \\
1.012048 \\
1.012037 \\
1.012011 \\
1.011970 \\
1.011915 \\
\end{tabular} & $\begin{array}{l}1.012849 \\
1.012850 \\
1.012835 \\
1.012806 \\
1.012762 \\
1.012704\end{array}$ & \begin{tabular}{|l|}
1.013653 \\
1.013651 \\
1.013633 \\
1.013601 \\
1.013554 \\
1.013493
\end{tabular} & $\begin{array}{l}1.014458 \\
1.014452 \\
1.014431 \\
1.014395 \\
1.014345 \\
1.014281\end{array}$ & \begin{tabular}{|l}
1.015262 \\
1.015252 \\
1.015228 \\
1.015159 \\
.1 .015136 \\
1.015070
\end{tabular} & $\begin{array}{l}1.016065 \\
1.016053 \\
1.016025 \\
1.015983 \\
1.015927 \\
1.015858\end{array}$ \\
\hline \begin{tabular}{r|}
6 \\
7 \\
8 \\
9 \\
10
\end{tabular} & $\begin{array}{r}0.999968 \\
.999929 \\
.999876 \\
.999808 \\
.999727\end{array}$ & $\begin{array}{l}1.000800 \\
1.000058 \\
1.000702 \\
1.000631 \\
1.000547\end{array}$ & $\begin{array}{l}1.001593 \\
1.001548 \\
1.001489 \\
1.001416 \\
1.001329\end{array}$ & $\begin{array}{l}1.002385 \\
1.002337 \\
1.002275 \\
1.002199 \\
1.002110\end{array}$ & $\begin{array}{l}1.003176 \\
1.003128 \\
1.003061 \\
1.002982 \\
1.002891\end{array}$ & $\begin{array}{l}1.003967 \\
1.003914 \\
1.003846 \\
1.003765 \\
1.003670\end{array}$ & $\begin{array}{l}1.004757 \\
1.004701 \\
1.004631 \\
1.004547 \\
1.004450\end{array}$ & $\begin{array}{l}1.005547 \\
1.005488 \\
1.005414 \\
1.005328 \\
1.005229\end{array}$ & $\begin{array}{l}1.006336 \\
1.006274 \\
1.006198 \\
1.006109 \\
1.006007\end{array}$ & $\begin{array}{l}1.007124 \\
1.007095 \\
1.006981 \\
1.006889 \\
1.006785\end{array}$ & $\begin{array}{l}1.007912 \\
1.007845 \\
1.007763 \\
1.007669 \\
1.007562\end{array}$ & $\begin{array}{l}1.008700 \\
1.008629 \\
1.008545 \\
1.008448 \\
1.008339\end{array}$ & $\begin{array}{l}1.009487 \\
1.009414 \\
1.009327 \\
1.009228 \\
1.009116\end{array}$ & $\begin{array}{l}1.010274 \\
1.010198 \\
1.010108 \\
1.010006 \\
1.009892\end{array} \mid$ & $\begin{array}{l}1.011061 \\
1.01098 \\
1.010890 \\
1.010785 \\
1.010668\end{array}$ & \begin{tabular}{|l|}
1.011847 \\
1.011765 \\
1.011670 \\
1.011563 \\
1.011444
\end{tabular} & \begin{tabular}{|l|}
1.012633 \\
1.012548 \\
1.012451 \\
1.012341 \\
1.012219 \\
\end{tabular} & $\begin{array}{l}1.013419 \\
1.013331 \\
1.0132231 \\
1.013119 \\
1.012995\end{array}$ & \begin{tabular}{|l}
1.014204 \\
1.014114 \\
1.014012 \\
1.013897 \\
1.013770
\end{tabular} & \begin{tabular}{|l}
1.014990 \\
1.014897 \\
1.014792 \\
1.014675 \\
1.014545
\end{tabular} & \begin{tabular}{|l}
1.015775 \\
1.015680 \\
1.015572 \\
1.015452 \\
1.015321
\end{tabular} \\
\hline $\begin{array}{l}11 \\
12 \\
13 \\
14 \\
15\end{array}$ & $\begin{array}{r}0.999632 \\
.999325 \\
.999404 \\
.999271 \\
.999126\end{array}$ & $\begin{array}{l}1.000450 \\
1.000339 \\
1.000217 \\
1.000081 \\
.999934\end{array}$ & $\begin{array}{l}1.001229 \\
1.00116 \\
1.000991 \\
1.000854 \\
1.000705\end{array}$ & $\begin{array}{l}1.002008 \\
1.001893 \\
1.001765 \\
1.001626 \\
1.001474\end{array}$ & $\begin{array}{l}1.002786 \\
1.002668 \\
1.002539 \\
1.002397 \\
1.002243\end{array}$ & $\begin{array}{l}1.003563 \\
1.003443 \\
1.003311 \\
1.003167 \\
1.003012\end{array}$ & $\begin{array}{l}1.004340 \\
1.004218 \\
1.004084 \\
1.003937 \\
1.003780\end{array}$ & $\begin{array}{l}1.005116 \\
1.004992 \\
1.004855 \\
1.004707 \\
1.004547\end{array}$ & $\begin{array}{l}1.005892 \\
1.005765 \\
1.005627 \\
1.005476 \\
1.005314\end{array}$ & $\begin{array}{l}1.006668 \\
1.006538 \\
1.006397 \\
1.006245 \\
1.006081\end{array}$ & $\begin{array}{l}1.007443 \\
1.007311 \\
1.007168 \\
1.007013 \\
1.006847\end{array}$ & $\begin{array}{l}1.008217 \\
1.008083 \\
1.007938 \\
1.007781 \\
1.007613\end{array}$ & $\begin{array}{l}1.008991 \\
1.008855 \\
1.008708 \\
1.008549 \\
1.008378\end{array}$ & $\begin{array}{l}1.009765 \\
1.009627 \\
1.009977 \\
1.009316 \\
1.009144\end{array}$ & $\begin{array}{l}1.010539 \\
1.010398 \\
1.010246 \\
1.010083 \\
1.009909\end{array}$ & \begin{tabular}{|l|}
1.011312 \\
1.01169 \\
1.011015 \\
1.010850 \\
1.010674
\end{tabular} & $\begin{array}{l}1.012086 \\
1.011940 \\
1.011784 \\
1.011617 \\
1.011438\end{array}$ & \begin{tabular}{|l|}
1.012859 \\
1.012711 \\
1.012553 \\
1.012383 \\
1.012203
\end{tabular} & \begin{tabular}{|l|}
1.013632 \\
1.013482 \\
1.013321 \\
1.013150 \\
1.012968
\end{tabular} & \begin{tabular}{|l|}
1.014405 \\
1.014253 \\
1.014090 \\
1.01316 \\
1.013732
\end{tabular} & \begin{tabular}{|l|}
1.015178 \\
1.015023 \\
1.014858 \\
1.014683 \\
1.014496
\end{tabular} \\
\hline $\begin{array}{l}16 \\
17 \\
18 \\
19 \\
20\end{array}$ & \begin{tabular}{|}
0.998970 \\
.998801 \\
.998622 \\
.998432 \\
.998230 \\
\end{tabular} & $\begin{array}{l}0.999775 \\
.999605 \\
.999424 \\
.999231 \\
.999028\end{array}$ & \begin{tabular}{|l|}
1.000544 \\
1.000371 \\
1.000188 \\
.999994 \\
.999789
\end{tabular} & $\begin{array}{l}1.001311 \\
1.001137 \\
1.000952 \\
1.000756 \\
1.000549\end{array}$ & $\begin{array}{l}1.002078 \\
1.001902 \\
1.001715 \\
1.001517 \\
1.001309\end{array}$ & $\begin{array}{l}1.002845 \\
1.002667 \\
1.002478 \\
1.002278 \\
1.002068\end{array}$ & $\begin{array}{l}1.003611 \\
1.003431 \\
1.003240 \\
1.003038 \\
1.002826\end{array}$ & $\begin{array}{l}1.004376 \\
1.004194 \\
1.004002 \\
1.003798 \\
1.003585\end{array}$ & $\begin{array}{l}1.005141 \\
1.004957 \\
1.004763 \\
1.004558 \\
1.004342\end{array}$ & $\begin{array}{l}1.005906 \\
1.005720 \\
1.005524 \\
1.005317 \\
1.005100\end{array}$ & $\begin{array}{l}1.006670 \\
1.006482 \\
1.006284 \\
1.006075 \\
1.005857\end{array}$ & $\begin{array}{l}1.007434 \\
1.007244 \\
1.007044 \\
1.006384 \\
1.006613\end{array}$ & $\begin{array}{l}1.008198 \\
1.008006 \\
1.007804 \\
1.007592 \\
1.007370\end{array}$ & $\left|\begin{array}{l}1.008961 \\
1.008767 \\
1.008564 \\
1.008350 \\
1.008126\end{array}\right|$ & $\begin{array}{l}1.009724 \\
1.00929 \\
1.009323 \\
1.009108 \\
1.008882\end{array}$ & \begin{tabular}{|l|}
1.010487 \\
1.010290 \\
1.010082 \\
1.009865 \\
1.009638
\end{tabular} & $\begin{array}{l}1.011250 \\
1.011051 \\
1.01082 \\
1.010622 \\
1.010394\end{array}$ & \begin{tabular}{|l|}
1.012012 \\
1.011811 \\
1.011601 \\
1.011380 \\
1.011149
\end{tabular} & $\begin{array}{l}1.012775 \\
1.012572 \\
1.012360 \\
1.012137 \\
1.011905\end{array}$ & \begin{tabular}{|l|}
1.013538 \\
1.013333 \\
1.013118 \\
1.012984 \\
1.012661
\end{tabular} & $\begin{array}{l}1.014300 \\
1.014094 \\
1.013877 \\
1.013652 \\
1.013416\end{array}$ \\
\hline $\begin{array}{l}21 \\
22 \\
23 \\
24 \\
25\end{array}$ & \begin{tabular}{|}
0.998019 \\
.997797 \\
.997565 \\
.997323 \\
.997071
\end{tabular} & $\begin{array}{r}0.998815 \\
.998591 \\
.998357 \\
.998113 \\
.997860\end{array}$ & \begin{tabular}{|}
0.999574 \\
.999348 \\
.999113 \\
.998868 \\
.998613
\end{tabular} & $\begin{array}{l}1.000332 \\
1.0000105 \\
.999868 \\
.999621 \\
.999365\end{array}$ & $\begin{array}{l}1.001090 \\
1.000861 \\
1.000623 \\
1.000374 \\
1.000116\end{array}$ & $\begin{array}{l}1.001848 \\
1.001617 \\
1.001377 \\
1.001127 \\
1.000867\end{array}$ & $\begin{array}{l}1.002604 \\
1.002372 \\
1.002131 \\
1.001879 \\
1.001618\end{array}$ & $\begin{array}{l}\text { 1. } 003361 \\
1.003127 \\
1.002884 \\
1.002631 \\
1.002368\end{array}$ & $\begin{array}{l}1.004117 \\
1.003882 \\
1.003637 \\
1.003382 \\
1.003118\end{array}$ & $\begin{array}{l}1.004873 \\
1.004636 \\
1.004389 \\
1.004133 \\
1.003868\end{array}$ & $\begin{array}{l}1.005628 \\
1.005390 \\
1.005141 \\
1.004884 \\
1.004617\end{array}$ & $\begin{array}{l}1.006383 \\
1.006143 \\
1.005893 \\
1.005634 \\
1.005366\end{array}$ & $\begin{array}{l}1.007138 \\
1.006896 \\
1.006645 \\
1.006385 \\
1.006115\end{array}$ & $\left|\begin{array}{l}1.007892 \\
1.007649 \\
1.007397 \\
1.00735 \\
1.006863\end{array}\right|$ & $\begin{array}{l}1.008647 \\
1.008402 \\
1.008148 \\
1.007884 \\
1.007612\end{array}$ & \begin{tabular}{|l|}
1.009401 \\
1.009155 \\
1.008899 \\
1.008634 \\
1.008360
\end{tabular} & \begin{tabular}{|}
1.010155 \\
1.009907 \\
1.009650 \\
1.009384 \\
1.009108 \\
\end{tabular} & \begin{tabular}{|l|}
1.010909 \\
1.010660 \\
1.010401 \\
1.010133 \\
1.009857
\end{tabular} & $\begin{array}{l}1.011663 \\
1.011412 \\
1.011152 \\
1.010883 \\
1.010605\end{array}$ & \begin{tabular}{|l|l}
1.012417 \\
1.012165 \\
1.011903 \\
1.011633 \\
1.011353
\end{tabular} & \begin{tabular}{|l|}
1.013171 \\
1.012917 \\
1.012654 \\
1.012382 \\
1.012102
\end{tabular} \\
\hline $\begin{array}{l}26 \\
27 \\
28 \\
29 \\
30\end{array}$ & $\begin{array}{l}0.996810 \\
.996539 \\
.996259 \\
.995971 \\
.995673\end{array}$ & $\begin{array}{r}0.997597 \\
.997325 \\
.997444 \\
.996754 \\
.996455\end{array}$ & $\begin{array}{l}0.998348 \\
.998075 \\
.997792 \\
.997500 \\
.997200\end{array}$ & $\begin{array}{r}0.999099 \\
.998824 \\
.998540 \\
.998247 \\
.997945\end{array}$ & $\begin{array}{r}0.999849 \\
.999572 \\
.999287 \\
.998992 \\
.998689\end{array}$ & $\begin{array}{r}1.000599 \\
1.000321 \\
1.000034 \\
.999338 \\
.999433\end{array}$ & $\begin{array}{l}1.001348 \\
1.001068 \\
1.000780 \\
1.000482 \\
1.000176\end{array}$ & $\begin{array}{l}1.002097 \\
1.001816 \\
1.001526 \\
1.001227 \\
1.000919\end{array}$ & $\begin{array}{l}1.002845 \\
1.002563 \\
1.002271 \\
1.001971 \\
1.001662\end{array}$ & $\begin{array}{l}1.003593 \\
1.0033399 \\
1.003017 \\
1.00215 \\
1.002405\end{array}$ & $\begin{array}{l}1.004341 \\
1.004056 \\
1.003762 \\
1.003459 \\
1.003147\end{array}$ & $\begin{array}{l}1.005089 \\
1.004802 \\
1.004507 \\
1.004203 \\
1.003890\end{array}$ & $\begin{array}{l}1.005836 \\
1.005548 \\
1.005251 \\
1.004946 \\
1.004632\end{array}$ & $\begin{array}{l}1.006583 \\
1.006294 \\
1.005996 \\
1.005689 \\
1.005374\end{array}$ & $\begin{array}{l}1.007330 \\
1.007040 \\
1.006740 \\
1.006432 \\
1.006116\end{array}$ & \begin{tabular}{|l|}
1.008077 \\
1.00785 \\
1.007485 \\
1.007176 \\
1.006858 \\
\end{tabular} & $\begin{array}{l}1.008824 \\
1.008531 \\
1.008229 \\
1.007919 \\
1.007600\end{array}$ & $\begin{array}{l}1.009571 \\
1.009277 \\
1.008974 \\
1.008662 \\
1.008342\end{array}$ & \begin{tabular}{|l|}
1.010318 \\
1.010022 \\
1.009718 \\
1.009405 \\
1.009084
\end{tabular} & \begin{tabular}{|l|}
1.011065 \\
1.010768 \\
1.010462 \\
1.010148 \\
1.009826
\end{tabular} & \begin{tabular}{|l}
1.011812 \\
1.011514 \\
1.011207 \\
1.010892 \\
1.010568
\end{tabular} \\
\hline
\end{tabular}


TABLE 2.-(continued)

\begin{tabular}{|c|c|c|c|c|c|c|c|c|c|c|c|c|c|c|c|c|c|c|c|c|}
\hline \multirow{2}{*}{$\begin{array}{c}\text { Temper- } \\
\text { ature } \\
\left({ }^{\circ} \mathrm{C}\right)\end{array}$} & \multicolumn{20}{|c|}{ Salinity (parts per thousand) } \\
\hline & 21 & 22 & 23 & 24 & 25 & 26 & 27 & 28 & 29 & 30 & 31 & 32 & 33 & 34 & 35 & 36 & 37 & 38 & 39 & 40 \\
\hline $\begin{array}{l}2 \\
3 \\
4 \\
5\end{array}$ & $\begin{array}{l}\text { 1. } 016869 \\
1.016853 \\
1.016822 \\
1.016777 \\
1.016718 \\
1.016646\end{array}$ & $\begin{array}{r}1.017672 \\
1.017653 \\
1.017619 \\
1.017571 \\
1.017509 \\
1.017434\end{array}$ & $\begin{array}{l}1.018476 \\
1.018453 \\
11.01416 \\
1.018365 \\
1.018300 \\
1.018222\end{array}$ & $\begin{array}{l}\text { 1. } 019279 \\
1.019254 \\
1.019213 \\
1.019159 \\
1.019091 \\
1.019011\end{array}$ & $\begin{array}{l}1.020083 \\
1.020054 \\
11.020011 \\
1.019953 \\
1.0,9883 \\
1.019799\end{array}$ & \begin{tabular}{|l|}
1.0208886 \\
1.020854 \\
1.020208 \\
1.02078 \\
1.020674 \\
1.020587 \\
\end{tabular} & $\begin{array}{l}1.021690 \\
1.021655 \\
1.021605 \\
1.021542 \\
1.021465 \\
1.021376\end{array}$ & $\begin{array}{l}1.022493 \\
1.022455 \\
1.022403 \\
1.022336 \\
1.022257 \\
1.022165\end{array}$ & \begin{tabular}{|l|}
1.023297 \\
1.023256 \\
1.023200 \\
1.02331 \\
1.023049 \\
1.022954
\end{tabular} & $\begin{array}{l}1.024101 \\
1.024057 \\
1.023998 \\
1.023926 \\
1.02341 \\
1.023743\end{array}$ & \begin{tabular}{|l|}
1.024906 \\
1.024858 \\
1.024796 \\
1.024721 \\
1.024634 \\
1.024533
\end{tabular} & $\begin{array}{l}1.025710 \\
1.025660 \\
1.025595 \\
1.025517 \\
1.025427 \\
1.025323\end{array}$ & $\begin{array}{l}\text { 1. } 026515 \\
1.026462 \\
1.026394 \\
1.026313 \\
1.026220 \\
1.026114\end{array}$ & $\begin{array}{l}1.027321 \\
1.027263 \\
1.027193 \\
1.027110 \\
1.027014 \\
1.026905\end{array}$ & $\begin{array}{l}1.028126 \\
1.028067 \\
1.027993 \\
1.027907 \\
1.027808 \\
1.027697\end{array}$ & \begin{tabular}{|l|}
1.028933 \\
1.028870 \\
1.028793 \\
1.028704 \\
1.02803 \\
1.028489 \\
\end{tabular} & $\begin{array}{l}1.029739 \\
1.029674 \\
1.029594 \\
1.029502 \\
1.029398 \\
1.029281\end{array}$ & \begin{tabular}{|l|}
1.030547 \\
1.030478 \\
1.030396 \\
1.030301 \\
1.030194 \\
1.030075
\end{tabular} & \begin{tabular}{|l|}
1.031354 \\
1.031233 \\
1.031198 \\
1.031100 \\
1.03090 \\
1.030869
\end{tabular} & $\begin{array}{l}1.032163 \\
1.032088 \\
1.032001 \\
1.031900 \\
1.031788 \\
1.031663\end{array}$ \\
\hline \begin{tabular}{r|r|}
6 \\
7 \\
8 \\
9 \\
10
\end{tabular} & $\begin{array}{l}1.016561 \\
1.016463 \\
1.016352 \\
1.016220 \\
1.016096\end{array}$ & $\begin{array}{l}1.017346 \\
1.017245 \\
1.017132 \\
1.017007 \\
1.016871\end{array}$ & $\begin{array}{l}1.018131 \\
1.018028 \\
1.017912 \\
1.017785 \\
1.017646\end{array}$ & $\begin{array}{l}1.018917 \\
1.018811 \\
1.018693 \\
1.018563 \\
1.018422\end{array}$ & $\begin{array}{l}1.019702 \\
1 \text { 1.019994 } \\
1.019473 \\
1.019341 \\
1.019198\end{array}$ & \begin{tabular}{|l|}
1.020488 \\
1.020377 \\
1.020254 \\
100202119 \\
1.019973
\end{tabular} & \begin{tabular}{|l|}
1.021274 \\
1.021160 \\
1.021035 \\
1.002898 \\
1.020749
\end{tabular} & $\begin{array}{l}1.022060 \\
1.021944 \\
1.021816 \\
1.021676 \\
1.021526\end{array}$ & \begin{tabular}{|l|}
1.022847 \\
1.022728 \\
1.02259 \\
1.022455 \\
1.022303
\end{tabular} & $\begin{array}{l}1.023634 \\
1.023512 \\
1.023379 \\
1.023235 \\
1.023080\end{array}$ & $\begin{array}{l}1.024421 \\
1.024297 \\
1.024161 \\
1.024014 \\
1.023857\end{array}$ & $\begin{array}{l}1.025208 \\
1.025082 \\
1.024944 \\
1.024795 \\
1.024635\end{array}$ & $\begin{array}{l}\text { 1. } 025996 \\
\text { 1. } 0225676 \\
1.025727 \\
1.025575 \\
1.025413\end{array}$ & $\begin{array}{l}1.026785 \\
1.026653 \\
1.026510 \\
1.026356 \\
1.026192\end{array}$ & \begin{tabular}{|l|}
1.027574 \\
1.027439 \\
1.027294 \\
1.027138 \\
1.026971
\end{tabular} & \begin{tabular}{|l|}
1.028363 \\
1.0282626 \\
1.028079 \\
1.027920 \\
1.027751
\end{tabular} & $\begin{array}{l}1.029153 \\
1.029014 \\
1.028864 \\
1.028703 \\
1.029532\end{array}$ & \begin{tabular}{|l|}
1.029944 \\
1.02982 \\
1.029650 \\
1.029487 \\
1.029313 \\
\end{tabular} & \begin{tabular}{|l|}
1.030735 \\
1.030591 \\
1.030436 \\
1.030271 \\
1.030095
\end{tabular} & $\begin{array}{l}1.031528 \\
1.031381 \\
1.031224 \\
1.031056 \\
1.030878\end{array}$ \\
\hline $\begin{array}{l}11 \\
12 \\
13 \\
14 \\
15\end{array}$ & $\begin{array}{l}1.015951 \\
1.015794 \\
1.015627 \\
1.015499 \\
1.015261\end{array}$ & \begin{tabular}{|l}
1.016724 \\
1.016555 \\
1.016396 \\
1.016216 \\
1.016026
\end{tabular} & \begin{tabular}{|l|}
1.017497 \\
11.017336 \\
1.017164 \\
1.016982 \\
1.016790
\end{tabular} & $\begin{array}{l}1.018270 \\
1.018107 \\
1.017933 \\
1.01749 \\
1.017555 \\
1.00\end{array}$ & $\begin{array}{l}1.019043 \\
1.01878 \\
1.018702 \\
1.018516 \\
1.018320\end{array}$ & \begin{tabular}{|l|}
1.019817 \\
1.01969 \\
1.019472 \\
1.019284 \\
1.019086 \\
\end{tabular} & \begin{tabular}{|l}
1.020591 \\
1.020421 \\
1.020241 \\
1.020051 \\
1.019851
\end{tabular} & $\begin{array}{l}1.021365 \\
1.021193 \\
1.021011 \\
1.02019 \\
1.020617\end{array}$ & \begin{tabular}{|l|}
1.022139 \\
1.021965 \\
1.021781 \\
1.021587 \\
1.021383 \\
\end{tabular} & \begin{tabular}{l|}
1.022914 \\
1.022738 \\
1.022552 \\
1.022356 \\
1.022150
\end{tabular} & \begin{tabular}{|l|}
1.023689 \\
1.023511 \\
1.023323 \\
1.023125 \\
1.022917
\end{tabular} & \begin{tabular}{|l}
1.024465 \\
1.024284 \\
1.024094 \\
1.023894 \\
1.023684
\end{tabular} & $\begin{array}{l}1.025241 \\
1.025558 \\
1.024866 \\
1.024664 \\
1.024452\end{array}$ & $\begin{array}{l}1.026017 \\
1.025833 \\
1.025638 \\
1.025434 \\
1.025221\end{array}$ & \begin{tabular}{|l}
1.026795 \\
1.026608 \\
1.026411 \\
1.026205 \\
1.025990
\end{tabular} & \begin{tabular}{|l|}
1.027572 \\
1.027383 \\
1.027185 \\
1.026977 \\
1.026760 \\
\end{tabular} & $\begin{array}{l}1.028351 \\
1.028160 \\
1.027959 \\
1.027749 \\
1.027530\end{array}$ & \begin{tabular}{|l|}
1.029130 \\
1.028937 \\
1.028374 \\
1.028522 \\
1.028302 \\
\end{tabular} & \begin{tabular}{|l|}
1.029910 \\
1.029714 \\
1.02910 \\
1.029296 \\
1.029073
\end{tabular} & $\begin{array}{l}\text { 1. } 030690 \\
\text { 1. } 030493 \\
\text { 1. } 030286 \\
\text { 1. } 030071 \\
1.029846\end{array}$ \\
\hline $\begin{array}{l}16 \\
17 \\
18 \\
19 \\
20\end{array}$ & $\begin{array}{l}1.015063 \\
1.014854 \\
1.014636 \\
1.01409 \\
1.014172\end{array}$ & $\begin{array}{l}1.015825 \\
1.015615 \\
1.015396 \\
1.015166 \\
1.014928\end{array}$ & $\begin{array}{l}1.016588 \\
1.016376 \\
1.01155 \\
1.0115924 \\
1.015684\end{array}$ & $\begin{array}{l}1.017351 \\
1.017138 \\
1.016914 \\
1.016882 \\
1.016440\end{array}$ & $\begin{array}{l}1.018114 \\
1.017899 \\
1.017674 \\
1.01740 \\
1.017196\end{array}$ & \begin{tabular}{|l|}
1.018878 \\
1.018661 \\
1.018434 \\
1.018198 \\
1.017953 \\
\end{tabular} & $\begin{array}{l}1.019642 \\
1.019423 \\
1.019194 \\
1.018956 \\
1.018710\end{array}$ & \begin{tabular}{|l|}
1.020406 \\
1.020185 \\
1.019955 \\
1.019715 \\
1.019467
\end{tabular} & $\begin{array}{l}1.021170 \\
1.0209047 \\
1.020215 \\
1.020475 \\
1.020225\end{array}$ & $\begin{array}{l}1.021935 \\
1.021710 \\
1.021477 \\
1.021234 \\
1.020983\end{array}$ & $\begin{array}{l}1.022700 \\
1.022474 \\
1.022239 \\
1.02194 \\
1.021741\end{array}$ & $\begin{array}{l}1.023466 \\
1.023238 \\
1.023001 \\
1.022755 \\
1.022500\end{array}$ & $\begin{array}{l}1.024232 \\
1.024002 \\
1.023763 \\
1.023516 \\
1.023260\end{array}$ & $\begin{array}{l}1.024999 \\
1.024767 \\
1.024527 \\
1.024278 \\
1.024020\end{array}$ & \begin{tabular}{|l}
1.025766 \\
1.025533 \\
1.025291 \\
1.025040 \\
1.024781
\end{tabular} & \begin{tabular}{|l|}
1.026534 \\
1.026299 \\
1.026055 \\
1.025803 \\
1.025542
\end{tabular} & $\begin{array}{l}1.027302 \\
1.027066 \\
1.026820 \\
1.026567 \\
1.026304\end{array}$ & \begin{tabular}{|l|}
1.028072 \\
1.027833 \\
1.027586 \\
1.027331 \\
1.027067 \\
\end{tabular} & \begin{tabular}{|l|}
1.028842 \\
1.028602 \\
1.028353 \\
1.02806 \\
1.027831 \\
\end{tabular} & $\begin{array}{l}\text { 1. } 029613 \\
\text { 1. } 029371 \\
1.029121 \\
\text { 1. } 028862 \\
1.028595\end{array}$ \\
\hline $\begin{array}{l}21 \\
22 \\
23 \\
24 \\
25\end{array}$ & $\begin{array}{l}1.013926 \\
1.013670 \\
1.013406 \\
1.013132 \\
1.012850\end{array}$ & $\left|\begin{array}{l}1.014680 \\
1.014423 \\
1.014157 \\
1.013882 \\
1.013599\end{array}\right|$ & $\left|\begin{array}{l}1.015434 \\
1.015176 \\
1.014908 \\
1.014632 \\
1.014348\end{array}\right|$ & $\begin{array}{l}1.016189 \\
1.015929 \\
1.015660 \\
1.015383 \\
1.015097\end{array}$ & $\begin{array}{l}1.016944 \\
1.016482 \\
1.016412 \\
1.016133 \\
1.015846\end{array}$ & \begin{tabular}{|l|}
1.017699 \\
1.017436 \\
1.017164 \\
1.016884 \\
1.016596
\end{tabular} & \begin{tabular}{|l|}
1.018454 \\
1.018190 \\
1.017917 \\
1.017636 \\
1.017346
\end{tabular} & $\begin{array}{l}1.019210 \\
1.018944 \\
1.018670 \\
1.018387 \\
1.018096\end{array}$ & \begin{tabular}{|l|}
1.019966 \\
1.019699 \\
1.019423 \\
1.019139 \\
1.018847
\end{tabular} & \begin{tabular}{|l|}
1.020723 \\
1.020454 \\
1.020177 \\
1.019892 \\
1.019598
\end{tabular} & $\begin{array}{l}1.021480 \\
1.021210 \\
1.020931 \\
1.020645 \\
1.020350\end{array}$ & $\begin{array}{l}\text { 1. } 022237 \\
\text { 1. } 021966 \\
\text { 1. } 021686 \\
\text { 1. } 021398 \\
\text { 1. } 021102\end{array}$ & $\begin{array}{l}1.022996 \\
1.022723 \\
1.022442 \\
1.022152 \\
1.021855\end{array}$ & $\begin{array}{l}1.023754 \\
1.023480 \\
1.023197 \\
1.022907 \\
1.022608\end{array}$ & \begin{tabular}{|l}
1.024514 \\
1.024238 \\
1.023954 \\
1.023662 \\
1.023362
\end{tabular} & \begin{tabular}{|l|}
1.025273 \\
1.024996 \\
1.024711 \\
1.024418 \\
1.02417
\end{tabular} & $\begin{array}{l}1.026034 \\
1.025756 \\
1.022469 \\
1.025175 \\
1.024873\end{array}$ & $\begin{array}{l}1.026795 \\
1.026516 \\
1.026228 \\
1.025932 \\
1.025629\end{array}$ & \begin{tabular}{|l|}
1.027558 \\
1.027276 \\
1.026897 \\
1.026691 \\
1.026386
\end{tabular} & $\begin{array}{l}1.028321 \\
1.028038 \\
1.027748 \\
1.027450 \\
1.027144\end{array}$ \\
\hline $\begin{array}{l}26 \\
27 \\
28 \\
29 \\
30\end{array}$ & $\begin{array}{l}1.012559 \\
1.012260 \\
1.011952 \\
1.011635 \\
1.011311\end{array}$ & $\begin{array}{l}1.013307 \\
1.013006 \\
1.012697 \\
1.012379 \\
1.012053\end{array}$ & $\left|\begin{array}{l}1.014054 \\
1.013752 \\
1.013442 \\
1.013123 \\
1.012796\end{array}\right|$ & $\begin{array}{l}1.014802 \\
1.014499 \\
1.014187 \\
1.013868 \\
1.013540\end{array}$ & $\begin{array}{l}1.015550 \\
1.015246 \\
1.014333 \\
1.014612 \\
1.014283\end{array}$ & \begin{tabular}{|l|}
1.016298 \\
1.015993 \\
1.015699 \\
1.015357 \\
1.015027
\end{tabular} & $\begin{array}{l}\text { 1. } 017047 \\
\text { 1. } 016741 \\
\text { 1. } 016426 \\
\text { 1. } 016103 \\
\text { 1. } 015772\end{array}$ & $\begin{array}{l}1.017796 \\
1.017489 \\
1.017173 \\
1.016499 \\
1.016517\end{array}$ & \begin{tabular}{|l|}
1.018546 \\
1.018237 \\
1.017920 \\
1.017595 \\
1.017262
\end{tabular} & $\begin{array}{l}1.019296 \\
1.018966 \\
1.018668 \\
1.018342 \\
1.018008\end{array}$ & \begin{tabular}{|l|}
1.020047 \\
1.019735 \\
1.019416 \\
1.019089 \\
1.018754
\end{tabular} & $\begin{array}{l}1.020798 \\
1.020485 \\
1.020165 \\
1.019837 \\
1.019501\end{array}$ & $\begin{array}{l}1.021549 \\
1.021236 \\
1.02015 \\
1.020586 \\
1.020249\end{array}$ & $\begin{array}{l}1.022302 \\
1.021987 \\
1.021665 \\
1.021335 \\
1.020997\end{array}$ & \begin{tabular}{|l|}
1.023055 \\
1.022739 \\
1.022416 \\
1.022085 \\
1.021747
\end{tabular} & \begin{tabular}{|l|}
1.024808 \\
1.023942 \\
1.023168 \\
1.022836 \\
1.022496
\end{tabular} & $\begin{array}{l}1.024563 \\
1.024245 \\
1.022920 \\
1.023587 \\
1.023247\end{array}$ & $\begin{array}{l}1.025318 \\
1.024999 \\
1.024673 \\
1.024340 \\
1.023666\end{array}$ & \begin{tabular}{|l|}
1.026074 \\
1.025754 \\
1.025427 \\
1.025093 \\
1.024751 \\
\end{tabular} & $\begin{array}{l}\text { 1. } 026831 \\
1.026510 \\
1.026182 \\
\text { 1. } 025847 \\
\text { 1. } 025504\end{array}$ \\
\hline
\end{tabular}


TABLE 3.-Settling time for a 10-micron-diameter quartz sphere in sea water and in pure water

\begin{tabular}{|c|c|c|c|c|}
\hline Depth (meters) & $\begin{array}{l}\text { Salinity } 1 \\
\text { (in parts per } \\
\text { thousand) }\end{array}$ & $\begin{array}{c}\text { Mean } \\
\text { tempera- } \\
\text { ture } \\
\left(0^{\circ} \mathrm{C}\right)^{1}\end{array}$ & $\underset{(\mathrm{cm} / \mathrm{sec})}{\text { Settling veloci ty }}$ & $\begin{array}{l}\text { Total time to } \\
\text { settle (hours) }\end{array}$ \\
\hline \multicolumn{5}{|c|}{ Sea water } \\
\hline $\begin{array}{r}0-200 \\
200-400 \\
400-600 \\
600-800 \\
800-1,000 \\
1,000-1,500 \ldots \\
1,500-2,000 \ldots \\
2,000-2,500 \ldots \\
2,500-3,000 \ldots \\
3,000-3,500 \\
3,500-4,000 \ldots \\
\end{array}$ & $\begin{array}{l}\text { 34. } 6 \\
34.6 \\
34.5 \\
34.4 \\
34.3 \\
34.5 \\
34.7 \\
34.8 \\
34.9 \\
34.9 \\
34.8\end{array}$ & $\begin{array}{r}10.8 \\
9.3 \\
6.5 \\
4.3 \\
3.3 \\
2.9 \\
2.7 \\
2.6 \\
2.4 \\
2.1 \\
1.6\end{array}$ & $\begin{array}{r}0.00648131 \\
.00620758 \\
.00572845 \\
.00539250 \\
.00524531 \\
.00518623 \\
.00514343 \\
.00513419 \\
.00509835 \\
.00505166 \\
.00497223\end{array}$ & $\begin{array}{r}857.27 \\
894.85 \\
969.93 \\
1,030.40 \\
1,059.32 \\
2,678.09 \\
2,699.78 \\
2,705.63 \\
2,724.80 \\
2,748.76 \\
2,793.30\end{array}$ \\
\hline $\mathbf{T}$ & & & & $\begin{array}{r}21,162.13 \\
\text { (881.76 days) }\end{array}$ \\
\hline \multicolumn{5}{|c|}{ Pure water } \\
\hline $\begin{array}{r}0-200 \\
200-400 \\
400-600 \\
600-800 \\
800-1,000 . \\
1,000-1,500 \ldots \\
1,500-2,000 \\
2,000-2,500 . \\
2,500-3,000 \\
3,000-3,500 \\
3,500-4,000 \\
\end{array}$ & 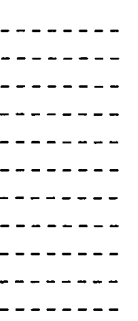 & $\begin{array}{r}10.8 \\
9.3 \\
6.5 \\
4.3 \\
3.3 \\
2.9 \\
2.7 \\
2.6 \\
2.4 \\
2.1 \\
1.6\end{array}$ & $\begin{array}{l}0.00696160 \\
.00673683 \\
.00620190 \\
.00579040 \\
.00559932 \\
.00553728 \\
.00550004 \\
.00547994 \\
.00544676 \\
.00539128 \\
.00530232\end{array}$ & $\begin{array}{r}798.08 \\
824.74 \\
895.66 \\
959.23 \\
992.06 \\
2,508.78 \\
2,525.25 \\
2,534.21 \\
2,549.72 \\
2,575.99 \\
2,619.17\end{array}$ \\
\hline Total & & & & $\begin{array}{r}19,782.89 \\
(824.29 \text { days })\end{array}$ \\
\hline
\end{tabular}

1 From Mathews (1939).

They are considered resistances to settling velocity and are called inertial forces. Stokes' law does not take these forces into consideration, as it applies only to a perfect sphere. Failure to consider these factors in velocity calculations results in significant errors for nonspherical particles whose Reynolds number exceeds 1.0. Blanchard (1967) experimentally determined that for a 25-micron-diameter quartz sphere the upper limit where Stokes' equation holds is at a Reynolds number of 0.02 .

The most important factor, other than fluid properties, affecting settling velocity is size. Shape has been considered secondary in importance, yet many of the discrepancies in settling velocity for a particular par- ticle size are due to differences in shape (Schultz and others, 1954). Composition is important because it determines the specific gravity of the particle: Also, many biological particles dissolve rapidly, and their size, shape, and surface texture may change as they settle. Some may be totally dissolved before reaching the bottom of the sea.

\section{CONCLUSIONS}

Regardless of the factors not considered by Stokes' law, it is apparent that determination of settling velocities in sea water must take into account the basic differences between fresh water and sea water. Where errors of as much as 6 percent are significant in calculating settling velocity, the viscosity and specific gravity of sea water must be taken into account. A new table giving absolute values of the viscosity of sea water should be carefully compiled to aid those actually involved in calculating the settling velocities of minerals in sea water. International sea water standards should be used for control. Such standards have been prepared by the Hydrographic Laboratory of the International Council for the Exploration of the Sea in Copenhagen, Denmark.

\section{REFERENCES}

Blanchard, M. B., 1967, Method for determining the density of microsize spherical particles: Geol. Soc. America Bull., v. 78, p. $385-404$.

Hidaka, Koji, 1954, A contribution to the theory of upwelling and coastal currents: Am. Geophys. Union Trans., v. 35, no. 3, p. $431-444$.

Hodgman, C. D., ed., 1960, Handbook of chemistry and physics, 42d ed.: Cleveland, Ohio, Chemical Rubber Publishing Co., 3,481 p. [repr. 1961 ].

Krümmel, O., and Ruppin, E., 1906, Utber die innere Reibung des Seewassers: Wiss. Meeresunters. (N.F.), 9 (Abt. Kiel), p. 27-36.

Mathews, D. J., 1939, Tables of the velocity of sound in pure water and sea water for use in echo-sounding and soundranging, 2d ed: Hydrographic Dept., The Admiralty, London, 52 p.

Schultz, E. F., Wilde, R. H., and Albertson, M. L., 1954, Influence of shape on the fall velocity of sedimentary particles: Omaha, Nebr., U.S. Army Corps Engineers, Missouri River Div., MRD Sediment Ser., no. 5, $161 \mathrm{p}$.

U.S. Navy Hydrographic Office, 1952, Tables for sea water density: Pub. 615, Washington, D.C., 265 p. 


\title{
THE GLACIATED SHELF OFF NORTHEASTERN UNITED STATES ${ }^{1}$
}

\author{
By R. N. OLDALE and ELAZAR UCHUPI, Woods Hole, Mass.
}

Work done in cooperation with the Woods Hole Oceanographic

Institution, Woods Hole, Mass.

\begin{abstract}
The Continental Shelf off northeastern United States is made up of basins-the sounds and the Gulf of Maine -flanked on the landward side by the Fall Zone and on the seaward side by a cuesta. Morphology of the shelf is believed to be the result of fluvial erosion during pre-Late Cretaceous, Paleocene, and Pliocene-enrly Pleistocene time, and glacial erosion during the Pleistocene. The bathymetry of the shelf and the topography of the basement (which is made up of Triassic and pre-Triassic rocks) show a drainage system developed during late Tertiary-early Pleistocene time and modified by glacinl erosion during the Pleistocene. Older erosion surfaces may have controlled the late Tertiary-early Pleistocene fluvial erosion. Folded sedimentary rocks below fluvially carved thalwegs in the Gulf of Maine indicate structural basins, probably of Triassic or Carboniferous age. Seismic velocities of the folded sedimentary rocks, however, suggest that the basins may be as young as Tertiary.
\end{abstract}

The glaciated shelf off northeastern United States is made up of lowlands flanked on the landward side by a gently sloping surface, the Fall Zone of Flint (1963), and on the seaward side by a cuesta and by end moraines of Pleistocene age. Long Island, Block Island, Rhode Island, and Nantucket Sounds are the major lowlands (fig. 1). The islands in this area, together with Georges and Browns Banks, are the topographic expressions of the cuesta and end moraines. The lowlands west of the Gulf of Maine are generally less than $40 \mathrm{~m}$ deep. Beneath Long Island Sound a valley slopes gently eastward. The bottoms of Block Island, Rhode Island, and Nantucket Sounds have gentle southerly slopes. The sea floor of Cape Cod Bay slopes north and that of Massachusetts Bay slopes east toward the Gulf of Maine (fig. 1). Small shallow, closed depressions occur in the bottom in some places.

In contrast, the bathymetry of the Gulf of Maine is

${ }^{1}$ Contribution No. 2334 of the Woods Hole Oceanographic Institution. quite complex (fig. 1). The bottom of the gulf forms a large low area, with an average depth of about $150 \mathrm{~m}$ below sea level (Uchupi, 1965a), bordered on the south by Georges and Browns Banks. The low area has an outlet, Northeast Channel, with a threshold depth of more than $240 \mathrm{~m}$ below sea level. In preglacial time Great South Channel was an outlet, but it is now choked with drift. Major features of the Gulf of Maine are the closed depressions such as Wilkinson, Jordan, and Georges Basins, which have maximum depths of more than $200 \mathrm{~m}$ and enclose areas of 5,000 to 10,000 sq $\mathrm{km}$ (Uchupi, 1965a). Separating the basins are ledges, banks, and swells such as Jeffreys Bank, Cashes Ledge, Stellwagen Bank, and Truxton Swell. A major divide, trending south, separates the Gulf of Maine into two large lowlands.

In the present report, a topographic chart of the basement has been compiled from published and unpublished sources (fig. 3). Data from this chart, and information from dredge hauls and seismic-profiler recordings have been used to reconstruct the geologic history of the Continental Shelf of the northeastern United States. As described below, the morphology of the shelf is believed to be a result of pre-Cretaceous fluvial erosion deposition during Cretaceous and early Tertiary time, fluvial erosion during late Tertiary and early Pleistocene time, and glacial erosion during the Pleistocene. In the western part of the Gulf of Maine, a fourth period of erosion, possibly during the Paleocene, influenced the shelf morphology.

\section{METHODS}

During 1963, 1964, and 1965, seismic-profiler records were taken on the shelf east of New York City by the U.S. Geological Survey-Woods Hole Oceanographic Institution Atlantic shelf and slope program. These 


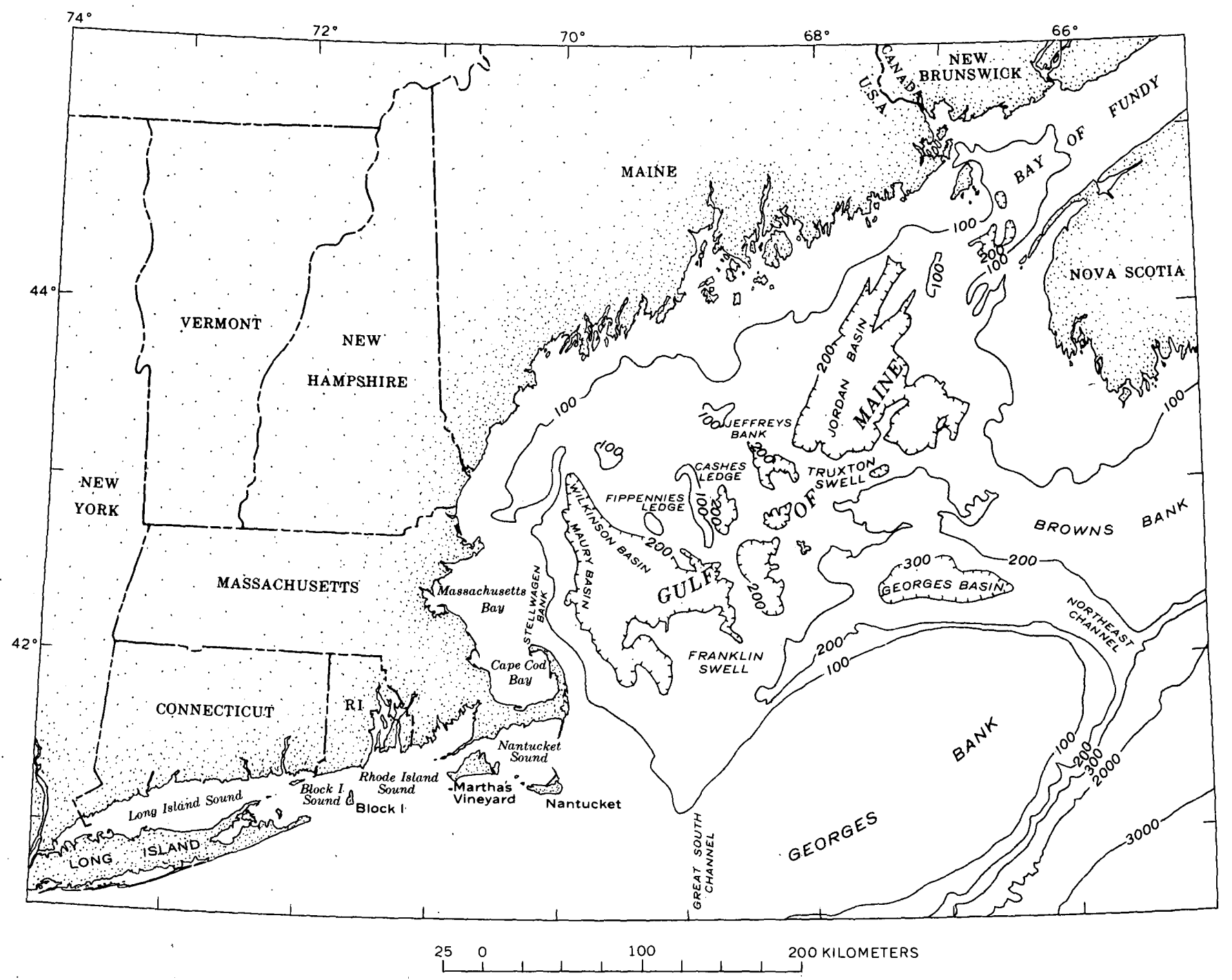

Figure 1.-Bathymetry of the Gulf of Maine (from Uchupi, 1965b). Depth-contour interval 100 and 1,000 m.

data and data from several other profiles taken by the Woods Hole Oceanographic Institution were used by Uchupi (1966) and Tagg and Uchupi $(1966,1967)$ to describe the morphology and structure of the Gulf of Maine, the sounds, and the Bay of Fundy. In this report, these data and profiler data from a report by McMaster and others (1968) were used to determine the topography of the basement surface. The depth to basement was computed by assuming a velocity of sound through water of $1.5 \mathrm{~km} / \mathrm{sec}$ and through unconsolidated sediments of $1.7 \mathrm{~km} / \mathrm{sec}$. The data were combined with basement topographic maps for the north side of Long Island Sound (U.S. Geol. Survey, 1967), for Long Island (Suter and others, 1949), southeastern Massachusetts (Oldale, 1969), Cape Cod Bay (Hoskins and Knott, 1961), and for the outer part of the shelf, continental slope, and upper continental rise
(Drake and others, 1959). The resulting chart (fig. 3) shows the configuration of the basement beneath the Continental Shelf off northeastern United States. A contour interval of $50 \mathrm{~m}$ for depths to $500 \mathrm{~m}$ and a $500-\mathrm{m}$ interval for greater depths were used.

\section{GEOLOGY}

Exposures along the coast, seismic compressive velocities, dredge samples, and seismic-profiler recordings indicate that crystalline and consolidated rocks of Paleozoic to middle Mesozoic age form the foundation of the shelf (Drake and others, 1954, 1959; Koteff and Cotton, 1962; Hoskins and Knott, 1961; McMaster and others, 1968; Oldale, 1969; Oldale and Tuttle, 1964, 1965; Suter and others, 1949; Tagg and Uchupi, 1966, 1967; Toulmin, 1957; Tuttle and others, 1961; Uchupi, 1966). These rocks are collectively termed "basement" 
in this report. In places, the basement offshore is probably composed of weakly metamorphosed to unmetamorphosed sedimentary and volcanic rocks similar to those in the Narragansett and Boston basins and northern New England (fig. 2). Triassic sedimentary rocks make up a large part of the basement in northeastern Gulf of Maine and the Bay of Fundy (Tagg and Uchupi, 1966) and probably occur in Long Island Sound as extensions of the Triassic basins in Connecticut.

The oldest unconsolidated sediments known to occur on the glaciated shelf are the Upper Cretaceous deposits exposed on Long Island, Block Island, and Mar- tha's Vineyard. Similar rocks, possibly folded, are believed to occur in Georges Basin (Uchupi, 1966) and as erosional remnants in Cape Cod Bay and Massachusetts Bay (Hoskins and Knott, 1961). In most areas, the Cretaceous deposits rest directly on basement.

Gently dipping or folded sedimentary rocks of possible Triassic or post-Triassic age occur in closed depressions in the deepest parts of Wilkinson and Maury Basins (Uchupi, 1966). Sediments of Eocene(?) age have been found in boreholes on outer Cape Cod (Zeigler and others, 1960) and are inferred to occur in Cape Cod Bay (Hoskins and Knott, 1961). Eocene sediments

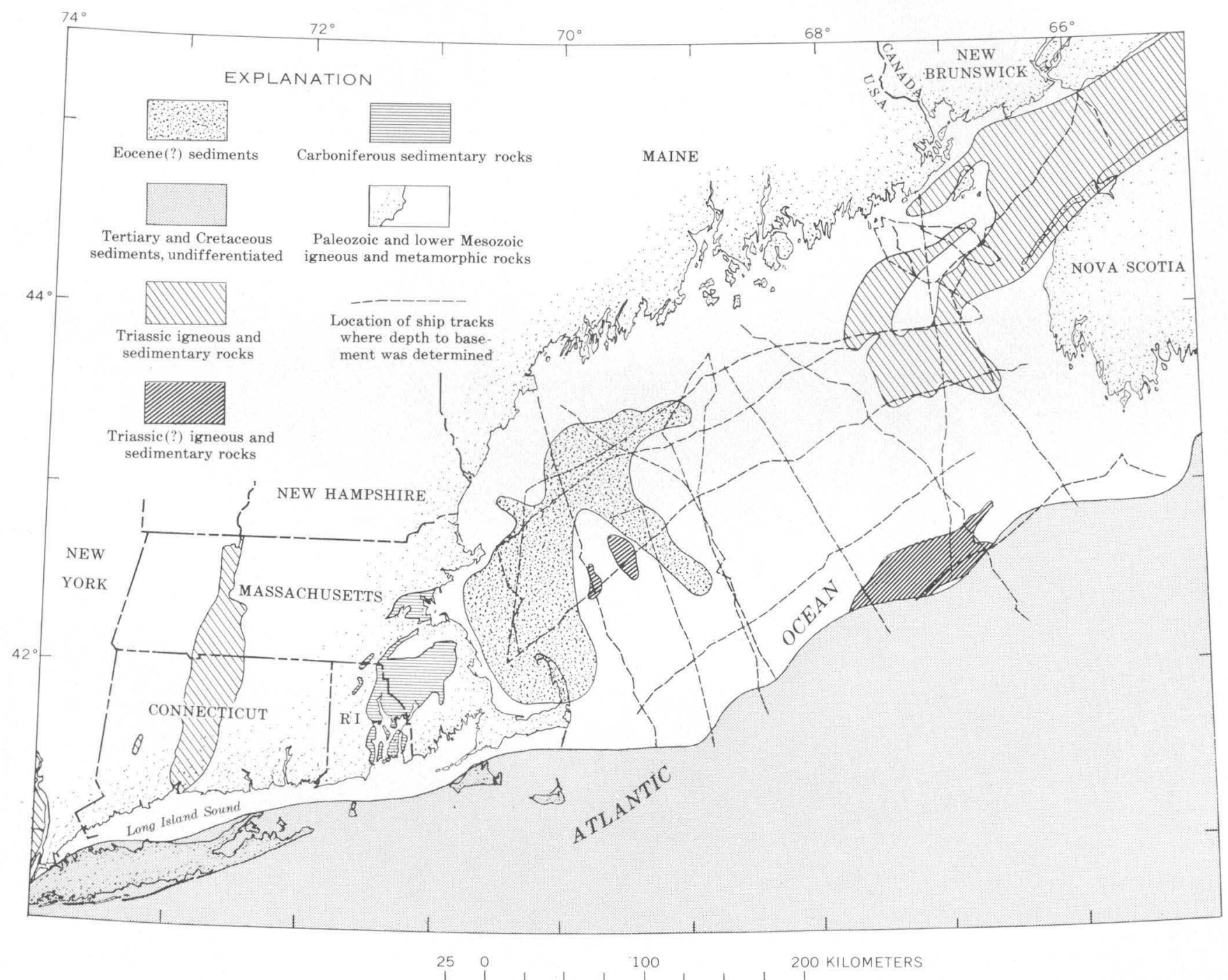

FIGURE 2.-Geologic map showing distribution of pre-Pleistocene rocks. Distribution of sedimentary, igneous, and metamorphic rocks offshore based on continuous seismic-profiler data (Hoskins and Knott, 1961; Uchupi, 1966; Tagg and Uchupi, 1966, 1967; McMaster and others, 1968) and on dredge hauls (Schlee and Cheetham, 1967; Toulmin, 1957). Distribution of sedimentary, igneous, and metamorphic rocks on land based on reports by Laguna, Suter, Perlmutter, and Brashears (1949), Zeigler, Hoffmeister, Geise, and Tasha (1960), Woodworth and Wigglesworth (1934), and geologic map of the United States. Track lines of continuous seismic profiles in the Gulf of Maine used to compile a topographic chart (fig. 3) are also shown. 
have also been reported from Fippennies Ledge (Schlee and Cheetham, 1967). Miocene strata occur in Massachusetts on Martha's Vineyard and at Marshfield and Duxbury, Mass. (Woodworth and Wigglesworth, 1934).

Pleistocene and Holocene deposits overlie the basement and Coastal Plain sediments in most places. On Long Island, Block Island, Martha's Vineyard, Nantucket, Cape Cod, and the north slope of Georges Bank the glacial deposits form end moraines as much as 100 $\mathrm{m}$ thick (Suter and others, 1949; Tuttle and others, 1961; Oldale, 1969; Oldale and Tuttle, 1964, 1965; and Knott and Hoskins, 1968). In the sounds and Cape Cod Bay the glacial deposits are generally thinner (Tagg and Uchupi, 1967; McMaster and others, 1968; Oldale, 1969; and Hoskins and Knott, 1961). Within the Gulf of Maine, the Pleistocene deposits are generally thin and discontinuous, although southwest of the Bay of Fundy, Northeast Channel, and Great South Channel they are more than $80 \mathrm{~m}$ thick (Uchupi, 1966). Deposits of Holocene age are thin and discontinuous over most of the shelf.

\section{BASEMENT MORPHOLOGY}

Beneath the glaciated shelf the morphology of the basement is similar in many respects to the present bathymetry of the shelf-a reflection of the importance of glacial erosion (figs. 1 and 3). In the Gulf of Maine the basement surface forms two large low areas separated by a south-trending divide. The low areas are bordered on the south by a discontinuous high area

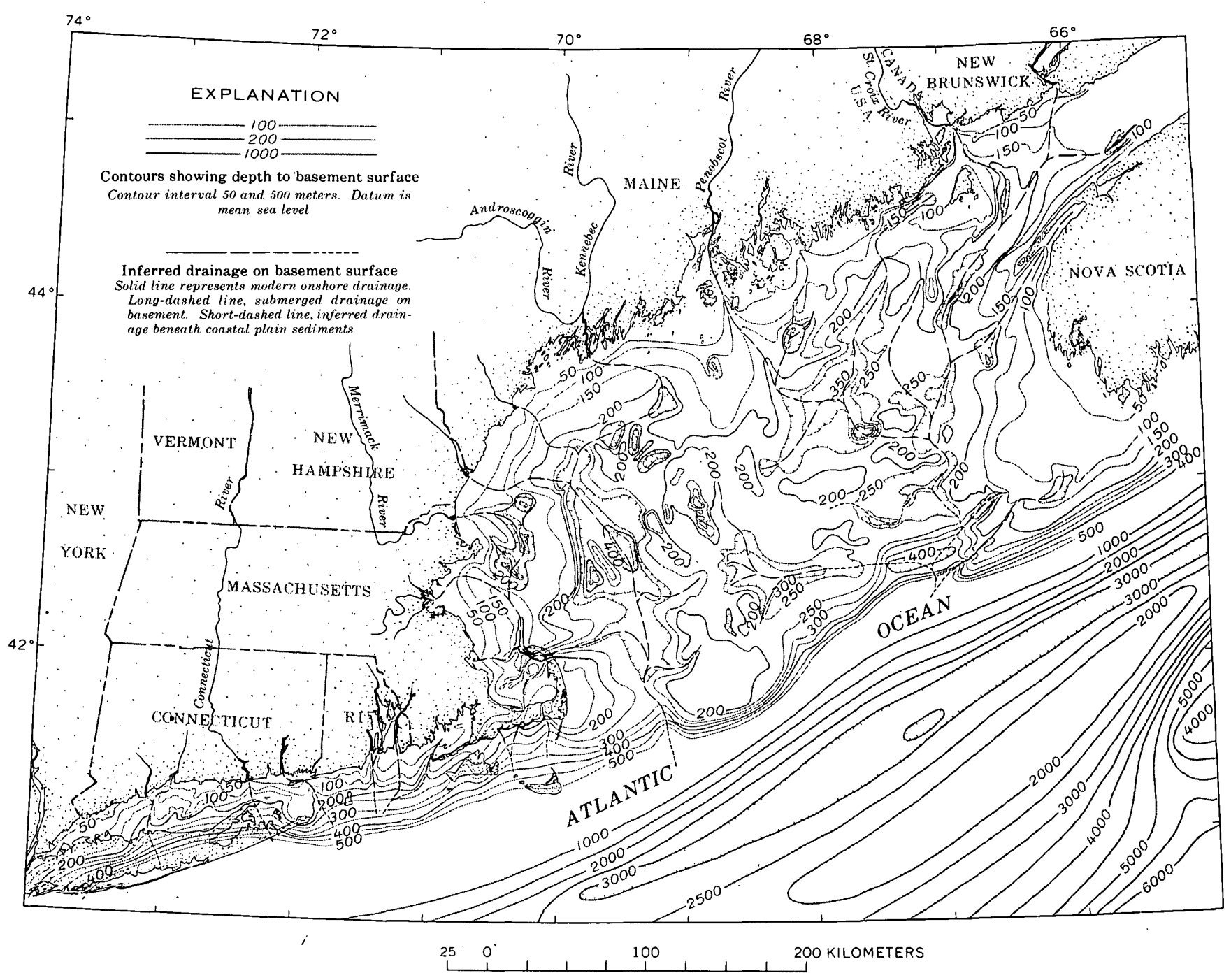

Figure 3.-Topographic chart of the basement surface, showing inferred offshore extensions of modern onland stream valleys. Depths of basement in the Gulf of Maine computed from continuous seismic-profiler data (see fig. 2). Other sources of data are Hoskins and Knott (1961), Cape Cod Bay; Oldale (1969), southeastern Massachusetts; McMaster, Lachance, and Garrison (1968), Rhode Island and Block Island Sounds; U.S. Geological Survey (1967), Long Island; Suter, Laguna, Perlmutter, and Brashears (1949), Long Island; and Drake, Worzel, and Beckman (1959), outer shelf and slope. 
that runs eastward from the southeast part of Cape Cod to southwest Nova Scotia. Two major gaps occur in the high area; one, in Great South Channel, connects with the western low area, and the other, in Northeast Channel, connects with the eastern low area. In Long Island, Nantucket, Rhode Island, and Block Island Sounds and beneath Long Island the basement surface slopes gently seaward, is relatively smooth, and has south-trending valleys.

The general increase in slope of the basement surface beneath the unglaciated shelf south of a line that runs roughly from New York City to the Scotian Shelf is not clearly understood. Its linearity, however, suggests that it has a structural origin.

The more detailed basement topography shows drainage systems that in most places are seaward extensions of modern onland streams. In the Gulf of Maine, two well-defined drainage systems are separated by a divide marked by Jeffreys Bank, Cashes Ledge, and Franklin Swell. Tributaries of the eastern system form offshore extensions of the St. Croix, St. John, and Penobscot Rivers. Several tributaries drain the divide between the lowlands and have no onshore extensions. This system reached the sea by way of Northeast Channel. A tributary of the western system connects with the Boston basin drainage. Other tributaries form submerged extensions of the Merrimack River and the Androscoggin and Kennebec system. As in the eastern basin, several tributaries have no onshore equivalents.

In Nantucket, Rhode Island, and Block Island Sounds, river valleys in the basement have southerly courses. Some are the submerged extensions of streams on land. Valleys beneath Buzzards Bay and Nantucket Sound appear to have no onland extensions. Within Long Island Sound, major tributaries form the offshore extensions of numerous onland rivers, including the Connecticut River.

\section{GEOLOGIC HISTORY}

Subsurface data suggest that the shelf east of New York City has undergone two and possibly three periods of erosion separated by periods of deposition. The earliest erosion surface is represented by the unconformity between the basement rocks and the deposits of Late Cretaceous age. Only the gross morphology of this surface has been determined, as beneath the cuesta it deepens rapidly. The surface has not been traced in detail by seismic methods or by drilling. North of the cuesta the pre-Late Cretaceous surface cannot be recognized except where it is locally overlain by isolated erosional remnants of Cretaceous strata. West of the Gulf of Maine the pre-Coastal Plain sur- face probably had little relief and sloped gently south. Extensions of modern onland streams probably followed southerly courses across the surface (Flint, 1963). In the Gulf of Maine, data on the pre-Late Cretaceous surface are equally lacking. It seems probable that the present bathymetry reflects the gross morphology of the pre-Coastal-Plain surface and that the Gulf of Maine formed two large lowlands. A divide, possibly marked by Jeffreys Bank, Cashes Ledge, and Franklin Swell, separated the lowlands. The western basin may have drained seaward by way of a valley beneath Great South Channel and the eastern basin through a valley within Northeast Channel.

Evidence of an early Tertiary period of erosion appears to be present in the western part of the Gulf of Maine. Continuous seismic-profiler studies in this area (Hoskins and Knott, 1961; Uchupi, 1966) show well-stratified deposits atop either basement or erosional remnants believed by Hoskins and Knott to be of Cretaceous(?) age on the basis of their compressional wave velocities. The occurrence of Eocene(?) strata in the subsurface of Cape Cod (Ziegler and others, 1960) and in Fippennies Ledge (Schlee and Cheetham, 1967) suggests that the stratified submarine deposits are also Eocene in age. Consequently, the stratigraphic sequence in the western part of the Gulf of Maine indicates a fluvial cycle of erosion, possibly during the Paleocene, that removed most of the Cretaceous deposits and exposed wide parts of the basement. This was followed by a cycle of deposition during middle and late Tertiary time that reburied the basement and the Cretaceous erosional remnants. Occurrence of Miocene deposits in Scituate and Marshfield, Mass. (Woodworth and Wigglesworth, 1934), indicates that these sediments extended some distance inshore from the present coastline and possibly covered much of the Fall Zone.

The cycle of deposition during middle to late Tertiary time was followed by a period of fluvial erosion, probably during Pliocene and early Pleistocene time. Stream erosion carved the cuesta and removed almost all the sediments north of the cuesta. Except for the western Gulf of Maine, the morphology and drainage produced at this time are represented by the basement surface north of the cuesta and in a general way by the bathymetry of the present shelf (figs. 1 and 3).

Beneath Long Island Sound, a major valley, the Sound River of Dana (1890), probably trended east. It was bordered on the north by a gently sloping surface cut on crystalline and consolidated sedimentary rock and on the south by the cuesta (Long Island) underlain by Upper Cretaceous sediments. At the east 
end of Long Island, the valley turned southward and cut into Upper Cretaceous strata. Major tributaries, offshore extensions of the modern streams in southern Connecticut, drained into the valley from the north. Short steep tributaries, cut into the steep north slope of the cuesta, drained into the valley from the south. South of Rhode Island and southeastern Massachusetts, major stream valleys, again extensions of modern onland streams, flowed south through water gaps cut in the cuesta. East- and west-flowing tributary streams probably drained the divides between the south-flowing streams.

In the Gulf of Maine, streams removed most of the shelf sediments, forming a lowland (the Gulf of Maine) and a cuesta (Georges Bank). North of the cuesta, two major drainage basins were developed, carved by extensions of modern onland streams and separated by a divide marked by Jeffreys Bank, Cashes Ledge, and Franklin Swell. Streams in the eastern basin drained seaward through Northeast Channel, and those in the western basin through Great South Channel; these channels are water gaps cut into the cuesta.

Pliocene and early Pleistocene fluvial erosion was followed by glaciation. Ice advanced onto the shelf several times and modified the surface by erosion and deposition. The ice followed the fluvially carved surface. Glacial erosion was concentrated in the valleys and in some places greatly modified them. The deep closed basins in the Gulf of Maine are the result of intense glacial scour in preglacial fluvial valleys, possibly on consolidated sediments. The southern limit of glaciation, delineated by textural changes in the shelf sediments (Schlee and Pratt, 1970) is approximated by the south shore of Long Island, Block Island, Martha's Vineyard, and Nantucket and the northern edge of Georges Bank. In Rhode Island Sound and Great South Channel, lobes of ice pushed the limit somewhat farther south. In Northeast Channel the glacial limit reached as far as the shelf break. North of the cuesta, ice eroded the basement surface, deepening the valleys. Locally, along the valley axes, the ice carved deep closed basins. In most places, however, glacial erosion and deposition modified but did not destroy the preglacial drainage patterns on the shelf. Thick accumulations of drift were deposited in the basins and in Great South and Northeast Channels. Elsewhere, a thin discontinuous layer of drift was deposited on the glacially modified Pliocene-early Pleistocene erosional surface. Near the glacial limit the ice built large moraines, and south of the limit melt water deposited a great amount of outwash.

\section{POST-PALEOZOIC TECTONIC ACTIVITY}

The major basins in the Gulf of Maine, Jordan, Georges, Wilkinson, and Maury Basins are floored in part with gently folded strata. The folded rocks in Jordan Basin are of Triassic age, but the age of the strata in the other basins is not definitely known. That the deposits are probably preglacial is indicated by their well-bedded nature in continuous seismic profiles. Furthermore, the folding is not the type generally produced by overriding ice. Compressional wave velocities measured in Maury and Wilkinson Basins (Drake and others, 1954) suggest that the strata may be unconsolidated and of Cretaceous or Tertiary age. This seems improbable, as, except for minor glacial deformation, folded strata of this age are not known elsewhere on the shelf off the northeastern United States. The rocks are most probably Triassic, because on continuous seismic-profiler records they are similar in all respects to the folded rocks in Jordan Basin, which are known to be Triassic from study of exposures along the shore. They could also be of Carboniferous age, similar to the rocks in Narragansett and Boston basins.

Whatever their age, their occurrence in closed depressions within the crystalline rocks must be the result of downfaulting. The faulting and folding indicate tectonic activity in the Gulf of Maine, probably in the Triassic, but possibly during the Carboniferous, Cretaceous, or Tertiary. These folded and relatively soft sedimentary rocks of Triassic ( ?) age appear to underlie all the major basins in the Gulf of Maine. Relief of the basins, consequently, appears to be due to differential fluvial and glacial erosion of the soft sediments that has resulted in the present morphology of the gulf. The wide occurrence of Triassic(?) strata within the Gulf of Maine further suggests that Triassic deposits may be more abundant within the shelf sediments than is believed at present, and that the deposits constitute a considerable part of the shelf's sedimentary blanket.

\section{REFERENCES}

Dana, J. D., 1890, Long Island Sound in the Quaternary era, with observations on the submarine Hudson River channel : Am. Jour. Sci., 3d ser., v. 40, p. 425-437.

Drake, C. J., Worzel, J. L., and Beckmann, W. C., 1954, Geophysical investigations in the emerged and submerged Atlantic Coastal Plain, pt. 9, Gulf of Maine: Geol. Soc. America Bull., v. 65, no. 10, p. 957-970.

Drake, C. J., Ewing, Maurice, and Sutton, G. H., 1959, Continental margins and geosynclines-The east coast of North America north of Cape Hatteras, in Ahrens, L. H., and others, eds., Physics and chemistry of the earth : New York, McGraw-Hill Book Co., v. 3, p. 110-198.

Flint, R. F., 1963, Altitude, lithology, and the Fall Zone in Connecticut: Jour. Geology, v. 71, no. 6, p. 683-697. 
Hoskins, Hartley, and Knott, S. T., 1961, Geophysical investigation of Cape Cod Bay, Massachusetts, using the continuous seismic profiler: Jour. Geology, v. 69, no. 3, p. 330-340.

Knott, S. T., and Hoskins, Hartley, 1968, Evidence of Pleistocene events in the structure of the continental shelf off the northenstern United States: Marine Geology, v. 6, p. 5-43.

Koteff, Carl, and Cotton, J. E., 1962, Preliminary results of recent deep drilling on Cape Cod, Massachusetts: Science, v. 137 , no. 3523, p. 34 .

McMaster, R. I., Lachance, T. P., and Garrison, L. E., 1968, Seismic-reflection studies in Block Island and Rhode Island Sounds: Am. Assoc. Petroleum Geologists Bull., v. 52, no. 3, p. $465-474$.

Oldale, R. N., 1969, Seismic investigations on Cape Cod, Martha's Vineyard, and Nantucket, Massachusetts, and a topographic map of the basement surface from Cape Cod Bay to the islands, in Geological Survey Research, 1969: U.S. Geol. Survey Prof. Paper 650-B, p. B122-B127.

Oldale, R. N., and Tuttle, C. R., 1964, Seismic investigations on Cape Cod, Massachusetts: Art. 145 in U.S. Geol. Survey Prof. Paper 475-D, p. D118-D122.

1.965, Seismic investigations in the Harwich and Dennis quadrangles, Cape Cod, Massachusetts, in Geological Survey Research 1965: U.S. Geol. Survey Prof. Paper 525-D, p. D101-D105.

Schlee, John, and Cheetham, A. H., 1967, Rocks on Eocene age on Fippennies Ledge, Gulf of Maine: Geol. Soc. America Bull., v. 78 , no. 5, p. 681-684.

Schlee, John, and Pratt, R. M., 1970, Atlantic Continental Shelf and Slope of the United States-Gravels of the northenstern part: U.S. Geol. Survey Prof. Paper 529-H. [In press]

Suter, Russell, Laguna, Wallace de, Perlmutter, N. M., and Brashenrs, M. L., Jr., 1949, Mapping of geologic formations and aquifers of Long Island, New York: New York Water Power and Control Comm. Bull. GW-18, 212 p.
Tagg, A. R., and Uchupi, Elazar, 1966, Distribution and geologic structure of Triassic rocks in the Bay of Fundy and the northeastern part of the Gulf of Maine, in Geological Survey Research 1966: U.S. Geol. Survey Prof. Paper 550-B, p. B95-B98.

1967, Subsurface morphology of Long Island Sound, Block Island Sound, and Buzzards Bay, in Geological Survey Research 1967: U.S. Geol. Survey Prof. Paper 575-C, p. C92-C96.

Toulmin, Priestley, 3d, 1957, Notes on a peralkaline granite from Cashes Ledge, Gulf of Maine: Am. Mineralogist, v. 42, nos. 11-12, p. 912-915.

Tuttle, C. R., Allen, W. B., and Hahn, G. W., 1961, A seismic record of Mesozoic rocks on Block Island, Rhode Island: Art. 240 in U.S. Geol. Survey Prof. Paper 424-C, p. C254C256.

Uchupi, Elazar, 1965a, Basins of the Gulf of Maine, in Geological Survey Research 1965 : U.S. Geol. Survey Prof. Paper 525-D, p. D175-D177.

$1965 \mathrm{~b}$, Map showing relation of land and submarine topography, Nova Scotia to Florida: U.S. Geol. Survey Misc. Geol. Inv. Map I-451, 3 sheets, scale 1:1,000,000.

1966, Structural framework of the Gulf of Maine: Jour. Geophys. Research, v. 71, p. 3013-3028.

U.S. Geological Survey, 1967, Engineering geology of the Northeast Corridor, Washington, D.C., to Boston, Massachusetts -Coastal plain and surficial deposits: U.S. Geol. Survey Misc. Geol. Inv. Map I-514-B.

Woodworth, J. B., and Wigglesworth, Edward, 1934, Geography and geology of the region including Cape Cod, the Elizabeth Islands, Nantucket, Martha's Vineyard, No Mans Land, and Block Island : Harvard Coll. Mus. Comp. Zoology Mem., v. $52,338 \mathrm{p}$.

Zeigler, J. M., Hoffmeister, W. S., Geise, Graham, and Tasha, Herman, 1960, Discovery of Eocene sediments in the subsurface of Cape Cod [Massachusetts] : Science, v. 132, no. 3437, p. 1397-1398. 


\title{
DETERMINATION OF COBALT IN GEOLOGIC MATERIALS BY SOLVENT EXTRACTION AND ATOMIC ABSORPTION SPECTROMETRY
}

\author{
By WAYNE MOUNTJOY, Denver, Colo.
}

\begin{abstract}
Cobalt content in geologic materials can be accurately and rapidly determined by use of a new solvent extraction-atomic absorption analytical method. In this method the cobalt is concentrated and separated from interfering elements by extracting the 2-nitroso-1-naphthol chelate of cobalt into methyl isobutyl ketone. A lower limit of $2 \mathrm{ppm}$ in a 1-g sample is readily attained. Analyses of seven reference samples confirmed the accuracy of the method.
\end{abstract}

In the atomic absorption determination of cobalt in aqueous solutions, significant interferences from $\mathrm{Ca}$, $\mathrm{Mg}, \mathrm{Na}, \mathrm{K}$ and $\mathrm{Fe}$ have been noted in an air-propane flame (Angino and Billings, 1967). In addition, the sensitivity of that method is inadequate for the determination of cobalt in many geologic materials without preconcentration. Extraction of an element into an organic solvent is often used in atomic absorption work to separate interfering elements, to concentrate the element, and to enhance the sensitivity of the determination (Allan, 1961). Mansell and Emmel (1965) extracted the ammonium pyrrolidine dithiocarbamate chelates of $\mathrm{Co}, \mathrm{Cr}, \mathrm{V}, \mathrm{Mo}, \mathrm{Mn}$, and $\mathrm{Ni}$ from brine into chloroform or methyl isobutyl ketone prior to their determination by atomic absorption. This method is not applicable to many types of rocks because iron is also extracted with the cobalt and it interferes with the determination of cobalt content.

This paper presents a solvent extraction-atomic absorption method for the determination of cobalt in the parts-per-million range in rocks. Interferences, such as iron and calcium, are removed by a modification of a method described by Sandell (1959) in which the 2-nitroso-1-naphthol complex of cobalt is extracted into chloroform prior to its colorimetric determination. His method has been modified for atomic absorption and simplified by substituting the lighter-thanwater solvent MIBK (methyl isobutyl ketone) for chloroform. Experiments using $\mathrm{Co}^{60}$ tracer show that approximately 98 percent of the cobalt complex is extracted with a single extraction using $10 \mathrm{ml}$ of MIBK.

The cobalt content of seven U.S. Geological Survey reference samples, ranging in concentration from 5 to $140 \mathrm{ppm}$, has been determined and compared with results obtained in other laboratories. The results are in good agreement.

\section{EXPERIMENTAL METHOD}

\section{Reagents}

Standard cobalt solutions.-Transfer $0.5000 \mathrm{~g}$ of pure cobalt metal to a liter volumetric flask. Add $25 \mathrm{ml}$ of concentrated hydrochloric acid and heat gently to dissolve. Cool and dilute to volume with water. This stock solution contains $500 \mu \mathrm{g} / \mathrm{ml}$ (micrograms per milliliter) Co. Dilute $10 \mathrm{ml}$ of this stock solution to $500 \mathrm{ml}$ with 2.5 percent $\mathrm{v} / \mathrm{v}$ hydrochloric acid $(1 \mathrm{ml}=10 \mu \mathrm{g} \mathrm{Co})$.

Sodium citrate solution. -40 percent $\mathrm{w} / \mathrm{v}$ in water.

2-nitroso-1-naphthol.-Dissolve $2 \mathrm{~g}$ of 2-nitroso-1naphthol in $100 \mathrm{ml}$ of glacial acetic acid, add $0.5 \mathrm{~g}$ of activated carbon, shake, and allow to settle before using. This solution is stable for at least 6 months.

\section{Instrument parameters and settings}

A Perkin-Elmer Model 303 atomic absorption spectrophotometer was used with the following operating conditions:

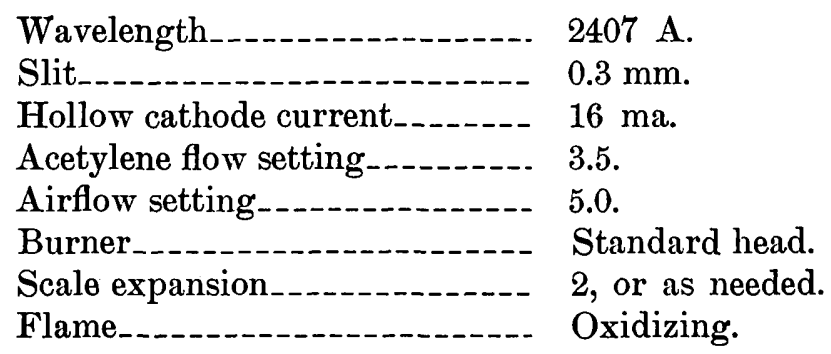




\section{Procedure}

Sample solution.-Weigh $1.000 \mathrm{~g}$ of sample and transfer to a $30-\mathrm{ml}$ zirconium crucible. Add $5 \mathrm{~g}$ of sodium peroxide and mix; then cover with an additional $2 \mathrm{~g}$ of sodium peroxide. Place a zirconium lid on the crucible and heat gently over an open flame until the contents melt. Increase the heat and maintain the crucible at bright-red heat for 2 minutes. Cool. Cautiously add $20 \mathrm{ml}$ of water to the crucible, and heat to dissolve the melt. Transfer the solution to a $250-\mathrm{ml}$ beaker, and wash the crucible with 2.5-percent $\mathrm{v} / \mathrm{v}$ hydrochloric acid. Combine wash and solution, add $20 \mathrm{ml}$ of 50-percent $\mathrm{v} / \mathrm{v}$ hydrochloric acid, and evaporate to dryness on the steam bath to dehydrate the silica. Add $5 \mathrm{ml}$ of 50-percent v/v hydrochloric acid and $20 \mathrm{ml}$ of water, and heat to dissolve soluble salts. Filter the solution through a retentive filter paper, and collect the filtrate in a $50-\mathrm{ml}$ volumetric flask. Wash the paper and residue three times with 2- to $3-\mathrm{ml}$ portions of 1-percent $\mathrm{v} / \mathrm{v}$ hydrochloric acid solution. Reserve the filtrate. Place the filter paper in a $20-\mathrm{ml}$ platinum crucible, and ash the paper in a muffle furnace at $500^{\circ} \mathrm{C}$. Cool. Add $5 \mathrm{ml}$ of hydrofluoric acid and $1 \mathrm{ml}$ of perchloric acid, and evaporate to dryness. Add $10 \mathrm{ml}$ of 2.5-percent $\mathrm{v} / \mathrm{v}$ hydrochloric acid to dissolve the salts. Add this solution to the reserved filtrate solution, and dilute to volume with water.

Extraction.-Transfer an aliquot of the diluted solution, containing 5-20 mg Co, to a $125-\mathrm{ml}$ separatory funnel. Adjust the volume of the solution to about $50 \mathrm{ml}$ with 2.5 -percent $\mathrm{v} / \mathrm{v}$ hydrochloric acid. Similarly prepare standard solutions as directed in the section, "Standardization." If the cobalt content of the sample is expected to be less than $10 \mathrm{ppm}$, transfer the entire sample solution to the separatory funnel. Add $10 \mathrm{ml}$ of sodium citrate solution, and mix. Adjust the $\mathrm{pH}$ to between 3 and 4 with $2 N$ hydrochloric acid or $2 \mathrm{~N}$ sodium hydroxide by using $\mathrm{pH}$ paper. Add $1 \mathrm{ml}$ of 30-percent hydrogen peroxide, and allow to stand 2 minutes. Add $2 \mathrm{ml}$ of the 2-nitroso1-naphthol solution, mix, and allow to stand $30 \mathrm{~min}$ utes. Add $10 \mathrm{ml}$ of MIBK, stopper, and shake for 1 minute. Drain off and discard the aqueous layer. Add $5 \mathrm{ml}$ of $2 N$ hydrochloric acid solution and shake gently for 20 seconds. Drain off and discard the hydrochloric acid solution. Add $5 \mathrm{ml}$ of $2 N$ sodium hydroxide solution, shake gently for 20 seconds, and discard the aqueous phase. Repeat this operation with an additional $5 \mathrm{ml}$ of sodium hydroxide solution. Wash the organic layer twice by shaking with $3-\mathrm{ml}$ portions of water, and discard the aqueous phase each time. The organic phase should be a reddish brown at this point, which indicates the removal of excess sodium hydroxide and chelating reagent. Drain the organic phase into a $15-\mathrm{ml}$ centrifuge tube, stopper, and centrifuge at about $1,500 \mathrm{rpm}$ for 5 minutes. Measure the absorption of the MIBK phase along with the reference standards on an atomic absorption spectrophotometer. Use a water-saturated solution of MIBK for a reference blank.

Standardization.-Prepare reference standards containing 2, 5, 10, and $20 \mu \mathrm{g}$ Co in the organic phase for a working curve by adding appropriate aliquots of the $10-\mu \mathrm{g} / \mathrm{ml}$ Co standard solution to a series of separatory funnels and process through the procedure starting at the section, "Extraction." Prepare the standard solutions concurrently with the sample solutions.

\section{RESULTS AND DISCUSSION}

Angino and Billings (1967) reported spectral interference on the $2407 \mathrm{~A}$ resonance line of cobalt by $\mathrm{Ca}$, $\mathrm{Mg}, \mathrm{Fe}, \mathrm{Na}$, and $\mathrm{K}$ when they used an air-propane flame. The solutions containing known amounts of cobalt and either $\mathrm{Mg}, \mathrm{Na}, \mathrm{K}, \mathrm{Fe}$ or $\mathrm{Ca}$ in 2.5-percent hydrochloric acid were prepared, and the interferences of these elements in an air-acetylene flame were determined. The analyses showed that (1) $\mathrm{Mg}$, $\mathrm{Na}$, and $\mathrm{K}$ at concentrations as high as $6,000 \mathrm{ppm}$ can be tolerated, and (2) $\mathrm{Ca}$ and $\mathrm{Fe}$ interfered at both levels tested (table 1). The 6,000-ppm Fe solutions gave readings equal to about $0.5 \mathrm{ppm}$ Co. The interference due to iron seems to be independent of the amount of cobalt up to at least $5 \mathrm{ppm}$, but the calcium interference is greatest when no cobalt is present and is very small in the presence of $5 \mathrm{ppm}$ Co. The reason for this is not known. The proposed extraction procedure removes these interferences and, in addition, concentrates the cobalt and increases the sensitivity of the atomic absorption determination. The sensitivity of cobalt in MIBK was found to be about $0.05 \mathrm{ppm}$ for 1-percent absorption, an enhancement of about 10 times that found for aqueous solutions.

A tracer technique was used to determine the effciency of the extraction of the cobalt complex into MIBK. $\mathrm{Co}^{60}$ was added to a solution containing 250 $\mathrm{mg}$ of U.S. Geological Survey sample W-1, then processed through the extraction procedure. The test indicated that approximately 98 percent of the cobalt was extracted into the MIBK with a single $10-\mathrm{ml}$ extraction. Therefore, MIBK was chosen in preference to chloroform or other organic solvents because of its excellent flame characteristics for atomic absorption work and because the stripping operation of the ex- 
TABLE 1.-Interference of diverse elements on the atomic absorption determination of cobalt in 2.5-percent hydrochloric acid solution

[Test solutions containing $\mathrm{Mg}, \mathrm{Na}$, or $\mathbf{K}$ show an interference equivalent to $<0.1 \mathrm{ppm}$ Col

\begin{tabular}{|c|c|c|c|c|}
\hline \multicolumn{2}{|c|}{ Composition of test solution } & \multirow{2}{*}{$\begin{array}{l}\text { Instru- } \\
\text { ment read- } \\
\text { ing on } \\
2 \times \text { scale }\end{array}$} & \multirow{2}{*}{$\begin{array}{c}\text { Apparent } \\
\text { cobalt } \\
(\mathrm{ppm})\end{array}$} & \multirow{2}{*}{$\begin{array}{c}\text { Net inter } \\
\text { ference } \\
\text { (ppm } \\
\text { cobalt) }\end{array}$} \\
\hline $\begin{array}{c}\text { Diverse element and amount } \\
(\text { ppm) }\end{array}$ & $\begin{array}{l}\text { Cobalt } \\
(\mathrm{ppm})\end{array}$ & & & \\
\hline
\end{tabular}

\begin{tabular}{|c|c|c|c|}
\hline 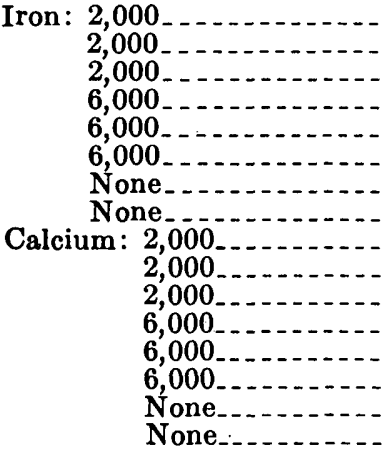 & $\begin{array}{r}\text { None } \\
2 \\
5 \\
\text { None } \\
2 \\
5 \\
2 \\
5 \\
\text { None } \\
2 \\
5 \\
\text { None } \\
2 \\
5 \\
2 \\
5\end{array}$ & $\begin{array}{r}\text { 2. } 5 \\
\text { 16. } 5 \\
\text { 34. } 8 \\
6.0 \\
\text { 19. } 6 \\
\text { 37. } 5 \\
14.8 \\
\text { 33. } 8 \\
2.7 \\
\text { 15. } 7 \\
\text { 33. } 2 \\
\text { 5. } 7 \\
\text { 17. } 2 \\
\text { 33. } 4 \\
\text { 14. } 2 \\
\text { 32. } 7\end{array}$ & $\begin{array}{l}0.2 \\
2.2 \\
5.2 \\
\text { 2. } 7 \\
5.6 \\
2.0 \\
5.0 \\
2.4 \\
\text { 5. } 1 \\
\text { 2. } 8 \\
\text { 5. } 1 \\
2.0 \\
5.0\end{array}$ \\
\hline
\end{tabular}

1 The stock iron solution was found to contain a measurable amount of cobalt; therefore, appropriate corrections were applied for iron.

traction procedure is simplified by the use of a lighterthan-water solvent.

The cobalt content of seven U.S. Geological Survey standard silicate rocks was determined. The results are shown in table 2. The averages of the results reported by other analysts and compiled by Fleischer (1969) and Flanagan (1969) are also included.
TABLE 2.-Comparison of cobalt data on U.S. Geological Survey reference samples

\begin{tabular}{|c|c|c|c|c|}
\hline \multirow{2}{*}{$\begin{array}{c}\text { Sample } \\
\text { No. }\end{array}$} & \multirow{2}{*}{$\begin{array}{l}\text { Rock } \\
\text { type }\end{array}$} & \multicolumn{2}{|c|}{$\begin{array}{l}\text { Atomic absorption } \\
\text { method } 1\end{array}$} & \multirow{2}{*}{$\begin{array}{l}\text { A verage of } \\
\text { published } \\
\text { data ? }\end{array}$} \\
\hline & & Run 1 & Run 2 & \\
\hline $\begin{array}{l}\text { G-2 } \\
\text { GSP-1 } \\
\text { A GV-1 } \\
\text { BCR-1. } \\
\text { W-1 } 1 . \ldots \\
\text { PCC-1 } 1 \ldots \\
\text { DTS-1 }\end{array}$ & $\begin{array}{l}\text { Granite } \\
\text { Granodiorite. } \\
\text { Andesite. } \\
\text { Basalt } \\
\text { Diabase } \\
\text { Peridotite } \\
\text { Dunite }\end{array}$ & $\begin{array}{r}5.0 \\
6.8 \\
14.4 \\
33 \\
44 \\
113 \\
140\end{array}$ & $\begin{array}{r}4.9 \\
7.0 \\
15.6 \\
39 \\
43 \\
117 \\
137\end{array}$ & $\begin{array}{r}4.9 \\
7.5 \\
15.5 \\
35.5 \\
50 \\
112 \\
132\end{array}$ \\
\hline
\end{tabular}

1 This work.

2 Value for $\dot{W}-1$ is recommended value of Fleischer (1969). Other values are averages cited by Flanagan (1969).

\section{REFERENCES}

Allan, J. E., 1961, The use of organic solvents in atomic absorption spectrophotometry: Spectrochim. Acta, v. 17, no. 4, p. $467-473$.

Angino, E. E., and Billings, G. K., 1967, Atomic absorption spectrometry in geology: New York, Elsevier Publishing Co., 144 p.

Flanagan, F. J., 1969, U.S. Geological Survey standards-[pt.] 2, First compilation of data for the new U.S.G.S. rocks: Geochim. et Cosmochim. Acta, v. 33, no. 1, p. 81-120.

Fleischer, Michael, 1969, U.S. Geological Survey standards[pt.] 1, Additional data on rocks G-1 and W-1, 1965-1967: Geochim. et Cosmochim. Acta, v. 33, no. 1, p. 65-79.

Mansell, R. E., and Emmel, H. W., 1965, Trace-metal extractions from brine with APDC and oxine: Atomic Absorption Newsletter, v. 4, no. 10, p. 365-366.

Sandell, E. B., 1959, Colorimetric determination of traces of metals, 3d ed.: New York, Interscience Publishers, Inc., $1032 \mathrm{p}$. 


\title{
A FIELD METHOD FOR THE DETERMINATION OF COLD-EXTRACTABLE NICKEL IN STREAM SEDIMENTS AND SOILS
}

\author{
By GARY A. NOWLAN, Denver, Colo.
}

\begin{abstract}
Readily extractable nickel is leached from the sample by brief treatment with $4 N$ nitric acid. Addition of ammonium citrate-ammonium hydroxide-sodium hydroxide buffer adjusts the $\mathrm{pH}$ to about 10. Thiosulfate ion in the buffer minimizes possible copper interference. Nickel is extracted and estimated by adding $\alpha$-furildioxime dissolved in benzene, shakIng to concentrate the yellow complex in the benzene, and comparing visually with standards. A concentration range of 0.25 to $60 \mathrm{ppm}$ is achieved when a $0.2-\mathrm{g}$ sample is used. An analysis may be done in 3 minutes or less and requires only simple equipment, making sample-site determinations possible.
\end{abstract}

Analytical methods involving ambient temperature solutions-commonly called "cold-extractable methods"-provide rapid determinations and require only simple equipment; therefore, they are useful in geochemical exploration as sorting techniques and for sample-site determinations in relatively inaccessible areas. Also, the contrast between anomalous and background values is often enhanced by using data from readily extractable metals. Recently, considerable interest has been expressed in the availability of a test of this type for nickel, undoubtedly because of current widespread activity in exploration for nickel. Accordingly, the method described herein is a potentially useful additional tool.

This method is based on the reaction between $\alpha$-furildioxime and nickel to yield a yellow complex that is soluble in several organic solvents. This well-known reaction has been the basis for several colorimetric procedures widely used in geochemical exploration for the determination of total nickel (see, for example, Stanton and Coope, 1958; Ward, Lakin, Canney, and others, 1963). Readily extractable nickel in soils or stream sediments is solubilized by leaching the sample for 30 seconds with $4 N$ nitric acid. Addition of ammonium citrate-ammonium hydroxide-sodium hydroxide buffer adjusts the pH to about 10 , which is opti- mum for the formation and extraction of the nickel complex. Thiosulfate ion in the buffer solution minimizes interference by copper. $\alpha$-Furildioxime in benzene solution is then added and the tube shaken; the resulting yellow nickel complex is concentrated in a thin floating layer of benzene for visual comparison with standards.

At least two other methods for readily extractable nickel determinations have been developed for use in geochemical exploration. Jacobson (1954) used $\alpha$ furildioxime dissolved in chloroform as the analytical reagent, concentrated hydrochloric acid as the extractant, and a citrate buffer. His standard series $(0,1,2.5$, 5 , and $10 \mathrm{ppm}$ ) suggests the range of his method to be from about 0.5 to $10 \mathrm{ppm}$. Because a filtration step is required, he reports that a single determination requires 10-15 minutes. Bloom (1962) has developed "total-nickel" and "available-nickel" procedures on the basis of the reaction between dimethylglyoxime and nickel in a buffered ammoniacal-citrate solution containing a detergent and hydroxylamine hydrochloride. In his "available-nickel" procedure the buffer is used as the extractant and xylene is used to extract the nickel dimethyglyoxime complex. About 2 minutes is required for a determination, and the lower limit of detection is about $5 \mathrm{ppm}$.

The range of the method described in the present paper is from $0.25 \mathrm{ppm}$ to $60 \mathrm{ppm}$ with a $0.2-\mathrm{g}$ sample; the upper limit can be extended by using a smaller sample size. Under optimum conditions less than 3 minutes is required for a determination. Emulsion formation in the organic layer caused by organic-rich samples can make color comparisons with the standard series difficult, but not impossible; it is the principal factor that can affect adversely both the productivity and sensitivity of the method. The lower detection limit permits the attainment of positive readings on nearly all background samples, at least samples from mafic 
terranes where the search for nickel is most likely to be concentrated.

\section{REAGENTS}

The assumption is made that readers interested in this method are familiar with the philosophy underlying the design and use of geochemical methods as well as the basic equipment and techniques necessary for the operation of a geochemical laboratory. Those individuals who need additional information may refer to Ward, Lakin, Canney, and others (1963).

The quantities suggested below are sufficient for 100 analyses. Reagent-grade chemicals and demineralized water should be used.

Buffer solution: Dissolve $50 \mathrm{~g}$ of ammonium citrate [ $\left(\mathrm{NH}_{4}\right)_{2}$ $\left.\mathrm{HC}_{6} \mathrm{H}_{8} \mathrm{O}_{7}\right]$ in $550 \mathrm{ml}$ of water. Add $85 \mathrm{ml}$ of conc $\mathrm{NH}_{4} \mathrm{OH}$, and mix. (Ammonium hydroxide is added before sodium thiosulfate to prevent the precipitation of sulfur.) Dissolve $200 \mathrm{~g}$ of sodium thiosulfate $\left(\mathrm{Na}_{2} \mathrm{~S}_{2} \mathrm{O}_{3} \cdot 5 \mathrm{H}_{2} \mathrm{O}\right)$ in the solution, and then add additional conc $\mathrm{NH}_{4} \mathrm{OH}$ to give a $\mathrm{pH}$ of 10.0. Add $4 \mathrm{~N}$ $\mathrm{NaOH}$ until the $\mathrm{pH}$ is 10.8-11.0. Finally, dilute the solution to 1 liter with water.

$\alpha$-Furildioxime solution, 0.2 percent: Dissolve $0.4 \mathrm{~g}$ of $\alpha$-furildioxime in $30 \mathrm{ml}$ of 95 -percent ethanol, and dilute this solution to $200 \mathrm{ml}$ with benzene.

Hydrogen peroxide, 30 percent. (See section, "Interfering elements.")

Nitric acid, $4 N$ : Dilute $25 \mathrm{ml}$ of conc $\mathrm{HNO}_{3}$ to $100 \mathrm{ml}$ with water.

Sodium hydroxide solution, $4 \mathrm{~N}$ : Dissolve $40 \mathrm{~g}$ of sodium hydroxide pellets in enough water to make $250 \mathrm{ml}$ of solution.

Standard nickel solution $(100 \mu \mathrm{g}$ per $\mathrm{ml})$ : Dissolve $0.2 \mathrm{~g}$ of clear uneffloresced crystals of nickel chloride $\left(\mathrm{NiCl}_{2} \cdot 6 \mathrm{H}_{2} \mathrm{O}\right)$ in 500 $\mathrm{ml}$ of $0.1 \mathrm{~N} \mathrm{HCl}$. From this solution prepare more dilute standard solutions $(10 \mu \mathrm{g} / \mathrm{ml}$ and $1 \mu \mathrm{g} / \mathrm{ml})$ prior to preparing the series of nickel standards.

\section{PROCEDURE}

The following procedure is given in terms of a single sample. When batch operation is used, the length of time of contact between sample and either acid or buffer is critical and must be closely controlled; therefore, steps 2-5 should be performed on no more than five samples at a time. Once the nickel complex has been extracted, large batches of sample solutions can be accumulated before the estimation step is carried out.

1. Place a $0.2-\mathrm{g}$ (weighed) or 0.2-cc (scooped) quantity of sample in a $25 \times 100$-mm test tube.

2. Add $1 \mathrm{ml}$ of $4 \mathrm{~N} \mathrm{HNO}_{3}$ to the tube.

3. Slosh the sample and acid for 30 seconds.

4. Add $10 \mathrm{ml}$ of buffer solution and mix.

5. Add $2 \mathrm{ml}$ of $\alpha$-furildioxime solution, stopper the tube, and shake it vigorously for 30 seconds.

6. Compare the color in the floating benzene layer visually against the standard series. Centrifuging the tube aids in breaking up any emulsion that may form and is strongly recommended for samples that contain much organic matter.

7. Calculate the content of readily extractable nickel according to the following formula:

Parts per million $(\mathrm{ppm})=$

$\frac{\text { micrograms }(\mu \mathrm{g}) \text { of nickel found }}{\text { sample weight }(\mathrm{g}) \text { or sample volume (cc) }}$.

Results are expressed as ppm weight/weight if a weighed sample is used, and as ppm weight/ volume if a scooped sample is used. The density of sieved soil or sediment samples is often about 1 , except for organic-rich samples, so $\mathrm{ppm}(\mathrm{w} / \mathrm{w}) \approx$ $\operatorname{ppm}(\mathrm{w} / \mathrm{v})$.

\section{PREPARATION OF STANDARDS}

1. To a series of $25 \times 100-\mathrm{mm}$ test tubes add $1 \mathrm{ml}$ of $4 N$ nitric acid.

2. From the appropriate nickel standard solutions transfer, respectively, $0,0.1,0.2,0.4,0.8,1.5,3.0$, 6.0 , and $12.0 \mu \mathrm{g}$ of nickel to the above series.

3. Add $10 \mathrm{ml}$ of buffer to each tube and mix.

4. To each tube add $2 \mathrm{ml}$ of $\alpha$-furildioxime solution, stopper the tube, and shake it vigorously for 30 seconds.

These standards are normally stable for several days and must be kept tightly capped to prevent solvent evaporation. Screwcap test tubes are suggested.

\section{DISCUSSION}

Data produced by cold methods of this type are useful in a relative sense only; there are no "correct" results as this term is conventionally used. Therefore, every sample must be treated as nearly alike as possible to avoid varying degrees of bias in a data set. Variability in the time of extraction is a well-known major source of bias in cold-extractable field tests; consequently the extraction time should be closely controlled.

\section{Stability of reagents}

The buffer solution loses ammonia very readily, with consequent drop in $\mathrm{pH}$, and thus the buffer must be kept in a closed container when not in use and the $\mathrm{pH}$ must be checked as frequently as conditions of temperature and use demand.

The $\alpha$-furildioxime solution is reasonably stable and does not deteriorate appreciably over a period of a few days even when kept at room temperature and exposed to light. When first prepared, the reagent solution usually is slightly yellow. A solution that is allowed to stand for a period of several weeks will first become darker yellow and then will gradually turn to orange. 
A solution that has darkened appreciably beyond the original slight yellow should be discarded, inasmuch as it will give low results. The useful life of the reagent can be extended for several weeks by protecting it from light and storing it under refrigeration; protection from light is more important. The solution should, of course, be protected from evaporation. During the analysis of samples, the initial yellow color of the reagent solution is removed when step 5 , the nickelextraction step, is performed; therefore, there is no difficulty in estimating the intensity of the yellow color of the $\alpha$-furildioxime-nickel complex.

Only normal precautions need be observed with the other reagents.

\section{Interfering elements}

An exhaustive study of interferences was not made. According to Ward, Lakin, Canney, and others (1963, p. 37), copper, cobalt, and ferrous iron can interfere. In the present study, copper and ferrous iron were found to be potentially serious interferences. Copper forms a brown complex with $\alpha$-furildioxime and causes a variable and often substantial undetected positive error. The inclusion of thiosulfate in the buffer solution minimizes the interferences of copper because the coppernickel ratio must then be at least 30 to 1 before copper will interfere.

Ferrous iron forms a blue to purple complex with $\alpha$-furildioxime that very effectively masks any color due to nickel. Interference by ferrous iron can be minimized if no more than a few minutes $(\leq 3)$ are allowed to elapse between the addition of the buffer and extraction with $\alpha$-furildioxime solution. For this reason the procedure specifies that steps 2-5 should be done to batches of 5 samples or less. If ferrous iron still interferes, add 2 drops of 30-percent hydrogen peroxide to the tube just before the $\alpha$-furildioxime is added; mix the contents and allow the mixture to stand for about a minute. Then add the $\alpha$-furildioxime and shake the tube and contents for 90 seconds. The longer shaking time is necessary because the $\mathrm{pH}$ is lowered by the addition of hydrogen peroxide.

The use of nitric acid as the leaching agent appears to minimize the extraction of ferrous iron and was chosen partly for that reason.

Cobalt forms a complex with $\alpha$-furildioxime which is very similar in color to the nickel complex, but the cobalt-nickel ratio must be at least 20 to 1 before a positive interference due to cobalt will result; even for a ratio of 50 to 1 the interference is not serious for a test of this type.
pH

Earlier published accounts of the reaction between nickel and $\alpha$-furildioxime state that optimum color development occurs with a $\mathrm{pH}$ range of 8.5-9.5 (Ward, Lakin, Canney, and others, 1963, p. 37). In the presence of thiosulfate and under the conditions of this method, the optimum $\mathrm{pH}$ range is from 9.8 to 10.3 ; above or below this range, formation and extraction of the nickel complex is slow and may be incomplete. The lower end of the $\mathrm{pH}$ range can be extended without serious error to 9.5 if a 60 -second shake is adopted, and even to 9.0 if a 2-minute shaking time is used. Excessive ammonium ion appears to inhibit color formation and extraction of nickel. The final $\mathrm{pH}$ adjustment of the buffer is accordingly made with sodium hydroxide to keep the ammonium-ion content as low as possible. Sodium hydroxide cannot be substituted completely for ammonium hydroxide in the preparation of the buffer, however, because the buffering capacity would be adversely affected.

The use of $10 \mathrm{ml}$ of buffer of $\mathrm{pH} 10.8-11.0$ and $1 \mathrm{ml}$ of $4 N$ nitric acid results in a $\mathrm{pH}$ of 9.9-10.1. Again, emphasis should be put on the necessity of keeping the buffer in a closed container when not in use and of checking the $\mathrm{pH}$ of the buffer occasionally, especially in hot weather.

A pH meter was used for all $\mathrm{pH}$ measurements made in the development of this procedure. If $\mathrm{pH}$ paper must be used under field conditions for checking the $\mathrm{pH}$ of the buffer, it should be sensitive to within \pm 0.2 $\mathrm{pH}$ units and, if possible, calibrated with a $\mathrm{pH}$ meter. Also, the nickel buffer should be used as the liquid for making the calibration because the buffer is a concentrated salt solution and such solutions can modify the color response of $\mathrm{pH}$ paper.

\section{Effect of organic matter}

Organic matter in a sample usually causes an emulsion to form in the benzene layer, which makes color comparisons with the standards difficult. No satisfactory solution to this problem is known. Centrifuging the tubes often helps considerably. These emulsions often break down slowly with time; therefore, allowing the organic extracts to stand for a short time prior to estimation is helpful if no centrifuge is available. However, anomalous samples can be recognized even when an emulsion is present. When an emulsion is present a different cutoff point for the lower limit of detection should be established.

Organic matter was not found to impart color to the benzene layer for the samples used in this study. 


\section{Reproducibility}

Replicate analyses of a group of 52 samples with cold-extractable nickel values distributed between $<0.5$ and $900 \mathrm{ppm}$ were made to evaluate the reproducibility of the method. The samples were soils and stream sediments from (1) a nickel-rich lateritic area, (2) a mafic terrane mineralized with nickel-cobalt-copper sulfides, and (3) an unmineralized mafic area. A period of 3 years elapsed between some sets of analyses. Replicate determinations generally agreed within a factor of 1.5 , and except very rarely, within a factor of 2 . This level of precision is considered satisfactory for a method of this type. Comparison of extractable-nickel values with total nickel values for this group shows that this test normally can be expected to extract about 2 to 25 percent of the total nickel present in most samples.

\section{REFERENCES}

Bloom, Harold, 1962, Field methods for the determination of nickel using dimethylglyoxime: Econ. Geology, v. 57, no. 4, p. $595-604$.

Jacobson, H. S., 1954, A geochemical test for nickel : Massachusetts Inst. Technology unpub. B.S. thesis, 24 p., 8 illus.

Stanton, R. E., and Coope, J. A., 1958, Modified field test for the determination of small amounts of nickel in soils and rocks : Inst. Mining and Metallurgy Bull. 623, p. 9-14.

Ward, F. N., Lakin, H. W., Oanney, F. C., and others, 1963, Analytical methods used in geochemical exploration by the U.S. Geological Survey : U.S. Geol. Survey Bull. 1152, 100 p. 


\title{
THE FLUORIMETRIC METHOD—ITS USE AND PRECISION FOR DETERMINATION OF URANIUM IN THE ASH OF PLANTS
}

\author{
By CLAUDE HUFFMAN, JR., and LEONARD B. RILEY, \\ Denver, Colo.
}

\begin{abstract}
The fluorimetric method for determining uranium in the parts-per-million range in plant ash and a study of its precision are presented. The precision of results in the range from 0.4 to $35 \mathrm{ppm}$ uranium in plant ash is expressed by a simple equation (standard deviation $=0.15+0.063 \mathrm{U}$, where $U$ is the observed uranium concentration in parts per million). This equation is based on 326 pairs of determinations, made during a period of about a year, on samples consisting of ash from sagebrush, piñon pine, ponderosa pine, and juniper.
\end{abstract}

During the years 1951 to 1956 , the U.S. Geological Survey on behalf of the U.S. Atomic Energy Commission investigated the application of botanical methods to uranium prospecting on the Colorado Plateau (Cannon, 1954). These studies included the fluorimetric determination of uranium in several thousand plant samples. Some 90 percent of these samples were found to contain less than $6 \mathrm{ppm}$ uranium on the basis of the plant ash. A value as low as $1 \mathrm{ppm}$ uranium was considered as above background in some localities (Cannon and Starrett, 1956). Thus, small differences in results were important in outlining mineralized areas. The method of analysis and study of its precision are given in this paper. This work was originally transmitted as Trace Elements Investigations Report 654 to the Division of Raw Materials of the Atomic Energy Commission on March 29, 1957. Current interest in geobotanical prospecting methods for uranium has prompted publication of the report here in order to make it readily available to the public.

Fluorimetric methods for uranium determination in many materials other than plants have been described by Grimaldi, May, Fletcher, and Titcomb (1954), and the method described here is essentially an adaptation of that developed by them.

Acknowledgments.-The assistance of Lewis F. Rader and Rollin E. Stevens during this study is grate- fully acknowledged. George T. Burrow, Edward J. Fennelly, and several summer assistants made most of the uranium determinations used for this study.

\section{THE FLUORIMETRIC METHOD FOR DETERMINING URANIUM IN PLANTS}

\section{Preparation of sample}

Dry the plant sample at $90^{\circ} \mathrm{C}$ for 24 hours. Grind the dried sample in a Wiley mill to pass a $1.5-\mathrm{mm}$ roundhole steel screen. Weigh $10 \mathrm{~g}$ of the ground plant material in a porcelain crucible and place it in a muffle furnace. Gradually raise the temperature of the furnace to about $300^{\circ} \mathrm{C}$ and maintain this temperature until the sample is well charred; then raise the temperature to $550^{\circ} \mathrm{C}$ and continue heating for about 2 hours. If the ash content is required, use a tared crucible in which to ash the sample, weigh the crucible and ash, and obtain the weight of the ash by difference. Mix the ash by stirring thoroughly before storage.

\section{Analysis of ash}

Weigh $50 \mathrm{mg}$ of the plant ash and transfer it to a 30 $\mathrm{ml}$ glass-stoppered test tube. Add $6 \mathrm{ml}$ of $15+85 \mathrm{HNO}_{3}$ to the sample. Bring the solution to a boil on a hotplate and boil gently for 5 minutes. Add $9.5 \mathrm{~g}$ of recrystallized $\mathrm{Al}\left(\mathrm{NO}_{3}\right)_{3} \cdot 9 \mathrm{H}_{2} \mathrm{O}$ to the test tube and heat it again over the hotplate to dissolve the aluminum nitrate. Cool the tube to room temperature and add $10 \mathrm{ml}$ of anhydrous ethyl acetate. Stopper and shake the tube for about 2 minutes. Centrifuge the solutions at $1,200 \mathrm{rpm}$ for 5 minutes. Carefully decant the upper ethyl acetate layer into a dry retentive filter paper held in the opening of a second test tube to cause the aqueous layer to remain in the first tube. Use of the dry filter paper results in a more complete separation of the aqueous layer from the ethyl acetate layer because it removes traces of elements 
in the aqueous layer that quench the fluorescence of the carbonate-fluoride phosphor. Pipet a 2-ml aliquot of the ethyl acetate into a 7-ml platinum dish of the dimensions given by Grimaldi, May, Fletcher, and Titcomb (1954, p. 103). Place the dish in a shallow pan that contains about one-eighth of an inch of water to keep the bottom of the dish cool. Ignite the ethyl acetate with a lighted taper and allow the ethyl acetate to burn completely. Dry the residue remaining in the platinum dish on a steam bath, then heat the dish briefly over an open flame, below a red heat; to remove any free nitric acid and organic matter in the residue before adding flux.

The flux is a carbonate-fluoride mixture that contains by weight 45.5 parts of sodium carbonate, 45.5 parts of potassium carbonate, and 9 parts of sodium fluoride. Two $\mathrm{g}$ of this flux are added to the residue in the platinum dish. Heat the dish over a burner at a low temperature until the flux melts. Then heat for an additional minute to keep the flux a little above the melting point, while swirling the flux to dissolve all the uranium and to obtain a uniform melt. Set the dish on a level Alundum plate to cool. Measure the fluorescence of the phosphor with a transmission fluorimeter such as that described by Kinser (1954). Determine the uranium in parts per million by reference to a standard curve.

\section{Standardization}

Standards containing $0.00 .025,0.050,0.2$, and $0.5 \mu \mathrm{g}$ of uranium are included with each set of samples, after the step of the addition of nitric acid, and carried through all subsequent steps, to prepare working curves and to correct for small time-distributed changes that may occur. Two linear working curves covering two scales of the fluorimeter are used. One curve ranges from 0.0 to $0.05 \mu \mathrm{g}$ uranium and the other from 0.0 to $0.5 \mu \mathrm{g}$.

\section{STUDY OF PRECISION}

Many determinations of uranium in plants collected during the season 1954-55 were made on two separate portions of ash from the same ashed sample. As a routine checking procedure, samples so duplicated included all those for which the first value obtained exceeded $1.0 \mathrm{ppm}$ uranium and a considerable number, randomly selected, below this value. An equation (standard deviation $=.15+0.0063 \mathrm{U}$, where $\mathrm{U}$ is the observed uranium concentration in parts per million) based on 326 duplicate determinations allows the precision of other routine determinations to be predicted with considerable assurance, if analyses are made by the described method.

The possibility that the precision of the uranium determination might be different for different plant species was first studied. The four species of plants studied were Artemisia sp? (sagebrush), Pinus edulis (piñon pine), Juniperus sp? (juniper), and Pinus ponderosa (ponderosa pine). The duplicate uranium determinations were collected for each species and subdivided into statistical classes, the ranges of which are given in table 1; then the arithmetic means, variances, and standard deviations were calculated. The equation used in calculating the variances $(V)$ was

$$
V=\frac{\Sigma d^{2}}{2 n}
$$

where $d$ is the difference between the duplicate determinations for each sample and $n$ is the number of paired determinations.

Table 1 shows that the standard deviations are virtually independent of the species but are dependent on the uranium content. Therefore, table 2 was prepared to show the determinations combined without regard to species. When these standard deviations are plotted against the corresponding arithmetic means, a close approximation to a straight line results (fig. 1). The regression line shown in the figure was obtained by the method of least squares; its equation is standard deviation $=0.15+0.063 \mathrm{U}$, where $\mathrm{U}$ is the uranium concentration in the ash, in parts per million. This equation allows a standard deviation to be estimated from a given uranium concentration within a range of 0.4 to $35 \mathrm{ppm}$ uranium.

Following are examples of the use of this equation for estimating expected standard deviations (s.d.) :

1. Observed concentration of uranium in ash $=0.7$

TABLE 1.-The arithmetic mean, variance, and standard deviation for duplicate uranium determinations grouped by plant species and ranges within species

\begin{tabular}{|c|c|c|c|c|c|}
\hline $\begin{array}{c}\text { Plant } \\
\text { species }\end{array}$ & $\begin{array}{l}\text { Range } \\
\text { (ppm) }\end{array}$ & $\begin{array}{l}\text { Number } \\
\text { of pairs of } \\
\text { determl- } \\
\text { nations }\end{array}$ & $\underset{\substack{\text { mean } \\
(\mathrm{ppm})}}{\text { Arithmetic }}$ & $\begin{array}{c}\text { Variance } \\
\left(\mathrm{ppmm}^{2}\right)\end{array}$ & $\begin{array}{c}\text { Standard } \\
\text { deviation } \\
\text { (ppm) }\end{array}$ \\
\hline Sagebrush.- & $\begin{array}{r}0.8-1.6 \\
1.6-3.2 \\
3.2-6.4 \\
6.4-12.8 \\
12.8-25.6 \\
25.6-51.2\end{array}$ & $\begin{array}{l}7 \\
29 \\
18 \\
10 \\
20 \\
11\end{array}$ & $\begin{array}{r}\text { 1. } 26 \\
2.43 \\
4.40 \\
9.64 \\
18.22 \\
34.77\end{array}$ & $\begin{array}{c}0.02429 \\
.09328 \\
.1839 \\
.4005 \\
\text { 2. } 202 \\
5.104\end{array}$ & $\begin{array}{r}0.16 \\
.31 \\
.43 \\
.63 \\
1.48 \\
2.26\end{array}$ \\
\hline Piñon pine & $\begin{array}{r}.0- \\
.8-1.6 \\
1.6-3.2 \\
3.2-6.4\end{array}$ & $\begin{array}{l}15 \\
46 \\
22 \\
14\end{array}$ & $\begin{array}{l}.65 \\
\text { 1. } 13 \\
\text { 2. } 31 \\
4.42\end{array}$ & $\begin{array}{l}.01700 \\
.02717 \\
.1182 \\
.1321\end{array}$ & $\begin{array}{l}.13 \\
.16 \\
.34 \\
.36\end{array}$ \\
\hline Juniper.... & $\begin{array}{r}.0- \\
.8-1.6 \\
1.6-3.2 \\
3.2-6.4 \\
6.4-12.8\end{array}$ & $\begin{array}{r}22 \\
30 \\
17 \\
11 \\
7\end{array}$ & $\begin{array}{l}.43 \\
1.19 \\
2.26 \\
4.28 \\
9.20\end{array}$ & $\begin{array}{l}.01636 \\
.05667 \\
.07559 \\
.1218 \\
.7329\end{array}$ & $\begin{array}{l}.13 \\
.24 \\
.27 \\
.35 \\
.86\end{array}$ \\
\hline $\begin{array}{l}\text { Ponderosa } \\
\text { pine. }\end{array}$ & $\begin{array}{r}.0- \\
.8-1.6 \\
1.6-3.2 \\
3.2-6.4\end{array}$ & $\begin{array}{r}6 \\
23 \\
10 \\
8\end{array}$ & $\begin{array}{l}.68 \\
\text { 1. } 10 \\
\text { 2. } 04 \\
\text { 4. } 85\end{array}$ & $\begin{array}{l}.03583 \\
.05957 \\
.08700 \\
.1788\end{array}$ & $\begin{array}{l}19 \\
24 \\
29 \\
42\end{array}$ \\
\hline
\end{tabular}


ppm. Then $U=0.7$ and s.d. $=0.15+(0.063)(0.7)$ $=0.19 \mathrm{ppm}$, or the expected standard deviation would be about $0.2 \mathrm{ppm}$, and the expected coefficient of variation would be 27 percent after rounding.

TABLE 2.-The arithmetic mean and standard deviation for duplicate uranium determinations grouped by ranges regardless of plant species

\begin{tabular}{|c|c|c|c|}
\hline Number of palrs of determinations & Range (ppm) & $\begin{array}{c}\text { Arithmetic } \\
\text { mean } \\
(\mathrm{ppm})\end{array}$ & $\begin{array}{c}\text { Standard } \\
\text { deviation } \\
\text { (ppm) }\end{array}$ \\
\hline 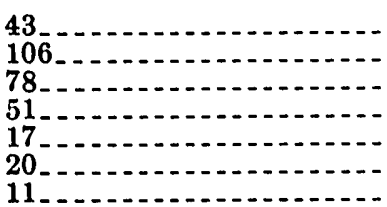 & $\begin{array}{r}0.0-0.8 \\
.8-1.6 \\
1.6-3.2 \\
\text { 3. } 2-6.4 \\
6.4-12.8 \\
\text { 12. } 8-25.6 \\
25.6-51.2\end{array}$ & $\begin{array}{r}0.54 \\
1.15 \\
2.31 \\
4.45 \\
9.46 \\
\text { 18. } 22 \\
\text { 34. } 77\end{array}$ & $\begin{array}{r}0.14 \\
.21 \\
.31 \\
.39 \\
.73 \\
\text { 1. } 48 \\
2.26\end{array}$ \\
\hline
\end{tabular}

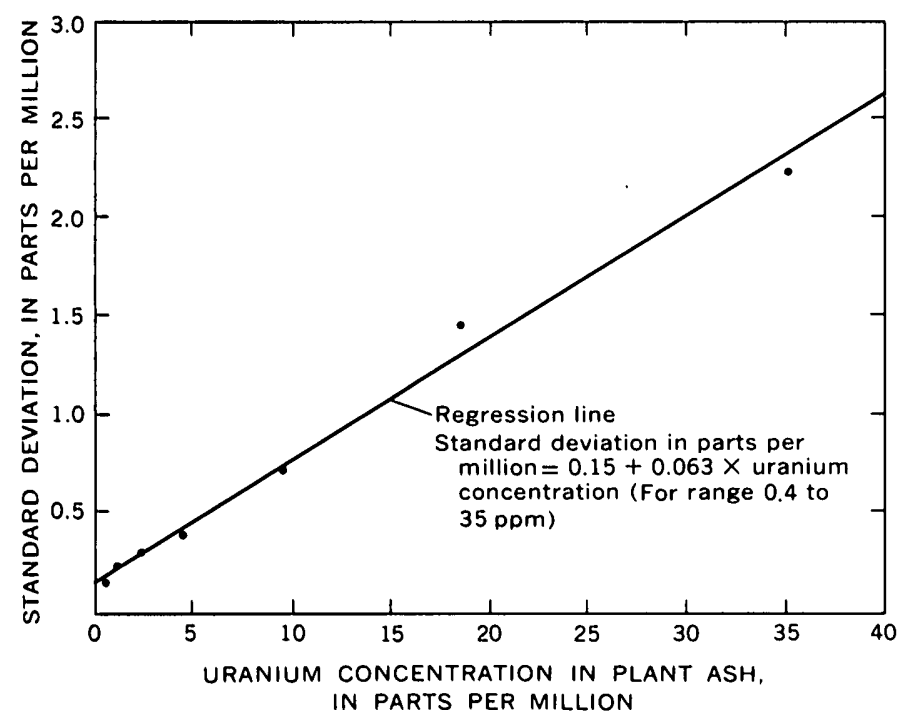

Froure 1.-Arithmetic means and standard deviations from table 2 and their regression line.
2. Observed concentration of uranium in ash $=10.0$ ppm. Then s.d. $=0.15+(0.063)(10.0)=0.78 \mathrm{ppm}$, or the expected standard deviation would be about $0.8 \mathrm{ppm}$, and the expected coefficient of variation would be about 8 percent after rounding.

For many purposes the equation could be rounded to standard deviation $=0.2+0.06 \mathrm{U}$. If many solutions are needed, the use of a graphical method similar to that shown in figure 1 may be helpful.

Two precautions in the use of this equation should be noted: (1) the precision measured is for the analysis of uranium in a given sample of plant ash; the equation does not give the precision to be expected from two samples from the same tree; and (2) the equation should not be extrapolated beyond the range of the uranium content of the samples used in its derivation (0.4-35 ppm U in ash).

A study of the accuracy of the fluorimetric method for determining uranium in plants, as contrasted with its precision, has not been attempted. However, the use of blanks and of known solutions as standards, as described in the procedure, gives considerable assurance that there is no appreciable bias in the method.

\section{REFERENCES}

Cannon, H. L., 1954, Botanical methods of prospecting for uranium [Colorado Plateau]: Mining Eng., v. 6, no. 2, p. 217-220.

Cannon, H. L., and Starrett, W. H., 1956, Botanical prospecting for uranium on La Ventana Mesa, Sandoval County, N. Mex.: U.S. Geol. Survey Bull. 1009-M, p. 391-407.

Grimaldi, F. S., May, Irving, Fletcher, M. H., and Titcomb, Jane, compilers, 1954, Collected papers on methods of analysis for uranium and thorium: U.S. Geol. Survey Bull. 1006, $184 \mathrm{p}$.

Kinser, C. A., 1954, The Model VI transmission fluorimeter for the determination of uranium : U.S. Geol. Survey Circ. 330, 9 p. 


\title{
CHEMICAL EXTRACTION OF AN ORGANIC MATERIAL FROM A URANIUM ORE
}

\author{
By M. L. JACOBS ${ }^{1}$, C. G. WARREN ${ }^{1}$; and H. C. GRANGER, \\ Fort Collins, Colo.; Denver, Colo.
}

\begin{abstract}
Organic material associated with uranium ore in the Ambrosia Lake mining district, New Mexico, is difficult to separate from inorganic contaminants by physical methods, is highly insoluble, and is nearly opaque to both the visible and infrared spectra. Thorough characterization of this organic matter by modern methods, however, must be preceded by purification and solution or volatilization without significant chemical changes. This study involves tests in which the organic material was found to be virtually insoluble in 15 diverse solvents, although as much as 30 percent was extracted by dimethyl sulfoxide. The dimethyl sulfoxide-soluble fraction consisted of a uranium-rich organic material in one deposit and a uranium-molybdenum-rich organic material in the other deposit. Infrared absorption spectra indicated that the extracted material contains carboxyl functional groups. Data obtained from chemical studies and from the mass spectrometer, in addition to the infrared spectra, indicated that the extract contains an aromatic component.
\end{abstract}

The close association between organic materials and many uranium deposits is well known (Szalay, 1954; 1958; Jones, 1958; Breger and Deul, 1956). The isolation and characterization of these organic materials are hindered by intimately associated inorganic substances, insolubility in most solvents, and lack of amenability to several modern analytical techniques. The organic uranium ore samples used in this study came from the Ambrosia Lake mining district near Grants, N. Mex. Physical methods of separating the organic material from inorganic contaminants are generally unsatisfactory. This study was designed primarily to find a chemical method of separation. Preliminary investigation of common separation procedures confirmed earlier reports (Granger and others, 1961) that the organic matter in the ore is insoluble in common solvents and is not amenable to ordinary methods of chemical purification. The study was then

1 Colorado State University, Fort Collins, Colo. expanded to include solvents that had not previously been used.

\section{GEOLOGIC SETTING}

The uranium mining district at Ambrosia Lake is approximately midway between Albuquerque and Gallup in west-central New Mexico, and is part of a belt of intermittent uranium deposits which trends northwesterly for more than 70 miles. Most of the uranium ore in the district is contained in sandstone units of the Morrison Formation of Late Jurassic age. Primary deposits of uranium ore in the district are coextensive with parts of the sandstone host rocks which are impregnated with a dark-brown to black diagenetic or epigenetic carbonaceous residue (Granger, 1968). These carbonaceous uranium deposits are as much as several thousand feet long, several hundred feet wide, and a few tens of feet thick, and they generally form tabular layers that are virtually suspended in the sandstone. Carbonaceous residue, as shown by X-ray diffraction analysis of hand-picked samples, contains coffinite, a uranium silicate mineral. Most geologists, however, have been of the opinion that only part of the uranium is in inorganic minerals and that part of it is combined with the organic fraction. This opinion has been caused, in part, by the chemical behavior of the ore during metallurgical testing for milling amenability (Kittel, 1963, p. 170).

\section{PROCEDURE}

In the following procedure the solvent DMSO (dimethyl sulfoxide) was used. For different solvents the procedure was slightly modified according to the physical properties of the solvents. Approximately $30 \mathrm{ml}$ of the solvent was placed in a modified Bailey-Walker extraction flask. The ore was ground with a mortar and pestle before extraction, and then a 25 -gram pulverized 
sample was placed in a glass sample cup, which has a medium-fritted glass bottom, and capped with a glass wool plug. A water-cooled Allihn condenser completed the extraction assembly.

A bunsen burner was used as a heat source. For solvents with a high boiling point, such as DMSO, it was necessary to wrap the outside of the extraction flask with asbestos tape in order to maintain reflux of the solvent.

The solvent was then heated to boiling at atmospheric pressure (approximately 640 millimeters of mercury) and a moderate reflux from the Allihn condenser was maintained. The extracted organic material, which was filtered nearly free of gross inorganic contamination by the fritted glass bottom of the extractor cup, was concentrated in the bottom of the extracting flask.

After an initial extraction during a 10 -hour period the solvent containing the product was collected and replaced with fresh solvent. This procedure was repeated twice more with the same sample so that each sample of ore was extracted three times with a total of about $90 \mathrm{ml}$ of solvent.

After $200-300 \mathrm{~g}$ of ore was treated, the extract was refiltered through No. 50 Whatman paper to remove any remaining traces of inorganic contaminants, and all but about $30 \mathrm{ml}$ of the solvent was removed in a simple distillation apparatus. The distillation was carried out under an inert atmosphere of $\mathrm{N}_{2}$ which swept through the liquid residue and had the effect of sweeping vapor from the distilling mixture so that lower residue temperatures could be maintained. The $20-30 \mathrm{ml}$ of solvent residue was then diluted with an equal volume of distilled water. When DMSO was the solvent, the addition of water caused a dark-brown precipitate to form. The precipitate was collected by centrifuging, then it was water washed three or four times or until a clear supernatant wash was obtained. It was then again washed in the same fashion using absolute ethanol. This washing extracted some color from the precipitate, but most of the precipitate was insoluble in the ethanol. The washed precipitate was then dried in a vacuum oven for $10-12$ hours at $80^{\circ} \mathrm{C}$ and $1 \mathrm{~mm} \mathrm{Hg}$.

\section{RESULTS}

Some of the solvents were tested because they had previously been used successfully to extract asphalt, coallike materials, and humic acids (Degens, 1965). Others were tested because of their general effectiveness in dissolving various organic and inorganic materials. The solvents that were tested were dimethyl sulfoxide, acetone, n-heptane, benzene, acetic anhydride, N,N-dimethyl formamide, 1, 2-propandiol cyclic carbonate; acetonitrile, 1-methyl naphthalene, carbon disulfide, toluene, pyridine, piperidine, diethyl ethyl phosphonate, aqueous sodium hydroxide, and aqueous hydrochloric acid. The solvent properties of these range from strongly basic to strongly acidic, and the boiling points range from about $50^{\circ} \mathrm{C}$ to $240^{\circ} \mathrm{C}$.

Only two of the solvents-dimethyl sulfoxide (DMSO) and N,N-dimethyl formamide-had any measurable effect on the original organic material. The $\mathrm{N}, \mathrm{N}$-dimethyl formamide extracted only a trace of the original material, but DMSO extracted a fairly large amount of it. Extracted organic material from which the metals had previously been removed with hydrochloric acid was found to be slightly soluble in 10percent aqueous sodium hydroxide.

Extraction of $300 \mathrm{~g}$ of ore from the Marquez mine with DMSO yielded about $2 \mathrm{~g}$ of an organic product which contained both uranium and molybdenum. The original ore contained about 1 percent organic carbon, estimated to indicate about 2 percent organic material. Therefore, about 30 percent of the organic material was extracted. A similar extract of ore from the Section 17 mine contained uranium but no molybdenum. Semiquantitative spectrographic analyses of the DMSO extracts are given in table 1 .

Most of the metals were removed from the DMSO extract by leaching with $12 M$ hydrochloric acid for 24 hours. The leached residue, which was dried at $80^{\circ} \mathrm{C}$ at $1 \mathrm{~mm}$ pressure, was then analyzed (by the Huffman Laboratories, Wheatridge, Colo.), and it accounted for 98.68 percent of the total weight: 55.31 percent carbon,

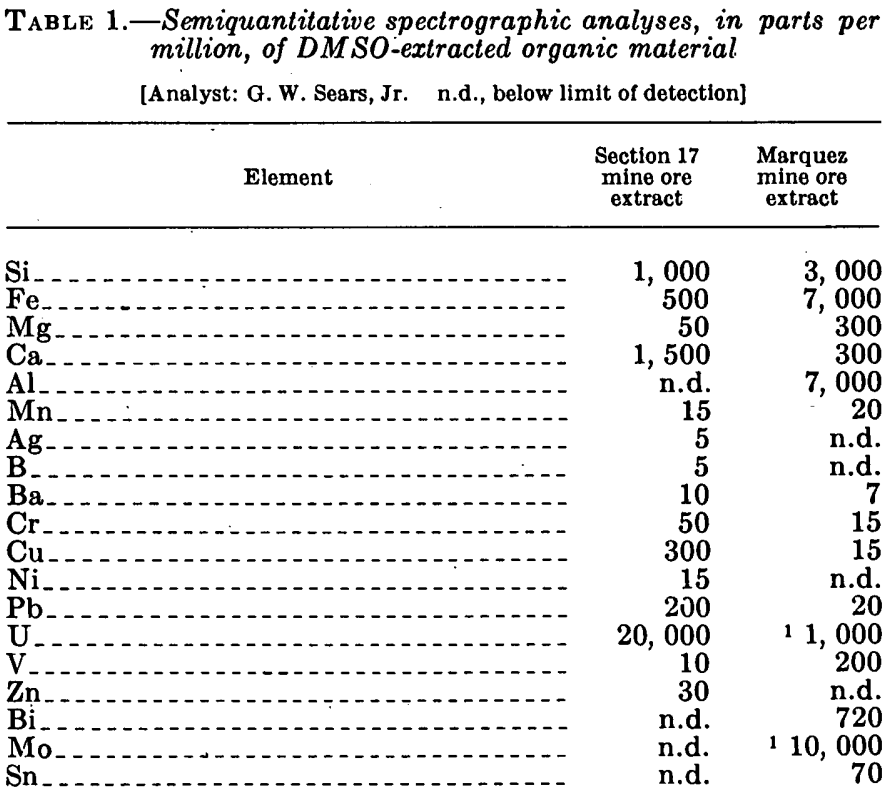

1 Oxidation of the DMSO extract at $900^{\circ} \mathrm{C}$ yielded 16.3 percent ash. $\mathrm{X}$-ray fluorescence analysis (analyst: J. S. Wahlberg) of the extracted material from the Marquez mine indicated contents of 11 percent $M 0$ and 1.2 percent $U$. These results seem more compatible with the ash content than do the spectrographic analyses. 
3.31 percent hydrogen, 28.52 percent oxygen, 10.33 percent sulfur, 0.01 percent nitrogen, and 1.20 percent unanalyzed solid residue which probably consisted largely of silica and alumina. The 1.32-percent deficiency in the analysis is due to the slightly hygroscopic nature of the acid-leached DMSO extract. When adjusted to the basis of 100 percent organic matter, the analysis is 56.74 percent carbon, 3.40 percent hydrogen, 29.26 percent oxygen, 10.60 percent sulfur, and less than 0.01 percent nitrogen.

The organic material may have been altered during extraction by reaction with DMSO (Epstein and Sweat, 1967). This solvent is a mild oxidizing agent and generally converts alcohols to the corresponding aldehyde or ketone; DMSO is reduced to methyl sulfide in this reaction. It also combines with acid anhydrides by the Pummerer reaction (Oae and others, 1963) in which DMSO breaks the anhydride bond and combines to form the corresponding ester. Both reactions are specific and only affect the reactive sites of molecules. Unreactive sites remain unaltered, and this part of the extracted material should resemble original organic portions of the ore.

The organic portion of the uranium ore, because of some of its chemical and physical properties, is difficult to study. It is nearly opaque to infrared radiation, although an ill-defined absorbance at the wavelength assigned to the carboxyl group (5.8 microns) was observed for the DMSO extract. Limited volatility restricted mass spectrometry to products obtained only when the sample was heated above $220^{\circ} \mathrm{C}$ in the mass spectrometer. Thermal breakdown fragments, tentatively identified, include benzene derivatives, phenol derivatives, methyl sulfides, and high-molecular-weight saturated fatty acids. Each of these fragments has a greater hydrogen content than the bulk product. Although the extract has not yet been completely identified in the mass spectrometer, several ill-defined fragments of the predominant molecule having apparent (hydrogen) unsaturation and molecular weights between 200 and 250 were observed. The apparent unsaturation of the fragments coupled with an error of 0.03 in their molecular weight determination prevented even tentative identification. These fragments had either a high oxygen content or a low hydrogen content, which corresponds to the chemical analysis of the bulk product.

The metal-free DMSO extract was determined chemically to have properties of an aromatic substance. It dissolved in a solution of lithium metal in hexamethylphosphoramide, which solution has been used to dissolve coals containing large aromatic groups.
Solution in this reagent is usually accepted to indicate aromatic character (H. W. Sternberg and C. L. D. Donne, of the U.S. Bur. Mines, Pittsburgh, Pa., Coal Research Center, written commun., 1968).

\section{CONCLUSIONS}

Extraction of two uranium ore samples with the DMSO procedure released as much as about 30 percent of the organic material associated with the uranium ore. Analyses indicate that the Marquez mine sample contained a uranium-molybdenum-rich organic substance and that the Section 17 mine sample contained a uranium-rich organic material. The extract is opaque, nonvolatile, and insoluble in most solvents. It is thermally stable to $220^{\circ} \mathrm{C}$. It has the chemical characteristics of an aromatic substance and a poorly defined absorbance at $5.8 \mu$ in the infrared spectrum which is characteristic of carboxyl groups.

\section{REFERENCES}

Breger, I. A., and Deul, Maurice, 1956, The organic geochemistry of uranium, in Page, L. R., Stocking, H. E., and Smith, H. B., compilers, Contributions to geology of uranium and thorium by the United States Geological Survey and Atomic Energy Commission for the United Nations International Conference on Peaceful Uses of Atomic Energy, Geneva, Switzerland, 1955: U.S. Geol. Survey Prof. Paper 300, p. 505-510.

Degens, E. T., 1965, Geochemistry of sediments-A brief survey : Englewood Cliffs, N. J., Prentice-Hall, 342 p.

Epstein, W. W., and Sweat, F. W., 1967, Dimethyl sulfoxide oxidations: Chem. Rev., v. 67, no. 3, p. 247-260.

Granger, H. C., 1968, Localization and control of uranium deposits in the southern San Juan basin mineral belt, New Mexico-An hypothesis, in Geological Survey Research 1968 : U.S. Geol. Survey Prof. Paper 600-B, p. B60-B70.

Granger, H. C., Santos, E. S., Dean, B. G., and Moore, F. B., 1961, Sandstone-type uranium deposits at Ambrosia Lake, New Mexico-An interim report: Econ. Geology, v. 56, no. 7, p. 1179-1210.

Jones, H. N., 1958, Selected annotated bibliography of the geology of uraniferous and radioactive native bituminous substances, exclusive of coals, in the United States: U.S. Geol. Survey Bull. 1059-D, p. 177-203.

Kittel, D. F., 1963, Geology of the Jackpile mine area, in Kelley, v. C., ed., Geology and technology of the Grants uranium region: New Mexico Bur. Mines and Mineral Resources Mem. 15, p. 167-176.

Oae, S., Kitao, T., Kawamura, S., and Kitaoka, Y., 1963, Model pathways for enzymatic oxidative demethylation, pt. 1, Mechanism of reaction of dimethyl sulfoxide with acetic anhydride: Tetrahedron, v. 19, no. 6, p. 817-820.

Szalay, A. S., 1954, The enrichment of uranium in some brown coals in Hungary : Acta Geol., v. 2, pts. 3-4, p. 299-311.

1958, The significance of humus in the geochemical enrichment of uranium, in United Nations International Conference on the Peaceful Uses of Atomic Energy, 2d, Geneva, 1958: p. 182-186. 


\title{
A DIE FOR PELLETIZING SAMPLES FOR X-RAY FLUORESCENCE ANALYSIS
}

\author{
By BRENT P. FABBI, Menlo Park, Calif.
}

\begin{abstract}
The preparation of pellets of powdered geological samples is a critical step in X-ray fluorescence analysis: A special die has been designed to produce smooth surfaces on extremely durable pellets and to provide a protective, hard outer ring and backing. The outer ring minimizes the deterioration of the edge that has in the past limited the usable life of the pellet. Repetitive preparations have shown reproducibility and homogeneity to be within normal counting statistics.
\end{abstract}

Smooth, mirrorlike reproducible pellet surfaces are an important requirement for analysis by $\mathrm{X}$-ray fluorescence, especially when the light elements sodium to titanium are being determined. Pressed samples having no supporting edge or backing are usable for only a very short period of time, owing to edge crumbling, and generally deteriorate before a complete analysis can be performed (Bean, 1966).

A pelletizing die that produces extremely durable pellets with smooth reproducible surfaces and is compatible with the Applied Research Laboratory Model 4451 hydraulic press has been designed by the author.

This die embodies features similar to those of the die designed by $\mathbf{A}$. K. Baird, which produces pellets with a strong backing and edge (Baird, 1961). A. V. Volborth improved the pellet-producing technique by using glass lenses to make reproducibly smooth pellet surfaces (Volborth, 1963). For use with the die designed, small samples (about 1 gram or less but of a size to meet critical thickness) can be taken for analysis instend of the 5 grams usually required with other techniques (Matocha, 1966).

Acknowledgments.-The author is indebted to C. $\mathrm{O}$. Ingamells, U.S. Geological Survey, for his advice and suggestions and to J. C. Morgenstern, also of the Survey, for building the die.

\section{DESCRIPTION OF DIE}

The design of the pelletizing die is shown in figure 1 ; all parts are made of carbon tool steel. Figure 2 is a drawing of the casting sleeve, piston, and pellet receiver; figure 3, a photograph of all die components; figure 4, a photograph of a finished pellet and a section cut through a pellet.

One inch must be cut off the ARL piston to accommodate the die. If the inner surface of the die outer shell is not completely smooth and flat, the glass lenses will crack. A 5-mil-thick piece of plastic cut to 1.35 inch diameter and placed between the bottom of the die and the glass will extend the usable life of the lens.

\section{PROCEDURE FOR MAKING PELLETS}

The following procedure is used for making pellets: Place a cleaned lens ${ }^{1}$ into the die outer shell and insert the die sleeve. Place the casting sleeve inside the die sleeve flush upon the lens and pour in the sample. Insert the casting piston slowly, so as to prevent fine powders from puffing out of the vents, and exert moderate pressure by hand on the casting piston to form a semirigid pancake out of the sample. After slowly withdrawing the casting sleeve and piston together, pour $20-30 \mathrm{ml}$ of methyl cellulose evenly over the sample. Insert the die piston and compact the pellet in the press at 30,000 pounds per square inch. Remove the die piston and sleeve assembly from the die outer shell and replace it in the press inverted (so that the pellet is at the top of the die sleeve). Place the pellet receiver over the sleeve assembly and apply minimal pressure to extrude the pellet. The window in the receiver allows one to observe when the pellet is extruded.

\section{PROCEDURE FOR CLEANING LENSES}

Before pressing the pellets, clean the lenses thoroughly to remove small glass particles (Adams, 1969). Wash the lenses with a stiff brush in soap and water, and rinse. Dip the lenses in a cleaning solution

\footnotetext{
$115 / 10^{-i n c h}$ flashlight lens-Fulton Manufacturing Co., Wauseon, Ohto
} 


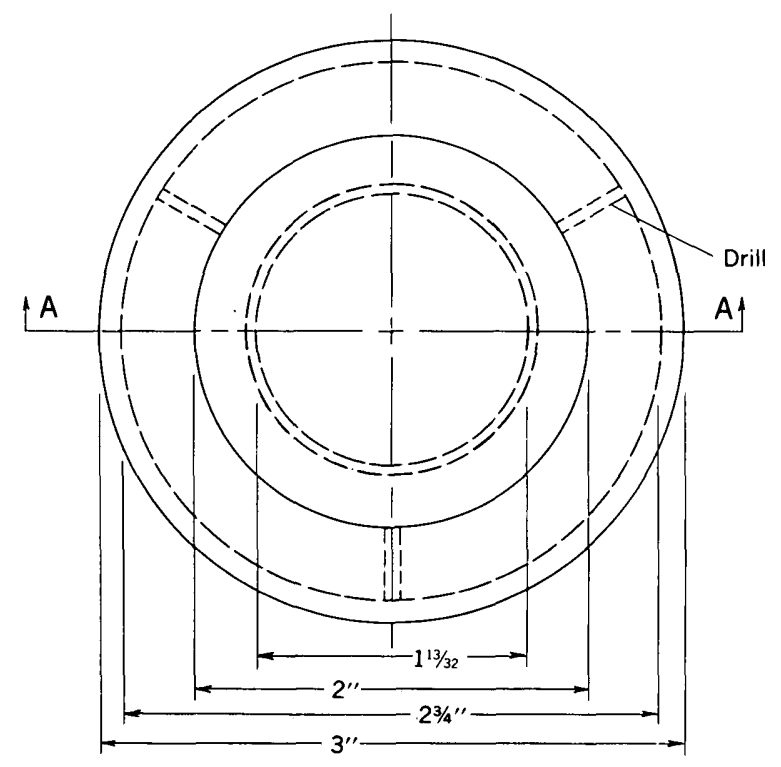

Outer shell

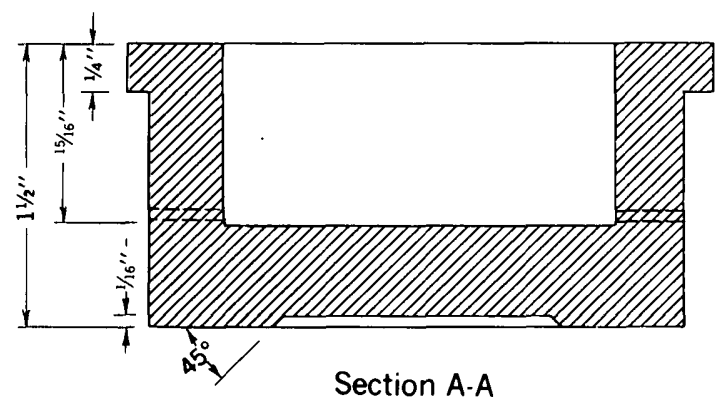

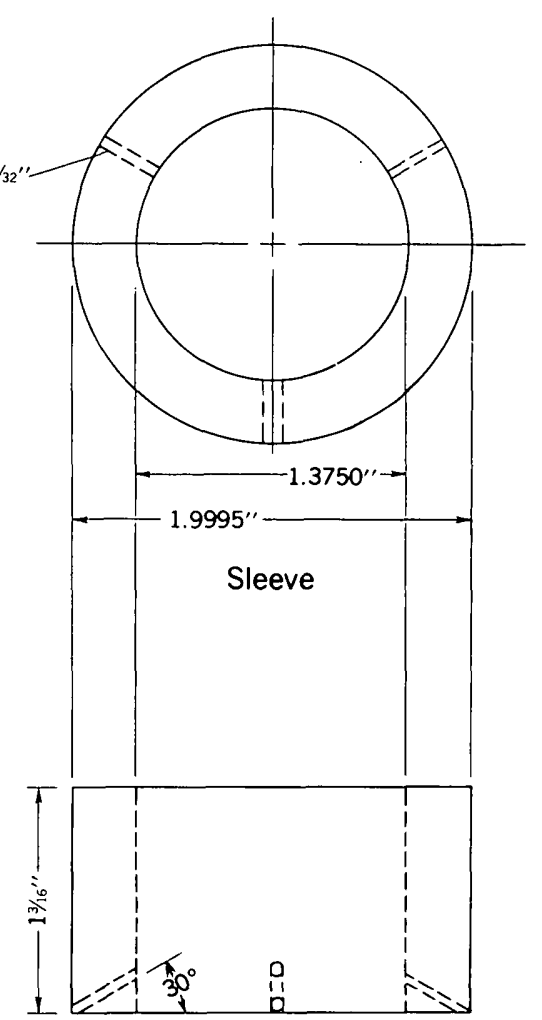

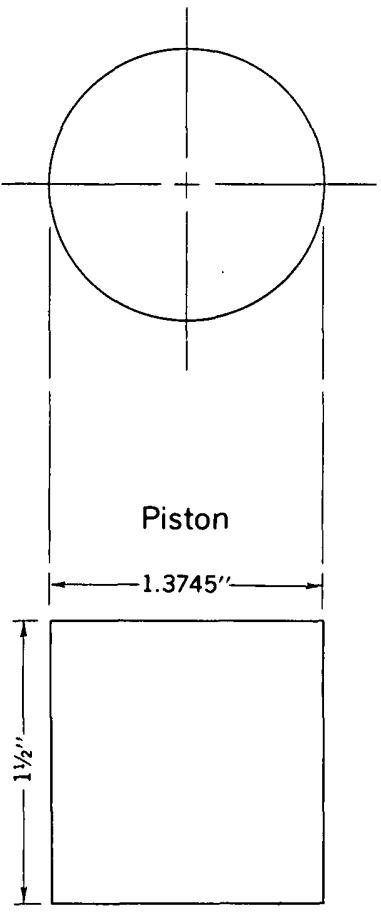

FTgURE 1.-Die for pelletizing samples for X-ray analysis. Plan view of sections.

of $\mathrm{CrO}_{3}$ and $\mathrm{H}_{2} \mathrm{SO}_{4}$ to remove any alkalies, and then rinse. Dip the lenses in $\mathrm{HCl}$ containing a few drops of $\mathrm{H}_{2} \mathrm{O}_{2}$ to remove $\mathrm{Cr}$, and rinse. Flush with distilled water and dry by placing the lenses between two large filter papers.

\section{RESULTS AND DISCUSSION}

Four replicate $(1: 1$, sample to chromatographic cellulose) pellets of the U.S. Geological Survey basalt standard, BCR-1, were prepared to determine sample homogeneity and pellet reproducibility. The average particle size observed with a microscope was $20 \mu$; however, some flakes of biotite were $60 \mu$. The samples were counted at the Fe peak and the Si peak for 1 million counts, the theoretical counting error being 0.20 percent at $2 \sigma$.

The relative deviation when counting $\mathrm{Fe}$ is 0.40 percent for the four replicates. Hence, at an $\mathrm{Fe}_{2} \mathrm{O}_{3}$ value of 13.29 with 95 -percent confidence, one could expect $13.29 \times \frac{2(0.40)}{100}= \pm 0.11$ percent or weight per- centage $\mathrm{Fe}_{2} \mathrm{O}_{3}=13.29 \pm 0.11$ percent, whereas the theoretical value obtainable is $13.29 \pm 0.03$ percent. The relative deviation when counting $\mathrm{Si}$ is 0.32 per-

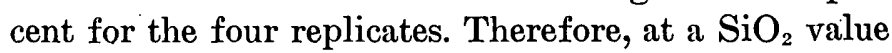
of 54.50 percent with 95 -percent confidence one could expect

$54.50 \times \frac{2(0.32)}{100}= \pm 0.35$ percent or weight percentage $\mathrm{SiO}_{2}=54.50 \pm 0.35$ percent, whereas the theoretical value obtainable is $54.50 \pm 0.11$ percent.

With respect to $\mathrm{SiO}_{2}$, the relative deviation of 0.32 percent suggests that the glass lenses do not contaminate the sample with $\mathrm{SiO}_{2}$. The relative deviation figures of 0.40 percent for $\mathrm{Fe}$ and 0.32 percent for $\mathrm{Si}$ include errors due to counting, placement, specimen inhomogeneities, uneven specimen surface, and mineralogical effects.

\section{REFERENCES}

Adams, P. B., 1969, The biology of glass: New Scientist, v. 41, no. 630 , p. $25-27$. 


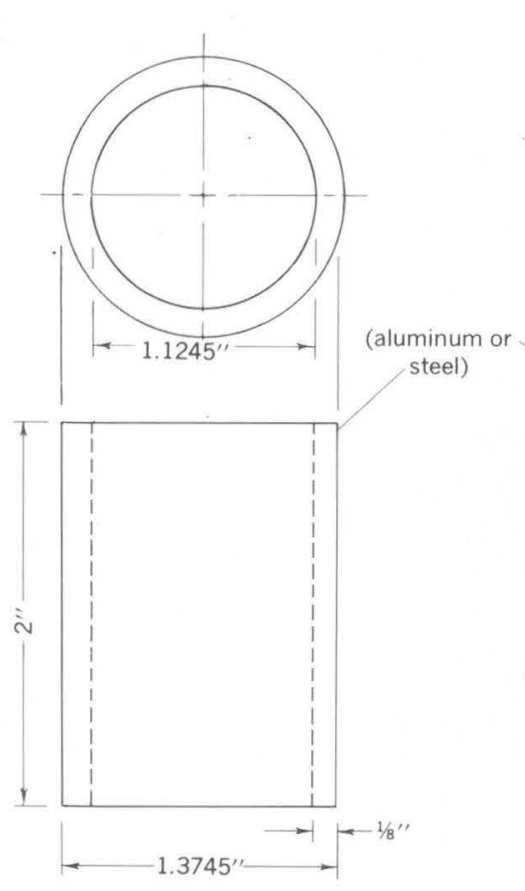

Sleeve
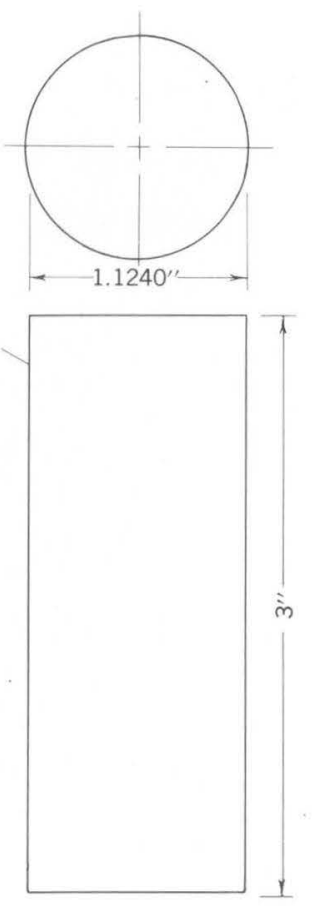

Piston

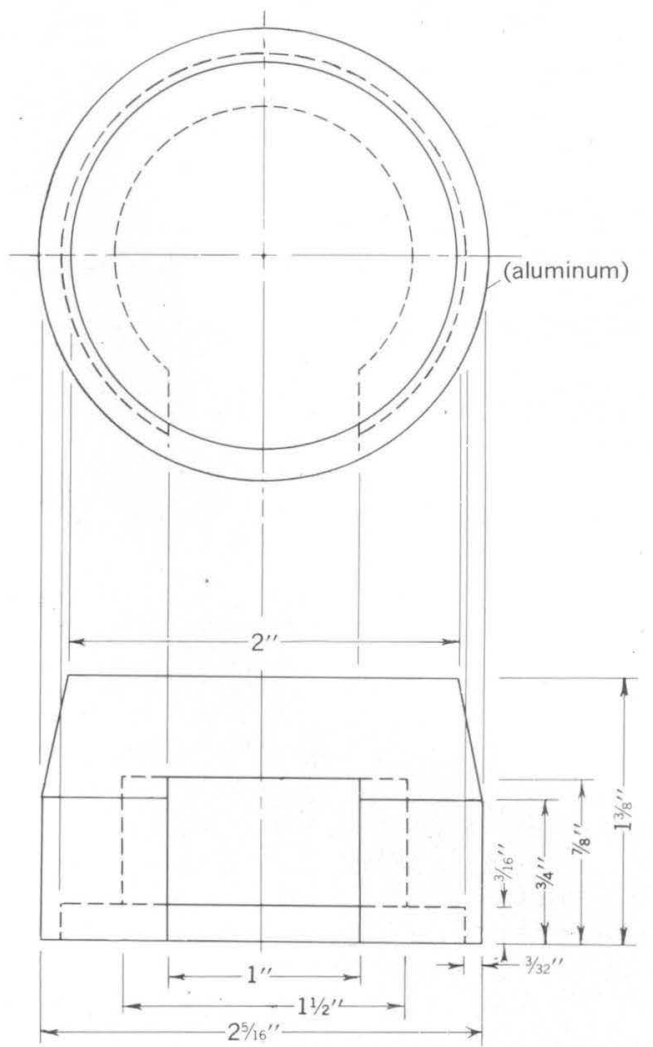

Pellet receiver

Casting sleeve and piston

Figure 2.-Casting sleeve, piston, and pellet receiver.

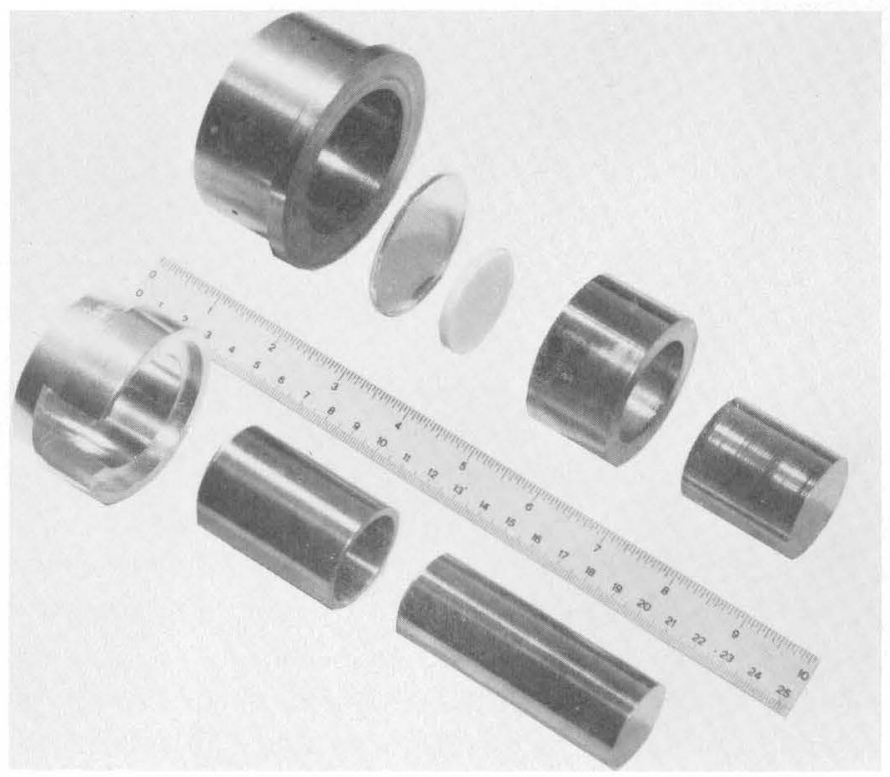

Figure 3.-Die components. From left to right above scale: outer shell, glass lens, pellet, die sleeve, and die piston; from left to right below scale: pellet receiver, casting sleeve, and casting piston.

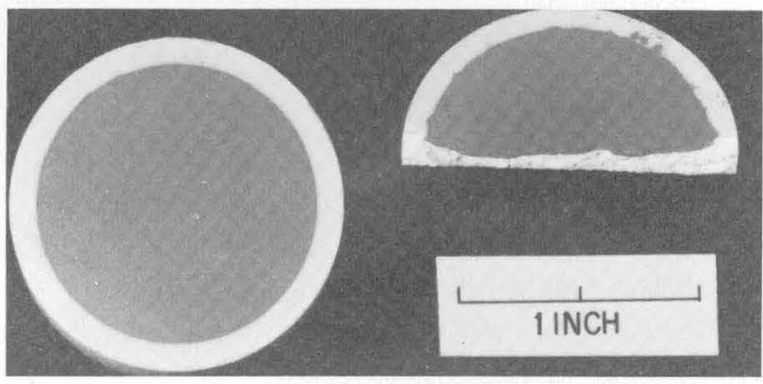

Figure 4.-Prepared pellet (left) and section through pellet.

Baird, A. K., 1961, A pressed-specimen die for the Norelco vacuum path X-ray spectrograph: Norelco Reporter, v. 8, no. 6 , p. $108-109$.

Bean, L., 1966, A method of producing sturdy specimens of pressed powders for use in X-ray spectrochemical analysis: Appl. Spectroscopy, v. 20, no. 3, p. 191-193.

Matocha, C. K., 1966, A new briquetting technique: Appl. Spectroscopy, v. 20, no. 4, p. 252-253.

Volborth, A. V., 1963, Total instrumental analysis of rockspt. A, X-ray spectrographic determination of all major oxides in igneous rocks and precision and accuracy of a direct pelletizing method: Nevada Bur. Mines Rept. 6, p. A1-A72. 


\title{
TRANSMISSIVITY AND STORAGE COEFFICIENT OF AQUIFERS IN THE FOX HILLS SANDSTONE AND THE HELL CREEK FORMATION, MERCER AND OLIVER COUNTIES, NORTH DAKOTA
}

\author{
By MACK G. CROFT and E. A. WESOLOWSKI, Bismarck, N. Dak.
}

Work done in cooperation with the North Dakota State Water

Commission and the North Dakota Geological Survey

\begin{abstract}
Since 1963, about 100 flowing stock and domestic wells have been drilled into the Fox Hills Sandstone and the Hell Creek Formation in Mercer and Oliver Counties, N. Dak. Aquifer tests were made on about half of the wells. The values obtained for transmissivity range from 13 to 3,100 gallons per day per foot, and average 510 gallons per day per foot. An analysis of the potentiometric surface in the southwestern part of Mercer County indicates a transmissivity of about 1,400 gallons per day per foot. The values for permeability average 16 gallons per day per square foot. Data indicate storage coefficient values are between $10^{-4}$ and $10^{-5}$. The aquifer tests indicate that the wells have specific capacities that range from less than 0.1 to 0.6 gallon per minute per foot.
\end{abstract}

The purpose of this investigation is to determine the transmissivity, storage coefficient, and permeability of aquifers in the Fox Hills Sandstone and Hell Creek Formation by use of data from flowing stock and domestic wells in Mercer and Oliver Counties, N. Dak. About 100 flowing wells have been drilled in this area since 1963. The investigation is part of the general cooperative water-resources study of the area which began in 1966.

Mercer and Oliver Counties, in west-central North Dakota, include approximately 1,840 square miles and are bordered on the north and east by the Missouri River.

The well-numbering system used in this report is based on the location of the well in the Federal system of rectangular surveys of public lands. The first numeral denotes the township north of a base line, the second denotes the range west of the fifth principal meridian, and the third denotes the section in which the well is located. The lowercase letters " $a$," "b," "c," and " $\mathrm{d}$ " designate, respectively, the northeast, northwest, southwest, and southeast quarter sections as well as the quarter-quarter sections. For example, well 14181-13db is in the NW1/4 SE $1 / 4$ sec. 13, T. 141 N., $R$. $81 \mathrm{~W}$.

Numerous geologic and hydrologic investigations of artesian aquifers have been made in North Dakota and adjoining areas. The earliest geologic investigations pertinent to this report were made by Lloyd and Hares (1915) and Stanton (1920). Recent geologic investigations have been made by Johnson and Kunkel (1959), Denson and Gill (1965), and Pipiringos, Chisholm, and Kepferle (1965). The flow-test method used to determine the transmissivity and storage coefficient was devised by Jacob and Lohman (1952). Hydrologic studies similar to this investigation were made of the Fox Hills Sandstone and the lower part of the Hell Creek Formation in Montana by Taylor $(1965,1968)$.

\section{GEOLOGY}

Geographically the area is part of the glaciated Missouri Plateau. Most of the flowing wells are in the stream valleys, which are incised 400 to 600 feet below the plateau surface.

Geologic formations exposed in the region range from Cretaceous to Quaternary in age. The bedrock formations, partly capped by a veneer of glacial drift, dip gently to the northwest at about 10 feet per mile into the Williston basin (Denson and Gill, 1965, pl. 5; Johnson and Kunkel, 1959, p. 1). Test drilling and core analyses in Mercer and Oliver Counties indicate that the Fox Hills Sandstone and the Hell Creek For- 
mation, both of Cretaceous age, consist of fine- to medium-grained sandstone intercalated with siltstone and shale. Most of the artesian wells are completed in sandstone in the upper part of the Fox Hills and in the lower part of the Hell Creek, but a substantial number of wells obtain water from the upper part of the Hell Creek, and a few itap beds of sandstone near the base of the overlying Tongue River Member of the Fort Union Formation of Tertiary age. An excellent description of these formations and a summary of the stratigraphy is available in Denson and Gill (1965, p. 7-9) and Johnson and Kunkel (1959).

The artesian head measured in wells perforated in the upper part of the Fox Hills Sandstone and in the lower part of the Hell Creek Formation, in the southwest corner of Mercer County, is contoured in figure 1. Wells completed in the upper part of the Hell Creek, in general, have lower heads and presumably represent a difterent aquifer system. Probably most wells tap only part of the sandstone beds forming these aquifer systems.

\section{HYDRAULIC PROPERTIES}

Methods of determining the hydraulic properties of aquifers by using a flowing artesian well were devised by Jacob and Lohman (1952). They developed equations for a graphical solution for transmissivity and the storage coefficient for short periods of flow, and a simpler equation for straight-line graphical solutions that gives accurate results with slightly longer periods of flow. The formulas for the straight-line solutions are:

$$
\begin{gathered}
T=\frac{264}{\Delta\left(s_{w} / Q\right)} \text { and } \\
S=2.1 \times 10^{-4} T\left(t / r_{w}{ }^{2}\right)_{0}, \text { or } \\
S=\frac{2.1 \times 10^{-4} T\left(t / r_{w}{ }^{2}\right)}{\log _{10^{-1}}\left[s_{v} / Q / \Delta\left(s_{v} / Q\right)\right]},
\end{gathered}
$$

in which

$T=$ coefficient of transmissivity, in gallons per day per foot,

$S=$ storage coefficient,

$s_{w}=$ drawdown, in feet,

$Q=$ flow rate, in gallons per minute,

$t=$ time between beginning of flow and flow measurement, in minutes, and

$r_{t o}=$ effective radius of the well through the aquifer, in feet.

The values, $s_{t o} / Q$, are plotted on the linear scale on semi$\log$ paper, and the corresponding values of $t / r_{v}{ }^{2}$ are plotted on the logarithmic scale. The slope, $\Delta\left(s_{v} / Q\right)$, is the change in $s_{v} / Q$ over one log cycle of $t / r_{w}{ }^{2}$. The value, $\left(t / r_{w}{ }^{2}\right)_{0}$, (equation 2) is taken at the point $\left(s_{w} / Q\right)=0$. When the slope of the curve is steep, equation 3 is used to avoid large extrapolation errors. In this case, the values of $t / r_{v}{ }^{2}$ and $s_{v} / Q$ are arbitrarily selected from a specific point on the line.

Eleven flow tests were conducted on wells in Mercer and Oliver Counties in the summer of 1968. The hydraulic properties of the aquifers derived from graphical solution using formulas 1,2 , and 3 are given in table 1 .

After each flow test was completed, a check of the calculated value for $T$ was made using the Theis (1935, p. 522) recovery formula. The formula is:

$$
T=\frac{264 Q}{s^{\prime}} \log _{10} t / t^{\prime}
$$

in which

$$
\begin{aligned}
& Q=\text { the weighted average discharge, in gallons per } \\
& \text { minute, }
\end{aligned}
$$

The results of the recovery tests are given in table 1 . In addition, recovery tests were made on 27 other wells in the fall of 1967 and the summer of 1968 for which it was not practicable to make flow tests. The data plots of many recovery tests have a slight, gradual change in slope, probably due to pressure-sensitive leaks in the well casings. In general the changes in the plot were not serious enough to invalidate the results.

\section{RESULTS OF AQUIFER TESTS}

The results of the 49 flow and recovery tests made in Mercer and Oliver Counties are summarized in table 1. The values obtained for transmissivity range from 13 to $3,100 \mathrm{gpd}$ (gallons per day) per foot and average 510 gpd per foot. The average was obtained by using the average results of the flow test and the recovery test as one value. The values for permeabilities (table 1) were obtained by dividing the thickness of the aquifer, obtained from a driller's log or electric log of the well, into the value for transmissivity. The permeabilities, which average 16 gpd per square foot, are comparable to the values obtained by Taylor (1968, $\mathrm{p}$. 16) for the Fox Hills Sandstone and the Hell Creek Formation in the Northern Powder River valley, Montana. The mean permeabilities obtained by Taylor ranged from 2.8 to 21.4 gpd per square foot.

The artesian storage coefficient is proportional to the thickness of the aquifer and generally ranges from $10^{-3}$ to about $10^{-5}$. Values for the storage coefficient calculated from field tests ranged from $1.7 \times 10^{-13}$ to $3.8 \times 10^{-4}$. However, those values smaller than $10^{-5}$ are probably not realistic. Because the effective well radius, $r_{w}$, appears as $r_{w}{ }^{2}$ in equations 2 and 3 , a slight error in $r_{w}$ would have considerable effect on the accuracy of $S$. 


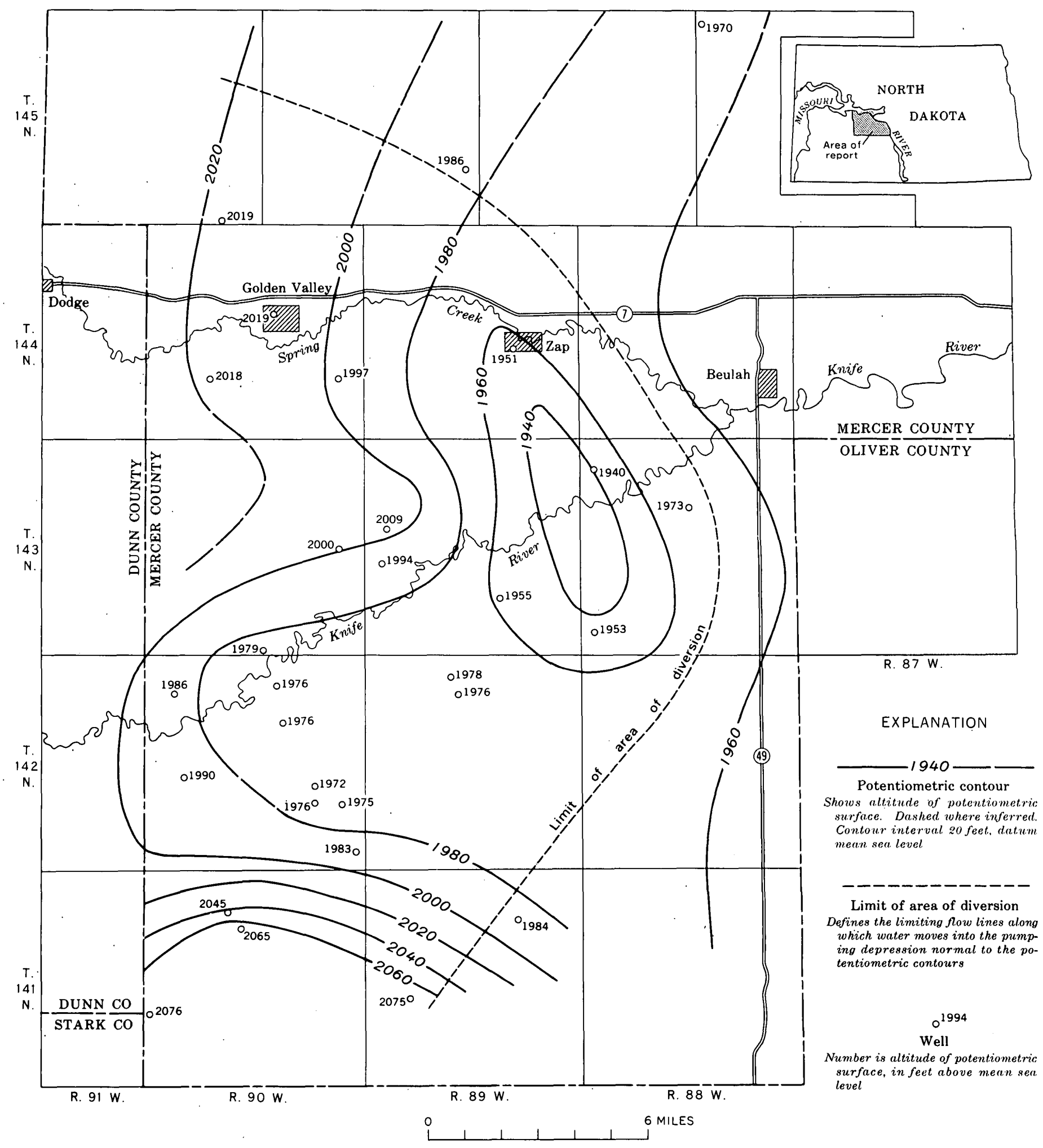

Figure 1.-Potentiometric surface of the upper part of the Fox Hills Sandstone and the lower part of the Hell Creek Formation, spring 1968, Mercer County, N. Dak. 
CROFT AND WESOLOWSKI

TABLE 1.-Results of flow and recovery tests

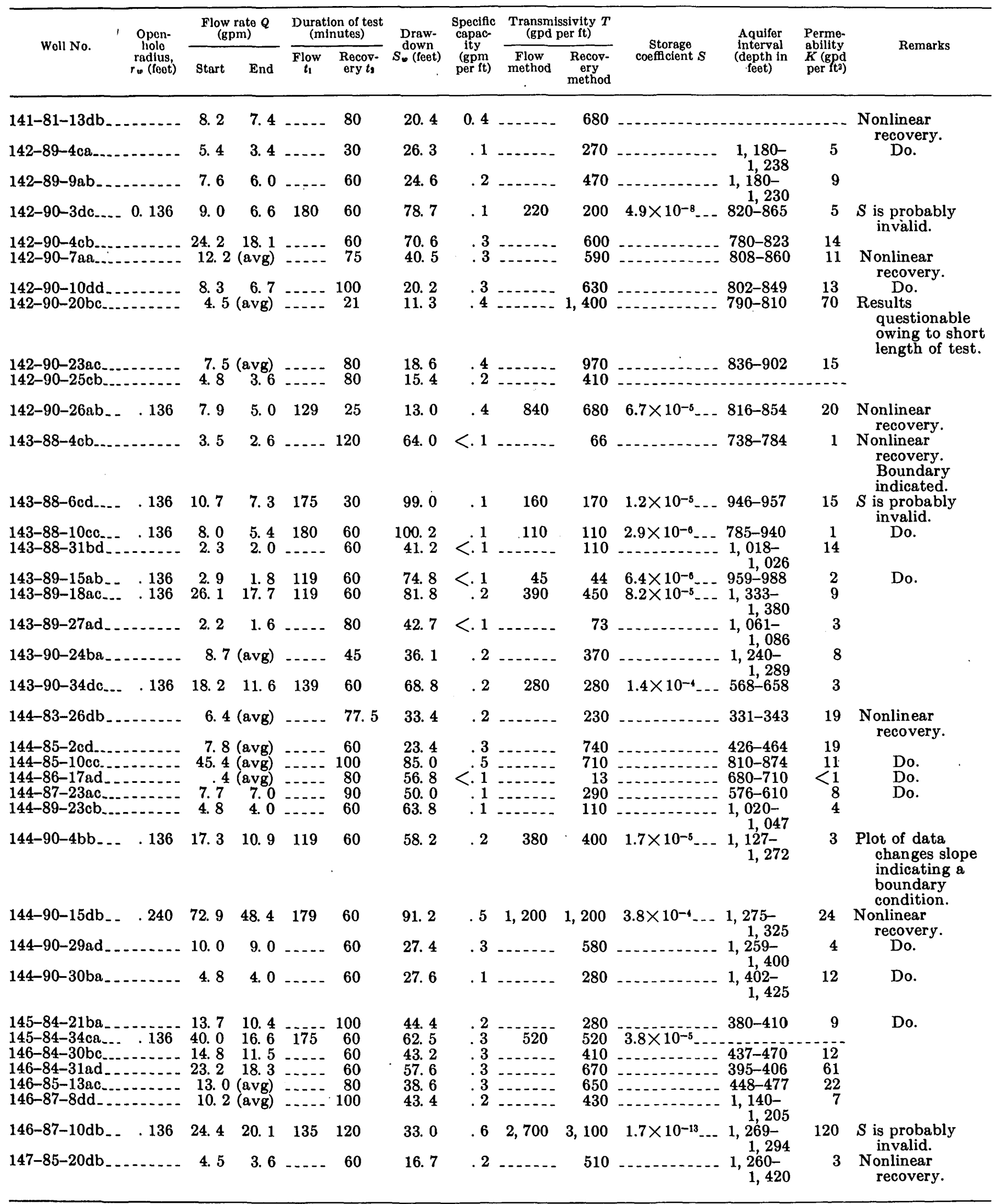


Therefore, (1) errors in determining the effective well radius and, in some places, caving or filling of the drill hole, (2) different percentages of penetration of the aquifer, and (3) variations in the thickness of the aquifier probably account for the considerable range in values of $S$ obtained from the field tests.

To check the accuracy of the $S$ values, the vertical compressibility of the aquifer was calculated with data obtained from a sonic log of an oil and gas test hole in sec. 34, T. 141, R. 85, in the southwest corner of Oliver County. This approach was used by Taylor (1968, p. 12-18) in the Powder River valley in Montana. A 200-foot section from the sonic $\log (1,060-1,260$ feet) indicated an average transit time of 126.3 microseconds per foot, or a longitudinal velocity of 7,920 feet per second. The vertical compressibility $\left(\beta_{k}\right)$, $1.12 \times 10^{-6} \mathrm{in}^{2} / \mathrm{lb}$, was obtained by solution of the formula (Birch, 1942, p. 64)

where

$$
\beta_{k}=\frac{3(1-\sigma)}{V_{p}^{2} \rho k(1+\sigma)},
$$

$\sigma$ is Poisson's ratio of the medium, expressed as a decimal fraction,

$V_{p}$ is the velocity of the longitudinal sound waves in the medium, in feet per second, and

$\rho k$ is the mass density of the aquifer skeleton, in pounds per cubic foot.

An assumed value of 0.10 was used for Poisson's ratio (Taylor, 1968, p. 14) and a value of 162.24 lbs per $\mathrm{ft}^{3}$, the density of the quartz, was used for the mass density of the aquifer skeleton. To obtain the results of $\beta_{k}$ in preferred units, the figures must be multiplied by 32 ft per $\sec ^{2}$, the acceleration due to gravity, and

$$
\frac{144 \mathrm{in}^{2}}{\mathrm{ft}^{2}} \text {. }
$$

The storage coefficient $(S)$ at many aquifer test sites was calculated with the vertical compressibility obtained from the sonic log by the formula (Jacob, 1950 , p. 334)

where

$$
s=\gamma_{v o} \theta m\left(\beta+\frac{\beta_{k}}{\theta}\right),
$$

$\gamma_{w}$ is the specific weight of water, $3.61 \times 10^{-2}$ pounds per cubic inch at the prevailing aquifer temperature,

$\theta$ is the porosity of the aquifer, expressed as a decimal fraction,

$\beta$ is the compressibility of water, approximately $3.3 \times 10^{-6}$ square inch per pound,

$\beta_{k}$ is the vertical compressibility of the solid skeleton of the aquifer, and $m$ is the saturated thickness of the aquifer, in inches.

A value of 0.40 was used for the aquifer porosity, approximately the value obtained in the laboratory from several cores. Most of the calculations gave values for the storage coefficient that were of the order of $10^{-4}$ to $10^{-5}$. This suggests that the values for storage coefficients that range from $10^{-4}$ to $10^{-5}$, obtained from the aquifer tests, are probably realistic.

Data obtained during the aquifer tests were used to determine the specific capacities of the wells. The values range from less than 0.1 to $0.6 \mathrm{gpm}$ (gallons per minute) per foot and average $0.3 \mathrm{gpm}$ per foot.

\section{GROUND-WATER FLOW ANALYSIS}

The transmissivity of the upper part of the Fox Hills Sandstone and the lower part of the Hell Creek Formation in the southwestern part of Mercer County was calculated from Darcy's law in the form, $Q=T I L . Q$ is the quantity of water expressed in millions of gallons per day (mgd), when $Q=5.28 \times 10^{-3}$ (TIL). 'T' is the coefficient of transmissivity, $I$ is the hydraulic gradient in feet per foot, and $L$ is equal to the length in miles through which the water moves, normal to the direction of flow. The method used to analyze the flow of ground water is described by Foley, Walton, and Drescher (1953, p. 76).

A potentiometric-surface map, constructed from heads measured in wells that tap the aquifer in the upper part of the Fox Hills and lower part of the Hell Creek, is shown in figure 1. The depression in the surface is due to an estimated discharge of $0.5 \mathrm{mgd}$ from wells tapping the aquifer. The average length, $L$, of the 1,980-2,000-foot contours across which all the water moves into the depression, inside the area of diversion, is 34 miles. The area of diversion defines the limiting flow lines along which water moves into the pumping depression, normal to the potentiometric contours. The hydraulic gradient, $I$, was calculated by using the formula, $I=\frac{C}{5,280 W_{A}}$, in which $C$ is the contour interval in feet and $W_{A}=\frac{A}{L}$ where $A$ is the area in square miles between the $1,980-2,000$-foot potentiometric contours where they are bounded by the line showing the limit of the area of diversion (fig. 1). Area $(A)$ was determined to be 62.4 square miles and the hydraulic gradient $(I)$ is 0.00208 feet per foot. The transmissivity of the aquifer determined by groundwater flow analysis is about $1,400 \mathrm{gpd}$ per foot.

Electric logs of oil and gas test holes in the southwestern part of Mercer County indicate that the several 
beds of sandstone in the upper part of the Fox Hills and lower part of the Hell Creek have an average aggregate thickness of 90 feet. The aquifer, therefore, would have an average permeability of about $\left(\frac{1,400}{90}\right)$ 16 gpd per square foot.

\section{CONCLUSIONS}

The results of 49 flow and recovery tests in Mercer and Oliver Counties indicate that sandstone beds within the Fox Fills Sandstone and Hell Creek Formation have transmissivities that range from 13 to $3,100 \mathrm{gpd}$ per foot and average 510 gpd per foot. Many of the wells on which aquifer tests were made are completed in the aquifer in the upper part of the Hell Creek Formation. Also, many wells do not entirely tap either aquifer. Therefore, the average figure of $510 \mathrm{gpd}$ per foot is not comparable to the figure for transmissivity of 1,400 gpd per foot obtained by Darcy's law for the aquifer in the upper Fox Hills Sandstone and lower Fell Creek Formation. The average of $16 \mathrm{gpd}$ per $\mathrm{ft}^{2}$ for permeability obtained from the aquifer tests and from the analysis of ground-water flow are in agreement.

\section{REFERENCES}

Birch, Francis, ed., 1942, Handbook of physical constants : Geol. Soc. America Spec. Paper 36, 325 p.

Denson, N. M., and Gill, J. R., 1965, Uranium-bearing lignite and carbonaceous shale in the southwestern part of the Williston basin-A regional study: U.S. Geol. Survey Prof. Paper 463, $75 \mathrm{p}$.
Foley, F. C., Walton, W. C., and Drescher, W. J., 1953, Groundwater conditions in the Milwaukee-Waukesha area, Wisconsin: U.S. Geol. Survey Water-Supply Paper 1229, 96 p.

Jacob, C. E., 1950, Flow of ground water, chap. 5, in Rouse, Hunter, Engineering hydraulics: New York, John Wiley and Sons, Inc., p. 321-386.

Jacob, C. E., and Lohman, S. W., 1952, Nonsteady flow to a well of constant drawdown in an extensive aquifer: Am. Geophys. Union Trans., v. 33, no. 4, p. 559-569.

Johnson, W. D., Jr., and Kunkel, R. P., 1959, The Square Buttes coal field, Oliver and Mercer Counties, N. Dak. : U.S. Geol. Survey Bull. 1076, $91 \mathrm{p}$.

Lloyd, E. R., and Hares, C. J., 1915, The Cannonball marine member of the Lance Formation of North and South Dakota and its bearing on the Lance-Laramide problem: Jour. Geology, v. 23, p. 523-547.

Pipiringos, G. N., Chisholm, W. A., and Kepferle, R. C., 1965, Geology and uranium deposits in the Cave Hill area, Harding County, S. Dak. : U.S. Geol. Survey Prof. Paper 476-A, $64 \mathrm{p}$.

Stanton, T. W., 1920, The fauna of the Cannonball marine member of the Lance Formation: U.S. Geol. Survey Prof. Paper 128-A, p. 1-60.

Taylor, O. J., 1965, Ground-water resources along Cedar Creek anticline in eastern Montana: Montana Bur. Mines and Geology Mem. 40, 99 p.

1968, Ground-water resources of the Northern Powder River valley, southeastern Montana: Montana Bur. Mines and Geology Bull. 66, $34 \mathrm{p}$.

Theis, C. V., 1935, Relation between the lowering of the piezometric surface and the ratio and duration of discharge of a well using ground-water storage: Am. Geophys. Union Trans., v. 16, pt. 2, p. 519-524. 


\title{
PRELIMINARY ANALYSIS OF RATE OF MOVEMENT OF STORM RUNOFF THROUGH THE ZONE OF AERATION BENEATH A RECHARGE BASIN ON LONG ISLAND, NEW YORK
}

\author{
By G. E. SEABURN, Mineola, N.Y. \\ Prepared in cooperation with the New York State Department of \\ Conservation, Division of Water Resources; Nassau County \\ Department of Public Works; Suffolk County Water Authority; and Suffolk: \\ County Department of Health
}

\begin{abstract}
A study of recharge basins on Long Island has provided information on the rate of movement of water through the zone of aeration. Pertinent data were collected during 38 storms from a basin in central Nassau County, where the depth to the water table is 35 feet below the bottom of the basin. In this basin the apparent downward rate of movement averaged 5.0 feet per hour; it ranged from an average of 3.0 feet per hour for storms in November through March to an average of 6.0 feet per hour for storms in April through October.
\end{abstract}

Recharge to the underlying ground-water reservoir of Long Island, N.Y., has been affected in recent years by the waves of urban and suburban development that are rapidly advancing eastward across the island. The construction of impervious surfaces has decreased the opportunity for ground-water replenishment by rainfall. To offset this loss of recharge the local water managers have expended considerable effort to artificially recharge the ground-water reservoir - the sole source of fresh water for about 2.5 million people living in Nassau and Suffolk Counties, Long Island (fig. 1).

Recharge basins were first used on Long Island to collect and dispose of storm runoff from highways and residential and industrial areas in 1935. At present (1969) there are about 2,000 basins in Nassau and Suffolk Counties. Little is known about the impact of the basins on the hydrology of Long Island. Accordingly, the U.S. Geological Survey, in cooperation with the New York State Department of Conservation, Division of Water Resources; the Nassau County Department of Public Works; the Suffolk County Water Authority; and the Suffolk County Department of

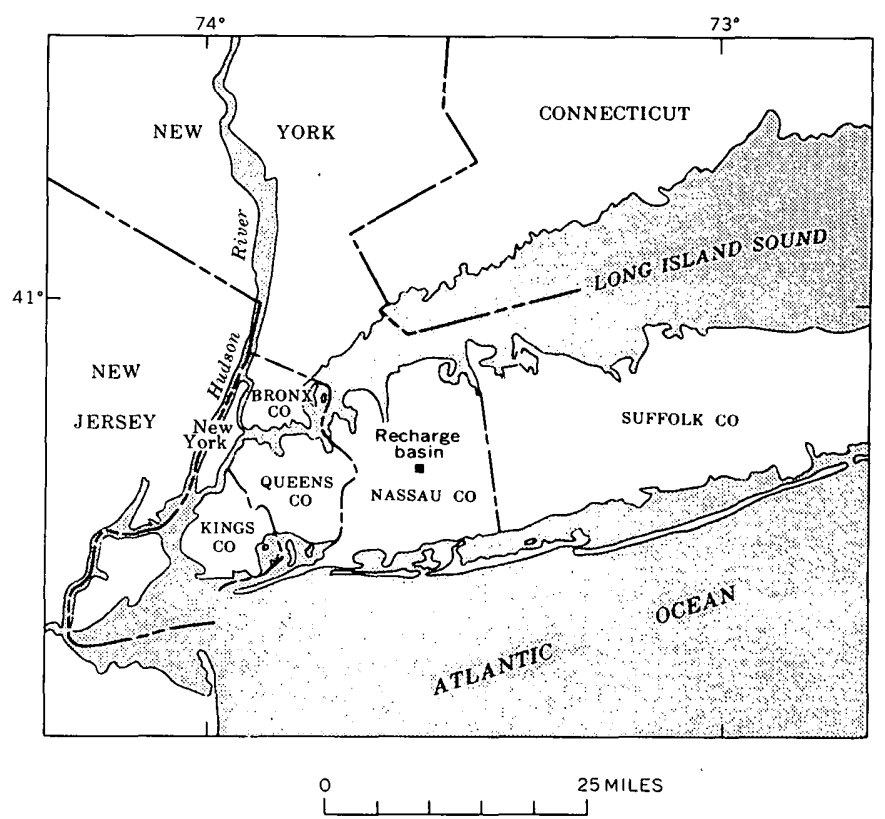

Figure 1.-Location of the recharge basin on Long Island, N.X., described in this study.

Health presently is involved in an investigation mainly designed to develop information on the quantity and quality of storm runoff to the basins. Specifically, data are being obtained on rainfall, inflow, infiltration rate, and on the chemical quality of the rainfall and of the inflow to the basins. The purpose of this paper is to describe the preliminary results of one aspect of the investigation-apparent rates of movement through the zone of aeration beneath one of the basins. 


\section{RECHARGE BASINS}

Most of the recharge basins on Long Island are unlined pits excavated to a depth of about 10 feet below land surface. They are used to dispose of storm runoff and to recharge the underlying ground-water reservoir. This method of storm-runoff disposal has, in most cases, proven to be more economical than the construction of long trunk sewers that discharge into streams or the ocean. The basins range in area from about 0.1 to 30.0 acres, and average about 2.0 acres. Storm runoff is carried by gutters to street inlets interconnected with storm sewers that discharge water into the basins. Figure 2 is a photograph of a typical recharge basin.

The basin considered in this report is in central Nassau County (fig. 1). It is excavated to approximately 12 feet below land surface in glacial outwash consisting of coarse sand and gravel. The outwash deposits are about 50 to 60 feet thick in the vicinity of the basin. The water table is about 35 feet below the basin floor. The area that contributes runoff to the basin is residential and consists of 15.0 acres having an impervious area of about 32 percent; about 11 percent of the drainage area is streets. On the average, about 7.5 acre-feet per year of storm runoff recharges the ground-water reservoir through this basin (Seaburn, 1970).

\section{STUDY TECHNIQUE}

The pertinent instrumentation at the basin is shown in figure 3. A more detailed description of the instru- mentation is given in a previous report (Seaburn, $1970)$.

The apparent rate of movement through the zone of aeration was computed by dividing the distance from the bottom of the basin to the water table by the elapsed time from the beginning of inflow to the basin to the beginning of a rise of the water table (hereafter referred to as the time lag). The water-table rise associated with a particular storm was assumed to have been caused simply by the downward movement to the water table of inflow associated with that storm. The effect of pressure transmission through the capillary fringe, which in the coarse-grained material beneath

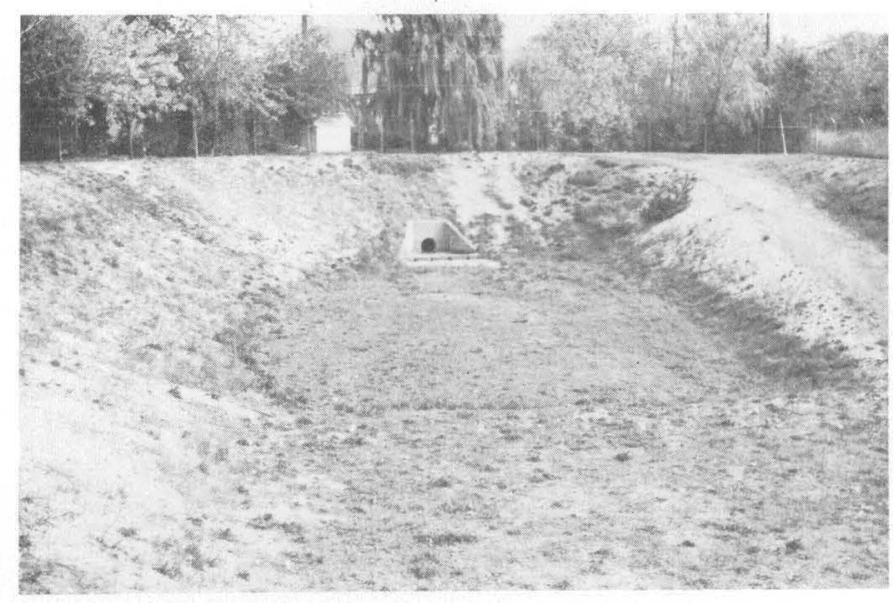

FIgURE 2.-Typical recharge basin on Long Island, N.Y.

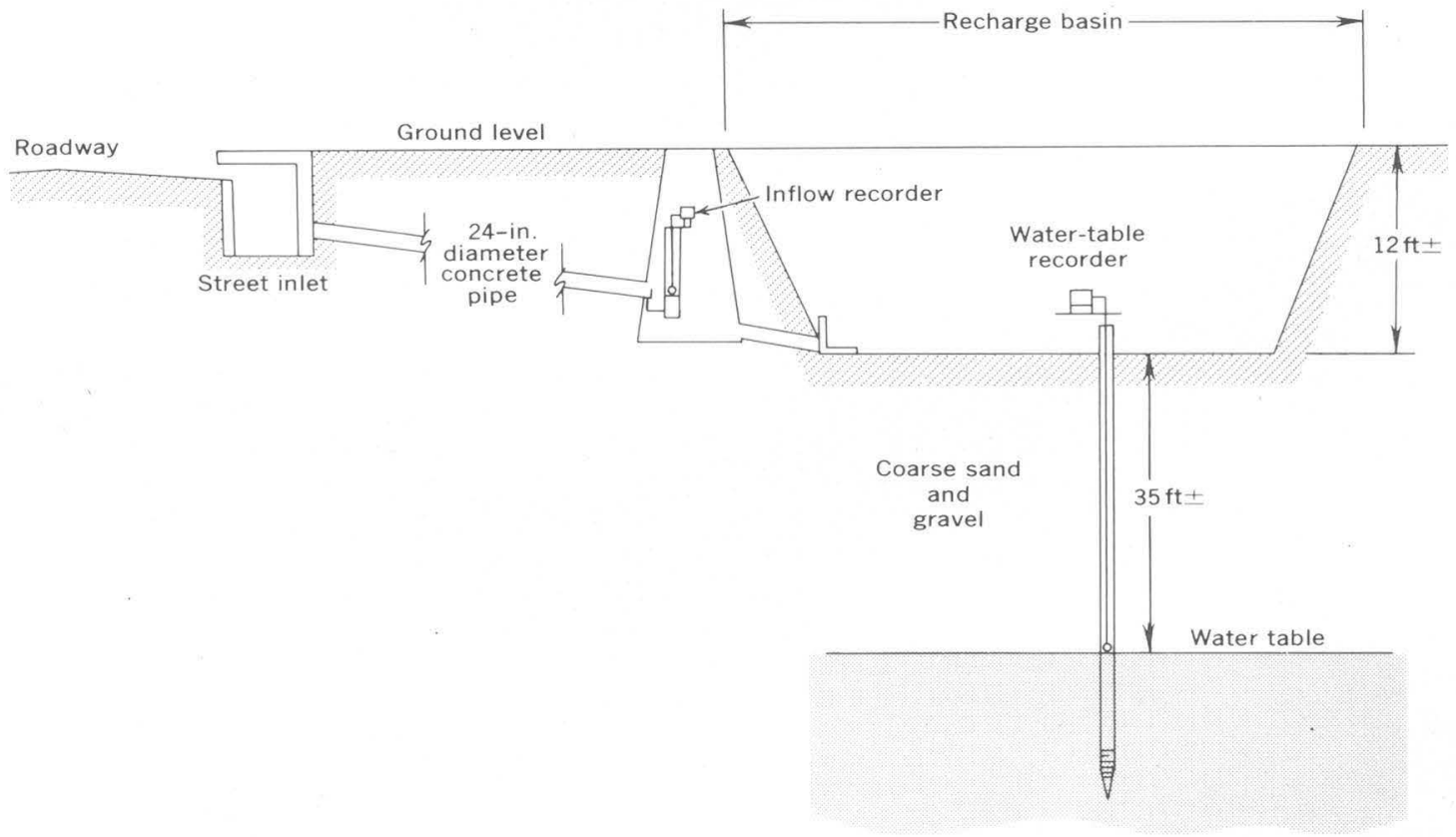

Figure 3.-Sketch of recharge basin, showing the drainage system and location of water-level recorders. (Not to scale.) 
the basin probably is only a few inches thick, is considered negligible. Moreover, numerous other complex factors associated with flow through the zone of aeration are deliberately disregarded and, as a result, the term "apparent rate of movement" is used to describe the observations considered in this report.

\section{RESULTS AND CONCLUSIONS}

Data for 38 storms were collected from June 1967 to December 1968. Rainfall during these storms ranged from 0.18 to 3.99 inches. The time lag and apparent rate of movement through the zone of aeration for each of the storms are listed in table 1. The time lag between

TABLE 1.-Time lag and apparent rate of movement of water through the zone of aeration beneath a recharge basin on Long Island, N.Y.

\begin{tabular}{ccc} 
Date of storm & $\begin{array}{c}\text { Time lag between } \\
\text { inflow to basin and } \\
\text { initial water-table } \\
\text { rise (hours) }\end{array}$ & $\begin{array}{c}\text { Apparent rate of } \\
\text { movement through } \\
\text { zone of aeration } \\
\text { beneath the re- } \\
\text { charge basin } \\
\text { (feet per hour) }\end{array}$ \\
\hline
\end{tabular}

1967:

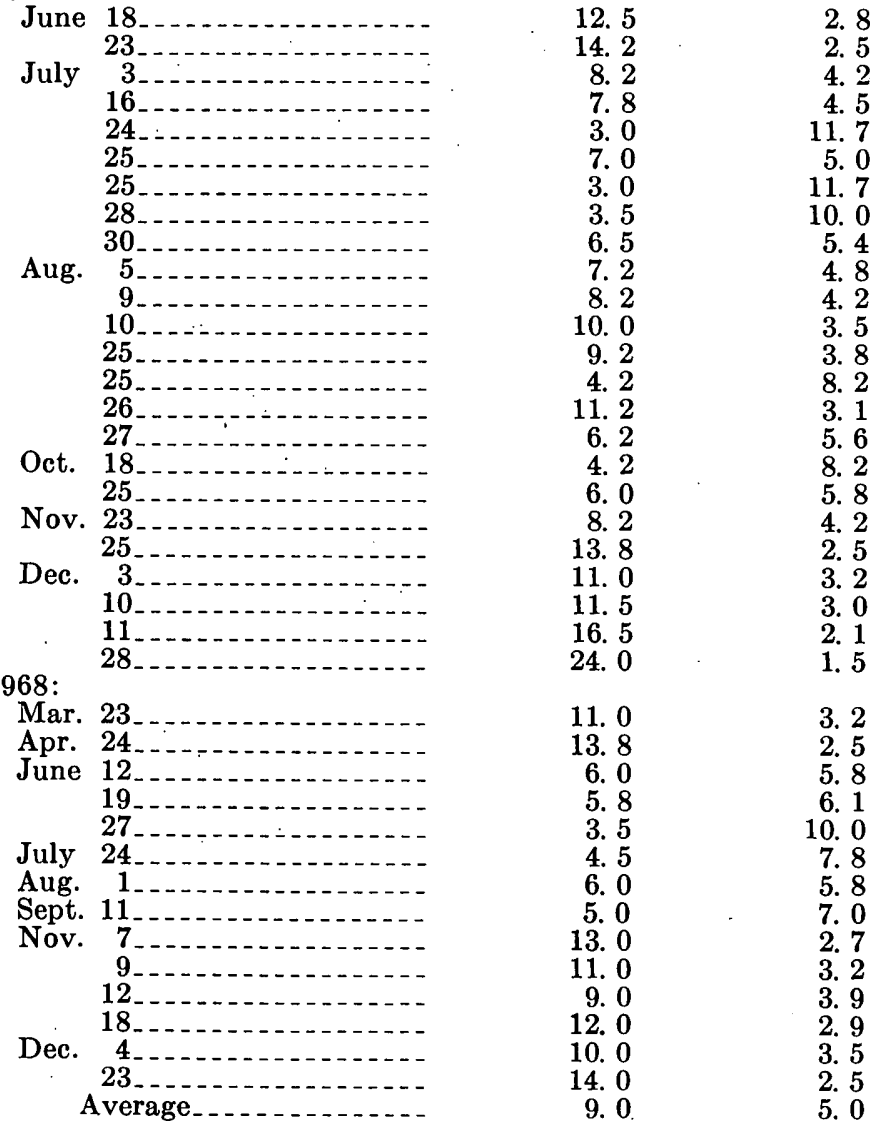

inflow to the basin and the initial rise of the water table ranged from 3 to 24 hours and averaged 9 hours. Variations in the time lag appear to be at least partly related to antecedent soil-moisture conditions and to the magnitude and intensity of rainfall. For example, time lag seems to have been longer after comparatively long periods of dry weather, and it seems to have been shorter for high-intensity storms and for storms of comparatively large magnitude. Presumably, soilmoisture deficiencies decrease the apparent rate of downward movement, and the higher hydraulic head in the partly filled basin during larger storms or during storms of high intensity increases the downward rate of movement.

On the average, the time lag also seems to have increased during the cold-weather months, perhaps because of the greater viscosity of the water. For example, the average time lag for storms during November through March was 12.7 hours, and the average time lag for the warm-weather months, April through October, was slightly more than 7 hours.

The computed average rate of apparent downward movement through the zone of aeration is 5.0 feet per hour for the 38 storms. The average rate during the winter months is 3.0 feet per hour, and that during the summer months is 6.0 feet per hour.

Even after intense storms or ones of long duration and associated large amounts of inflow to the basin, the basin floor commonly is dry within a few hours. This fact also suggests that the infiltration rate and the rate of movement in the zone of aeration are moderately. high.

Others (Isbister 1966, p. 49) have noted time lags of downward movement through the zone of aeration on Long Island ranging from less than 1 to more than 10 months. The average time lag noted by Isbister, in an area where the depth to water is roughly comparable to that beneath the basin described in the present report, is 2-3 months. However, Isbister's observations were made in an area underlain by glacial till of low permeability, and the observations noted in this report are believed to be more nearly representative of conditions in areas underlain by the highly permeable glacial outwash.

\section{REFERENCES}

Isbister, John, 1966, Geology and hydrology of northeastern Nassau County, Long Island, N.Y.: U.S. Geol. Survey Water-Supply Paper 1825, 89 p.

Seaburn, G. E., 1970, Preliminary results of hydrologic studies at two recharge basins on Long Island, N.Y.: U.S. Geol. Survey Prof. Paper 627-C, p. 17. 


\title{
GROUND-WATER INFLOW TOWARD JORDAN VALLEY FROM UTAH VALLEY THROUGH VALLEY FILL NEAR THE JORDAN NARROWS, UTAH
}

\author{
By R. W. MOWER, Salt Lake City, Utah \\ Work done in cooperation with the Utah Department of \\ Natural Resources, Division of Water Rights
}

\begin{abstract}
About 2,500 acre-feet of ground water annually is moving generally northward from Utah Valley toward Jordan Valley through unconsolidated valley fill near the Jordan Narrows, Utal. The computation of underflow was made at a section in which the saturated fill averages about 125 feet in thickness and is between 2,700 and 4,000 feet wide. The fill consists of sediments ranging from clay to coarse gravel in size, and it has an average hydraulic conductivity of about 3,200 cubic feet per day per square foot. Underlying and bounding the fill on the enst and west sides of the narrows are semiconsolidated or consolidated rocks of low average hydraulic conductivity through which there is little underflow.
\end{abstract}

The amount of ground water that enters Jordan Valley from Utah Valley as underflow through unconsolidated valley fill near the Jordan Narrows was estimated as a part of an investigation of the water resources of Salt Lake County, Utah. The amount of underflow could not be measured directly; but an estimate was made using a version of Darcy's law, $Q=K I A . Q$ is the amount of water flowing through a selected cross section of the saturated material; $K$, the average hydraulic conductivity of the material, is the amount of water in cubic feet per day that flows through a cross-sectional area of 1 square foot under a hydraulic gradient of 1.0 at the prevailing water temperature; $I$ is the hydraulic gradient, a dimensionless number; and $A$ is the area of the saturated cross section in square feet. The location of the section where underflow was computed is near the center of sec. 23 , T. 4. S., R. 1 W. (fig. 1). The methods used in obtaining information needed to determine the underflow are discussed below.

The main aquifer near the Jordan Narrows consists of unconsolidated stream and lake deposits of clay, silt, sand, and gravel. Underlying and bounding the east and west sides of the aquifer are fine-grained, semiconsolidated and consolidated materials of low hydraulic conductivity. The lithology and extent of the unconsolidated materials that compose the aquifer were determined from examination of exposures in excavations and streambanks, from well drillers' logs, from examinations of drill cuttings from one test well, and from the interpretation of several geophysical explorations. The geophysical methods included a seismicrefraction survey (R. E. Mattick, written commun., 1966), a gravity survey (D. R. Mabey, written commun., 1967), and an electrical resistivity exploration (Zohdy and Jackson, 1969). The results of the electrical resistivity exploration, when studied together with well $\operatorname{logs}$ and water levels in wells, did not disclose any thick section of saturated unconsolidated fill beneath Point of the Mountain. The greatest section of sand and gravel revealed along the electrical sounding profile $\left(C-C^{\prime}\right.$ in fig. 1$)$ is 300 feet thick and lies between U.S. Highway 91 and the Union Pacific Railroad (Zohdy and Jackson, 1969, fig. 2). This material thins rapidly toward the east, south of Point of the Mountain, and in that area it probably lies above the saturated zone.

The material underlying the unconsolidated fill is of low hydraulic conductivity and probably is the same as or similar to the semiconsolidated material that crops out along the Jordan River. (See fig. 1.) The materials that compose the aquifer and some of the materials of low hydraulic conductivity underlying the aquifer are represented by strip logs along section $A-A^{\prime}$ in figure 2, and by the following lithologic log: 




Base from USGS topographic map, scale, 1:24,000

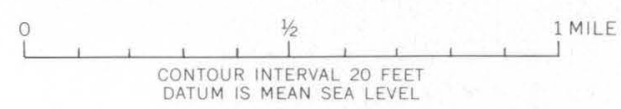

EXPLANATION

\section{0}

Approximate contour on the ground-water surface Contour interval 10 feet; datum mean sea level

$$
\leftarrow
$$

Direction of ground-water movement

$$
1
$$

Observation well

Number indicates well mentioned in text or used in another illustration
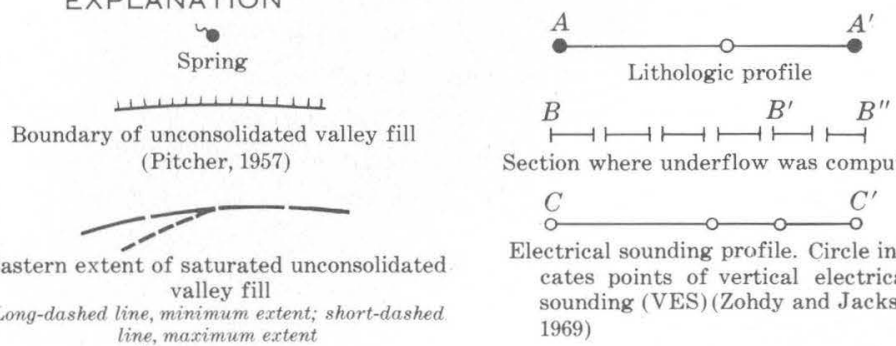

Section where underflow was computed C $C^{\prime}$

Electrical sounding profile. Circle indicates points of vertical electrical sounding (VES) (Zohdy and Jackson, 1969)

Figure 1.-Map of the Jordan Narrows and vicinity, Salt Lake and Utah Counties, Utah, showing locations of profiles and selected observation wells, extent of saturated unconsolidated valley fill, and contours on the ground-water surface in November 1965. 
ALTITUDE

IN FEET

4700

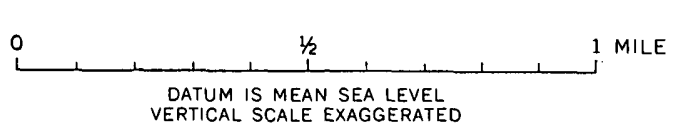

VES

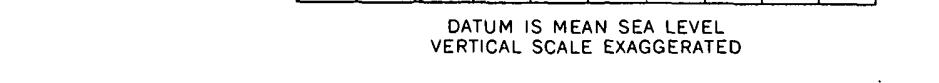

$4600-$

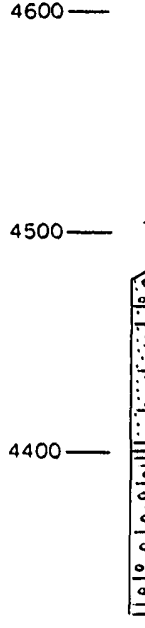

4300
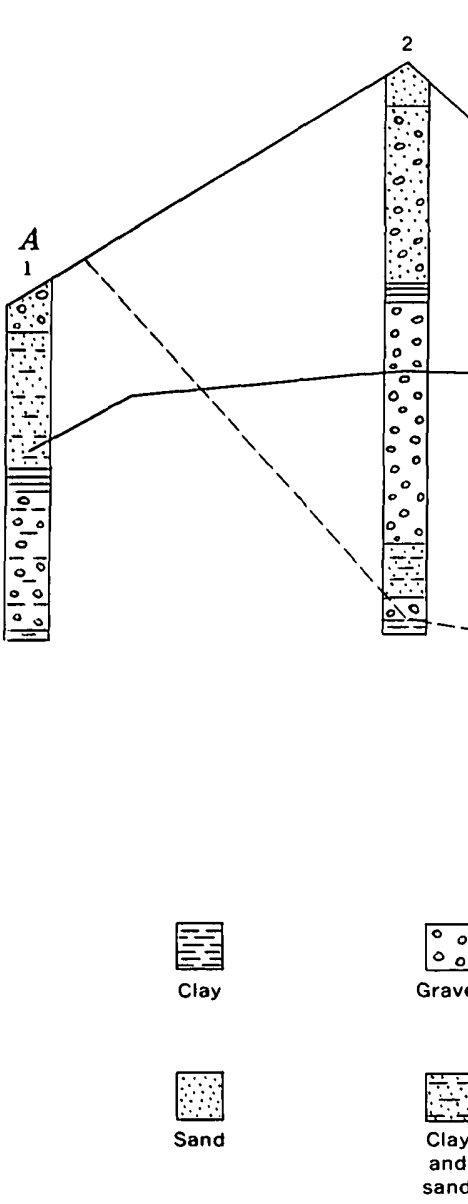

- S200-

EXPLANATION

FIGURE 2.-Lithologic profile showing strip logs generalized from geologists' and drillers' logs and lithologic interpretations of vertical electrical soundings (VES) (Zohdy and Jackson, 1969), near the Jordan Narrows, Utah.

Log of well 4 in SE1/4NW1/4SE1/4 sec. 23, T. 4 S., R. 1 W.

Log by R. D. Feltis, U.S. Geological Survey, from well samples. Altitude of land surface, $4,494.7$ feet above mean sea level.

\section{Description}

Colluvium; composed of small cobbles, gravel, sand, silt, and clay .............. Gravel, very fine to very coarse; and very fine to very coarse sand; some small cobbles. Silt, brown; contains sand and fine to medium gravel

Gravel, very fine to very coarse; and very fine to very coarse sand.

Silt, brown and bluc-gray, clayey; contains brown sand and fine gravel. (feet)
Gravel, very fine to very coarse; blue-gray sand, very fine to very coarse; and small

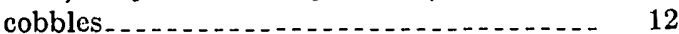
122

Silt, brown, and blue-gray, clayey and sandy; contains very fine to very coarse gravel.... Silt, dark gray; and very fine to very coarse

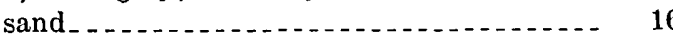
Sand, very fine to very coarse; and very fine to medium gravel...................... Gravel, very fine to very coarse; in a matrix of sand, silt, and clay; hard drilling....... 6

Quartzite............................... 
Water is unconfined in the upper part of the aquifer near the Jordan Narrows, and it is poorly confined in the lower part by thin discontinuous beds of silty and sandy clay. The confining beds themselves are moderately permeable, however, and there is appreciable movement of water between the upper and lower parts of the aquifer. The ground-water surface (figs. 1 and 2) shows that the water is moving from Utah Valley toward the Jordan Valley. Some of the water is discharged by wells, evapotranspiration, and springs north of the Jordan Narrows, however, before it reaches the main artesian aquifer in the Jordan Valley.

The quantity of underflow through the Jordan Narrows was computed at a narrow section of the saturated unconsolidated valley fill. The west end of the section can be located accurately because it abuts an outcrop of semiconsolidated fine-grained material of low average hydraulic conductivity. The location of the east end of the section is less precise because it is marked by the intersection of the water table and semiconsolidated or consolidated material of low hydraulic conductivity, which is concealed beneath the north slope of Point of the Mountain (fig. 1). By correlation of water-level data, data showing depth to material of low hydraulic conductivity in wells, and data from the electrical sounding profile, it was possible to determine a range for the location of the east end of the section. The minimum width of the section so estimated is about 2,700 feet ( $B-B^{\prime}$ in figs. 1 and 3 ), and the maximum width is about 4,000 feet $\left(B-B^{\prime \prime}\right.$ in figs. 1 and 3$)$.

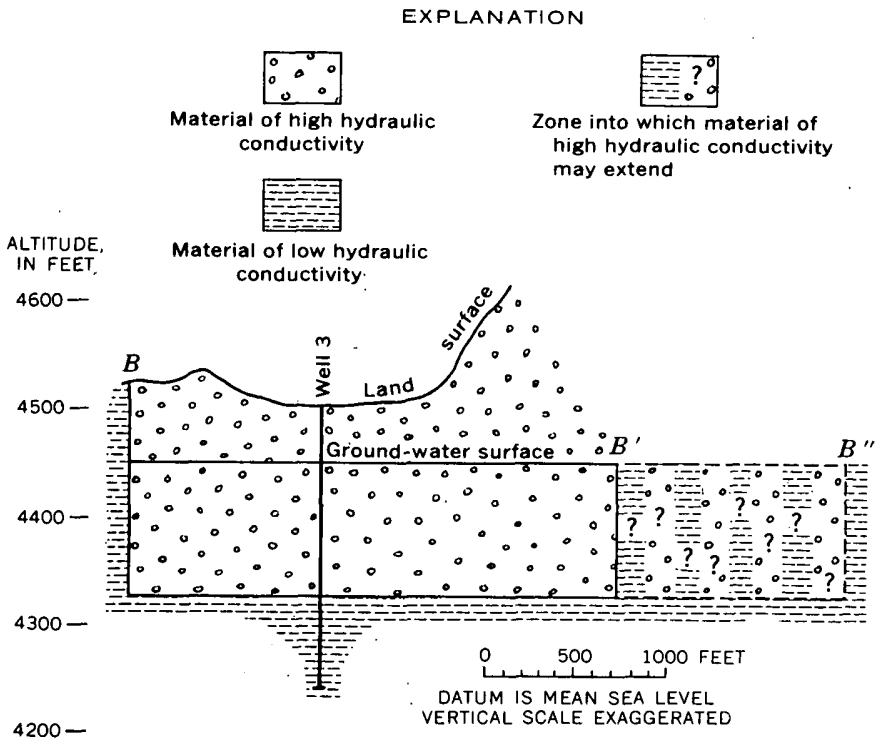

Figure 3.-Section along $B-B^{\prime}-B^{\prime \prime}$ (fig. 1), showing idealized zones used in computation of underflow from Utah Valley to Jordan Valley near the Jordan Narrows.
The thickness of saturated unconsolidated valley fill near the middle of the section across the aquifer is about 125 feet at well 3 . If 125 feet is used as an average thickness for the entire section, therefore, the saturated cross-sectional area $(A)$ is 340,000 square feet for the minimum width of 2,700 feet and 500,000 square feet for the maximum width of 4,000 feet.

The average hydraulic gradient $(I)$ of the underflow at the section was determined from water levels in wells 2,3 , and 4 .in figures 1 and 2 , and is about 0.0002 .

An aquifer test was made in order to estimate the hydraulic conductivity $(K)$ at the section by pumping well 3 and observing the amount and rates of waterlevel drawdown in wells 3 and 4 . The hydraulic conductivity was determined from the nonequilibrium equation of the flow of ground water that was developed by Theis (1935) and from a.method developed by Theis, Brown, and Meyer (Bentall, 1963, p. 331340 ). The average hydraulic conductivity is high, about 3,200 cubic feet per day per square foot.

The Darcy equation, applied to the section of minimum width $\left(B-B^{\prime}\right)$, yields:

$$
\begin{aligned}
Q= & (3,200 \mathrm{ft} \text { per day })(0.0002)\left(340,000 \mathrm{ft}^{2}\right) \\
& =218,000 \mathrm{ft}^{3} \text { per day, }
\end{aligned}
$$

or about 1,800 acre-feet per year. Applied to the section of maximum width $\left(B-B^{\prime \prime}\right)$, the equation yields :

$$
\begin{aligned}
Q= & \left(3,200 \mathrm{ft} \text { per day) }(0.0002)\left(500,000 \mathrm{ft}^{2}\right)\right. \\
& =320,000 \mathrm{ft}^{3} \text { per day, }
\end{aligned}
$$

or about 2,700 acre-feet per year. The quantity of underflow through the semiconsolidated and consolidated material bounding the aquifer is small, certainly not exceeding 10 percent of the quantity of underflow in the aquifer. The total underflow from Utah Valley toward Jordan Valley, therefore, is between 2,000 and 3,000 acre-feet per year; and it probably averages about 2,500 acre-feet per year.

\section{REFERENCES}

Bentall, Ray, 1963, Methods of determining permeability, transmissibility, and drawdown: U.S. Geol. Survey Water-Supply Paper 1536-I, p. 243-341.

Pitcher, G. G., 1957, Geology of the Jordan Narrows quadrangle, Utah: Brigham Young Univ., Research Studies, Geology Series, v. 4, no. 4, $46 \mathrm{p}$.

Theis, C. V., 1935, The relation between the lowering of the piezometric surface and the rate and duration of discharge of a well using ground-water storage: Am. Geophys. Union Trans., v. 16, p. 519-524.

Zohdy, A. A. R., and Jackson, D. B., 1969, Electrical sounding profile east of the Jordan Narrows, Utah, in Geological Survey Research 1969: U.S. Geol. Survey Prof. Paper 650-C, p. C83-C88. 


\title{
WATERBORNE STYRENE IN A CRYSTALLINE BEDROCK AQUIFER IN THE GALES FERRY AREA, LEDYARD, SOUTHEASTERN CONNECTICUT
}

\author{
By I. G. GROSSMAN, Hartford, Conn. \\ Work done in cooperation with the Connecticut Water \\ Resources Contmission
}

\begin{abstract}
Styrene, a synthetic hydrocarbon which is only slightly soluble in water, was readily waterborne in the Gales Ferry area, Connecticut in 1961-64. Following shallow burial in 1960, styrene moved downward with vadose water through thin glacial till into the bedrock aquifer, which consists in large part of schist and quartzite of the Plainfield Formation of Cambrian(?) age and in small part of granite gneiss of the Sterling Plutonic Group of Mississippian (?) or older age. Movement from two contaminating sources to cones of depression at six domestic wells was principally westward and northward along foliation joints and cross joints. Maximum overall movement exceeded 300 feet. Removal of the sources of contamination produced water of satisfactory chemical quality in 2 yenrs or less.
\end{abstract}

Field investigations in southeastern Connecticut (Cervione and others, 1968; Thomas and others, 1968) disclosed more than a dozen instances of ground-water contamination in an area of about 440 square miles. Among these, intrusion of salt water was the most common. Another contaminant, though less common, is of unusual interest because detailed chemical and hydrologic data collected and later made available by State and private agencies permit a credible reconstruction of the sequence of events. The properties of this contaminant, styrene, are fairly representative of those of several other hydrocarbons that are widely used and stored in southeastern Connecticut and in other areas. Moreover, the availability of detailed geologic maps permitted use of the pollutant to trace the circulation of ground water in crystalline bedrock, a subject largely neglected in Connecticut since Ellis' (1909) pioneer study.

Acknowledgments.-Data on bedrock wells at Gales Ferry were obtained from the State Water Resources
Commission in Hartford, from Robert Brumble, and from George Crafts, Jr. Clarence E. Brown, Jr., Assessor, furnished maps and residential data; Ken Stober, of Dow Chemical Co., contributed hydrochemical data; and Miss Helen Paulson made available her extensive file of pertinent information.

\section{SEQUENCE OF EVENTS}

The postwar growth of industry along the Thames River estuary between Norwich and Groton stimulated nearby suburban growth. Construction of one-family homes equipped with individual water wells and septic tanks began at Gales Ferry (fig. 1) in 1959 and continued until about 15 new homes had been completed by 1961. An obnoxious odor in water drawn from one of the 15 wells was subsequently reported from several other wells in the area (New London Evening Day, 1962). Analyses of water samples for a study sponsored by the State Water Resources Commission (Benoit and Adamson, duplicated report, p. $4^{1}$ ) identified the principal odorous contaminant as styrene, an aromatic hydrocarbon. Because of the intense heat it generates during combustion, waste styrene had been used to burn brush in clearing land for the development. At least two leftover drums partially filled with styrene had reportedly been buried beneath 1 to 4 feet of fill at two separate places at Gales Ferry.

In 1961 and 1962, all known contaminating material was removed from the ground, and filters of the acti-

\footnotetext{
1 Benott, R. J., and Adamson, T. E., 1962, Synthetle organic chemicals in ground water-contamination of wells in Ledyard, Conn.: General Dynamics, Electric Boat Research and Develop. Dept., Groton, Conn., duplicated rept., 29 p.
} 


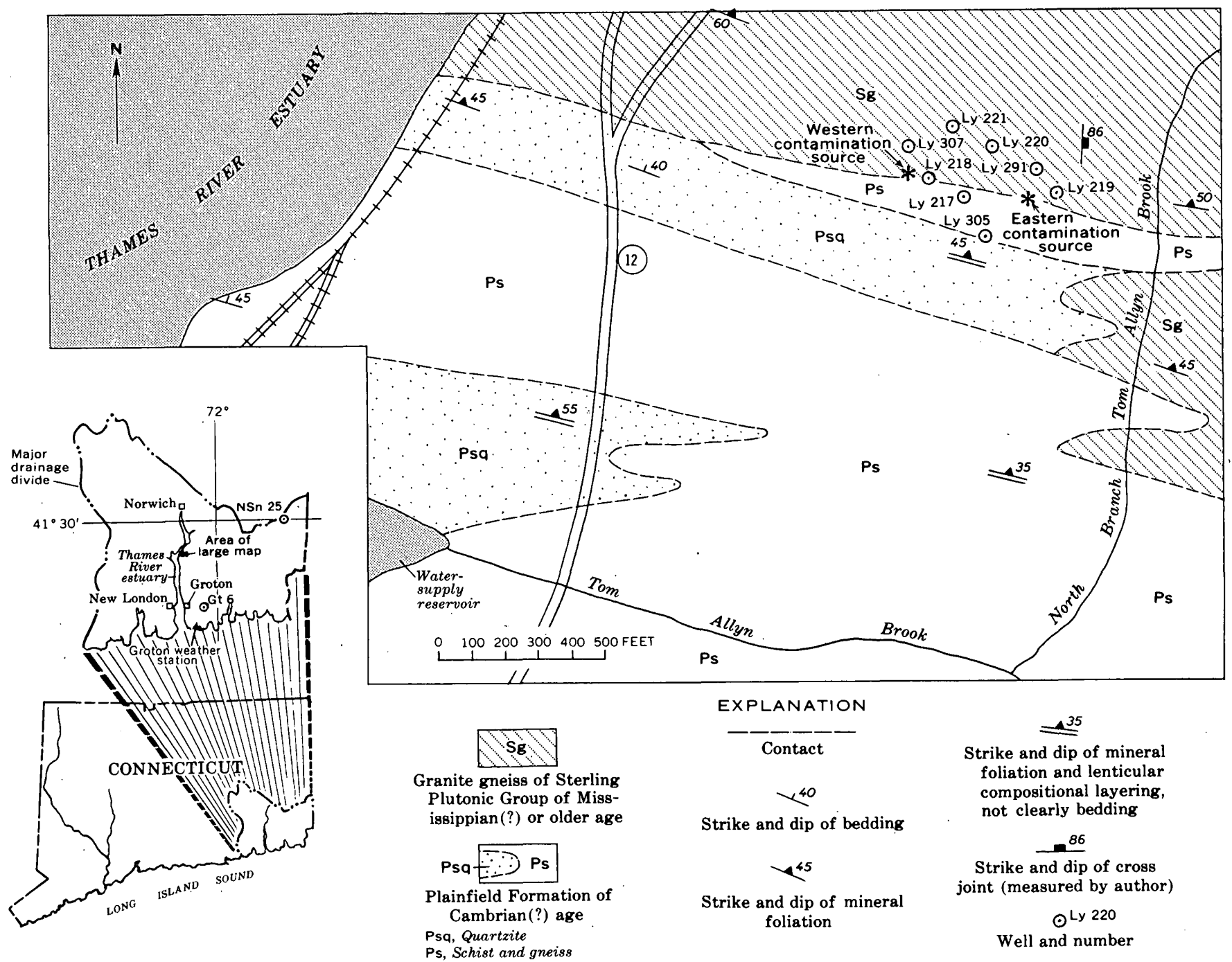

Fiqure 1.-Geohydrologic map of the Gales Ferry area, Connecticut, showing locations of wells and sources of contamination. Geology adapted from Goldsmith $(1960,1967 \mathrm{~b})$.

vated charcoal type were installed on some of the wells in 1962. After removal of the contaminants, and filtration, most wells yielded water of satisfactory quality by early 1964 . By the end of 1964 , no styrene was detected in any of the wells previously affected, even in samples drawn before filtration.

\section{TOPOGRAPHY AND GEOLOGY}

The subdivision is on a small hill that is about 100 feet above sea level and that slopes generally westward, except in the east near Tom Allyn Brook. The direction of ground-water movement is also generally westward, toward the Thames River estuary. The principal surficial deposit in the immediate area is a light-gray silty, sandy, and gravelly till with some clay and boulders, mapped as ground moraine (Goldsmith, 1960). The till is locally thin; the depth to bed- rock in seven wells ranges from 7 to 16 feet and averages 10 feet. The underlying bedrock includes two units (fig. 1). The younger unit underlies the northern part of the area and consists of granite gneiss of the Sterling Plutonic Group of Mississippian(?) or older age (Goldsmith 1966, p. J2). It is an orange-pink to light-gray, medium-grained, gneissic biotite granite; the main constituents are quartz, microcline, and oligoclase, with 2-7 percent biotite and iron oxides. The older unit underlies the rest of the area and consists of the Plainfield Formation of Cambrian(?) age (Goldsmith, 1967a, 1967b). A small subunit of this formation occupies a west-trending central band at the north edge of the older unit and consists of quartzfeldspar schist and gneiss with accessory minerals and some thin-bedded quartzite. A larger west-trending subunit directly to the south consists largely of 
quartzite that is thick- to thin-bedded and white or tan to light gray; with thin interlayers of schist and gneiss. The bedding, mineral foliation, and lenticular compositional layering of the bedrock in the immediate area all strike about N. $70^{\circ} \mathrm{W}$. and $\operatorname{dip} 45^{\circ} \mathrm{N}$. to $50^{\circ} \mathrm{N}$.

A conspicuous set of joints, here called foliation joints, is exposed west of the area in a roadcut on the east side of State Route 12. These joints strike N. $70^{\circ}$ W. and $\operatorname{dip} 50^{\circ} \mathrm{N}$., parallel to the bedrock layering and foliation. They influence the topography and the shape of some outcrops in the area. Goldsmith (written commun., Feb. 6, 1969) reports that joints of another set noticeably affect the topography in the Gales Ferry area; these cross joints commonly strike N. $20^{\circ}$ E. to N. $10^{\circ}$. E., although some strike as far west as $10^{\circ} \mathrm{W}$.; all are vertical or dip steeply (see fig. 1, northeast part). Despite glacial modification of the drainage, the lower reach of Tom Allyn Brook is roughly parallel to the strike of the foliation joints. However, this direction also coincides with the shortest distance to the Thames estuary here. The north branch of Tom Allyn Brook also flows westward toward the estuary, but it turns abruptly southward and follows a course approximately parallel to the cross joints (fig. 1).

The spacing of joints ranges from less than 1 inch to more than 6 feet and averages about 3 feet. The joints have been studied by the writer chiefly at a few accessible points along the principal roads such as State Route 12 (fig. 1), where blasting and drilling for roadcuts have accentuated the jointing. The spacing of joints in undisturbed rock is therefore undoubtedly wider, probably 4 or 5 feet. Many joints are strongly weathered at the surface to widths of as much as 1 inch and to depths of several inches. Some strongly weathered and widened joints are near unweathered, tightly closed ones belonging to the same set. A third set, sheeting joints, is developed in the granite gneiss. These joints are subparallel to the general land surface. Additionally, random or local joints that do not form persistent sets, and irregular widely spaced fractures, cut the bedrock. Hydrogeologic and chemical data collected for this study indicate how joints control the movement and storage of water in the bedrock.

Logs available for 3 of 8 wells in the immediate area, Ly 221, Ly 291, and Ly 305 (fig. 1), indicate the spacing and continuity of joints in the bedrock, which is largely schist. The 3 wells tap a combined total of 9 fractures in an apparent bedrock thickness of 550 feet, so that the average spacing of the fractures is about 60 feet. As previously indicated, the average spacing of joints at a few bedrock outcrops is thought to be about 4 or 5 feet. Few of the vertical or near-vertical joints are likely to be intersected by vertical wells. Thus, if the effect of the angle of dip on joint spacing is neglected, less than 1 joint out of 10 exposed at the surface is continuous enough and wide enough to provide ground water to a bedrock well in the area.

\section{CHEMISTRY}

Styrene is a synthetic aromatic hydrocarbon with the formula $\mathrm{C}_{6} \mathrm{H}_{5} \mathrm{CH}: \mathrm{CH}_{2}$, produced from ethylene and benzene for use in synthetic rubber manufacture, in polystyrene molding resins, in styrene copolymers, and as an intermediate in the manufacture of many synthetic chemicals. It is a clear, colorless or faintly colored liquid with a disagreeable odor, that polymerizes to a dark tarry substance after prolonged burial or exposure to air. In liquid or vapor form it is irritating to the eyes, skin, and respiratory tract. High concentrations have an anesthetic action. The maximum allowable concentration is generally considered to be $200 \mathrm{mg} / \mathrm{l}$ in air for 8 hours. The threshold limit value is $100 \mathrm{mg} / \mathrm{l}$ according to the American Conference of Government Industrial Hygienists (Sax, 1968, p. 1012). Solubility of styrene in water at a temperature of $20^{\circ} \mathrm{C}$ is $290 \mathrm{mg} / \mathrm{l}$.

Analyses for styrene were made at the Electric Boat Co. at Groton, Conn. A few analyses were made by ultraviolet spectrophotometry comparing the $247.5-\mu$ absorption peak of water samples with standard aqueous solutions of solvent-grade styrene (Benoit and Adamson, duplicated report, p. 5). However, most analyses were semiquantitative determinations made by organoleptic (odor) tests on progressive dilutions of ground-water samples. The odor-threshold level by this method, which was based on personnel-panel tests on standard solutions, was determined to be between 0.1 and $0.2 \mathrm{mg} / \mathrm{l}$. Benoit and Adamson state that the correlation between the results of using the two methods was reasonably good. However, their comparative data based on the two methods (Benoit and Adamson, duplicated report, p. 22), indicate that values obtained from organoleptic determinations are generally lower than those from spectrophotometric tests, presumably because of styrene volatility and consequent loss during repeated dilution.

\section{HYDROLOGY}

Figure 1 shows the locations of 8 wells in the immediate area; 6 reportedly produced styrene-contaminated water at least once in the period 1961-64, and 2 (Ly 305 and Ly 307) did not. Table 1 lists pertinent well data. All the wells that were affected are close to the two burial sites; other wells situated farther away continued to produce water of satisfactory quality throughout this period. 


\begin{tabular}{|c|c|c|c|c|c|c|}
\hline Well No. & $\begin{array}{l}\text { Depth } \\
\text { of well } \\
(\mathrm{ft})^{1}\end{array}$ & $\begin{array}{l}\text { Static } \\
\text { water } \\
\text { level } \\
(\mathrm{ft})^{1} 1\end{array}$ & $\begin{array}{c}\text { Yield } \\
\text { (gnm) }\end{array}$ & $\begin{array}{c}\text { Specific } \\
\text { capacity } \\
\text { (gpm per } \\
\text { ft) }\end{array}$ & $\begin{array}{c}\text { Depth } \\
\text { to } \\
\text { bedrock } \\
\text { (ft)1 }\end{array}$ & Principal aquifer \\
\hline $\begin{array}{l}\text { Ly } 217 \ldots \\
\text { Ly } 218 .- \\
\text { Ly } 219 .- \\
\text { Ly } 220 .- \\
\text { Ly } 221 .- \\
\text { Ly } 291 .- \\
\text { Ly } 305-- \\
\text { Ly } 307 .-\end{array}$ & $\begin{array}{r}103 \\
98 \\
143 \\
135 \\
320 \\
98 \\
132 \\
65\end{array}$ & $\begin{array}{l}21 \\
20 \\
20 \\
22 \\
16 \\
20 \\
30 \\
18 \pm\end{array}$ & $\begin{array}{l}5 \\
61 / 4 \\
61 / 4 \\
5 \\
5 \\
24 \\
21 / 2 \\
5\end{array}$ & $\begin{array}{r}0.06 \\
.08 \\
.05 \\
.04 \\
.02 \\
.39 \\
.02 \\
<.12\end{array}$ & $\begin{array}{c}7 \\
10 \\
12 \pm \\
10 \\
8 \\
10 \\
16 \\
16 \pm\end{array}$ & $\begin{array}{l}\text { Schist. } \\
\text { Do. } \\
\text { Do. } \\
\text { Granite gneiss. } \\
\text { Schist. } \\
\text { Do. } \\
\text { Quartzite. } \\
\text { Granite gneiss. }\end{array}$ \\
\hline
\end{tabular}

1 Below land surface.

Glacial till in the immediate area probably is largely unsaturated. This interpretation is based on evidence of free hydraulic connection between the till and bedrock in representative wells (figs. 2 and 3 ) and on well records which indicate that the static water level is below the top of the bedrock in all of the eight wells (table 1). Therefore, movement of vadose water through the unsaturated zone in till and bedrock is dominantly vertical. Vertical movement is indirectly corroborated by the finding of the remaining styrene, in the form of black tarry polystyrene, close to the original area of the two contamination sources when they were excavated, with little evidence of lateral spreading.

Available data suggest that ground water in the immediate area is recharged directly from local precipitation. Figure 2 shows daily precipitation at Groton for a 3-week period in March 1962 (weather station shown on inset map, fig. 1). Also shown for comparison are styrene determinations of water samples collected semiweekly from two wells, Ly 219 and Ly 291. It is evident that the styrene content of water from both wells declined, though at an undeterminable rate, during periods of little or no rainfall, and rose following substantial rainfall. The precise timing and magnitude of the response are uncertain, owing to the spacing of the samples. However, the greatest rise took place after the heaviest rainfall on March 12.

The rises are very rapid, with a lag of only about 1 day. The presence of detergent in ground water in the area (Benoit and Adamson, duplicated report, p. 1) undoubtedly increased the solubility and mobility of waterborne styrene. All or most of the styrene is believed to have been carried in solution in water. Perlmutter, Lieber, and Frauenthal $(1964$, p. C172), in a study made in the South Farmingdale area of Long Island, concluded that ground water contaminated with detergents moved through glacial outwash (sand and gravel) at a rate estimated to be about 1 foot per day (under a hydraulic gradient of about 12 feet per

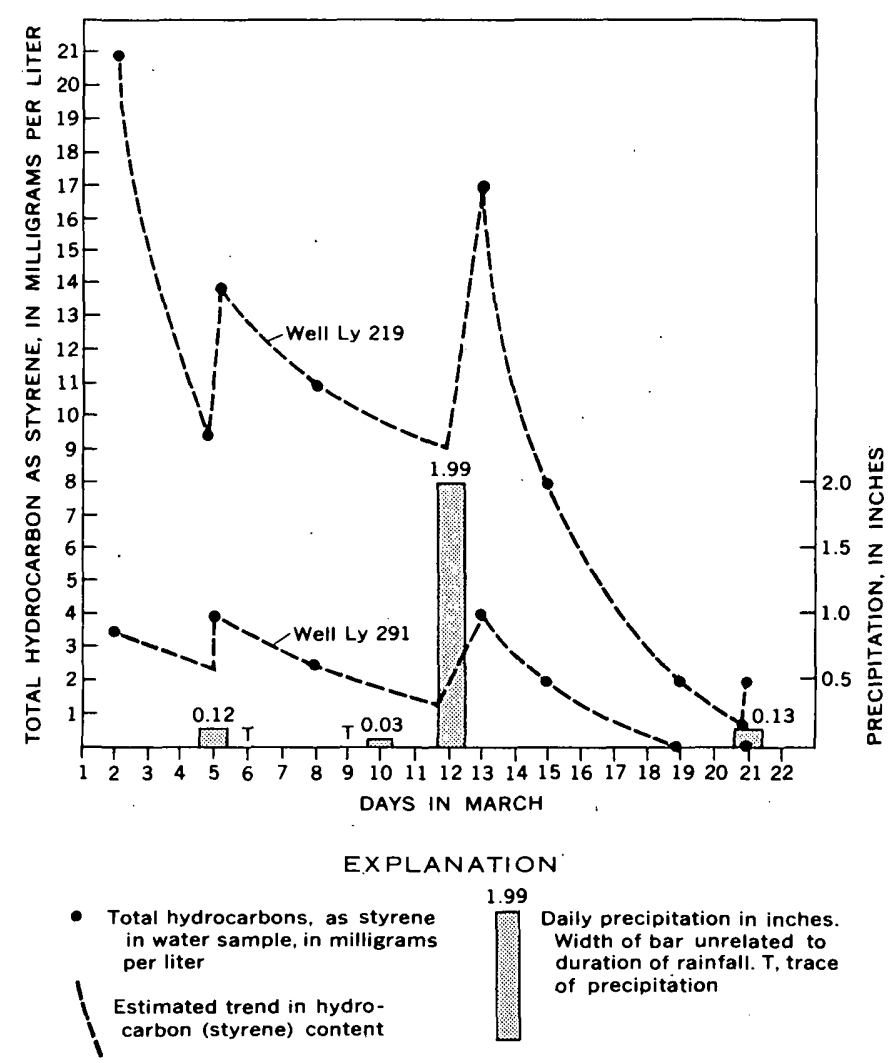

FIGURE 2.-Relation between daily precipitation at Groton and total hydrocarbon content (as styrene) of water from two bedrock wells at Gales Ferry, Conn., in March 1962.

mile), except in the vicinity of pumped wells where its rate of movement was greater. The rapid movement of vadose water in the vicinity of wells Ly 219 and $\mathrm{Ly}$ 291 is due to the thinness of the till and its sandiness, as previously indicated, and also to its loosening and consequent loss of natural compaction following excavations for construction and roadbuilding in the subdivision. The hydraulic gradient of ground water in the immediate area is steeper than that in the South Farmingdale area by a factor of about 20 . In the bedrock, the abundance of planar joints and of their intersections, which form plunging pipes, facilitated the rapid movement of ground water which amounted to about 50 feet per day horizontally. Also, local pumping from closely spaced wells produced intersecting cones of depression, further steepening the hydraulic gradient in the direction of the pumping wells.

Seasonal and annual changes in styrene content of ground water from four wells combined are shown in figure 3. The locations of the wells, Ly 217, Ly 218, Ly 219, and Ly 291, are shown in figure 1. The graph shows pronounced seasonal fluctuations, with a maximum styrene content in the late summer and fall alternating with a minimum styrene content in the spring. Annual precipitation (about 48 inches) generally is 


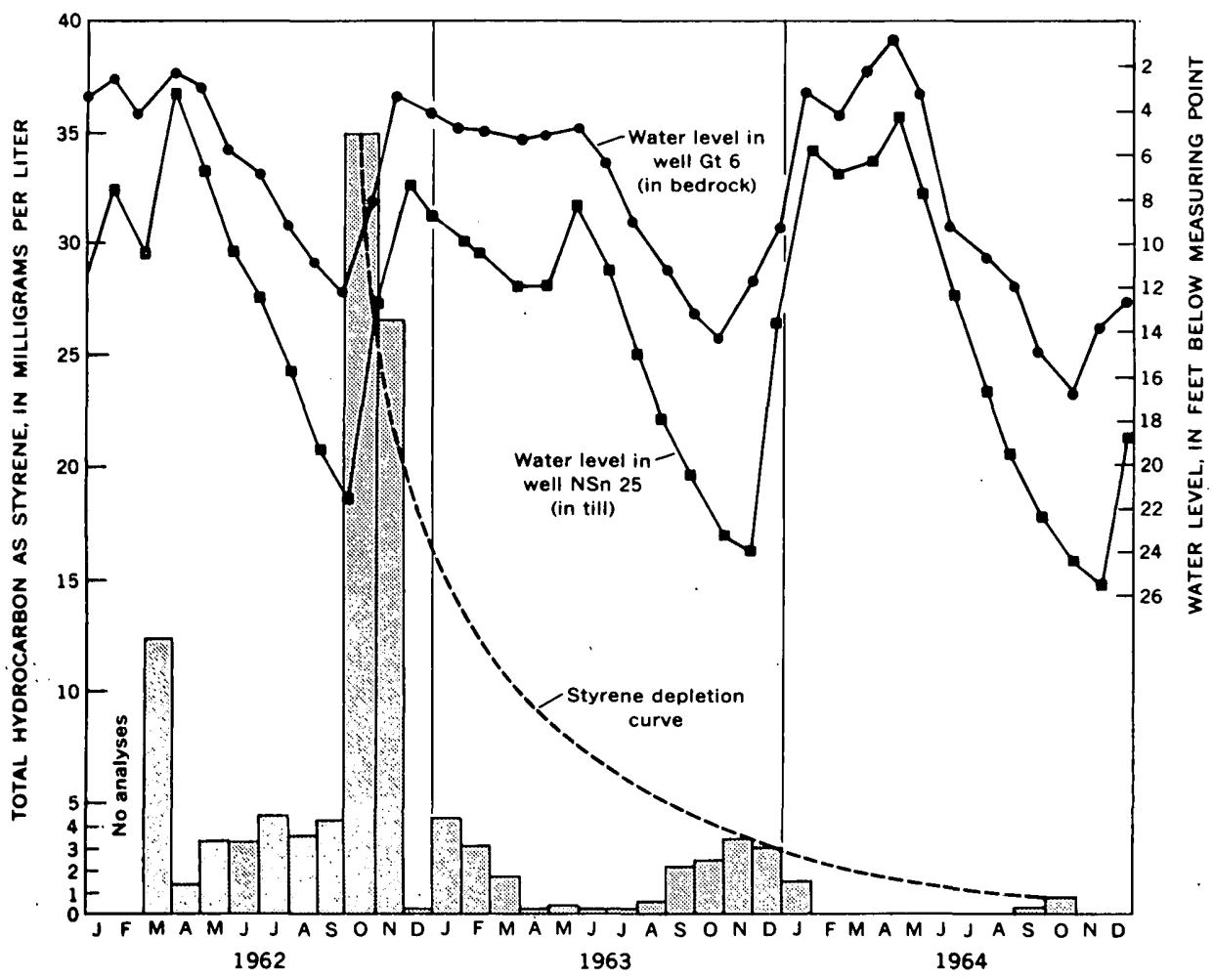

Figure 3.-Relation between water levels in two observation wells and total hydrocarbon content (as styrene, patterned area) of water from four bedrock wells at Gales Ferry, Conn., 1962 to 1964.

evenly distributed throughout the year, but groundwater discharge exceeds recharge during the late spring and summer, chiefly owing to heavy evapotranspiration losses. Hydrographs of two nearby observation wells (locations shown in fig. 1), Gt 6 in crystalline rock and NSn 25 in till (Meikle, 1967, p. 8; Meikle and Baker, 1965, p. 12), indicate that the seasonal low positions of the water table closely coincide in time with the seasonal highs in styrene content of the ground water (fig. 3). The inverse relationship between ground-water level and styrene concentration is seemingly contradicted by the direct relationship between rainfall and styrene concentration in 2 of the 4 wells, as shown in figure 2. Evidently waterborne styrene was slowly moving into the aquifer, but its movement was accelerated during periods of substantial rainfall, especially during the period of relatively effective recharge in the autumn. The inverse relationship is ascribed to concentration of waterborne styrene in a smaller section of the bedrock aquifer and to seasonal expansion of local cones of depression. The cones intermittently deepen and grow in size during the summer because of increased domestic consumption from a thinner saturated section of the bedrock aquifer. Thus, their growing radii intercepted a greater vertical and horizontal extent of the aquifer, including parts con- taminated by waterborne styrene. In addition, high styrene concentration during seasonal lows may reflect lack of dilution by new ground water.

Long-term changes in styrene content of ground water shown in the graph (fig. 3) reflect changing hydrochemical conditions in the aquifer resulting from emplacement and removal of the two sources of contamination shown in figure 1 . The western source was buried in the spring of 1960 , and the eastern source is believed to have been buried sometime in the same year. All known styrene-contaminated soil at the western burial site, amounting to about 5 cubic yards, was removed in November 1961, and at least twice as much material was removed from the eastern burial site in October of 1962 . The graph (fig. 3) shows that the concentration of styrene peaked in the month and year when the second of the two contaminating sources was removed. Thereafter, annual styrene highs were successively smaller, as shown by the styrene depletion curve, until the fall of 1964 when measurable styrene was detectable in only one of the four wells. The data indicate that styrene may persist in a crystalline bedrock aquifer for at least 2 years after removal of contaminating sources under the conditions described. They also demonstrate that delineation of the movement and storage of contaminated ground water is 
facilitated by study of water levels, a largely neglected technique in southeastern Connecticut.

The sequence in which the wells produced waterborne styrene indicates how water moves through the bedrock. Six wells are reported to have produced water with recognizable styrene odor, in the following order: Ly 291, Ly 219, Ly 217, Ly 218, Ly 220, and Ly 221. The early arrival of waterborne styrene in the first two wells, Ly 291 and Ly 219, is attributed to their closeness to the eastern burial site, where bedrock was reportedly struck at a depth of 6 to 8 feet below the road surface, and where styrene-contaminated soil and fill were found to extend down to bedrock. Movement of waterborne styrene is believed to have been largely north-northeastward, downdip along north-dipping foliation joints. Movement dominantly along cross joints is considered unlikely because they are vertical or near vertical, and the $\log$ for Ly 291 indicates that it penetrated four water-bearing fractures in an apparent thickness of only 88 feet of bedrock. Within the foliation joints, however, movement was undoubtedly more rapid at their intersections with cross joints; these larger openings, by their geometry, formed northeastplunging pipes. Even in the unlikely possibility that the contaminating slug was confined to these pipes and did not spread out as it moved downdip about 75 feet (about 50 feet horizontally), it would have been very close to the two wells-about 15 feet from Ly 291 and about 20 feet from Ly 219. Ly 219 responded much more strongly to local recharge (rainfall) than did Ly 291, as shown in figure 2. Its greater sensitivity is presumably due to its larger cone of depression; its yield is only about a quarter that of Ly 291, and both supplied about the same amount of water for domestic needs.

The third well, Ly 217, is about halfway between the two sources of contamination and updip from both, if movement is thought to have taken place solely along foliation joints. As ground water presumably moved westward along foliation joints in the schist toward the Thames estuary, pumping from Ly 217 would expand its cone of depression northward along northtrending cross joints, thereby intercepting the westmoving slug of contaminated water. It is possible, however, that another small source of styrene was buried in the area. Also, it is known that some subsurface water circulates above the bedrock surface. Omission of this aspect of the study, owing to incomplete data, is not believed to affect the validity of the conclusions developed here.

Well Ly 305 is closer to the eastern source of contamination than Ly 217 but is farther south. Well Ly 305 never produced waterborne styrene, either because of its location or because of a difference in the bedrock joint pattern; it is the only well in the immediate area known to tap quartzite. That the joints it penetrates are few and tight is indicated by its yield of $21 / 2$ gallons per minute, the lowest recorded in the area. Ly 218, the fourth well, is very close to the western burial site and may have been the only one contaminated by it. Its delayed response is due in part to the smaller size of the western contamination source and to delayed pumping -its users were the last of the six affected homeowners to take up residence. A puzzling feature of the western burial site is that contaminated soil extended to a depth of only 6 feet when it was excavated in November 1961, although digging continued to a depth of 10 feet.

The fifth well to be affected, Ly 220, is situated at a greater distance from the eastern burial site than any of the previously affected wells. The overall flow-line distance to this well may be estimated by the algebraic addition of its three component movements: westward along foliation joints for a distance of about 110 feet, northward along vertical joints for about 60 feet, and diagonally downward for about 180 feet. The estimated total of about 350 feet is only an approximation; it is greater if flow lines followed a more circuitous route, and smaller if movement was largely along northplunging pipes formed by joint intersections, as previously indicated. Sheeting joints may have shortened the overall distance to this well, which taps granite gneiss. Ly 221 was the sixth and last well affected. It reportedly produced waterborne styrene only twice, in May 1962. Ly 307 was unused until March 1962 and, with the exception of Ly 305, was the only well in the immediate area unaffected by waterborne styrene.

The sequence of decontamination in the wells corroborates some conclusions based on their contamination. As previously indicated, the western burial site was excavated in early November 1961, and measurable styrene in water from Ly 218 disappeared after autumn 1962. The eastern burial site was excavated in October 1962, and no styrene was detected in water from Ly 291 after March 1963 nor from Ly 219 after September 1963. Ly 217, situated farther down the hydraulic gradient from the eastern site, yielded water samples with measurable styrene until autumn 1964.

\section{CONCLUSIONS}

(1) Till and bedrock in southeastern Connecticut are vulnerable to contamination by hydrocarbons. Stratified drift-the principal aquifer-is believed to be more vulnerable because it is far more permeable than till or bedrock, and water is pumped from it at much higher rates.

(2) Within the bedrock aquifer, waterborne hydrocarbons, as exemplified by styrene in this investigation, 
may move readily from one bedrock unit or subunit to another, despite the fact that the hydrocarbons are only slightly soluble in water. In the Gales Ferry area, contamination persisted for at least 2 years following removal of buried sources, and the contaminants migrated more than 300 feet along joints into cones of depression resulting from small-scale pumping for individual family dwellings.

(3) Detailed mapping of joints is necessary to trace pollution in the bedrock, the principal aquifer serving privately owned rural and suburban needs in southeastern Connecticut and nearby areas.

\section{REFERENCES}

Cervione, M. A., Jr., Grossman, I. G., and Thomas, C. E., Jr., 1968, Hydrogeologic datn for the lower Thames and southeastern constal river basins, Connecticut: Connecticut Water Resources Bull. 16, $65 \mathrm{p}$.

Ellis, E. E., 1909, A study of the occurrence of water in crystalline rocks, in Gregory, H. E., Underground water resources of Connecticut: U.S. Geol. Survey Water-Supply Paper 232, p. 54-103.

Goldsmith, Richard, 1960, Geologic map of the Uncasville quadrangle, Connecticut, surficial geology: U.S. Geol. Survey Geol. Quad. Map GQ-138.
1966, Stratigraphic names in the New London area, Connecticut: U.S. Geol. Survey Bull. 1224-J, 9 p.

1967a, Bedrock geologic map of the Montville quadrangle, New London County, Conn. : U.S. Geol. Survey Geol. Quad. Map GQ-609.

$1967 \mathrm{~b}$, Bedrock geologic map of the Uncasville quadrangle, New London County, Conn. : U.S. Geol. Survey Geol. Quad. Map GQ-576.

Meikle, R. L., 1967, Ground-water levels in Connecticut 19651966 ; Connecticut Water Resources Bull. 13, 12 p.

Meikle, R. L. and Baker, J. A., 1965, Ground-water levels in Connecticut 1960-1964: Connecticut Water Resources Bull. 7, $26 \mathrm{p}$.

New London Evening Day, 1962, Report shows private wells at Woodridge are "Questionable" : New London, June 19, 1962.

Perlmutter, N. M., Lieber, Maxim, and Frauenthal, H. L., 1964, Contamination of ground water by detergents in a suburban environment-South Farmingdale area, Long Island, New York, in Geological Survey Research 1964 : U.S. Geol. Survey Prof. Paper 501-C, p. C170-C175.

Sax, N. I., 1968, Dangerous properties of industrial materials, 3d ed.: New York, Reinhold Book Corp., 1,251 p.

Thomas, C. E., Jr., Cervione, M. A., Jr., and Grossman, I. G., 1968, Water resources inventory of Connecticut, pt. 3 , Lower Thames and southeastern coastal river basins: Connecticut Water Resources Bull. 15, 105 p., 4 pl. 


\title{
MEANDERING OF THE ARKANSAS RIVER SINCE 1833 NEAR BENT'S OLD FORT, COLORADO
}

\author{
By FRANK A. SWENSON, Denver, Colo.
}

Abstract.-Bent's Old Fort, constructed on the Santa Fe Trail in 1833 in southeastern Colorado, has been established as a National Historical Monument. The U.S. National Park Service is interested in determining the relative position of the fort, at the time it was occupied, to the meandering Arkansas River. Available data indicate there has been relatively little shift in the meanders of the river at this location.

Before 1846 the Arkansas River formed the international boundary between Mexico and the United States. The Santa Fe Trail, leading from the Missouri River at Independence, Mo., to Santa Fe, was an important commercial artery. The trail led across the dry plains of Kansas to the Great Bend of the Arkansas River and then westward along the north bank. Near present Dodge City, Kans., the Santa Fe Trail forked. One branch continued across Mexican territory to the southwest, but the main branch continued on the north side of the Arkansas River toward the west.

In 1833 William and Charles Bent, with their partner Ceran St. Vrain, established a trading post and fort on the north bank of the Arkansas River where the trail crossed the river and headed up Timpas Creek toward Raton Pass to the southwest. The remains of this fort, now preserved as Bent's Old Fort National Historical Site, is in Otero County 8 miles east of La Junta in southeastern Colorado.

At the request, and with the informal cooperation, of the U.S. National Park Service, an investigation was made to determine, if possible, the relative location of the meandering Arkansas River during the time Bent's Old Fort was occupied from 1833 until it was abandoned and destroyed in 1849.

\section{LOCATION OF BENT'S OLD FORT}

Bent's Old Fort was built of adobe on the edge of a low terrace projecting southeastward into the flood plain of the Arkansas River. An early visitor described the fort as lying 300 yards from the river. Other descriptions indicated that the ford across the river was east of the fort. This meager information is all that has been found regarding the Arkansas River at the time the fort was occupied, from 1833 until 1849. No maps or other pertinent data are available that date back to the time the fort was occupied.

\section{CHARACTER OF THE ARKANSAS RIVER}

The Arkansas River, in the reach under consideration, is a broadly meandering stream. It flows approximately 6 miles to cover a linear distance of 3 miles. These meanders are developed on a flood plain that, in general, is uniformly less than $3 / 4$ mile wide. The flood plain is entirely developed in unconsolidated materials and underlain by 30 to 40 feet of fill. The river gradient is about 5 feet per mile, and the sediment load carried is moderately heavy, consisting largely of silt and sand in this reach of river. The flow of the Arkansas River has ranged from no flow to 200,000 cubic feet per second during the period of stream-gaging record at La Junta, 8 miles upstream. Large diversions of water are made for irrigation, which accounts in part for the wide range in discharge of the stream. Rapid snowmelt in the mountains or cloudbursts within the basin also cause heavy flooding within the area. The maximum flood recorded was on June 4, 1921, and it resulted from a cloudburst during the period of heavy snowmelt.

\section{MIGRATION OF MEANDERS}

Few specific data are available regarding the rate of lateral migration of meanders in a stream. When sudden channel shifts transfer territory from one country to another, as happened on the Rio Grande at El Paso, Tex., or from one State to another, as has happened along the Missouri River between Iowa and Nebraska, much publicity results. The presence of many oxbow 
lakes in various degrees of filling along many of our streams tends to indicate that lateral shifts of channel and migration of meanders are exceedingly common. Wolman and Leopold (1957) present a table compiling data on lateral migration of rivers across valleys. Some of the data on which this table is based are admittedly crude, but the wide range in rates of lateral movement is of interest. Some of the streams show no appreciable movement in periods of up to 50 or 60 years; others are believed to have shifted laterally hundreds of feet a year over long periods.

It would appear that the Arkansas River in eastern Colorado, with its flood plain developed on erodible, unconsolidated material, could be expected to have appreciable lateral shifts and downstream migration of meanders. The fact that it carries a moderate load of sand and smaller sized material, and ranges widely in discharge, would serve to increase meandering of the stream. The presence of meander scallops on the edges of the terraces bordering the flood plain and more or less filled oxbow lakes tends also to confirm such movement in the past.

\section{PAST COURSES OF THE ARKANSAS RIVER NEAR BENT'S OLD FORT}

Early descriptions state that the Arkansas River was about 300 yards from the fort between 1833 and 1849 , but they do not say if it was this close on the south or east. The location of the ford on the Santa Fe Trail indicates that the river ran east of the fort. No maps or charts showing the relative position of the fort and the Arkansas River are known.

The first survey of the area was made during July and August 1869, when the U.S. General Land Office laid out the section lines south of the river. In the course of this survey a meander line was run which was intended to depict the ordinary high-water line and the sinuosities of the river. This was accomplished by starting at a known point where the section line intersected the river and chaining from this point on a stated bearing to another station located on the ordinary high-water line. A total of 14 such points; shown on figure $1 A$, were so located. The notes from this survey were taken into the office, plotted, and the course of the river, as depicted in figure $1 A$, was sketched on the plat.

During March 1882 a similar General Land Office survey was made to lay out the sections north of the Arkansas River. No meander line along the north bank of the river was run, but wherever section lines crossed the river, points were located on both banks, presumably at the ordinary high-water line. Here again the survey notes were taken into the office, the data were
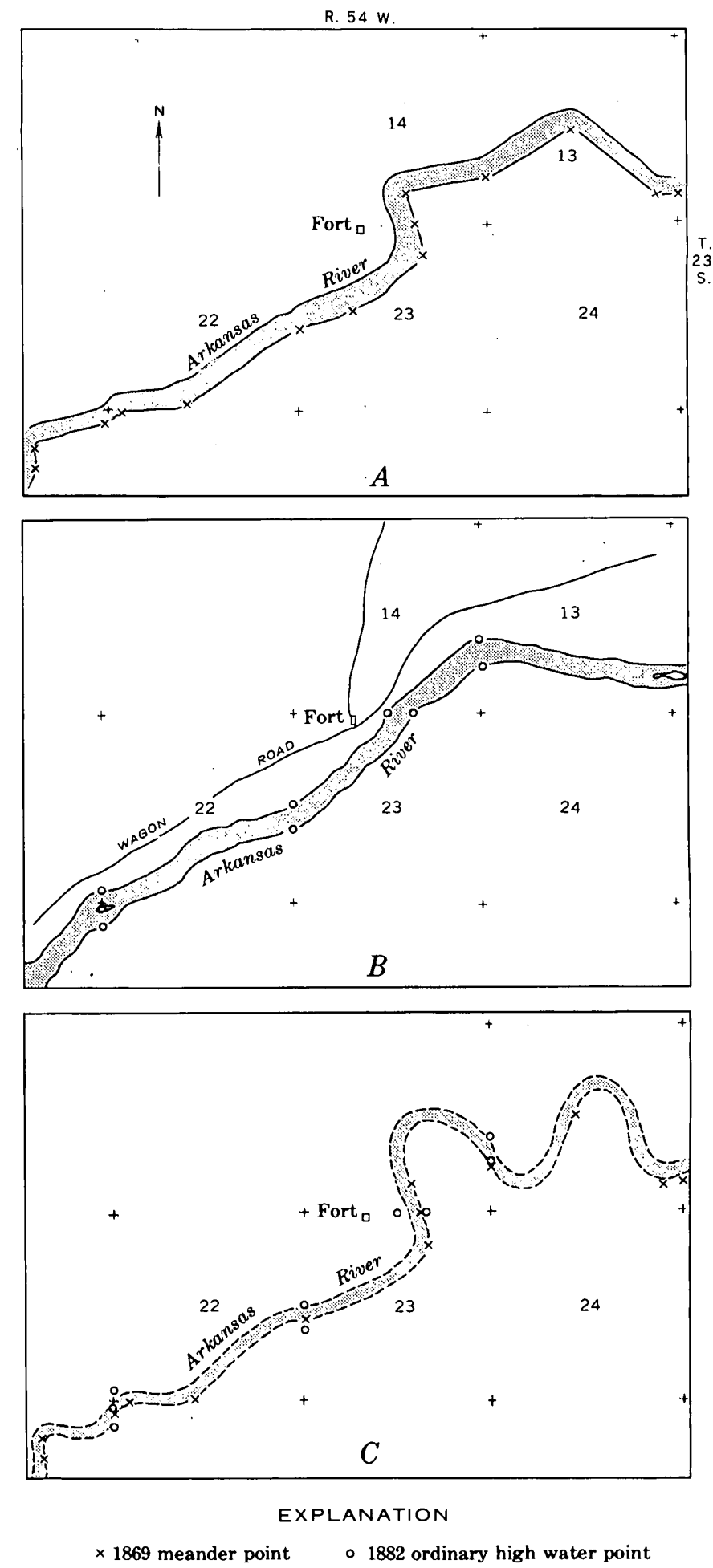

Figure 1.-Meanders of the Arkansas River near Bent's old Fort. $A$, General Land Office plat of July-August 1869 survey south of river in T. 23 S., R. 54 W.; $B$, General Land Offle plat of March 1882 survey north of river; $C$, composite of points from $A$ and $B$ with an interpretation (sketched in) of the course of the river as it probably actually existed at that time (1869). 
plotted, and the course of the river was depicted as shown on figure $1 B$. This plotting would indicate a rather straight stream, entirely out of character with the river as we know it today.

When the points established by the 1869 and 1882 surveys are plotted together, there is much better control on the course of the river. The fact that there is very close agreement at all locations where the points from the separate surveys fall on section lines tends to indicate that both surveys were remarkably accurate. Some shifts of the river during the 13-year interval might be expected, and also there is the personal factor - selecting a point to establish the expected ordinary high-water mark of the stream. With the cumulative control provided by the points from the separate surveys, the writer has made an interpretation of the course of the Arkansas River as of the 1869 survey. This interpretation (fig. $1 C$ ) shows a meandering stream very much like the present Arkansas River. The stream, as plotted, is about 1,000 feet from Bent's Old Fort which closely approximates the 300 yards reported. The crossover of the flow of water from one meander to the other would occur east of the fort, and this would be the logical location of the ford where the Santa Fe Trail crossed the Arkansas River. Thus, it would seem that the location of the Arkansas River in relation to the fort, at the time the fort was in use between 1833 and 1849, has been roughly established.

The earliest aerial photographs available for this reach of the Arkansas River were taken November 20, 1936. There is a long time period between the 1869 1882 surveys and 1936 , but there appears to have been little significant lateral migration of the meanders or shifting of the Arkansas River during the intervening 67 years (fig. 2). The largest shift of the channel was south of the fort where the river moved about 900 feet north of the meander point established in 1869 . Immediately east of the fort there appears to have been no lateral migration of the upstream limb of the meander. This might be considered unusual as the current from the fairly straight upstream reach of the stream impinges against the bank at this point. The reason that lateral migration has not taken place to any great extent is that the point of impact is at the edge of the flood plain and the streambank is high, extending down from the surface of the stream terrace directly to the water surface.

Near the apex of the meander in section 14 and along the downstream limb, between 1869 and 1936, a lateral shift of the meander totaling more than 500 feet in places has occurred. There has been major shifting of the course of the river along the meander in section 13 also, except where the meander impinges on the edge of the flood plain.

Between November 1936 and July 1947 (fig. 3) there was very little shifting of the course of the Arkansas River in the large meanders in sections 13 and 14 . Upstream, however, in sections 22 and 23 , major changes in the stream took place. The rather straight course of 1869-82, more or less maintained through 1936, became very sinuous by 1947 . Another major change also took place during this short period-the Arkansas River became a braided stream. Islands were few and of small size in 1936, but they became numerous and of large size by 1947 , and this tendency has remained as shown by the 1964 (fig. 4) map. Since 1936 there has been a large increase in the amount of water diverted from the river for irrigation, and this removal of water during low flows of the summer is believed to be re-

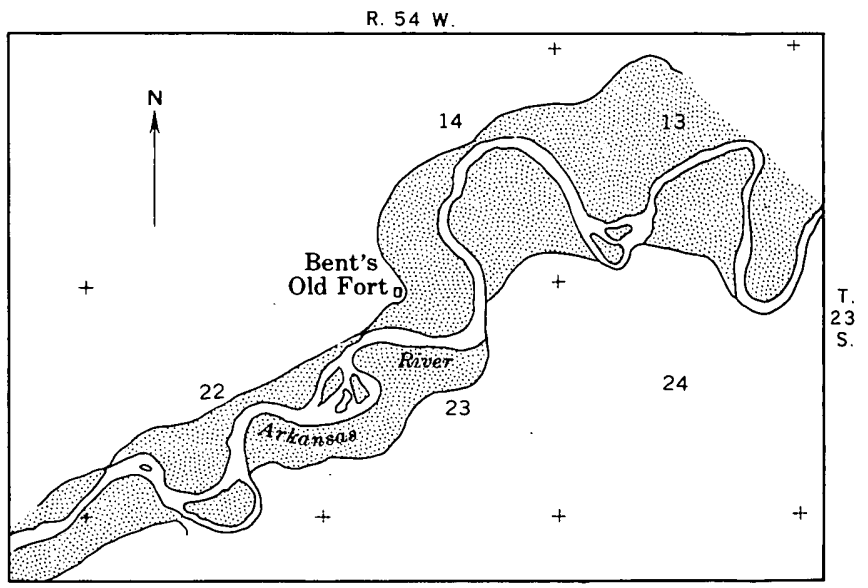

Figure 3.-Arkansas River course and flood plain (patterned), July 1947, mapped from aerial photographs. Note increase in number and size of islands since 1936 (fig. 2). terned), November 1936, mapped from first aerial photographs available. 
R. 54 W

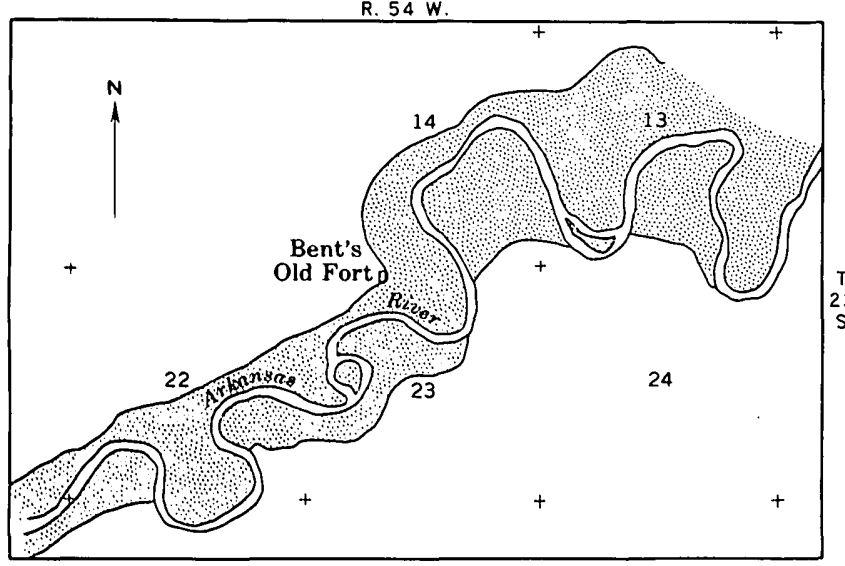

Frourn 4.-Arkansas River course and flood plain (patterned), June 1964, mapped from aerial photographs. sponsible for the development of the more braided character of the Arkansas River.

\section{CONCLUSIONS}

Despite the fact that the Arkansas River, in the reach near Bent's Old Fort, has well-developed mean$T_{23}$ ders and the river is flowing on easily erodible material, there has been relatively little shift of the stream since 1869. Little progressive migration of meanders downstream has occurred.

\section{REFERENCE}

Wolman, M. C., and Leopold, L. B., 1957, River flood plainsSome observations on their formation: U.S. Geol. Survey Prof. Paper 282-C, p. 87-109. 


\title{
TRENDS IN RUNOFF
}

\author{
By P. H. CARRIGAN, JR., and E. D. COBB, \\ Washington, D.C.
}

Work done in cooperation with the U.S. Atomic Energy Commission

\begin{abstract}
Trend analysis of long-term precipitation records suggests that runoff is free of trend since at least 1830 over most of the world. The findings, reviewed in this report, of other investigators of hydrologic trends indicate that trends in runoff throughout much of the world seem to be nonexistent since the early part of the last century.
\end{abstract}

A trend in runoff is considered to exist when a tendency for a hydrologic variable to increase or decrease persists over a long period of time (several decades).

The presence of trends in hydrology can have considerable significance on decisions relative to the development of water resources. For instance, low-flow storage requirements might be increased if a negative or decreasing trend in runoff exists. The presence of trends makes the statistical analysis of hydrologic data more difficult; one consequence is that the derived statistical inferences are less reliable. Such inferences play a part in the selection of sites for nuclear reactors and other nuclear facilities that are dependent on streamflow for cooling water and whose operation would be affected seriously by flooding.

Several investigators have studied secular trends in runoff or in climatic variables affecting runoff. Results of their work are briefly reviewed in this paper, and the results of additional trend analysis by the authors are presented. The purpose of this report is to examine the existence or nonexistence of trends in runoff for the period from about 1830 to 1960 . Only the occurrence of trends representing large areas is considered as it is recognized that localized trends or inhomogeneities may exist because of local environmental changes such as may occur around large cities or large industrial complexes.

Acknowledgments.-This investigation was financed in part by the Division of Reactor Development and
Technology, U.S. Atomic Energy Commission. Tabulation of precipitation data on punchcards was obtained from the National Weather Records Center, Environmental Science Services Administration. Some computations were performed at the Numerical Analysis Laboratory, University of Arizona, Tucson, Ariz.

\section{PRIOR INVESTIGATIONS OF RUNOFF TRENDS}

Among those who have studied trends in annual runoff are C. C. McDonald and W. B. Langbein, M. W. Busby, V. M. Yevdjevich, and John Hidore.

McDonald and Langbein (1948) plotted 5-year moving averages for seven streamflow stations, with 35 to 73 years of record each, in the Pacific Northwest. The smoothed runoff declined in each plot, but McDonald and Langbein did not consider a continued decline likely. The annual runoff in the Columbia River basin appeared to be affected by antecedent as well as the current year's precipitation. The response of runoff to a relatively short-term downward trend in precipitation seems to create a longer termed declining trend in runoff. However, the continued downward trend in runoff in the Columbia River basin may be due to causes other than precipitation, as the long-term precipitation indices (1800-1944) and the long-term precipitation on the basin (1916-1944) appear to be free of declining trends. Unaccounted water usage or various activities of man could conceivably be responsible for the Columbia River trends.

Busby (1963) compared mean-annual runoff for the period $1921-45$ to that for $1931-60$ at 25 streamflow stations in the United States. No geographically persistent difference in runoff between the two periods was noted.

Yevdjevich (1963) assembled records of annual runoff for 140 long-term streamflow stations (40-150 
years) in North America, Europe, and elsewhere in the world. From statistical analyses of these records he concluded, "There is no evidence that the climatic factors as related to water resources have changed significantly in the last 150 years." Furthermore, he found that the effective annual precipitation (for the most part annual runoff') is a random process.

Hidore (1966) computed the 50-year linear trend of annual runoff at 31 streamflow stations located throughout the United States. From a study of his work, a general nationwide trend in runoff was found.

Annual flood series for 45 streamflow stations in the United States with 43 to 75 years of record appear to be trend free, according to Carrigan and Huzzen (1967). Similarly, the annual series of 1-day and 7-day annual minimum flows for another set of streamflow stations in the eastern United States, with 45-47 years of record, seem free of trends (Matalas, 1963).

\section{PRIOR INVESTIGATIONS OF PRECIPITATION TRENDS}

Many investigations of trends in precipitation have been reported. Most studies limit consideration of trend to the annual precipitation series observed at a few stations in a limited region of the world. A few other studies encompass analyses of trends in seasonal precipitation or in storm rainfall.

Either annual rainfall, averaged over western Europe, appears to trend upward between 1677 and 1940, or an abrupt increase in precipitation occurred about 1750 ; perhaps an inhomogeneity in the records is indicated (Brooks, 1954).

Smith (1963) studied seasonal trends in Great Britain. The March rainfall at Stonyhurst was stationary from 1851 to about 1910 and trended downward from 1910 to 1951 , while that at Kew was stationary for the period 1851 to 1951. June rainfall in England was stationary from 1730 to about 1830 and trended downward from 1830 to 1950 , while that at Wales was stationary for the period from 1730 to 1950 . The JuneJuly rainfall for England and Wales definitely trended downward from 1730 to 1950 . The October rainfall at Kew trended downward for the period from 1850 to 1950, and the November rainfall trended upward for the same period.

No significant trends in either annual or seasonal precipitation have been found in several areas of India for records extending back to the 1800's (Rao, 1963; Rao and Jagannathan, 1963).

Landsberg (1960) carefully selected stations in rural areas of the United States, to insure homogeneity, for a study of precipitation changes between the periods 1906-30 and 1931-55. Precipitation changes between periods did not generally appear significant, although a decrease from the first time period to the following period may have occurred in areas of the Rocky Mountains, Great Plains, and on the western side of the Appalachians. At the same time an increase may have occurred in the areas east of the Cascades, around the Great Lakes, and in northern New England.

No statistically significant trends in long-term records of precipitation appear to exist in Arizona and western New Mexico according to Sellers (1960) and Hastings (1959).

Results of several investigations seem to indicate no significant precipitation trends at the following locations and periods of record : Rome, Italy (1751-1950); Nicosia, Cyprus (1900-50) ; Beirut, Lebanon (18801950) ; Alexandria (1870-1950), and Cairo (18901950), Egypt; Khartoum, Sudan (1900-50) ; and the Dead Sea (1815-1950) (Rosenan, 1963) ; Cape Town, South Africa (1841-1960) (Hofmeyr and Schulze, 1963) ; Algiers, Algeria (1843-1962) (Dubief, 1963); and the U.S.S.R. (1841-1960) (Buchinsky, 1963).

\section{REPORTED TRENDS IN TEMPERATURE}

Many investigations, for example, those by Brooks (1954), Callendar (1961), Dzerdzeevskii (1963), Willett (1950), and Mitchell (1963) have been made of airtemperature trends. Mitchell's studies show that world temperature trends were upward by about $1^{\circ} \mathrm{F}$, from about 1880 to 1940 , and downward since then. Changes have generally been greatest in the northern hemisphere. Mitchell indicates that trends have been worldwide in scope and not confined to landmasses.

Such trends in temperature could possibly have some effect on evapotranspiration rates. However, the temperature trends that have been observed are so small that the effects of slightly changed evapotranspiration rates probably do not have a significant effect on runoff patterns.

\section{TREND ANALYSIS OF SELECTED PRECIPITATION RECORDS}

Regression analysis, use of moving averages, and use of correlograms are techniques for discerning the presence of trends. If linearity of trend is assumed, the $t$-test is used herein to determine if the regression coefficient, representing the trend, is statistically significant. (See Dixon and Massey, 1957, p. 194.)

The computed trend is only an estimate of the true trend. The true trend has a specified probability of lying somewhere between the confidence limits $C+$ and $C$ - as defined by the $t$-statistic. If the confidence band lying between $C+$ and $C$ - is small, then the magnitude of the trend can be estimated with assurance; 
however, if the confidence band includes zero, the trend is considered statistically insignificant.

As demonstrated later, the duration of the period used in trend analysis greatly influences the result in trend studies. For instance, analysis of a 90-year period of record may reveal successively the absence or presence of a statistically significant trend in the first 10, $20, \ldots, 90$ years of record. Thus, a trend analysis never conclusively demonstrates existence or absence of a significant trend with increasing period of record, though stronger inference can be drawn about the presence of trend when the analysis is based on a long period of record.

\section{STUDY OF LONG-TERM PRECIPITATION RECORDS}

This study of trends in long-term precipitation records includes 16 records, beginning prior to 1848 , selected from "World Weather Records" (Clayton, 1927, 1934; Clayton and Clayton, 1947; Conover, 1959; and U.S. Weather Bureau, 1965). Each record was examined for the presence of statistically significant trends in the mean and variance of precipitation, and for first- and second-order trends, by linear regression with time.

If a first-order trend is present the annual magnitudes of precipitation change linearly with time. If a second-order trend is present, the squared deviation of annual magnitudes about either the long-term mean or the computed first-order trend changes with time.

The possibility of nonhomogeneous records was recognized. An analysis of variance was made by comparing the variability of each 10-year period of annual precipitation record to the variability for the period of record. If the analysis indicated nonhomogeneity for records with no significant trend or for records after any computed and significant trend had been removed, the record was deleted from the study. Twenty-two records were tested for homogeneity, and only 16 were retained for further analysis ir this study.

The following variables were substituted for $y$ in the regression equation $y=a+b t$, where $t$ is time and $a$ and $b$ are the regression coefficients, to statistically test for first- and second-order trend:

1. $P$, annual magnitudes of each monthly and annual precipitation,

2. $\Delta P^{2}$, the square of the deviations of annual precipitation from the mean for the period of record, and

3. $\Delta P_{T}^{2}$, the square of the deviations of the annual precipitation about the linear regression of $P$ with time.

The regression coefficients for each of the trend equations using annual values of $P, \Delta P^{2}$, and $\Delta P_{T}^{2}$ are given in table 1. The coefficients for regression of monthly values of $P$ with time are given in table 2 .

While there are some statistically significant trends with time, there is no consistency for either monthly or annual records in the first- or second-order measures of trend or by geographic distribution.

Correlograms (variation of serial-correlation coefficient with lag time), and power spectra (distribution of variance with frequency), were computed for most records. No cycles are evident in the spectra for annual precipitation (see also Alexander, 1957, and Brier, 1961). The correlograms all indicate a lack of longterm serial dependence, thus providing additional evidence of the lack of trends. A trend would cause a correlogram to vary about some value other than zero for large lags. However, all the computed correlograms varied about zero for large lags.

Cross-correlation coefficients were computed to determine if dependence existed between records. Dependence between records would more strongly substantiate trends found for one particular region. Only 5 of the 45 cross-correlation coefficients computed were significantly different from zero at the 5-percent level, as shown in table 3. Of the five statistically significant coefficients, only one (Bangalore-Madras, India, about 180 miles apart) seems to have any physical significance, based on geographical proximity, and trends at these two stations were found to be not significantly different from zero.

TABLE 1.-Regression coefficients for various measures of trend in annual precipitation

[Asterisk (*) indicates coefficiont significantly different from zero at 5-percent level]

\begin{tabular}{|c|c|c|c|c|}
\hline \multirow{2}{*}{ Station name } & \multirow{2}{*}{ Period } & \multicolumn{3}{|c|}{ Regression coefficients } \\
\hline & & $\underset{(\mathrm{mm} / \mathrm{yr})}{P}$ & $\underset{\left(\mathrm{mm}^{2} / \mathrm{yr}\right)}{\Delta P^{2}}$ & $\underset{\left(\mathrm{mm}^{2} / \mathrm{yr}\right)}{\Delta P_{T}^{2}}$ \\
\hline $\begin{array}{l}\text { Adelaide, } \\
\text { Australia. }\end{array}$ & $1839-1950$ & -0.220 & -39.5 & -38.5 \\
\hline $\begin{array}{l}\text { Sydney, } \\
\text { Australia. }\end{array}$ & $1840-1950$ & -1.80 & -432 & -337 \\
\hline $\begin{array}{l}\text { Bangalore, } \\
\text { India. }\end{array}$ & $1837-1960$ & .188 & -215 & -220 \\
\hline $\begin{array}{l}\text { Calcutta, India } \\
\text { Madras, India }\end{array}$ & $\begin{array}{l}1829-1960 \\
1813-1960\end{array}$ & $\begin{array}{r}-.800 \\
.085\end{array}$ & $\begin{array}{l}-716 \\
-192\end{array}$ & $\begin{array}{l}-787 \\
-191 \\
* 552\end{array}$ \\
\hline $\begin{array}{l}\text { Cape Town, } \\
\text { South Africa. }\end{array}$ & $1842-1960$ & -.653 & $* 664$ & $* 553$ \\
\hline Jerusalem, Israel_ & $1847-1960$ & $*-1.35$ & $* 575$ & $*-815$ \\
\hline $\begin{array}{l}\text { Copenhagen, } \\
\text { Denmark. }\end{array}$ & $1821-1960$ & .329 & 133 & 130 \\
\hline Milan, Italy & $1768-1960$ & .073 & 90.8 & 96. 6 \\
\hline $\begin{array}{l}\text { Frankfurt, West } \\
\text { Germany. }\end{array}$ & $1837-1960$ & .413 & -34.3 & -5 \\
\hline $\begin{array}{l}\text { Toronto, } \\
\text { Canada. }\end{array}$ & $1846-1960$ & $*$ *. 899 & -120 & -92.9 \\
\hline $\begin{array}{l}\text { New Orleans, La } \\
\text { Philadelphia, Pa_ }\end{array}$ & $\begin{array}{l}1839-1960 \\
1820-1960\end{array}$ & $\begin{array}{l}* 3.02 \\
-.333\end{array}$ & $\begin{array}{r}*-3770 \\
-72.2\end{array}$ & $\begin{array}{r}*-3250 \\
-77.4\end{array}$ \\
\hline $\begin{array}{l}\text { Portsmouth, } \\
\text { Ohio. }\end{array}$ & $1830-1950$ & .533 & -389 & -320 \\
\hline $\begin{array}{l}\text { St. Louis, Mo_- } \\
\text { St. Paul, Minn_- }\end{array}$ & $\begin{array}{l}1837-1960 \\
1837-1960\end{array}$ & $\begin{array}{r}*-1.72 \\
-.485\end{array}$ & $\begin{array}{l}-238 \\
-122\end{array}$ & $\begin{array}{l}-203 \\
-148\end{array}$ \\
\hline
\end{tabular}


TABLE 2.-Regression coefficients, in millimeters/year, for trend in monthly precipitation [Asterisk (*) indicates coefficient significantly different from zero at 5-percent level]

\begin{tabular}{|c|c|c|c|c|c|c|}
\hline \multirow[b]{2}{*}{ Station namo } & \multicolumn{6}{|c|}{ Month } \\
\hline & Jan. & Feb. & Mar. & Apr. & May & June \\
\hline 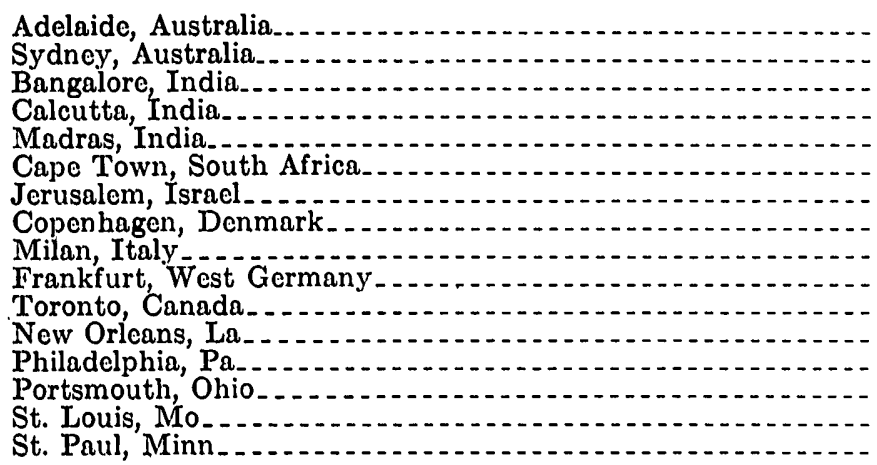 & $\begin{array}{r}0.0648 \\
-.0688 \\
-.0163 \\
.0257 \\
.110 \\
-.0574 \\
-.293 \\
.0532 \\
-.0701 \\
.0784 \\
.0086 \\
-.112 \\
.0003 \\
.0353 \\
.0147 \\
-.0404\end{array}$ & $\begin{array}{r}0.0478 \\
* .584 \\
.0650 \\
.0292 \\
.0323 \\
-.0203 \\
-.351 \\
-.0030 \\
.0056 \\
.0844 \\
-.119 \\
.241 \\
-.0008 \\
.123 \\
-.123 \\
.0353\end{array}$ & $\begin{array}{r}-0.0170 \\
-.0577 \\
-.0838 \\
-.0231 \\
-.0030 \\
-.0655 \\
-.0958 \\
-.0736 \\
* .151 \\
-.0152 \\
-.0292 \\
* .547 \\
.0737 \\
* .285 \\
-.108 \\
.0401\end{array}$ & $\begin{array}{c}-0.0838 \\
-.469 \\
.155 \\
-.183 \\
.0272 \\
.0820 \\
*-.263 \\
.0119 \\
.0535 \\
.0764 \\
.0826 \\
.424 \\
-.0091 \\
.163 \\
.0005 \\
-.121\end{array}$ & $\begin{array}{c}-0.0973 \\
-.116 \\
-.115 \\
-.296 \\
-.108 \\
-.121 \\
-.0093 \\
.0392 \\
.0346 \\
-.0120 \\
-.110 \\
.346 \\
-.0429 \\
.0472 \\
-.263 \\
-.0620\end{array}$ & $\begin{array}{r}-0.128 \\
.0698 \\
-.0881 \\
-.0304 \\
.0394 \\
-.284 \\
-.0011 \\
-.0304 \\
.0355 \\
.0043 \\
-.0424 \\
.149 \\
-.0155 \\
-.0795 \\
*-.410 \\
.0630\end{array}$ \\
\hline \multirow[b]{2}{*}{ Station namo } & \multicolumn{6}{|c|}{ Month } \\
\hline & July & Aug. & Sept. & Oct. & Nov. & Dec. \\
\hline $\begin{array}{l}\text { Adelaide, Australia } \\
\text { Sydney, Australia } \\
\text { Bungalore, India } \\
\text { Calcutta, Indiaa } \\
\text { Madras, India } \\
\text { Cape Town, South Africa } \\
\text { Jerusalem, Israel. } \\
\text { Copenhagen, Denmark } \\
\text { Milan, Italy, West Germany } \\
\text { Frankfurt, West } \\
\text { Toronto, Canada } \\
\text { New Orleans, La. } \\
\text { Philadelphia, Paa } \\
\text { Portsmouth, Ohio } \\
\text { St. Louis, Mo Mo } \\
\text { St. Paul, Minn }\end{array}$ & $\begin{aligned} & 0 . 109 \\
&-. 140 \\
& .187 \\
& .0025 \\
&-.0696 \\
& .0475 \\
& 0.0805 \\
&-.0420 \\
&-.0911 \\
& .0157 \\
& .339 \\
&-.0229 \\
&-.189 \\
&-.260 \\
&-.0221\end{aligned}$ & $\begin{aligned}-0.0780 \\
-.131 \\
-.137 \\
-.383 \\
.0638 \\
-.109 \\
-.0003 \\
.0944 \\
-.0346 \\
.115 \\
-.0559 \\
.168 \\
.121 \\
.105 \\
-.133 \\
-.0683\end{aligned}$ & $\begin{aligned} 0.0269 \\
-.0345 \\
-.0716 \\
.0255 \\
-.0653 \\
-.0429 \\
-.0028 \\
.0481 \\
-.0855 \\
.0556 \\
* .214 \\
* .703 \\
-.0693 \\
-.0234 \\
.0175 \\
* .249\end{aligned}$ & $\begin{array}{c}0.0439 \\
-.370 \\
.218 \\
.122 \\
.148 \\
-.0419 \\
-.0195 \\
.0368 \\
.0320 \\
-.0280 \\
.0061 \\
-.0991 \\
*-.177 \\
-.181 \\
-.0787 \\
-.0036\end{array}$ & $\begin{array}{c}-0.0033 \\
-.0551 \\
.121 \\
.139 \\
-.109 \\
*-.0993 \\
.254 \\
-.0294 \\
-.0271 \\
-.0029 \\
*-.214 \\
-.186 \\
-.102 \\
-.0386 \\
-.160 \\
-.0401\end{array}$ & $\begin{array}{r}-0.0109 \\
. .153 \\
-.0676 \\
-.0472 \\
.0097 \\
-.0376 \\
*-.465 \\
.857 \\
.0261 \\
.0802 \\
*-.227 \\
.0838 \\
-.0876 \\
-.0861 \\
*-.220 \\
-.0226\end{array}$ \\
\hline
\end{tabular}

TABLE 3.-Cross-correlation coefficients for annual precipitation at stations with complete, or nearly complete, records [Asterisk (*) indicates coefficients significantly different from zero at the 5-percent level]

\begin{tabular}{|c|c|c|c|c|c|c|c|c|c|}
\hline Station namo & $\begin{array}{l}\text { Adolaide, } \\
\text { Australia }\end{array}$ & $\begin{array}{l}\text { Sydney, } \\
\text { Australia }\end{array}$ & $\begin{array}{c}\text { Bangalore, } \\
\text { India }\end{array}$ & $\begin{array}{c}\text { Calcutta, } \\
\text { India }\end{array}$ & Madras, & $\begin{array}{l}\text { Cape Town, } \\
\text { South Africa }\end{array}$ & $\begin{array}{l}\text { Copenhagen, } \\
\text { Denmark }\end{array}$ & $\begin{array}{l}\text { Milan, } \\
\text { Italy }\end{array}$ & $\begin{array}{c}\text { Frankfurt, } \\
\text { West Germany }\end{array}$ \\
\hline $\begin{array}{l}\text { Sydney, Australia. } \\
\text { Bangalore, India.. } \\
\text { Calcutta; India. } \\
\text { Madras, India. } \\
\text { Cape Town, South } \\
\text { Africa... } \\
\text { Copenhagen, Denmark } \\
\text { Milan, Italy } \\
\text { Trankfurt, West } \\
\text { Germany } \\
\text { St. Paul, Minn., Ü.S.A. }\end{array}$ & $\begin{array}{r}-0.091 \\
*-.202 \\
.102 \\
.089 \\
-.043 \\
-.062 \\
.010 \\
-.056 \\
-.123\end{array}$ & $\begin{array}{r}-0.073 \\
-.050 \\
-.147 \\
.025 \\
.133 \\
.044 \\
-.023 \\
-.086\end{array}$ & $\begin{array}{r}0.033 \\
* .230 \\
-.085 \\
.059 \\
.073 \\
\\
.031 \\
-.128\end{array}$ & $\begin{array}{r}0.017 \\
-.117 \\
-.177 \\
.033 \\
\\
.085 \\
-.064\end{array}$ & $\begin{array}{r}-0.039 \\
-.001 \\
-.006 \\
-.042 \\
-.038\end{array}$ & $\begin{array}{r}-0.055 \\
.119 \\
-.155 \\
.114\end{array}$ & $\begin{array}{r}* 0.209 \\
.219 \\
-.128\end{array}$ & $\begin{array}{r}0.081 \\
-.077\end{array}$ & *0. 268 \\
\hline
\end{tabular}

Regression coefficients for annual precipitation versus multiple 20-year periods were computed for a few stations as shown in table 4 . The regression analysis was performed on each of the last $20,40,60, \ldots$., 180 years of record. The results of the computation seem to indicate that 60 or more years of record may be needed for trend analysis before the computed trend approaches a stable value. This outcome emphasizes that one cannot always place confidence in estimates based on short periods of record.

\section{CONCLUSIONS}

Data presently available indicate that no generally significant first- or second-order trends exist in precipitation records throughout the world since at least the mid-nineteenth century. This tends to support the 
TABLE 4.-Variation in regression coefficients of annual precipitation, in millimeters/year, with length of record

\begin{tabular}{|c|c|c|c|c|c|c|c|c|c|}
\hline \multirow{2}{*}{ Station name } & \multicolumn{9}{|c|}{ Length of record (years) } \\
\hline & 20 & 40 & 60 & 80 & 100 & 120 & 140 & 160 & 180 \\
\hline $\begin{array}{l}\text { Adelaide, Australia } \\
\text { Bangalore, India } \\
\text { Copenhagen, Denmark } \\
\text { Milan, Italy } \\
\text { Portsmouth, Ohio } \\
\text { St. Paul, Minn }\end{array}$ & $\begin{array}{r}-5.37 \\
\text { 3. } 05 \\
9.39 \\
10.6 \\
1.23 \\
-5.28\end{array}$ & $\begin{aligned}-0.407 \\
5.23 \\
2.63 \\
4.00 \\
-2.30 \\
.0142\end{aligned}$ & $\begin{aligned} 0.211 \\
.988 \\
\text { 1. } 15 \\
-1.31 \\
-2.450 \\
-2.30\end{aligned}$ & $\begin{aligned}-0.0729 \\
1.11 \\
.958 \\
-1.93 \\
-1.345 \\
-1.27\end{aligned}$ & $\begin{array}{r}-0.276 \\
.376 \\
.775 \\
-.746 \\
.691 \\
-1.30\end{array}$ & $\begin{array}{r}-0.0079 \\
.496 \\
-1.19 \\
.395 \\
-.645\end{array}$ & $\begin{array}{r}0.314 \\
-.794\end{array}$ & -0.580 & -0.219 \\
\hline
\end{tabular}

conclusions by several investigators that trends are not generally apparent in runoff for streams in the United States since about the turn of the century. A study by Yevdjevich (1963) has indicated that runoff in Europe and the United States may be trend free since at least 1810.

There is strong evidence that temperature trends exist. Temperature trends may imply evapotranspiration trends. However, observed temperature trends have been small, about $1^{\circ} \mathrm{F}$ over the 60 -year period 1880-1940. The effects on runoff of such a small temperature trend are probably not significant.

\section{REFERENCES}

Alexander, G. N., 1957, Are there climatic cycles?-Melbourne's rainfall examined: Australian Inst. Agr. Sci. Jour., v. 23, no. 3, p. 235-237.

Brier, G. W., 1961, Some statistical aspects of long-term fluctuations in solar and atmospheric phenomena: New York Acad. Sci. Annals, v. 95, p. 173-187.

Brooks, C. E. P., 1954, The climatic changes of the past thousand years: Experientia, v. X, no. 4, p. 153-158.

Buchinsky, I. E., 1963, Climatic fluctuations in the arid zone of the Ukraine, in Changes of climate: UNESCO Arid Zone Research Ser., v. 20, p. 91-95.

Busby, M. W., 1963, Yearly variations in runoff for the conterminous United States, 1931-60: U.S. Geol. Survey WaterSupply Paper 1669-S, 49 p.

Callendar, G. S., 1961, Temperature fluctuations and trends over the Earth: Royal Meteorol. Soc. Quart. Jour., v. 87, no. 371, p. 1-12.

Carrigan, P. H., Jr., and Huzzen, C. S., 1967, Serial correlation of annual floods: Internat. Hydrology Symposium, Fort Collins, Colo., Sept. 1967, Proc., p. 322-328.

Clayton, H. H., 1927, World weather records : Smithsonian Misc. Colln., v. 79, 1,199 p.

_ 1934, World weather records, 1921-30: Smithsonian Misc. Colln., v. 90, 616 p.

Clayton, H. H., and Clayton, F. L., 1947, World weather records : Smithsonian Misc. Colln, v. 105, 646 p.

Conover, J. H. (ed.), 1959, World weather records, 1941-50: U.S. Weather Bureau, 1,361 p.

Dixon, W. J., and Massey, F. J., Jr., 1957, Introduction to statistical analysis : New York, McGraw-Hill, 488 p.

Dubief. J., 1963, Contribution au problème des changementes de climat survenus aux cours de la période couverte par les observations météorologiques faites dan le nord de l'Afrique, in Changes of climate: UNESCO Arid Zone Research Ser., v. 20, p. $75-79$.

Dzerdzeevskii, B. L., 1963, Fluctuations of general circulation of the atmosphere and climate in the twentieth century, in Changes of climate: UNESCO Arid Zone Research Ser., v. 20, p. $285-295$.

Hastings, J. R., 1959, Vegetation change and arroyo cutting in southeastern Arizona during the past century, an historical review: Arid Lands Colloquia, Univ. Arizona, p. 24-39.

Hidore, John, 1966, Fifty-year linear trends of runoff on selected watersheds in the United States: Jour. Hydrology, v. 4, no. 1, p. 98-102.

Hofmeyr, W. L., and Schulze, B. R., 1963, Temperature and rainfall trends in South Africa during the period of meteorological records in Changes of climate: UNESCO Arid Zone Research Ser., v. 20, p. 81-85.

Landsberg, H. E., 1960, Note on recent climatic fluctuations in the United States: Jour. Geophys. Research, v. 85, no. 5, p. 1519.

McDonald, C. C., and Langbein, W. B., 1948, Trends in runoff in the Pacific Northwest: Am. Geophys. Union Trans., v. 29 , no. 3, p. 387-397.

Matalas, N. C., 1963, Autocorrelation of rainfall and streamflow minimums: U.S. Geol. Survey Prof. Paper 434-B, 10 p.

Mitchell, J. M., Jr., 1963, On the world-wide pattern of secular temperature change, in Changes of climate: UNESCO Arid Zone Research Ser., v. 20, p. 161-181.

Rao, K. N., 1963, Climatic changes in India, I. Methods for the study of climatic changes and trends in Madras rainfall, in Changes of climate: UNESCO Arid Zone Research Ser., v. 20, p. $49-52$.

Rao, K. N., and Jagannathan, P., 1963, Climatic changes in India, II. Rainfall, in Changes of climate: UNESCO Arid Zone Research Ser., v. 20, p. 53-66.

Rosenan, N., 1963, Climatic fluctuations in the Middle East during the period of instrumental record, in Changes of climate: UNESCO Arid Zone Research Ser., v. 20, p. 67-73.

Sellers, W. D., 1960, Precipitation trends in Arizona and western New Mexico': 2sth Ann. Snow Conf., Santa Fe, N. Mex., Apr. 1, 1960, Proc., p. 81-94.

Smith, L. P., 1963, The significance of climate variations in Britain, in Changes of climate: UNESCO Arid Zone Research Ser., v. 20, p. 455-463.

U.S. Weather Bureau, 1965, World weather records, 1951-60, North America, v. 1: U.S. Weather Bureau, 535 p.

IVillett, H. C., 1950, Temperature trends of the past century: Royal Meteorol. Soc. Centenary Proc., p. 192-206.

Yevdjevich, V. M., 1963, Climatic fluctuations studied by using annual flows and effective annual precipitations, in Changes of climate: UNESCO Arid Zone Research Ser., v. 20, p. 183-199. 


\title{
GROUND WATER-SURFACE WATER RELATION DURING PERIODS OF OVERLAND FLOW
}

\author{
By JAMES F. DANIEL, LOUIS W. CABLE, \\ and RONALD J. WOLF, Indianapolis, Ind.
}

\begin{abstract}
The ground-water exchange mechanism at the stream interface during periods of overland runoff was investigated by means of observation wells installed in the flood plain on the White River near Noblesville, Ind. Ground-water discharge decreases with the beginning of a stream rise, ceases after a short time interval, and then bank storage occurs. A volume of discharge from the aquifer equal to that which entered as bank storage at the study site was dissipated 54 hours after an overbank peak, 42 hours after a medium peak and 50 hours after a small peak. The results were used to formulate a theoretical method for stream-hydrograph separation of base flow and overland flow. The separation method shows no ground-water runoff until bank storage and channel storage volumes have been dissipated. All discharge in the stream before and after this period is equal to that contributed by the aquifer system.
\end{abstract}

In the course of a recent water-resources investigation in Indiana, it was desirable to separate streamdischarge hydrographs into overland runoff and baseflow components. The principal problem was what occurs when the stream level rises rapidly owing to floodflow. How, then, should the stream-discharge hydrograph be separated? A search of the available literature on the subject found numerous methods, none of which seemed to deal satisfactorily with floodflow conditions. To answer this question it was necessary to acquire a better understanding of the reaction of the subsurface flow system to a rise in stream level. Pogge (1966) has reported some significant information concerning the relation of surface and subsurface flow systems, and Cooper and Rorabaugh (1963) have described the theoretical reaction of ground-water levels to a symmetrical flood pulse when and where the initial ground-water levels were horizontal.

A limited research project was designed to investigate the mechanism of ground-water discharge at the stream interface and to develop a method for analyzing ground-water runoff. To accomplish this it was neces- sary to: (1) observe the reaction of ground-water levels to fluctuations in stream level, (2) determine from these observations the direction of ground-water movement as it changes with time, and (3) relate these data to the stream-discharge hydrograph.

Acknowledgment.-Special thanks is extended to Mr. Tom Benefiel for permission to install observation wells on his property in the course of the investigation.

\section{SITE SELECTION AND WELL INSTALLATION}

A field site was chosen on the White River adjacent to the U.S. Geological Survey stream-gaging station, between Cicero and Strawtown, near Noblesville, Ind. (fig. 1). At the site the alluvium is composed of sand and gravel capped by a layer of silt and clay about 6 to 7 feet thick. The potentiometric level in the sand and gravel is usually above the base of the silt-clay layer so that artesian or leaky- artesian conditions gen-

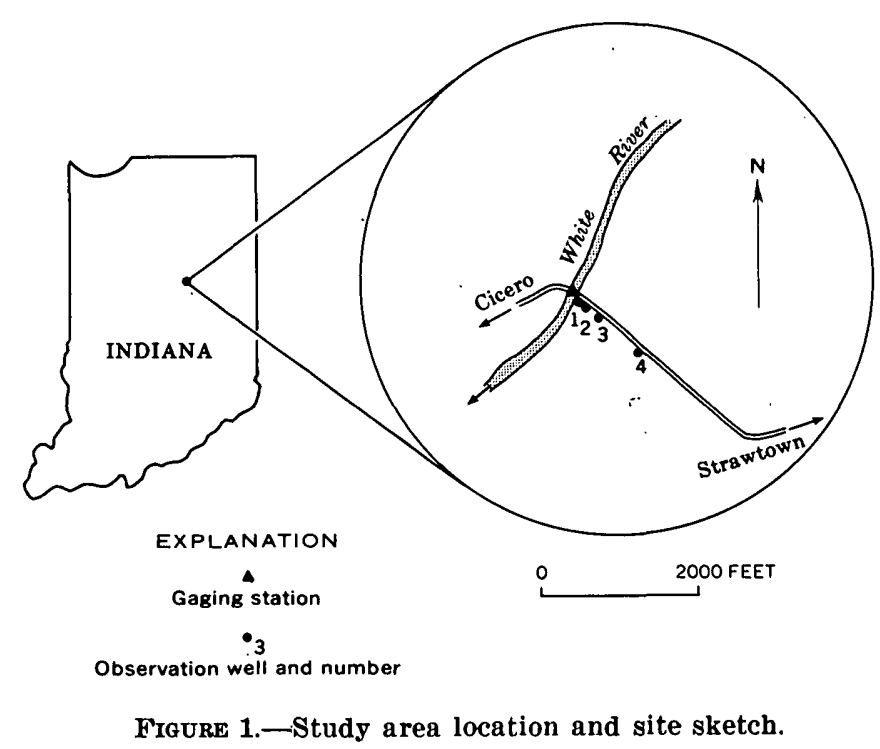


erally prevail. In extended dry periods, however, the water level drops below the confining layer of silt and clay.

Four observation wells, consisting of 2-inch pipe with 60-gauze screen set approximately 9 feet below land surface, were installed on line with the gage and perpendicular to the river. Elevations referenced to existing gage datum were determined for each well.

After the site was chosen and the observation wells were installed, periodic measurements of water level were made to define the direction of subsurface flow. Measurements were made during floods in the late winter and spring of 1968. Analyses of the exchange mechanism for three peaks which occurred are discussed. The stream-stage hydrographs for one relatively small peak, one medium peak, and one relatively high peak (overbank) are shown in figure 2.

\section{METHODS AND RESULTS OF STUDY}

The method used in the analysis of these peaks will be illustrated using peak 3 of figure 2. Potentiometric profiles for stages $A-E$ are shown in figure 3.

Under recession conditions (stage $A$ ), ground-water movement is toward and into the stream. As the stream level rises above the water level in the adjacent aquifer (stage $B$ ) the hydraulic gradient at the interface is reversed and water moves from the stream into the banks. Immediately after the beginning of the rise, therefore, the discharge of ground water into the stream ceases. However, ground water continues to move from the valley margins toward the stream, but its progress is blocked by the opposing gradient. As a result, the amount of ground water that would normally have been discharged into the stream is tempo-

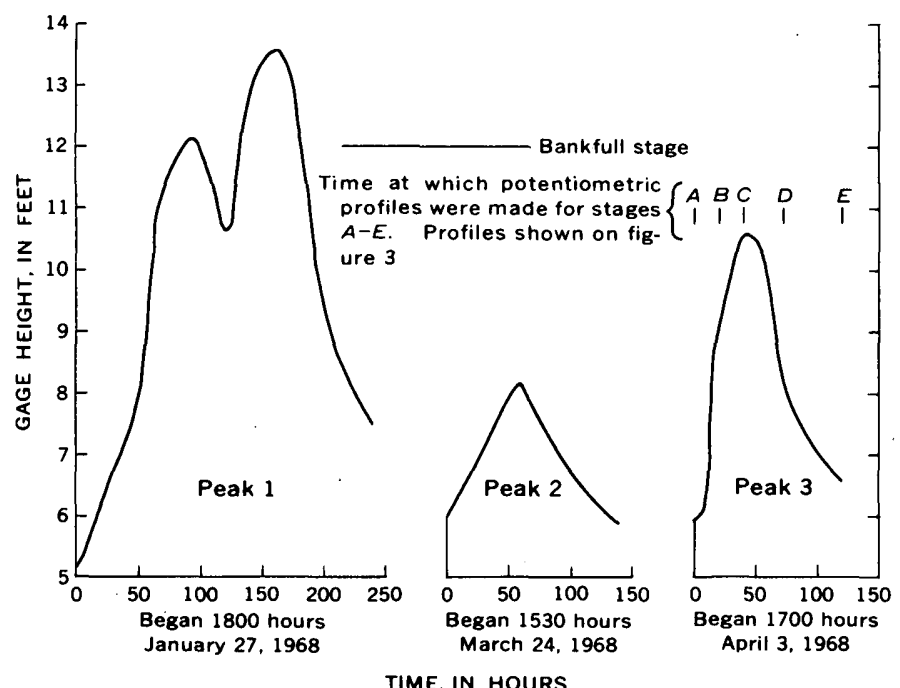

FIGURE 2.-Stream-stage hydrographs for three storm-peak flows in winter and spring of 1968.
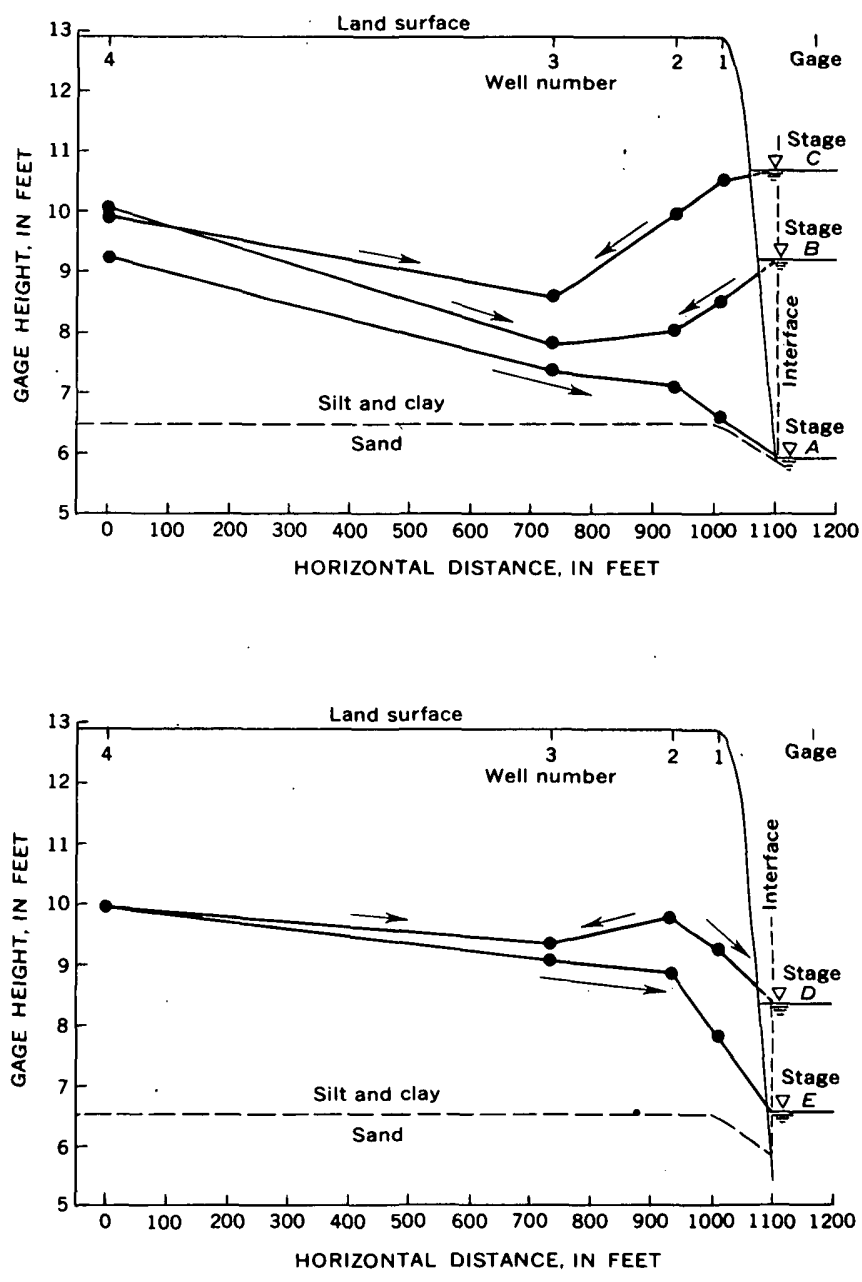

Figure 3.-Potentiometric profiles of storm peak 3 (fig. 2) at stages and times shown on figure 2. Arrows indicate flow direction.

rarily stored. This is indicated by corresponding rises in the water level in the observation wells (stage $C$ ). Soon after the peak stream stage, the water in bank storage (Langbein and Iseri, 1960) begins to move back into the stream. At stage $E$, a gradient toward the stream has been reestablished throughout the section.

A convenient method for analyzing the volumetric exchange of water between the stream and the ground is by use of Darcy's law. It is stated mathematically as the equation.

where

$$
Q=T i L,
$$

$Q=$ discharge,

$T=$ transmissivity,

$i=$ hydraulic gradient, and

But

$L=$ width of section.

$$
Q=\frac{V}{t}
$$


where

$$
V=\text { volume, and }
$$

$t=$ time.

And, for small increments of time $(\Delta t)$,

$$
\Delta Q=\frac{\Delta V}{\Delta t} \text {. }
$$

If we substitute in equation 1 and rearrange,

$$
\Delta V=T i L \Delta t \text {. }
$$

Where artesian conditions apply, $T$ is constant. Therefore, if we assume a unit width,

$$
\Delta V \propto i \Delta t \text {. }
$$

We cannot actually determine $\Delta V$ for our site from equation 4 as we do not know $T$. However, using equation 5 at some point in our section we can compute the gradient, plot it versus time, and then mechanically integrate the graph and use it to determine the direction of flow, the time at which bank storage begins, and the time at which an equivalent volume has left the bank. Such a plot is shown in figure 4 , superimposed on the streamflow hydrograph.

Several factors in this graph deserve discussion. First, it should be emphasized that only the flow vector component which is perpendicular to the stream can be determined from this single line of wells. This is sufficient to determine the mechanism of flow interchange.

Second, all gradients were determined at well 2. It is unlikely that the instantaneous gradient at well 2 is the exact apparent gradient indicated by the difference of

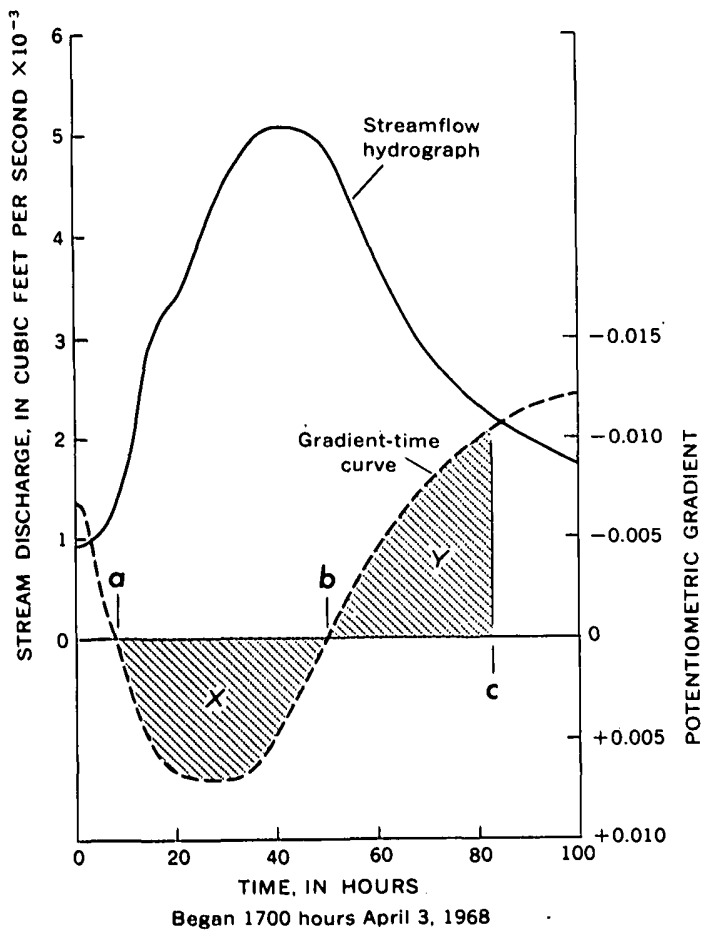

Froune 4.-Chronologic plot of potentiometric gradient and streamflow hydrograph of storm penk 3. See text for description of letters. water levels in wells 1 and 2 , or, in wells 2 and 3 . Because of this, the gradient at well 2 has been computed as the average of the gradient from well 1 to well 2 and the gradient from well 2 to well 3. Any difference between the computed gradient and the actual gradient would shift the curve only slightly to the left or the right. The shift should not be enough to affect the conclusions which have been reached here.

The shaded areas in figure 4 are proportional to the volume of bank storage. Area $X$ has been planimetered and area $Y$ has been computed to equal area $X$. At time $a$ (in figure 4), water begins to enter the aquifer through the banks. At time $b$, the gradient reverses and water begins to return to the stream. At time $c$, a volume of water has been returned to the stream which is equal to that which entered the aquifer from the stream. In other words, by time $c$, the volume of bank storage has been returned to the stream.

The work of Cooper and Rorabaugh (1963) can be used to test the reasonableness of this result. Figure 5iii shows the function of $Q$ at the interface for a symmetrical flood, obtained from their figure 102, p. 361. Peak 3 seems to have characteristics more closely resembling a symmetrical peak than the asymmetric one presented on p. 364 of Cooper and Rorabaugh's report. The duration of stage oscillation $(\tau)$ has been used here as 80 hours, which was computed by doubling the time from the beginning of the rise until the peak. Assuming a $T$ of 30,000 square feet per day, a storage coefficient $(S)$ of 0.01 , and a width to the aquifer boundary of 6,000 feet results in their $\beta$ value of 0.1 .

The shape of the bank storage curve as it reaches well 2 should be slightly elongated and slightly dampened because of the short time lag involved as the effect moves from the interface to well 2. Because $Q$ is proportional to gradient, the shape of this curve can be used in a direct comparison with the measured gradient at well 2.

Bank storage, however, is only, one component of the measured gradient at well 2. Two other components, the initial gradient in the aquifer and the increased gradient due to local recharge (see rise of water level at well 4 between stage $A$ and stage $B$ in figure 3 ), must also be accounted for. The gradient due to flow in the aquifer is shown in figure $5 i$. Had there been no stream peak, the gradient at well 2 would probably decrease slightly as shown for comparison purposes. The effect of local recharge would be to increase the gradient at well 2 (although not necessarily linearly as shown in figure 5ii) to a maximum at which time it would begin to decay, probably exponentially. It has been assumed here that the maximum has not been reached at the time the bank storage volume is de- 

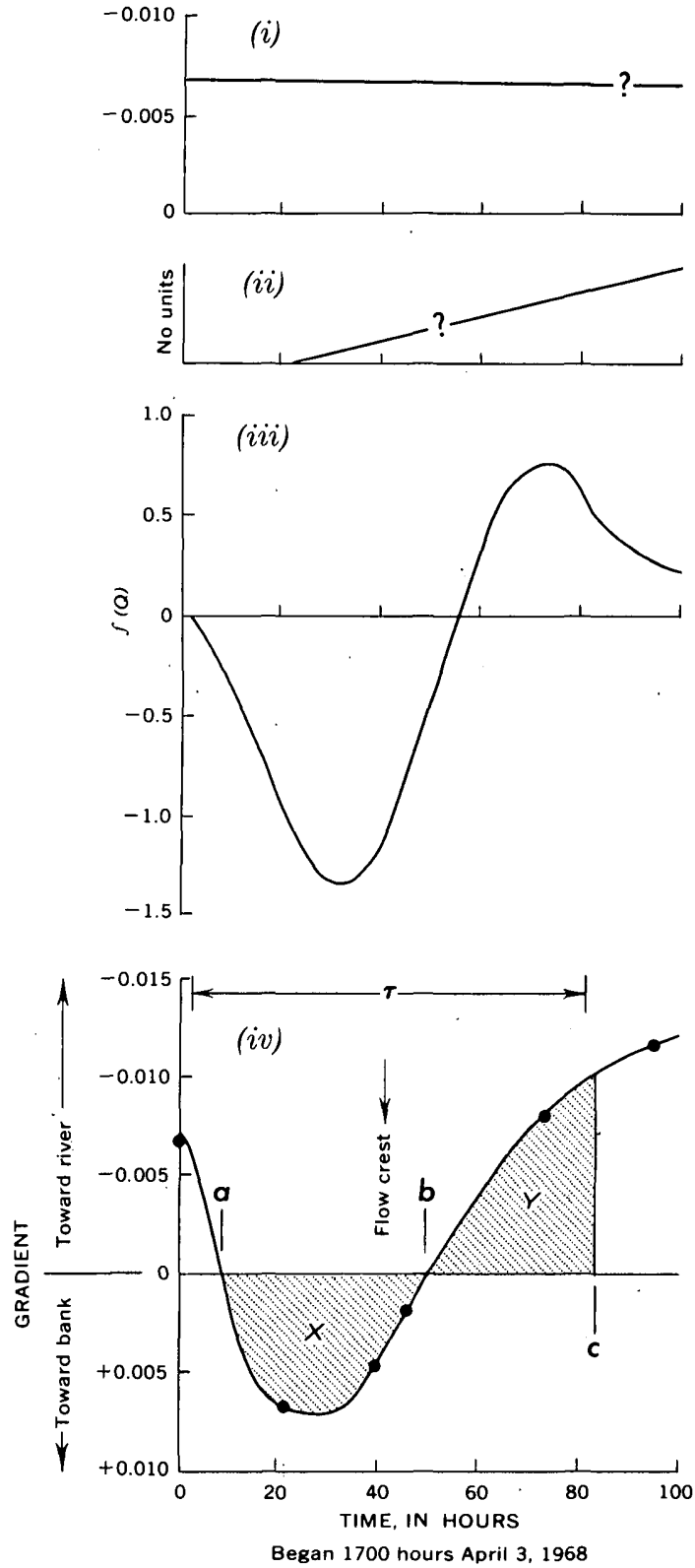

Fiaure 5.-Components of gradient compared with measured gradient at well 2 during storm peak 3 . $i$, recession component; $i$, local recharge component; $i i$, stage oscillation component at interface $(f(Q))$; $i v$, measured potentiometric gra dient. Dots in iv indicate computed data points.

pleted. No units have been put on the local recharge component, figure $5 i i$.

The sum of these three components (figs. $5 i, 5 i i, 5 i i i$ ) should be the measured gradient at well 2 (fig. 5iv). Because there is little information about the magnitudes of the components, only a qualitative comparison can be made. The addition of the three components does result in a curve whose shape is similar to that obtained from measurements. Therefore, some degree of verification is implied.
Cooper and Rorabaugh (1966, p. 363) show that approximately 65 percent of bank storage would remain in the ground at 84 hours on the gradient curve when the bank storage component alone is considered. Therefore, shaded area $Y$ (fig. 5iv) represents the entire volume of bank storage, but it is composed of a mixture of bank storage (about 35 percent) and the combination of aquifer discharge and local recharge (about 65 percent).

Even though the mixture may continue to discharge for a time equal to several flood periods, the bankstorage volume has been accounted for at time $c$ so that all volume of discharge after that may be considered the volume of ground-water discharge, or base flow.

The resulting curves for peaks 1 and 2 are shown in figure 6 .
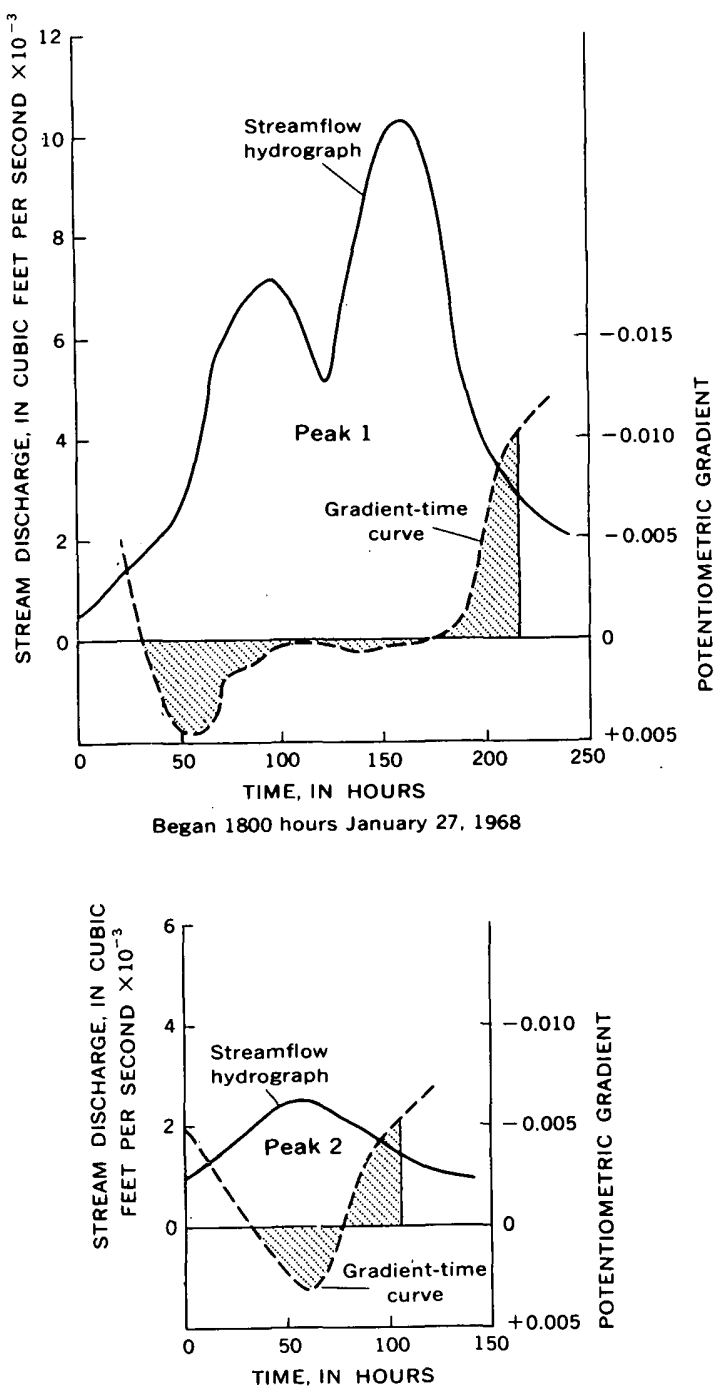

Began 1530 hours March 24, 1968

FIgURE 6.-Chronologic plots of potentiometric gradients and streamflow hydrographs of storm peaks 1 and 2. 
If the equivalent-volume concept is applied to the problem of hydrograph separation, the idealized separation method would be that shown in figure 7 .

At the beginning of the rise, base flow begins to decrease; at time $a$ (fig. 7), bank storage begins; at time $b$, a volume equivalent to bank storage is gone; at time $c$, all flow toward the stream is now base flow.

The difference between the base flow (dashed line, fig. 7) and the total flow (solid line) in the stream is due to the accumulation of channel storage which occurs during the peak. This additional channel storage can also be handled by the equivalent-volume method. All that is required is to wait until the channel storage volume has passed the gage and call that time $c$.

The decrease in base flow between the beginning of the rise and time $a$ occurs in a very short time, actually, a small fraction of a day. If separation were performed by dropping to zero instantaneously, little loss in accuracy would result, especially for a daily hydrograph.

By use of an instantaneous decrease and subtraction of channel storage as a block, the separation method

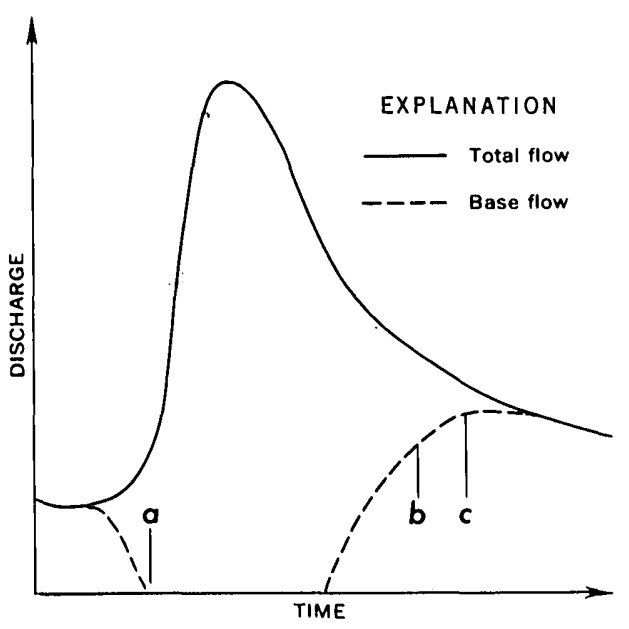

Fraure 7.-Idealized base-flow separation; $a, b$, and $c$, are time points referred to in text.

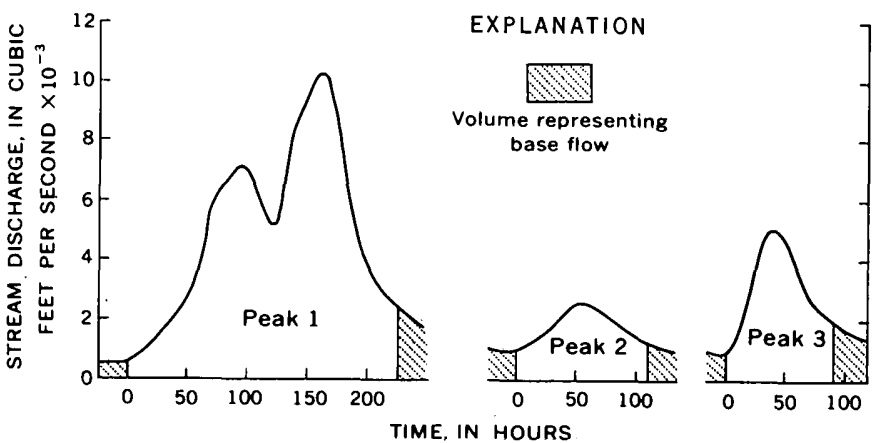

Figure 8.-Streamflow hydrographs of the storm peaks of figure 2 , with final separation of base flow indicated.

has been used on the three peaks discussed; the results are shown in figure 8.

\section{SUGGESTION FOR FUTURE STUDIES}

Before the indicated separation method can be applied with any reasonable degree of confidence, the temporal distribution of bank-storage depletion throughout a basin should be investigated. The method shown is based on data for one point and probably does accurately represent bank-storage depletion in the watercourse aquifer along the main-stem channel of the basin. However, the effect of tributary-depletion timing cannot be evaluated with the available data. An investigation of tributary depletion including the routing of tributary base flow to the gaged point would yield data which could be used to complete a hydrograph separation technique.

\section{REFERENCES}

Cooper, H. H., Jr., and Rorabaugh, M. I., 1963, Ground-water movements and bank storage due to flood stages in surface streams: U.S. Geol. Survey Water-Supply Paper 1536-J, p. 343-366.

Langbein, W. B., and Iseri, K. T., 1960, General introduction and hydrologic definitions:: U.S. Geol. Survey Water-Supply Paper 1541-A, 29 p.

Pogge, E. C., 1966, Mechanics of bank seepage during flood flows : Univ. Iowa Ph.D. dissert., 241 p. 


\title{
THE RELATIONSHIP BETWEEN SURFACE WATER AND GROUND WATER IN SHIP CREEK NEAR ANCHORAGE, ALASKA
}

\author{
By JOHN B. WEEKS, Anchorage, Alaska
}

Work done in cooperation with the city of Anchorage and the Greater Anchorage Area Borough

\begin{abstract}
Ship Creek drainage basin is an important recharge area for the Anchorage artesian aquifer. Discharge records show Ship Creek loses an average of $25 \mathrm{cfs}$ in the recharging area and gains about $22 \mathrm{cfs}$ in the reach below the recharge area. A water-budget analysis demonstrates that of this gain at least $11 \mathrm{cfs}$ is ground-water return flow from the recharge area.
\end{abstract}

Ship Creek has its headwaters in the Chugach Mountains and discharges into Cook Inlet near downtown Anchorage, Alaska. Its stream course traverses 10 miles of alluvial gravel and glacial outwash deposits in the lowlands and foothills. Since the last glaciation, Ship Creek has built an extensive alluvial fan at the foot of the Chugach Mountains (fig. 1). This fan provides about one-fourth of the total recharge to the artesian aquifer system which underlies the city of Anchorage.

The geology of the Anchorage area has been described by Trainer (in Cederstrom and others, 1964) and Miller and Dobrovolny (1959). As schematically shown in figure 2, the surficial gravels in the reach of Ship Creek basin below the gaging station at Elmendorf Air Force Base are underlain by a clay bed which is exposed at the mouth of Ship Creek. This clay stratum forms the confining layer of the underlying artesian aquifer and the lower boundary of the unconfined aquifer in Ship Creek basin downstream from the Elmendorf gage.

Two gaging stations are operated on Ship Creek. Continuous discharge records have been obtained since 1946 at the Fort Richardson diversion dam, and are published as Ship Creek near Anchorage. This station is located on exposures of metamorphic rock upstream from the alluvial fan. Six miles downstream, the second gaging station has been operated since 1963. This station, Ship Creek at Elmendorf AFB, is located downstream from the alluvial fan and about 4 miles above the mouth of the stream.

Discharge records show that for the period of record the mean annual flow over the diversion dam is 150 cubic feet per second and that 6 miles downstream at Elmendorf the discharge is $125 \mathrm{cfs}$. Previous investigators (Cederstrom and others, 1964; Waller, 1964; Sommers and Marcher, 1965) recognized that this reach of Ship Creek was a losing reach. A recent investigation by the author has shown that part of this loss returns to the stream below the Elmendorf gaging station.

A series of seepage measurements was made to determine the relationship between surface water and ground water in Ship Creek basin. Concurrent discharge measurements were made at the Elmendorf gaging station and at Post Road near the mouth of Ship Creek (fig. 1). The measurements were made during periods of steady stage and no local surface runoff. The discharge measurements near the mouth were made above the tide-affected reach so that drainage from bank storage did not contribute to the measured discharge. Under these conditions, any increase in discharge downstream must be due to ground-water inflow. Table 1 tabulates the measurement data as well as all previously available seepage data.

Two of the previously existing seepage runs were disregarded because they were made under conditions which did not conform to the above measuring criteria. Climatologic records show that the seepage run on April 27, 1959, was made while surface runoff from snowmelt was contributing to streamflow. The seepage run on May 16, 1967, was made during a period of rising stage so that the measured gain was affected by 

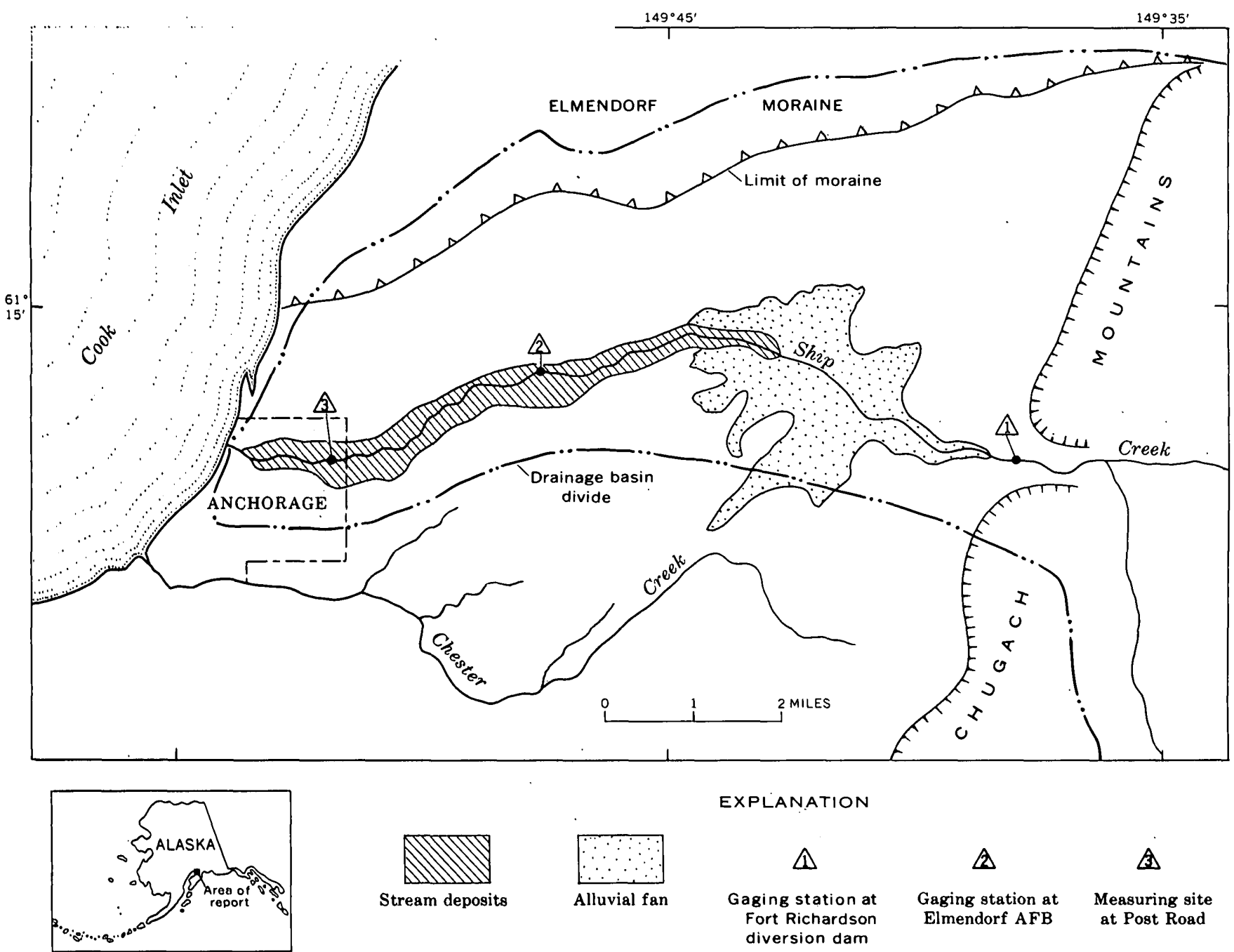

EXPLANATION

$\Delta$

Gaging station at Fort Richardson diversion dam

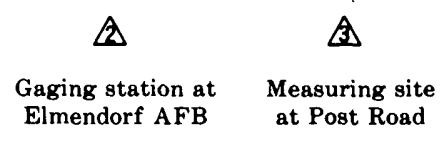

FraURE 1.-Sketch of the Anchorage area, showing gaging stations and selected features in Ship Oreek basin.

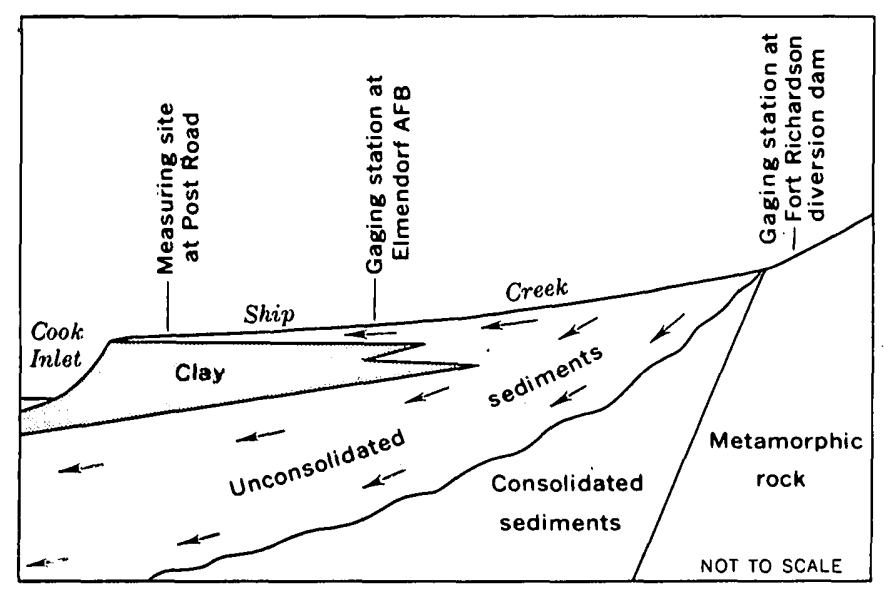

Fiqure 2.-Idealized geologic cross section along Ship Creek, showing the general direction (arrows) of ground-water movement. channel storage in the reach. If these two seepage runs are disregarded, the average gain in the reach for the remaining nine runs is $21.5 \mathrm{cfs}$ and the standard deviation is $1.9 \mathrm{cfs}$.

Seepage measurements were not made duing the summer months, although the major part of the annual runoff occurs during this period. The mean daily discharge during the high-flow period generally ranges from 200 to $600 \mathrm{cfs}$, and the discharge measurements are only accurate to about 10 percent. For a discharge of $200 \mathrm{cfs}$, the possible error in the difference between two measurements is $\pm 40 \mathrm{cfs}$, and for $600 \mathrm{cfs}, \pm 120$ cfs. Therefore, ground-water inflow cannot be reliably determined during high flows because the measurement errors will be nearly as large as, if not larger than, the ground-water contribution to streamflow.

The seepage data show that Ship Creek gains about $22 \mathrm{cfs}$ in the reach below the Elmendorf gaging sta- 
TABLE 1.-Ship Creek seepage measurements made at the Elmendorf Air Force Base gage and near Post Road, in cubic feet per second.

\begin{tabular}{|c|c|c|c|}
\hline \multirow{2}{*}{ Date } & \multicolumn{2}{|c|}{ Discharge measurements } & \multirow{2}{*}{$\begin{array}{l}\text { Seepage } \\
\text { gain }\end{array}$} \\
\hline & $\begin{array}{c}\text { Elmendorf } \\
\text { gage }\end{array}$ & Post Road & \\
\hline 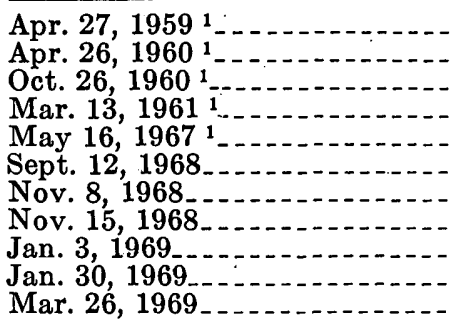 & $\begin{array}{r}28.3 \\
20.4 \\
172 \\
19.2 \\
182 \\
75.0 \\
17.6 \\
2.8 \\
2.3 \\
1.4 \\
1.3\end{array}$ & $\begin{array}{r}80.8 \\
44.6 \\
193 \\
40.8 \\
191 \\
97.0 \\
41.6 \\
24.0 \\
21.3 \\
23.3 \\
19.9\end{array}$ & $\begin{array}{l}52.5 \\
24.2 \\
21.0 \\
21.6 \\
9.0 \\
22.0 \\
24.0 \\
21.2 \\
19.0 \\
21.9 \\
18.6\end{array}$ \\
\hline
\end{tabular}

1 Data collected prior to this study.

tion during the low-flow period. Because the groundwater levels are higher in the summer than in the winter, the ground-water contribution to streamflow is likely to be greater during the high-flow period than during the low-flow period. Thus, it can be concluded that the mean annual gain is at least $22 \mathrm{cfs}$ and possibly more. This discharge is supplied in part by ground-water inflow from the recharge area above the Elmendorf gage. This can be shown by the following analysis of the unconfined aquifer in the reach of Ship Creek basin below Elmendorf.

The clay bed underlying Anchorage is exposed along the coastline and forms a ground-water dam which prevents discharge from the unconfined aquifier to Cook Inlet except through Ship Creek. Field observations have located only minor seeps from the bluffs along the coast. The glacial deposits of the Elmendorf moraine (fig. 1) form a barrier to ground-water movement to the north, and a topographic high forms an unconfined ground-water divide to the south. Thus, except for vertical leakage through the clay, the only sources of recharge to the unconfined aquifer are infiltration of precipitation and ground-water inflow from the recharge area above the Elmendorf gage.

The average annual precipitation at Anchorage is 15.14 inches for the 25 years of record, and the area tributary to Ship Creek in the reach below Elmendorf is about 10 square miles. This average precipitation on the tributary area is equivalent to only about $11 \mathrm{cfs}$ per year. Because direct runoff and evapotranspiration losses reduce the amount of precipitation available for recharge, the recharge to the unconfined aquifer must be less than $11 \mathrm{cfs}$. Therefore, if changes in storage are neglected, at least $11 \mathrm{cfs}$ must be ground-water inflow to account for the 22-cfs gain in Ship Creek.

Potentiometric levels in the reach of Ship Creek basin below Elmendorf have dropped approximately 25 feet in the last 10 years. The seepage data indicate that no significant change in the gain has occurred dur-

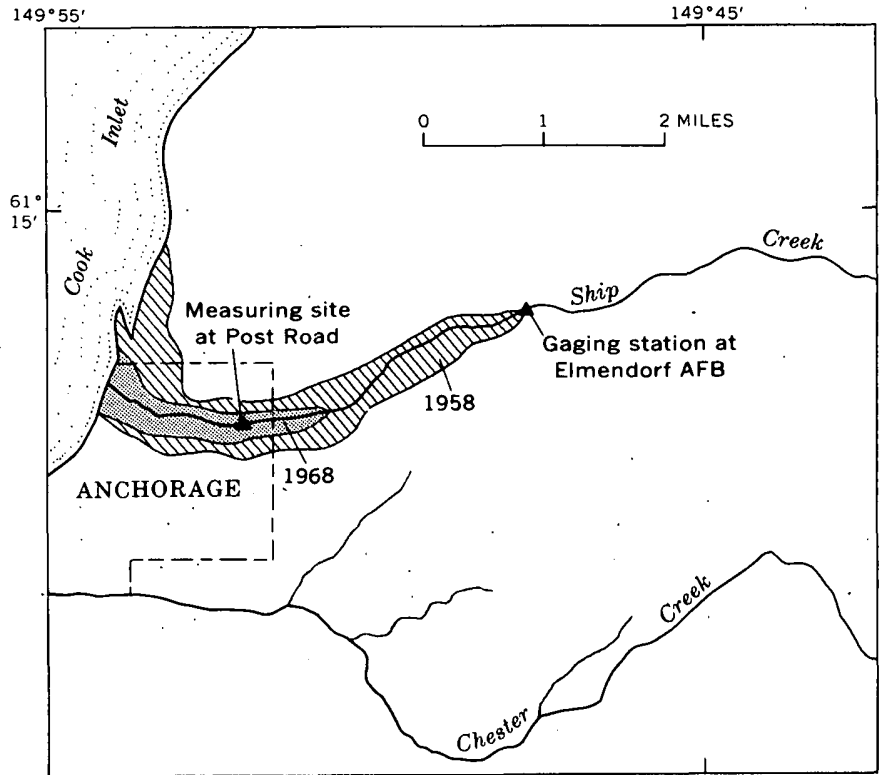

FigURE 3.-Sketch showing change in area of Ship Creek basin where artesian potentiometric levels were above land surface in 1958 and 1968 , as indicated by patterns.

ing this period (standard deviation of $1.9 \mathrm{cfs}$ ), and field observations have disclosed that most of the gain occurs in the first half mile below the Elmendorf gage. Because the present potentiometric surface is below stream level in this reach (fig. 3), vertical leakage through the clay cannot contribute to streamflow. The 11-cfs gain must come from the recharge area above the Elmendorf gaging station. Consequently, any estimate of recharge to the aquifer system from the area of Ship Creek basin between the diversion dam and the gage at Elmendorf must account for this return flow.

The presence of recent stream deposits along Ship Creek (fig. 1) suggests that the 11-cfs return flow may be largely in the form of underflow. That is, about half of the 25 cfs that is lost in the upper reach of Ship Creek actually recharges the aquifer system, and the remaining half moves through the highly permeable gravels under and adjacent to the stream downgradient.

\section{REFERENCES}

Cederstrom, D. J., Trainer, F. W., and Waller, R. M., 1964, Geology and ground-water resources of the Anchorage area, Alaska: U.S. Geol. Survey Water-Supply Paper 1773, 108 p.

Miller, R. D., and Dobrovolny, Ernest, 1959, Surficial geology of Anchorage and vicinity, Alaska: U.S. Geol. Survey Bull. 1093, $128 \mathrm{p}$.

Sommers, D. A., and Marcher, M. V., 1965, Water resources appraisal of the Anchorage area, Alaska: U.S. Geol. Survey open-file report, $34 \mathrm{p}$.

Waller, R. M., 1964, Hydrology and the effects of increased ground-water pumping in the Anchorage area, Alaska: U.S. Geol. Survey Water-Supply Paper 1779-D, 36 p. 
PRAIRIE POTHOLES AND THE WATER TABLE

\author{
By C. E. SLOAN, Denver, Colo.
}

Abstract.-Prairie potholes, or sloughs, are water-holding depressions of glacial origin that occur in the prairies of the northern conterminous United States and southern Canada. The water table in the prairie-pothole region is a shallow surface that is a subdued image of the general topography. In detail, however, small variations in topography are not reflected, and in cross sections the water table is almost a straight line linking pothole water surfaces. Salinity and permanence of contained water differ widely among potholes and are influenced by ground-water flow which, in turn, is partially dependent on the configuration of the water table surrounding the pothole. Ground-water inflow, throughflow, and outflow result when the adjacent water table is correspondingly high, intermediate, and low. Relative permanence and salinity increase or decrease as net ground-water movement ranges from inflow to outflow.

Prairie potholes, also called sloughs, are water-holding depressions of glacial origin that occur north of the Missouri River in the prairies of the United States and Canada. This vast region (fig. 1) includes most of northeastern North Dakota, the eastern part of South

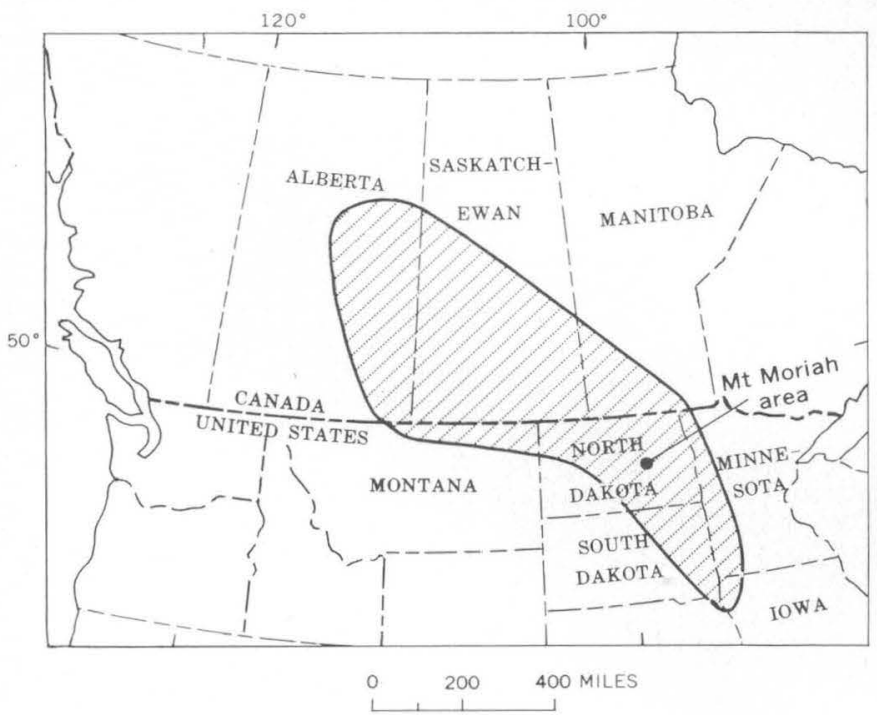

Figure 1.-Location of the prairie-pothole region (patterned area) and the Mt. Moriah study area.
Dakota, small areas in western Iowa, Minnesota, and northeastern Montana, and the southwestern part of Manitoba, southern Saskatchewan, and southeastern Alberta.

The relation of the water table to pothole hydrology was studied in the Mt. Moriah area (fig. 1) in northern Stutsman County, N. Dak. The Mt. Moriah area is at the eastern edge of the Coteau du Missouri, an extensive area of dead-ice moraine that extends from South Dakota northwest across North Dakota into Canada. Prairie potholes are most numerous in hummocky, knob and kettle topography resulting from glacial stagnation. An oblique areal view of the northwestern part of Mt. Moriah area (fig. 2) shows typical prairie potholes in stagnation moraine.

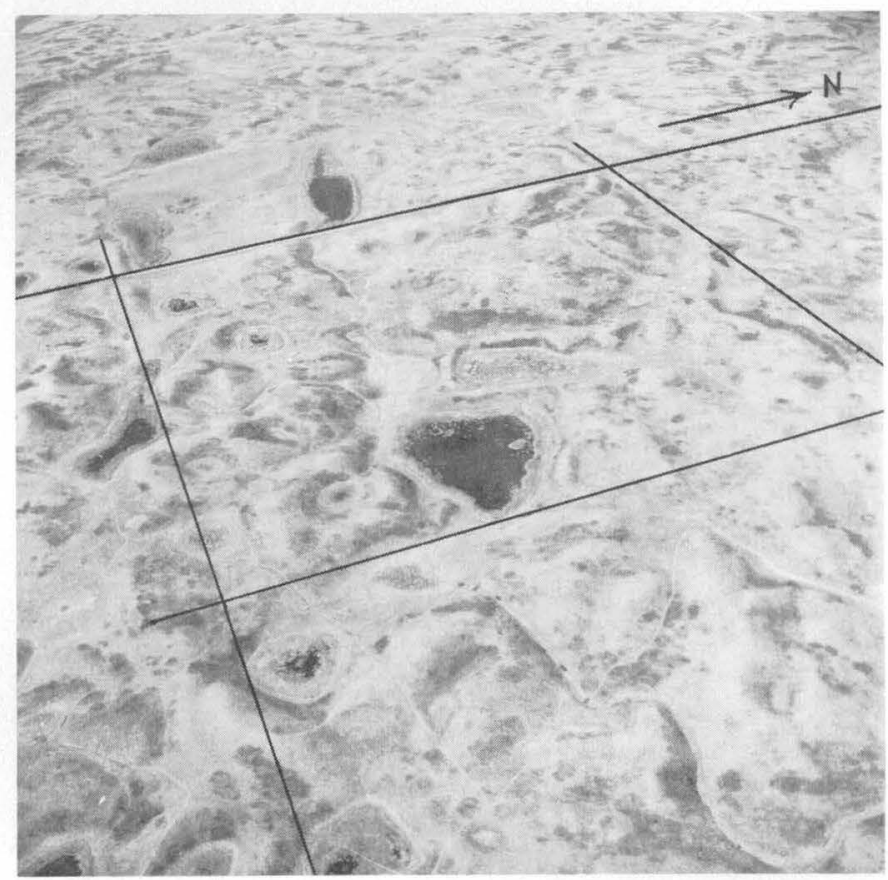

FIgure 2.-Prairie potholes in dead-ice moraine in Mt. Moriah study area. NW1/4 sec. 21, T. 144 N., R. 67 W., in center of photograph.

U.S. GEOL. SURVEY PROF. PAPER 700-B, PAGES B227-B231 


\section{CHARACTERISTICS OF PRAIRIE POTHOLES}

Prairie potholes are characterized by wide variations in hydrologic and topographic characteristics. The permanence of ponds in potholes ranges from many that exist for only a few days following spring snowmelt, to a few that are more or less permanent. Pothole water ranges from very fresh to brines that are several times more concentrated than sea water. The water area varies from a few tens of square feet to several square miles. Water areas larger than about 40 acres are usually called lakes. Potholes do not differ a great deal in depth; almost all are shallow, seldom exceeding 4 or 5 feet, and commonly are less than 3 feet deep.

Prairie potholes are a vital wetland habitat for migratory waterfowl, and provide livestock water supplies. When drained, potholes provide land for agriculture. Owing to agricultural drainage, pothole wetlands are diminishing rapidly.

Water-budget studies by the U.S. Geological Survey show that among prairie potholes in North Dakota seepage rates differ significantly. Average outflow seepage ranged from 0.0008 to 0.0088 foot per day in 10 study potholes, during the period 1960 to 1964 (Shjeflo, 1968). This tenfold difference in seepage occurred within a narrow range of pothole classes including only semipermanent and seasonal potholes. For a discussion of pothole clásses, see Stewart and Kantrud (1969). Observations of pothole water levels in several study areas in Stutsman County indicate that outflow seepage rates are much higher from ephemeral and temporary potholes.

A seepage rate of 0.5 foot per day was observed in an ephemeral pothole in the NW1/4 sec. 12, T. $142 \mathrm{~N}$., R. $68 \mathrm{~W}$., during the period April 11-16, 1969. Conversely, net inflow seepage of 0.003 foot per day was determined in a saline lake in the SW1/4 sec. 7, T. 139 N., R. 69 W., during the period Aug. 9-Nov. 1, 1967. It is likely that all intermittent and permanent saline lakes and some brackish to saline semipermanent potholes have net inflow seepage. In spite of the limited data, it is obvious that a wide range of seepage conditions prevails in the prairie-pothole region.

There is a general relationship between pothole permanence, salinity, and rate of decline of water surface. With rapid decline, a pothole is less permanent and is fresher than a pothole that has a slow decline.

Observation wells near selected potholes in the Mt. Moriah area (table 1) show that relative salinity is low and rate of decline is high where the water table slopes down away from the pothole and that the converse is true where the water table slopes down toward the pothole.

Evapotranspiration, precipitation, and runoff do not
TABLE 1.-Relation of water-table configuration to specific conductance and rate of decline of pond surface at selected potholes in the Mt. Moriah, N. Dak., area, 1967

\begin{tabular}{rrrr}
\hline Pothole & Water-table slope (direction) & $\begin{array}{c}\text { Specific } \\
\text { conductance } \\
(\mu \text { mhos/ } \\
\left.\mathrm{cm} \text { at } 25^{\circ} \mathrm{C}\right)\end{array}$ & $\begin{array}{c}\text { Rate of } \\
\text { decline } \\
\text { (ft per day) }\end{array}$ \\
\hline 42 & 360 & 0.042 \\
34 & & 775 & .027 \\
15 & & .025 \\
\end{tabular}

vary a great deal from pothole to pothole in a local area, but seepage rates, salinity, and permanence of potholes can vary greatly. Inflow in a local area is not highly variable among potholes with similar basin characteristics. The greatest variable in the waterbudget items among local potholes is the seepage rate. Two variables affect the seepage balance at a pothole: these are the configuration of the adjacent water table and the permeability of the surrounding drift. Because the permeability of the surrounding drift is grossly similar from pothole to pothole in glacial till, or in glacial outwash, the water-table configuration is the principal variable that controls seepage.

The water table, defined as, "that surface within the saturated zone at which the pressure is atmospheric," (Lohman, 1965, p. 92), is continuous with the water surface in prairie potholes (fig. 3 ). The water table in poorly permeable glacial till is a shallow irregular surface that is a subdued image of the topography. The continuous zone of capillary saturation above the water table includes that part of the saturated zone wherein the water pressure is less than atmospheric. The thickness of the capillary zone varies with the

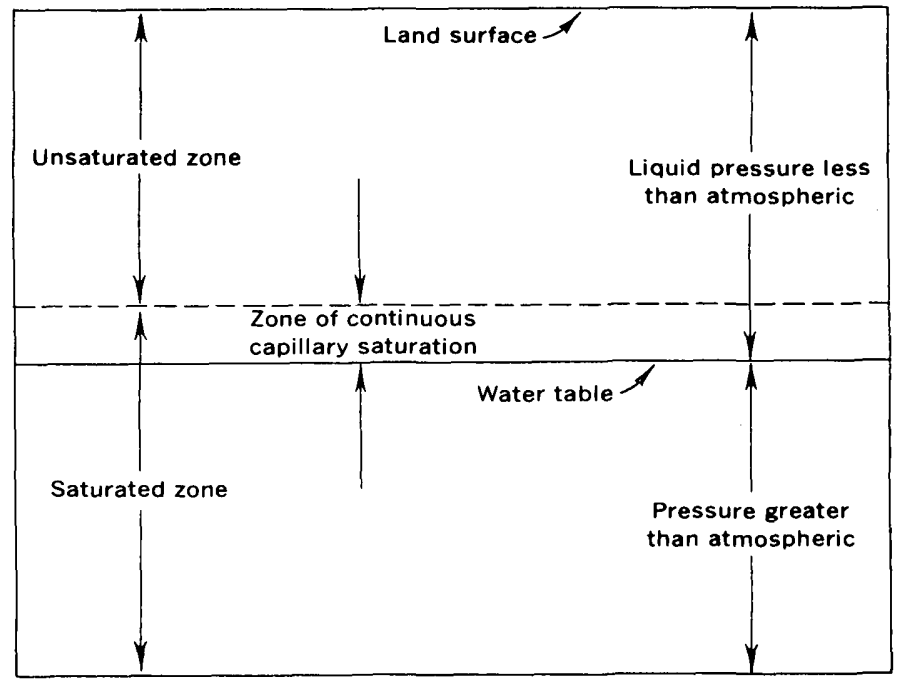

FraURE 3.-Water-table diagram. 
grain size and is greatest in fine-grained materials, where it may be as much as 6 feet.

\section{GROUND-WATER CONDITIONS NEAR PRAIRIE POTHOLES}

Some investigators of prairie-pothole hydrology have assumed that potholes are insulated, or perched, bodies of surface water separated from a regional water table by an unsaturated zone of impervious strata. This assumption greatly simplifies water-budget studies because it neglects the influence of groundwater inflow or outflow. The assumption is based largely on the following observations:

1. Water levels in potholes and nearby observation wells are usually different, frequently as much as 1 foot or more. The difference has been interpreted as proof that there is no hydraulic connection between the water in the pothole and the water in the surrounding glacial drift. Such differences are characteristic of glacial till and result from the low permeability of the till and the large hydraulic gradients necessary to move ground water through it.

2. Many test holes drilled in poorly permeable glacial till appear to be dry. In such instances, water does not fill the drill hole immediately, and till samples obtained during drilling seem to be dry. Saturated gravel, sand, or silt in glacial till yields water to drill holes readily and thoroughly wets the drilling samples. Water release from till is comparatively slow, however, and drill holes that do not penetrate any stratified materials require a much longer time before water in the drill hole reaches equilibrium with the surrounding ground water. In these dry holes the weight of the drilling equipment can physically squeeze water out of the samples, and the frictional heat generated by the drilling operation can vaporize the water in the drilling samples and drive it off. Hot steaming samples are commonly observed when drilling in glacial till, and the resulting samples, although saturated in place, appear dry and crumbly rather than wet and sticky when they are brought to the surface.

3. Water levels in closely spaced wells frequently differ, particularly if the wells are cased to different depths. Cased wells in till usually act as piezometers such that the water level represents the fluid pressure at the bottom, or screened part, of the casing. Large vertical fluid-pressure gradients are common in glacial till because of its low permeability. If the water levels in such wells are misinterpreted as points on the water table, there would seem to be a series of perched water tables. From this erroneous conclusion, it is logical to assume that the potholes are also perched.

4. Closely spaced potholes are frequently separated by a large vertical distance and a steep water-table gradient, occasionally as high as 25 percent. Such high water-table gradients are inconsistent with normal water-table gradients that have been described in unconfined aquifers. They are consistent, however, with the low permeability conditions that obtain in the glacial till surrounding the potholes.

All of the aforementioned conditions, seemingly anomalous, are typical of ground-water conditions surrounding prairie potholes, primarily because of the low permeability of glacial till. These conditions, atypical of aquifer systems, have been construed to indicate that ground-water flow systems are unrelated to prairie-pothole hydrology.

\section{RESULTS OF INVESTIGATION}

Twenty-eight observation wells were drilled during October 1965 in the Mt. Moriah area in sec. 21, T. 144 N., R. 67 W., Stutsman County, N. Dak., to determine the position of the water table between potholes. There are 104 prairie potholes in sec. 21 , and they have a total area of about 58 acres. The potholes range in size from 0.01 to 7.1 acres and have a total shoreline of about 9.6 miles.

The Mt. Moriah area is on the eastern slope or escarpment of the Coteau du Missouri, a poorly drained slope that is transitional between the undrained Coteau surface of high-relief stagnation moraine to the west, and well-drained, low-relief ground moraine of the drift prairie to the east. The altitude ranges from 1,880 feet above mean sea level in the northwestern part of the section to 1,705 feet in the northeastern part, a slope of 175 feet to the mile, or 3.3 percent. Local slopes up to 25 percent are common in the area.

The test holes that were augered in the Mt. Moriah area ranged from 14 to 67 feet in depth, and averaged about 24 feet. Some stratified material, including thin stringers of sand, silt, or gravel, was found in 21 of the 28 test holes. Glacial till was found in all the holes, and was overlain directly by the soil zone in all but three of the test holes. The glacial till in the Mt. Moriah area consists of a heterogeneous mixture of unconsolidated gravel, sand, silt, and clay, that is well jointed and oxidized near the surface. Both jointing and oxidation tend to diminish with depth. A buried oxidized zone was found in one hole at a depth of 43 feet. Only four test holes were sufficiently deep to penetrate the surficial oxidized zone, which in these holes ranged in depth from 27 to 45 feet. A calcareous marl containing many small fossil gastropods and pelecypods was found at a depth of about 12 feet in one hole.

Ground water attained equilibrium in all but five of 


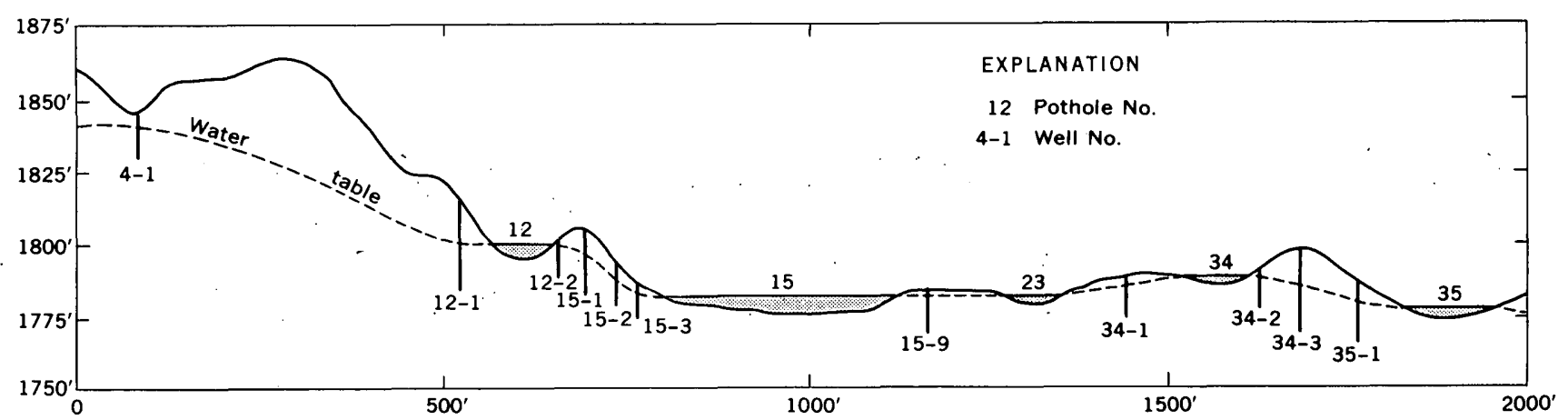

Figure 4.-Profile of water table and potholes in the Mt. Moriah area. Vertical exaggeration $\times 4$.

the test holes immediately after drilling. The five test holes that did not show an immediate response to ground water reached equilibrium within a few hours. At the time the wells were drilled, depths to the static water level ranged from about 2 to 15 feet, and averaged about $51 / 2$ feet from the land surface. The 4 -inchdiameter test holes were cased with $11 / 2$-inch thinwalled aluminum conduit. The conduit was perforated by cutting slots at about 2 -inch intervals on two sides through the bottom 3 feet of pipe and at about 6 -inch intervals through the remainder of the saturated zone. Washed pea gravel was placed around the bottom few feet of perforated pipe as a stabilizing gravel pack, and till was packed in the annular space around the upper part of the pipe to provide a surface seal. The pipes protruded above the ground surface from about 0.25 to 1.75 feet, and were covered to exclude precipitation. After casing, the wells were pumped and developed with compressed air to promote free circulation of ground water into the well. Observations of these wells show that in cross section (fig. 4) the water table is nearly a straight line linking the water surfaces of potholes.

The water levels in observation wells that were in the zone of phreatophytic vegetation adjacent to potholes rose and fell in response to variations in climatic and ground-water flow conditions in much the same way as the pothole water surfaces did, but with much greater amplitude. Thus ground-water levels were often significantly above or below the pothole water surface. Normally, recharge to ground water in the spring raised the ground-water levels considerably above the adjacent potholes, but as evapotranspiration rates increased in late spring and summer, discharge from the wet meadow zone lowered ground-water levels, which eventually dropped below the level of the adjacent potholes. Figure 5 is a diagrammatic sketch that shows the relationship of the water-table configuration to inflow and outflow seepage, pothole permanence, and salinity.
Water-level recorders on shallow observation wells show a diurnal fluctuation of the water level within the well. The diurnal fluctuations (fig. 6) consist of drawdown during the day and recovery during the night.

Shallow observation wells with water levels less than 5 feet below the land surface respond rapidly to infiltration from precipitation, but deeper wells where the water level is greater than 10 feet below the surface show a definite lag and much less response to precipitation infiltration.
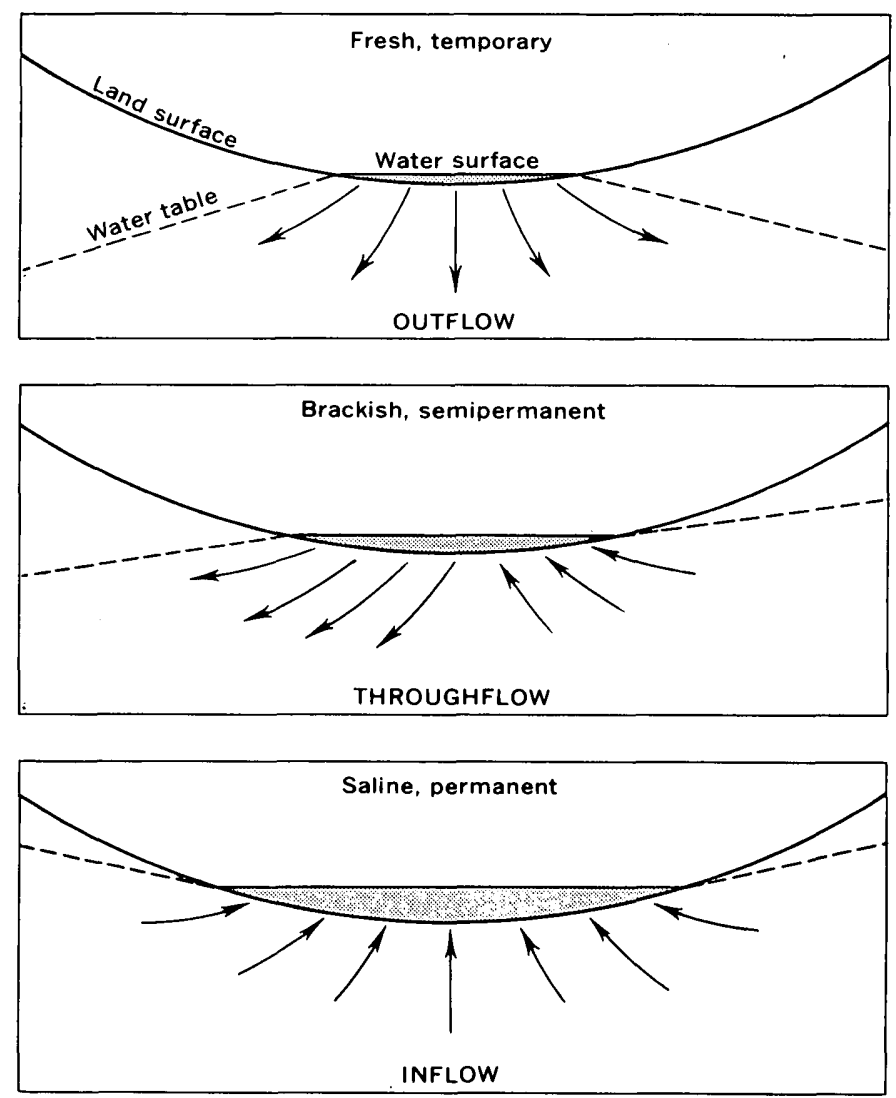

Figure 5.-Water-table configuration and its relation to pothole hydrology. 


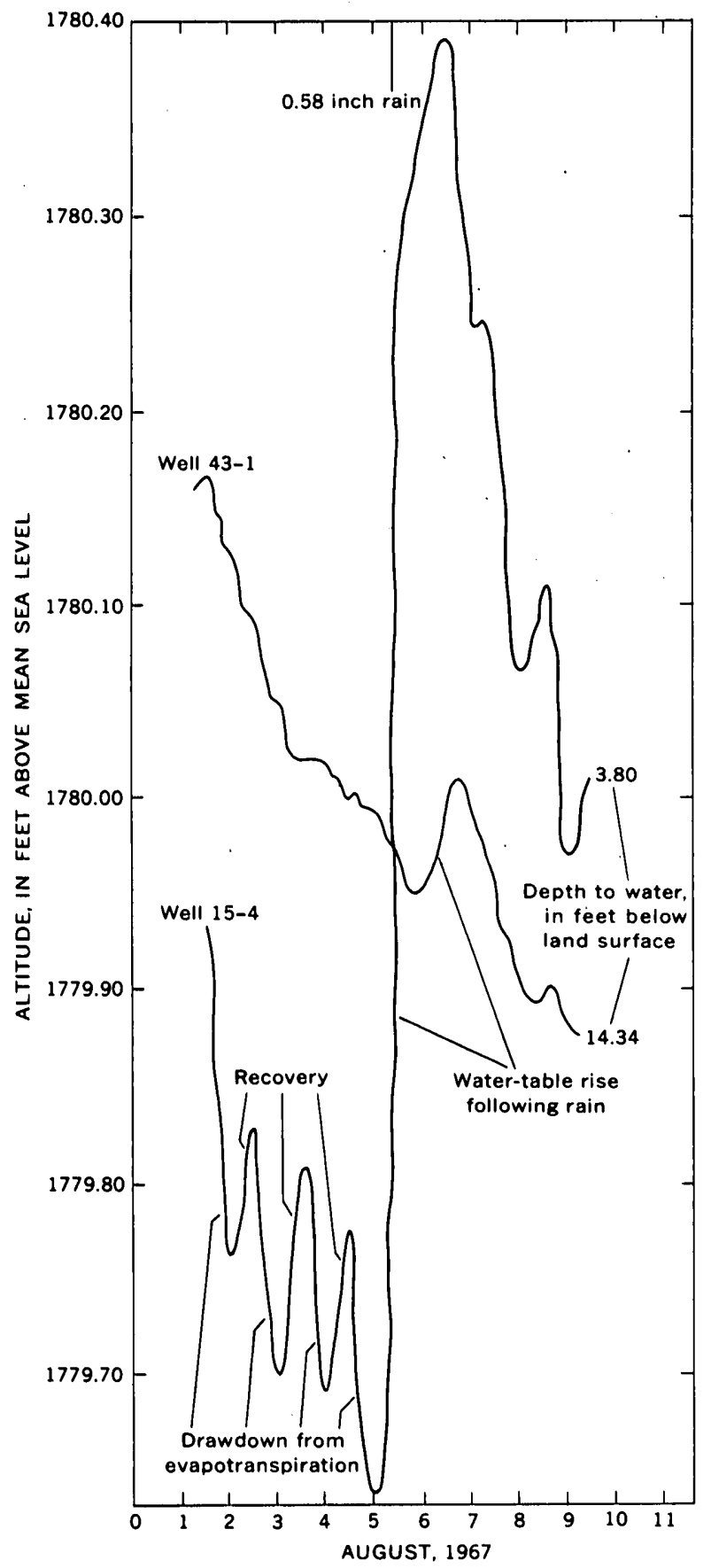

Fraure 6.-Observation-well hydrographs showing contrast between shallow and deeper well behavior. Note diurnal fluctuntion and strong response to precipitation infiltration in shallow well.

\section{SUMMARY}

In summary, investigations in the Mt. Moriah area indicate that the water table is a shallow curved surface linking pothole water surfaces. Regionally, the water table follows the topography. In detail, however, small variations in topography are not reflected and in cross section the water table is almost a straight line linking pothole water surfaces. A summer drawdown depression that results from evapotranspiration by phreatophytes occurs in the water table surrounding potholes. The configuration of the water table surrounding the pothole has a marked influence on the permanence and salinity of the water in the pothole through its control on inflow and outflow seepage.

\section{REFERENCES}

Lohman, S. W., 1965, Geology and artesian water supply, Grand Junction area, Colorado: U.S. Geol. Survey Prof. Paper $451,149 \mathrm{p}$.

Shjeflo, J. B., 1968, Evapotranspiration and the water budget of prairie potholes in North Dakota: U.S. Geol. Survey Prof. Paper 585-B, 49 p.

Stewart, R. E., and Kantrud, H. A.,. 1969, Proposed classification of potholes in the glaciated prairie region, in Small water areas in. the prairie pothole region-Transactions of a seminar: Canadian Wildlife Service Rept. Ser. no. 6, Ottawa, Canada. 


\title{
HYDROLOGIC AND BIOTIC EFFECTS OF GRAZING VERSUS NONGRAZING NEAR GRAND JUNCTION, COLORADO
}

\author{
By GREGG C. LUSBY, Denver, Colo.
}

Work done in cooperation with the U.S. Department of the

Interior, Bureau of Land Management

\begin{abstract}
The effect of grazing on the hydrology of saltdesert type rangeland has been studied near Grand Junction, Colo., for the past 14 years. Measurements of precipitation, runoff, erosion, and vegetation have been made in four pairs of watersheds. One of each pair has been grazed by cattle and sheep as is normal in the region, and the other has not been used since the beginning of the study. Measurements made 10 years apart show that all four grazed watersheds have had a slight increase in the amount of bare soil and rock and a decrease in ground cover; cover on ungrazed watersheds has remained virtually unchanged. Runoff in the ungrazed watersheds has been about 30 percent less than in the grazed watersheds, and sediment yield has been about 45 percent less. The greatest change in each of the relationships occurred about 3 years after livestock was excluded from one watershed of each of the pairs. Preliminary studies indicate that within areas of similar physiography, runoff is directly related to the percentage of bare soil present on a watershed.
\end{abstract}

The statement that a deterioration of rangeland and an increase in erosion and sediment yield took place in the Western United States at about the time of settlement by white man has been made by numerous writers. This change has been attributed, in many instances, to the effect of grazing by domestic animals and has been fairly well documented. It would seem logical that if grazing were the cause of deterioration of rangeland, the elimination of grazing would cause an improvement.

Thousands of acres of land in the Colorado Plateaus physiographic province are contributing large quantities of sediment and very little water to downstream reaches of the Colorado River and its tributaries. This sediment yield and flash-type runoff not only perpetuate the nonproductivity of the rangeland, but damage farmland, irrigation works, and flood-control projects downstream. The terrain in most of the area is rugged and highly dissected, making any kind of mechanical treatment very difficult and expensive. The control of livestock grazing is one of the most obvious treatments to be applied. The purpose of this study is, therefore, to determine the effect of the elimination of grazing on runoff, sediment yield, and vegetation on salt-desert type rangeland.

\section{STUDY AREA}

The study area is located in the Badger Wash basin in western Colorado a few miles east of the UtahColorado boundary, about 25 miles west of Grand Junction, Colo. Badger Wash is tributary to the Colorado River (fig. 1). The part of the basin being studied is at an altitude of about 5,000 feet and drains

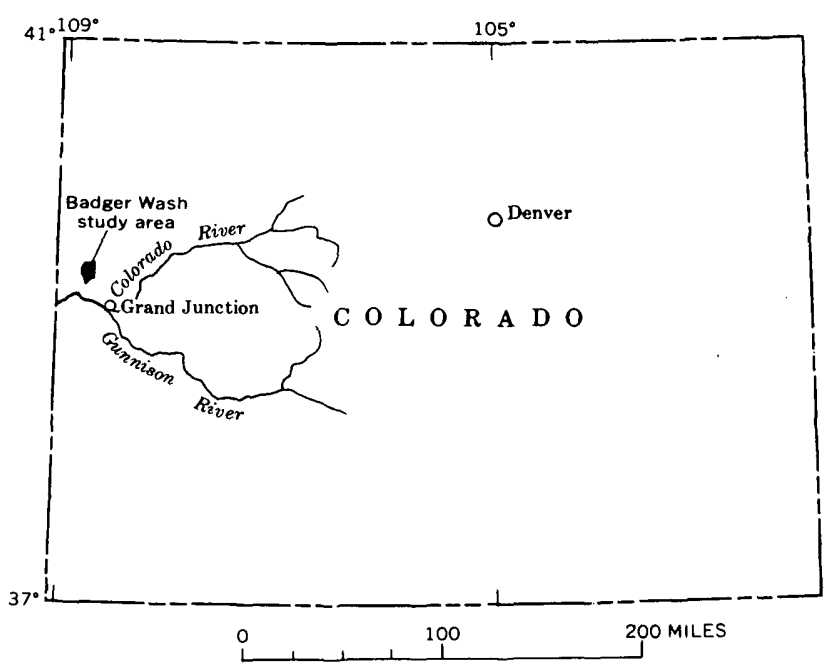

FuaURe 1.-Index map of Colorado, showing location of Badger Wash study area. 
the hilly land between the Book Cliffs and the flat, irrigated section of the Grand Valley.

Although the entire Badger Wash basin is underlain by the Mancos Shale of Late Cretaceous age, the lithology differs somewhat in various parts of the basin. The shale in the western and upper parts of the basin contains a number of thin sandstone beds less than 1 foot thick. Because of their greater resistance to erosion, these layers cause an alternation of steep and gentle slopes. The gently sloping areas are on top of sandstone beds. Channels are similarly affected; they are moderately incised on the relatively steep slopes underlain by shale and have wide, shallow cross sections on the sandstone. On the eastern side of the basin, the sandstone beds are absent, and the topography is more uniform, with very steep hillslopes merging with gentle colluvial slopes at their bases. Channels are everywhere incised into the shale.

Soil in the area is poorly developed and generally consists of a shallow weathered mantle overlying the Mancos Shale. The most extensive soil material in the area is a residual mixture of weathered shale and sandstone chips.

The climate at Badger Wash is arid to semiarid. Average annual precipitation based on 38 years of record at Fruita, Colo., about 16 miles southeast of the study area, is 8.7 inches. Precipitation from April to October occurs generally from convective storms. Temperature during July ranges from about $55^{\circ}$ to $98^{\circ} \mathrm{F}$, and humidity in the desert area is extremely low.

Vegetation at Badger Wash is of the salt-desert shrub type, but several subtypes may be distinguished as well. These subtypes reflect local differences in soil characteristics and available soil moisture. On the lower part of the main drainage, black greasewood (Sarcobatus vermiculatus) is dominant. Pure stands of mat saltbush (Atriplex cormugata) occur on alkaline flats in the upper reaches of the main-valley alluvium.

Big sagebrush (Artemisia tridentata) and rubber rabbitbrush (Chrysothamnus nauseosus) grow along the tributaries, mainly on alluvial soils. On the uplands, sandy soils support shadscale (Atriplex confertifolia) and a relatively dense understory of galleta (Hilaria jamesii). The predominant plant on clay soils is Nuttall saltbush (Altriplex nuttallii). On mixed soils, the vegetation is made up of species found on both clay and sandy soils (Lusby and others, 1963).

In 1953, representatives of four Federal agenciesthe Geological Survey, Forest Service, Bureau of Land Management, and Bureau of Reclamation-under the auspices of the Pacific Southwest Inter-Agency Committee, selected four pairs of watersheds on public lands within the Badger Wash drainage basin for intensive study. These watersheds range in size from 12 to 105 acres. Each pair was selected to be as nearly similar as possible with respect to size, soil, aspect, geology, topography, and vegetation. One of each pair of watersheds was fenced to exclude livestock. The other was to be grazed by both cattle and sheep during the winter and spring, as is normal for the area. A reservoir in which runoff and sediment could be measured was constructed at the lower end of each watershed. Precipitation recorders were established in each pair of watersheds to measure areal distribution of rainfall. Precipitation amounts were computed using the Thiessen polygon method (Thiessen, 1911). Gully cross sections and hillside transects were established which could be surveyed to determine the relative magnitude of channel and hillslope erosion. Twentyfour vegetation transects were established in each watershed for use in determining cover, trends, and use. Records of cover were obtained along the transects using a loop method similar to that described by Parker (1951). Each transect also served at the side of a 2 -foot-wide belt transect on which forage utilization estimates were made.

During the early years of the study, a trend toward more sediment yield and runoff from grazed areas than from ungrazed areas was noted. The change was attributed in a previous report (Lusby, 1965) to the trampling effect of livestock on soil that was loosened by frost heave. This present report more completely defines the changes in runoff and sediment yield.

\section{RESULTS}

The evaluation of the effects of grazing on the hydrology of the study watersheds is dependent on trend comparisons of paired watersheds, because there was no calibration period at the beginning of the study. The assumption is made that the characteristics that determine runoff and erosion are similar for paired watersheds. Although this assumption may not be strictly true, the trends in four pairs of watersheds should be indicative of the actual events taking place.

\section{Precipitation}

Rainfall during the study period 1956-66 was generally below the long-term avenage. Average annual precipitation at Fruita was 8.24 inches during the period, which compares with the long-term average of 8.75 inches. The below-average yearly precipitation probably had no direct effect on the study, but may have suppressed the recovery of vegetation not being grazed.

Of primary importance in this study is the equality of precipitation over each pair of watersheds. Con- 
siderable variation of precipitation among the pairs of watersheds has been observed, but differences between watersheds of each pair have been rather slight. The yearly difference in summer rainfall between grazed and ungrazed watersheds averaged 3 percent, but the total rainfall for 13 years on each pair of watersheds did not differ by more than 1.8 percent. No definite pattern of rainfall was observed over the basins.

Figure 2 shows the average summer precipitation for grazed versus ungrazed watersheds and indicates that precipitation amounts have been quite similar for paired watersheds.

\section{Runoff}

Runoff at Badger Wash occurs almost wholly in response to summer rains. Very infrequently, rainstorms may occur during the winter that produce some runoff. Snow generally does not accumulate enough to cause runoff in the spring.

For the purpose of this paper, the comparison of average runoff from the four grazed basins with that from the four ungrazed basins is used to define the effect of basin use. Figure $3 A$ shows a mass diagram, by years, of such a comparison. No runoff occurred in 1956,1958 , and 1966. The average slope of the line after 1956 is about 1.3 , indicating that the grazed watershed was producing 30 percent more runoff than the ungrazed watershed. This change apparently started almost immediately after livestock were excluded in the winter of 1953 , but the greatest difference did not occur until about 3 years later. The individual pairs

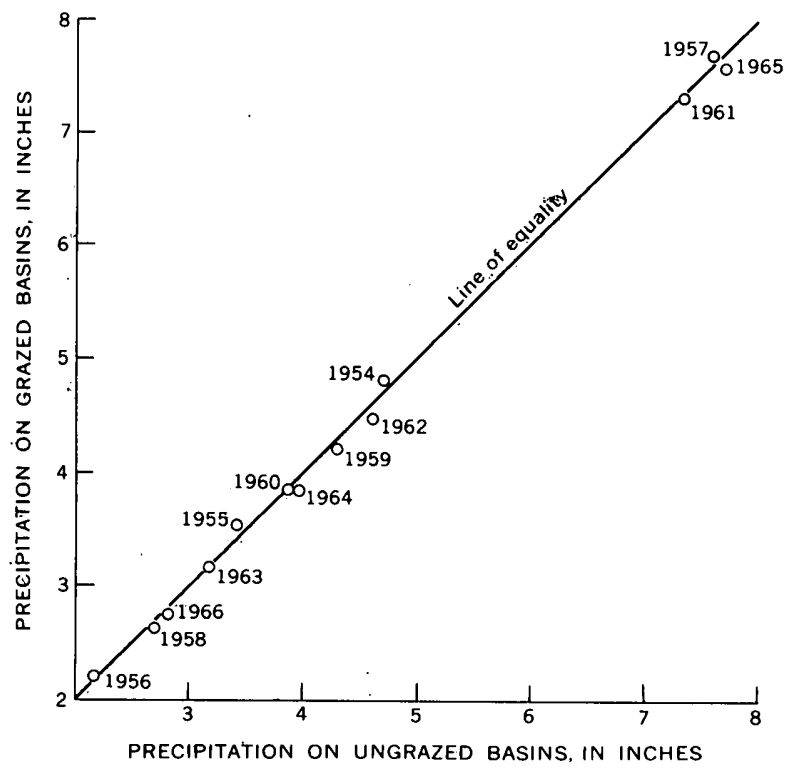

Figure 2.-Comparison of summer rainfall on grazed and ungrazed watersheds at Badger Wash.
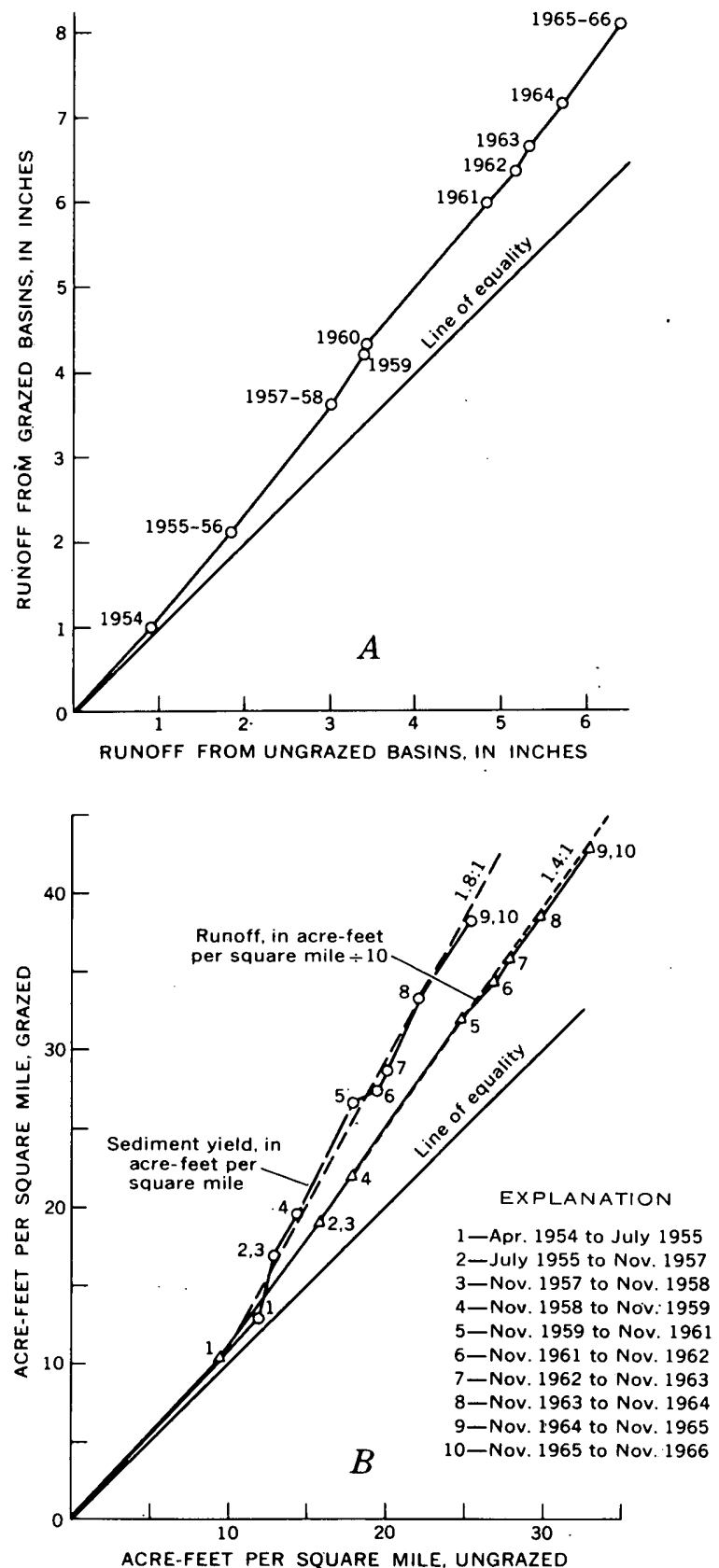

Figure.3.-Mass diagrams. $A$, runoff in grazed and ungrazed basins at Badger Wash, by year; $B$, sediment yield and runoff at Badger Wash, by periods.

of watersheds all show the same pattern as the average except for one pair that is complicated by the presence of an upstream reservoir sediment deposit. The slope of the mass line for three pains of watersheds ranges from 1.40 to 1.45 during the latter part of the study period.

A plot of runoff in a grazed basin versus that in an ungrazed basin, by storms, (not shown here) indicates a different relation before and after the break in the 
mass plot indicated in figure $3 A$. During 1954-55 the points are characterized by the regression equation $Y=0.0059+1.09 X$, with a correlation coefficient of 0.99 . During $1956-66$, the points are characterized by a regression equation of $Y=0.0386+1.13 X$, with a correlation coefficient of 0.98 .

\section{Sediment yield}

Sediment yield was measured by surveying the catchment reservoirs at the end of 10 periods during the study. The results of these measurements, together with runoff for the same periods, are shown graphically in figure $3 B$. After the first period, April 1954 to July 1955 , the mass curve departed from the line of equality and assumed a slope of about 1.8 to 1 . At the same time the runoff line assumed a slope of about 1.4 to 1 . The measurements of sediment do not assume so smooth a curve as do those of runoff because of the compaction of sediment during dry periods. When surveys are made during periods of large runoff and sediment yield, the reservoirs usually contain water; thus measurements are of sediment that is not compacted. During dry periods, the reservoirs are usually dry, allowing the sediment to become compacted and to shrink. The trend of the sediment-yield line is indicative of compacted sediment. Volume weight of deposited sediment has been measured to be from 80 to 100 pounds per cubic foot or about 2,000 tons per acre-foot.

\section{Watershed cover}

Measurements of watershed cover made by U.S. Forest Service personnel indicate that at the beginning of the study no significant difference existed between plant cover on watershed pairs, although the ungrazed watersheds contained an average of 5 percent more bare soil than those that are grazed (Lusby and others, 1963). Periodic measurements of watershed cover indicate no large or sudden changes, but measurements made in the fall of 1953 and the fall of 1963 show some definite changes for the entire period. These changes are shown in figure 4.

Although some of the changes shown are not of large magnitude, they appear to be important as far as percentage is concerned. From the bar graphs shown, it appears that the ungrazed watersheds remained in about the same condition as at the start of the study and most changes took place in the grazed basins. The marked increase in bare soil and rock on all grazed watersheds, accompanied by a decrease in shrub overstory, litter and moss, and ground cover index, indicate that the grazed watersheds were in worse condition hydrologically at the end of the study period than at the beginning. This may have been caused by several dry years or increased grazing pressure because of the availability of water in the area, or by both.
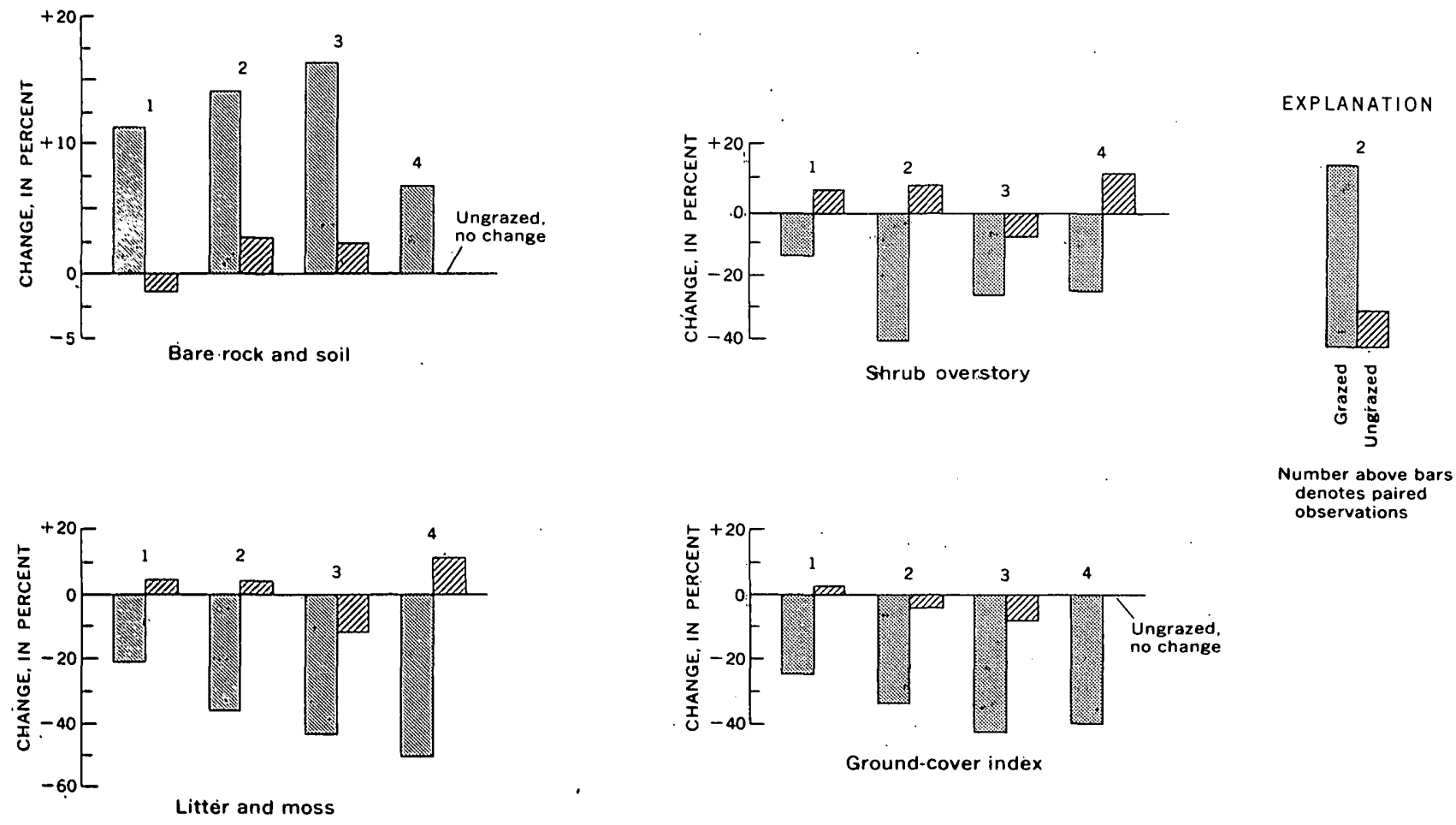
observations

Froure 4.-Changes in watershed cover from fall 1953 to fall 1963 . Change is expressed in percentage of value measured in 1953. 


\section{Source of sediment}

At the beginning of the study, permanent cross sections were established on gullies in the paired watersheds, and transects were established on the hillsides to determine the source of sediment being produced. The average change in elevation of the ground surface on cross sections and transects is used to determine the sediment source. Sections in all watersheds show erosion in the gullies.

The gullies in grazed watersheds have about twice as much erosion as those in ungrazed watersheds. The greatest amount of gully erosion apparently took place in one of the grazed, more sandy areas in which the channels are established in alluvium. The most erosion shown by hillside transects took place in the grazed, mixed-soil type watershed that has the steepest topography in the Badger Wash area.

Although no definite statement can be made concerning the actual volume of material removed by each type of erosion, the relative extent of each type may be obtained by comparing measurements of gully erosion and hillside erosion. Sheet erosion of the hillsides appears to be more dominant in the three watersheds that have the steepest topography. In two of the ungrazed watersheds, the ground surface was actually higher in 1966 than in 1954, probably because of expansion of the soil from frost heave.

\section{Runoff in relation to watershed characteristics}

Recent investigations by F. A. Branson and J. R. Owen, of the U.S. Geological Survey (oral commun., 1969), indicate that a useful correlation may exist between the amount of bare soil and quantity of runoff. Figure 5 shows this relation for 17 watersheds on which measurements are available at Badger Wash. The points have a significant correlation coefficient of 0.81 about the computed regression line. Although the fit about the regression line is not extremely close, the trend is indicative of a relation between bare soil and average annual runoff. Investigations in other areas indicate that the same sort of relation may exist, but at a different level. What may actually exist is a similar relation dependent on the particular physiographic and climatologic characteristics of the region. If this relation can be defined by future work, it may be useful in predicting runoff from ungaged areas.

\section{SUMMARY}

After the initial 2 years of study, ungrazed watersheds at Badger Wash have averaged 30 percent less runoff than grazed watersheds, during periods of

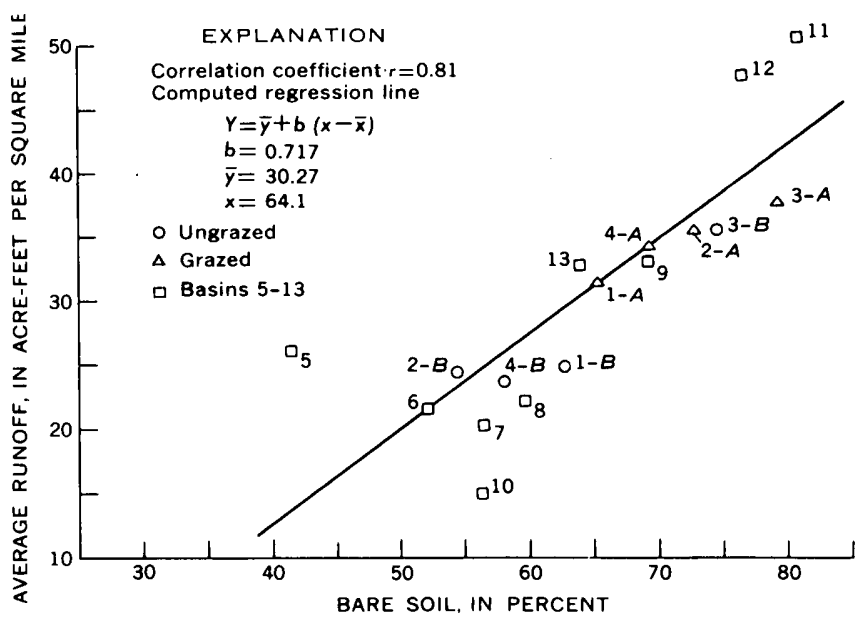

Frgure 5.-Percentage of soil which is bare versus average runoff for 14 years in basins at Badger Wash (loop method, 1967-68).

similar rainfall. At the same time, ungrazed watersheds have averaged 45 percent less sediment yield than have grazed watersheds.

The difference in runoff and sediment yield took place soon after livestock were excluded and was not accompanied by a corresponding difference in watershed cover, although at the end of 11 years, significant differences were noted in bare soil and rock, litter and moss, shrub overstory, and ground-cover index. The hydrologic changes have been described in a previous report as being caused by the trampling effect of livestock on soil that was loosened by frost heave (Lusby, 1965).

A definite relation between bare soil and runoff at Badger Wash was established. Investigations in other areas show that a similar relation for different regions may exist. If further investigation is able to define this relation more fully, the relation might be a worthwhile predictive tool.

\section{REFERENCES}

Iusby, G. C., 1965, Causes of variation in runoff and sediment yield from small drainage basins in western Colorado: U.S. Dept. Agriculture Misc. Pub. 970, paper 14, p. 94-98.

Iusby, G. C., Turner, G. T., Thompson, J. R., and Reid, V. H., 1963, Hydrologic and biotic characteristics of grazed and ungrazed watersheds of the Badger Wash basin in western Colorado, 1953-58: U.S. Geol. Survey Water-Supply Paper 1532-B, p. 1-73.

Parker, K. W., 1951, A method for measuring trend in range condition on national forest ranges: U.S. Dept. Agriculture, Forest Service, $26 \mathrm{p}$.

Thiessen, A. H., 1911, Precipitation for large areas: Monthly Weather Review, v. 39, p. 1082-1084. 


\title{
SANDBAR DEVELOPMENT AND MOVEMENT IN AN ALLUVIAL CHANNEL, RIO GRANDE NEAR BERNARDO, NEW MEXICO
}

\author{
By J. K. CULBERTSON and C. H. SCOTT, Albuquerque, N. Mex.
}

\begin{abstract}
Donic sounder records were used to document the development and movement of transverse bars in the Rio Grande conveyance channel near Bernardo, N. Mex. Rate of movement was about $\mathbf{3 5 0}$ and $\mathbf{3 7 0}$ feet per day for two transverse bars observed. Depth of flow was less and velocity of flow was greater over the bars than in the dune reaches, but the water-surface slopes were equal. Median size of bed-surface material on the backs of bars was finer than the bed-surface materinl in the dune reaches. The mechanics of formation and movement of transverse bars is obscure; however, the bars may be formed by the coalescence of large dunes, and movement is caused by scour of the bar at the upstream end and deposition at the downstream end. A natural sorting of bed material at the upstream end of the bar is also indicated.
\end{abstract}

Bed configuration of an alluvial channel represents the result of the interaction between the water-sediment mixture flowing in the channel and the material of which the bed is composed. Bed configuration determines the resistance to flow and is of importance to the hydraulic engineer dealing with channels with deformable boundaries.

Simons, Richardson, and Albertson (1961) described the various bed configurations observed in a laboratory flume. Of the configurations observed in the flume, ripples, dunes, and a transition zone in the lower-flow regime, and plane bed (with sediment movement), standing waves, and antidunes in the upper regime occur in natural alluvial channels, although not all of these configurations may be observed in any given channel.

The Task Force on Bed Forms in Alluvial Channels (1966), in their classification of bed forms, included bars as bed forms occurring in field streams in addition to the forms that also occur in flumes. The Task Force on Bed Forms (1966, p. 53) classified bars as point bars, alternating bars, transverse bars, and tributary bars. Point and tributary bars are the result of channel geometry, and alternating and transverse bars are the result of flow conditions. Transverse bars are of in- terest because they represent a transition condition between dune bed and plane bed (with sediment movement). Bars, in general, were described by the Task Force as being approximately triangular in cross section, with gentle upstream slopes and with downstream slopes that are approximately the same as the angle of repose of the bed material. Transverse bars were described as occupying nearly the full channel width, and occurring as isolated and as periodic forms along a channel.

Barton and Lin (1955) observed a transverse bar in a $4 \times 70$-foot laboratory flume and described it as a large sand wave in profile, distinctly higher and many times longer than the dunes in the neighborhood. The general wave front was not normal to the direction of flow, and the velocity of the bar was greater than that of the dunes. The water surface was so erratic that uniform flow no longer existed. Sandbars often had rather steep fronts but only slightly inclined backs.

Brooks (1958) observed similar bars in flumes 10.5 and 33.5 inches wide and described them as long, thick deposits of sand with smooth, flat tops over which the water flowed with reduced depth, increased velocity, and greater sediment load. In the remainder of the flume the bed was covered with dunes for which the friction factor remained large.

The purpose of this paper is to describe a transverse bar and the associated hydraulic and sediment characteristics found in a natural alluvial channel. A possible cause of formation of the bars is suggested.

\section{STUDY CHANNEL}

The Rio Grande conveyance channel near Bernardo, N. Mex. (fig. 1), in which the bars were observed, is approximately 35,000 feet in length. Water enters the channel from the river through headgates which have a capacity of about 2,000 cubic feet per second, which is also the maximum capacity of the conveyance channel. 


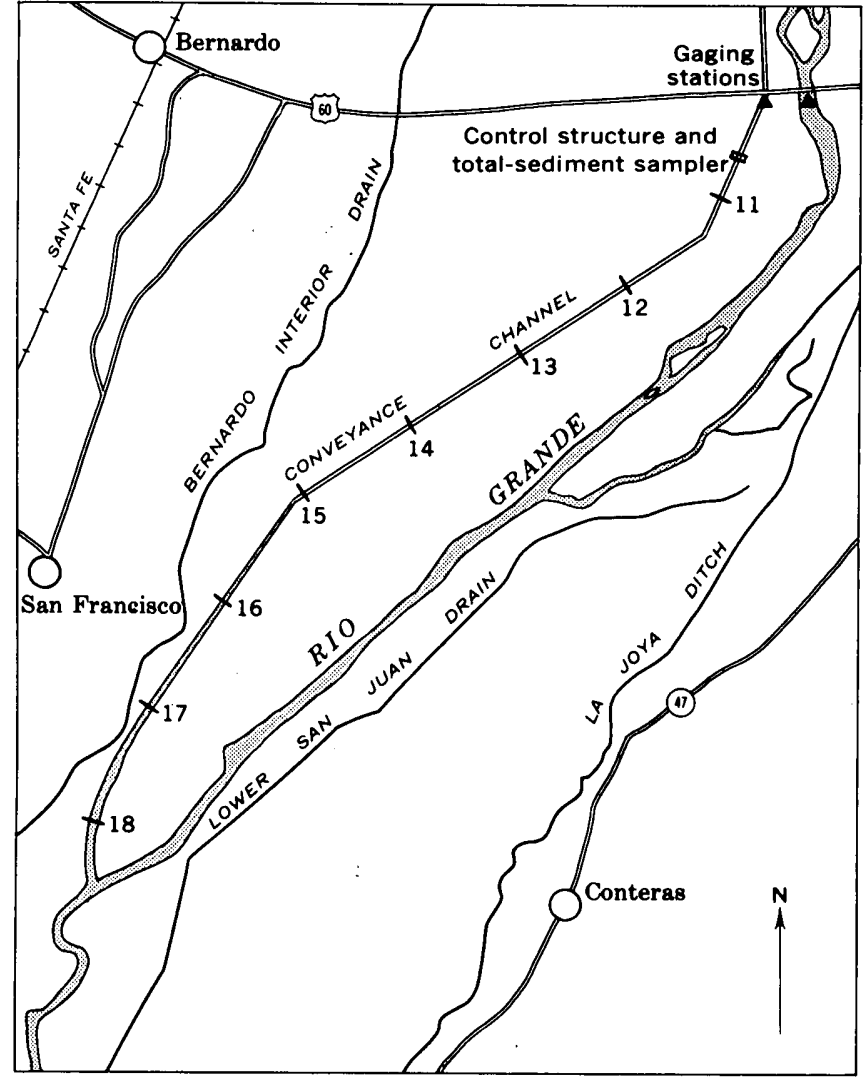
1 MILE

Figure 1.-Location map of Bernardo conveyance channel from gaging station to mouth. Numbered points are observation cross sections.

Flows in excess of 2,000 cfs are carried in the main river channel which serves as a floodway. A concrete control structure is located approximately 20,000 feet downstream from the headgates. Observation cross sections are numbered consecutively and are located at 2,000-foot intervals along the length of the channel. The first observation section is approximately 400 feet downstream from the headgates. The reach in which the data were obtained on the bars extended from section 12 to section 15 , a distance of 6,000 feet.

\section{BAR OCCURRENCE}

In May 1965, flow in the conveyance channel had been controlled at about 900 cfs for about 11 days, with the remainder of the flow in the floodway. The channel bed had formed into large dunes. Suspendedsediment concentration at the gaging station was relatively constant, varying from about 3,000 to 5,000 milligrams per liter. An experiment was carried out to determine how the large dune bed forms would change as the result of periodically increasing the discharge at the headgates. A number of transverse bars were produced, apparently caused by the periodic increase in discharge.

On May 24, a longitudinal profile was obtained with a sonic sounder prior to the first opening of the gates. Discharge was then increased from about 900 to 1,000 cfs. Eleven hours after the gates were opened another longitudinal profile was obtained to determine changes in the bed configuration. No discernible change in the bed configuration was noted. Also, water-surface slope did not change appreciably.

The discharge was increased to 1,100 cfs on May 25 and to 1,200 cfs on May 26. No discernible change in the bed configuration or water-surface slope was observed during this period. On May 27, a large, transverse bar had formed upstream from section 12 . Sonicsounder records obtained daily, beginning May 24, showed no evidence of the bar prior to May 27. The bar was well developed by May 28 and continued to move as a discrete form until May 30 . Figure 2 shows profiles obtained with the sonic sounder for the period May 26 through May 30. The water discharges shown are the means for the 8-hour period prior to the time that the profile was obtained, and the sediment concentrations shown are the daily mean concentrations of samples collected at the gaging station, 4,000 feet upstream from section 12. This particular reach is shown because one distinct bar developed and could be distinguished on the profiles from day to day. The average length of the bar from May 28 to May 30 was about 350 feet, and it covered the entire width of the channel. The average rate of travel of this bar was about 350 feet per day.

Other bars also were observed in the channel farther downstream during this period. Some of these bars were forming on May 26 and were distinct in form; by May 27 they were progressing down the channel. These bars moved as periodic forms, but the length and number of bars within a series changed from day to day, indicating that the bars coalesced and broke up again as they moved down the channel.

In July, another bar was observed for a period of about 7 days. The water discharge was greater than 1,000 cfs prior to the formation of this bar, but the bed form remained large dunes. On July 9 , a short-duration rise occurred with a peak discharge of $1,680 \mathrm{cfs}$. The discharge then decreased and fluctuated between 1,100 and $1,200 \mathrm{cfs}$ for the next 6 days. When first observed on July 12 , the bar was about 1,350 feet long. On July 15, a longitudinal profile showed that the front of the bar had moved about 1,200 feet downstream, and the length had increased to about 1,450 feet. By July 19, the bar front had moved another 1,380 feet downstream, and it had broken into two 


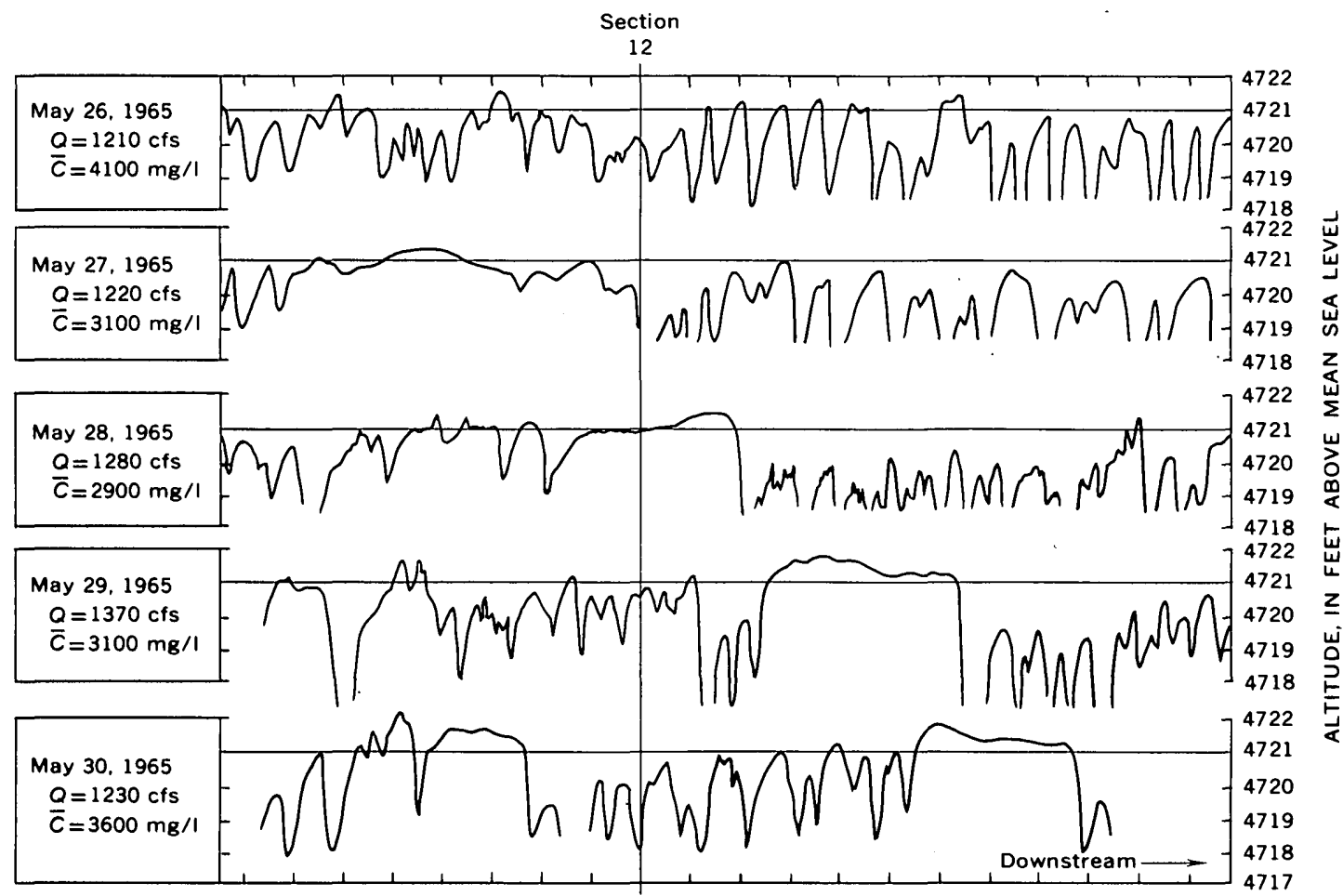

DISTANCE, IN HUNDRED-FOOT INTERVALS

Froure 2.-Longitudinal profiles, May 26 through May 30, near section 12 . $Q$, discharge and $\bar{C}$, suspended sediment concentration.

sections (fig. 3). The average rate of movement for this 7 -day period was 370 feet per day. During this period, no other bars were observed in the channel.

\section{HYDRAULIC CHARACTERISTICS}

The bars observed in the conveyance channel are actually reaches of plane bed, and the depth is less over the bar than it is over the dune reaches. As an example, on May 29, the average depth obtained from in sounder profile at the centerline of the channel, as shown on the profile in figure 2, was 5.4 feet upstream, 4.0 feet on the bar, and 6.4 feet downstream. Computed velocity was 3.43 feet per second in the dune reach upstream of the bar, $4.74 \mathrm{fps}$ over the bar, and $2.74 \mathrm{fps}$ in the dune reach downstream. The elevation of the top of the bar was approximately the same as the elevation of the tops of the dunes upstream and downstream from the bar. The higher mean elevation of the bar indicates aggradation in the reach occupied by the bar.

The smaller depth of flow over the bar did not result only from an increase in mean bed elevation over the bar. Figure 4, shows a profile of the water surface over a short reach obtained when a bar similar to those discussed in this report was moving through the channel on February 3, 1965. The profile includes a transition reach between the dune and the plane-bed reaches through which the slope of the water surface was steeper than the slope upstream or downstream from the transition. Although the profile of the water surface was not extended the full length of the bar, the slope in the transition reach at the downstream end of the bar would be flatter than the slope upstream or downstream from the transition. The slopes in the dune reach and the slopes in the plane-bed reach of the bar were equal; therefore, the same discharge occurred at the same slope for two depths and two velocities because of the change in resistance to flow.

\section{SEDIMENT CHARACTERISTICS}

Samples of bed material were obtained on July 19 upstream and downstream from the bar and also at three cross sections on the bar. The locations of the sampling sites are shown by the median diameters indicated on figure 3 , and the size distribution of bed material is shown on figure 5. The bed material was definitely finer on the bar than in the dune sections upstream and downstream from the bar. The size distribution of the samples indicated that the material in the dune reaches was very slightly coarser upstream from the bar than downstream, and also that the coarsest material on the bar appeared at the upstream 


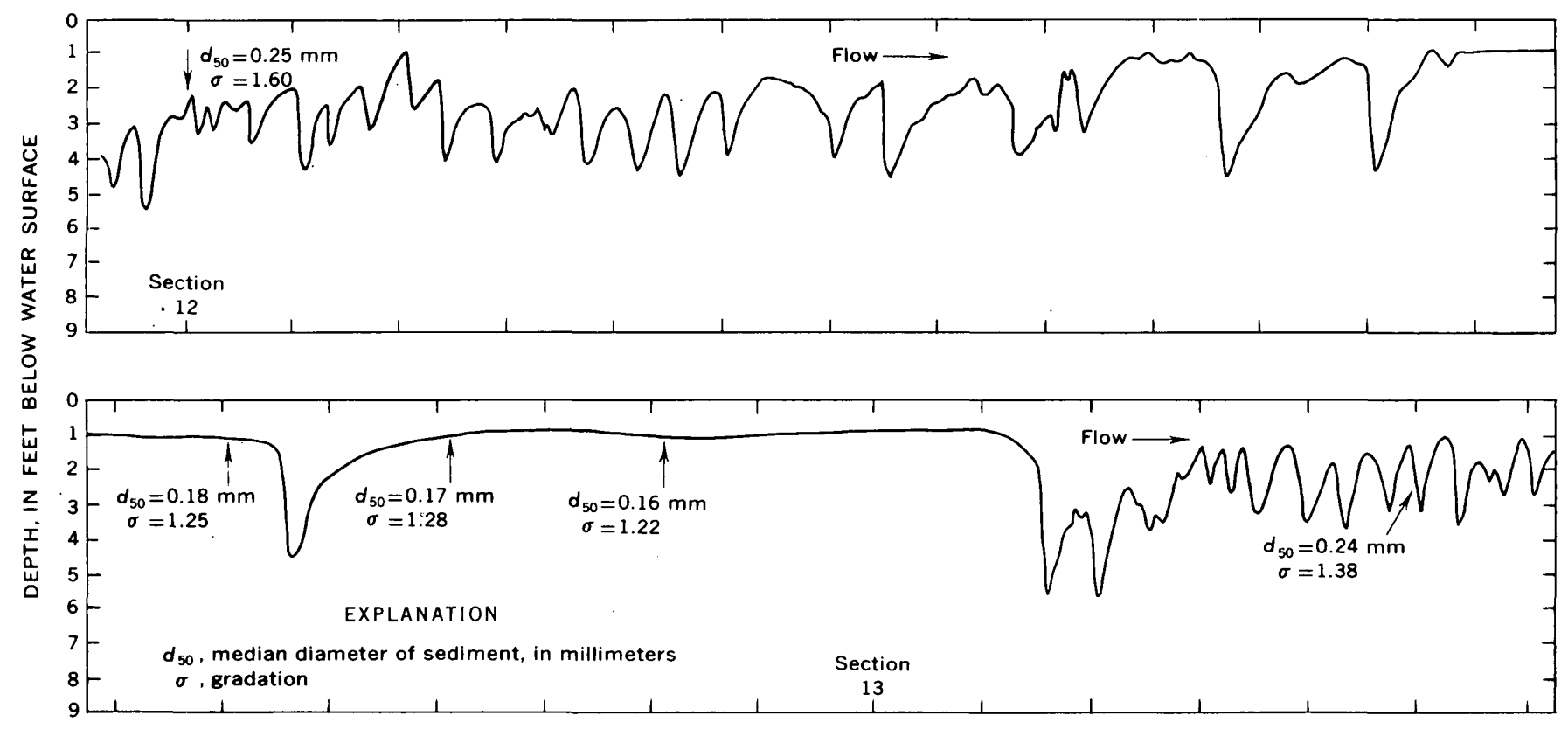

DISTANCE, IN HUNDRED-FOOT INTERVALS

FraUre 3.-Longitudinal profile of bar for July 19, near sections 12 and 13, with particle sizes and mean depths shown.

end and the finest at the downstream end of the bar. Large numbers of bed-material samples that have been collected in connection with the studies in the conveyance channel show that the median diameter of material on bars and in plane-bed reaches is always between 0.15 and $0.18 \mathrm{~mm}$ and in dune reaches between 0.23 and $0.30 \mathrm{~mm}$.

Einstein and Chien (1958) noted that soundings in the Missouri River at Omaha, Nebr., showed that the bed of the river was deeper and rougher on one side and shallower and smoother on the other side. Me-

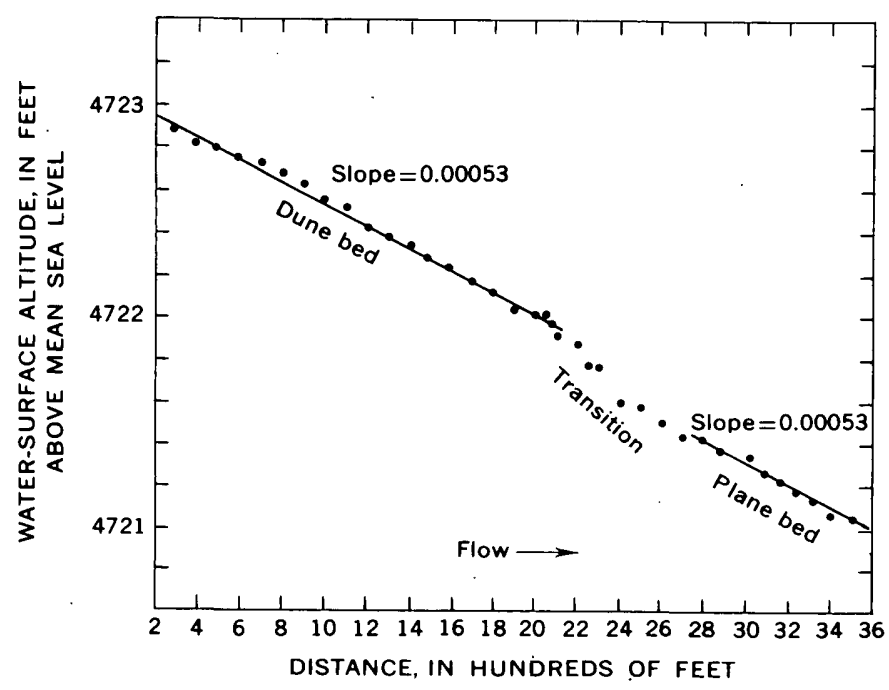

Figure 4.-Profile of a 3,600-foot reach of the water surface, February 3, 1965. chanical analysis of a large number of bed-material samples indicated that the average bed-material size was $0.24 \mathrm{~mm}$ on the rough side and $0.15 \mathrm{~mm}$ on the smooth side.

\section{BAR FORMATION AND TRANSPORT}

Barton and Lin (1955) and Brooks (1958) suggested no reasons for the formation of the bars that they observed in flumes. There is not sufficient infor-

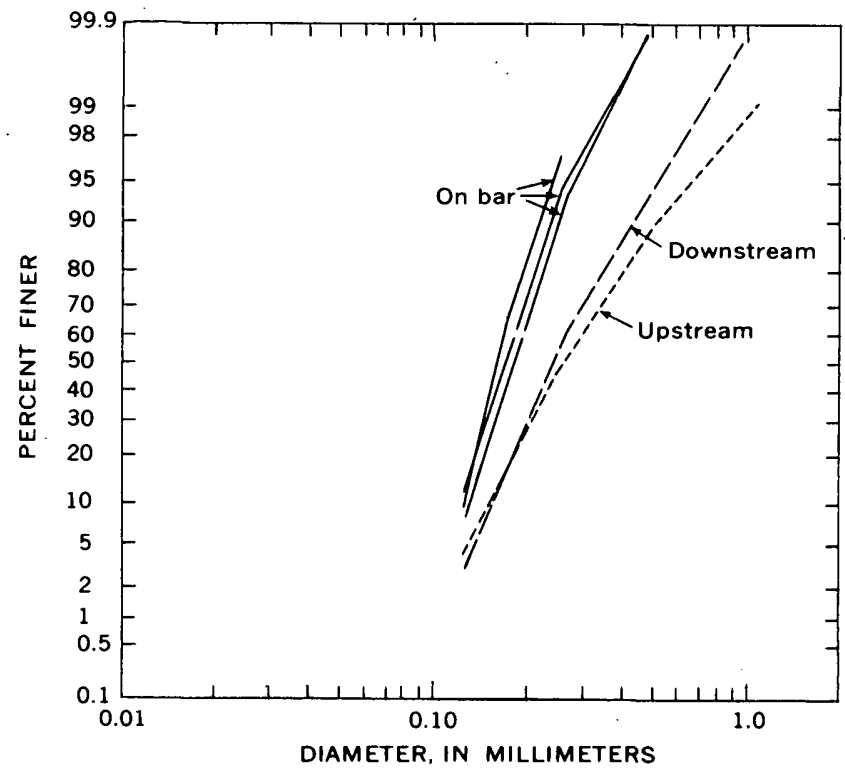

Figure 5.-Particle size distribution of bed-material samples obtained July 19. 
maton to show definitely the cause of the development of the bars in the conveyance channel. The bars that have been observed appear to change length mainly by the coalescing of shorter bars to form longer bars, or the breaking up of long bars to form short bars. The bars may be formed by the coalescence of large dunes.

Once a bar is formed, the manner in which the bar moves can be explained in terms of the sedimenttransport characteristics of sand channels and of the size distribution of bed material upstream from, downstream from, and on the bar. Data available for the conveyance channel, as well as for other studies, indicate that the rate of transport of sands varies generally with about the cube of velocity for both dune-bed and plane-bed reaches; therefore, the transport rate over the bar is greater than that over the dune-bed reaches upstream or downstream from the bar because of the higher velocity. Because of the principle of continuity, this differential transport must be accounted for by scour of the bar at the upstream end, and deposition downstream from the bar if the length of the bar is not changed. There is some evidence to indicate that a bar, once formed, may grow in length as material is added. The size of the bed material is coarser upstream and downstream from the bar than that on the bar, and particle size upstream from the bar appears to be coarser than that downstream. The difference in size distribution in the dune reaches upstream and downstream is slight, but the finer material on the bar indicates that a natural sorting process is taking place in the vicinity of the upstream end of the bar as the bar is scoured. The mechanism by which the material is sorted is not known. However, the bars in the conveyance channel have been observed only for flows greater than 1,000 cfs, which would suggest that the formation and movement of the bars is related to flow conditions. Also, the presence of the fine material on the bar suggests that the bars would not form with a bed material that is uniform in size.

\section{SUMMARY}

In summary, a sonic sounder was used to document the formation and movement of transverse bars in the Rio Grande conveyance channel near Bernardo, N.
Mex. A bar with an average length of 350 feet moved at an average rate of 350 feet per day while a bar with a length which varied from 1,350 to 1,450 feet moved at an average rate of 370 feet per day. The bars are actually reaches of plane bed, full channel width, with smaller depth of flow over the bar than over the dune reaches. The elevation of the bar is approximately the same as the tops of the dunes, which indicates aggradation in the reach occupied by the bar. Slopes of the water surface over the bar and over the dune reaches are equal, but the depth is decreased and velocity increased over the bar. Therefore, the same discharge occurred at the same slope but at different depths and velocities because of the change in resistance to flow between the dune and bar reaches. Samples of bed material show that the median diameter on the bar was $0.18 \mathrm{~mm}$ and that the median diameter in the dune bed reaches was $0.24 \mathrm{~mm}$.

There is not sufficient information to show definitely the cause of development of bars, but it is possible that large dunes coalesce initially to form them. Once formed, movement of the bar is caused by scour of material at the upstream end and deposition at the downstream end. The finer bed material on the bar indicates that a natural sorting process is taking place at the upstream end of the bar. The formation and movement of the bars is evidently related to flow conditions in the channel, and bars probably would not form with bed material that is uniform in size.

\section{REFERENCES}

Barton, J. R., and Lin, Pin-Nam, 1955, A study of sediment transport in alluvial channels: Report No. CER55JRB2, Colorado State Univ., Ft. Collins, Colo.

Brooks, N. H., 1958, Mechanics of streams with movable beds of fine sand: Am. Soc. Civil Engineers Trans., v. 123, p. $526-549$.

Einstein, H. A., and Chien, Ning, 1958, Discussion of mechanics of streams with movable beds of fine sand: Am. Soc. Civil Engineers Trans., v. 123, p. 553-562.

Simons, D. B., Richardson, E. V., and Albertson, M. L., 1961, Flume studies using medium sand $(0.45 \mathrm{~mm})$ : U.S. Geol. Survey Water-Supply Paper 1498-H, 76 p.

Task Force on Bed Forms in Alluvial Channels of the Committee on Sedimentation, 1966, Nomenclature for bed forms in alluvial channels: Am. Soc. Civil Engineers Proc., Jour. Hydraulics Div. v. 92, no. HY3, p. 51-64. 


\title{
SPECTROCHEMICAL DETERMINATION OF MICROGRAM QUANTITIES OF GERMANIUM IN NATURAL WATER CONTAINING HIGH CONCENTRATIONS OF HEAVY METALS
}

\author{
By ALEX E. DONG, Sacramento, Calif.
}

\begin{abstract}
A procedure is described for the chemical separation and determination of microgram quantities of germanium in water containing high concentrations of heavy metals. Before being subjected to spectrochemical determination, germanium is selectively isolated from other major and minor elements in the water in order to avoid undesirable dilution effects. The average error for eight determinations is $\pm \mathbf{9}$ percent, and the relative standard deviation is 8.0 percent, a level of precision satisfactory for spectrochemical determination of trace quantities of germanium.
\end{abstract}

In an investigation of minor elements in California water, Silvey (1967) reported that the occurrence of germanium was unique because it was found only in oil-field brine and spring water. In all other water types, such as ground water, surface water from streams and lakes, and sea water, germanium was not detected. Silvey suggested that the presence of germanium was of geochemical significance and indicated that the water containing germanium may be of deep- . seated origin or may have circulated at great depth within the earth's crustal material.

At the Sacramento laboratory of the U.S. Geological Survey, microgram quantities of germanium in water samples are spectrochemically determined by the method of Silvey and Brennan (1962). However, oilfield brine and spring water samples contain large quantities of heavy metals such as iron, manganese, nickel, aluminum, lead, copper, and others, that are coprecipitated along with germanium during the chemical precipitation step. The masking of the germanium by the other heavy metals is known as the dilution effect. Past experience has indicated that the presence of as little as $100 \mu \mathrm{g} / \mathrm{l}$ (migrograms per liter) of extraneous metals may prevent the quantitative determination of germanium.

A literature search revealed no suitable analytical methods which would overcome this difficulty. Spectro- chemical methods of Mitchell and Scott (1948), Heggan and Strock (1953), and Silvey and Brennan (1962), are best applied to water containing low concentrations of minor elements. Various existing spectrochemical procedures involving the direct arcing of residues obtained by evaporation of water samples cannot be used, because the large bulk residue (especially from highly mineralized water) would undoubtedly worsen the dilution effect. Therefore, an analytical method that would permit quantitative and selective determination of germanium in water of high heavy-metal content was needed.

The method described here involves chemical separation of germanium from other major, minor, and trace elements in water, so that the dilution effect can be overcome.

The chemical separation of germanium is accomplished by using a technique similar to that described by Morrison and Freiser (1965, p. 209). This technique involves the extraction of germanium as a chloride complex, first with carbon tetrachloride and then with an ammonium oxalate-oxalic acid solution. Germanium in the resulting extract is then determined spectrochemically.

The water sample to be analyzed is filtered through a membrane filter having a pore size of 0.45 micron. The original sample is concentrated or diluted as necessary to obtain a $50-\mathrm{ml}$ aliquot containing 0.5 to $100 \mu \mathrm{g}$ of germanium. The aliquot is placed in a $500-\mathrm{ml}$ separatory funnel, and $180 \mathrm{ml}$ of concentrated hydrochloric acid is added. The resulting solution is extracted twice with $30-\mathrm{ml}$ portions of carbon tetrachloride; each extraction is shaken for 2 minutes. The organic layers are transferred to another separatory funnel and again extracted twice, for 2 minutes, with $30 \mathrm{ml}$ of an ammonium oxalate-oxalic acid solution. 
This solution is prepared by dissolving $5: 0 \mathrm{~g}$ of ammonium oxalate and $0.5 \mathrm{~g}$ of oxalic acid in 1 liter of deionized water; the $\mathrm{pH}$ of the solution is adjusted to 5 with ammonium hydroxide.

Germanium in the oxalate extract is then spectrochemically determined by the technique of Silvey and Brennan (1962). Briefly, the technique involves the precipitation of germanium in the oxalate extract by chelating reagents, 8-quinolinol, tannic acid, and thionalide. The precipitate is converted to the oxide form by charring at $450^{\circ} \mathrm{C}$ and is then subjected to direct-current arcing. Spectral transmittance of analytical and internal standard lines is converted to relative-intensity ratios which are plotted against standards containing known quantities of germanium to form working curves from which the quantities of unknown are read. Germanium standard solutions are prepared from spectrochemically pure germanium oxide obtained from the Jarrell-Ash Div., Fisher Scientific Co. ${ }^{1}$ The instrument and spectrochemical operating conditions are as follows:

Blectrodes (National Spectrographic Labs, Inc., cupped graphite electrodes) :

Anode - -

Cathode ---.-- No. 1040.

Annlytical gap------------ $4 \mathrm{~mm}$.

Arc current_-_-_-_-_- $6.5 \mathrm{amp}$.

Preburn -.---.-- None.

Dxposure time--.---.------ Complete burn.

Spectrograph -----_--_-- 2.4-m Wadsworth, Jarrel-Ash

Slit width-_--.--- $40 \mu$.

Photographic emulsion.-..-- SA-1, Dastman Kodak Co.

Developer -......-.-.- D-11 $65^{\circ} \mathrm{F}, 3$ minute, Eastman Kodak Co. ${ }^{1}$

Emulsion calibration.-..---- Two-step iron arc.

Analysis line.--_-..--..--- Ge $(2651.2 \mathrm{~A})$.

Internal standard line.-.-.-- $\operatorname{Pd}(3287.2 \mathrm{~A})$.

An analyical working curve shown in figure 1 is prepared from germanium standards ranging from $0.5 \mu \mathrm{g}$ to $100 \mu \mathrm{g}$. It is approximately linear and exhibits a slope near unity.

The effectiveness of the chemical separation of germanium from extraneous metals was investigated by spiking, with various known amounts of germanium, synthetic water samples containing 2.5 grams of each of the following elements : iron, manganese, lead, nickel, copper, aluminum, and cobalt. The spiked samples were subjected to chemical separation and the spectrochemical procedure described above. The average quantity of germanium recovered was 96 percent of the amount present, as shown in table 1.

To check the accuracy and precision of the method,

\footnotetext{
1 Brand names are cited for identiflcation purposes only; the citation does not constitute endorsement of a particular brand by the U.S. Geo loglcal Survey.
}

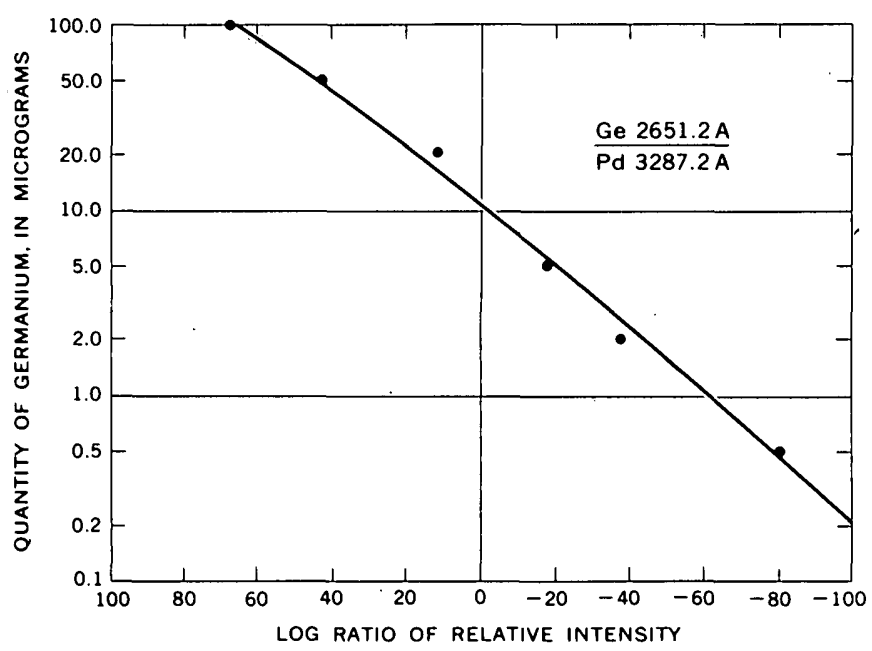

Figure 1.-Typical analytical curve for germanium prepared from germanium standards ranging from $0.5 \mu \mathrm{g}$ to $100 \mu \mathrm{g}$.

TABLE 1.-Recovery test for germanium from synthetic water samples containing 2.5 grams of $\mathrm{Fe}, \mathrm{Mn}, \mathrm{Pb}, \mathrm{Ni}, \mathrm{Cu}, \mathrm{Al}, \mathrm{Co}$

\begin{tabular}{|c|c|c|c|}
\hline Determination & $\begin{array}{c}\text { Germanium } \\
\text { added } \\
\text { (micrograms) }\end{array}$ & $\begin{array}{l}\text { Germanium } \\
\text { found } \\
\text { (micrograms) }\end{array}$ & $\begin{array}{l}\text { Recovery } \\
\text { (percent) }\end{array}$ \\
\hline $\begin{array}{l}1 \\
2 \\
2 \\
3 \\
4\end{array}$ & $\begin{array}{l}0.50 \\
5.0 \\
20 \\
100\end{array}$ & $\begin{array}{l}0.43 \\
6.0 \\
18 \\
90\end{array}$ & $\begin{array}{r}86 \\
120 \\
90 \\
90\end{array}$ \\
\hline
\end{tabular}

eight synthetic sample solutions containing a known quantity of germanium were prepared. These synthetic samples were subjected to the chemical separation and spectrochemical procedure described above. The germanium content of each sample was determined from the analytical working curve. The results are shown in table 2. The average error for eight determinations was \pm 9 percent and a relative standard deviation of 8 percent, a level of precision satisfactory for spectrochemical determination of trace quantities of germanium.

TABLE 2.-Accuracy and repeatability of determining germanium in highly mineralized water

\begin{tabular}{rrrrr}
\hline Determination number & $\begin{array}{c}\text { Quantity of } \\
\text { germanium } \\
\text { present } \\
\text { (micrograms) }\end{array}$ & $\begin{array}{c}\text { Quantity of } \\
\text { germanium } \\
\text { found } \\
\text { (micrograms) }\end{array}$ & $\begin{array}{c}\text { Error } \\
\text { (percent) }\end{array}$ \\
\hline & & 10.0 & 9.0 & 10 \\
& & 10.0 & 11.4 & 14 \\
& & 10.0 & 10.5 & 5 \\
\hline 7 & 10.0 & 9.5 & 5 \\
\hline & & 10.0 & 11.0 & 10 \\
& & & & \\
\hline
\end{tabular}




\section{REFERENCES}

Heggan, G. E., and Strock, L. W., 1953, Determination of trace elements : Anal. Chemistry, v. 25, p. 859-863.

Mitchell, R. L., and Scott, R. O., 1948, Applications of chemical concentration by organic reagents to spectrographic analysis: Spectrochim. Acta, v. 3, p. 367-378.

Morrison, G. H., and Freiser, Henry, 1965, Solvent extraction in analytical chemistry: New York, John Wiley and Sons, $269 \mathrm{p}$.

Silvey, W. D., 1967, Occurrence of selected minor elements in the waters of California: U.S. Geol. Survey Water-Supply Paper 1535-L, $24 \mathrm{p}$.

Silvey, W. D., and Brennan, Robert, 1962, Concentration method for the spectrochemical determination of seventeen minor elements in natural waters: Anal. Chemistry : v. 34, p. 784-786. 


\title{
EVALUATION OF A METHOD FOR ESTIMATING SEDIMENT YIELD
}

\author{
By LYNN M. SHOWN, Denver, Colo.
}

\begin{abstract}
A method for estimating annual sediment yield, developed by the Pacific Southwest Inter-Agency Committee, was tested in 28 small watersheds ranging in size from 0.02 to 37 square miles. These watersheds for which hydrologic records exist are in arid and semiarid areas of western Colorado, north-central New Mexico, and east-central Wyoming, and represent, a variety of geologic, climatic, ecologic, and topographic conditions. Estimates of sediment yield correlated closely with sediment yields mensured in reservoirs, but the estimates were usually lower than the measured yields. The method was designed to make general sediment classifications for areas greater than 10 square miles, but it also appears to work nearly as well for watersheds that are as small as 0.1 square mile.
\end{abstract}

Sediment-yield records for drainage areas of less than 500 square miles in wildland areas of the Western United States are scarce. Managers of land in these areas need estimates of sediment yield to aid in decisions which concurrently affect water, soil, timber, forage, and recreation. A sedimentation task force of the Pacific Southwest Inter-Agency Committee (PSIAC) prepared a guideline method for field evaluation of sediment yields, in conjunction with a discussion of factors affecting sediment yields in the Pacific Southwest area.

The purpose of this investigation was to determine the usefulness of the PSIAC method for extrapolating sediment-yield information to areas lacking records.

\section{METHOD}

The method developed by the PSIAC (1968) consists of rating the watershed on the basis of nine factors shown in table 1. A numerical rating is arrived at by summing the values assigned to the factors. A suggested range of values for each factor is included in the table. If a factor would be likely to result in a small sediment yield, a value near the lower end of the range is assigned. A value near the upper end of the range is assigned when the factor would cause the sediment yield to be large. For example, surface geol-

\begin{tabular}{|c|c|c|c|}
\hline Factor & $\begin{array}{l}\text { Rating } \\
\text { range }\end{array}$ & \multicolumn{2}{|c|}{ Main characteristics considered } \\
\hline Surface geology _... & $0-10$ & Rock type. & Weathering. \\
\hline Soils_ _ _ _ _ & $0-10$ & $\begin{array}{l}\text { Texture. } \\
\text { Aggregation. } \\
\text { Shrink-swell. } \\
\text { Rockiness. }\end{array}$ & $\begin{array}{l}\text { Salinity. } \\
\text { Caliche. } \\
\text { Organic matter. }\end{array}$ \\
\hline Climate.......... & $0-10$ & $\begin{array}{l}\text { Storm frequei } \\
\text { duration. } \\
\text { Snow. } \\
\text { Freeze-thaw. }\end{array}$ & $y$, intensity, and \\
\hline Runoff .............. & $0-10$ & $\begin{array}{l}\text { Vclume per ur } \\
\text { Peak flow per }\end{array}$ & $\begin{array}{l}\text { area. } \\
\text { hit area. }\end{array}$ \\
\hline Topography_._. & $0-20$ & $\begin{array}{l}\text { Steepness of } u \\
\text { Relief. } \\
\text { Fan and flood }\end{array}$ & $\begin{array}{l}\text { and slopes. } \\
\text { ain development. }\end{array}$ \\
\hline Ground cover. & $-10-10$ & $\begin{array}{l}\text { Vegetation. } \\
\text { Litter. } \\
\text { Rocks. } \\
\text { Understory d } \\
\text { trees. }\end{array}$ & elopment under \\
\hline Land use $\ldots$ & $-10-10$ & $\begin{array}{l}\text { Percentage cu } \\
\text { Grazing inten } \\
\text { Logging. } \\
\text { Roads. }\end{array}$ & $\begin{array}{l}\text { vated. } \\
\text { y. }\end{array}$ \\
\hline Upland erosion $\ldots$ & $0-25$ & $\begin{array}{l}\text { Rills and gulli } \\
\text { Landslides. }\end{array}$ & channels \\
\hline $\begin{array}{l}\text { Channel erosion } \\
\text { and sediment } \\
\text { transport. }\end{array}$ & $0-25$ & $\begin{array}{l}\text { Bank and bed } \\
\text { Flow depths. } \\
\text { Active headcu } \\
\text { Channel veget }\end{array}$ & rosion. \\
\hline
\end{tabular}

ogy would be assigned a value of 10 in an area underlain by soft fissile shale, and a value of 1 in an area underlain by several thick basalt flows.

Each factor except topography is paired with another factor that has a similar influence on sediment yield. The pairings are: surface geology and soils, climate and runoff, ground cover and land use, and upland and channel erosion. Each factor is rated separately, but the one it is paired with is usually considered concurrently, and the degree of interdependence of the two is reflected in the similarity or lack of similarity in their respective ratings. 
The upland erosion and the channel erosion-sediment transport factors are dependent on the other seven factors (table 1); therefore, high values for the two erosion factors should correspond to high values for the other seven. If the ratings do not check in this manner, the PSIAC sedimentation task force suggested that either special erosion conditions exist or the first seven factors in table 1 should be reevaluated.

The numbers assigned to the factors are summed, and the total rating value is used to obtain a probable sediment yield range as shown in table 2.

Type of relief and its associated vegetation was delineated in each watershed by use of topographic maps and aerial photographs, and the percentage of the basin area covered by each type was estimated so that weighted average ratings could be obtained for the factors shown in table 1.

One or two pace-point transects (Evans and Love, 1957) were run in each type to measure bare soil and cover of vegetation, mulch, and rock. A notch was cut in one boot sole at the toe, and whatever appeared in the notch every second step was recorded on a multiple tally counter until 100 observations were made. In large areas of a single type, longer transects were used and observations were made every fourth or sixth step. Observations of rilling, gullying, pedestaling, erosion pavement, and sediment deposition were made along each transect. Surface soils in each type were examined for texture and cohesiveness.

The main channel(s) and some tributaries were examined to evaluate (1) channel morphology as related to flow, (2) channel erosion, (3) headcut activity, and (4) sediment deposition. Slope of bottom lands, intermediate pediment areas, and steep uplands was determined with an Abney hand level.

To statistically compare the estimated sediment yields with reservoir sediment yields it was necessary to obtain a specific value for the estimate rather than the range of values shown in table 2. Figure 1 was, therefore, prepared by plotting the upper values of the rating ranges and those of the corresponding estimated sediment yields given in table 2.

TABLE 2.-Rating ranges and corresponding estimated sediment yield ranges prescribed in the Pacific Southwest Inter-Agency Committee method for evaluating sediment yields using terrain characteristics

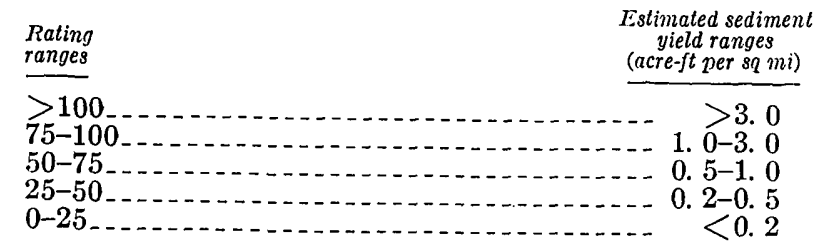

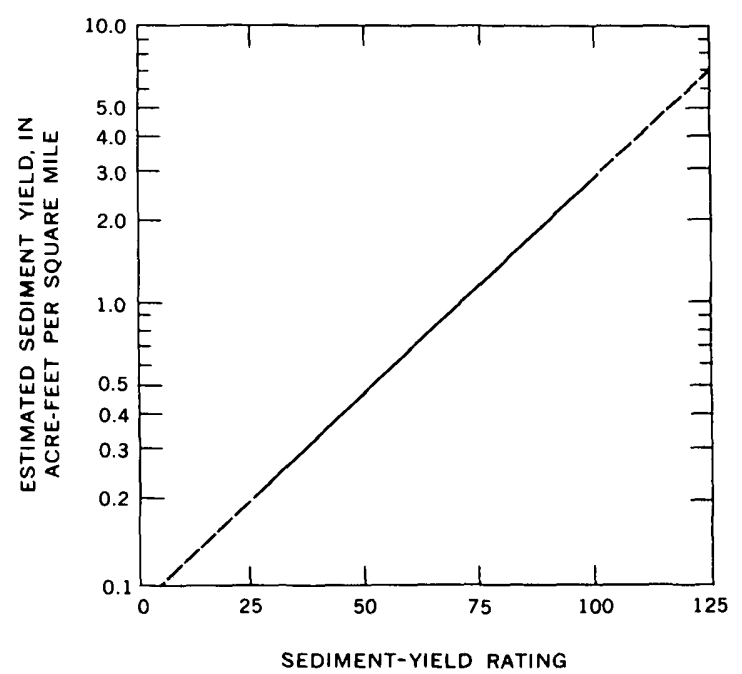

Figure 1.-Graph from which sediment-yield estimates were obtained after the watersheds 'had been rated by the Pacific Southwest Inter-Agency Committee method.

\section{STUDY AREAS}

\section{Badger Wash}

Nine watersheds were evaluated in the Badger Wash drainage (Lusby and others, 1963) on Mancos Shale about 25 miles west of Grand Junction, Colo. Ratings were made on individual watersheds of 0.02 to 0.48 square mile in area, and the entire Badger Wash study area of 6.5 square miles was also evaluated as one watershed.

The steepest watersheds, which have slopes ranging from 10 to 100 percent, are underlain by soft shale. $\mathbf{A}$ loose, erodible silty-clay loam soil, in which roots penetrate to a depth of 4 to 8 inches, covers these steepest watersheds. Other Badger Wash watersheds with slopes of from 3 to 30 percent are underlain primarily by layered sandstone. Soils on these watersheds are fine sandy loams, have very little structure, and contain roots to a depth of 8 to 12 inches. Six of the Badger Wash watersheds included in this study are underlain by interbedded sandstone and shale, resulting in intermediate conditions with respect to the shaly and sandy watersheds mentioned above. Their slopes range from 5 to 50 percent, and the soils are loams, usually mantled with sandstone fragments.

One marked geomorphic feature of the Badger Wash watersheds is their relative lack of bottom land. The topography consists of steep, rilled upper slopes, dissected moderately steep pediment slopes, and raw gullies. The gullies, which usually extend to the divides, have relatively steep gradients and provide efficient transport of sediment from the eroding slopes to the reservoirs. These features exist because the 
watersheds are situated at the upper ends of tributaries and because the soils are easily eroded and transported.

The vegetation at Badger Wash is mainly of the saltdesert shrub type, with an understory of galleta (Hilaria jamesii) in the areas of coarsest soils. Dominant shrubs are shadscale (Atriplex confertifolia), Nuttall saltbush (Atriplex nuttallii), and rabbitbrush (Chrysothamnus $\mathrm{spp}$ ).

Average annual precipitation at Badger Wash is about 8.5 inches. Most of the sediment yield results from intense summer rainstorms (Lusby and others, 1963). Fifteen years of records on precipitation, runoff, and sediment yields were obtained from G. C. Lusby (written commun., 1969).

\section{New Mexico}

Five watersheds of this study are in the Cornfield Wash drainage about 55 miles northwest of Albuquerque, N. Mex.

Individual watersheds range from 0.29 to 7.33 square miles in size, and the entire 21.3-square-mile Cornfield Wash drainage was also evaluated as one watershed. The soils are mainly fine sandy loams derived from interbedded sandstones and shales and normally contain roots to a depth of 2 to 3 feet. The range of slopes is similar to that of Badger Wash drainage, but the area of steep slopes (50 to 100 percent) is much less at the Cornfield Wash watersheds than it is at Badger Wash. The dominant plant on the upland in most watersheds is galleta, but there is blue grama (Bouteloua gracilis) and big sagebrush. (Artemisia tridentata) mixed with galleta in some areas. The sandstonecapped ridgetops are usually covered with one-seed juniper (Juniperus monosperma). The bottom lands of some of the basins have been overgrazed for a number of years, and the perennial vegetation there has been replaced by Russian-thistle (Salsola kali).

The average annual precipitation at Cornfield Wash is about 11 inches. July and August are the months of highest precipitation. The largest volume of runoff occurs in August, and lesser amounts occur in June, July, and October, as shown by the 10-year record 195160 (Burkham, 1966).

Two watersheds of 0.67 and 1.06 square miles, which are tributary to San Luis Wash, about 45 miles northwest of Albuquerque, N. Mex., were also rated. The morphology of these watersheds is characterized by large alluvial fans extending from the base of a sandstone escarpment. Roots penetrate 2 to 3 feet into the sandy loam soils, and grass is the dominant vegetation. Blue grama, galleta, and alkali sacaton (Sporobolus airoides) occur in varying proportions, depending on soil moisture conditions. Scattered juniper (Juniperus spp.) occurs on the escarpment, and scattered cholla (Oppuntia arborescens) occurs with the grasses on the fans. Annual precipitation at these watersheds is about 12 inches; two-thirds of this occurs during the period May through September (U.S. Weather Bureau, 1967). Sediment-yield records for these watersheds and for the Zia watershed. were taken from the small-watershed report by Peterson (1962).

The Zia watershed is about 30 miles north of Albuquerque, N. Mex., just south of the Jemez Mountains. The 2.4-square-mile drainage is on a dissected, rocky terrace. The soil consists of sand mixed with gravel and cobbles, and it supports stunted juniper and some understory of blue grama and snakeweed (Gutierrezia sarothiae). The depth of root penetration is about 1 foot. Annual precipitation is about 10 inches, 6 inches of which occurs during the May through September period (U.S. Weather Bureau, 1967).

\section{Wyoming}

The watersheds in the upper Cheyenne River basin in east-central Wyoming are on shale, sandstone, or interbedded formations containing both these rock types (Hadley and Schumm, 1961). Watershed areas range from 0.17 to 7.52 square miles. Soil textures range from very sandy loam to clay, and roots penetrate most of the soils to a depth of 2 to 3 feet. Plant cover is predominantly grass, but in some areas big sagebrush is mixed with the grass. Western wheatgrass (Agropyron smithii), blue grama, and grasslike sedges (Carex spp.) are the major types found there.

Annual precipitation is about 13 inches in the western, sandy part of the upper Cheyenne River basin and is 1 to 2 inches greater in the area underlain by shale near the Wyoming-South Dakota border (U.S. Department of Commerce, 1968). The highest monthly precipitation occurs in May and June, with lesser amounts in April, July, August, and September. Cloudbursts are likely to occur in July, August, and September. Precipitation and sediment-yield information was obtained from the reports of Culler (1961) and Hadley and Schumm (1961). The sediment-yield records vary in length from 7 to 25 years.

The 37-square-mile Logan Draw drainage above Rongis Reservoir in the Wind River basin, about 30 miles southeast of Riverton, Wyo., was the largest and most complex watershed examined. The upper 70 percent of the watershed below the steep face of the Beaver Rim has a gravelly, silt loam soil resulting from the erosion and transport of a complex of sedimentary and metamorphic rocks. Roots penetrate to a depth of about 2 feet in this soil. Big sagebrush with an understory of junegrass (Kaeleria cristata) is the major vegetative 
type in the upper area. Another 20 percent of the watershed has a silty-clay soil derived from Cody Shale. Roots penetrate this soil about 1 foot. This area is covered with Nuttall saltbrush and bottlebrush squirreltail (Sitanion hystrix). The remaining 10 percent of the watershed is comprised of high, grass-covered plateaus and of bottomlands covered with greasewood (Sarcobatus vermiculatus). Average annual precipitation is estimated to be about 10 inches (N. J. King, oral commun., 1969). Runoff occurs from snowmelt and rains in the spring, and from occasional torrential summer storms (Peterson, 1961). Additional hydrologic information, including a 16-year record of sediment yield through July 1968, was obtained from King (1959) and from N. J. King and G. C. Lusby (written commun., 1969).

\section{RESULTS AND DISCUSSION}

Figure 2 shows the relationship of estimated sediment yields obtained with the PSIAC method to measured sediment yields for three sets of watersheds. In all three sets, with the exception of the low-sediment-yielding watersheds in Wyoming, the estimates tend to be lower than reservoir values, as most of the points lie above the 1:1 lines in figure 2 . Also, the mean sediment-yield estimate for all sites is 1.4 acre-feet per square mile, and the mean for the reservoir records is 1.73 .

The tendency for the estimated sediment yields to be lower than reservoir records is attributed to the author's bias in rating some of the factors lower than they should have been, but no factor was consciously rated consistently low. After the watersheds had been rated, it was apparent that the channel erosion and sediment transport factor had not been rated high enough for some of the steeper watersheds having raw gullies. The ratings were accordingly increased for some of the Badger Wash and New Mexico watersheds, resulting in smaller differences between the estimated and measured sediment yields. The correlation of measured runoff with values for the runoff factor in the method was rather poor; the coefficient of correlation $(r)$ was 0.34 . No objective means of adjusting values for the runoff factor was found.

The correlation of watershed area with the difference between reservoir measurements and the estimates was very poor $(r=0.13)$. Apparently, on very small watersheds, the PSIAC method sufficiently accounts for expected larger sediment yields per unit area caused by greater average slope, intense storms covering the whole watershed, and small transit losses. This indicates that the method may have application in the de-

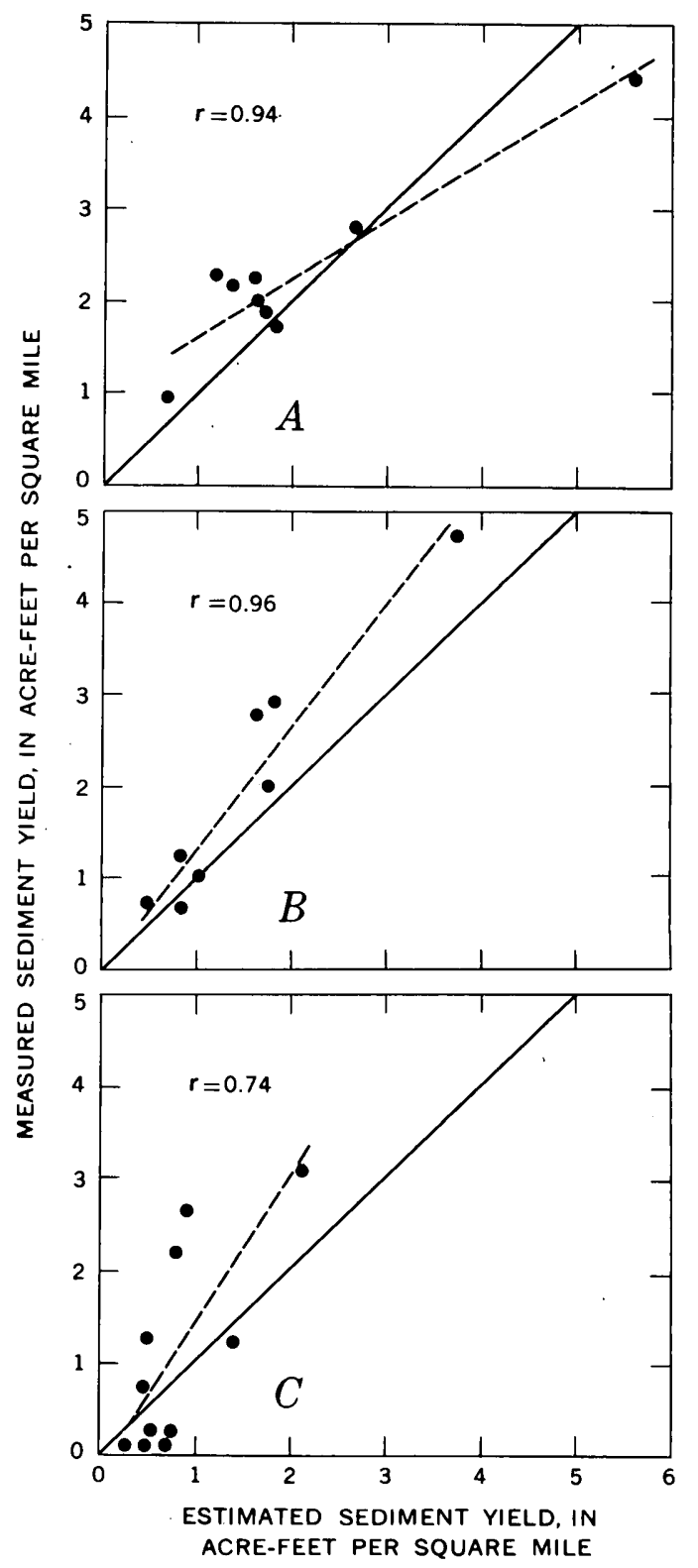

Figure 2.-Graphs showing relationship of estimated sediment yields to measured sediment yields, determined by the Pacific Southwest Inter-Agency Committee method, for reservoirs in three sets of watersheds: $A$, Badger Wash, Colo. ; $B$, New Mexico; $C$, Wyoming. All correlation coefficients $(r)$ are significant at the 1 percent level. The solid lines are lines of equality where the estimated sediment yields equal the measured sediment yields. The dashed lines are regression lines fitted to the points.

sign of structures for small watersheds and in proposals for land treatment, in addition to its use for making broad sediment classifications of larger areas.

In applying this method, good records from gaged areas, where available, should be used to check the estimates. If the estimates and records do not reasonably 
correspond, then the rating should be adjusted and the adjusted rating could then be used as a guide when applying the method in areas similar to the gaged one. If a team of classifiers are going to survey an area, it would be well that all members agree on their interpretation of the characteristics used to rate the factors. This should prevent wide differences between sedimentyield estimates made by two or more classifiers who rate similar areas.

The regression coefficients (slopes of the dashed lines in fig. 2) are not significantly different for New Mexico and Wyoming watersheds, but the coefficient for the Badger Wash watersheds is significantly different from the other two at both the 1- and 5-percent levels. The most likely reason for the different slope for the Badger Wash relation is the magnitude of the point near the upper end of the line in figure $2 A$. The estimated sediment yield represented by that point is more than 1 acre-foot per square mile larger than the measured sediment yield, and this causes the upper end of the line to be lower.

Scatter about the regression line is greatest for the Wyoming sites (fig. $2 C$ ). It is the author's belief that much of the scatter is due to the difficulty in evaluating the sediment-transport factor. There are active flood plains, particularly in the lower reaches of many of the Wyoming watersheds examined. It is apparent that sediment is being trapped by the grass cover on the flood plains, but it was difficult to judge how much sediment was retained and how much moved on to the reservoirs. This difficulty partly accounts for the estimated sediment yields being greater than measured sediment yield for about half of the points in figure $2 C$.

The two points at the lower right in figure $2 C$ are for reservoirs that were known to spill large amounts of water, and the recorded sediment-yield figures for them are probably too low. For the two watersheds r $>$ presented by the upper two points on the left side of figure $2 C$, it appeared that the present-day sediment yield was much less than that shown by the reservoir records, which were obtained prior to 1950 . These watersheds are probably grazed less intensively now, resulting in lower sediment yields than during the period of record.

\section{REFERENCES}

Burkham, D. E., 1966, Hydrology of Cornfield Wash area and effects of land-treatment practices, Sandoval County, N. Mex., 1951-60: U.S. Geol. Survey Water-Supply Paper 1831, 87 p. [1967].

Culler, R. C., 1961, Hydrology of stock-water reservoirs in Upper Cheyenne River basin : U.S. Geol. Survey Water-Supply Paper 1531-A, $136 \mathrm{p}$.

Evans, R. A., and Love, R. M., 1957, The step point method of sampling-a practical tool in range research: Jour. Range Management, v. 10, p. 208-212.

Hadley, R. F., and Schumm, S. A., 1961, Sediment sources and drainage-basin characteristics in upper Cheyenne River basin: U.S. Geol. Survey Water-Supply Paper 1531-B, $198 \mathrm{p}$.

King, N.J., 1959, Hydrologic data, Wind River and Fifteen Mile Oreek basins, Wyoming, 1947-54: U.S. Geol. Survey Water-Supply Paper 1475-A, $44 \mathrm{p}$.

Lusby, G. C., Turner, G. T., Thompson, J. R., and Reid, V. H., 1963, Hydrologic and biotic characteristics of grazed and ungrazed watersheds of the Badger Wash basin in western Colorado, 1953-58: U.S. Geol. Survey Water-Supply Paper 1532-B, $73 \mathrm{p}$.

Pacific Southwest Inter-Agency Committee, 1968, Report on factors affecting sediment yield in the Pacific Southwest area: Water Management Subcommittee, Sedimentation Task Force, $10 \mathrm{p} ., 2$ tables.

Peterson, H. V., 1962, Hydrology of small watersheds in Western States: U.S. Geol. Survey Water-Supply Paper 1475-I, p. 217-356.

U.S. Department of Commerce, 1968, Climatological dataAnnual summary for Wyoming: v. 77, no. 13.

U.S. Weather Bureau, 1967, Normal annual precipitation and normal May-September precipitation [New Mexico]: Isohyetal map prepared by the Water-Supply Forecast Center, Western Region, Salt Lake City, Utah, for Environmental Sci. Serv. Adn. 


\title{
DOSAGE REQUIREMENTS FOR SLUG INJECTIONS OF RHODAMINE BA AND WT DYES
}

\author{
By F. A. KILPATRICK, Washington, D.C.
}

\begin{abstract}
Time-of-travel measurements, simulation studies of waste and thermal pollution, dispersion tests, and dilutiontype discharge measurements, in streams and estuaries, involve the slug injection of specific amounts of fluorescent dyes. Curves relating quantities of dye required for slug injections into streams are developed from data from nearly 500 field time-oftravel tests. Separate relationships are developed for Rhodamine BA and Rhodamine WT dyes. The application of the relationships is illustrated by an example.
\end{abstract}

The slug injection of specific amounts of fluorescent dyes is involved in time-of-travel measurements, studies of waste and thermal pollution, dispersion tests, and dilution-type discharge measurements. Various rule-of-thumb and empirical formulas have been developed to aid in selecting the amount of dye needed to produce measurable concentrations at downstream locations. Probably the most commonly used formula is that of Wilson, which for Rhodamine B or BA 40 -percent dye is

$$
¥_{d}=4.00 \times 10^{-5} \frac{Q L}{V} C_{p}
$$

where

$$
\begin{aligned}
\Psi_{d}= & \text { volume of dye, in gallons of solution, } \\
Q= & \text { discharge in reach, in cubic feet per second, } \\
L= & \text { length of reach, in miles, } \\
V= & \text { mean velocity, in feet per second, and } \\
C_{p}= & \text { the peak concentration, in micrograms per } \\
& \quad \text { liter }(\mu \mathrm{g} / \mathrm{l}) \text { desired at the lower end of the } \\
& \quad \text { reach. }
\end{aligned}
$$

This is an empirical formula determined by fitting a $45^{\circ}$ line through a log plot of $\Psi_{d}$ (for 40-percent dye) versus $\frac{Q L}{V}$ (when $C_{p}=1 \mu \mathrm{g} / \mathrm{l}$ ) for data from 52 time-of-travel tests (Wilson, 1968). Wilson emphasizes the need for a proportionally greater percentage of dye where velocities are low, and that lesser quantities may be used where velocities are large. He suggests that values of $C_{p}$ as low as $1 \mu \mathrm{g} / \mathrm{l}$ and as high as $10 \mu \mathrm{g} / \mathrm{l}$ should be used in the formula for streams having high and very low velocities, respectively. Thus, in effect, velocity is a parameter not given suitable weight in the above formula. The limited data available to Wilson, as well as their scatter, did not justify a more sophisticated analysis. Nor is Wilson's formula applicable where Rhodamine WT dye is used, as no such data existed at that time. Evidence indicates that Rhodamine WT is a more conservative tracer than Rhodamine $\mathrm{B}$ or BA, for it adheres less readily to sediment.

\section{DOSAGE RELATIONSHIPS FOR RHODAMINE B AND BA DYE}

About 400 pieces of data involving use of Rhodamine $\mathrm{B}$ or BA dyes, and about 85 pieces of data involving use of Rhodamine WT dye are available. Because of the differences in the dyes, dosage relationships for each type are developed. Because of the number of data points and the expectation that velocity needed independent consideration, plots of $\frac{Q_{m} L}{V}$ versus $\Psi_{d}$ for four selected ranges of velocity were made. The terms are the same as previously defined by Wilson, except that $\forall_{d}$ is in liters instead of gallons and $Q_{m}$ is the maximum discharge in the reach. As shown in figure 1, for Rhodamine $\mathrm{B}$ and $\mathrm{BA}$ dyes, four different curves varying with velocity result. For the sake of clarity and to show the scatter, only data for the ranges from 0 to 0.20 foot per second and from 2 to $5.7 \mathrm{fps}$ are shown. The scatter is significant, especially for lower velocities. When low flow and hence low velocities exist, complex pool and riffle conditions often prevail, and longitudinal dispersion is generally great with subsequent above-average reduction in peak concentrations. The large exposure time associated with slow velocities also produces high dye losses. The need for increased dye quantities under such conditions is evident in the curves. The uppermost 


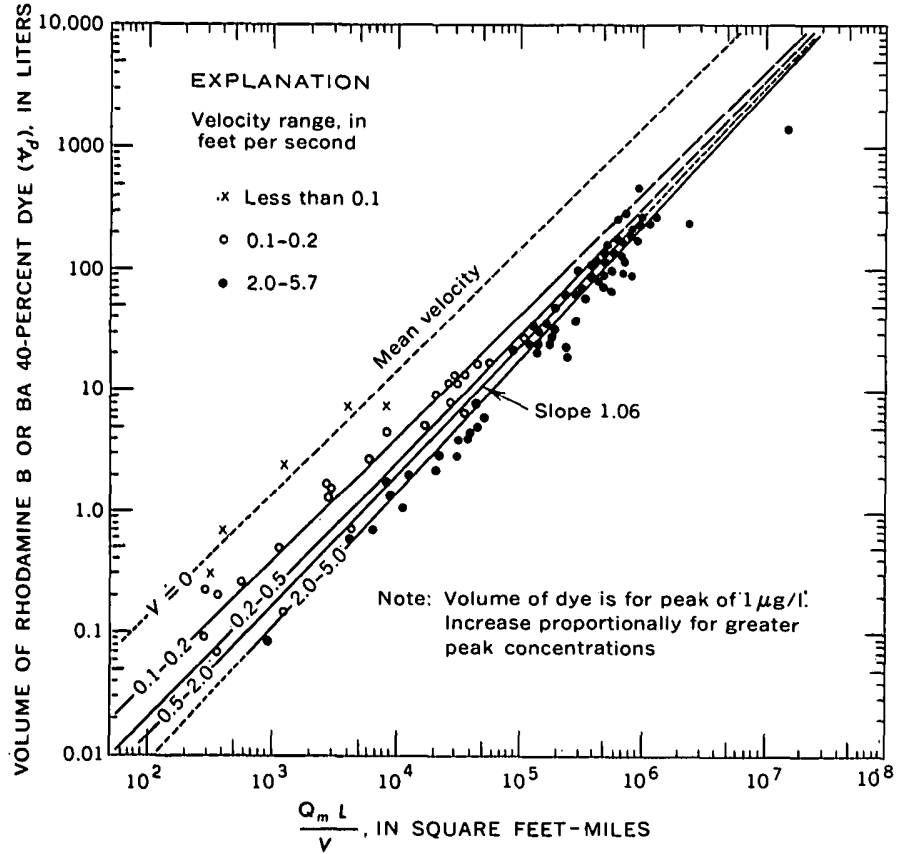

Froure 1.-Quantity of Rhodamine B or BA 40-percent dye required for slug injection to produce a peak concentration of $1 \mu \mathrm{g} / \mathrm{A}$ at a distance downstream, $L$, at a mean velocity, $V$, and with a maximum discharge, $Q_{m}$, in the reach.

curve for conditions where velocities approach zero has been shown to provide a means of selecting dosages which would virtually guarantee a desired or greater peak concentration under such conditions. Because no simple, single equation can be written which defines the curves of figure 1 , it is recommended that they be used directly.

As noted, $\boldsymbol{F}_{d}$ is now defined as liters rather than gallons. On small streams where fractional parts of a gallon of dye may be needed, graduated laboratory cylinders and flasks marked in milliliters and liters provide for the convenient dispensing of the smaller quantities. If larger quantities are to be measured in pounds, $\Psi_{d}$ in liters may be converted to quantity in pounds, $W_{i l}$, by the equation

$$
W_{d .}=2.2 F_{d} S_{g} \text {. }
$$

where $S_{y}$ is the specific gravity of the dye: 1.03 for Rhodamine BA, and 1.12 for Rhodamine B solutions.

In the curves shown on figure 1, the discharge is specified to be the maximum in the test reach and not necessarily that at the injection 'site. The maximum dilution of the dye cloud, and hence the reduction in the magnitude of the peak, will result at the lower end of a reach where the discharge is usually the maximum. This factor should be given due consideration especially where there is a sizable increase in discharge from the injection point to the last sample point.

\section{DOSAGE FORMULA FOR RHODAMINE WT DYE}

Shown in figure 2 is a plot of $\Psi_{d}$ for Rhodamine WT 20-percent dye versus $\frac{Q_{m} L}{V}$ for 85 tests. As can be seen, these data show less scatter, show no clearly defined variation with velocity, and may be defined by the equation

when $C_{p}=1 \mu \mathrm{g} / \mathrm{l}$

$$
\digamma_{d}=3.4 \times 10^{-4}\left(\frac{Q_{m} L}{V}\right)^{0.93} C_{p}
$$

Data for velocities less than $0.2 \mathrm{fps}$ were not available. Although no family of curves varying with velocity is defined for Rhodamine WT dye where extremely low velocities and irregular channels exist, good judgment might dictate increased dosages.

For convenience, the required dye quantity might be just as easily taken directly from the curve of figure 2 . It should be emphasized that all the curves are for a peak concentration of $1.0 \mu \mathrm{g} / \mathrm{l}$, and dye quantities and costs must be increased directly in proportion to any increase in the desired peak. In the event the curve of figure 2 is not available, a simpler formula based on a fit of a $45^{\circ}$ line through the data is

$$
\digamma_{d}=2 \times 10^{-4} \frac{Q_{m} L}{V} C_{p}
$$

Formula 4 should not be used where values of $Q_{m} L / V$ are greater than $1 \times 10^{5}$, as excessive dosing may result and the monetary difference becomes significant. The

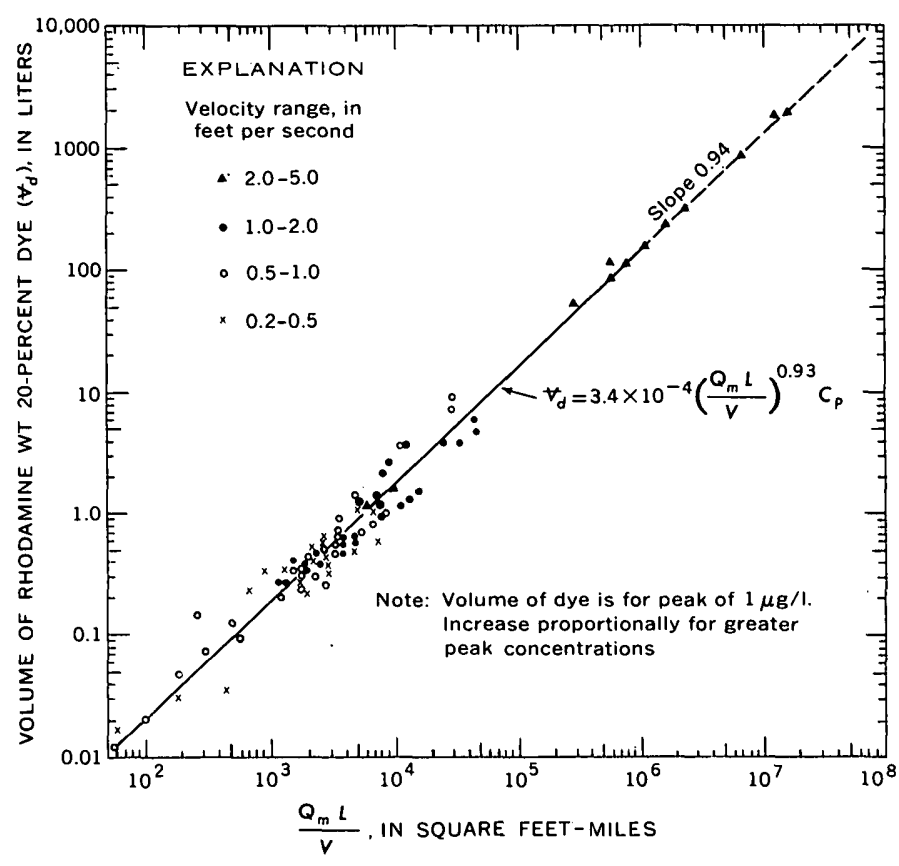

FIgURE 2.-Quantity of Rhodamine WT 20-percent dye required for slug injection to produce a peak concentration. of $1 \mu \mathrm{g} / \mathrm{l}$ at a distance downstream, $L$, at a mean velocity, $V$, and with a maximum discharge, $Q_{m}$, in the reach. 
formula may also be useful in determining quantities of Rhodamine WT dye needed for slug-injection dye-dilution type discharge measurements. It is noteworthy that the Cobb-Bailey formula developed for this purpose and in equivalent units (Dunn, 1968, p. 10) may be written as

$$
\Psi_{d}=2.2 \times 10^{-4} \frac{Q_{m} L}{V} C_{p}
$$

For Rhodamine WT 20-percent dye, the quantity in pounds, $W_{d}$, may be determined by the equation

$$
W_{d}=2.62 \Psi_{d} \text {. }
$$

Comparison of the single curve for Rhodamine WT dye with the family of curves for Rhodamine $B$ and $\mathrm{BA}$ dyes indicates that less of the $\mathrm{WT}$ is required where the value of $\frac{Q_{m} L}{V}$ is $=3 \times 10^{4}$, or greater.

Unless relatively high velocities exist, WT dye will prove advantageous even at lower values of $\frac{Q_{m} L}{V}$ because, in the concentrations specified, Rhodamine WT 20-percent dye costs less. When we consider its superior handling characteristics, the more accurate and stable fluorometer calibrations which result from its use, as well as its lower costs, Rhodamine W'T dye should become the unquestionable choice as a tracer until a better dye becomes, available.

\section{ESTIMATING MEAN VELOCITIES}

In the estimation of needed dye quantities for timeof-travel, dispersion, dilution-gaging, or other tracertype studies, arrival at an estimate of the mean velocity in the reach may be difficult. In effect, what is to be measured must be estimated. Generally, velocity estimates are high compared with the velocity eventually measured. Two factors usually result in high estimates. Current-meter measurements made at about the test discharge are usually examined, and because such measurements are made at selected channel sections, they will usually indicate a higher mean velocity than is typical of the stream reach. Such data, though, probably provide a safety factor when scheduling sampling to ensure measurement of the leading edge of the dye cloud. The second reason for high velocity estimates is that in a visual reconnaissance of the stream, there is a tendency to give too much weight to the velocities observed in riffles. By contrast, the slower pools between riffles commonly occupy a greater proportion of a stream reach than the riffles.

The above applies mostly to measurements made at low and medium discharges. At higher flows, when pools and riffles are nonexistent, mean velocities taken from current-meter measurements are frequently in close agreement with dye time-of-travel measurements. Under such circumstances, a sampling schedule which will ensure sampling the leading edge of the dye cloud may be based on the higher point velocities noted in past current-meter measurements.

\section{DISCUSSION AND APPLICATION}

Variation in slope is the most noticeable difference of the curves of figures 1 and 2. The slope of the curve for Rhodamine BA dye (for a velocity range of 0.5 to 2.0 fps) is 1.06, as compared to 0.93 for Rhodamine WT dye. The difference is due to the difference in the loss characteristics of the two types of dyes. A quantity of the more conservative Rhodamine WT dye will travel a greater distance with less reduction in concentration than a comparable amount of Rhodamine BA dye. Experience has indicated that with Rhodamine WT, longer reaches can be traced without initially injecting excessively large quantities. As can be shown by the example in figure 3, where a water user is in the test reach, peak concentrations may be kept to a lower level by using Rhodamine WT, whereas the use of Rhodamine $\mathrm{BA}$ might require further reach subdivision, if maxi-

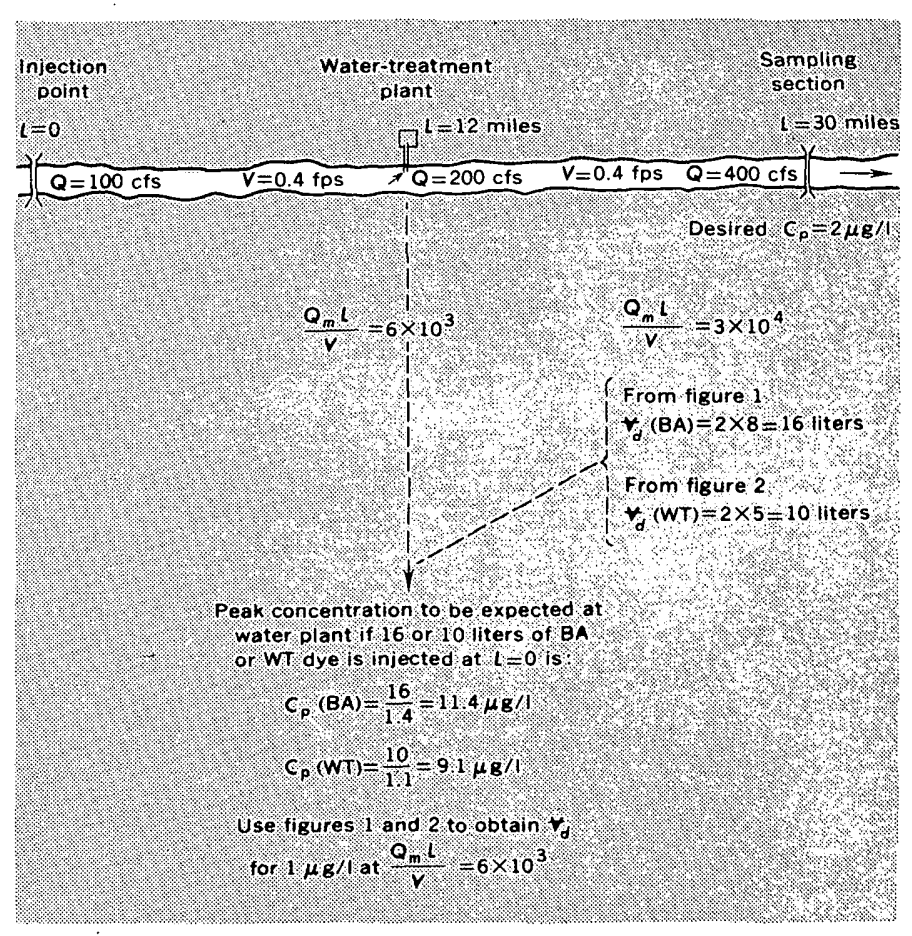

Frgure 3.-Example illustrating the determination of dye quantities, comparison of dye quantities, and examination of probable peak concentration at an intermediate point in the test reach. 
mum concentrations are not to exceed $10 \mu \mathrm{g} / \mathrm{l}$, the recommended limit set by the U.S. Geological Survey.

The example in figure 3 also illustrates that the discharge at the point in question is the all-important factor in determining the peak concentration which will exist. Had the discharge at the water-treatment plant been 400 cubic feet per second instead of $200 \mathrm{cfs}$, the peak concentrations at the plant would have been significantly less.

\section{REFERENCES}

Wilson, J. F., 1968, An empirical formula for determining the amount of dye needed for time-of-travel measurements, in Geological Survey Research, 1968: U.S. Geol. Survey Prof. Paper 600-D, p. D54-D56.

Dunn, Bernard, 1968, Nomographs for determining amount of rhodamine $\mathrm{B}$ dye for time-of-travel studies, in $\mathrm{E}$. B. Chase and F. N. Payne (compilers), Selected techniques in water-resources investigations, 1966-67: U.S. Geol. Survey Water-Supply Paper 1892, p. 9-14. 


\title{
COMPARISON OF A PROPELLER FLOWMETER WITH A HOT-FILM ANEMOMETER IN MEASURING TURBULENCE IN MOVABLE-BOUNDARY OPEN-CHANNEL FLOWS
}

\author{
By J. P. BENNETT and R. S. McQUIVEY, \\ Fort Collins, Colo.
}

\begin{abstract}
The hot-film anemometer may be used in measuring turbulence in large-scale movable-boundary open-channel flows if a correction is made for the drift of the velocity-voltage relation of the sensor. The propeller flowmeter may be used for making turbulence measurements in such flows if corrections are made for the frequency response and spatial averaging of the propeller. The true power spectral density, $S(\omega)$, of the turbulence velocity may be obtained from $S(\omega)=S_{\text {oo }}(\omega)|H(\omega)|^{-2} \eta(\omega)^{-1}$, where $S_{\mathrm{oo}}(\omega)$ is the power spectral density of the propeller meter, $|H(\omega)|$ is the amplitude of the meter system function, and $\eta(\omega)$ is the efficiency of spatial resolution. Measurements of turbulence intensity and power spectral density were made with both hotfilm anemometer and propeller flowmeter in large-scale openchannel flows. The power spectral densities from the instruments are similar in shape except at the higher frequencies where effects of propeller spatial averaging appear. The efficiency of the propeller flowmeter as a device for measuring turbulence increases as the scale of the turbulence increases.
\end{abstract}

In hydraulic-engineering research the present great need is for an instrument that can measure the characteristics of turbulence in flowing water in all situations. To obtain the statistical parameters describing turbulence, one should use a measuring system which has (1) a frequency response adequate to follow the velocity fluctuations instantaneously (2) a sensor smaller than the areal extent of the smallest velocity fluctuations containing significant energy, and (3) a readily obtainable and stable relation between the system output and the actual velocity. If the system does not satisfy these requirements in some respect, suitable corrections must be applied to the measurements.

Two instruments which can be used to determine the characteristics of turbulence in water are the hot-film anemometer and the propeller flowmeter. Neither of these is, however, completely satisfactory for making turbulence measurements under the conditions encoun- tered in natural flows. The hot-film anemometer is unstable when used in water containing suspended or dissolved impurities, and the propeller flowmeter has too low a frequency response and covers too great an area to respond completely to the turbulence-velocity fluctuations at a point.

This paper is presented to show how, despite their shortcomings, the hot-film anemometer and the propeller flowmeter can be used to measure the characteristics of turbulence in water and to compare measurements made with them in large-scale movable-boundary open-channel flow.

\section{INSTRUMENTATION SYSTEMS}

The transformation of the output of a measuring system to obtain turbulence statistics requires an application of the theories of the transient response of systems; however, before these theories can be applied, one must understand the systems to be used. The hotfilm anemometer and the propeller flowmeter measuring systems can best be understood by discussing the principles of operation of the sensors and the equipment necessary to convert sensor behavior into an analyzable output.

The hot-film anemometer is similar to the hot-wire anemometer used in airflow measurements. The velocity sensor is electrically heated, and the heat is convected away by the flow, the rate of convection being proportional to the flow velocity. In water, a constant-temperature anemometer is generally used. In the constanttemperature anemometer, the circuitry is designed to keep the temperature of the velocity sensor constant by keeping its resistance constant. This is accomplished by varying the voltage across the sensor so that the 
heat generated in it is always equal to the heat convected away from it by the flow. The output of the anemometer is therefore a voltage which can be related to the flow velocity using the calibration curve of the measuring system.

The velocity sensor consists of a coating of platinum 50 to $100 \times 10^{-8} \mathrm{~cm}$ thick which is fused to the surface of a supporting head form of glass. The head form may be a cylinder, wedge, cone, or strip (for use on a flat surface). For use in water, the platinum is generally coated with a thin quartz film. A ThermoSystems parabolic hot-film probe was used in this study. The circuitry, in larger part a self-balancing wheatstone bridge, was that of the Thermo-Systems Model 1050 anemometer module used in conjunction with a Model 1051-6 monitor and power supply module and a Model 1057 signal conditioner module. The frequency response range of the anemometer module is zero to 80 kilohertz.

The propeller of a flowmeter consists of two or more airfoils wrapped around a central supporting shaft. The movement of water past the propeller produces lift and drag on the airfoils, and these forces produce a driving and resisting torque, respectively, on the propeller shaft. For each particular water velocity, there is an angular propeller velocity at which the torque due to lift just equals the torque due to drag and to bearing friction. This is the equilibrium angular velocity for the particular velocity past the propeller. Thus, the equilibrium angular velocity of the propeller is a measure of the linear velocity of the waterflow.

The flowmeter used in this study has standard Ott minor propellers and a meter body especially constructed to provide 30 pulses of output per revolution of the shaft. The meter body consists of an outer case, a propeller mounting shaft riding in two stainlesssteel bearings, a 30 -toothed gear fixed to the shaft, and an electrode mounted in a case directly above the gear (see fig. 1). Figure 2 shows the Ott minor propellers and the meter body. In operation the meter case is filled with water, and, as the shaft turns, changes in resistance are produced between the electrode and the gear as the teeth move by. The changes in resistance between electrode and gear cause amplitude modulation of a $20-\mathrm{kHz}$ carrier signal produced by a Mimosa apparatus, manufactured by Waterloopkundig Laboratorium, Delft, Holland. The Mimosa converts the amplitude-modulated signal into a square wave having the frequency at which the teeth of the gear pass the electrode. The signal is fed to an electronic counter which measures the period of individual samples of the square wave. The counter is used in conjunction with a digital-to-analog converter which converts the

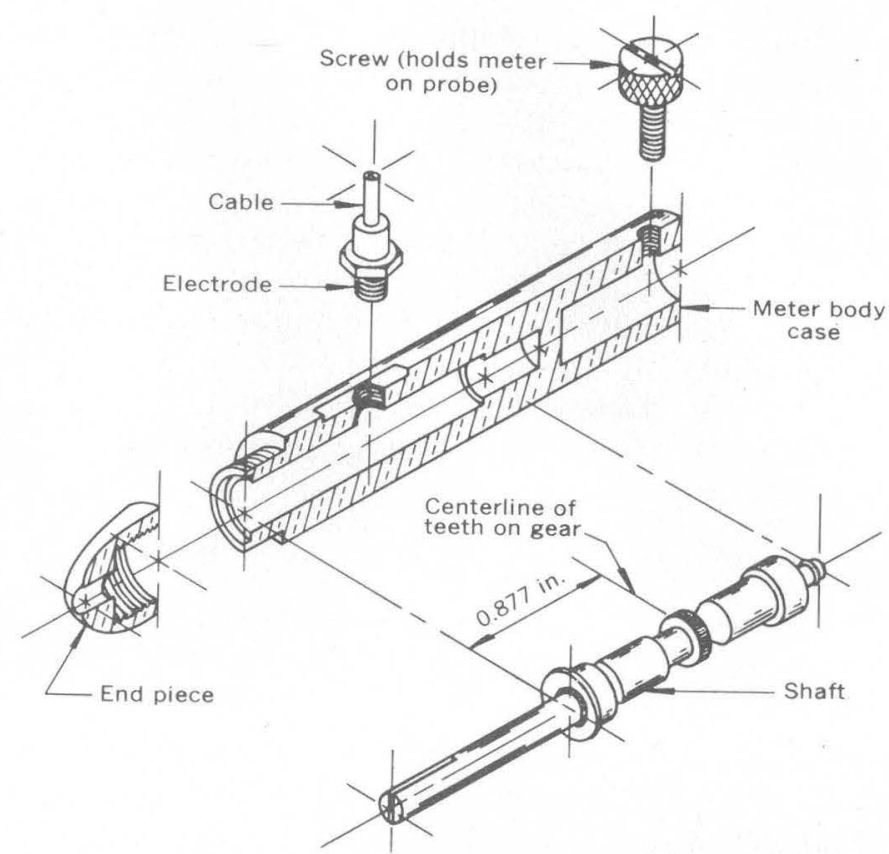

Figure 1.-Section through centerline of meter body case and assembled shaft.

digital-counter output into an analog voltage proportional to the period of the square wave. This voltage can be recorded on strip-chart or magnetic-tape recorders; it is inversely proportional to the angular velocity of the propeller. The time constant of the flowmeter instrumentation system for the velocities encountered in this study is on the order of 5 milliseconds. This corresponds to a cutoff frequency of $32 \mathrm{~Hz}$.

\section{CORRECTIONS FOR EFFECT OF INSTRUMENTATION ON TURBULENCE STATISTICS}

The point velocity of a flowing fluid in a particular direction consists of a time-mean component and a

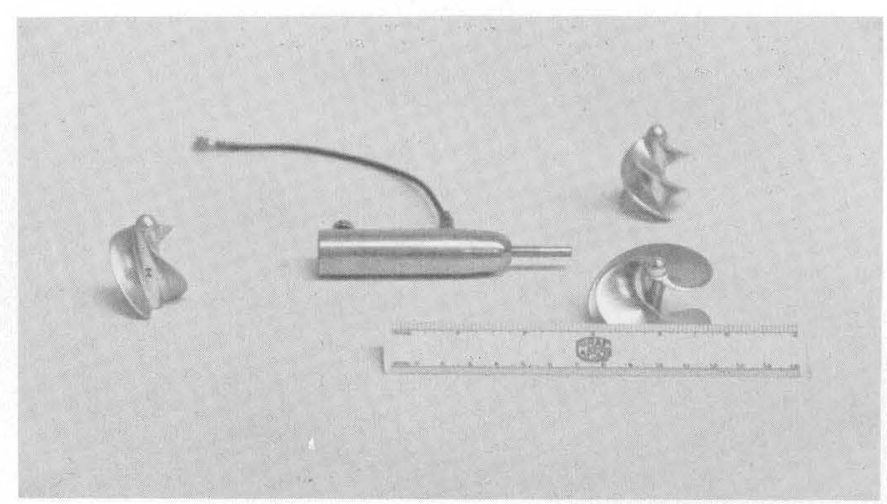

FIguRe 2.-Flowmeter body and Ott minor propellers (left, $2-3$; upper right, 1-3; and lower right, 1). Six-inch ruler shows scale. 
randomly fluctuating component. The randomly fluctuating component is commonly called the turbulence component, or the turbulence in the chosen direction at the point. The direction of mean flow is generally specified as the $x$ direction. In this direction, the total velocity $u(t)$, at a point is defined as $u(t)=\bar{U}+u^{\prime \prime}(t)$, where $\bar{U}$ and $u^{\prime \prime}(t)$ are, respectively, the time-mean and the randomly fluctuating components of velocity at the point.

The most commonly used statistical parameter describing $u^{\prime \prime}(t)$ is the intensity of turbulence, $u^{\prime}$. It is defined as

$$
u^{\prime}=\sqrt{\overline{u^{\prime}}}=\lim _{T \rightarrow \infty} \sqrt{\frac{1}{2 T} \int_{-T}^{T}\left[u^{\prime \prime}(t)\right]^{2} d t} .
$$

The square of the intensity, $\overline{u^{\prime}}$ may be thought of as being twice the kinetic energy of the turbulence per unit of mass.

The time autocorrelation, $R(\tau)$, of turbulence-velocity fluctuations in the $x$ direction at a point in space is defined by

$$
R(\tau)=\lim _{T \rightarrow \infty} \frac{1}{2 T} \int_{-T}^{T} u^{\prime}(t) u^{\prime}(t+\tau) d t,
$$

where $u^{\prime}(t)=\frac{u^{\prime \prime}(t)}{u^{\prime}}$. The autocorrelation gives the average relation of the velocity fluctuation at a point to the velocity fluctuation at the same point at a time, $(t-\tau)$, in the past.

The power spectral density, $S(\omega)$, of the turbulence is the Fourier transform of $R(\tau)$,

$$
S(\omega)=\int_{-\infty}^{\infty} R(\tau) e^{-i \omega \tau} d \tau
$$

where $\omega=2 \pi f$ is the angular frequency in radians per second, $f$ is frequency in $\mathrm{Hz}$, and $i=\sqrt{-1}$. By inverse Fourier transformation

$$
\overline{u^{\prime}}=\overline{u^{\prime}} R(0)=\overline{u^{\prime}} \int_{-\infty}^{\infty} S(f) d f
$$

Thus, $S(f)$ may be thought of as a function describing the distribution of turbulent energy among the various Fourier components making up $u^{\prime}(t)$.

In addition to being thought of as velocity fluctuations at a point, turbulence may be thought of as a group of eddies or rotating masses of fluid being convected downstream at the mean stream velocity. Two parameters which are descriptive of these eddies are the macroscale, $L_{x}$, and the microscale, $\lambda_{x}$. The macroscale is defined as

$$
L_{x}=\bar{U} \int_{0}^{\infty} R(\tau) d \tau
$$

whereas the microscale is

$$
\frac{1}{\lambda_{x}^{2}}=\frac{4 \pi^{2}}{\bar{U}^{2}} \int_{0}^{\infty} \dot{f}^{2} S(f) d f .
$$

The macroscale is generally thought of as being characteristic of some average eddy size, whereas the microscale is characteristic of the size of the smallest eddies which are responsible for the dissipation of energy. Using Taylor's hypothesis (Bennett, 1968), an eddy with a diameter, $L$, can be related roughly to a particular frequency, $f_{L}$, in the power spectral density by $f_{L}=\bar{U} / L$. Thus, at a particular mean velocity, $\bar{U}$, turbulence with a coarse structure (large $L_{x}$ ) will have its energy concentrated at a lower frequency than will turbulence with a finer structure (small $L_{x}$ ).

The velocity sensor of the hot-film anemometer has a sufficiently high frequency response (Richardson and others, 1967) and is small enough (Bennett, 1968) so that it can be treated as an ideally responding pointvelocity sensor when making turbulence-velocity measurements in water. Thus there is no need to correct the turbulence statistics as measured by the hot-film anemometer for frequency response or size of the sensor. However, the anemometer's usefulness is limited in sediment- and debris-laden streams by a drift of the velocity-voltage relation which occurs when impurities collect on the sensor. Another limitation on the usefulness of hot-film sensors in this type of flow is their fragility and cost. In this study, the drift was compensated for by using a method of Richardson and McQuivey (1968).

The output voltage of the hot-film anemometer measuring system is proportional to velocity. The intensity of this voltage is converted to the turbulent intensity by using a method of Richardson and McQuivey (1968), from

$$
u^{\prime}=\frac{d \bar{U}}{d \bar{E}} e^{\prime}
$$

where $\frac{d \bar{U}}{d \bar{E}}$ is the slope of the mean velocity-versusvoltage calibration curve for the measuring system, and the voltage intensity, $e^{\prime}$, is the root mean square of the system output voltage.

The propeller flowmeter is such a stable velocitymeasuring device that drift is not a problem and need not be corrected for. However, the frequency response of the propeller is inadequate to follow velocity fluctuations instantaneously. Also, the propeller is too large to justify the assumption that it is measuring the flow velocity at a point. The inadequate frequency response is due to the inertia of the propeller. It may be said to cause an "inertial averaging" of the velocity fluctuations. Similarly, the size of the propeller causes a spatial averaging of the velocity fluctuations.

The inertial and spatial averaging characteristics of the propeller cause the output velocity registered by the meter at a given instant to be different from the 
true velocity along the propeller axis. This causes the statistics measured by the propeller flowmeter to be different from the true statistics of the turbulence. The output velocity $u_{*}(t)$, registered by a propeller flowmeter at a given instant may be defined as $u_{*}(t)=\bar{U}+$ $u_{*}^{\prime \prime}(t)$, where $u_{*}^{\prime \prime}(t)$ is the fluctuating component of the output and $\bar{U}$ is the average velocity at the propeller axis. In a fashion, analogous to equations 1 and 2, one may define for the output of the propeller flowmeter measuring system, an autocorrelation, $R_{00}(\tau)$, and power spectral density, $S_{00}(\omega)$, as:

$$
R_{o o}(\tau)=\lim _{T \rightarrow \infty} \frac{1}{2 T} \int_{-T}^{T} u_{*}^{\prime}(t) u_{*}^{\prime}(t+\tau) d t
$$

and

$$
S_{o 0}(\omega)=\int_{-\infty}^{\infty} R_{o o}(\tau) e^{-i \omega r} d \tau
$$

where $u_{*}^{\prime}(t)=\frac{u_{*}^{\prime \prime}(t)}{u_{*}^{\prime}}$ and $u_{*}^{\prime}=\lim _{T \rightarrow \infty} \sqrt{\frac{1}{2 T} \int_{-T}^{T}\left[u_{*}^{\prime \prime}(t)\right]^{2} d t}$

Thus $R_{00}(\tau)$ and $S_{00}(\omega)$ are the autocorrelation and power spectral density of the fluctuations of turbulence velocity after distortion by the inertial and spatial averaging characteristics of the propeller flowmeter mensuring system.

Bennett (1968), using linear-systems theory, showed that the power spectral density of a propeller flowmeter can be corrected for the spatial and inertial averaging of the turbulence-velocity fluctuations by the propeller. The true power spectral density, $S(\omega)$, of the turbulence velocity can be obtained from the output power-spectral density, $S_{00}(\omega)$, by using the relation

$$
S(\omega)=S_{o o}(\omega)|H(\omega)|^{-2} \eta(\omega)^{-1},
$$

where $H(\omega)$ is the system fucntion of a propeller turning in a time-varying velocity field which is uniform in space, and $\eta(\omega)$ is the efficiency of spatial resolution of the propeller in a particular type of turbulence-velocity field.

Briefly, the system function may be thought of as a transformation, characteristic of a particular system, which acts on the input of the system to produce its output. It is used to correct for the inertial averaging of the propeller. Lee (1960) presents a detailed discussion of the system function. It can be determined from experiments in which a sinusoidal velocity variation is produced by oscillating the flowmeter back and forth in the direction of mean motion with a known angular frequency and amplitude. This oscillation occurs while the meter is being towed at a known mean velocity through still water. The absolute value of the system function is the ratio of the amplitude of the output velocity to the amplitude of the input velocity.
Bennett (1968) reported that the system function for Ott minor propellers $1,1-3$, and 2-3 is mean-velocity dependent and, that owing to a complex coefficient in the first-order differential equation of the system, it differs from the system function for a classical firstorder system. Figure 3 gives the absolute value of the system function for an Ott minor 1-3 propeller.

The efficiency of spatial resolution, $\eta(\omega)$, as presented by Bennett (1968), may be thought of as a transformation acting on an input-power spectral density to produce an output-power spectral density; $\eta(\omega)$ is used to correct for the spatial averaging of the propeller. The efficiency is a function not only of propeller dimensions and geometry, but also of the structure of the turbulence being measured. The finer the structure of the turbulence, the more its energy is contained in the high frequencies, and the lower will be the efficiency of spatial resolution of the propeller. This is because the higher the frequency of the velocity fluctuations, the smaller must be the eddies which produce them, and the smaller eddies are the ones which are spatially averaged by the propeller.

The efficiency of spatial resolution must be evaluated for each type of propeller in each type of turbulenceflow field. Bennett (1968) has evaluated $\eta(\omega)$ for Ott minor propellers $1,1-3$, and $2-3$ in an open-channel flow with an artifically roughened boundary. He used equation 9 in the form

$$
\eta(f)=\frac{S_{o o}(f)}{S(f)|H(f)|^{2}},
$$

where $f=\omega / 2 \pi, S_{00}(f)$ is from the propeller flowmeter and $S(f)$ from a hot-film anemometer. The $\eta(f)$ 's so obtained are given in figure 4 . The recovery efficiency, $\eta(f)$, was found to be a function of a propeller diameter, $(d)$, to turbulent-macroscale- $\left(L_{x}\right)$ ratio, $d / L_{x}$, and of a parameter of spectral energy distribution, $L_{x} / \bar{U}$, where $\bar{U}$ is the local mean velocity.

The calibration equation of a propeller in terms of the output voltage of the digital-to-analog converter may be written

$$
\bar{U}=A+\frac{B}{t_{p}}=A+\frac{B}{K \bar{E}},
$$

where $\bar{t}_{p}=1 / n, n$ is frequency of propeller revolution, and $K$ is a proportionality constant between propeller period, $\bar{t}_{p}$, and voltage, $\bar{E}$. By differentiating equation 11 with respect to $\bar{E}$, one obtains

$$
\frac{d \bar{U}}{d \bar{E}}=\frac{-B}{K \bar{E}^{2}} .
$$

This is the relation used in equation 6 for conversion of voltage fluctuations to velocity fluctuations for propeller flowmeters. 


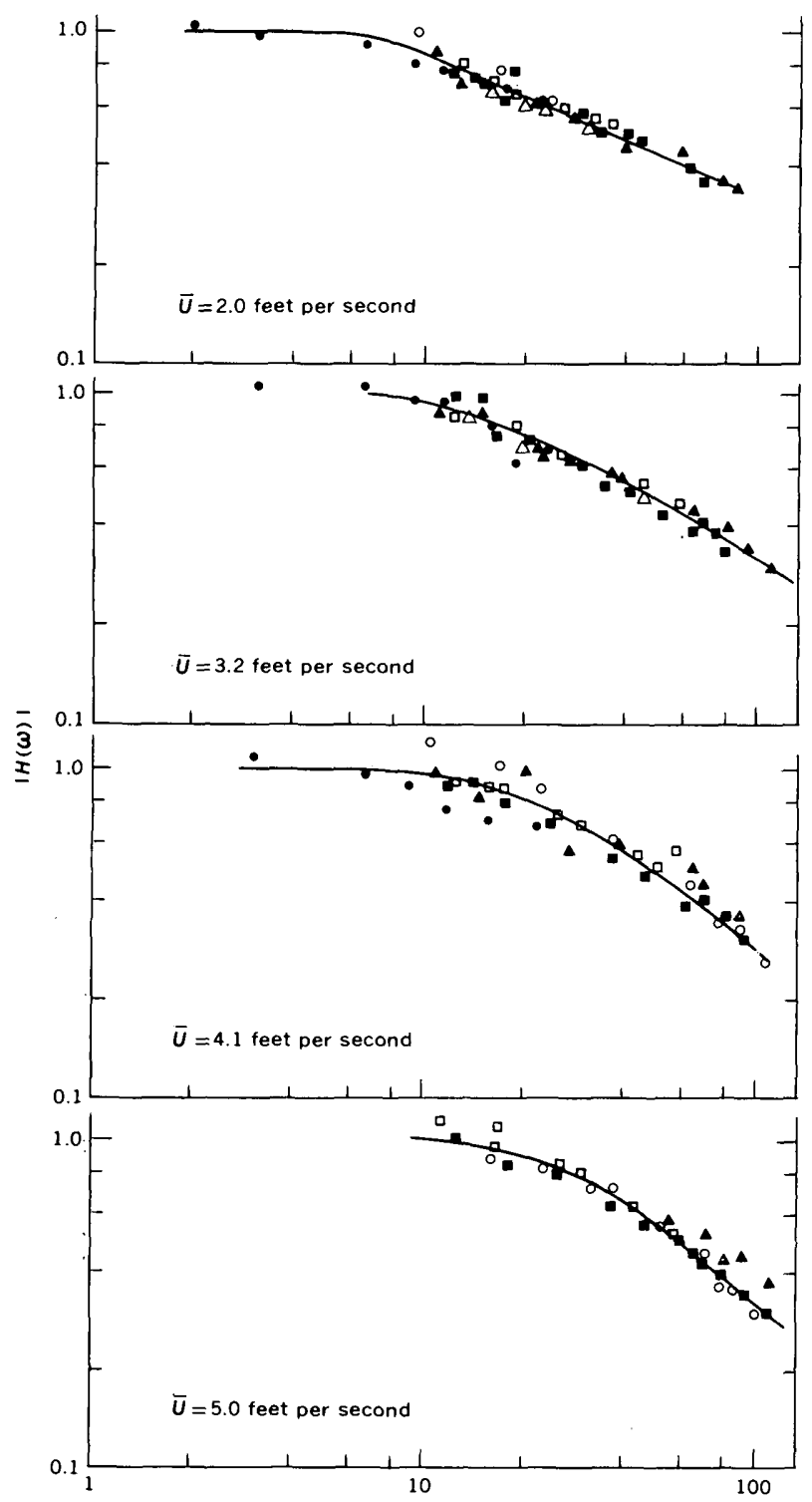

$\omega$, IN RADIANS PER SECOND

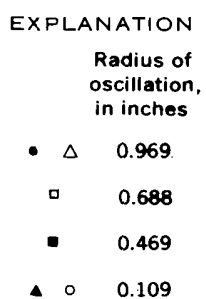

Figure 3.-Absolute value of the system function, $|\boldsymbol{H}(\boldsymbol{\omega})|$, as a function of angular frequency, $\omega$, for a 1-3 propeller. Two symbols for the same radius indicate measurements were made on different days.

\section{FIELD MEASUREMENTS OF TURBULENCE-VELOCITY INTENSITIES AND POWER SPECTRAL DENSITIES}

The data were taken at two cross sections on the Rio Grande near Albuquerque, N. Mex. The first set of

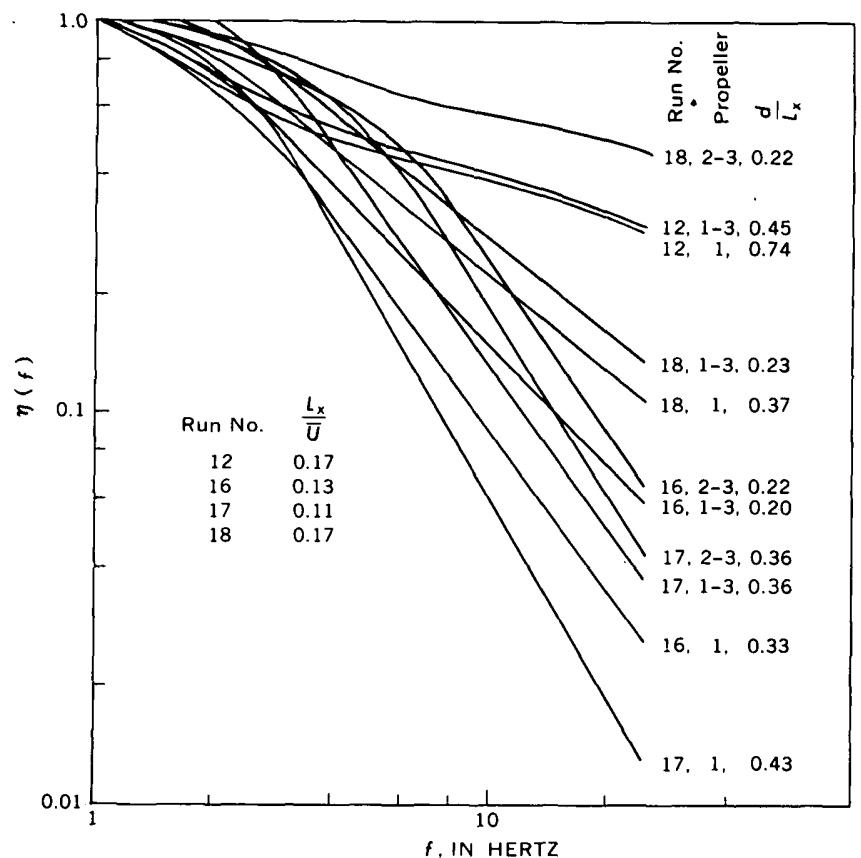

FrguRe 4.-Efficiency of spatial resolution, $\eta(f)$, as a function of frequency, $f$, for three Ott minor propellers tested in an open-channel flow with an artificially roughened boundary.

measurements was taken in the Atrisco Feeder Canal, 15 miles north of Albuquerque; the second set in the Bermardo conveyance channel, 70 miles south. The mean values of the flow parameters for the cross section are given in table 1 . All the flowmeter measurements were taken using an Ott minor 1-3 propeller. The measurements in a particular vertical were taken by first traversing the entire depth with the hot-film sensor, then with the propeller flowmeter; the vertical positions of the two instruments during measurements were not always the same.

Richardson and McQuivey (1968) report that in

TABLE 1.-Flow parameters for the field measurements

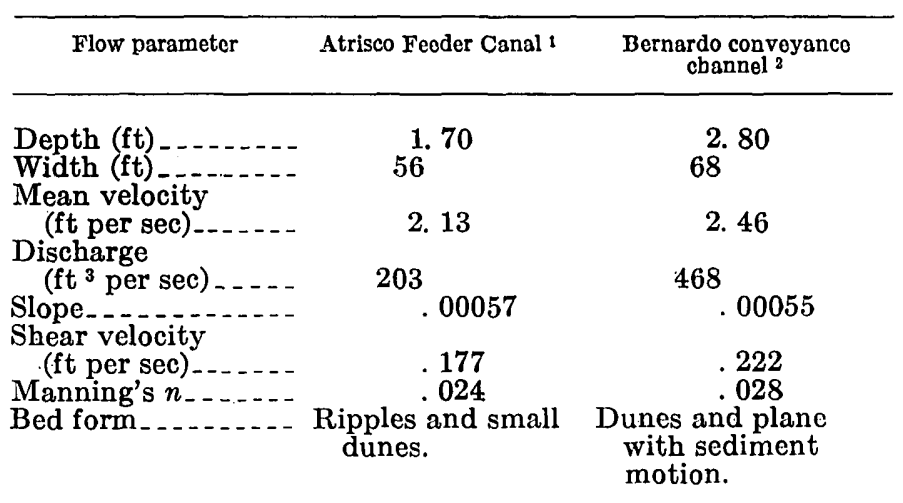

Power spectral densities and turbulence intensities were measured. The measure ments of power spectral densities were taken at a velocity of 1.59 feet per second,

mean depth of 1.83 feet, and 12 feet left of canal centerlinc. 12-inch-high dunes, the rest was plane. 
turbulence in open-channel flow, the bulk of the energy occurs at much lower frequencies (below $10 \mathrm{~Hz}$ ) than it does in air. For this reason, the power spectral densities of this study were obtained by digital-computer methods, wherein the low-frequency resolution is limited only by the length of record which can be processed. Data processing by digital methods could not be accomplished in the field, so the output voltages from the measuring systems were recorded on magnetic tape for later analysis. The output from the hot-film anemometer was recorded directly; that from the propeller flowmeter measuring system had to be amplified before it could be recorded. The a-c amplifier used had a lowfrequency cutoffl of $1 \mathrm{H} / \mathrm{x}$.

In addition to measurements of power spectral density, several measurements were made in which only longitudinal turbulence intensities, $u$, werc obtained. The voltage intensity for substitution into equation 6 was obtained from an analog root-mean-square (rms) voltage meter or, when available, from the output of the computation program for power spectral density. The analog rms meter had a low-frequency cutoff of $0.5 \mathrm{~Hz}$, and $n$ high-frequency-response flat well beyond the range of frequencies of interest. The $0.5-\mathrm{H} \%$ cutoff prevents the rms meter from measuring all the turbulence cnergy contained in the velocity fluctuations having frequencies of less than $0.5 \mathrm{~Hz}$.

Because the output of the hot-film anemometer could be corrected for drift, and because the hot-film anemometer is tree of inertial and spatial averaging problems, the results of the hot-film measurements have been used as standards for judging the performance of the propeller flowmeter.

\section{MEASUREMENT OF POWER SPECTRAL DENSITY}

Power spectral densities, $S_{o o}(f)$, obtained from the propeller output for the measurements in the Atrisco Feeder Canal are given in figure 5, where $y$ is the distance above the bed and $Y$ the total depth of flow. The broken curves on this figure are the power spectral densities after they have been corrected for the system function. Owing to the differences in roughness height and spacing between the Atrisco channel and the artificially roughened channel in which Bennett (1968) measured the efficiency of spatial resolution (fig. 4), it was felt that the $\eta(f)$ 's of figure 4 should not be used as corrections for the field data. (In any case, the $L_{x} / \bar{U}$ 's of figure 5 are, except for $5 D$, all outside the range of $L_{x} / \bar{U}$ of figure 4.) Thus no corrections for the efficiency of spatial resolution could be made; $\eta(f)$ was assumed to be 1.0. Power spectral densities obtained from the hotfilm anemometer over the same relative depth range are presented in figure 6 .

The effect of the spatial averaging of the propeller on the power spectral density of the turbulence can be seen in figure 7. In this figure, the power spectral densities corrected for the system function of the propeller as shown in figure 5 have been plotted along with those of the hot-film anemometer from figure 6 for the nearest available relative depth. The spectra of figures 5 , 6 , and 7 have been computed using a digital version of equation 2. Thus those spectra are normalized. Owing to the normalizing procedure, there is a vertical positioning difference between the propeller curves and the hot-film curves of figure 7 . This is due not only to propeller characteristics but to the exclusion from the
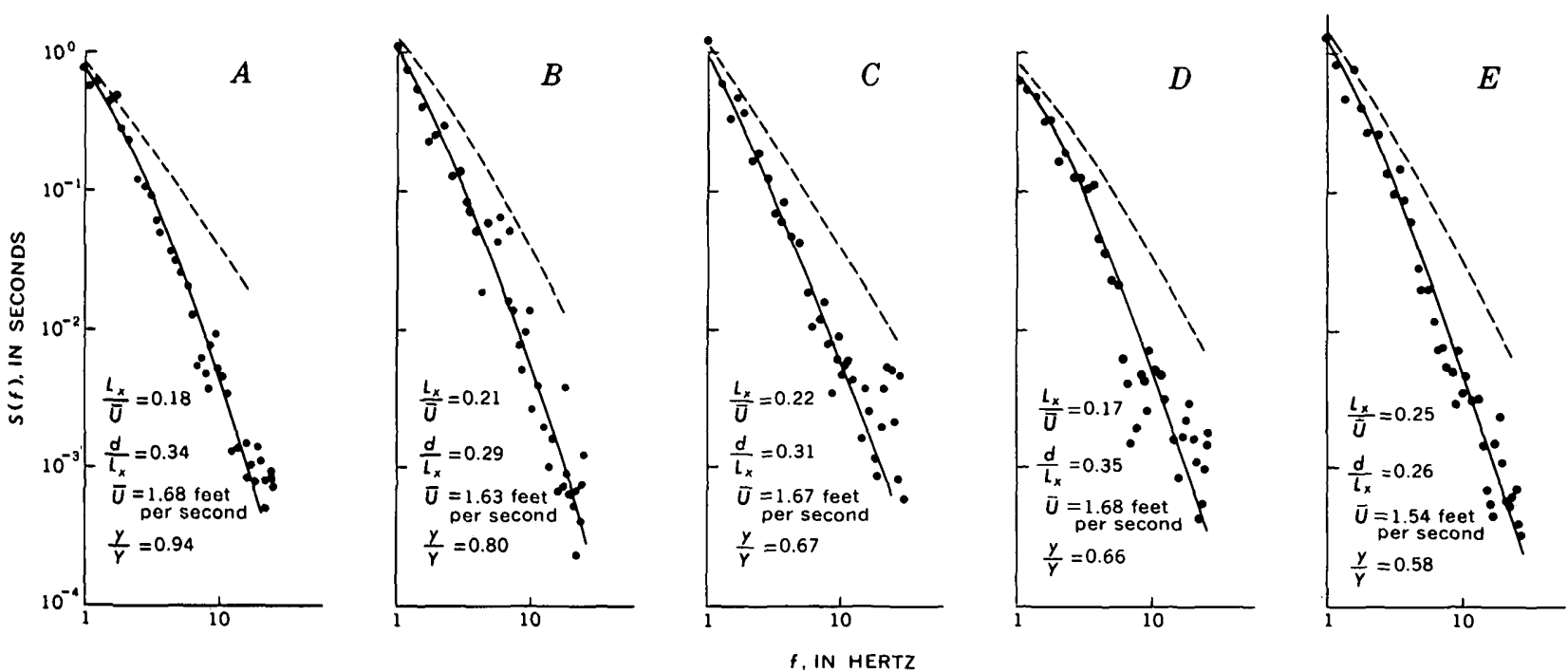

Troume 5.-Power spectral densities $S(f)$ as functions of frequency $f$; propeller output (solid line) corrected for propeller frequency response (broken line). Measurements made in Atrisco Feeder Canal. 


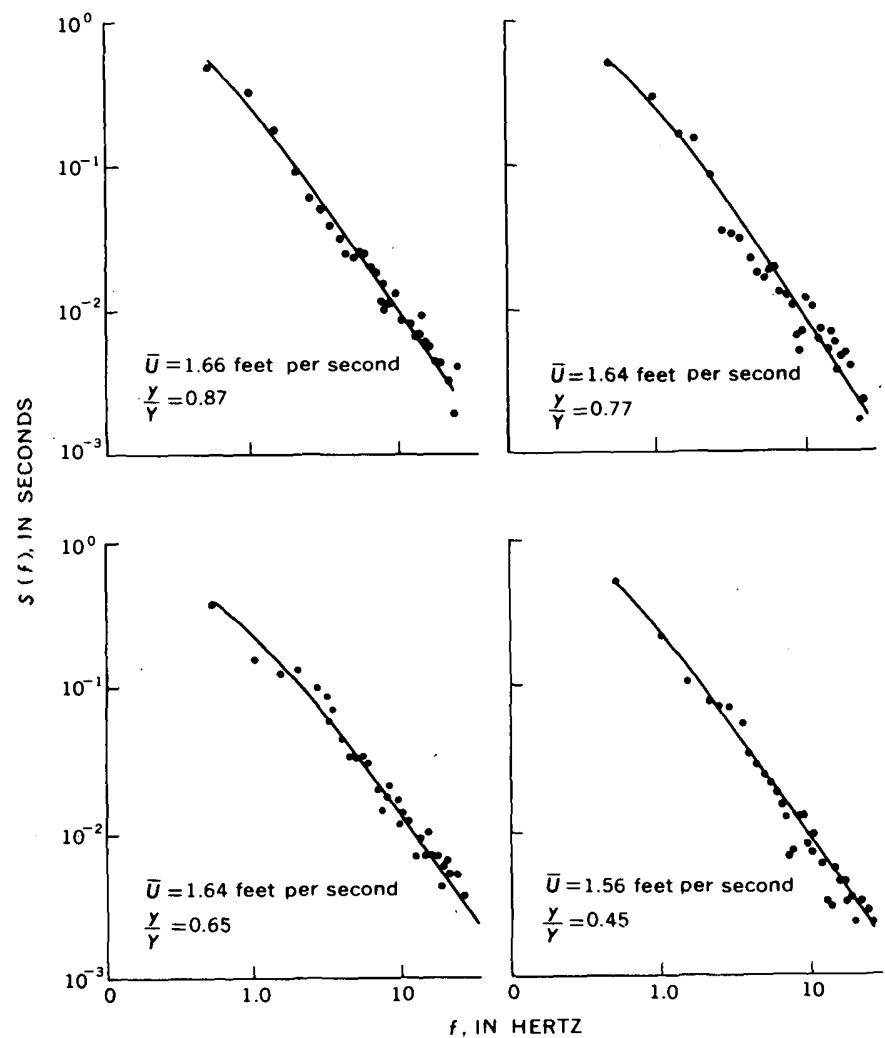

Fraure 6.-Power spectral densities, $S(f)$, as measured with a hot-film anemometer; measurements made in Atrisco Feeder Canal.

propeller spectrum by the a-c amplifier of the frequencies below $1 \mathrm{~Hz}$. (Since the frequencies below $1 \mathrm{~Hz}$ are excluded, the area to the left of $1 \mathrm{~Hz}$ is too small, and the normalized propeller curves are shifted upward to compensate.) Discounting the vertical positioning difference, the shapes of the curves are very similar at the low-frequency end. However, the power spectral density of the propeller has a greater slope over the high-frequency part which indicates the effect of the spatial averaging of the propeller on the smaller eddies.

\section{MEASUREMENT OF TURBULENCE INTENSITY}

Analysis of measurements of velocity determined by hot-film anemometer by digital computer is undoubtedly the most accurate means of obtaining turbulent intensities. This method is, however, time consuming and expensive. The use of a propeller flowmeter in combination with an analog rms meter is a faster and cheaper method for obtaining such measurements; however, this procedure involves two factors which cause measured intensities to be lower than those which

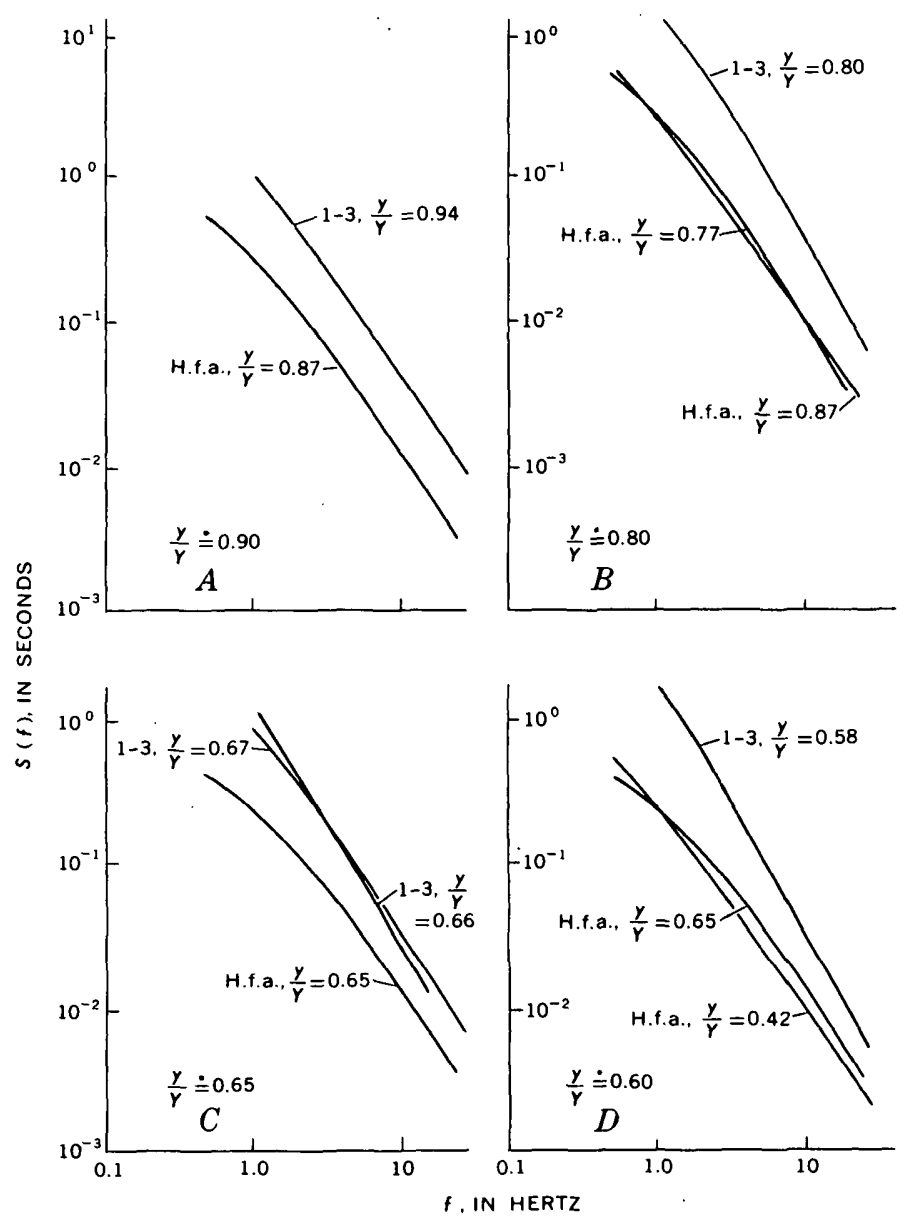

Figure 7.-Comparison of power spectral densities made by a hot-film anemometer (H.f.a.) with those made by the propeller flowmeter fitted with an Ott minor propeller (1-3) ; measurements made in Atrisco Feeder Canal.

actually occur. The first factor is the reduction in turbulent energy output by the propeller meter due to inertial and spatial averaging. The second is the energy loss due to the $0.5-\mathrm{Hz}$ low-frequency cutoff of the ana$\log$ rms meter. Neither of these factors can be corrected for because the exact shape of the power spectral density of the turbulence being measured is unknown. An indication of the order of magnitude of these errors can, however, be obtained from some of the measurements which were taken by the writers. The turbulent intensity and mean velocity profiles are given in figures 8 and 9.

The ratio of the intensity measured by the propeller meter-rms meter combination to the intensity measured by the hot-film anemometer using digital data analysis methods can be defined as an efficiency, $e^{\prime \prime}$, of the propeller meter-rms meter measuring system. From figures $8 B$ and $9 B$, values of $e^{\prime \prime}$ range from 0.05 at $y / Y=0.7$ of the 

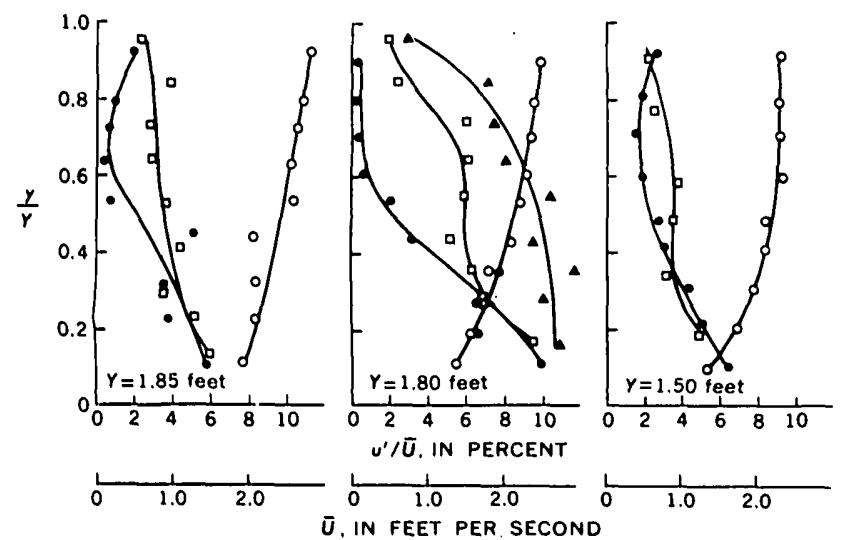

$A, 12$ feet from right
bank

$B$. Centerline of channel

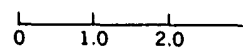

C. 12 feet from left

EXPLANATION

- Moan velocity - Propeller intensity, a H.f.a. intensity,
rms meter rms meter
Frouks 8.-Mean velocity, $\bar{\theta}$, and turbulent intensity, $u^{\prime} / \bar{U}$, as functions of relative depth, $y / Y$; measurements made in Atrisco Feeder Oanal.

centerline Atrisco run to 0.95 at $y / Y=0.2$ of the centerline Bermardo run. The values of $e^{\prime \prime}$ are very low in the Atrisco reach, and fairly large in the Bernardo reach. The reasons for this are: (a) The flow in the Atrisco reach. was shallow and over small roughness elements. The flow in the Bernardo reach was deeper and over large roughness elements. These conditions should cause the turbulence to be of a larger scale in the Bermardo reach; thus the efficiency of the spectral recovery should

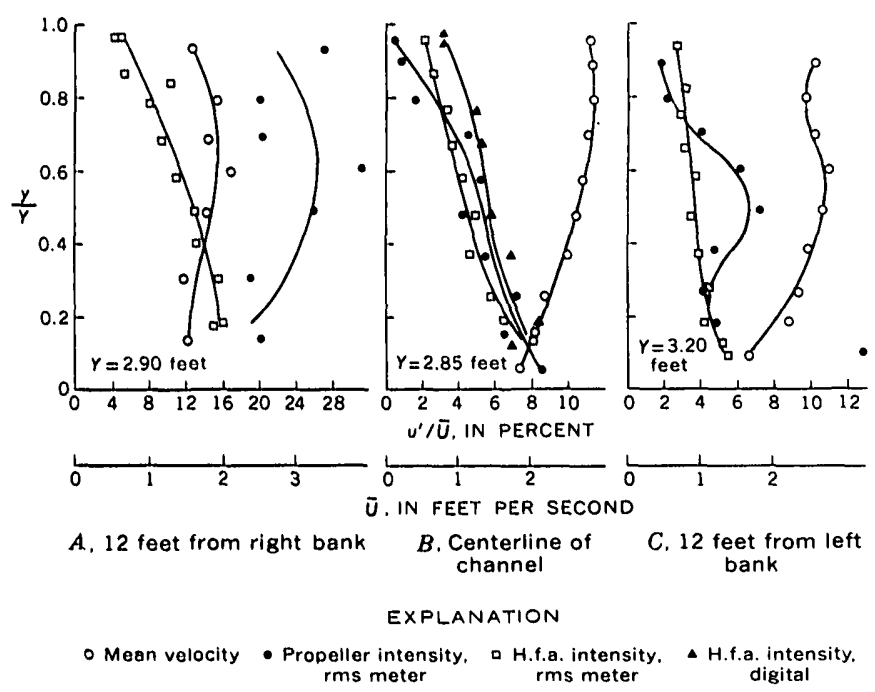

Froure 9.-Mean velocity, $\bar{U}$, and turbulent intensity, $u^{\prime} / \bar{U}$, as functions of relative depth, $y / Y$; measurements made in Bernardo conveyance channel. be greater in the Bernardo reach. (b) The flow velocity in the Bernardo reach was larger; thus the loss due to inertial averaging should have been less there (see fig. 3).

A comparison of the intensities obtained from the rms meter for both the hot-film anemometer and the propeller meter for the runs of figures 8 and 9 gives an indication of an efficiency, $e^{\prime \prime \prime}$, of the propeller in recovering the turbulence energy above $0.5 \mathrm{~Hz}$ (the low-frequency cutoff of the rms meter). Values of $e^{\prime \prime \prime}$ range from 0.1 at $y / Y=0.7$ of figure $8 B$ to 1.8 for $y / Y=0.40$ of figure $9 C$. This discussion excludes figure $7 A$ where the intensities measured by the propeller meter are as much as 3.5 times greater than those measured by the hot-film anemometer. This is because, at large intensities, the peculiarities of the digital-to-analog converter cause the rms meter to give voltage readings which are too high. Again, the propeller is more efficient in the flow of the Bernardo reach than in the Atrisco reach. The reasons for this are listed in the preceding paragraph.

The differences in performances of the rms meter in these two flows is significant. By comparing the intensity measurements obtained from the hot-film anemometer using the rms meter and digital methods, one can see that the rms meter is more efficient in the flow at the Bernardo reach. Because the rms meter has a low-frequency cutoff of $0.5 \mathrm{~Hz}$, this means that the Atrisco turbulence has more energy at the low frequencies than does the Bernardo turbulence.

Finally, one notes on studying figures 8 and 9 that the intensities measured by the propeller meter and the hot-film anemometer, using the rms meter, are almost identical (except 9A) up to about three-tenths of the depth of flowing water. This indicates that the turbulence structure over the lower three-tenths of the depth of the flowing water is coarse and of low frequency.

\section{CONCLUSIONS}

Several conclusions can be drawn from these measurements in movable-boundary open channels. First, power spectral densities measured by a propeller flowmeter after correction for the system function of the propeller are similar in shape to those measured by a hot-film anemometer, except at the higher frequencies where spatial averaging becomes significant. Second, the propeller flowmeter when used for measuring turbulence intensities becomes more efficient as the scale of the turbulence increases. Finally, the structure of movable-boundary open-channel turbulence is very coarse and of a low frequency over the lower threetenths of the depth of flowing water. 


\section{REFERENCES}

Bennett, J. P., 1968, Turbulence measurement with a propeller flow meter: U.S. Geol. Survey open-file report, $171 \mathrm{p}$.

Lee, Y. W., 1960, Statistical theory of communication: New York, John Wiley and Sons, Inc., 509 p.

Richardson, E. V., and McQuivey, R. S., 1968, Measurement of turbulence in water: Am. Soc. Civil Engineers Proc., Jour. Hydraulics Div., v. 94, no. HY2, p. 411-431.

Richardson, E. V., McQuivey, R. S., Sandborn, V. A., and Jog, P. M.; 1967, Comparison between hot-film and hot-wire measurements of turbulence, in Developments in mechanics : Midwestern Mech. Conf., 10th, Fort Collins, Colo., 1967, proc., v. 4, p. 1213-1225. 


\section{SUBJECT INDEX}

[For mujor headings such as "Dconomlc geology," "Petrology," "S urface water," see under State names or refer to table of contents]

Aeromagnetic studies, basement terranes, California..

Trinidad quadrangle, Colorado................

Age determinations, Precambrian batholith, Colorado..

Alaska, petrology, Seward Peninsula.................

petrology, southeastern part. surface water-ground water relationship, Anchorage area............

Aluralagus virginiae, n. sp., description..............

Analyses. See specific types: Atomic absorption, Fluorimetric, Mass spectrometric, Neutron activation, Spectrochemical, X-ray, $\mathrm{X}$-ray fluorescence.

Apatite, relation of $\mathrm{CO}_{2}$ content to regional facies, Idaho and Wyoming-

Aquifers, contamination, Connecticut.............

recharge-discharge relationship, Anchorage area, Alaska.............

transmissivity and storage coefficients, North Dakota. . . .........

Arizona, petrology, southern part. ...............

vertebrate paleontology, southern part........

Arkansas River, meander-migration study, southeastern Colorado.....

Artificial recharge, from recharge basins, New York...

Sec also Recharge studies.

Atomic absorption determination, cobalt..........

\section{B}

Bent's Old Fort National Historical Monument, Colo., river meanders near................

\begin{tabular}{|c|c|c|}
\hline \multirow[t]{2}{*}{ Page } & \multirow[b]{2}{*}{$\begin{array}{c}\text { Biotite, copper content, as ore } \\
\text { indicator }\end{array}$} & Page \\
\hline & & B1 \\
\hline B66 & $\begin{array}{l}\text { Bisons, Pleistocene, new occur- } \\
\text { rence in Colorado_ } 137\end{array}$ &, 141 \\
\hline 78 & $\begin{array}{l}\text { Black Hills, S. Dak., iron de- } \\
\text { posits }\end{array}$ & 93 \\
\hline 86 & $\begin{array}{c}\text { Blueschist facies, Seward Pe- } \\
\text { ninsula, Alaska_. }\end{array}$ & 33 \\
\hline 21 & $\begin{array}{r}\text { Breccia blocks, Colorado, moved } \\
\text { by gravitational slid- } \\
\text { ing }\end{array}$ & 43 \\
\hline 224 & C & \\
\hline 131 & $\begin{array}{r}\text { California, geophysics, south- } \\
\text { west coast_. }\end{array}$ & 66 \\
\hline & $\begin{array}{c}\text { Carbon dioxide, content in } \\
\text { apatite, relation to } \\
\text { regional facies.....- }\end{array}$ & 9 \\
\hline & $\begin{array}{c}\text { Channel studies, sandbar de- } \\
\text { velopment and trans- } \\
\text { port. }\end{array}$ & 237 \\
\hline 9 & $\begin{array}{c}\text { Clay minerals, seaward variation } \\
\text { in Maryland } \\
\text { See also Kaolinite. }\end{array}$ & 150 \\
\hline 203 & $\begin{array}{r}\text { Cobalt, determination by atomic } \\
\text { absorption spectrom- } \\
\text { etry }\end{array}$ & 174 \\
\hline 22 & $\begin{array}{l}\text { Colorado, geochronology, Front } \\
\text { Range area_. }\end{array}$ & 86 \\
\hline 190 & $\begin{array}{l}\text { geomorphology, southeast- } \\
\text { ern part. }\end{array}$ & 210 \\
\hline 1 & $\begin{array}{c}\text { geophysics, } \\
\text { part }\end{array}$ & 78 \\
\hline & petrology, central part...... & 14 \\
\hline 131 & $\begin{array}{l}\text { part. } \\
\text { stratigraphy, central part... }\end{array}$ & $\begin{array}{l}245 \\
141\end{array}$ \\
\hline 210 & south-central part......... & 43 \\
\hline 19 & $\begin{array}{l}\text { surface water, western part_ } \\
\text { vertebrate paleontology, cen- }\end{array}$ & 232 \\
\hline 19 & tral part............. & 137 \\
\hline 174 & $\begin{array}{l}\text { Connecticut, ground-water con- } \\
\text { tamination, south- } \\
\text { eastern part. }\end{array}$ & 203 \\
\hline & Conodonts, Triassic, Israel _. _. _ & 124 \\
\hline & $\begin{array}{r}\text { Contamination, ground water, } \\
\text { caused by styrene.-- }\end{array}$ & 203 \\
\hline & $\begin{array}{l}\text { Continental Shelf, off northeast- } \\
\text { ern United States, } \\
\text { geomorphology....- }\end{array}$ & 167 \\
\hline
\end{tabular}

Copper, in biotite, as ore indicator

Cutler Formation, Utah, paleobotany ..............

\section{D}

Density studies, in situ rock, Nevada Test Site....

Die, for pelletizing $\mathrm{X}$-ray fluorescence samples.........

Dry Union Formation, Colorado, breccia blocks........

Dyes, tracer, dosage requirements for

Page

B1

109

\section{E}

Eocene, Kentucky, mineralogy -Equipment. See Instruments and equipment.

\section{F}

Fission-track method, determination of uranium distribution in fossil hard parts..........

Flowmeters, comparison of two types..............

Fluorimetric analysis, uranium, determination in plant ash............

Foraminifera, use in stratigraphic correlation in Idaho..

Fox Hills Sandstone, North Dakota, ground water ..............

Franciscan basement rocks, California, geophysics. . -

\section{G}

Gardiners Clay, Long Island, N.Y., stratigraphy.--

Geochemical prospecting, copper content of biotite as ore indicator........

Geochronology. See Age determinations.

Germanium, determination in natural water....... 
Gravitational sliding, of breccia blocks, Colorado_... -

Gravity studies, as indicator of buried pluton, Montana

basement terranes, California..............

Nevada Test Site and Hot Creek Valley, Nev...

Trinidad quadrangle, Colorado..............

Grazing, hydrologic and biotic effects of . ..........

Greenschist facies, Seward Peninsula, Alaska_.........

\section{H}

Heavy metals, Alaska in layered pluton.............

Nevada, reconnaissance studies. . ...........

Hell Creek Formation, North Dakota, ground water.

High-calcium limestone, Pennsylvania, potential deposits. .............

Hot Creek Valley, Nev., subsurface gravity studies..

Hot-film anemometer, use in turbulent-flow measurements

I

Idaho, paleontology, Custer County ........... petrology, south-central part. . . . . .........

Indiana, ground water-surface water relation, central part............

Inflow, ground-water, Jordan Valley, Utah........ turbulence measuring systems, comparison ...

Instruments and equipment, die for pelletizing X-ray fluorescence samples

Iron deposits, Black Hills, S. Dak

Israel, paleontology, southern part..............

$$
\text { J }
$$

Jordan Valley, Utah, groundwater inflow .......

\section{$\mathbf{K}$}

Kaolinite, authigenic, in Wilcox Formation, Kentucky
Kentucky, mineralogy, Jackson Purchase region.....

\section{L}

Laumontite-leonhardite, formation, central Colorado ................

Leporidae, Pleistocene, Arizona

Limestone, high-calcium deposits, Pennsylvania.......

Long Island, N.Y., ground-water recharge basins......

stratigraphy

\section{M}

Mafic rocks, in layered pluton, Alaska

Magnetic studies. See Aeromagnetic studies.

Marine geology, Continental Shelf off New England .............

aryland, part _...........

Mass spectrometric analysis, separation of organic material from uranium ore for..........

Meander migration study, Arkansas River, Colorado

Mesozoic. See Triassic.

Methods and techniques, determination of dosage for tracer dyes in surface water.

determination of germanium in natural water....

determination of uranium distribution in fossil hard parts by fission tracks..............

evaluation of method for sediment-yield estimation..........

extraction of organic material from uranium ore

field determination of nickel in sediments and soils.

fluorimetric determination of uranium in plant ash

Miocene, Maryland, stratigraphy -

Mississippian, Idaho, paleontology . . . .........

Montana, gravity studies, Little Belt Mountains

\section{$\mathbf{N}$}

Neutron activation analysis, fission-track method.-

Nevada, economic geology, northeastern part...sance studies.........

Open-channel flow, instruments for turbulence measurements compared.

Overland flow, effect on ground water-surface water relation..........

Paleocene, off northeastern United States, geomorphology ..........

Paleozoic, Colorado, breccia blocks...............

See also Mississippian and Permian.

Peccaries, Pleistocene, new occurrence in Colorado_- 137, 141

Pennsylvania, limestone deposits, Lancaster County ...-

Permian, Idaho and Wyoming, petrology ............

Utah, paleobotany.......

Phosphate, Nevada, reconnaissance studies . .......

Phosphoria Formation, relation of $\mathrm{CO}_{2}$ content of apatite to regional facies.............

Pikes Peak batholith, Colorado, Rb-Sr dating -......

Plant fossils, Permian, Utah...-

Plants, ash, uranium determination

Pleistocene, Arizona, vertebrate paleontology . .......

Colorado, fossil vertebrate discoveries............

Colorado, stratigraphy .....

Long Island, N.Y., stratigraphy ...............

off northeastern United States, geomorphology ............. 
Pliocene, off northeastern United States, geomorphology ............

Pluton, buried, indicated by gravity studies in Montana........... lnyered, Mount Fairweather, Alaska ...............

Prairie potholes, hydrology ...... Precambrian, Alaska, petrology -

Colorado, geochronology....

South Dakota, iron.........

Precipitation records, trend analysis, use in study of runoff.

Protoblechnum bradyi Mamay and Breed, new fossil plant species..........

Q

Quartz grains, settling velocity in water

Quaternary. See Pleistocene.

\section{$\mathbf{R}$}

Rabbits, Pleistocene, Arizona..Range recovery, effects of grazing on, western Colorado.

Recharge studies, Anchorage area, Alaska.........

Sce also Artificial recharge.

Rhodamine dyes, dosage requirements for............

Rubidium-strontium age, Precambrian batholith, Colorado............

Runoff, effects of grazing on, western Colorado....

movement through zone of aeration beneath recharge basins... ....

trend analyses from longterm precipitation records..............

S

Salinian rocks, California, geophysics.
Page

B167
Sandbar development and transport, New Mexico..

Sediment yield, effects of grazing on, western Colorado evaluation of estimation method............

Sediments, clay-mineral variation in ...........

field determination of nickel in ..............

Settling velocity, grains in water-

Soils, field determination of nickel in ............

Solvent extraction, use in cobalt determination by atomic absorption spectrometry ........

South Dakota, iron deposits, Lawrence County....

Spectrometry. See Atomic absorption determination.

Spectrochemical analysis, germanium in natural water - . . . .

Storage coefficients, aquifers, North Dakota........

Streamflow, dosage requirements for tracer dyes....

Styrene, as ground-water contaminant..........

Tertiary, Montana, gravity studies...............

See also Paleocene, Eocene, Miocene. Pliocene.

Thermal springs, zeolitic deposits, central Colorado.....

Tracer dyes, dosage requirements for -

Transmissivity coefficients, aquifers, North Dakota...

Trend analysis, precipitation records, in study of runoff -................

Triassic, Israel, paleontology . . .
Page

Turbulent flow, instruments for measurement compared.............

B254

\section{$\mathbf{U}$}

Ultramafic rocks, in layered pluton, Alaska.....

Page

\section{w}

Water, settling velocity of grains in ...............

Watersheds, sediment-yield estimation............

Water table, indicated by prairie pothole water surface ...............

White Knob Limestone, Idaho, paleontology .........

Wilcox Formation, Kentucky, kaolinite in .......

Wyoming, petrology, central part. ............ sediment studies, east-central part.............

\section{$\mathbf{X}$}

$\mathrm{X}$-ray analysis, peak-pair method for estimating $\mathrm{CO}_{2}$ content of apatite...

$\mathrm{X}$-ray fluorescence analysis, pelletizing samples for..

\section{$\mathbf{Z}$}

Zeolitization, in central Colorado 
•

$x$ 
AUTHOR INDEX

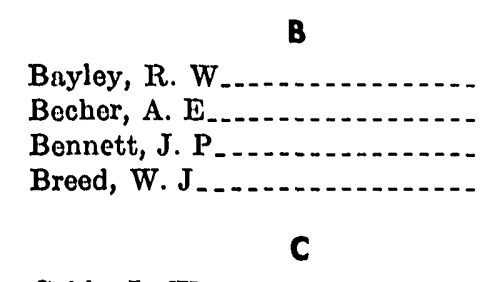

Cable, L. W.

Carrigan, P. H., Jr. . . . .

Cobb, E. D.

Coleman, R. G............

Cone, G. C.

Croft, $\mathrm{G}$ G

Culbertson, J. K. . . . . . . . . .

\section{D}

Daniel, J. F....................

Dong, A. E...................

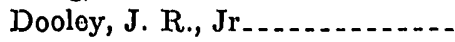

Downey, J. S...................

Drewes, Farald.

\section{$\mathbf{F}$}

Fabbi, B. P

\section{G}

Granger, H. C.

Grossman, I. G............

Gulbrandsen, R. A.......

\section{H}

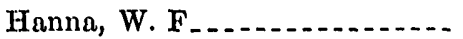

Healey, D. L.................

Hedge, C. E................

Fuddle, J. W. . .

Huffman, Claude, Jr.

Page
B93
102
254
109


219
214
214
33
1
1
190
237


219
242
90
131
1

187

184

203

9

66

52

86

124

181

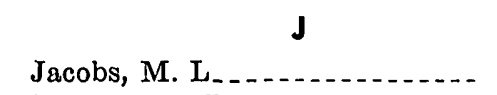

Page

Johnson, R. B..............

K

Kachadoorian, Reuben

Keefer, W. R . ........... 63

Ketner, K. B. . . . 105

Kilpatrick, F. A ........ 250

Kleinkopf, M. D._._._...... 63, 78

\section{$\mathbf{L}$}

Lewis, G. E_ . . . .

Lindvall, R. M.

Lovering, T. G............ 1

Lusby, G. C........... 232

\section{M}

MacKevett, E. M., Jr_._. _..._ 21

McQuivey, R. S............. 254

Mamay, S. H......... 109

Mamet, B. L. . . . . . . . 118

Meisler, Harold............. 102

Mountjoy, Wayne............ 174

Mower, R. W

Nowlan, G. A........... 177

\section{0}

Oldale, R. N.

Owen, J. P.

Peterson, D. L.... 78

Plafker, George............... $\begin{array}{rrr} & \text { R } & \text { Page } \\ \text { Riley, L. B..... } & \text { B181 }\end{array}$

Rosholt, J. N._... 90

\section{S}

Sainsbury, C. L. 33

Scott, C. H._. . .

Scott, G. R

Seaburn, G. E. _........ 196

Sharp, W. N............. 14

Shown, L. M._._. 245

Sims, J. D_._. .

Skipp, Betty_............... 118

Sloan, C. E..._.

Stefansson, Karl............ 150

Swenson, F. A. ............ 210

Szabo, B. J. . . . . . . . . 90

\section{$\mathbf{T}$}

Taylor, R. B. . .

\section{U}

Uchupi, Elazar........

Upson, J. E............. 157

Van Alstine, R. E_........... 43

\section{w}

Warren, C. G............ 184

Weeks, J. B. . . . . .

Wesolowski, E. A_..._._._._. 190

Winegard, C. I._._. . . . _... 161

Witkind, I, J. . . .

Wolf, R. J._... 219

B267 